Editora Poisson

\title{
Administração Rural Volume 1
}

\author{
1a Edição
}

Belo Horizonte

Poisson

2018 
Editor Chefe: Dr. Darly Fernando Andrade

\section{Conselho Editorial}

Dr. Antônio Artur de Souza - Universidade Federal de Minas Gerais

Msc. Fabiane dos Santos Toledo

Dr. José Eduardo Ferreira Lopes - Universidade Federal de Uberlândia

Dr. Otaviano Francisco Neves - Pontifícia Universidade Católica de Minas Gerais

Dr. Luiz Cláudio de Lima - Universidade FUMEC

Dr. Nelson Ferreira Filho - Faculdades Kennedy

Ms. Valdiney Alves de Oliveira - Universidade Federal de Uberlândia

Dados Internacionais de Catalogação na Publicação (CIP) A238

Administração Rural - Volume 1/ Organização

Editora Poisson - Belo Horizonte - MG:

Poisson, 2018

$352 \mathrm{p}$

Formato: PDF

ISBN : $978-85-7042-029-9$

DOI : $10.5935 / 978-85-7042-029-9$

Modo de acesso: World Wide Web

Inclui bibliografia

1. Administração 2. Rural. I. Título

CDD-658

O conteúdo dos artigos e seus dados em sua forma, correção e confiabilidade são de responsabilidade exclusiva dos seus respectivos autores.

Baixe outros títulos gratuitamente em www.poisson.com.br contato@poisson.com.br 


\section{Sumárīo}

Capítulo 1: Integração avícola: importância socioeconômica da atividade para os produtores da mesorregião oeste paranaense

Ivanete Daga Cielo, Weimar Freire da Rocha Júnior, Fernanda Cristina Sanches

Capítulo 2: Os mercados institucionais na agricultura familiar: desempenho do programa nacional de alimentação escolar entre 2009 a 2014

Josiane Castro Pereira, Alessandra Troian, Edenilson T. Lencina Machado

Capítulo 3: Lavanderias comunitárias em Rio Branco - AC: alternativa de trabalho para mulheres com vulnerabilidade econômica

Oleides Francisca de Oliveira, Josefa Estevo de Souza Araújo, Jean Marcos da Silva

Capítulo 4: Uma análise cross-section do avanço do desmatamento na região da amazônia ocidental

Meyrianny Santana Reis, Elane Conceição de Oliveira, Neuler André Soares de Almeida

Capítulo 5: Índice de desenvolvimento rural dos municípios do estado do Pará

Marcus Vinicius Mendonça, Adriano Nascimento da Paixão, Nilton Marques de Oliveira, Rodolfo Alves da Luz

Capítulo 6: Comércio internacional e desenvolvimento regional: as exportações dos setores de uva e de manga do estado de Pernambuco

Maria Raíza Vicente da Silva, Maria Gilca Pinto Xavier

Capítulo 7: Pronaf, capital social e empreendedorismo rural: modelo conceitual para o desenvolvimento da agricultura familiar Leonardo Guimarães Medeiros

Capítulo 8: A armazenagem de grãos no Brasil: evolução e perspectivas ...... 


\section{Sแma์}

Capítulo 9: Nível de eficiência do programa bolsa floresta nas unidades de conservação do Amazonas: uma análise envoltória de dados.

Loiseane Santos Correia Pinto, Elane Conceição de Oliveira, Neuler André Soares de Almeida

Capítulo 10: Os impactos da seca na economia familiar nordestina

Maricelia Almeida da Silva, Lucas Ferreira Lima

Capítulo 11: O sistema agroindustrial do urucum na microrregião de Dracena-SP

Wagner Luiz Lourenzani, Evandro Jardim dos Santos, Ana Elisa Bressan Smith Lourenzani

Capítulo 12: A ocupação das terras agricultáveis nos estados do MATOPIBA.. 153 José de Ribamar Sá Silva, Innar Fernandes Feitoza, Benjamin Alvino de Mesquita

Capítulo 13: A formação do preço das commodities arroz, milho e soja no Brasil

Elizangela Beckmann, Antônio Cordeiro de Santana

Capítulo 14: Caroço de algodão integral na dieta de cordeiros confinados: Uma análise produtiva e econômica na região sudeste do Mato Grosso, Brasil

Miller de Jesus Teodoro, Henrique Leal Perez, Geovanne Ferreira Rebouças, Matheus Sodré Ferreira, Poliana Fernandes de Almeida, Affonso Amaral Dalla Libera

Capítulo 15: Determinantes do tempo total de aprovação de Eventos GM de algodão, milho e soja na união europeia

Maurício Benedeti Rosa, Diego Sarti de Souza, Dallas Kelson Francisco de Souza, Rosane Nunes de Faria

Capítulo 16: Análise da viabilidade do retorno econômico-financeiro das atividades leiteira e avícola

Silvana Dalmutt Kruger, Mauricio Antônio Bottini, Fabio José Diel, Vanderlei Gollo

Capítulo 17: Pós-graduação lato sensu na modalidade de educação a distância: um estudo de caso em uma parceria público/privada para oferta do curso de especialização em cooperativismo solidário e crédito rural

Simão Ternoski, Zoraide da Fonseca Costa, Felipe Polzin Druciaki, Maria Aparecida Crissi Knuppel 


\section{Sumário}

Capítulo 18: Café: uma análise do potencial da cadeia produtiva do café no crescimento econômico da Microrregião de Patos de Minas

Ravilla de Castro Barbosa, Julienne de Jesus Andrade Widmarck, Áurea Lúcia Silva Andrade, Deivisson Costa de Carvalho, Vivian Raniere Mendes Silva

Capítulo 19: Pib, produção e emprego dos municípios que compõem a região do Alto Paranaíba: uma análise a partir da perspectiva do agronegócio

Vivian Raniere Mendes Silva, Fábio André Teixeira, Julienne de Jesus Andrade Widmarck, Hernani Martins Júnior, Ravilla de Castro Barbosa

Capítulo 20: Aspectos da produção e exportação cafeeira na região do Triângulo Mineiro/Alto Paranaíba e sul de Minas

Isaac Resende Araújo, Joabe Santos Sousa, Ricardo Freitas Martins da Costa, Fábio André Teixeira, Julienne de Jesus Andrade

Capítulo 21: Impacto da mecanização na qualidade de emprego na cultura do café medido a partir dos indicadores de qualidade do emprego (IQE).....

Fábio André Teixeira, Antônio Marcos de Queiroz , Ricardo Freitas Martins da Costa, Walter Luiz dos Santos Júnior, Joabe Santos Sousa

Capítulo 22: Evolução da distribuição da renda domiciliar per capita e sua decomposição para o setor rural goiano no período 2001-2015

Edson Roberto Vieira, Danilo Troncoso Chaves Martines, Antônio Marcos de Queiroz, Cleidinaldo de Jesus Barbosa

Capítulo 23: Programa Chapéu de Palha: solução ou perpetuação da pobreza na zona canavieira?

Érika Sabrina Felix Azevedo, Tales Wanderley Vital

Capítulo 24: Identificação e análise de vantagens competitivas em empresas de aquicultura

Luisa Paseto

Autores 


\section{Capítulo 1}

\section{INTEGRAÇÃO AVÍCOLA: IMPORTÂNCIA SOCIOECONÔMICA DA ATIVIDADE PARA OS PRODUTORES DA MESORREGIÃO OESTE PARANAENSE}

\section{Ivanete Daga Cielo}

Weimar Freire da Rocha Júnior

\section{Fernanda Cristina Sanches}

Resumo: A atividade avícola é um setor em expansão no Brasil, à exemplo, pode-se apontar o sistema agroindustrial (SAG) avícola do Paraná, que representa 11\% do agronegócio do Estado. Este SAG é também o maior gerador de emprego e renda do agronegócio paranaense. Dos setores da agroeconomia, a avicultura é o que tem mais potencial de geração de empregos haja vista que demanda muita mão de obra para produção e industrialização. Nesse cenário, como objetivo central, esse estudo buscou investigar os impactos socioeconômicos refletidos no cotidiano dos produtores avícolas, bem como, identificar a o perfil e características desses sujeitos. Para tanto, este estudo de cunho qualitativo, reflete os resultados de um questionário aplicado in loco a 133 avicultores da Mesorregião Oeste do Paraná. A pesquisa buscou delimitar o perfil dos produtores bem como, a importância socioeconômica da avicultura para esses atores. Os principais resultados apontam para um cenário favorável, no qual o sistema de produção é avaliado de forma positiva pelos agentes envolvidos, no qual os produtores demonstram-se, de modo geral, satisfeitos, tanto em relação à lucratividade quanto à garantia do retorno sobre o investimento realizado em suas propriedades. 


\section{INTRODUÇÃO}

O agronegócio no Brasil é responsável por grande parte do desenvolvimento econômico do país. O setor apresenta um papel fundamental na balança comercial brasileira, além de ser um grande gerador de emprego e renda (UBABEF, 2013). Nesse cenário, aponta-se como destaque $\mathrm{O}$ setor da avicultura. A produção de frango de corte tem impressionado pelo dinamismo e pela competência conquistada nas últimas décadas. O ganho de produtividade associado à coordenação da cadeia avícola, possibilitou ao Brasil conquistar uma posição de destaque, ocupando a $1^{a}$ colocação no ranking dos países exportadores de carne de frango e 0 3o maior produtor mundial. Atualmente, a carne de frango brasileira é exportada para mais de 150 países (MINISTÉRIO DA AGRICULTURA, PECUÁRIA E ABASTECIMENTO - MAPA, 2014).

No contexto atual, o setor avícola é de fundamental importância para a economia brasileira. Dados da UBABEF (2013) e do MAPA (2014) apontavam para a existência de aproximadamente 720 mil trabalhadores atuando nas indústrias de abate e processamento de frango; e, outros 3,5 milhões ocupando vagas geradas direta $e$ indiretamente pelo setor. Além disso, os dados apontam que o setor é responsável por uma movimentação financeira de cerca de $\mathrm{R} \$ 36$ bilhões em negócios, com uma participação de 1,5\% no PIB brasileiro.

Esse dinamismo e desenvolvimento do setor resultam de uma série de fatores que contribuíram significativamente para que fossem alcançados os atuais ganhos de produtividade e competitividade. Para autores como Zilli (2003), MacDonald e Korb (2006) e Jesus Júnior et al. (2007), entre esses fatores têm destaque as inovações tecnológicas na área de genética, de alimentação, de equipamentos e de manejo, aliado à implantação do sistema de produção através de contratos de integração entre produtores rurais e agroindústria. Esse sistema de produção de frangos é conhecido no mercado e, mais recentemente, por pesquisadores da área como "sistema de integração" e será discutido com maior profundidade no decorrer dos próximos capítulos.

Apesar de vários estados brasileiros produzirem frango, segundo dados da ABPA (2017), a produção está concentrada nos estados do Paraná, Santa Catarina, Rio Grande do Sul e São Paulo, os quais produziram conjuntamente em 2016, 72,96\% da produção doméstica, calculada em 12,9 mil toneladas. Entre os estados produtores, o Paraná detém o título de maior produtor e exportador nacional, respondendo por $33,46 \%$ do total produzido nacionalmente e por $35,85 \%$ das exportações de carne de frango do país. A carne de frango produzida no Paraná é comercializada em mais de 130 países, injeta um valor superior a US\$ 2 bilhões anuais na economia do Estado.

O sistema agroindustrial (SAG) avícola paranaense, de acordo com a Secretaria da Agricultura e do Abastecimento do Paraná SEAB-PR (2013), representa $11 \%$ do agronegócio do Estado. É também responsável pela geração de 660 mil empregos diretos e indiretos no Estado cerca de $7 \%$ da população paranaense, sendo a maior geradora de emprego e renda do agronegócio paranaense. Dos setores da agroeconomia, a avicultura é o que tem mais potencial de geração de empregos porque demanda muita mão de obra para produção e industrialização.

Inserida nesse contexto, a Mesorregião Oeste Paranaense (MROP) tem uma posição de destaque no cenário avícola estadual, responsável pelo abate de $33,7 \%$ do total produzido no estado (IPARDES, 2017). Além da presença de grandes empresas privadas e cooperativas agroindustriais de abate e processamento de frangos, a Mesorregião se destaca pela produção de milho e soja, principais matérias primas para fabricação de ração. Ademais, o agronegócio responde por mais da metade do PIB anual do Oeste do Paraná. O setor é responsável por $R \$ 12$ bilhões por ano, enquanto que a soma de todas as riquezas dos 50 (cinquenta) municípios que formam a MROP apenas chega aos $R \$ 23$ bilhões. Já o SAG do frango representa anualmente para a Mesorregião o equivalente a $R \$ 4,2$ bilhões do PIB, ou seja, $18,2 \%$ do total das riquezas produzidas e $35 \%$ do total do agronegócio regional (IPARDES, 2017).

Nesse contexto, considera-se relevante conhecer o perfil dos avicultores vinculados contratualmente a agroindústrias da Mesorregião Oeste Paranaense. Isto posto, apresenta-se uma questão central a ser respondida: Qual é a importância socioeconômica da atividade avícola para os produtores? Para a obtenção de respostas a 
esse questionamento, esse estudo tem como objetivo central investigar os impactos socioeconômicos refletidos no cotidiano dos produtores avícolas, bem como, identificar a o perfil e características desses sujeitos.

Compreender esses aspectos se faz relevante, tendo em vista a importância econômica da atividade para a MROP e o fato de que os produtores são peça fundamental para o êxito do sistema agroindustrial do frango de corte. A pesquisa também se faz proeminente para auxiliar no estabelecimento de políticas públicas mais afetivas para 0 setor.

Para atingir o objetivo proposto, o presente estudo está estruturado em cinco partes centrais. Além desta introdução, a segunda parte tece considerações acerca do setor avícola brasileiro. Na terceira parte, os procedimentos metodológicos aqui adotados, são explicitados. A quarta parte apresenta os principais resultados encontrados. As considerações finais e as sugestões para pesquisas futuras compõem a quinta parte. Por fim, as referências encerram este estudo.

\section{O SETOR AVÍCOLA BRASILEIRO}

A agroindústria avícola brasileira tem merecido posição de destaque no cenário do agronegócio nacional e internacional, constituindo-se dentro do complexo de carnes, a atividade mais dinâmica. Historicamente, o desenvolvimento dessa atividade em escala comercial, surge com maior intensidade ao final da década de 1950, nos estados de São Paulo e Minas Gerais, a partir da importação dos Estados Unidos de linhagens híbridas de frango de corte (RIZZI, 1993).

Nos anos subsequentes, principalmente a partir de 1970, o complexo agroindustrial avícola de frango de corte, impulsionado pelas transformações no aparato produtivo da economia brasileira, passou por um processo de mudanças na base técnica de produção, modernização e, consequente aumento no número de indústrias processadoras em diversos estados, principalmente na Região Sul.

Assim, a atividade antes praticamente restrita à Região Sudeste, desloca-se para o Sul do país, principalmente para o estado de Santa Catarina e começa uma nova fase de exponencial crescimento, modernização e expansão (BARCZSZ; LIMA FILHO, 2009).

Autores como Rizzi (1993) e Canaver et al. (1997) afirmam que a expansão das agroindústrias processadoras de carne de frango, sobretudo, na Região Sul, foi viabilizada pela política agrícola, fortemente vinculada pelas condições de liquidez financeira internacional e pela política de crédito que subsidiou a instalação de frigoríficos e de aviários. Nesse mesmo período, intensificaram-se as importações de tecnologias genéticas e técnicas ambientais, sanitárias, nutricionais, de abate e de processamento, modificando, assim, o sistema produtivo da avicultura.

Aliado a isso, o setor foi favorecido por contribuições advindas do avanço tecnológico, a exemplo da biotecnologia, microeletrônica e automação. A evolução tecnológica na avicultura resultou, sobretudo, em ganhos de eficiência na produtividade propiciando melhorias na conversão alimentar (consumo de ração do animal em um período de tempo, dividido pelo seu ganho de peso em um período de tempo) e progressiva redução no tempo necessário para $\mathrm{o}$ abate. Esse ganho de eficiência pode ser comprovado através dos dados do Quadro 1.

Quadro 1 - Evolução média dos coeficientes de produção de frango de corte no Brasil.

\begin{tabular}{|c|c|c|c|}
\hline Ano & Peso frango vivo $(\mathrm{g})$ & Conversão alimentar & Idade de abate - dias \\
\hline 1930 & 1500 & 3,50 & 95 dias \\
\hline 1940 & 1550 & 3,00 & 70 dias \\
\hline 1950 & 1580 & 2,50 & 56 dias \\
\hline 1960 & 1600 & 2,25 & 49 dias \\
\hline 1970 & 1700 & 2,15 & 49 dias \\
\hline 1980 & 1800 & 2,05 & 49 dias \\
\hline 1985 & 1900 & 2,00 & 47 dias \\
\hline 1990 & 1940 & 2,00 & 45 dias \\
\hline 1995 & 2050 & 1,98 & 43 dias \\
\hline 2000 & 2250 & 1,88 & 42 dias \\
\hline 2005 & 2300 & 1,82 & 41 dias \\
\hline
\end{tabular}

Fonte: Elaborado pelos autores a partir dos dados da UBABEF (2011). 
Embora os dados disponíveis datam de 2011 e referem-se a média nacional, cabe destacar que em 2018, na avicultura da MROP, há registros de conversão alimentar na ordem 1,69, batendo recorde nos índices de eficiência nacional para 0 no setor (AGROEMDIA, 2018). Entretanto, é importante destacar que, dependendo da destinação da carne, tanto o peso quanto o tempo médio de engorda podem sofrer modificações. De acordo com Salviano (2011, p. 38), "algumas agroindústrias estão produzindo para mercados altamente exigentes em termos de qualidade do produto e faixa específica de peso que acarreta conversões alimentares variáveis".

Além dos fatores tecnológicos, as alterações na forma de produção, passando de processo produtivo autônomo para a integração entre agroindústrias e produtores, foram fundamentais para o desenvolvimento da atividade no Brasil. Para autores como Rizzi (2004), Pereira, Melo e Santos (2007) e Salviano (2011) essa estratégia de integração possibilitou às empresas ganhos de eficiência obtida através da qualidade em termos de padronização da matéria-prima, redução de custos industriais nas operações de abate, padronização de carcaças, abastecimento constante, dentre outras. O sistema integração permitiu, ainda, a rápida transferência tecnológica, principalmente através dos serviços de assistência técnica e consequente melhoria nos níveis de produtividade.

Se, por um lado, o avanço tecnológico e as mudanças no processo produtivo foram responsáveis pelo aumento da produção de frangos de corte, por outro lado, o acelerado processo de urbanização em função dos processos migratórios rural-urbano e da inserção com maior intensidade da mulher no mercado de trabalho ampliaram as bases industriais de bens de consumo; e, consequentemente o tamanho do mercado. Assim, o consumo de carne de frango evoluiu rapidamente e, em poucas décadas, passou a ser a principal fonte proteica da população (RIZZI, 1993). O crescimento e a evolução do consumo de carne de frango no Brasil podem ser melhor visualizados através do Gráfico 1.

Gráfico 1 - Evolução do consumo brasileiro de carne de frango (Kg/hab.)

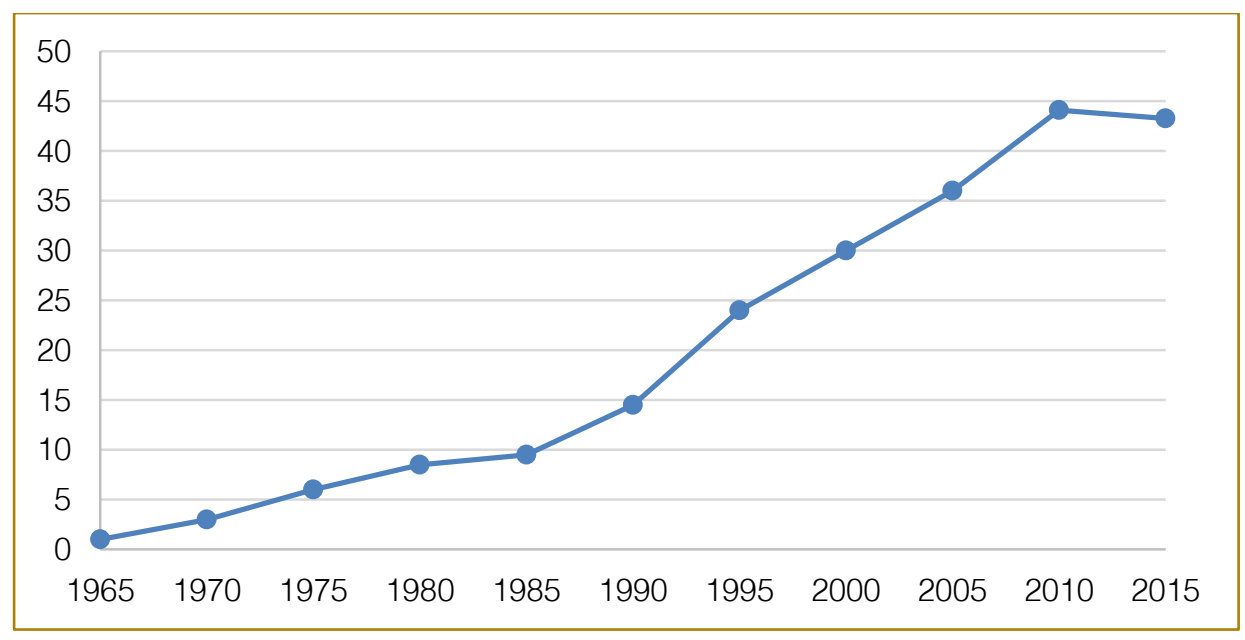

Fonte: Elaborado pelos autores a partir dos dados da Embrapa (2003), UBABEF (2014) e ABPA (2017).

Desde o início da produção em escala do frango de corte, na década de 1960, ocorreu significativo crescimento do consumo da carne de frango no País. No entanto, ao longo do período, percebe-se ligeira desaceleração de consumo na primeira parte da década de 1980. De acordo com Wilkinson (1993), esta retração foi resultado da forte concorrência das exportações subsidiadas dos EUA e da Comunidade Econômica Europeia (CEE), atual EU, aliada à recessão econômica do país, afetando o desempenho do mercado interno e, por consequência, do consumo per capita. Porém, não se tratou apenas de retração de consumo interno, mas, de redução de produção, consumo interno e exportação.

A partir de 1985, o consumo de carne de frango apresentou um exponencial crescimento, impulsionado principalmente 
pelas mudanças no estilo de vida e de hábitos alimentares do brasileiro, passando a utilizar cada vez mais a carne de frango como base da sua alimentação. Para Lima Filho et al. (2005) o fator saúde é um dos elementos considerados determinantes na compra da carne de frango, uma vez que, ao longo dos anos, os consumidores foram convencidos através de inúmeras estratégias de marketing, que a carne branca de frango é de melhor qualidade, comparativamente às carnes bovinas e suínas.

A tendência de elevação do consumo de carne frango continuou ao longo das décadas de 1990 e 2000, superando em 2006 a carne bovina, mais consumida no país até aquele ano. Em 2013, o consumo médio por habitante de carne bovina foi de $36,2 \mathrm{~kg}$, contra $41,8 \mathrm{~kg}$ de carne de frango (MAPA, 2014).

Paralelamente ao crescimento do consumo, as características do mercado de aves também vêm mudando. No início da década de 1960, a maior parte da produção era composta de frango "standard", vendido a preços baixos sem muitos requisitos em relação à qualidade. Com as alterações nos hábitos alimentares e nos padrões culturais da população, as indústrias passaram a focar ações em relação à qualidade adaptando-se às necessidades dos consumidores.

Nesse sentido, intensificou-se a produção e comercialização de produtos certificados, de origem regional controlada, além de produtos com maior valor agregado a exemplo dos cortes diferenciados de frangos temperados, embutidos e defumados. Tais estratégias utilizadas, além de ampliar a oferta e atender às demandas do novo público consumidor alavancaram ainda mais o setor, que já estava em franco desenvolvimento (RIZZI, 1993).

Atualmente, a avicultura brasileira oferece uma gama de produtos destinados para as mais distintas faixas de renda, atendendo às necessidades de praticidade e conveniência não só para o mercado interno, mas exportando parte de sua produção para distintos países.

No entanto, a importância da avicultura vai além da produção de proteína animal, é um dos setores que mais emprega no país, contribuindo para o aumento significativo da economia. Considerando sua importância econômica, o setor avícola, tornou-se essencial em regiões como Sudeste e principalmente na região Sul, onde está concentrada a maior parte da produção nacional.

Em estados como Paraná e Santa Catarina, primeiro e segundo maiores produtores de carne de frango no país, respectivamente, a avicultura assume papel de maior relevância. A importância do setor não reside apenas na geração direta de empregos e renda, mas na economia indireta gerada pelo setor, a exemplo da produção agrícola, empreendimentos rurais, logística, máquinas e equipamentos, alimentação animal, varejo entre outras (IPARDES, 2002).

De acordo com Rizzi (1993) a concentração da atividade na região Sul e consequente instalação de inúmeras agroindústrias, foi impulsionada pelo processo de modernização agrícola acorrida a partir de 1970 e pelas próprias características da região como polo de atração de capitais tanto nacionais como estrangeiros. Além disso, empresas que possuíam negócios na produção de suínos e de cereais, principalmente na região Sul, passam a atuar também no setor avícola, deslocando a atividade inicialmente implantada na região Sudeste para o Sul do Brasil.

O Gráfico 2 apresenta a atual distribuição da produção avícola brasileira por Unidade Federativa, bem como, a evolução e a participação ao longo dos últimos anos. 
Gráfico 2 - Evolução na participação dos Estados nos abates - Brasil - 2003-2017.

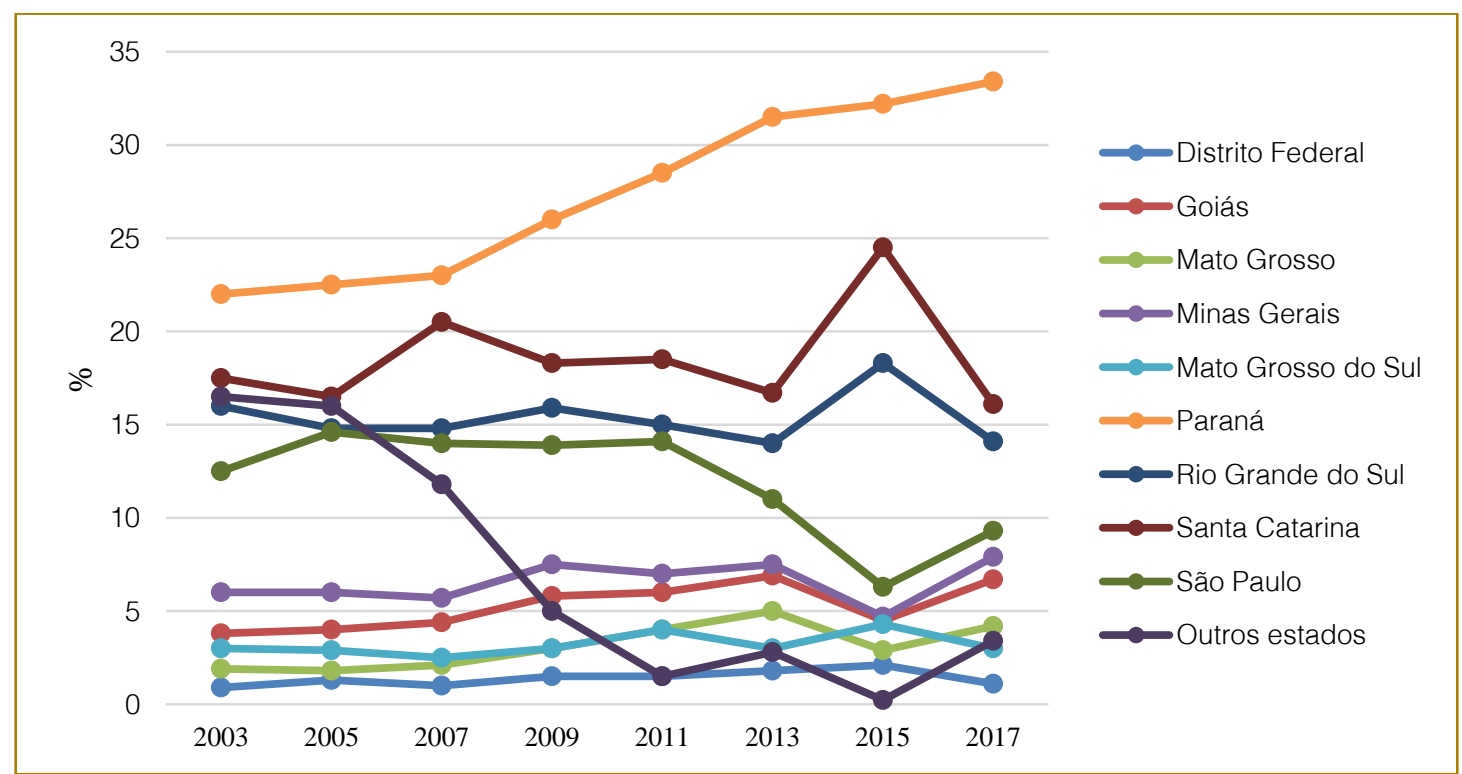

Fonte: Elaborado pela autora a partir dos dados da ABPA (2017).

De acordo com o Gráfico 2, é perceptível a evolução na participação dos Estados no abate de frango, denotando a supremacia da capacidade produtiva no setor de frango de corte do Estado do Paraná. O Estado ocupa ao longo da década o posto de maior produtor de frango, distanciando-se de demais Estados produtores como Santa Catarina, Rio Grande do Sul e São Paulo. Durante o período avaliado, a atividade apresentou significativo crescimento, passando de $21,9 \%$ para mais de $30 \%$ de participação na produção total do país. Esse crescimento é atribuído principalmente pela oferta de grãos no estado aliado ao sistema integrado de produção.

Por outro lado, estados com tradição na avicultura de corte, a exemplo de Santa Catarina, Rio Grande do Sul e São Paulo, não obtiveram o mesmo desempenho, mantendo os índices de produção nos mesmos patamares ao longo da década. A participação dos estados no abate de frango é apresentada através da Figura 1.

Figura 1 - Participação dos Estados no abate de frango em 2017 (\%).

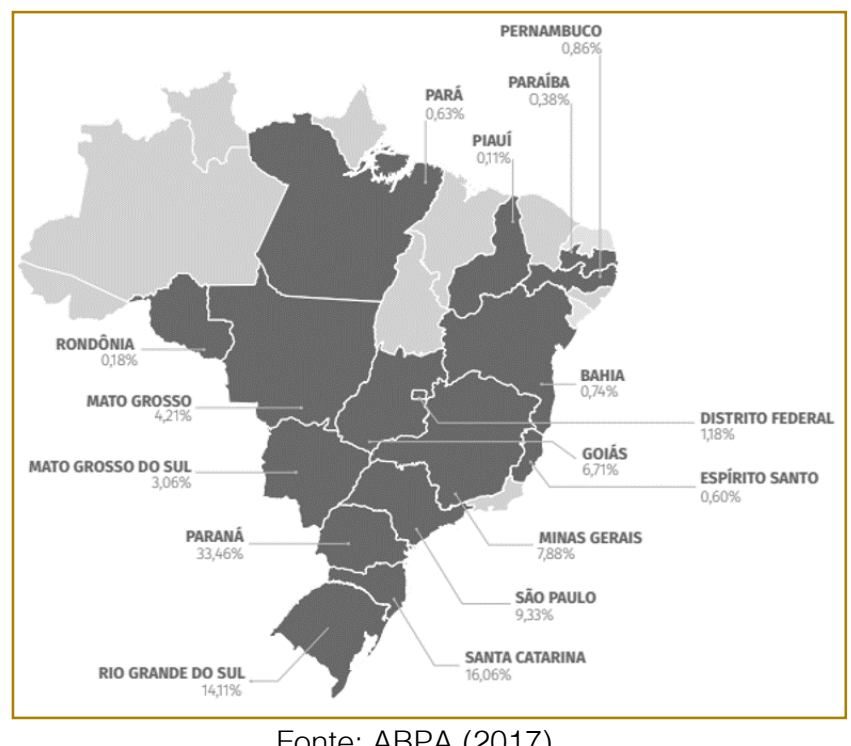

Fonte: ABPA (2017). 
Em relação à distribuição da produção avícola nos distintos Estados brasileiros, destaca-se a concentração da atividade na Região Sul, líder histórica na produção nacional e responsável por $63,63 \%$ da produção total de aves abatidas em 2017. Embora a atividade tenha se expandido para outras regiões, a dimensão que assumiu na Região Sul, dificilmente será obtida nas demais fronteiras, em função do encadeamento e estruturação do SAG avícola estabelecido nestes estados. Lima (1984), já chamava a atenção para o processo de concentração na região Sul ainda nos seus primórdios da expansão da avicultura brasileira e apregoava que dificilmente em outras regiões do Brasil haveria atividades no mesmo nível de desempenho.

A justificativa do ponto de vista do autor se baseava em fatores como características culturais da população, estrutura fundiária dos estados embasada no processo de emigração estrangeira e a concentração da produção dos insumos básicos da avicultura (soja e milho), como fatores que propiciam a performance positiva do setor. Em relação à produção dos insumos básicos, o autor destaca que a proximidade da atividade avícola aos centros de produção de grãos implica menores custos globais e melhor desempenho do setor, mesmo que se tenha que transportar posteriormente o produto final para um mercado consumidor distante (LIMA, 1984).

\section{PROCEDIMENTOS METODOLÓGICOS}

Este estudo objetiva analisar características do sistema de produção de frango de corte na Mesorregião Oeste Paranaense. Especificamente, busca-se compreender a importância socioeconômica da avicultura para os produtores de frango da região em estudo. Nesse sentido e, no intuito de buscar respostas à questão de pesquisa, a abordagem qualitativa fundamenta o arcabouço metodológico predominante no estudo, tanto em função da natureza do problema quanto pelo nível de aprofundamento desejado.

Para tanto, as ideias centrais da pesquisa são fundamentadas em Richardson (1999), o qual cita que o recurso qualitativo se apresenta como forma adequada para a compreensão dos fenômenos sociais, justo porque se fundamenta na análise de diferentes perspectivas e nas reflexões dos pesquisadores a respeito de sua investigação como parte do processo de produção de conhecimento.

Quanto aos objetivos, a pesquisa pode ser caracterizada como de cunho exploratório, descritivo e explicativo. Inicialmente, o estudo se desenvolve através de uma pesquisa exploratória baseada em dados secundários, a exemplo de bibliografias acerca do tema em questão, relatórios técnicos e demais documentos pertinentes. Essa etapa buscou identificar a existência de agroindústrias avícolas e seus sistemas de integração, na região de investigação.

Posteriormente, com o intuito de elucidar as especificidades da investigação proposta e, consequentemente, aumento do conhecimento acerca do objeto de estudo, realizou-se uma pesquisa de caráter descritivo. Gil (2009, p. 42) menciona que a pesquisa descritiva, "têm como objetivo primordial a descrição das características de determinadas populações ou fenômenos ou, então, o estabelecimento de relações entre variáveis".

O universo da pesquisa foi composto por 3013 estabelecimentos produtores de frango de corte instalados na Mesorregião Oeste Paranaense. Para a delimitação da amostra, fez-se uso da amostragem estratificada não proporcional, uma vez que foram selecionados elementos em cada subgrupo da população, obtendo uma amostra com distribuição equilibrada de produtores de frangos integrados a cada uma das sete agroindústrias. Em relação a essa forma de amostragem, Gil (2009, p.123) postula que "há situações em que esse procedimento é o mais adequado, particularmente naquela em que se tem interesse na comparação entre os vários estratos". Cabe ressaltar que essa forma amostral foi utilizada em função do objetivo central da presente tese.

Considerando o caráter qualitativo da pesquisa, o fechamento amostral ocorreu pelo processo intitulado saturação teórica, que suspende a inclusão de novos participantes quando os dados obtidos, passam a apresentar, na avaliação do pesquisador, uma certa redundância ou repetição, não mais contribuindo significativamente ao aperfeiçoamento da reflexão teórica fundamentada nos dados que estão sendo coletados. Ou seja, as informações fornecidas pelos novos participantes da pesquisa pouco 
acrescentariam ao material já obtido (FONTANELLA; RICAS; TURATO, 2008).

Assim sendo, a quantidade de entrevistas com os produtores não foi definida com exatidão a priori, mas sim, estabelecida à medida que a pesquisa foi se desenvolvendo. Ao final, foram obtidas 133 entrevistas com avicultores. Estes foram investigados, acerca do sistema de integração avícola do qual fazem parte. Para tanto, aplicou-se um roteiro de questões realizadas in $10 c 0$ nas propriedades, localizadas em distintos municípios da Mesorregião Oeste do Paraná. O questionário buscou delimitar o perfil dos produtores a partir de questões envolvendo: faixa etária; gênero; grau de instrução; mão de obra e tamanho das propriedades; capacidade produtiva e quantidade de granjas. Ademais, investigou questões relacionadas à importância socioeconômica da avicultura para os atores envolvidos, por meio dos aspectos: motivações que impulsionaram o investimento na área; tempo de atuação na avicultura; forma de custeio para implantação das granjas e por fim, o apontamento de existência de políticas públicas de fomento à atividade.

Os dados coletados, foram interpretados utilizando-se da análise de conteúdo. Tal proposição metodológica justifica-se porque a análise de conteúdo conduz à descrição objetiva e sistemática do conteúdo de mensagem, permitindo a sua manipulação tanto do teor, quanto de expressões deste conteúdo. Nesse enfoque, evidenciam-se, assim, indicadores que permitam inferir sobre uma outra realidade que não da mensagem (RICHARDSON, 1999; BARDIN, 2004).

Por fim, cabe destacar que esta pesquisa se trata de um recorte de um estudo mais amplo, desenvolvido como tese doutoral de um dos autores deste artigo.

\section{RESULTADOS E DISCUSSÕES}

\subsection{PERFIL DOS PRODUTORES DE FRANGO DE CORTE VINCULADOS AO SISTEMA DE INTEGRAÇÃO AVÍCOLA}

Para uma análise sistêmica da integração avícola, considerada como um modelo exitoso para a produção de aves, faz-se necessário conhecer a percepção daqueles que estão em sua base, ou seja, os produtores de aves. Assim, o presente estudo dedica-se a apresentar as opiniões dos 133 produtores investigados acerca do sistema de integração avícola do qual fazem parte.

Os produtores avícolas investigados na pesquisa estão espacialmente distribuídos em distintos municípios da Mesorregião Oeste Paranaense, como pode ser observado na Figura 2, cuja coloração apresenta com quais agroindústrias se relacionam contratualmente.

Figura 2 - Quantitativo de entrevistas realizadas por município e por agroindústria.

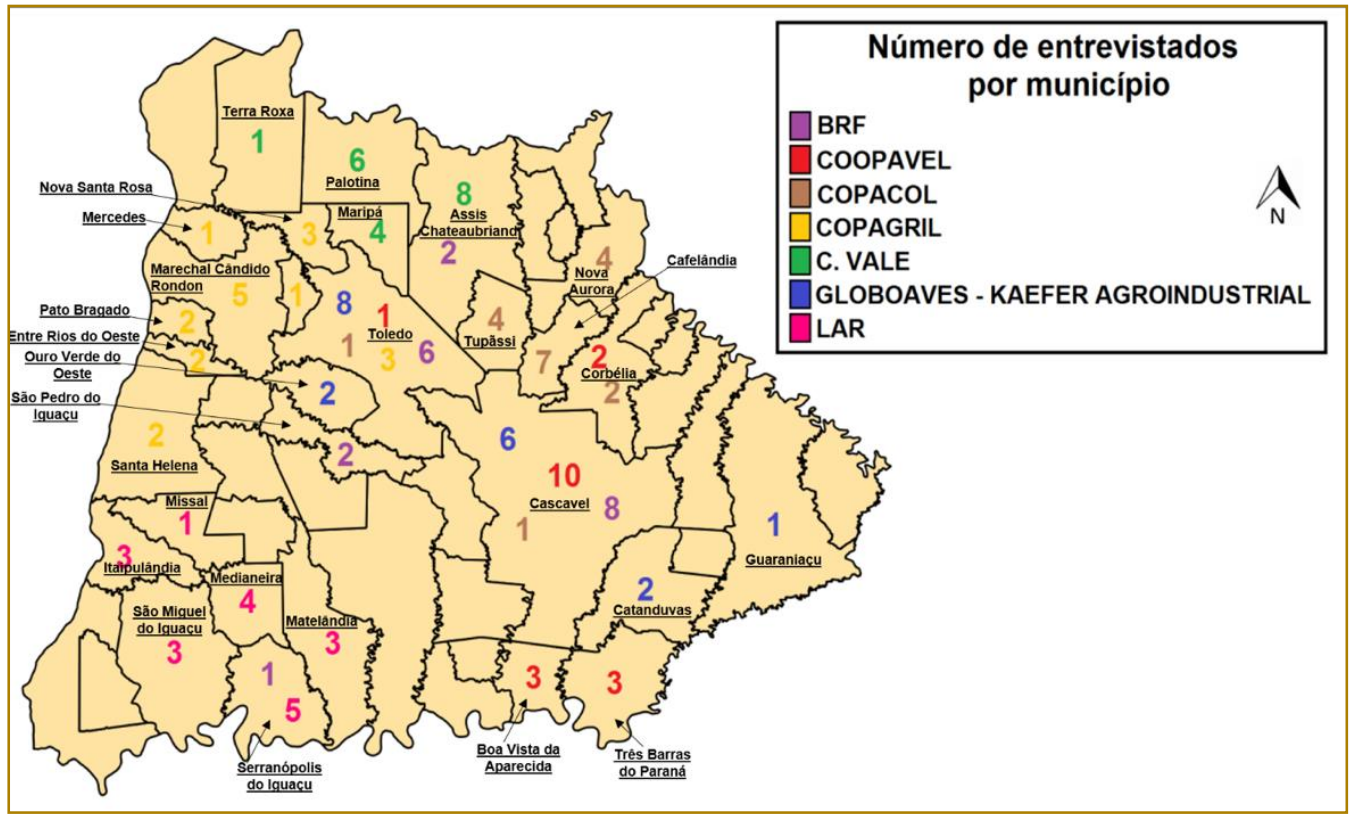

Fonte: dados da pesquisa. 
O Município de Cascavel detém o maior número de produtores entrevistados, justamente por contar com duas agroindústrias instaladas. Entretanto, constatou-se a presença de diversos produtores que residem nesse município, mas que produzem aves para empresas com sede em outros municípios, a exemplo da Copacol e da BRF. Esse fato denota a existência de flexibilidade das agroindústrias em relação à delimitação da fronteira territorial de atuação.

Muito embora, a redução da área de atuação é uma política, explicitada nos discursos dos gestores das agroindústrias, a atividade ainda é desenvolvida em um número significativo de municípios e, em muitos casos, distantes das agroindústrias. Essa distância geográfica gera custos em logística e dificuldades para a concentração da atividade. Por outro lado, um maior distanciamento entre as granjas possibilita maior controle em relação à biossegurança, reduzindo o risco de contaminação entre granjas e aumentando a qualidade sanitária dos plantéis. Ou seja, em uma eventual epidemia, este distanciamento pode gerar uma externalidade positiva.

Em relação ao perfil do produtor, o primeiro aspecto considerado está relacionado ao gênero dos avicultores. Contatou-se que a produção de aves é uma atividade mais frequentemente desenvolvida por homens, compreendendo $77,45 \%$ dos respondentes. Já a presença feminina, representa apenas $22,55 \%$.

Entretanto, cabe destacar que a participação das mulheres nessa etapa da produção tende a um crescimento significativo, impulsionado, por um lado, pelos avanços tecnológicos que facilitaram o trabalho nas granjas e, por outro, pela própria natureza da atividade. O cuidado com as aves em granjas automatizadas demanda mais de aspectos subjetivos, características físicas e comportamentais mais comuns e atinentes às mulheres, do que da força física.

A pesquisa revelou ainda que as mulheres estão mais satisfeitas com a atividade e conseguem obter melhores resultados nos lotes produzidos, comparativamente aos homens. Cientes dessa nova realidade positiva, as agroindústrias têm desenvolvido ações visando incentivar a participação feminina na atividade, não apenas como gestoras dos negócios, mas como mão de obra responsável pelo manejo das granjas.

Além das questões de gênero, a pesquisa investigou também a faixa etária dos produtores de frango da MROP. Dados detalhados da idade dos produtores podem ser visualizados no Gráfico 3.

Gráfico 3 - Faixa etária dos produtores de frango da MROP.

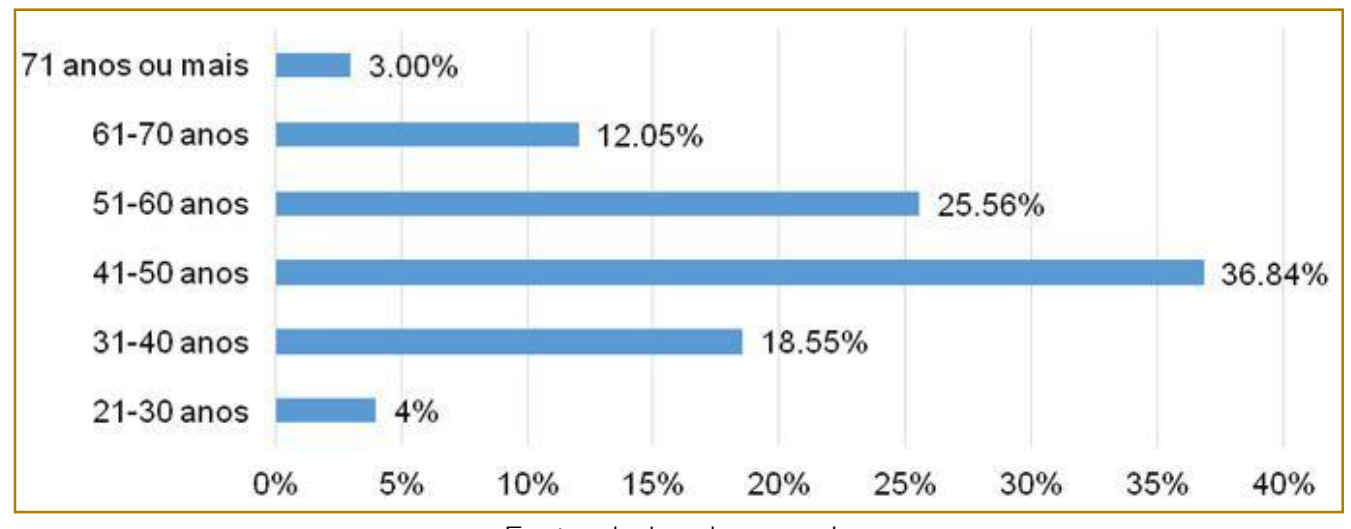

Fonte: dados da pesquisa.

A faixa etária predominante entre os produtores entrevistados situa-se entre os 41 a 50 anos e, portanto, formada por pessoas com capacidade produtiva para 0 desempenho da função. Chama a atenção, porém, o fato da pouca inserção de jovens na atividade. Apenas 4\% dos entrevistados têm menos que 30 anos. Em contrapartida, $15,05 \%$ possuem idade superior a 60 anos.

Esses dados comprovam a preocupação dos gestores das agroindústrias de que a avicultura tem pouca atratividade entre os mais jovens, uma vez que a sucessão geracional nesta atividade não tem 
acompanhado as exigências de aumento de produção de matéria-prima para as agroindústrias. Assim, o envelhecimento da população aliada à baixa inserção dos jovens na atividade avícola pode se constituir em um dos gargalos da avicultura moderna.

Por outro lado, os avanços tecnológicos no sistema de produção de aves e os novos paradigmas de gestão difundidos nas agroindústrias do setor têm promovido mudanças positivas no perfil do produtor de aves da MROP. Para além da imagem simples de homem do campo, o avicultor apresentase como um empresário rural, que investe constantemente em novas tecnologias e em desenvolvimento profissional. O perfil dos avicultores aponta para profissionais especializados, com visão empresarial e com níveis educacionais superiores à média nacional para populações urbanas. Isso pode ser visualizado no gráfico a seguir.

Gráfico 4 - Grau de instrução dos produtores avícolas comparativamente à população urbana e rural brasileira.

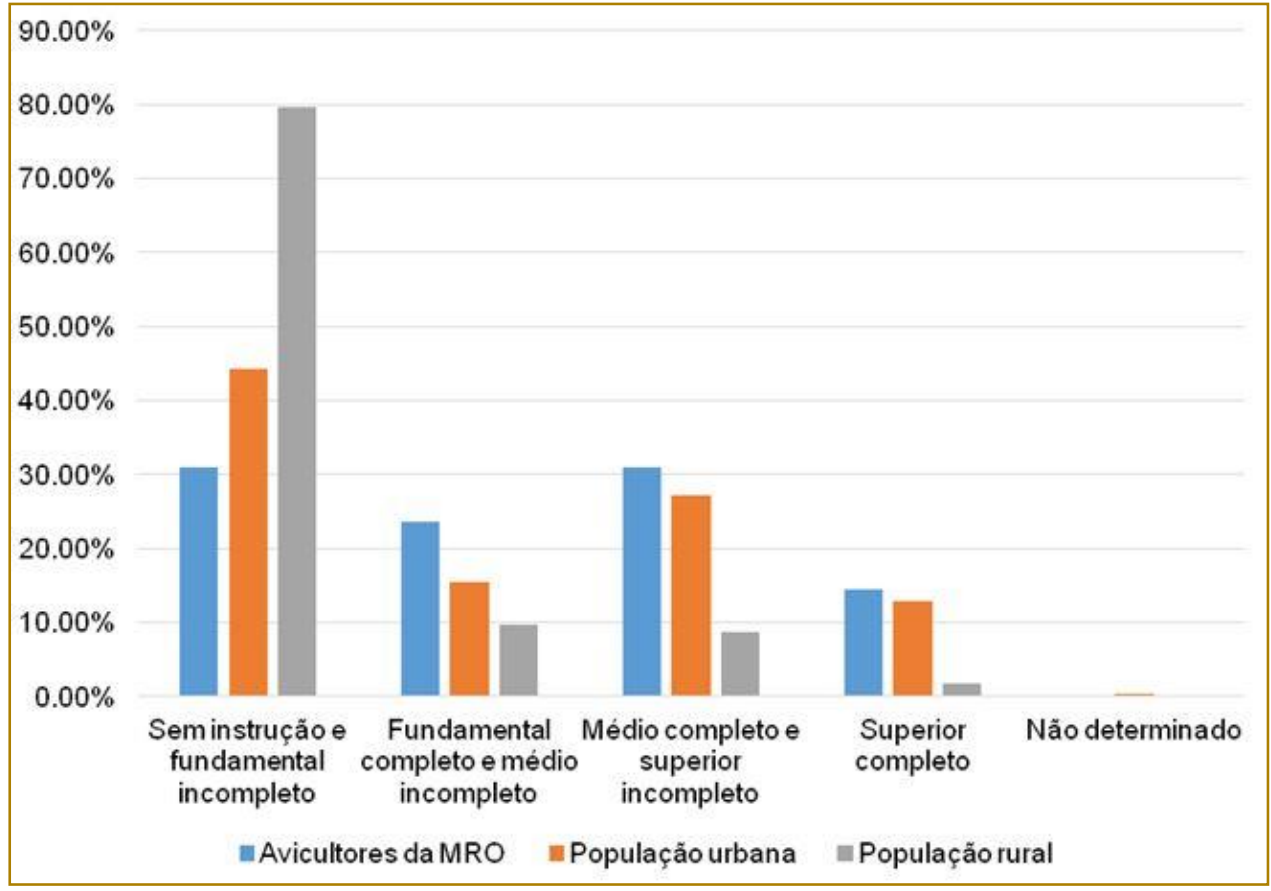

Fonte: IBGE (2010); Dados da pesquisa de campo.

Os produtores investigados possuem melhores níveis de escolaridade, tanto comparativamente à população urbana quanto rural do Brasil. Entretanto, se comparados a apenas dados da população rural, as diferenças ficam ainda mais evidentes. Observa-se, por exemplo, que $79,60 \%$ da população rural acima de 25 anos é composta por pessoas sem instrução e com ensino fundamental incompleto, enquanto que, para os avicultores da MRO esse índice é de apenas 30,93\%.

Há que se destacar também que o percentual de produtores com ensino superior completo é maior do que aquele apresentado pela população residente na área urbana (14,43\% e $12,90 \%$ respectivamente) e que $3,75 \%$ dos produtores possuem especialização lato sensu. Ou seja, o percentual de produtores com especialização na MROP é superior à média nacional da população rural que concluiu a graduação.

Esses índices de qualificação implicam em vantagens competitivas do SAG avícola da MROP frente a outras regiões do Estado e do Brasil. Pessoas com grau de instrução mais elevado possuem maior capacidade de absorver as informações, de acessar as novas tecnologias e, por consequência, obter maior produtividade em sua área de atuação.

Outra característica peculiar do sistema integração na MROP diz respeito ao tamanho das propriedades rurais em que a atividade avícola é desenvolvida. O Gráfico 5 classifica esses imóveis rurais de acordo com a sua dimensão em hectares. 
Gráfico 5 - Dimensão das propriedades rurais em hectares.

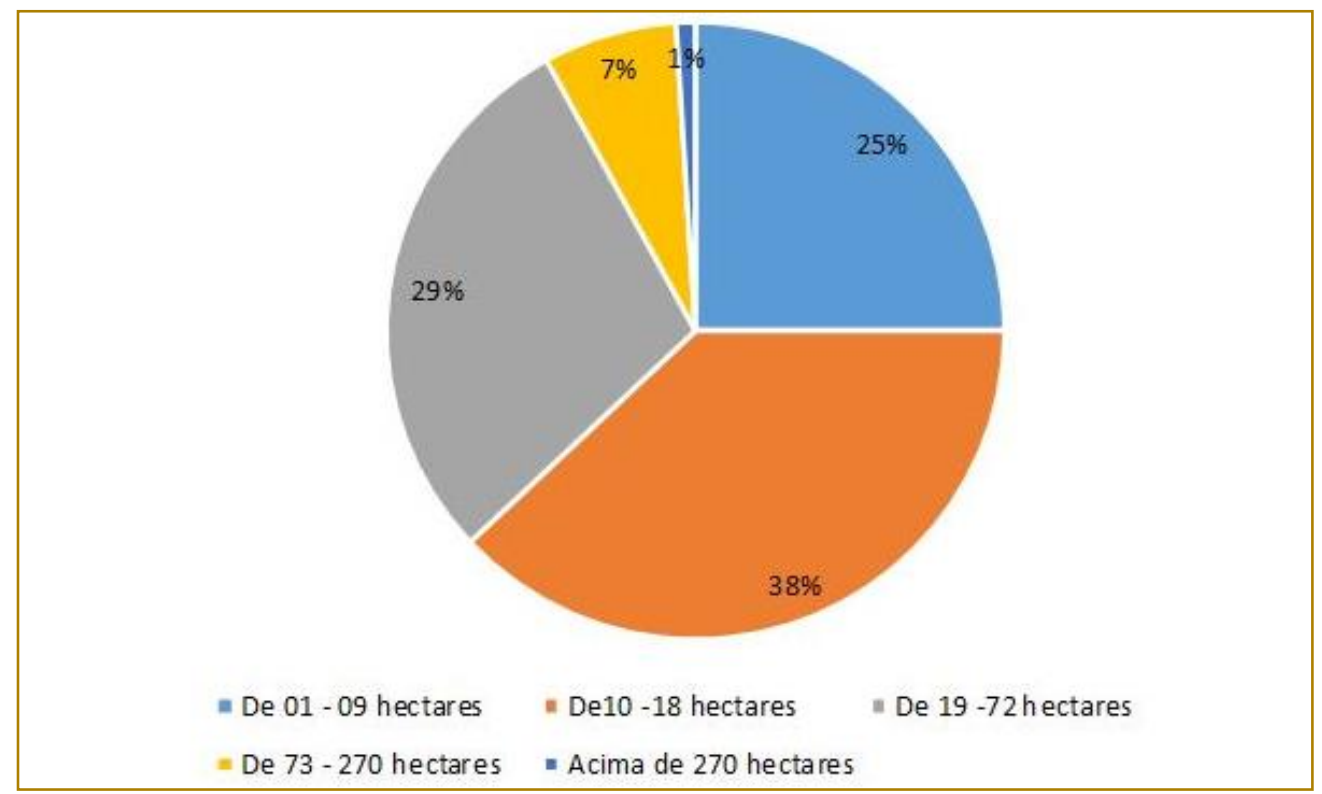

Fonte: dados da pesquisa.

De acordo com o que estabelece a Lei $n^{\circ}$ 8.629, de 25 de fevereiro de 1993, pequena propriedade é o imóvel rural cuja área compreendida tem de um a quatro módulos fiscais; média propriedade é imóvel rural cuja área é superior a quatro e até 15 módulos fiscais; e, por fim, a grande propriedade é aquela com mais de 15 módulos fiscais.

Ressalta-se que a dimensão dos módulos fiscais é variável, sendo fixada para cada município, levando em conta o tipo de exploração predominante na área, a renda obtida com tal exploração, bem como outras explorações existentes no município que, embora não predominantes, sejam significativas em função da renda ou da área utilizada. Para a maior parte, $(86 \%)$ dos municípios da Mesorregião Oeste, de acordo com o Sistema Nacional de Cadastro Rural INCRA (2014) um módulo fiscal compreende uma área de 18 hectares, já para os demais municípios (14\%) um modulo fiscal é composto por 20 hectares.

É perceptível, através do Gráfico 5, constatar que $92 \%$ das propriedades são classificadas como de pequeno porte. Deste total, 63\% são considerados minifúndio, ou seja, aquelas propriedades rurais com área de até um módulo fiscal e, do total, 25\% possuem área que varia de um a nove hectares ou seja até
$50 \%$ de um módulo fiscal. Sete por cento das propriedades investigadas são consideradas de médio porte a apenas um por cento das propriedades pode ser considerada de grande porte, ou seja, possui área superior a 15 módulos fiscais. Portanto, pode-se inferir que a produção de aves na região de abrangência da pesquisa caracteriza-se por ser uma atividade desenvolvida, em sua maioria, de pequenas propriedades rurais.

A pesquisa revela também que paralelamente às questões de dimensão das propriedades rurais, e até mesmo como consequência da pequena dimensão das propriedades, a atividade avícola é desenvolvida, prioritariamente, a partir do uso de mão de obra familiar, realidade presente em $71 \%$ das propriedades investigadas. Em 29\% das propriedades, o trabalho de cuidados das aves é desenvolvido utilizando-se de mão de obra contratada. No entanto, é relevante mencionar que, mesmo com a contratação de funcionário, em muitos casos, o trabalho é desenvolvido de forma conjunta, tanto com o uso de mão de obra familiar quanto com a contratação de funcionários.

Outro dado levantado pela pesquisa refere-se ao quantitativo de granjas por propriedades e a capacidade de alojamento dessas granjas. 
Gráfico 6 - Quantitativo de granjas por propriedade e capacidade de alojamento por granjas.

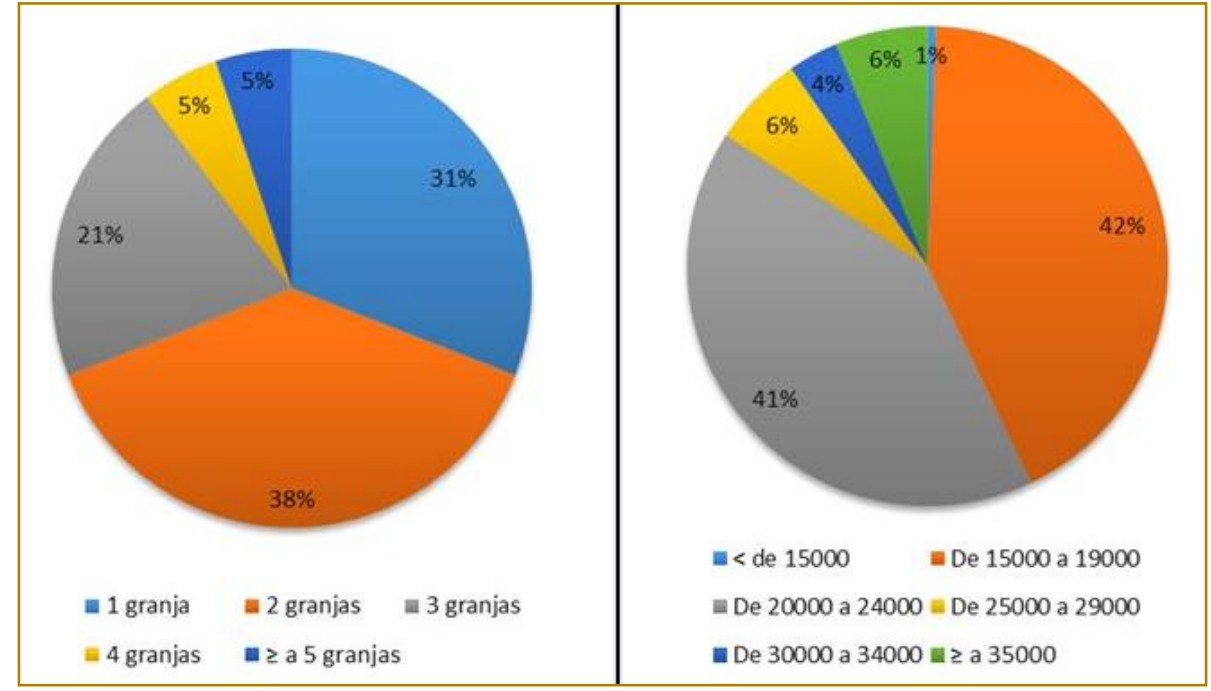

Fonte: dados da pesquisa.

Os dados apresentados no Gráfico 6 corroboram com as informações já mencionadas referente ao delineamento do perfil da atividade avícola, ou seja, uma atividade desenvolvida por pequenos produtores rurais. Isso porque $69 \%$ dos produtores possuem até duas granjas em suas propriedades; $21 \%$ possuem três granjas e, apenas $10 \%$ dos entrevistados possuem quatro granjas ou mais em suas propriedades. Paralelamente ao quantitativo de granjas, está sua capacidade produtiva. Os dados da pesquisa apontam também que $42 \%$ das granjas são de pequeno porte, com capacidade para alojar de 15.000 a 19.000 aves e que apenas 9\% das granjas têm capacidade de alojar um número igual ou superior a 30.000 aves.

Ponderando sobre o perfil delineado para o avicultor da MROP, é possível inferir que assumir a tendência de concentração de atividade em um número menor de propriedades, com granjas cada vez mais automatizadas e com maior capacidade de produção, coloca à margem do sistema a maior parcela dos atuais produtores. Assim sendo, os aspectos apresentados apontam que a avicultura é uma atividade predominantemente familiar e desenvolvida por pequenos produtores rurais, portanto com reduzida capacidade para investir em modernização das granjas, como requer o novo sistema desejado pelas agroindústrias.

\subsection{IMPORTÂNCIA SOCIOECONÔMICA DA AVICULTURA DE CORTE PARA OS PRODUTORES}

É relevante o fato apontado na literatura existente que a avicultura de corte se constitui numa importante atividade econômica para a MROP, tanto em relação ao volume de carne produzida quanto no número de empregos diretos e indiretos gerados ao longo de todo o SAG. Entretanto, para o produtor de aves, os ganhos vão além da geração de empregos ou mesmo do auto emprego e da permanência da família no campo. Representam, para $60 \%$ dos produtores entrevistados, a principal fonte de renda da propriedade rural. Para $40 \%$, a atividade apresenta-se como fonte de renda secundária na propriedade, sendo desenvolvida em consonância com a produção de grãos (principal fonte de renda para 79,85\% dessas propriedades), produção de leite, de suínos e peixes. Para os demais, $11,36 \%$ dessa parcela, a principal fonte de renda advém de atividades não agropecuárias.

Quanto aos motivos que impulsionaram os produtores agrícolas a investir na avicultura, a possibilidade de uma renda extra às atividades agropecuárias desenvolvidas, aparece como principal propulsor para $57,42 \%$ dos produtores. As principais motivações elencadas pelos produtores para a implantação dos aviários estão expostas no Quadro 2. 
Quadro 2 - Principais motivos para instalação das granjas de aves de corte.

\begin{tabular}{|l|c|c|}
\multicolumn{1}{|c|}{ Principais motivos para instalação das granjas } & \multicolumn{2}{c|}{ Ocorrência nas } \\
& \multicolumn{1}{c|}{ entrevistas realizadas } \\
\hline Renda extra & 76 & 57,42 \\
\hline Viabilizar a pequena propriedade & 18 & 13,53 \\
\hline Diversificação da propriedade & 17 & 12,78 \\
\hline Renda em menor tempo & 12 & 9,02 \\
\hline Renda mais estável & 12 & 9,02 \\
\hline Segurança maior de renda em relação à lavoura & 11 & 8,27 \\
\hline Utilizar a cama de aviário como adubo para a lavoura & 8 & 6,01 \\
\hline Gosto pela atividade & 7 & 5,26 \\
\hline Manter a família no campo & 6 & 4,51 \\
\hline Aposentadoria & 5 & 3,75 \\
\hline Compra da propriedade com a granja já instalada & 3 & 2,25 \\
\hline Herança & 2 & 1,03 \\
\hline
\end{tabular}

Fonte: dados da pesquisa.

Além da possibilidade de uma renda extra às atividades agropecuárias desempenhadas, a avicultura representa uma forma de viabilizar a pequena propriedade e diversificar a produção, permitindo ao produtor condições de obter renda em menor espaço de tempo, comparativamente às demais atividades agropecuárias. Com a avicultura, em média, o produtor tem entrada de recursos financeiros para gerir a propriedade a cada dois meses, tempo significativamente menor em relação à suinocultura (seis meses) e à produção de soja e milho, com safras anuais.

Ainda, é conveniente destacar que a opção do produtor pela avicultura pode representar uma possibilidade de renda mais estável e maior segurança em relação à produtividade, principalmente se comparada à produção de grãos. Na avicultura, os resultados estão diretamente relacionados às boas práticas de manejo e demais variáveis passíveis de controle, enquanto que na produção de grãos esses resultados sofrem interferência de aspectos que fogem do controle do produtor, a exemplo das intempéries climáticas. Entretanto, para uma parcela dos produtores entrevistados, a atividade não possibilita ganhos diretos. Para eles, a motivação para ingressar no setor deu-se em função da possibilidade de utilizar a cama dos aviários como adubo para o cultivo de diversas culturas, principalmente para a produção de grãos. Dentre esses produtores, estão aqueles com maiores áreas cultiváveis e que não têm na avicultura a principal fonte de renda da propriedade rural.

Independentemente dos objetivos para o ingresso na atividade avícola, a possibilidade de financiamentos para instalação dos galpões e do aparato tecnológico necessário ao funcionamento das granjas é um dos fatores que impacta positivamente na decisão de investir na avicultura. A pesquisa aponta que dos 133 produtores entrevistados, 88\% recorreram a financiamentos para a implantação das granjas. Portanto, apenas $12 \%$ implantaram suas granjas com recursos próprios.

Dado o perfil do produtor de aves, composto em sua maioria, (92\%), por pequenos produtores e o montante necessário para a construção das granjas, (valor médio de $\mathrm{R} \$$ $500.000,00$ ), o elevado índice de produtores que recorrem a financiamentos para o ingresso na atividade é plenamente justificável. Todavia, é interessante destacar que a obtenção de financiamentos a esses pequenos produtores realiza-se através de parcerias entre agentes financeiros, integradoras e produtores, que possibilitam a contratação de recursos com flexibilidade no pagamento e menor exigência de garantias por parte do produtor. 
O modelo de parceria para financiamento adotado no setor avícola, é diretamente intermediado pelas empresas integradoras, que se responsabilizam pela elaboração dos projetos de viabilidade, agilizam a parte documental para os produtores, além de auxiliá-los na escolha da linha de crédito mais viável, de acordo com sua capacidade de pagamento.

Para a construção das granjas, as linhas de crédito do Banco Nacional de Desenvolvimento Econômico e Social (BNDES) são as mais buscadas pelos produtores de frango. Além do BNDES, o Banco Regional de Desenvolvimento do Extremo Sul (BRDE) também possui linhas de crédito específicas para a expansão da atividade avícola. No entanto, o BNDES e o BRDE não financiam diretamente ao produtor e a liberação dos recursos é realizada por intermédio de um agente financeiro (banco ou cooperativa de crédito). Na MROP, o SICREDI é o agente financeiro que mais realiza essas operações (57\%), seguido pelo Banco do
Brasil, responsável por 20\% dos financiamentos.

Outras instituições financeiras também foram apontadas como agentes responsáveis pelos financiamentos, a exemplo do Banco Itaú, Unibanco e Real. Além dessas instituições financeiras, programas do governo estadual, a exemplo do "Panela Cheia", fomentaram a construção de aviários, principalmente na década de 1990. Esse programa foi responsável pelo financiamento das granjas de $8 \%$ dos entrevistados.

As facilidades de acesso ao crédito, as formas e prazos flexíveis de pagamento dos financiamentos não se restringem à construção de novas granjas, mas a reformas e atualização de padrão tecnológico. Essa possibilidade de obtenção de recursos para melhorias nas granjas impulsiona os produtores para investir e, por consequência, manter-se na atividade, mesmo em período de crises no setor e baixa lucratividade, o que pode ser visualizado através do Gráfico 7.

Gráfico 7 - Tempo de atuação dos produtores de frango da MROP.

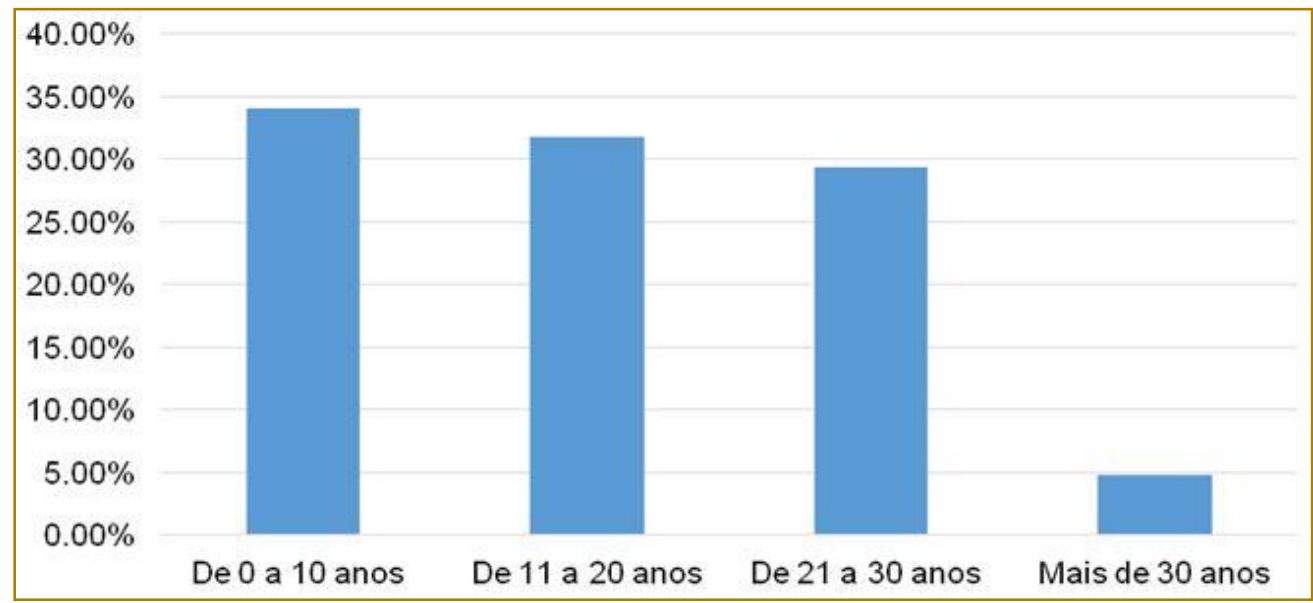

Fonte: dados da pesquisa.

Os dados referentes ao tempo de atuação dos produtores da MROP apontam, por um lado, para um cenário de crescimento do setor, despertando grande interesse entre os proprietários rurais da região de abrangência da pesquisa. Prova disso é que $34,11 \%$ do total dos entrevistados ingressaram na avicultura nos últimos 10 anos; destes, $18,82 \%$ atuam há menos de cinco anos. A pesquisa revela também baixo índice de desistência da atividade, evidenciado pelo significativo tempo de atuação dos produtores
(34,16\% atuam há mais de 20 anos na avicultura).

Confrontando os dados atinentes ao tempo de atuação dos produtores com a questão do financiamento da atividade, constatou-se que um número considerável de produtores ainda possui parcelas a serem pagas aos agentes financeiros referentes à construção das granjas.

Os resultados revelam que aproximadamente um terço dos aviários da MROP foi construído na última década e que o tempo médio de 
contratação dos financiamentos do setor é para um prazo de 10 anos. Esse cenário aponta para a necessidade de cautela em todos os elos do SAG avícola, a fim de evitar eventuais crises do setor que podem comprometer a competitividade do SAG.

\section{CONSIDERAÇÕES FINAIS}

A relação de trabalho conferida pelo sistema em estudo, propicia, sobretudo, aos pequenos produtores a possibilidade de obtenção de renda em um menor período de tempo, comparativamente à produção de grãos, e do aproveitamento da mão de obra familiar, principalmente do trabalho feminino. Entretanto, o trabalho nas granjas submete os avicultores a extenuantes jornadas de trabalho, não obtendo, praticamente, tempo para as suas relações familiares e convívio social. Além disso, a execução dessas atividades favorece o desenvolvimento de problemas de saúde para o produtor, em função dos fatores de risco aos quais estão expostos.

Faz-se mister afirmar que, mesmo apresentando percalços, sobretudo em função de que os pressupostos comportamentais e as dimensões das transações afetam de maneira distinta os agentes da relação, o sistema de produção é avaliado de forma positiva pelos agentes envolvidos. A pesquisa aponta ainda para a existência de parcela expressiva de produtores satisfeitos, tanto em relação à lucratividade quanto à garantia do retorno sobre o investimento.

\section{REFERÊNCIAS}

[1]. AGROEMDIA. Cooperativa paranaense tem recorde de produtividade integrada de aves. Disponível em: <https://agroemdia.com.br/2018/03/25/cooperativaparanaense-tem-recorde-de-produtividadeintegrada-de-aves/>. Acesso em: 30 mar. 2018.

[2]. Associação Brasileira de Proteína Animal ABPA- Relatório Anual, 2017. Disponível em: <http://www. http://abpabr.com.br/setores/avicultura/publicacoes/relatoriosanuais $>$. Acesso em: $03 \mathrm{fev}$.

[3]. BARCZSZ, S. S.; LIMA FILHO, D. O. Agroindústria exportadora de frango de corte sulmato-grossense $e$ os aspectos de internacionalização. Revista em Agronegócios e Meio Ambiente, v.2, n.2, p. 9-33, mai./ago. 2009.
Esse cenário de contentamento das partes aponta para a permanência do modelo de produção vigente e manutenção das atuais regras estabelecidas contratualmente. O que pode sofrer alteração é apenas o modus operandi, e transformar a configuração de atividade desenvolvida por pequenos avicultores com o uso de mão obra familiar para médias e grandes propriedades rurais, com capacidade para concentrar e aumentar a escala de produção. Mudanças dessa natureza possibilitariam ganhos às agroindústrias e competitividade ao SAG.

Ao mesmo tempo, podem gerar problemas socioeconômicos para uma parcela de produtores que, em detrimento à baixa capacidade de investimentos, ficariam à margem do novo sistema, e com ativos específicos inutilizados em suas propriedades. Entretanto, visto sob outra ótica, a mudança no perfil do produtor poderá impor às agroindústrias novas formas de atuação e coordenação do sistema. $\mathrm{Na}$ medida em que se reduz a quantidade de avicultores, estes passam a atuar com uma maior escala de produção; consequentemente, o poder de barganha dos produtores se potencializa, aumentando os conflitos de interesses entre os agentes.

Por fim, sugere-se como discussões para novas pesquisas, estudos mais aprofundados dos possíveis impactos regionais da concentração da atividade e exclusão dos pequenos produtores de frango da região.

[4]. BARDIN, L. Análise de conteúdo. Lisboa: Edições, 2004.

[5]. CANAVER, M. D.; TALAMINI, D. J. D.; CAMPOS, A. C.; SANTOS FILHO, J. I. A Cadeia Produtiva do Frango de Corte no Brasil e na Argentina. Concórdia: EMBRAPA - CNPSA, 1997.

[6]. EMBRAPA - Empresa Brasileira de Pesquisa Agropecuária (2003). Produção de Frango de Corte. Disponível em: <http://www.cnpsa.embrapa.br/aves/>. Acesso em: 30 mar. 2018.

[7]. FONTANELLA, B. J. B.; RICAS, J.; TURATO, E. R Amostragem por saturação em pesquisas qualitativas: contribuições teóricas. Cadernos de Saúde Pública. 24(1), 17-27., 2008. 
[8]. GIL, A. C. Como elaborar projetos de pesquisa. $4^{\underline{a}}$ ed. São Paulo: Atlas, 2009.

[9]. INCRA - INSTITUTO NACIONAL DE COLONIZAÇÃO E REFORMA AGRÁRIA. Sistema Nacional de cadastro rural. Disponível em: $<$ http://www.incra.gov.br/>. Acesso em: 30 mar. 2018.

[10]. IPARDES - INSTITUTO PARANAENSE DE DESENVOLVIMENTO ECONÔMICO E SOCIAL. Análise da competitividade da cadeia agroindustrial de carne de frango no Estado do Paraná: sumário executivo. Curitiba: UFSCAR, $2002 . \quad$ Disponível em: <http://www.ipardes.gov.br/webisis.docs/cadeia_a groindustrial_aves_sumario_executivo.pdf > . Acesso em: 20 fev. 2018.

[11]. IPARDES - INSTITUTO PARANAENSE DE DESENVOLVIMENTO ECONÔMICO E SOCIAL. Oeste Paranaense: O terceiro espaço relevante especificidades e diversidades. Disponível em: $<$ http://www.ipardes.gov.br/index.php?pg_conteud o=1\&cod_noticia=870 > . Acesso em: 30 mar. 2018.

[12]. JESUS JUNIOR, C. de; et al,. A cadeia da carne de frango: tensões, desafios e oportunidades. Agroindústria: BNDES Setorial, $2007 . \quad$ Disponível em: <http://www.bndes.gov.br/conhecimento/bnset/set 2607.pdf>. Acesso em: 10 mar. 2018.

[13]. LIMA FILHO, D. O. SPROESSER, R. L. TRENDEZINI, C. A. O. MORETI, L. Determinantes da compre de frango: saúde ou preço? Informações econômicas, São Paulo, v. 35, n.12, dez., 2005.

[14]. LIMA, M. A. A. Mudança Tecnológica, Organização Industrial e Expansão da Produção de Frango de Corte no Brasil. Dissertação (Mestrado) - Departamento de Economia. São Paulo: USP, 1984.

[15]. MACDONALD, J. M; KORB, P. Agricultural contracting update: contracts in 2003. Electronic report from Economic Research Service (USDA). Economic Information Bulletin. n. 9, jan., 2006. Disponível em: <http://www.ers.usda.gov>. Acesso em: 15 fev. 2018

[16]. MAPA - Ministério da Agricultura, Pecuária e Abastecimento. Aves. Disponível em: $<$ http://www.agricultura.gov.br/animal/especies/ave s/notícias>. Acesso em: 12 mar. 2018.

[17]. PEREIRA, C. M. M. A.; MELO, M. R.; SANTOS, M. H. O Agronegócio do frango de corte: um estudo de caso sob a ótica da economia dos custos de transação. Informações Econômicas, São Paulo, v. 37, n. 1, jan., 2007.
[18]. RICHARDSON, Roberto Jarry. Pesquisa social: métodos e técnicas. São Paulo: Atlas, 1999.

[19]. RIZZI, A. T. A indústria de frangos no Brasil: constituição e transformações. In: Congresso Brasileiro de História Econômica, Conferência Internacional de História de Empresas, 2004, Belo Horizonte (MG). Anais. Belo Horizonte: $2004 . \quad$ Disponível em: <http://www.abphe.org...99/Textos/ADAIR.pdf> Acesso em: 23 mar. 2018

[20]. RIZZI, A. T. Mudanças Tecnológicas e Reestruturação da Indústria Agroalimentar: o caso da indústria de frangos no Brasil. Tese (Doutorado) - Campinas: Unicamp, 1993

[21]. SALVIANO , P. A. P. Análise das relações contratuais no sistema de integração vertical de produção de aves de corte no município de Rio Verde - Goiás, sob a ótica da nova economia institucional. 92 f. Dissertação (Mestrado em Desenvolvimento Regional) - Faculdades Alves Faria, Goiânia, 2011.

[22]. SEAB - Secretaria da Agricultura e do Abastecimento do Paraná. Conjuntura Agropecuária. Disponível em: <http://www.agricultura.pr.gov.br/>. Acesso em: 05 mar. 2018

[23]. União Brasileira de Avicultura - UBABEF. Relatório Anual, 2011. Disponível em: $<$ http://www.ubabef.com.br/publicacoes>. Acesso em: 03 fev. 2018.

[24]. União Brasileira de Avicultura - UBABEF. Relatório Anual, 2013. Disponível em: $<$ http://www.ubabef.com.br/publicacoes>. Acesso em: 03 fev. 2018

[25]. União Brasileira de Avicultura - UBABEF. Relatório Anual, 2014. Disponível em: <http://www.ubabef.com.br/publicacoes>. Acesso em: 03 fev. 2018

[26]. WILKINSON, J. Estudo da competitividade da indústria brasileira: competitividade na indústria de abate e preparação de carnes. Campinas: IE/UNICAMP - IEI/UFRJ- FDC - FUNCEX, 1993. Disponível em: <http://www.dominiopublico.gov.br/download/texto/ ci000044.pdf>. Acesso em: 18 jan. 2018.

[27]. ZILLI, J. B. Os fatores determinantes para a eficiência econômica dos produtores de frango de corte: uma análise estocácia. 2003. 130f. Dissertação (Mestrado em Economia Aplicada) Escola Superior de Agricultura Luiz de Queiroz. Universidade de São Paulo, Piracicaba, 2003. 


\section{Capítulo 2}

\section{OS MERCADOS INSTITUCIONAIS NA AGRICULTURA FAMILIAR: DESEMPENHO DO PROGRAMA NACIONAL DE ALIMENTAÇÃO ESCOLAR ENTRE 2009 A 2014}

\section{Josiane Castro Pereira}

\section{Alessandra Troian}

\section{Edenilson T. Lencina Machado}

Resumo: No Brasil, somente nas últimas décadas é que os olhares se voltam para os agricultores familiares, no entanto, mesmo dentro de um cenário que guia ao desenvolvimento, a agricultura familiar enfrenta vários entraves e desafios no acesso aos mercados. Reconhecendo as dificuldades de escoar a produção, o governo brasileiro, a partir de 2003 passou a criar medidas que fomentam a aquisição e a comercialização de produtos alimentícios diretamente da agricultura familiar, como os mercados institucionais. Neste sentido, o presente estudo objetiva analisar a dinâmica do Programa Nacional de Alimentação Escolar. Como objetivos secundários tem-se: a) descrever o PNAE desde sua criação até as modificações recentes; b) verificar a evolução na disponibilidade de crédito e o número de acesso no período de 2009 a 2014 e; c) identificar os entraves e desafios no acesso ao programa. Para tanto, metodologicamente a pesquisa caracteriza-se como qualitativa e exploratória, a partir da técnica da revisão bibliográfica a da análise de dados secundários obtidos no site do Fundo Nacional de Desenvolvimento da Educação. Como principais resultados que há evolução crescente nos valores repassados pelo programa, mesmo que o número de alunos tenha se estagnado durante o período. Em relação aos entraves e desafios sofridos pela agricultura familiar no acesso ao PNAE destaca-se a falta de planejamento e a logística.

Palavras chave: Agricultura Familiar. Mercado Institucional. Alimentação Escolar. Desenvolvimento. 


\section{INTRODUÇÃO}

A década de 1990 marca o reconhecimento do Estado brasileiro à agricultura familiar com a criação do Programa Nacional de Fortalecimento da Agricultura Familiar (PRONAF). A formulação da política obedeceu às reivindicações dos movimentos sociais rurais, apoiada também em definições conceituais da comunidade acadêmica nacional. Desde então, o debate sobre a atuação e a importância da agricultura familiar no desenvolvimento brasileiro vem recebendo força, estimulado, sobretudo, pelas noções de desenvolvimento sustentável, segurança alimentar e geração de emprego e renda (SCHNEIDER, 2006).

A agricultura familiar brasileira é diversa em relação à situação dos produtores, aos modos de vida, ao meio ambiente e à aptidão das terras, não apenas entre as regiões, mas também dentro de cada região. Ela também está relacionada diretamente às questões culturais, à segurança alimentar, à diversidade na produção, à valorização do ambiente em que está inserida e, consequentemente, ao desenvolvimento local. Mesmo dentro de um cenário que guia ao desenvolvimento, a agricultura familiar enfrenta vários entraves e desafios no acesso aos mercados.

O desafio fundamental para a pequena propriedade, conforme Wilkinson (1999), é a agroindustrialização autônoma, à agregação de valor e à inserção dinâmica nos mercados. Neste sentido, o mercado pode ser definido como um conjunto de instituições sociais em que se verifica normalmente um grande número de trocas de mercadorias de um tipo específico, sendo essas trocas facilitadas e estruturadas por essas instituições (HODGSON, 1994). Já os mercados institucionais, onde as esferas de governo utilizam o poder de compra do estado para apoiar a agricultura familiar, são uma ferramenta importante de valorização da produção da agricultura familiar.

Os mercados institucionais podem ser definidos como uma configuração específica de mercado em que as redes de troca assumem estrutura particular, previamente determinada por normas e convenções negociadas por um conjunto de atores e organizações, em que o Estado geralmente assume papel central, notadamente através de compras públicas (GRISA, 2009). Ainda conforme Grisa (2009), a política pública ao eleger a agricultura familiar como protagonista central do abastecimento dos mercados institucionais apresenta-se como opção estratégica na indução de nova dinâmica de desenvolvimento.

O marco do mercado institucional no Brasil é 2003, quando surgem programas de governo, como o Programa de Aquisição de Alimentos (PAA) criado através da Lei Federal ํㅡ 10.696 e o Programa Nacional de Alimentação Escolar (PNAE) criado a partir da Lei Federal no 11.947, em 2009. Os programas se tornaram um meio de aproximar produtor e consumidor, ampliando a participação dos agricultores familiares. Tais programas buscam a redução da fome, estimulando hábitos saudáveis, fortalecendo a agricultura familiar no âmbito de economias regionais (GRISA, 2012).

O Programa de Aquisição de Alimentos (PAA) surgiu em 2003, como proposta integrante do programa Fome Zero, carro-chefe das ações do governo Luís Inácio Lula da Silva para o combate à fome e à miséria. Já o Programa Nacional de Alimentação Escolar caracterizase como uma ferramenta essencial no desenvolvimento de agricultores familiares, pois possibilita o acesso a mercados locais. A política da merenda escolar foi implementado no Brasil no ano de 1955 passando por diversas reestruturações, de uma política de suplementação alimentar transformou-se em uma importante política pública de desenvolvimento.

O PNAE passou por reformulações importantes no ano de 2009, além de atuar pela segurança alimentar e nutricional dos estudantes, visa fomentar os preceitos do desenvolvimento sustentável, valorização da cultura alimentar, alimentação saudável e alocação dos sistemas agroalimentares. O programa promove o desenvolvimento local e cria estratégias para a comercialização de produtos não visados pelo mercado convencional, criando possibilidades para desenvolver sistemas agroalimentares alternativos para a agricultura familiar (FNDE, 2017; GRISA, 2014; MALINA, 2012).

Os agricultores familiares têm no PNAE uma ferramenta de incentivo para a produção alimentícia. A oferta de alimentos com qualidade e a valorização da produção familiar potencializa a afirmação de identidade desses agricultores, fortalecendo o tecido social e a dinamização das economias locais. Neste sentido, presente estudo 
objetiva analisar a dinâmica do Programa Nacional de Alimentação Escolar. Os objetivos específicos são: a) descrever o Programa Nacional de Alimentação Escolar desde sua criação até as modificações recentes; b) verificar a evolução na disponibilidade de crédito e o número de acesso no período de 2009 a 2014 e; c) identificar os entraves e desafios no acesso do Programa Nacional de Alimentação Escolar. Metodologicamente a pesquisa caracteriza-se como qualitativa e exploratória, a partir da técnica da revisão bibliográfica a da análise de dados secundários obtidos no site do Fundo Nacional de Desenvolvimento da Educação (FNDE).

\section{AGRICULTURA FAMILIAR E OS MERCADOS: A IMPORTÂNCIA DE UMA POLÍTICA ALIMENTAR NA COMERCIALIZAÇÃO}

A seguir será apresentado um panorama geral da agricultura familiar no Brasil, sua definição e especificidades. Também será discutido o conceito de mercado, voltando-se para a inserção do agricultor familiar no mercado institucional. Em seguida é apresentado o Programa Nacional de Alimentação Escolar como uma política de comercialização para a agricultura familiar.

\subsection{AGRICULTURA FAMILIAR E MERCADOS}

A agricultura familiar ao adquirir seu espaço e valorização nas últimas duas décadas, passou a fazer parte da agenda política do Brasil como estratégia de desenvolvimento rural. Conforme a FAO:

A agricultura familiar inclui todas as atividades agrícolas de base familiar e está ligada a diversas áreas do desenvolvimento rural [...]. Tanto em países desenvolvidos quanto em países em desenvolvimento, a agricultura familiar é a forma predominante de agricultura no setor de produção de alimentos. (FAO, 2014, p. 2).

Assumindo uma identidade diferente do capitalismo, que se caracteriza pela exploração da mais valia através do trabalho assalariado e pela busca da maximização do lucro, a produção dos agricultores familiares vai ao encontro da satisfação das suas necessidades e da reprodução social da família. Nesse sentido, os agricultores familiares são os protagonistas do processo onde a dinâmica social ocorre (SANTOS, 2008).

A partir deste cenário, insere-se o papel dos mercados nas estratégias da agricultura familiar de desenvolvimento rural. As transformações que afetam a vida e as atividades econômicas dos agricultores, assim como de outros atores do espaço rural, estão permeadas por formas de interação, trocas e construção de circuitos de comércio (CONTERATO et al., 2013).

A inserção em cadeias curtas de comercialização, em mercados de proximidade entre agricultores e consumidores, com a diversidade de valores e saberes trocados social, cultural e economicamente, traz uma nova perspectiva para agricultores familiares. Conforme Ploeg (2008), os circuitos curtos entre produção e consumo têm importância no fomento e construção social de economias locais e podem contribuir para os segmentos sociais que historicamente foram marginalizados e excluídos pela lógica da modernização.

Neste contexto, uma mudança nas últimas décadas no acesso aos mercados foi à criação dos mercados institucionais. Através de políticas públicas do governo federal, foram criadas oportunidades para a comercialização da produção de alimentos oriundos da agricultura familiar através do Programa de Aquisição de Alimentos (PAA) e do Programa Nacional de Alimentação Escolar (PNAE). Segundo Silva et al., (2014), os mercados institucionais surgem como uma forma do Estado proteger, de alguma forma, as populações excluídas, nessa perspectiva, os mercados institucionais passam a ter um duplo propósito, por um lado, suprir com alimentos populações vulneráveis e, por outro, auxiliar no escoamento de determinados produtos agrícolas.

O acesso aos mercados institucionais pela agricultura familiar representa benefícios tanto para os agricultores, que se beneficiam com o escoamento de sua produção, mas também possibilita aos indivíduos uma maior diversidade e oferta de alimentos de qualidade. Ao ingressar no mercado, a agricultura familiar fortalece o tecido social e produtivo do desenvolvimento local, mesmo enfrentando entraves e desafios para escoar a sua produção, os agricultores familiares encontram no acesso aos mercados a estratégia fundamental de comercializar seus produtos (SCHNEIDER; ESCHER, 2011). 


\subsection{A ALIMENTAÇÃO ESCOLAR: DE UMA POLÍTICA EDUCACIONAL PARA UM MERCADO GOVERNAMENTAL}

A educação alimentar nas escolas brasileiras surge entre os anos de 1930 e 1940, através das reinvindicações dos movimentos sociais. Reconhecia-se por parte do Governo Federal a importância da alimentação nas escolas como maneira de promover a permanência dos alunos e também a diminuição da desnutrição infantil no país, contudo o governo não possuía recursos financeiros para esta iniciativa, esses desafios mantêmse até o ano de 1979 (MEC, 2006).

$\mathrm{Na}$ década de 1950 a alimentação escolar começa a ser pensada como um programa público, um dos marcos dessa mudança foi o surgimento do Plano Nacional de Alimentação e Nutrição, denominado Conjuntura Alimentar e o Problema da Nutrição no Brasil, o qual representava o primeiro programa de merenda escolar sob responsabilidade pública (FNDE, 2017).

Em 31 de março de 1955, Juscelino Kubitscheck de Oliveira assinou o Decreto $\mathrm{n}$. 37.106, criando a Campanha da Merenda Escolar (CME). O nome dessa campanha foi se modificando até, em 1979, foi denominado Programa Nacional de Alimentação Escolar (PNAE), conhecido popularmente por "merenda escolar" (MEC, 2006, p.16).

Desde a criação, o PNAE passou por diversas reestruturações, de uma política de suplementação alimentar transformou-se em uma importante política pública de desenvolvimento. Dentro deste contexto, destaca-se a influência do Programa de Aquisição de Alimentos (PAA), criado em 2003 e que veio fomentar a revisão dos Programas Alimentares, especialmente o da Alimentação Escolar. A partir do sucesso do PAA o PNAE, existente desde a década de 1940, ganha nova forma e passa a ser discutido como instrumento de segurança alimentar e desenvolvimento sustentável por meio das compras públicas de pequenos agricultores locais (BRASIL, 2009).

A renovação do Programa Nacional de Alimentação Escolar, a partir da Lei n. 11.947 de 16 de junho de 2009, além dos benefícios para os estudantes, constitui-se como um passo significativo em prol da agricultura familiar. A Lei determinou que pelo menos $30 \%$ do valor destinado à alimentação escolar brasileira deve ser investido na compra direta de produtos oriundos da agricultura familiar.
Art. 14. Do total dos recursos financeiros repassados pelo FNDE, no âmbito do PNAE, no mínimo 30\% (trinta por cento) deverão ser utilizados na aquisição de gêneros alimentícios diretamente da agricultura familiar e do empreendedor familiar rural ou de suas organizações, priorizando-se os assentamentos da reforma agrária, as comunidades tradicionais indígenas e comunidades quilombolas (BRASIL/FNDE, 2009, p.02).

As modificações nas regulamentações do PNAE confirmam importantes alterações na forma de desenvolvimento do país. De acordo com Triches e Schneider (2010, p.933-945) a atual configuração do PNAE caracteriza-se como decorrente de "[...] um modelo de desenvolvimento que promove não só crescimento econômico como também justiça social, conservação ambiental e saúde pública. "

A comercialização dos produtos da agricultura familiar via PNAE, permite aos agricultores o aumento da biodiversidade nas propriedades familiares; estimulando circuitos curtos de comercialização, proporcionando renda as famílias e o desenvolvimento da economia local. As compras institucionais garantem que a identidade regional da agricultura familiar prevaleça, contribuindo para maior integração entre o mercado e os agricultores (SABOURIN; XAVIER; TRIOMPHE, 2009).

Assim, as compras institucionais assumem uma das mais importantes políticas públicas para a agricultura familiar, se tornando um instrumento de fortalecimento da categoria, promovendo, consequentemente, o desenvolvimento da economia local com o escoamento de sua produção, bem como proporcionando uma alimentação segura e saudável para os estudantes. No entanto, ainda se depara com alguns entraves, tanto no acesso, por parte dos agricultores familiares, quanto no número de alunos atendidos. Temas que serão discutidos na discussão dos resultados.

\section{METODOLOGIA}

O estudo caracteriza-se como qualitativo, a partir do método dedutivo. Segundo Denzin e Lincoln (2006, p. 88) a pesquisa qualitativa "[...] envolve uma abordagem interpretativa do mundo, o que significa que seus pesquisadores estudam as coisas em seus 
cenários naturais, tentando entender os fenômenos em termos dos significados que as pessoas a eles conferem". Já o método dedutivo, de acordo com Munhoz (1982), consiste no caminho de investigação que tacitamente admite para casos particulares a validade de conclusões geradas a partir de regras de comportamentos gerais, naturalmente válidas numa avaliação global.

Como técnicas de pesquisa foram usadas a revisão bibliográfica e a coleta e análise de dados secundários. De acordo com Gil (2008), a revisão de literatura caracteriza-se como um estudo exploratório, por meio de uma pesquisa bibliográfica, estabelecida com base em materiais já elaborados, livros e artigos científicos.

Os dados secundários utilizados no presente estudo foram obtidos nos sítios oficiais a saber: Fundo Nacional de Desenvolvimento da Educação (FNDE); Instituto de Pesquisa Econômica Aplicada (IPEA); Instituto Brasileiro de Geografia e Estatística (IBGE). Também foram utilizados dados de relatórios da Secretária da Agricultura Familiar e do Ministério do Desenvolvimento Agrário (MDABRASIL). Ressaltasse que foi realizada a correção monetária dos valores através do corretor de valores do Banco Central do Brasil com a utilização do Índice Geral de PreçosDisponibilidade Interna (IGP-DI) - base novembro de 2017.

Salienta-se que o período de análise é de 2009 a 2014 em função da disponibilidade de dados no site do Fundo Nacional de Desenvolvimento da Educação no momento da realização da pesquisa. A análise dos dados se deu por meio do método analítico.
Segundo Gerhardt e Silveira (2009), a análise tem como objetivo organizar os dados de forma que fique possível o fornecimento de respostas para o problema proposto. Assim, os principais resultados serão apresentados no item a seguir.

\section{PNAE: ANÁLISE DA EVOLUÇÃO NA DISPONIBILIDADE DE CRÉDITO E O NúMERO DE ACESSOS DE 2009 A 2014.}

A seção visa verificar a evolução na disponibilidade de crédito e o número de alunos atendidos pelo PNAE. Neste sentido, quanto ao valor repassado pelo FNDE ao PNAE e o número de alunos atendidos pelo programa durante o período de 2009 a 2014, é possível visualizar que houve aumentos consideráveis ano a ano nos recursos repassados. A quantidade de alunos beneficiados teve sua maior participação no ano de 2009, quando atinge 47 milhões de alunos atendidos pelo programa.

A partir da análise dos dados é possível perceber a trajetória do programa em relação ao seu desenvolvimento em termos de recursos investidos e alunos atendidos. Essa evolução de recursos destinadas ao PNAE, revelam a importância do programa para o cenário nacional, tanto na relação de segurança alimentar oferecidas aos alunos como também ao desenvolvimento da agricultura familiar, que passa a se beneficiar desse mercado. Neste sentido, o gráfico 01 , abaixo, é uma representação dos valores repassados pelo FNDE ao Programa Nacional de Alimentação Escolar e aos alunos atendidos no período de 2009 a 2014.

Gráfico 1 - Recursos repassados (em bilhões de R\$) e alunos atendidos pelo PNAE no período de 2009 a 2014

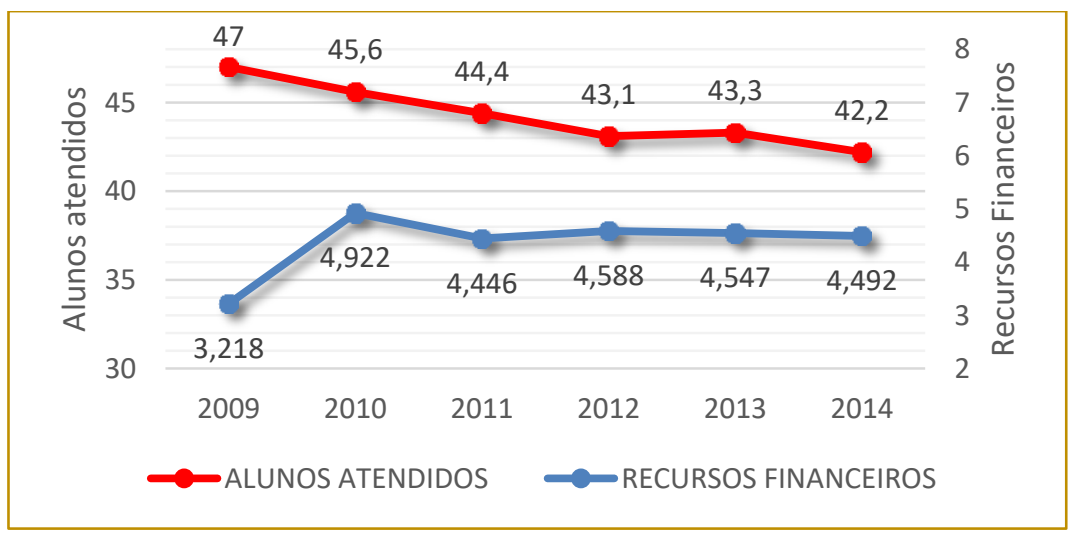

Fonte: Elaboração própria com base nos dados do FNDE (2015). 
Através do gráfico 01 é possível observar a evolução crescente dos recursos financeiros a partir da implementação da Lei $n^{\circ}$ 11.947/2009. Os recursos tiveram aumentos consideráveis ao longo dos anos, porém o mais significativo acontece entre 2009 e 2010, em 2009 o valor repassado passa de $R \$ 3,218$ bilhões para $R \$ 4,922$ bilhões em 2010. Ou seja, há um aumento de 52,95\% no valor repassado neste período. Os anos posteriores seguem apresentando elevação, porém constantes, oscilando de 4,446 (2011) a 4,492 bilhões (2014) de reais.

Uma das explicações para o aumento no repasse dos recursos nos anos de 2009 a 2010, é o reajuste dos valores repassados pela União aos estados e municípios, além de inclusão de novas categorias nos anos seguintes. Em 2009 a União repassava $\mathrm{R} \$ 0,22$ por aluno, por dia letivo, com exceção dos estudantes das escolas indígenas, para os quais o valor per capita era de $R \$ 0,44$ (FNDE, 2009). Em 2010, esses valores passam para $R \$ 0,30$ por dia para cada aluno matriculado em turmas de préescola, ensino fundamental, ensino médio e Educação de Jovens e Adultos (EJA). As creches e as escolas indígenas e quilombolas passaram a receber $R \$ 0,60$, e as escolas que oferecem ensino integral por meio do Programa Mais Educação, $\mathrm{R} \$ 0,90$ por dia (FNDE, 2014).

Outro destaque para o período é que o ano de 2010 foi o primeiro ano de obrigatoriedade da compra da agricultura familiar. Saraiva et al., (2010) apontam que no Brasil 47,4\% dos municípios adquiriram alimentos da agricultura familiar para o PNAE e 0 percentual de compra nestes municípios foi, em média, de 22,7\%. A região Sul do país apresentou o maior percentual de compra de alimentos da agricultura familiar $(71,3 \%)$ e 0 Centro-Oeste apresentou o menor (35,3\%). Ainda, outra mudança significativa foi a inclusão do atendimento, em 2013, para os alunos que frequentam o Atendimento Educacional Especializado - AEE, para os da Educação de Jovens e Adultos (EJA) semipresencial e para aqueles matriculados em escolas de tempo integral, atendendo mais de $20 \%$ da população brasileira (PAZ et al., 2009).

A inserção do Programa Mais Educação em 2009 aumentou a oferta educativa nas escolas públicas por meio de atividades optativas como acompanhamento pedagógico, meio ambiente, esporte e lazer, direitos humanos, cultura e artes, cultura digital, prevenção e promoção da saúde, educação científica e educação econômica. Com isso o PNAE passou a repassar um per capita maior para os alunos que aderem ao programa, com a exigência de que as entidades executoras devem ofertar três refeições ao dia para esses alunos (FNDE/MEC, 2015).

Destaca-se que as mudanças ocorridas no PNAE proporcionam maiores oportunidades de comercialização, dentre essas modificações para o agricultor familiar, a sua adesão ao programa, também sofreu mudanças. No início, com a resolução do FNDE no 38 de 2009 (BRASIL, 2009), previase que cada agricultor poderia vender no máximo até $R \$ 9$ mil reais por ano, valor que passou para $R \$ 20$ mil a partir da resolução do FNDE ํㅡ 25 de 2012 (FNDE, 2017) considerando-se o conjunto de entes públicos executores da alimentação escolar.

Ressalta-se que há prefeituras no Brasil em que a situação dos mercados institucionais chegou a um nível que se pode definir como de amadurecimento, no qual se tem a compra de $100 \%$ dos produtos da agricultura familiar local ou regional para o abastecimento das escolas e creches do município, enquanto outras municipalidades apenas deram os primeiros passos no sentido de adequaremse à nova realidade do PNAE. Essa mudança de mentalidade trouxe consigo a possibilidade de que a agricultura familiar tivesse acesso a recursos que em 2013 alcançaram a marca de $\mathrm{R} \$ 4,547$ bilhões de reais. Houve ainda uma evolução ininterrupta dos recursos aplicados através do PNAE, assim como o número de alunos atendidos, que em 2013, alcançou um máximo histórico de 43,3 milhões (DOS ANJOS; BECKER, 2017).

Segundo dados do FNDE (2013), sobre a evolução dos investimentos em alimentação escolar de 2000 a 2013, destaca-se que, em 2000, o PNAE atendia cerca de 37,1 milhões de alunos com um investimento de $\mathrm{R} \$ 901,7$ milhões. Em 2013, foram atendidos aproximadamente 43 milhões de alunos com um investimento de cerca de $\mathrm{R} \$ 4,547$ bilhões, esse aumento vultuoso tanto nos investimentos quanto nos alunos atendidos, demonstra a contribuição que este mercado institucional pode trazer para a reprodução social dos agricultores familiares. 
Em relação a elevação do recurso financeiro dedicado ao PNAE, um dos eixos de apoio foi política econômica adotada pelo governo no período, ações foram implementadas pelo governo petista de Luís Inácio Lula da Silva (2003 - 2006), em primeiro e Dilma Vana Rousseff, em seu segundo mandato (2011 2016) (IPEA, 2012; MATTEI, 2012). A plataforma do governo Lula em seu primeiro mandato teve a alimentação fortemente vinculada ao fortalecimento da agricultura familiar, segurança alimentar e nutricional ganharam um novo ímpeto e estes atores encontraram possibilidades para institucionalizarem suas ideias.

O segundo mandato do Luís Inácio Lula da Silva (2007 a 2011) se caracterizou pelo eixo desenvolvimento com distribuição de renda e educação de qualidade, um importante intelectual que teve papel decisivo na formulação e implementação do projeto Fome Zero, foi o professor José Graziano da Silva. Segundo Menezes (2010, p.247), esse projeto "representou a culminância de todo um processo anterior de formulações e práticas na luta contra a fome e pela segurança alimentar e nutricional no Brasil experimentadas por governos (nos níveis municipal e estadual) e organizações sociais".

Ainda com relação aos valores repassados para o PNAE, no período de 2014 podemos observar que o valor repassado atinge os 4,492 bilhões de reais, contemplando 42,2 milhões de estudantes. Segundo dados do FNDE, $\quad \mathrm{R} \$ 1,08$ bilhões foi adquirido de produtos oriundos de agricultores familiares, obedecendo a lei que obriga os 30\%. (FNDE, 2017). Ao verificarmos a evolução desses investimentos, verifica-se um crescimento de $39,58 \%$ nos recursos financeiros despendidos durante o período de 2009 a 2014, em relação ao número de alunos atendidos pelo programa durante o mesmo período observase uma queda de $10,21 \%$, em nível nacional. Diante desses dados, mesmo havendo uma queda no atendimento de estudantes, o programa é considerado não apenas um direito dos estudantes, mas também uma das estratégias de Segurança Alimentar e Nutricional.

Ainda com relação ao gráfico 01, pode-se observar que o programa vem ganhando força e impulsionado por mudanças foi adquirindo confiança dos governos, que passam a ter como prioridade a alimentação escolar, redução da pobreza e da fome, e luta por justiça social. No entanto, ao analisarmos a variável/número de alunos atendidos é possível notar que o mesmo não apresenta aumento contínuo durante o período analisado. O período o qual o número de alunos apresentou acesso significativo, foi no ano de 2009, com o total de 47 milhões de alunos recebendo pelo menos uma refeição diária, nesse mesmo ano a alimentação escolar ganha novos ares, assumindo em seu cardápio produtos frescos e de qualidade adquiridos através da agricultura familiar.

Ao enxergarmos a redução de alunos atendidos durante os anos de 2010 a 2014 temos que relacionar que esse número é repassado conforme matriculas que são efetuadas nas escolas públicas que participam do PNAE. De acordo com Rocha et al., (2014), que pesquisou os fatores que incidem na qualidade da implementação do PNAE nos municípios brasileiros, muitas vezes o número repassado não é o mesmo de alunos matriculados e atendidos.

O número real de alunos atendidos é uma importante ferramenta de controle e de avaliação da implementação do PNAE, mas infelizmente é um dado que não está disponível na maior parte das prefeituras. É com base no número de alunos matriculados que o governo federal calcula o valor a ser repassado aos municípios para a compra de gêneros alimentícios para o PNAE. (ROCHA et al., 2014).

Pode-se perceber que apesar do número de alunos ter estagnado e até mesmo ter sofrido reduções ao longo do período apresentado, o volume de recursos aplicados vem continuamente crescendo, principalmente em função dos reajustes do valor per capita. Outro dado relevante para a análise é que nem todas as categorias do programa são atendidas desde o começo do período analisado, um exemplo são os alunos da modalidade do ensino médio e Educação de Jovens e Adultos (EJA), os quais são comtemplados com a participação no programa a partir do ano de 2010 (FNDE, 2017).

A merenda escolar representa um atrativo para a frequência de considerada porcentagem de alunos matriculados nas escolas públicas, consistindo numa atividade integrada ao ensino. O PNAE ganha uma dimensão social maior, à medida que em face da pobreza de significativas parcelas da população brasileira, cresce o número de crianças que vão à escola em jejum e/ou que 
se alimentam em casa de maneira inadequada. Para muitos alunos das escolas brasileiras, a merenda é sua única refeição diária (FLÁVIO et al., 2004).

De acordo com os estudos de Castro (2010), sobre o financiamento da educação pública no Brasil, a população brasileira na faixa etária atendida pela educação básica vem decrescendo e tende a seguir esse ritmo nos próximos anos. Segundo dados do MEC/2016, mais de três milhões de alunos entre a idade de quatro a dezessete anos estão fora da escola, esse resultado também é uma das variáveis que explica a diminuição de alunos atendidos pelo PNAE. Os dados do Censo Escolar de 2015 mostram que as matrículas diminuíram em todas as etapas de ensino, menos na creche, que atende as crianças até os três anos de idade.

O ensino médio, que já reduzia as matrículas pelo menos desde 2010, teve, desde então, a maior queda, entre 2014 e 2015, de 2,7\%. O número de estudantes passou de 8,3 milhões para 8,1 milhões. Os cenários da educação infantil e do ensino médio são diferentes. Enquanto no ensino médio, a falta de atratividade, a busca por trabalho, a gravidez na adolescência faz com que estudantes abandonem os estudos, no ensino infantil faltam salas de aula para incluir todas as crianças. No ensino médio, a maior parte dos jovens está na cidade e, na pré-escola, está no campo (INEP/MEC, 2016). Dessa forma, de acordo com Castro (2010), faz-se necessário a política de alimentação escolar atentar-se para a evolução das matrículas na educação básica, a fim de otimizar a distribuição de recursos de acordo com a modalidade de ensino e, por conseguinte, melhor atender o alunado. Ressaltando que a diminuição quantitativa por acesso à educação pode implicar aumento da demanda qualitativa desse acesso e também pela permanência na escola.

A alimentação escolar é de suma importância para o desenvolvimento dos escolares, a permanência destes na escola, além de garantir a educação garante a formação de hábitos alimentares saudáveis. Apesar de haver uma redução do número de estudantes atendidos pelo PNAE nos últimos anos, destaca-se alguns resultados positivos do programa, sobretudo para a agricultura familiar que passa a se inserir em novos mercados, proporciona a valorização cultural dos alimentos, além de se tornar um instrumento concreto de desenvolvimento.
Segundo Triches e Baccarin (2016), o PNAE é potencial em auxiliar na reversão dos quadros alimentares e nutricionais vigentes no país, além de promover a reprodução da agricultura familiar.

De acordo com Martins (2015), a partir de pesquisas com agricultores orgânicos e agroecológicos do Paraná, os principais resultados do ponto de vista dos agricultores após participação na chamada pública eletrônica, são: 100\% dos pesquisados acreditam que houve aumento da organização, estímulo ao cooperativismo e à participação de mulheres, aumento na aceitação da alimentação escolar e elevação da autoestima dos agricultores; para 95,5\% houve aumento no faturamento da cooperativa; $86,6 \%$ atestam estímulo à produção orgânica; $81,8 \%$ confirmam aumento da participação de jovens e retorno de familiares à propriedade rural; 79,5\% informam maior inclusão digital dos agricultores; e 75\% declaram ter ocorrido maior diversificação da produção e maior aproximação entre produtores e consumidores.

Ainda, Carvalho (2009), lembra que a alimentação escolar movimenta bilhões de reais por ano na compra de bens e serviços pelos estados e municípios. Ao mesmo tempo, tem-se revelado como potencial mercado institucional de fomento às economias locais e regionais, de inclusão social e de respeito à cultura local e ao meio ambiente.

Neste sentido, Villa Real (2011), descreve experiências nos municípios de Rolante (RS), Belo Horizonte (MG), Fernandes Pinheiro (PR), Nova lorque e Roma, que através da compra de gêneros alimentícios de pequenos produtores locais puderam oferecer aos escolares uma alimentação de qualidade, além de proporcionar novas oportunidades aos produtores locais, contribuindo para o desenvolvimento com sustentabilidade.

Por fim, Belik e Souza (2009), estudando programas de alimentação escolar na América Latina, concluíram que os municípios que fizeram localmente as compras conseguiram ampliar a renda da população e dinamizaram o comércio regional. No entanto, o estudo mostrou que são poucos os programas descentralizados e geridos democraticamente. Existem inúmeras conquistas a serem celebradas no âmbito do programa, porém muitas barreiras e desafios 
ainda precisam ser enfrentados pela agricultura familiar no acesso ao PNAE, os quais serão abordados no 4.1 a seguir.

\subsection{ENTRAVES E DESAFIOS DO PROGRAMA NACIONAL DE ALIMENTAÇÃO ESCOLAR}

As políticas públicas como o PNAE contribuem para a transformação social e econômica, tanto para os contextos locais de sua implementação, quanto para o cenário nacional e de emancipação para grupos e indivíduos espalhados por todo o país (ROZENDO; BASTOS; MOLINA, 2014). No entanto, apesar das inúmeras conquistas, a implementação e operacionalização local das compras institucionais, enfrentam alguns obstáculos. Ainda são muitos os entraves e os desafios a serem superados pelo Programa Nacional de Alimentação Escolar, dentre eles destaca-se: a) falta de planejamento (sazonalidade na produção, e elaboração de cardápios); b) chamada pública; c) excesso de formalidade/burocracia; d) repasse dos recursos; e) dificuldade para manter uma escala de produção;/atravessadores f) logística e transporte.

Um dos principais entraves para a compra de agricultura familiar é a falta de planejamento, ou planejamento inadequado, do gestor para a execução da compra. Conforme Carvalho (2009), deve-se conhecer a realidade local dos agricultores para que o gestor possa planejar sua compra respeitando sazonalidades, vocação produtiva, entre outras. As especificidades da agricultura, como a sazonalidade, o fato de alguns alimentos necessitarem de períodos mais longos para sua produção, outros de condições climáticas diferenciadas, exige um eficiente planejamento. Neste sentido, muitos agricultores têm dificuldades em cumprir com a entrega dos alimentos.

Conforme Saraiva et al., (2013), o não atendimento dos $30 \%$ de compra da agricultura familiar se dá pela inviabilidade de fornecimento regular e constante dos alimentos. Ou seja, os agricultores não conseguem fornecer constantemente para a alimentação escolar.

O planejamento requer a verificação das características dos diferentes produtos, pois alguns alimentos possuem ciclos produtivos mais longos, outros são mais sensíveis as alterações climáticas (sazonalidade), interferindo no abastecimento. Ao mesmo tempo, os agricultores precisam realizar um planejamento da produção dos alimentos, de acordo com a demanda para reduzir as oscilações e garantir uma oferta estável do produto (SARAIVA et al., 2013, p.933)

Para Aroucha (2012), ampliação e a regularidade continuada de oferta de gêneros alimentícios para 0 atendimento das demandas crescentes do mercado institucional da alimentação escolar apresentam também o problema a ser resolvido que são as variações decorrentes das condições climáticas e agroecológicas, que levam a sazonalidades de produção de parte da diversidade de espécies alimentares, com as suas respectivas variedades e raças.

Outro fator que se caracteriza como um entrave no acesso ao PNAE é a programação dos cardápios, muitas vezes o cardápio é preparado sem a presença das cooperativas. Diante disso, surge a ligação dessa dificuldade com outra já citada, a sazonalidade dos alimentos. Quem prepara o cardápio precisa conhecer a cadeia produtiva dos alimentos, pois do contrário pode inserir um alimento que não está em fase final de comercialização, portanto os obstáculos criam uma "teia", onde cada dificuldade se relaciona com outras (PAIVA, 2011).

O processo de aquisição dos gêneros alimentícios para a alimentação escolar pelo programa deve ser formalizado por meio da chamada pública e celebrado por contrato entre as entidades executoras do PNAE e os agricultores familiares, com a finalidade de garantir o cumprimento dos princípios constitucionais da administração pública e as leis específicas que regulamentam a dispensa de licitação para a aquisição desses itens (BRASIL, 2009; 2017). Neste sentido, as barreiras relativas ao sucesso da implementação das chamadas públicas para - mercado institucional estão ligadas a maneira que os editais são divulgados, mais especificamente no que se referem à participação e à integração dos agricultores para o fornecimento pelo PNAE. É de suma importância que exista a conexão entre os agricultores, Conselho de Alimentação Escolar (CAE), a EMATER e as escolas. Ou seja, é necessário que todos os participantes do programa tenham o conhecimento necessário do processo, para que assim seja compartilhado entre todos anseios e preocupações a serem resolvidos. O compartilhamento culmina em uma ação educativa, constituindo um espaço social 
para promoção de valores e atitudes que buscam o desenvolvimento da autonomia e do senso de responsabilidade individual desses agentes (VILLAR et al., 2013).

Entre os documentos exigidos para o fornecimento ao PNAE, estão o Extrato da Declaração de Aptidão ao Pronaf (DAP), CPF/CNPJ, projeto de venda e declaração de que os gêneros alimentícios a serem entregues são produzidos pelo agricultor ou associados relacionados no projeto de venda, a documentação exigida faz com que muitos agricultores desistam de comercializar com o PNAE, destacando-se as limitações de acesso a DAP (FNDE, 2013; MDA, 2017).

Outra dificuldade encontrada no acesso ao programa é o valor de referência das chamadas públicas, pois muitas vezes esses valores são menores que os preços de mercado, desmotivando o agricultor, que vai optar em vender nas feiras livres do que escoar sua produção para a alimentação escolar (TRICHES; BACCARIN, 2016). Para Triches e Schneider (2010), além de estruturar a demanda, é preciso que o Estado invista na oferta e interfira no mercado, ou seja, que dê meios para que os agricultores possam efetivamente comercializar seus produtos para o PNAE.

Os agricultores antes de se inserirem no mercado institucional, escoavam sua produção sem passar por processos burocráticos, eram considerados produtores de alimentos, e a relação existente era unicamente direta entre consumidor e produtor. De acordo com Ramos (2011), a oportunidade de entrega de produtos oriundos da agricultura familiar para a alimentação escolar veio interligada com diversas alterações e, em razão delas, os agricultores encontram dificuldades para participar do programa, dentre as quais, a obrigatoriedade de licitar todos os recursos utilizados para as compras e a adequação das formalidades para comprovação de padrões de qualidade dos produtos.

Para Belik (2012), o aperfeiçoamento do PNAE termina por gerar uma situação de contrassenso em que as conquistas levam a um aumento de expectativas, o que torna a implementação mais complexa e, por conseguinte, mais difícil de ser realizada de acordo com padrões definidos.

Conforme Triches e Grisa (2015), o excesso de formalidade, que em sua essência visa diminuir o favorecimento e a impessoalidade, tem se tornado uma pedra de tropeço para agricultores familiares dificultando o acesso aos programas e políticas públicas de fortalecimento da agricultura familiar. Isso porque, existe a ideia de que o processo de aquisições públicas de alimentos para 0 PNAE fere os princípios da legalidade, da racionalidade, da concorrência, da democracia, abrindo precedentes para corrupção. Segundo os autores o endurecimento das regras para o funcionamento público, faz-se necessário.

Ainda com relação aos entraves no acesso ao PNAE, Carvalho (2009), destaca a questão de alocação dos recursos. A proposta do PNAE é destinar os recursos para os municípios, conforme o número de alunos matriculados nas instituições participantes do programa. Assim, as grandes metrópoles são as principais destinatárias desses recursos, o entrave aqui encontrado é que muitas vezes essas regiões não são beneficiadas com agricultores familiares próximos ao local, com isso o programa não é acessado, ocasionando em uma grande perda para os agricultores que estão aptos para a comercialização.

Em relação a produção, segundo Reinach et al., (2012), os agricultores apontam que a falta de capital de giro para investir na compra de equipamentos que auxiliariam na produção, tais como colheitadeiras, tratores, galpões de armazenagem, faz com que haja uma redução na produtividade, tornando o valor agregado dos alimentos mais altos, devido à baixa produção e elevada perda. Assim, os agricultores defendem que as incertezas do mercado os desmotivam a fazer tais investimentos.

Segundo Triches e Schneider (2010), os agricultores familiares faziam suas transações comerciais via venda direta ou por atravessadores, ao haver a necessidade de se firmar contratos públicos para poder comercializar, esse fornecimento tem uma ruptura, o qual necessita se adequar aos novos parâmetros para escoar sua produção. Tem ainda a padronização dos produtos fornecidos, os alimentos necessitam estar em padrão de qualidade, higienização, tais como possuir embalagem. Ao descrever essas mudanças, percebe-se que essas são necessárias para o controle de qualidade, porém o agricultor que não possui amparo de cooperativas ou associações para se enquadrar nessas novas exigências, acaba desistindo de acessar o programa. 
Ainda com relação aos entreves do programa, Prado et al., (2013), destacam o problema de adequação dos agricultores familiares á essas exigências de comercialização via PNAE, ao afirmar que a produção em pequena escala dos produtores não consegue atender a demanda necessária de gêneros alimentícios. A logística de abastecimento na aquisição de alimentos é fundamental para manter o adequado valor nutricional da alimentação escolar. No entanto, a logística é um dos grandes "gargalos" enfrentados pelos agricultores, nem todos os municípios têm condições de oferecer o frete ou o transporte desses produtos para o local de destino. Assim, os agricultores fazem as entregas utilizando seus próprios veículos, já que terceirizar um frete é uma solução inviável, contudo, isso se torna mais uma despesa para o agricultor, que ao passar o valor final de seu produto, vê a renda diminuir cada vez mais (BARBOSA; ALMEIDA, 2013). Para Prado et al., (2013), a falta de treinamento técnico dos agricultores é um fator importante, que dificulta todo o processo logístico desde a colheita até a entrega.

Souza (2012), aborda o entrave da logística salientando que em grande parte das negociações os agricultores acabam arcando sozinhos com custos que vão além daqueles específicos da produção agropecuária.
Assim, torna-se oneroso para o produtor o fornecimento no PNAE, principalmente no caso da produção de hortaliças e frutas para serem comercializados in natura, produtos com preço mais baixo, sem valor agregado e de transporte mais delicado devido a perecibilidade. Outro fator importante no PNAE é garantia da qualidade dos alimentos, segundo Schneider (2013), é necessário que a logística em relação à coleta e à distribuição dos alimentos seja eficaz para que os produtos sejam consumidos em tempo adequado.

Diante do que foi exposto verifica-se resultados semelhantes aos encontrados por Soares (2011) e Baccarin et al., (2012), que apontam algumas dificuldades para a operacionalização do PNAE. Dentre os principais gargalos apresentados, estão: falta de planejamento, dificuldades de acesso e entendimento das chamadas públicas, excesso de normatização/burocracia no programa, dificuldades de logística e adequação com a padronização dos alimentos. Esses obstáculos enfrentados criam lacunas entre os interlocutores do programa dificultando o desenvolvimento da economia local e regional. Visando tornar mais claro visualmente os entraves, desafios e as conquistas do PNAE, o quadro 01 abaixo apresenta as principais discussões realizadas ao longo da seção.

\section{Quadro 01 - Síntese dos entraves, desafios e conquistas do PNAE}

\begin{tabular}{|c|c|c|c|}
\hline ENTRAVES & DESAFIOS & CONQUISTAS & AUTORES \\
\hline Falta de planejamento. & $\begin{array}{l}\text { - Sazonalidade na produção. } \\
\text { - Elaboração de cardápios. } \\
\text { - Vocação produtiva. } \\
\text {-Dificuldades de } \\
\text { fornecimento regular e } \\
\text { constante dos alimentos. } \\
\text {-Diálogo com os autores } \\
\text { envolvidos na } \\
\text { comercialização. }\end{array}$ & $\begin{array}{l}\text {-Inserir-se em } \\
\text { cooperativas e } \\
\text { associações. } \\
\text {-Contar com maior número } \\
\text { de profissionais na } \\
\text { elaboração de cardápios. } \\
\text { - Suporte tecnológico aos } \\
\text { nutricionistas. }\end{array}$ & $\begin{array}{l}\text { - Saraiva et al., } \\
\text { (2013). } \\
\text { - Aroucha (2012) } \\
\text {-Carvalho (2009) } \\
\text {-Paiva (2011) }\end{array}$ \\
\hline Chamadas públicas. & $\begin{array}{l}\text { - Divulgação dos editais. } \\
\text { - Integração e participação } \\
\text { dos agricultores. }\end{array}$ & $\begin{array}{l}\text { - O processo licitatório } \\
\text { passa a extinguir-se a } \\
\text { partir da lei } 11.947 / 2009 \text {. }\end{array}$ & $\begin{array}{l}\text {-Villar et al., } 2013 \\
\text { Triches e Baccarin, } \\
\text { 2016) } \\
\text {-Triches e } \\
\text { Schneider (2010) }\end{array}$ \\
\hline $\begin{array}{l}\text { Excesso de formalidade/ } \\
\text { burocracia. }\end{array}$ & $\begin{array}{l}\text { - Excesso de } \\
\text { regulamentação } \\
\text { - Limitações na } \\
\text { documentação necessária. }\end{array}$ & $\begin{array}{l}\text {-Formulação mais simples } \\
\text { na implementação das } \\
\text { leis. }\end{array}$ & $\begin{array}{l}\text { - Triches e Grisa } \\
\text { (2015). }\end{array}$ \\
\hline
\end{tabular}


(continuação...)

\begin{tabular}{|c|c|c|c|}
\hline ENTRAVES & DESAFIOS & CONQUISTAS & AUTORES \\
\hline Repasse de Recursos. & $\begin{array}{l}\text { - O valor repassado por } \\
\text { aluno ainda é considerado } \\
\text { muito baixo. } \\
\text {-Valores dos alimentos nas } \\
\text { chamadas públicas, } \\
\text { menores que os preços de } \\
\text { mercado. } \\
\text { - Falta de capital de giro } \\
\text { para investir na produção. }\end{array}$ & $\begin{array}{l}\text { - No ano de } 2017, \text { o } \\
\text { governo atual anunciou } \\
\text { aumento de } 20 \% \text { nos } \\
\text { valores repassados, para } \\
\text { alunos de ensino } \\
\text { fundamental e médio, já } \\
\text { para as demais categorias } \\
\text { o reajuste foi de } 7 \% \text {. }\end{array}$ & $\begin{array}{l}\text { - Carvalho (2009). } \\
\text { - Reinach et al., } \\
\text { (2012). }\end{array}$ \\
\hline $\begin{array}{c}\text { Dificuldade para manter } \\
\text { uma escala de } \\
\text { produção;/atravessadores. }\end{array}$ & $\begin{array}{l}\text { - Atravessadores. } \\
\text { - Registros de inspeção } \\
\text { sanitária e outras } \\
\text { certificações. } \\
\text { - Planejamento das entregas } \\
\text { de acordo com os prazos } \\
\text { estabelecidos. } \\
\text { - Padronização dos } \\
\text { alimentos. }\end{array}$ & $\begin{array}{l}\text {-Redução de } \\
\text { atravessadores. } \\
\text { - Criação de marcas } \\
\text { coletivas das } \\
\text { cooperativas. }\end{array}$ & $\begin{array}{l}\text { - Triches e } \\
\text { Schneider (2010). } \\
\text { - Wilkinson (2008). } \\
\text { - Reinach et al., } \\
\text { (2012). }\end{array}$ \\
\hline $\begin{array}{l}\text { Transporte, logística, } \\
\text { sazonalidade. }\end{array}$ & $\begin{array}{l}\text { - Estratégias para vendas de } \\
\text { alimento. } \\
\text { - Manter o valor nutricional } \\
\text { do alimento. } \\
\text { - Lucro do produtor fica mais } \\
\text { baixo, ao ter que arcar com o } \\
\text { transporte. }\end{array}$ & $\begin{array}{l}\text { - Melhor relação campo- } \\
\text { cidade. } \\
\text { - Estimulo a economia } \\
\text { local. } \\
\text { - Melhor alimentação das } \\
\text { crianças. }\end{array}$ & $\begin{array}{l}\text { - Barbosa e } \\
\text { Almeida, (2013) } \\
\text { - Schneider (2013) } \\
\text { - Prado (2013). } \\
\text { - Saraiva (2013). }\end{array}$ \\
\hline
\end{tabular}

Fonte: Elaboração própria com base na literatura consultada.

A discussão realizada nesta seção apresenta os principais entraves encontrados pelos agricultores familiares para escoar a sua produção via PNAE. Dentre eles destaca-se as dificuldades operacionais como grande obstáculo para a inserção dos produtores no programa. Segundo Triches e Baccarin (2016), a adesão às compras locais e a estruturação da oferta de produtos da agricultura familiar local dependem muito da disponibilidade e da vontade política dos gestores locais.

Apesar das diversas dificuldades citadas ao longo do estudo é evidente a contribuição do PNAE para a agricultura familiar, um dos marcos desse desenvolvimento é sem dúvida a obrigatoriedade da Lei no 11.947/2009, que estabelece que $30 \%$ dos alimentos adquiridos sejam oriundos da produção dos agricultores familiares. Muitas barreiras são impostas no acesso a esse mercado institucional, porém, o agricultor precisa "lutar" por esse acesso, de maneira que as questões burocráticas sejam solucionadas, a logística tenha apoio dos municípios, e que as cooperativas passem a ser a peça-chave na organização dessa categoria tão importante para o desenvolvimento local.

\section{CONSIDERAÇÕES FINAIS}

O Programa Nacional de Alimentação Escolar ao longo de sua trajetória passou por sucessivas mudanças em sua concepção e elaboração, quando implementado no Brasil caracterizava-se como uma política assistencialista de complementação alimentar, no decorrer de suas reestruturações transformou-se em uma política pública de desenvolvimento. Tais modificações foram fundamentais para garantir um continuo processo de aprimoramento do programa. A principal e mais inovadora alteração do PNAE ocorreu a partir da implementação da Lei $n^{\circ}$ $11.947 / 2009$, a qual garantiu avanços significativos tanto em âmbito econômico como social, a partir da obrigatoriedade de compra de alimentos oriundos da agricultura familiar. 
A partir da análise realizada no presente estudo pode-se observar que desde a implementação da Lei no 11.947/2099 os recursos repassados pelo FNDE apresentaram evolução crescente (2009 a 2014). As explicações encontradas através dos dados e de pesquisas, apontam variáveis como inserção de novas categorias atendidas pelo programa e políticas de governo a qual priorizavam programas de segurança alimentar como o PNAE.

Em relação ao número de alunos atendidos, o ano que mais teve participação foi em 2009. Nesse ano é inserido o Programa mais Educação, o qual aumentou a oferta de alunos atendidos. Um indicador que ajudou na compreensão dessa análise, é o fator de que o número de escolas atendidas não afeta na mesma proporção de alunos atendidos, ou seja, existem especificidades em cada região atendida pelo PNAE, como o recurso é direcionado conforme a categoria de ensino, algumas regiões apresentam maiores índices de recursos pois atendem categorias que recebem um valor mais elevado do FNDE, mesmo que a mesma apresenta menos alunos matriculados.

É possível observar que os recursos destinados ao PNAE, revelam a importância que o programa conquistou desde sua implementação. O aumento crescente das verbas destinadas à alimentação escolar expressa que o mercado institucional se tornou um potencial meio de desenvolvimento através da qualidade dos alimentos oferecidos. Mesmo havendo uma queda no número de alunos atendidos, os recursos destinados ao programa tiveram aumentos significativos. Destarte, o PNAE contribui no aprendizado das crianças e na valorização da cultura local, através dos alimentos oferecidos; proporcionando um desenvolvimento na economia através da inserção do agricultor familiar no mercado institucional.

No entanto, apesar da relevância do programa, ainda se encontra muitos entraves e desafios encontrados pela agricultura familiar para conseguir acessar o PNAE.
Dentre as dificuldades observadas encontram-se falta de planejamento, a divulgação das chamadas públicas, o excesso de burocracia, a questão de transporte e sazonalidade dos alimentos, dentre outros. Esses gargalos a serem enfrentados pelos agricultores familiares se tornam um desafio para os mesmos permanecerem exercendo suas atividades vinculadas ao programa. Desse modo, uma das estratégias seria o agricultor participar de cooperativas e associações para que possa dialogar com os autores envolvidos e sanar suas dúvidas e dificuldades.

Por fim, o Programa Nacional de Alimentação Escolar através de sucessivas mudanças, possibilitou um continuo processo de aprimoramento o qual contribui ao oferecer alimentos de qualidade aos alunos de rede pública e auxilia no desenvolvimento da agricultura familiar ao escoar a produção desses agricultores.

\section{NOTAS}

1 - A pesquisa é resultado do trabalho de conclusão de curso da primeira autora. Monografia apresentada em novembro de 2017.

2 - Aliado ao Partido dos Trabalhadores (PT). Coligação: Partido Liberal (PL), Partido Comunista do Brasil (PCdoB), Partido da Mobilização Nacional (PMN), Partido Comunista Brasileiro (PCB).

3 - Aliada ao Partido dos Trabalhadores (PT). Coligação: Partido do Movimento Democrático Brasileiro (PMDB), Partido Democrático Trabalhista (PDT), Partido Comunista do Brasil (PCdoB), Partido Socialista Brasileiro (PSB), Partido da República (PR), Partido Republicano Brasileiro (PRB), Partido Social Cristão (PSC), Partido Trabalhista Cristão (PTC) e Partido Trabalhista Nacional (PTN).

4 - Declaração de Aptidão ao Pronaf: Documento comprobatório de que a unidade de produção é familiar. (MDA, 2017). 


\section{REFERÊNCIAS}

[1]. AROUCHA, E. P. T. L. AGRICULTURA FAMILIAR NA ALIMENTAÇÃO ESCOLAR: Estudo de oportunidades e de desafios. Dissertação (Mestrado em Ecologia Humana e Gestão Socioambiental). Universidade do Estado da Bahia. 2012.

[2]. BACCARIN, J. G. et al. Agricultura familiar e alimentação escolar sob a vigência da Lei 11.947/2009: adequação das chamadas públicas e disponibilidade de produtos no estado de São Paulo em 2011. In: Anais... L Congresso da SOBER, Espírito Santo, de 22 a 25 de julho, 2012

[3]. BARBOSA, N. F.; ALMEIDA, L. M. M. C. Gestão da alimentação escolar em Goiânia: uma análise do Comitê de Apoio à Agricultura Familiar no Programa Nacional de Alimentação Escolar em Goiás. Revista Eletrônica de Educação da Faculdade Araguaia, Goiânia, v. 4, n. 4, p. 242-254, 2013.

[4]. BELIK, W. Experiência de Programas e Desenvolvimento Local em São Paulo - Brasil. Agroalimentaria, Mérida-Venezuela v. 18, n 34; p. $57-72$, jan. / jun. 2012.

[5]. BELIK, W.; SOUZA, L. Algumas reflexões sobre os programas de alimentação escolar na América Latina. Planejamento e Políticas Públicas, Brasília, n.33, p. 103-122, jul./dez. 2009.

[6]. BRASIL. Lei no 11.947, de 16 de junho de 2009. Dispõe sobre o atendimento da alimentação escolar e do Programa Dinheiro Direto na Escola aos alunos da educação básica; altera as Leis nos 10.880, de 9 de junho de 2004, 11.273, de 6 de fevereiro de 2006, 11.507, de 20 de julho de 2007; revoga dispositivos da Medida Provisória no 2.17836, de 24 de agosto de 2001, e a Lei no 8.913, de 12 de julho de 1994; e dá outras providências. Diário Oficial [da] República Federativa do Brasil, Brasília, DF, 17 jun. 2009.

[7]. BRASIL.MEC.INEP. Educação para todos: avaliação da década.2000. Brasília: MEC/INEP,2016.Acessoem:http://www. publicações inep.gov.br/arquivos/\%7bdebc5505-6BOE-4AF1BCAE-OD384B6AB419\%7D avaliação 127.pdf> Acesso em 12 fev.2018.

[8]. CARVALHO. D.G. Licitações sustentáveis, alimentação escolar e desenvolvimento Regional: uma discussão sobre o poder de compra governamental a favor da sustentabilidade. Planej Pol Públicas, n.32, p. 115-148, jan./jun. 2009

[9]. CASTRO NETO, N; DENUZI, V. S. S.; RINALDI, R. N.; STADUTO, J. A. R. Produção Orgânica: Uma Potencialidade Estratégica para a Agricultura Familiar. Revista Percurso, Maringá, v. 2, p. 47-72, 2010.

[10]. CONTERATO, M. A., NIEDERLE, P. A., TRICHES, R. M., MARQUES, F. C., SCHULTZ, G. Mercados e agricultura familiar: interfaces, conexões e conflitos. Porto Alegre: Via Sapiens, 2013.

[11]. DENZIN, N. K.; LINCOLN, Y. S. O planejamento da pesquisa qualitativa: teorias e abordagens. Porto Alegre: Bookman, Artmed, 2006.

[12]. DOS ANJOS, F. S.; BECKER, C. Agricultura familiar e mercados institucionais: o desenvolvimento como liberdade. Revista Econômica do Nordeste, v.45, n.5, p.107-118, 2017.

[13]. FLÁVIO, E. F; BARCELOS, M. F. P.; LIMA, A. L. Avaliação química e aceitação da merenda escolar de uma escola estadual de Lavras- MG. Ciências Agrotécnicas, Lavras, v. 28, n. 4, p. 840847, jul./ago., 2004.

[14]. FUNDO NACIONAL DE DESENVOLVIMENTO DA EDUCAÇÃO (FNDE). Resolução CD/FNDE n4ㄴ, de dois de abril de 2015. Altera a redação dos artigos 25 a 32 da Resolução/CD/FNDE no26, de 17 de junho de 2013, no âmbito do Programa Nacional de Alimentação Escolar (PNAE). Disponível em: <http://migre.me/sbn8t>. Acesso em:10 jan 2018.

[15]. FUNDO NACIONAL DE DESENVOLVIMENTO DA EDUCAÇÃO (FNDE). Portal do Fundo Nacional do Desenvolvimento da Educação. Histórico. 2017. Disponível em: < www.fnde.gov.br>. Acesso em: 13 ago.2017.

[16]. GERHARDT, T. E. (Org.); SILVEIRA, D. T. (Org.). Métodos de Pesquisa. Porto Alegre: Editora da UFRGS, 2009.

[17]. GIL, A. C. Métodos e Técnicas de Pesquisa Social. 6aㅡ edição, São Paulo, Atlas, 2008.

[18]. GRISA, C. Desenvolvimento local, políticas públicas e meios de vida: uma análise do Programa de Aquisição de Alimentos (PAA). In: Anais... 47ํㅡㄹ Congresso da SOBER, Porto Alegre, 2009.

[19]. GRISA, C. Políticas Públicas para a Agricultura Familiar no Brasil: produção e institucionalização das idéias.2012.280f. Tese (Doutorado em Desenvolvimento, Sociedade e Agricultura), Universidade Federal Rural do Rio de Janeiro, 2012.

[20]. GRISA, C.; WESZ Jr., V. J.; BUCHWEITZ, V.D. Revisitando O PRONAF: velhos questionamentos, novas interpretações. Rev. Econ. Sociol. Rural, v.52, n.2, p. 323-346, 2014.

[21]. HODGSON, G. Economia e instituições: manifesto por uma economia institucionalista moderna. Oeiras: Celta, 1994.

$\begin{array}{llcc}\text { [22]. IPEA - INSTITUTO DE PESQUISA E } & \text { DE } \\ \text { ECONOMIA } & \text { APLICADA. } & \text { Capítulo } & 7 .\end{array}$ Desenvolvimento Rural. In: IPEA. Políticas sociais: acompanhamento e análise, n. 20, 2012. 
[23]. MALINA, L. L. Chamada Pública: Instrumento Legal de Compras da Agricultura Familiar para a Alimentação Escolar. In: CORÁ, M. A. J.; BELIK, W. (Orgs). Projeto Nutre SP: Análise da inclusão da agricultura familiar na alimentação escolar no estado de São Paulo. São Paulo: Instituto Via Pública, 2012.

[24]. MARTINS, A. A. P. Opinião dos agricultores familiares sobre o fornecimento de alimentos orgânicos para o Programa Nacional de Alimentação Escolar do Paraná. Dissertação (Mestrado em Segurança Alimentar e Nutricional). Universidade Federal do Paraná, Curitiba, 2015.

[25]. MATTEI, L. A reforma agrária brasileira: evolução do número de famílias assentadas no período pós-redemocratização do país. Estudos Sociedade e Agricultura, v. 20, n. 1, p. 301-325, 2012.

[26]. MENEZES, F. Participação social no Fome Zero: a experiência do CONSEA. In: GRAZIANO DA SILVA, J., DEL GROSSI, M.E. e FRANÇA, C.G. Fome Zero: a experiência brasileira. Brasília (DF): MDA, 2010.

[27]. MINISTÉRIO DA EDUCAÇÃO. Políticas de Alimentação Escolar. (Org). CHAVES, L G.; BRITO, R.R-Brasília: Centro de Educação a DistânciaCEAD, Universidade de Brasília, 2006.

[28]. MINISTÉRIO DO DESENVOLVIMENTO AGRÁRIO. Secretaria da Agricultura Familiar. Declaração de Aptidão ao Pronaf. Brasília, DF, $2017 . \quad$ Disponível em: $<$ http://www.mda.gov.br/sitemda/saf/dap $>$. Acesso em: 17 de junho de 2017.

[29]. MUNHOZ, D.G. Economia Aplicada: técnicas de pesquisa e análise econômica. Brasília: UnB, 1982.

[30]. Organização das Nações Unidas para a Alimentação e a Agricultura /INCRA. Projeto de cooperação técnica INCRA/ Organização das Nações Unidas para a Alimentação e a Agricultura. Novo retrato da agricultura familiar. O Brasil redescoberto. Brasília, 2014.

[31]. PAIVA, J. B. de. Hábitos alimentares regionais no âmbito do Programa Nacional de Alimentação Escolar em um município do sertão baiano: uma abordagem qualitativa. 2011. Dissertações (Mestrado e, Alimentos Nutrição e Saúde). Universidade Federal da Bahia, Salvador, 2011.

[32]. PAZ, C. R.; TEO, A.; CORRÊA, E.N.; GALLINA, L. S.; FRANZOLI, C. National school meal program: adhesion, acceptance and circunstances of food distribution in school.2009.

[33]. PLOEG, J. D. van der. Camponeses e Impérios alimentares: lutas por autonomia e sustentabilidade na era da globalização. Porto Alegre: UFRGS, 2008.

[34]. PRADO, T. R. et al. Agricultura familiar na alimentação escolar: estudo de caso em dois municípios de Minas Gerais. Nutrire, São Paulo, v. 38, n. 3, p. 256-268, dez. 2013.

[35]. RAMOS, M. O. As crianças estão se sentindo importantes: avanços na alimentação escolar a partir da lei 11.947/2009 e da compra da agricultura familiar. Revista Trajetória Multicursos, Osório, v.2, n. 2, p. 4-19, Edição Especial. p. 15ago. 2011..

[36]. REINACH, S.; CORÁ, M. A. J.; BONDUKI, M. R. P. C. A Inclusão da Agricultura Familiar no Programa Nacional de Alimentação Escolar. In: Anais... XXXVI Encontro da ANPAD. Rio de Janeiro, Rio de Janeiro, 22 a 26 de setembro de 2012.

[37]. ROCHA, A. A. B. M. et al. Programa Nacional de Alimentação Escolar: uma análise sobre os fatores que incidem na qualidade da sua implementação nos municípios brasileiros, 2014. Dissertação (Mestrado em Ciências Políticas). Universidade Estadual de Campinas, Campinas, 2014.

[38]. ROZENDO, C.; BASTOS, F.B.C; MOLINA, W.S.L. A implementação das novas diretrizes do PNAE: desafios institucionais. In: Anais...VI Encontro da Rede de Estudos Rurais, 2014, Campinas. VI Encontro da Rede de Estudos Rurais. Campinas,2014.

[39]. SABOURIN, E.; XAVIER, J. H. V.; TRIOMPHE, B. Um olhar sobre os enfoques $e$ métodos no Projeto Unaí. In: OLIVEIRA, M. N. de; XAVIER, J. H. V.; ALMEIDA, S. C. R. de (Ed.). Projeto Unaí: pesquisa e desenvolvimento em assentamentos de reforma agrária. Planaltina, DF: Embrapa Cerrados, 2009.

[40]. SANTOS, M.; Concepções de geografia, espaço e território. Geo UERJ , n. 10, v.2, n.18, p. 24-42, 2008.

[41]. SARAIVA, E. B. et al. Panorama da compra de alimentos da agricultura familiar para o Programa Nacional de Alimentação Escolar. Scielo Brasil. Ciênc. Saúde Coletiva, Rio de Janeiro, v.18, n. 4, pp.927-935, 2013

[42]. SCHNEIDER, S.; ESCHER, F. A contribuição de Karl Polanyi para a sociologia do desenvolvimento rural. Sociologias, Porto Alegre, v.13, n. 27, p.180-220, maio/ago. 2011.

[43]. SCHNEIDER, A. A participação da agricultura familiar no Programa Nacional de Alimentação Escolar no município de São Lourenço do Sol. 2013. Trabalho de Conclusão de Curso (Graduação em Ciências Econômicas). Universidade Federal do Rio Grande do Sul, 2013.

[44]. SILVA, W. H. da et al., Agricultura familiar e mercados institucionais: uma análise acerca da operacionalização do Programa Nacional de Alimentação Escolar no município de Unaí, MG. Unaí: INESC, 2014.

[45]. SOARES, P. Análise do programa de aquisição de alimentos na alimentação escolar em um município de Santa Catarina. 2011. Dissertação 
(Mestrado em Nutrição). Universidade Federal de Santa Catarina, Florianópolis. 2011.

[46]. TRICHES, R.M.; SCHNEIDER, S. Reconstruindo o "elo perdido": a reconexão da produção e do consumo de alimentos através do Programa de Alimentação Escolar no município de Dois Irmãos (RS). Revista Segurança Alimentar Nutricional. Campinas, v.17, n.1, p.1-15, jan. 2010.

[47]. TRICHES, R.M; GRISA, C. Entre mudanças e conservadorismos: uma análise dos Programas de Aquisição de Alimentos (PAA E PNAE) a partir da retórica de intransigência. Revista NERA, Presidente Prudente, v.18, n.26, p.10-27, jan/jun.2015.

[48]. TRICHES, R.M.; BACCARIN, J.G. Interações entre alimentação escolar e agricultura familiar para o desenvolvimento local. In: TEO, C.R.P.A; TRICHES, R.M. (Org.). Alimentação Escolar: construindo interfaces entre saúde, educação e desenvolvimento. Chapecó: Argos, v. 1, p. 89-109, 2016.
[49]. VILLAR, B. S.; SCHWARTZMAN, F.; JANUARIO, B. L.; RAMOS, J. F. Situação dos municípios de São Paulo com relação à compra direta de produtos da agricultura familiar para o Programa Nacional de Alimentação Escolar (PNAE). Revista Brasileira de Epidemiologia, v. 16, n. 1, p. 223-226, 2013.

[50]. VILLA REAL, L.C. A problemática da produção e consumo de alimentos e o lugar da alimentação escolar: uma revisão de literatura, 2011.

[51]. WILKINSON, J., Cadeias Produtivas para Agricultura Familiar. Revista de Administração. Lavras, v.1, n.1, p. 34-41, jan./jun., 1999.

[52]. WILKINSON, J. Sociologia econômica e o funcionamento dos mercados: inputs para analisar os micro e pequenos empreendimentos agroindustriais no Brasil. Revista Ensaios, Porto Alegre, v. 23, n. 2, p. $805-825,2002$.

[53]. WILKINSON, J. Mercados, redes e valores: o novo mundo da agricultura familiar. Porto Alegre: UFRGS, 2008. 


\section{Capítulo 3}

\section{LAVANDERIAS COMUNITÁRIAS EM RIO BRANCO - AC: ALTERNATIVA DE TRABALHO PARA MULHERES COM VULNERABILIDADE ECONÔMICA}

\section{Oleides Francisca de Oliveira \\ Josefa Estevo de Souza Araújo \\ Jean Marcos da Silva}

Resumo: Na década de 1970, o estado do Acre foi marcado pelo processo de imigração dos povos que viviam na floresta. Sob o olhar Político, visava-se o desenvolvimento da Amazônia. Com isso, muitas famílias que habitavam as florestas, foram obrigadas a migrarem para a cidade de Rio Branco - AC. O objetivo deste trabalho é identificar as relações interpessoais, econômicas e trabalhistas de lavanderias comunitárias em Rio Branco - AC como alternativa de trabalho para mulheres com vulnerabilidade econômica. O presente artigo trata-se de uma abordagem qualitativa e um estudo de campo. Os dados foram analisados por meio da técnica de análise de discurso. Observou-se que a estrutura econômica está na organização social local, uma vez que se entende a força das tradições e dominações culturais, é possível compreender a necessidade e viabilidade econômica regional.

Palavras-chave: Trabalho. Classe. Lavadeiras. Economia. 


\section{INTRODUÇÃO}

O movimento migratório no estado do Acre na década de 1970 foi marcado pela saída dos povos que viviam na floresta para as cidades, principalmente para o município de Rio Branco, em consequência da venda de seringais para grupos econômicos de outros estados. Nesse processo de transição, foram notórias as mudanças: além do espaço geográfico, as relações culturais, sociais e econômicas. Para as mulheres que até então eram apenas auxiliares de seus maridos ou de seus pais nos seringais, essas mudanças foram ainda maiores.

Diante das necessidades econômicas destas mulheres, devido à falta de emprego e preparo para o mercado de trabalho, na década 1990 foram inauguradas as lavanderias comunitárias, promovidas pelo poder público, cuja proposta era oferecer uma alternativa de trabalho para as mulheres sem profissão e estudo.

Neste contexto, estudou-se as lavadeiras de duas lavanderias comunitárias de Rio Branco: Lavanderia Maria Barbosa do Nascimento, localizada no bairro Cidade Nova e a Lavanderia Maria Júlia da Conceição no bairro Novo Horizonte, afim de compreender o modo de trabalho, relações interpessoais e perfil sócio econômico dessa classe de trabalhadoras.

A priori, fez-se um esboço histórico da cultura e do trabalho da mulher amazônica. Entendendo a importância do conhecimento cultural e social, e sua relevância para possíveis avanços econômicos. O objetivo deste trabalho é identificar as relações interpessoais, econômicas e trabalhistas de lavanderias comunitárias em Rio Branco - AC como alternativa de trabalho para mulheres com vulnerabilidade econômica.

Nesse sentido, esta pesquisa é importante por compreender as alternativas de trabalho para mulheres de baixa renda, dentro das Lavanderias Comunitárias de Rio Branco, pelo viés socioeconômico por meio da práxis política e social, Estado e alternativas de trabalho assim como, investigar, quais os motivos que levam as trabalhadoras das lavanderias comunitárias de Rio Branco, a optar por esta forma de trabalho, avaliando também as vantagens e desvantagem para as lavadeiras.

A justificativa desse trabalho leva em consideração ainda, as necessidades econômicas decorrentes da década de 1970, na chegada das famílias dos seringueiros para a cidade, o que gera uma série de problemas, entre estes aborda-se o desemprego e o trabalho informal, trazendo para a atualidade essa relação, no processo histórico e social das lavadeiras, compreendendo neste, a criação de uma nova força de trabalho e desigualdade social. Essas mudanças econômicas e sociais fazem parte do sistema capitalista, com constantes crises, que levam o ser humano a adaptar-se e criar novas condições e alternativas de trabalho.

O primeiro capítulo aborda os procedimentos metodológicos. O segundo capítulo trata de um esboço histórico, da cultura e do trabalho da mulher amazônica, com bases na dominação tradicional, fundamentadas nas tradições e costumes, de uma cultura machista. Busca-se compreender as mudanças culturais e familiares relacionadas ao trabalho dessas mulheres por meio das mudanças impostas pelo capitalismo, no processo de imigração.

Em seguida, relata-se o aspecto histórico das lavanderias comunitárias de Rio Branco. Apresenta-se forma de funcionamento, desde a sua primeira inauguração em 1990, até o modo de funcionamento atual, afim de mostrar as mudanças políticas das lavanderias comunitárias e as mudanças na sua estrutura física e sua gestão.

\section{MULHER, CULTURA E TRABALHO}

Neste capítulo, fez-se um recorte da história das lavadeiras da Lavanderia Comunitária de Rio Branco, através de relatos históricos e da memória coletiva, que retratam a construção social, baseada nas tradições e culturas. Como o assunto específico de abordagem são as mulheres no exercício do seu trabalho por meio das Lavanderias Comunitárias, que é uma iniciativa da Prefeitura Municipal de Rio Branco. Neste capítulo buscou-se entender as origens sociais, culturais e históricos relacionadas às trabalhadoras destas lavanderias.

Na maioria das culturas a mulher é totalmente excluída do preparo para o mercado de trabalho através de costumes impostos pela sociedade, no Acre não é diferente, desde os Seringais, as mulheres foram educadas dentro de uma cultura machista, e dominadora, com muita influência dos 
nordestinos, principalmente originários do estado do Ceará para os seringais acreanos, na época da colonização da borracha. No entanto, o trabalho sempre esteve presente na vida das mulheres, elas ajudavam no corte de seringa, no roçado, e o trabalho da casa e o cuidado dos filhos eram exclusivamente delas, sem nenhuma ajuda do gênero masculino. Muitas vezes fazendo o mesmo serviço que os homens, e ainda tendo que arcar com as suas obrigações de casa.

Segundo Weber (1999) há três tipos puros de dominação: A de caráter racional; de caráter tradicional e de caráter carismático. Aqui destaca-se a dominação tradicional, "Baseada na crença cotidiana na santidade das tradições vigentes desde sempre e na legitimidade daqueles que, em virtude dessas tradições, representam a autoridade" (WEBER, 1999, p. 141).

Eram poucas as profissões que elas podiam exercer, entre as mais comuns, estavam as de: costureira, bordadeira, lavadeira, e para as que tinham uma posição social mais elevada, a de professora.

A Priori, a dominação vinha por parte do pai, depois o domínio era repassado para seu marido. A cultura e tradições ditam regras bem explicadas em relação ao comportamento do homem e da mulher, tendo liberdade quando se sujeitam aos padrões sociais, a quebra desses padrões implica em uma série de consequência, é nesse contexto social que muitas lavadeiras identificam a história de suas avós e mães. Segundo Pessoa (2007, p. 73), "As manifestações culturais estão sempre relacionadas à consciência de valores dos grupos que ditam as normas de conduta social, isto é, os grupos de referência de determinados lugares e épocas".

A questão cultural e social sempre foi o grande divisor em relação ao gênero masculino e gênero feminino, principalmente em relação ao trabalho.

Pessoa (2007), retrata muito bem a questão de gênero e trabalho. Por volta de 1920 e 1930, no Acre, essa questão era mais latente. Para as mulheres eram destinados os trabalhos domésticos e o cuidado dos filhos. Sem exercerem nenhum tipo de direito político, e muitas vezes, nem mesmo o direito de escolherem seus companheiros, sendo que muitas delas antes mesmo de nascer já estavam prometidas em casamento para algum conhecido ou parente de seus pais.

A cultura e as tradições sociais não thes davam direito de escolha, pois as normas já estavam pré-estabelecidas e impostas. Eram regras que, por muitos anos, as mulheres foram reféns desses costumes. No entanto, o trabalho sempre esteve aliado a figura feminina, não com a finalidade de emancipála e sim de escravizá-la. As marcas da dominação tradicional

foram enraizadas na cultura acreana, uma construção social, que mesmo com o passar dos anos ainda se faz presente, e seus prejuízos foram inúmeros. "As mulheres índias eram capturadas com dupla finalidade: para o trabalho no seringal e para serem esposas e escravas" (PESSOA, 2007, p. 87)

O Sistema Econômico Capitalista sempre esteve presente nas civilizações que foram surgindo e progredindo de alguma maneira devido a sua própria natureza, em um determinado momento construindo e em outro determinado momento destruindo, inclusive as condições da sua existência em seu próprio habitat, e em nome desse Capitalismo defende-se um "progresso" que leva ao crescimento, sem um desenvolvimento que beneficie a todos sem distinção de gênero e com uma distribuição de renda mais igualitária.

Harvey (2011), afirma que, o sistema econômico capitalista, trouxe mudanças em todas as esferas da sociedade, transformando também o modo de vida das pessoas até mesmos nas relações culturais, envolvendo gênero e trabalho. No Acre esse "progresso" chega na década de 70, em consequência da venda dos seringais para fazendeiros vindo principalmente do sul e sudeste do país. "Até meados dos anos 1970, nota-se políticas regionais Top-Down, com ênfase na demanda e na correção das disparidades inter- regionais" (DINIZ e CROCCO 2006).

Embora distintas de suas derivações de política econômica, as teorias mencionadas partilhavam o entendimento de que não era garantido automaticamente pelas forças de mercado, sendo necessária a intervenção estatal para que os desequilíbrios regionais fossem superados. (DINIZ e CROCCO, 2007, p. 11)

As famílias migradas dos seringais para a capital em Rio Branco/Acre, não tinham 
estudos e nem profissão, porém o contexto social agora é outro, não estavam mais nas matas, não tinham os seringais, enquanto nas florestas, tinham os peixes e caças, faziam a coleta de castanha e praticavam a agricultura familiar. Contexto esse propício a inúmeros problemas sociais. Nasce aqui a necessidade do desenvolvimento de nova atividade para o sustento da família.

\subsection{ATIVIDADE COMUNITÁRIA}

Diferente do seringal, o dinheiro tinha que ser usado diariamente, para ajudar no sustento da casa, as mulheres passaram a trabalhavam em casas de família, outras em feiras, trazendo recurso financeiro para casa, iniciando a quebra da cultura machista, de que só o homem, poderia ser o provedor principal da casa, agora na grande maioria dessas famílias a mulher passa de ajudadora a provedora do lar.

A lavagem de roupa também fazia parte dessa escala de trabalho, sendo preferida por muitas mulheres, pela flexibilidade de horário de trabalho, o que dava para conciliar com suas obrigações de casa, e o cuidado com as crianças, e marido.

Segundo Vieira e Ximenes (2012) é na atividade comunitária que percebemos no trabalho as dimensões instrumental e comunicativa que o envolvem, visto que a decomposição da atividade em determinadas ações pressupõe que elas se liguem, mediante a relação entre o indivíduo e os membros da coletividade.

O grande salto que a humanidade dá em relação aos outros animais e que possibilita essa ação planejada do homem sobre a natureza é a criação de instrumentos. A utilização de um instrumento está estreitamente vinculada à consciência do fim da ação. Assim, ele deixa de ser um mero objeto e passa a carregar consigo conceitos que ultrapassem uma condição natural (VIEIRA e XIMENES, 2012).

O aprendizado da atividade de lavadeiras foi desenvolvida de ensinamento de mãe para filha, que à acompanhava quando do exercício dessa atividade lavando roupas para fora, na beira do Rio Acre. Essas mulheres, movida pela necessidade econômica, passam a trabalhar como lavadeiras, serviço que nos seringais era no âmbito familiar, que agora sai da esfera familiar, como uma modalidade de trabalho, cada vez mais frequente, por mulheres que de alguma maneira tinham que garantir 0 sustento de suas famílias.

O desenvolvimento dessa atividade foi identificada por várias mulheres, que compartilhavam o mesmo espaço, trocando experiências criando uma relação de trabalho, com o mesmo objetivo de renda para o sustento da família. Com o passar do tempo foram se organizando, com apoio de representação comunitária junto a prefeitura, adquirindo espaço, tecnologia de maquinas e equipamentos tornando uma simples atividade comunitária em economia sustentável.

O número de mulheres lavadeiras vai se tornando cada vez maior, decorrente a uma situação de mercado, considerando o cenário econômico vivido por elas, o que antes era um grupo de mulheres que lavavam roupa na beira do rio, aos poucos vai ganhando forma, decorrente a um grupo e pessoas que vivem na mesma situação, essa classe de lavadeiras, tinham em comum a necessidade de sobreviver dentro do Sistema Econômico Capitalista.

Para Weber 1999, p.176 as classes são determinadas por:

As "classes" não são comunidades sentido aqui adotado, mas representam apenas fundamentos possíveis (e frequentes) de uma ação social. Falamos de uma "classe" quando 1) uma pluralidade de pessoas tem em comum um componente causal específico de suas oportunidades de vida, na medida em que 2) este componente está representado, exclusivamente, por interesses econômicos, de posse de bens e aquisitivos, e isto 3 ) em condições determinadas pelo mercado de bens ou de trabalho "situação de classe" (WEBER, 1999, p. 176).

A classe de lavadeiras foi assim identificada, por exercer de forma rotineira o desempenho laboral que recebiam um certo valor combinado entre as partes pelo exercício de lavagem de roupa. A correlação existente entre a lavadeira e o contratado era informal, valia- se pela consciência do indivíduo pelo pagamento.

Segundo Góis (2005) apud Vieira e Ximenes (2012) apesar de apontar a correlação existente entre o modo de participação em atividades comunitárias e o tipo de consciência dos indivíduos. 
Vieira e Ximenes (2008a) relacionam os conceitos de conscientização e atividade comunitária. Os autores enfatizam a imbricação entre psiquismo e realidade material, na qual ambos possuem a necessidade da presença do diálogo; afirmam ainda a superação de uma apreensão espontânea na relação consciência e mundo. Assim, os autores defendem que

conscientização e atividade comunitária fazem parte de um mesmo processo, pois "[...] a interação com a realidade, por meio de suas dimensões instrumental e comunicativa, produz mudanças na forma de o indivíduo se relacionar consigo, com o outro e com o mundo" Isso aponta para o fato de que mudanças nas formas de interação com o outro implicam necessariamente novas formas de apreensão da ação sobre a realidade (LURIA, 2005 apud VIEIRA e XIMENES, 2012).

Para realizar seu trabalho essas mulheres disponibilizavam, do recurso natural: Rio, sua força de trabalho, ou, tipo de serviço oferecido no mercado, além do saber adquirido na experiência do trabalho do cotidiano. A classe de lavadeiras foi constituída nesse espírito de luta pela sobrevivência dentro de um sistema que por si só já às tinha excluído, ou aberto precedentes para uma nova modalidade de trabalho.

\subsection{HISTÓRIA DAS LAVANDERIAS COMUNITÁRIAS EM RIO BRANCO/AC}

Em 30 de Julho de 1990, na gestão do Prefeito Jorge Kalume, foram inauguradas as Lavanderias Comunitárias: Maria Barbosa do Nascimento, localizada na rua Nossa Senhora da Conceição no bairro Cidade Nova. E a Lavanderia Comunitária Maria Julia da conceição, está localizada na rua Luiz Galvez, conjunto, Novo Horizonte Bairro Sobral.

Essas lavanderias representavam uma alternativa de trabalho para as mulheres de baixa renda, vindas geralmente dos seringais, desprovidas de qualquer capacitação para o mercado de trabalho. Sem nenhuma qualificação educacional e profissional, disponibilizando apenas a sua força de trabalho.

Com a mudança de Prefeito, essas Lavanderias ficaram esquecidas por mais de uma década, as lavadeiras relatam que a falta de água era frequente, e que não tinham nenhum apoio por parte da Prefeitura, apenas usavam o espaço público que ficou praticamente nas mãos delas, sem nenhuma gestão por parte do poder Público. Na Gestão do Prefeito Raimundo Angelim, as lavanderias passam por reformas e ganha maquinário industrial.

A lavadeira $X$ relata um pouco da sua experiência na lavanderia.

Conheci a lavanderia através de uma cunhada, para mim foi uma grande oportunidade de trabalho, pois podia trabalhar e cuidar dos meus filhos. Dentro da lavanderia tenho muitas amizades, tanto com as amigas de trabalho como com os clientes [...] nesses anos tivemos fazes boas e ruins na lavanderia, mas a pior época foi em 97, quando tivemos a nossa água cortada, e para lavar roupa tínhamos que pegar água da vizinha, além das péssimas condições que a gente trabalhava.

A lavanderia relatada pela Lavandeira $X$ são também, uma maneira da Prefeitura dá resposta a uma a necessidade de um grupo de mulheres que já sobrevivia desse trabalho. A classe de lavadeiras, composta por mulheres na sua maioria vindas dos seringais, que outrora não tinha nenhum ambiente adequado para realizar seu trabalho a não ser os rios, igarapés e trapiches improvisados, a partir daí passa e a ter um endereço.

\section{PROCEDIMENTOS METODOLÓGICOS}

O presente trabalho trata-se de uma pesquisa bibliográfica e um estudo de campo, pela coleta de dados através de entrevista, questionário semiestruturado. $\mathrm{O}$ enfoque que conectará as teorias abordadas é qualitativo, tendo em vista as próprias qualificações do objetivo que se pretende atingir, qual seja: identificar as relações interpessoais, econômicas e trabalhistas de lavanderias comunitárias em Rio Branco - AC, como alternativa de trabalho para mulheres com vulnerabilidade econômica.

Creswell (2010) destaca que na pesquisa qualitativa os dados de documentos podem ser abundantemente utilizados e recomenda que em uma pesquisa qualitativa a questão de pesquisa assume duas formas, uma questão central e as subquestões. 
Diante disto, a presente investigação classifica-se como sendo um estudo com abordagem qualitativa.

A opção pela abordagem qualitativa de pesquisa deve-se preponderantemente à concepção filosófica que se adotou nesta investigação. Levando-se em consideração a concepção pragmática, pode-se compreender a adoção desta.

Segundo Creswell (2010) essa concepção é também chamada de paradigma, lembrando ainda que o pesquisador na concepção pragmática, centra-se no problema de investigação. Permitindo-se utilizar diversas abordagens metodológicas desde que sejam úteis para se trabalhar o problema de investigação, permanecendo-se livres para optar pelos métodos e estratégias de pesquisa que melhor se adequem aos seus propósitos de pesquisa.

Nessa pesquisa, torna-se necessária a abordagem de método qualitativo, sobretudo, em virtude da intenção em descobrir a existência de coisas novas no ramo de estudo. Os instrumentos de pesquisas quantitativos, embora sejam úteis para testar as teorias de análise, não conseguiriam ou permitiriam a descoberta de novos conhecimentos como os métodos qualitativos propiciam.

Assim, o instrumento de coletas de dados qualitativo aparece como uma possibilidade. Somando-se a esta constatação, nota-se que a coleta de dados qualitativos ocorreu dispensando grandes custos e tempo adicionais. Por outro lado, reconhece-se que a análise de tais dados exigirá tempo adicional.

Como estratégias para a análise dos dados coletados e construção dos resultados, adotou-se a seguinte técnica de análise: Análise do discurso.

A análise do discurso foi empregada para observar os argumentos e posicionamentos dos entrevistados. Com isto, analisou-se as entrevistas por meio da identificação de passagens e de partes importantes destas entrevistas, incluindo-as em categorias.

A pesquisa foi aplicada em duas lavanderias comunitárias de Rio Branco, entrevistando doze lavadeiras: sete na Lavanderia Maria Barbosa do Nascimento, localizada no bairro
Cidade Nova e cinco na Lavanderia Maria Júlia da Conceição no bairro Novo Horizonte.

\section{DOS RESULTADOS: PERFIL SOCIOECONOMICO DAS LAVADEIRAS}

Com base na pesquisa feita com as lavadeiras das lavanderias comunitárias de Rio Branco, muitas delas vindas para Rio Branco com seus pais nessa época. As lavadeiras com mais de 50 anos relatam que seus pais eram Seringueiros, suas mães, eram ajudadoras nos seringais, e responsáveis pela casa e filhos, essas mulheres vindas juntamente com as suas famílias dos Seringais, para Rio Branco, em busca de melhores condições, porém, sem nenhum tipo de preparo profissional, ou amparo de políticas por parte do Estado.

No estado do acre o êxodo populacional teve incentivo do governador acreano Francisco Wanderlei Dantas, afinado com as diretrizes de modernização do governo federal, facilitando a compra das terras vendidas por seringalistas falidos, querendo incentivar a agropecuária no estado. Esses incentivos buscavam o crescimento econômico, no entanto uma parte significante dos povos acreanos não se enquadravam nessa nova política econômica.

Mais de dois terços das terras acreanas foram ocupadas, resultando na expulsão de mais de 40 mil seringueiros, posseiros, e índios para Rio Branco e outras cidades do estado. Com essa migração gerada pelo poder do capitalismo, houve mudanças não somente geográfica, mas também nas relações interpessoais, no modo de vida dessas pessoas, nas relações familiares e trabalhistas.

A síntese da metodologia é apresentada na figura no. 01 , refere-se a divisão de faixa etária de idade, renda e escolaridade das senhoras lavadeiras das duas lavanderias.

$\mathrm{Na}$ Lavanderia Maria Barbosa do Nascimento, podemos identificar pela letra " $X$ " com idade acima de 40 anos três lavadeiras, a letras " $Y$ " idade de 30 a 40 anos duas e pela letra "J" também duas entre 25 a 30 anos. $\mathrm{Na}$ Lavanderia Maria Júlia da Conceição, as lavadeiras foram identificadas: duas com idade acima de 40 anos letra "A", duas na faixa etária de 30 a 40 , letra "B" e uma de 28 anos letra "C". 
Figura 1 - Abordagens para a análise e coleta de dados, lavadeiras entrevistadas

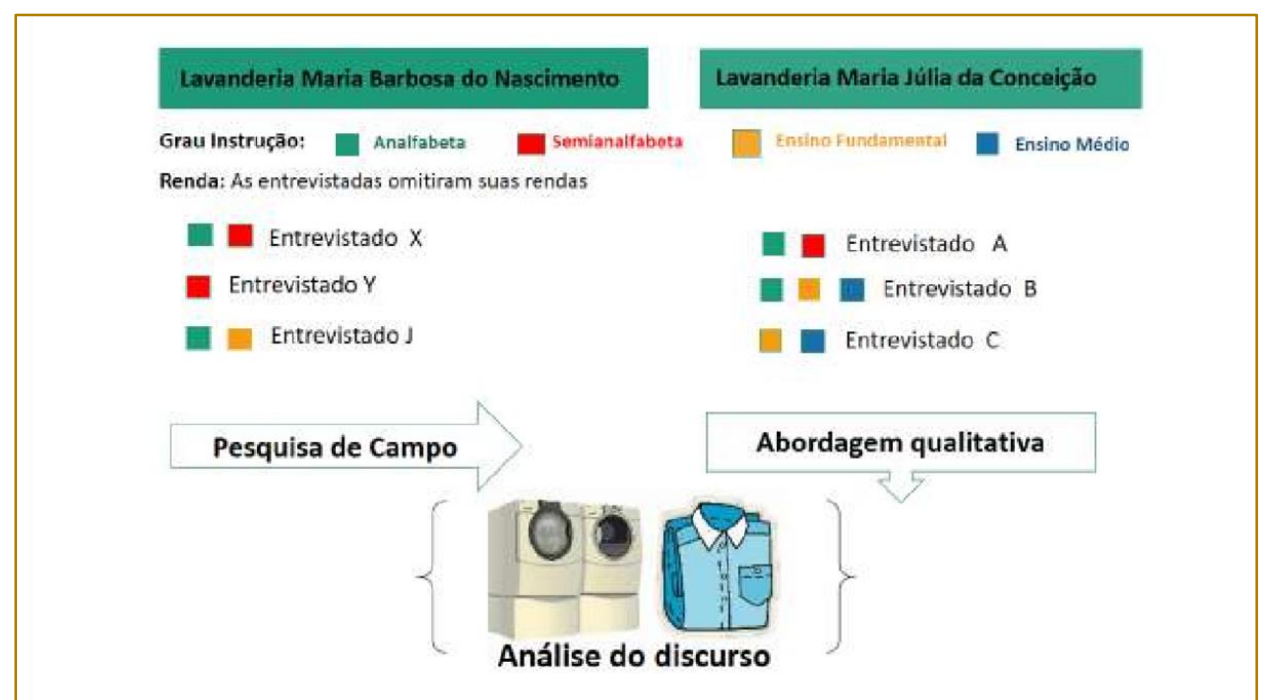

Fonte: elaboração dos autores, a figura da máquina de lavar foi retirada do domínio público da rede mundial de computares, 2017.

Ainda que apresentada de forma sintética a metodologia desse trabalho pode-se verificar a essência do conteúdo pela análise do discurso nas entrevistas realizadas com as senhoras das duas lavanderias.

Com os dados aplicados na entrevista com as doze lavadeiras obteve-se $\mathrm{o}$ seguinte resultado:

\subsection{FUNCIONAMENTO E INVESTIMENTOS DAS LAVANDERIAS}

A idade predominante das duas lavanderias e na faixa etária de acima de 40 anos, com escolaridade, analfabetas e semialfabetizadas, observa-se também que as lavadeiras de faixa etária de 25 a 30 anos estão presentes nas duas lavanderias, com escolaridade de ensino fundamental e médio.

A omissão de renda, deve-se a falta de instrução, controle e da necessidade de utilização do valor recebido para suprir suas necessidades imediatas. Já nos últimos dez anos esse controle se dá pela coordenação das lavanderias.

A Prefeitura de Rio Branco, através da Coordenadoria Municipal do Trabalho e Economia Solidária (COMTES), vem desde 2005, realizando o acompanhamento das lavadeiras, através da implantação de um conjunto de ações, visando a organização administrativa das lavanderias, por meio da elaboração de um regimento interno, o qual regulamenta o funcionamento, as relações comerciais com os clientes e as relações interpessoais entre as integrantes do grupo.

Com base em relatórios da Prefeitura Municipal de Rio Branco, em julho de 2008 houve a reforma da Lavanderia Maria Barbosa do Nascimento, e em Agosto de 2010 a da Lavanderia Maria Julia da Conceição, instalando encanação, bem como infraestrutura de agua e esgoto, além de instalação de máquinas industriais.

No entanto em um mundo cada vez mais competitivo, tanto a modernização ou expansão das atividades existentes quanto ao desenvolvimento de novas atividades tem como pré-requisito a implementação, privada e pública. (DINIZ, SANTOS e CROCCO, 2007, p. 94).

O espaço de trabalho continua sendo dá da Prefeitura Municipal de Rio Branco, assim como a responsabilidade da água e luz do local, a Prefeitura em decorrência de muitos furtos no local também disponibiliza 4 vigias, dois para cada lavanderia, a fim de garantir a segurança do local no período noturno, o espaço é de uso coletivo, tendo a capacidade receber 16 lavadeiras em cada lavanderia. A lavanderia possui uma pequena recepção, uma copa, área de utilização das máquinas industriais, área de ocupação das pias tanquinhos e centrífugas, espaço para passar as roupas e um banheiro. 
Para ingressar na lavanderia, é feito um cadastro pela COMTES, atual responsável pelo acompanhamento das lavanderias.

O uso dos equipamentos (lavadora industrial e secadora) é feito de modo coletivo, todas as lavadeiras, tem acesso, respeitando uma rotatividade de uso entre elas, já os demais equipamentos como tanquinho e centrifuga, cada lavadeira é responsável pela compra e manutenção, sendo de uso particular. A limpeza do local é feita pelas lavadeiras, obedecendo uma escala acordada pelas mesmas. A maioria das lavadeiras fazem suas principais refeições como café da manhã e almoço na lavanderia neste caso a compra de gás, água, copos descartáveis, material de limpeza, e alimento perecível para consumo, também é de responsabilidade das lavadeiras.

As embalagens descartáveis dos materiais industriais utilizados nas lavagens de roupas são armazenados em sacos apropriados de lixo, e levados pela coleta de lixo.

$\mathrm{Na}$ reforma de 2008 as lavanderias foram equipadas com maquinário industrial. A Lavanderia Maria Barbosa do nascimento no bairro Cidade Nova recebeu os seguintes equipamentos:

- $\quad 01$ Lavadora de roupas industrial, 06 ferros industriais e 06 mesas de passar.

- 01 secadora de roupas industrial com capacidade de lavagem de $50 \mathrm{kl}$. A Lavanderia Maia Julia Barbosa no bairro novo horizonte recebeu:

- 01 Lavadora de roupas industrial, 06 ferros industriais no valor e 06 mesas de passar roupa.

Esses recursos foram adquiridos para dá melhores condições de trabalho para as lavadeiras, no entanto alguns equipamentos, com mesas e ferro de passar não foram muito bem aceitos pelas lavadeiras de ambas lavanderias, elas acham a mesa muito alta e o ferro muito pesado, preferindo utilizar a própria mesa e seu próprio ferro de passar.

Inovação não é somente tecnologia de ponta, é considerada também, reorganização no conceito de empreender, e busca constante em capacitação. Neste sentido podemos nos perguntar, quais são os critérios avaliados para compra de equipamentos, já que alguns dele não atendem de fato a necessidade dessa classe trabalhadora.
O compartilhamento dos mesmos valores culturais, mesmas rotinas, mesmas organizações, mesma comunidade, mesma vida social geram uma atmosfera de relações sociais e um conjunto de conhecimentos tácitos que não podem ser transferidos por códigos formais. O compartilhamento e a absorção desses exigem um contato face a face, só possível através da proximidade. A interação local gera externalidades, realimenta os fluxos de conhecimento, aprendizado e inovação, reduz os custos de circulação e coleta de informações, socializa o aprendizado, a cooperação, a socialização dos riscos, o contato face a face (RALLET e TORRE, 1999) tradução nossa.

Em julho deste ano, a Lavanderia Comunitária Maria Julia da Conceição foi revitalizada, o espaço comunitário ganhou uma secadora indústria que tem capacidade para secar 50 $\mathrm{kg}$ de roupas.

As lavanderias contam hoje com 23 mulheres cadastradas pela Coordenadoria do Trabalho e Economia Solidária, (COMTES), sendo que 16 delas estão cadastradas na lavanderia Maria Barbosa do Nascimento, bairro Cidade Nova e 07 lavadeiras na lavanderia Maria Julia da Conceição, bairro Novo Horizonte.

Foi criado pela Coordenadoria Municipal do Trabalho e Economia Solidaria, (COMTES), atual responsável pelas lavanderias comunitárias, um Regimento Interno para as lavanderias, afim de estabelecer regras e ordem para manter o bom funcionamento das lavanderias. $O$ que antes era apenas um espaço público aberto para qualquer pessoa que tivesse interesse em lavar roupa, agora nesse espaço existe um controle com regras que segue um modo de comportamento estabelecido pela Prefeitura de Rio Branco, com base nos princípios da economia solidária, no que se diz no regimento interno "Com base em outros princípios em que o objetivo não é simplesmente o lucro, mas, acima de tudo resgatar a autoestima dos participantes, o desejo de viver, proporcionando a inserção social e econômica no seio da sociedade".

Neste regimento estão estabelecidas regras entre elas algumas como: Horário de funcionamento; Escala de limpeza para as lavadeiras, Eleição de uma representante para representar a classe de lavadeiras junto a Prefeitura, importante dizer que a representante, segundo o regimento vai trabalhar em parceria com a Prefeitura 
Municipal de Rio Branco; Criação de um conselho; Advertência pela COMTES em caso de: discussão entre integrantes da lavanderia, discussão na frente de cliente, falta injustificada ao serviço, descumprimento de regras de boa convivência e manutenção da lavanderia como limpeza do prédio, luta corporal ente membros da lavanderia.

As lavanderias possuem uma tabela de preço padrão para as duas lavanderias, estabelecida pelas lavadeiras, a tabela de preço fica no mural na recepção da lavanderia para que os clientes possam ver e comparar preços. Roupas mensais tem valor diferenciados.

A partir daí percebemos que a estrutura administrativa das lavanderias comunitárias, começam a mudar, o que antes era apenas um espaço de trabalho para lavadeiras, agora existem regras, embasadas em um regimento interno e uma ideologia nos princípios da economia solidária.

\section{ANÁLISE DOS RESULTADOS}

Ao longo de duas décadas é possível perceber no perfil social e econômico das lavadeiras, algumas mudanças, nas relações sociais, na forma de vida cotidiana e maneira de pensar. No primeiro momento foi-se avaliado, o perfil das lavadeiras da ingressada na década de 1990, na continuidade as lavadeiras remanescentes a partir dessa década, equivale lembrar que temos nas lavanderias mulheres que estão desde a primeira inauguração até os dias de hoje.

Podemos dizer que nas Lavanderias Comunitárias passou duas gerações, a primeira geração, na década de 1990, era composta por mulheres, em faixa etária de 25 a 45 anos, em sua grande maioria vinda dos seringais, semianalfabetas, tinham em média de quatro a seis filhos, não tinham outra opção de trabalho a não ser doméstica ou lavadeira.

Conforme a pesquisa realizada na Lavanderia Comunitária: Maria Julia da Conceição foi possível conversar com duas lavadeiras que ingressaram na lavanderia na década de 1990, e permaneceram até os dias de hoje. Uma, nascida em 18 de novembro de 1953, estudou até a segunda série do ensino fundamental, seu pai era seringueiro. Ela teve quatro filhos, entrou na lavanderia em janeiro de 1994, aos 41 anos de idade. Seu marido não tinha trabalho fixo. Ela conta que, a base da economia de casa vinha das suas lavagens de roupa, e a oportunidade que encontro para manter economicamente sua família foi a lavanderia comunitária. Hoje aos 62 anos de idade ainda lava roupa, conta que pretende parar de trabalhar, que ainda não parou porque o único benefício que recebe é um auxílio doença por consequência de uma gastrite, no entanto, mesmo já cansada ainda enfrenta o trabalho como lavadeira diariamente.

A outra lavadeira, nascida em 14 de janeiro de 1959, estudou até a quarta série do ensino fundamental, seu pai era soldado da borracha. Teve três filhos entrou na lavanderia em maio de 1994, aos 35 anos de idade. Seu marido trabalha até hoje como pintor. Ela conta que antes de ser lavadeira trabalhava como feirante nas feiras de Rio Branco. Abandonou o trabalho de feirante para ser lavadeira, porque podia levar seus filhos que ainda era pequeno para lavanderia. Hoje aos 57 anos de idade ainda trabalha como lavadeira. Ela relata que deu a seus, filho aquilo que ela não teve, trabalhou muito para que eles pudessem ir à escola. Fala que uma de suas filhas também é lavadeira, porém não quer que a filha permaneça na lavanderia, que diferente dela a filha tem estudo, e tem a capacidade de ter um emprego que possa garantir um melhor futuro, e que possa garantir uma aposentadoria.

Nas lavanderias temos 06 lavadeiras que ingressaram na década de 1990. 04 delas sabem ler, e duas não sabem ler nem escrever.

Estado civil: 03 delas são casadas, 02 viúvas e 01 separada. Essas mulheres nunca tinham tido nenhum contato com o mercado de trabalho, não buscarão outra modalidade de trabalho, continuando como lavadeiras até os dias de hoje. Nenhuma delas contribui com a previdência social. Situação que preocupa principalmente as lavadeiras de mais idade, pois sabem que não poderão receber aposentadoria.

As lavadeiras mais novas têm outro perfil. A faixa etária dessas mulheres é de 18 a 40 anos; 05 delas tem o ensino médio completo, 03 delas estão estudando, as demais não estudam. 02 delas faz cursos técnicos, 01 delas trabalha meio período na lavanderia e no outro trabalha como auxiliar de limpeza em um Hospital da rede pública. 
Todas elas são mães de família (são juntas com seus maridos). Essas têm em média de um a três filhos, tendo em comum com as lavadeiras da década de 1990 apenas a profissão que exerciam antes de serem lavadeiras, que era o trabalho como doméstica, porém afirmam deixar o trabalho de doméstica, pelo fato de estar presa a um horário de trabalho, de não ter perspectiva de aumento de salarial, e a irregularidade trabalhista, em sua grande maioria os patrões não queriam assinar suas carteiras de trabalho. Nenhuma delas contribui com a previdência social. Percebeu-se na fala das lavadeiras o orgulho, quando elas afirmam que trabalham para elas mesmas, sem terem patrão.

Foi possível observar também dentro das lavanderias, o grau de parentescos entre elas, sendo que muitas dessas mulheres que lavam roupas hoje são filhas de lavadeiras que ingressaram na lavanderia na década de 1990.

Há uma relação familiar dentro do âmbito de trabalho das lavanderias. A maioria dessas mulheres ingressaram na lavanderia por intermédio do chamado de uma parente, que Ihe apresentou as lavanderias. Essa relação nem sempre é harmônica, sendo que em alguns casos os conflitos entre parentes se tornam ainda maior.

Segundo o relatório de gestão da Coordenadoria Municipal do Trabalho e Economia Solidária, do ano de 2016 a lavanderia Maria Julia da Conceição, que conta hoje com 7 lavadeiras fixas as quais são responsáveis pelo sustento das famílias das mesmas. A família beneficiada dessa lavanderia gerou em média um volume de entrada de $R \$ 16.800,00$ (dezesseis mil e oitocentos reais), com divisão igualitária para as famílias. Já a Lavanderia Maria Barbosa do Nascimento que conta hoje com 16 lavadeiras fixas, gerou em média um volume de entrada de $\mathrm{R} \$ 38.400,00$ (quarenta e oito mil e quatrocentos reais), com divisão igualitária para as famílias.

A maneira de pensar dessas lavadeiras, ao longo do tempo também mudou, as novas lavadeiras, estão nas lavanderias mas não querem permanecer lá, elas dizem que estão lá por questões financeiras, porém encaram o trabalho de lavadeira como um trabalho alternativo.
As primeiras lavadeiras eram semianalfabetas, tinham a lavanderia como grande oportunidade de trabalho, gastaram todo o seu tempo e força como lavadeira, muitas delas hoje muitas delas apresentam problemas de saúde, como reumatismo, problemas de coluna, deformação das unhas, e problemas de pele, decorrente a grande exposição a frieza, pois passam praticamente o dia todo molhadas e também no sol.

Na década de 1990, as lavanderias contavam com o apoio da prefeitura Municipal de Rio Branco, em relação ao espaço construído, a água e a energia, as regras nesse ambiente de trabalho era regida pelas próprias trabalhadoras, assim como negociação valores de lavagem, e regras de funcionamento, as regras estabelecidas era na ordem pessoal.

Nesta segunda fase as lavanderias passam por várias mudanças administrativas, baseadas em leis, estatutos, incorporando uma nova filosofia de trabalho, segundo Weber (2003) a dominação de caráter racional ou legal:

Toda dominação organizada que pretende manter certa continuidade administrativa requer uma conduta humana direcionada à obediência aqueles que pretendem ser depositários do poder legitimo. Por outro lado, em virtude desse tipo de obediência, a dominação organizada pressupõe o controle daqueles recursos materiais necessários em caso de utilização da violência física. Portanto, a dominação organizada requer um controle do pessoal burocrático e da existência de instrumentos materiais de administração (WEBER, 2003, p.14).

Como vimos nos capítulos anteriores, as lavanderias comunitárias nasceram em consequência da necessidade socioeconômica iniciada na década de 1970, tentando das respostas ao desemprego em 1990, e em 2005 constrói sua forma social alternativa, pautada no sistema administrativo. Segundo Harvey, 2011, "As tendências de crises no capitalismo não resolvidas e sim, contornadas".

A economia solidária é, então, vislumbrada como a formação de um novo modo de produção socialista, mas um tanto diferente do socialismo real que vigorou até agora. Para Singer, é preciso admitir que é necessário conservar o mercado, regularizado e dirigido por entidades extra 
mercado, isso depende da radicalização da experiência democrática. (LECHAT, 2004, p. 215).

Nesse sentido, é preciso um comprometimento dos gestores, que vai além das questões eleitorais, na busca de implementação de Políticas Públicas que fomentem uma economia de emancipação social. Levando em consideração a história e cultura de cada território, baseado no conhecimento e na aprendizagem.

\section{CONSIDERAÇÕES FINAIS}

Esse estudo enfocou as lavanderias comunitárias de Rio Branco, sua forma de trabalho, como políticas públicas, para mulheres de baixa renda, buscando entender na história e na cultura, as relações sociais e econômicas e políticas.

$\mathrm{Na}$ primeira parte desse projeto procurou-se chamar atenção, para a influencias das tradições e culturas do Estado do Acre, nas relações entre gêneros, que implicam na relação de trabalho. Culturas e tradições, que foram se perdendo com a força das mudanças nas relações sociais, familiar e

\section{REFERÊNCIAS}

[1]. CRESWELL, J. W. W. Projeto de pesquisa: métodos qualitativo, quantitativo e misto. 2. ed. Porto Alegre: Bookman, 2010.

[2]. DINIZ, Clélio; CROCCO, Marcos. Economia Regional e Urbana Contribuições teóricas recentes. Belo Horizonte: UFMG, 2006.

[3]. GÓIS, C. W. L. Psicologia Comunitária: atividade e vivência. Fortaleza: Publicações Instituto Paulo Freire de Estudos Psicossociais, 2005.

[4]. HARVEY, David. O Enigma do Capital: e as crises do capitalismo. Tradução de João Alexandre Peschanski. São Paulo: Boitempo, 2011.

[5]. LECHAT, Noelle Marie Paule. Trajetórias intelectuais e o campo da Economia Solidária no Brasil. Tese de Doutorado. Campinas, 2004.

[6]. LURIA, A. Desenvolvimento Cognitivo. São Paulo: Ícone, 2005.

[7]. PESSOA, Enock da Silva. Trabalhadores da Floresta do Alto Juruá: Cultura e Cidadania na Amazônia. 2oe edição. Rio Branco: Edufac, 2007.

[8]. PREFEITURA MUNICIPAL DE RIO BRANCO. Coordenadoria do Trabalho e Economia Solidaria. Relatório anual das lavanderias comunitárias 2011. Rio Branco. 2011. trabalhista trazidas pelo sistema econômico capitalista.

Na segunda parte descreveu-se a história das Lavanderias Comunitárias, apontando a necessidade econômica da década de 1990, e o fortalecimento da classe de lavadeiras. Procurou-se mostrar as mudanças no espaço físico das lavanderias e gestão. Foram apresentados dados socioeconômicos das lavadeiras, e mudanças nas concepções metais das lavadeiras da década de 1990 até o ano de 2016.

A pretensão deste trabalho foi mostrar as consequências de uma política top-down, que não levam em consideração a história e cultura de um povo. Consequências estas que trazem marcas por longos anos, e que acarretam prejuízos na esfera social e econômica da sociedade. Também chamar atenção para gestão das políticas públicas, que mais do que nunca precisam ser fortalecidas, para valorizar a geração de emprego e renda para mulheres de baixa renda. Principalmente nos dias atuais, haja visto a crise econômica que se instala no país.

[9]. PREFEITURA MUNICIPAL DE RIO BRANCO. Coordenadoria do Trabalho e Economia Solidaria. Relatório de Gestão das lavanderias comunitárias 2016. Rio Branco. 2016.

[10]. RALLET, Alain e TORRE, André. (1999) Is geographical proximity necessary in the innovation networks in the era of global economy, GeoJournal, 49, 373-380.

[11]. VIEIRA, E. M.; XIMENES, V. M. Atividade Comunitária e Conscientização: Uma Investigação a Partir da Participação Social. Barbarói, Santa Cruz do Sul, n.36, p.91-112, jan./jun. 2012.

[12]. VIEIRA, E. M.; XIMENES, V. M. Conscientização: em que interessa este conceito à Psicologia? Psicologia Argumento. v. 26, n. 52, 2008a, p. 23-33.

[13]. WEBER, Max. Economia e Sociedade: Fundamentos da Sociologia Compreensiva. 3o edição. Tradução de Regis Barbosa e Karen Elsabe Barbosa. Brasília: UNB, 1994.

[14]. . Economia e sociedade: Fundamentos da Sociologia Compreensiva. Tradução de Regis Barbosa e Karen Elsabe Barbosa; Brasília, UNB, 1999.

[15]. . A Política como Vocação. Brasília: Ed. UNB, 2003. 


\section{Eapítulo 4}

\section{UMA ANÁLISE CROSS-SECTION DO AVANÇO DO DESMATAMENTO NA REGIÃO DA AMAZÔNIA OCIDENTAL}

\section{Meyrianny Santana Reis}

Elane Conceição de Oliveira

Neuler André Soares de Almeida

Resumo: A região Amazônica em especial a Amazônia Ocidental que possui quatro estados a saber Amazonas, Acre, Rondônia e Roraima, têm sido motivos de preocupação por parte do governo brasileiro que sofre pressão internacional em virtude do crescente desmatamento da floresta e da adoção de politicas de desenvolvimento voltadas para a exploração intensiva da terra e orientação de sua produção para o mercado externo. Diante do exposto este estudo em questão se propôs a analisar quais as variáveis que influenciam o aumento da taxa de desmatamento de forma mais específica medir o grau de influência das variáveis PIB per capita; Índice de Desenvolvimento Humano (IDH) e produção de gado sobre as taxas de desmatamento na região. Adotou-se o modelo de regressão com dados em corte transversal utilizando o método dos Mínimos Quadrados Ordinários (MQO). Os resultados mostram que a variável IDH foi a mais significativa sendo que uma variação de $1 \%$ desta variável impacta a taxa de desmatamento nos municípios da Amazônia Ocidental em 2,27\%. Conclui-se que o modelo corrobora o resultado de outros estudos, porém a análise carece de mais variáveis e a utilização de outros modelos, mais dinâmicas com um período maior tempo.

Palavras-chave: Amazônia ocidental; Corte transversal; Desmatamento; Regressão; Floresta 


\section{INTRODUÇÃO}

As estratégias geopolíticas de ocupação, integração e segurança da Amazônia culminaram em uma série de políticas públicas para o desenvolvimento da região nos moldes do modelo capitalista. No entanto, as primeiras tentativas abrangentes de planejamento socioeconômico para a região começaram apenas na década de 1950, intensificando-se, nas décadas de 1960 e 1970, o processo de desenvolvimento e ocupação como meta de alta prioridade para o país (MAHAR, 1978, p.3).

Assim, com o novo governo estabelecido em 1964, o planejamento do desenvolvimento para a Amazônia começou a tomar novo rumo por meio de uma maior eficiência no mecanismo de planejamento regional e um papel mais importante da iniciativa privada (MAHAR, 1978, p. 21), sendo nas décadas de 1960 e 1970 que o Governo Federal apoiou intensamente 0 desenvolvimento capitalista na Amazônia, acentuando assim as transformações econômicas e sociais na região (IANNI, 1986, p. 55). Principalmente nos anos de 1964 a 1978, o que ocorreu na Amazônia foi um desenvolvimento extensivo do capitalismo. Isto é, no extrativismo, na agricultura e na pecuária, desenvolveram-se as relações capitalistas de produção, juntamente com as forças produtivas, esclarece lanni (1986).

O mesmo autor relata ainda que além do desenvolvimento extensivo e intensivo do capitalismo na Amazônia ter sido dinamizado nos moldes do modelo de "economia aberta" adotado pela ditadura militar, a economia Amazônica ingressou na etapa da grande empresa privada, nacional e estrangeira. Isso não significa que antes de 1964 as atividades econômicas da região não estivessem articuladas, em maior ou menor grau, com o mercado nacional e estrangeiro. O fato é que tanto a Superintendência do Plano de Valorização Econômica da Amazônia (SPVEA), criada em 1953, quanto o Banco de Crédito da Amazônia, que vinha do Banco da Borracha, não exerceram influências notáveis nas atividades econômicas da região; em geral, até 1964, o máximo que se fez foi preservar as atividades produtivas predominantes, como o extrativismo da borracha, relata lanni.

Surge então a "Operação Amazônia", cuja pedra angular foi a Lei no. 5.173/1966. A futura política regional traçada pela Lei seria orientada para estabelecer "polos de desenvolvimento" e grupos de populações estáveis e autossuficientes; além de objetivar estimular a migração, proporcionar incentivos ao capital privado, desenvolver a infraestrutura e pesquisar o potencial de recursos naturais (MAHAR, 1978, p. 21-22). Sem embargos, a gênese dessa política adotada pelo governo federal para a região estava ancorada na teoria da polarização econômica de Perroux, de 1960. Benchimol (1977, p. 469) relata que a noção de espaço econômico exposta por Perroux, na França, trouxe uma nova contribuição para a economia; permitindo a Perroux, com base na segunda noção de espaço econômico (campo de atuação de forças), formular sua teoria de pólos de crescimento, em torno dos quais surgem os centros dinâmicos de uma economia.

Para lanni (1986, p. 60-61), essas transformações decorrentes da Operação Amazônia se intensificaram na região com a criação (a) da Superintendência de Desenvolvimento da Amazônia (SUDAM), em 1966, cujo objetivo era atrair investidores privados, nacionais e estrangeiros e dinamizar os setores agrícolas, pecuários, minerais e a indústria na região; (b) do Banco da Amazônia (BASA), no mesmo ano de 1966 e (c) da Superintendência da Zona Franca de Manaus (SUFRAMA), em 1967, responsável pelos incentivos fiscais da Zona Franca de Manaus (ZFM).

Esta última foi criada pela Lei no $3.173 / 57$, durante o governo desenvolvimentista de Juscelino Kubitschek; alterada, após 10 anos, pelo Decreto-Lei no 288/67; e, regulamentada pelo Decreto no 61.244/67. A ZFM é disciplinada como uma área de livre comércio de importação e exportação e de incentivos fiscais especiais, destinada a criar no interior da Amazônia um centro industrial, comercial e agropecuário, dotado de condições econômicas para promover o desenvolvimento regional. Mas, sem desmerecer a forte influência da teoria de Perroux na constituição dessa política, o grande argumento para sua institucionalização, esclarece Benchimol (1977, p. 741), foi de caráter geopolítico, dentro de uma estratégia de segurança e desenvolvimento: criar no centro da Amazônia um polo dinâmico comercial, industrial, agrícola e de serviços para servir de apoio logístico à ocupação do mediterrâneo e do grande arco de fronteira cisandina e 
subguiana, em equivalência à ação observada nas outras amazônias não brasileiras.

O chegar o "milagre brasileiro", década de 1970, esse período foi marcado pela agressiva política econômica do I Plano Nacional de Desenvolvimento (I PND) direcionada, em geral, para o crescimento econômico do País e, em especial, para o processo de integração da Amazônia. O objetivo da atuação do Governo Federal na região era realizar a "integração nacional" através do ambicioso programa de construção rodoviária, em conjunto com assentamentos rurais ao longo das vias principais. Esse processo de integração e ocupação da região foi ancorado no PIN (Programa Nacional de Desenvolvimento 1970), no PROTERRA (Programa de Redistribuição de Terras - 1971) e, posteriormente, no II PND e POLAMAZÔNIA (Programa de Polos Agropecuários e Agrominerais da Amazônia - 1974). Essas políticas federais para a região reconheceram que a Amazônia não era uma região deprimida como o Nordeste, mas uma potencial fronteira de recursos. As fronteiras de recursos, de acordo com Becker (1982), são zonas de povoamento novo, em que o território virgem é ocupado e tornado produtivo, sendo caracterizada pela grande distância dos centros de população, indicando que no passado não eram consideradas excelentes para ocupação e cultivo. Becker explica ainda que por seu valor estratégico e pelo alto valor de seus recursos naturais, a região é capaz de atrair inovações e efeitos difusores do desenvolvimento, tais como capital, tecnologia, população - tanto de centros nacionais como de centros mundiais, tornando-se verdadeiro campo de atração de forças externas.

Portanto, nessas décadas acentuaram-se as transformações econômicas e sociais na Amazônia. Segundo Mahar (1978), o que ocorreu na Amazônia foi o desenvolvimento extensivo e intensivo do capitalismo, sendo dinamizadas relações capitalistas de produção no extrativismo, na agricultura e na pecuária nos moldes do modelo de "economia aberta" adotada pela ditadura militar. O autor expõe que a economia Amazônica ingressou na etapa da grande empresa privada, nacional e estrangeira. Logo, as políticas federais baseadas em um modelo de economia dependente e coadunadas com as estratégias geopolíticas do modelo capitalista de produção foram o carro chefe para o processo de ocupação, integração e desenvolvimento da região. Supõe-se que a verdadeira intenção de tornar a região de fronteira capitalista de recursos em uma região produtiva era modernizar a economia primária exportadora, de modo a aumentar a sua capacidade para produzir para os mercados internos e externos.

Uma das consequências disso foi a mudança no uso e ocupação do solo seguida de perda de biodiversidade em regiões florestais, entre as quais, a floresta amazônica. Segundo Fearnside (2003, p. 45), o uso da terra e a mudança do uso da terra na Amazônia contribuem para mudanças climáticas globais de diversas maneiras; no período de 19811990, a emissão comprometida líquida globais de gases causadores do efeito estufa na Amazônia brasileira somaram 6,6\% da emissão total antropogênica global, incluindo combustíveis fósseis e mudanças do uso da terra.

Com relação às mudanças do uso da terra na região, Alencar et. al. (2004, p. 25) e Higuchi et al. (2009, p. 38) relatam que os principais usos do solo amazônico são voltados para agropecuária, produção de madeira, produção de energia (hidrelétricas, petróleo e gás natural) e exploração mineral; sendo que estes diferentes usos de solo já provocaram desmatamento total na Amazônia Legal (até 2007) de, aproximadamente, 70 milhões hectares ou $697.838 \mathrm{~km} 2$, que correspondem a $14,1 \%$ da cobertura florestal da região.

O desmatamento médio anual, segundo Higuchi et. al. (2009, p. 39), de 1978 a 2007, foi de $17.821 \mathrm{~km} 2$, ou seja, 1.782600 hectares. A emissão anual de carbono (equivalente) desde 1978 é de 223 milhões de t C (78\%) enquanto que a emissão brasileira via queima de combustível fóssil em seu primeiro inventário nacional de emissões foi de 64 milhões de t C (22\%), explica o autor.

Acrescenta ainda Higuchi que a emissão total do Brasil pode ser estimada em 287 milhões $t$ C ou 1 milhão t CO2; esta emissão o coloca em 5o lugar na lista dos maiores emissões do mundo, perdendo apenas para China, EUA, Índia, Rússia e Japão.

Mas, um dos grandes questionamentos que se levanta em relação a essa região é se de fato ela é fonte ou sumidouro de dióxido de carbono para atmosfera global (NOBRE, 2001, p. 197-224). A questão é que esta 
importante indagação ainda permanece em aberto. Isto porque por muitas décadas, imaginou-se que a emissão devida aos desmatamentos e queimadas de crescentes áreas da floresta tropical inevitavelmente significaria que a região deveria ser fonte de CO2 para a atmosfera. Mas já há evidências científicas sobre o balanço de carbono da floresta não perturbada tem mostrado que estas florestas tropicais podem estar acumulando carbono por fotossíntese mais do que perdendo por meio de respiração das plantas e decomposição da matéria orgânica, isto é, poderiam estar retirando (sequestrando) carbono da atmosfera, explica o autor.

Em contrapartida, estudos têm demonstrado que o Polo Industrial de Manaus (PIM) não é um fator que influencia no desmatamento do Amazonas. Freitas e Nascimento (2009, p. 114), ao realizarem uma análise de correspondência do desmatamento no Estado do Amazonas, identificou entre os resultados que o desmatamento apresenta baixa relação com o PIB per capita; e, todos os municípios, com exceção de Manaus, com alto desmatamento apresentam PIB per capita baixo. Da mesma forma, Diniz e Oliveira (2009, p. 115) realizaram um estudo que, na sua primeira etapa, ao testar a hipótese de causalidade de Granger entre o desmatamento e as principais variáveis que o explicam, observou que: há uma causalidade bi- direcional de Granger entre o desmatamento e as variáveis, área ocupada, culturas permanentes e temporárias, rebanho bovino, educação de adultos e crédito agrícola, ou seja, há um efeito dinâmico nas duas direções.
Entretanto, Diniz expõe que, em relação às variáveis população, matrícula de crianças e PIB per capita, o efeito da causalidade foi unidirecional no sentido das mesmas para o desmatamento, muito embora não exista um efeito do direcionamento do desmatamento sobre o PIB per capita. De fato, o aumento do desmatamento pode não ser capaz de incentivar novos investimentos, capaz de manter o ritmo crescente da economia, a despeito de um efeito sobre a atividade agropecuária. Diniz conclui que o comportamento da variável PIM denota que este tem a influência de diminuir o desmatamento.

Para tanto, o objetivo deste trabalho é realizar uma análise com dados em painel (painel data) para verificar quais as variáveis mais influenciam o desmatamento na Amazônia Ocidental. E de forma mais específica medir o grau de influência das variáveis PIB per capita; IDH e produção de gado sobre as taxas de desmatamento na região.

\subsection{A AMAZÔNIA OCIDENTAL: BREVE CONTEXTUALIZAÇÃO}

A Amazônia Ocidental localiza-se no centro geográfico da Amazônia, criada pelo Decreto de Lei 356/68, é composta pelos estados do Amazonas, Acre, Rondônia e Roraima. Ocupa cerca de $2.194 .599 \mathrm{~km}^{2}$ e detém $42,97 \%$ da extensão territorial da Amazônia Legal, abrigando aproximadamente $57 \%$ das áreas de florestas da região, consolida-se como a parte mais preservada da Amazônia.

Figura 1. Amazônia Ocidental

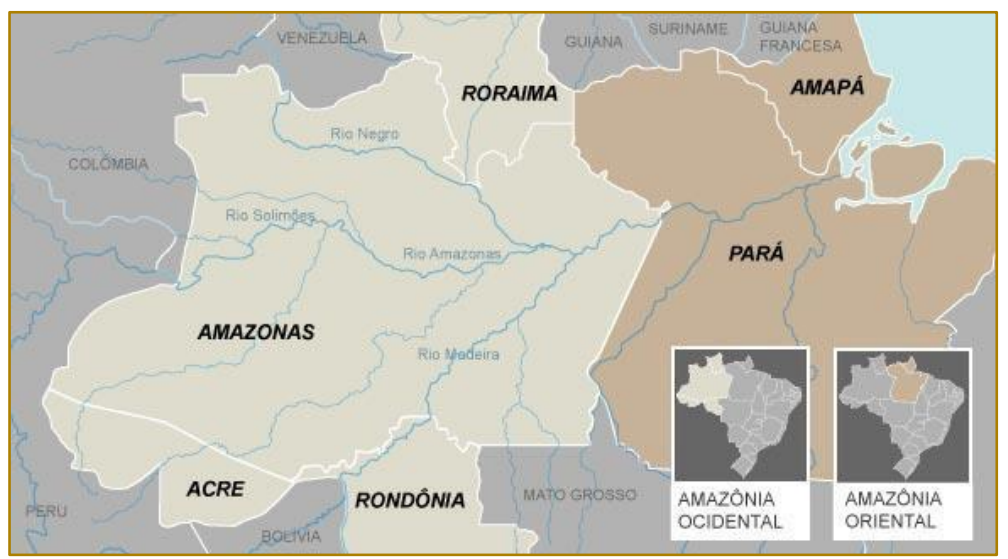

Fonte: www.ruralpecuaria.com.br (2018) 
O Amazonas se destaca como o maior Estado do Brasil e sua capital Manaus tornou-se a $6^{\circ}$ cidade mais rica do país. A base da economia do estado é o Polo Industrial de Manaus (PIM), que abriga inúmeras empresas nacionais e internacionais, gerando emprego, renda e arrecadação de tributos. Com aproximadamente 600 indústrias, gera cerca de meio milhão de empregos diretos e indiretos. O PIM é o principal mecanismo de atuação da Zona Franca de Manaus (ZFM), um modelo de desenvolvimento econômico que representa a mais importante política pública implementada pelo Governo na região. Teve seu início de fato, através do Decreto Lei 288 de 28 de fevereiro de 1967, quando passa a conceder incentivos fiscais e extrafiscais às empresas interessadas em instalar-se na área de atuação da ZFM, tornando-a atrativa para as grandes indústrias. Dessa forma, o projeto entra definitivamente em funcionamento, tendo como objetivo impulsionar o desenvolvimento da Amazônia Ocidental, uma região considerada extremamente estratégica.

Segundo o Instituto Brasileiro de Geografia e Estatística (IBGE), o Produto Interno Bruto (PIB) do Amazonas alcançou, em 2015, $\mathrm{R} \$ 86,6$ bilhões, o 15a maior do país. A participação do Produto Interno Bruto a preços correntes do estado no Produto Interno Bruto a preços correntes do Brasil foi de $1,44 \%$.

O Estado do Acre tem como uma das principais atividade econômicas e modelo de ocupação o extrativismo vegetal, especificamente a borracha, castanha e madeira e, a partir da década de 70 , com o declínio da borracha e o agravamento da situação econômica nas comunidades extrativistas, a introdução da pecuária e agricultura. A forma de ocupação do território e a organização de atividades econômicas no Acre não foram capazes de criar um modelo de desenvolvimento duradouro, apesar dos últimos dados evidenciarem o Acre como um dos estados que mais crescem em termos de PIB, apresenta um dos piores desempenhos quando comparado aos demais estados do país juntamente com Roraima e Amapá.

Segundo dados do IBGE, o PIB estadual em 2015 foi de 13,6 bilhões, representando $0,23 \%$ do Produto Interno Bruto a preços correntes no Brasil, ocupando o 26을 entre os maiores do país, estando a frente somente de Roraima, que apresentou um PIB de 10,4 bilhões, representando $0,17 \%$ do PIB brasileiro.

Rondônia é o $3^{0}$ estado mais rico da região norte, a economia do estado de Rondônia tem como principais atividades a agricultura, a pecuária, a indústria alimentícia e o extrativismo vegetal. A expansão da fronteira agrícola em Rondônia teve grande importância para 0 desenvolvimento agropecuário no estado, e consequentemente, a destruição de grandes áreas de floresta. $\mathrm{O}$ estado se destaca por ser grande exportador de carne bovina, possuindo ainda alta produtividade no setor agropecuário leiteiro nacional. De acordo com dados da Empresa Brasileira de Pesquisa Agropecuária (Embrapa), de 2009, o estado foi responsável pela produção anual de 747 milhões de litros de leite.

Em 2015, de acordo com o IBGE, o PIB do estado foi de 36,56 bilhões.

Representando 0,61\% do PIB nacional a preços correntes.

Quadro 1. PIB Amazônia Legal - 2015

\begin{tabular}{|c|c|c|}
\hline Estado & PIB & $\begin{array}{c}\text { Participação no PIB } \\
\text { brasileiro (\%) }\end{array}$ \\
\hline Amazonas & 86.560 .496 & 1,44 \\
\hline Acre & 13.622 .323 & 0,23 \\
\hline Rondônia & 36.562 .837 & 0,61 \\
\hline Roraima & 10.354 .355 & 0,17 \\
\hline Total & 147.100 .011 & 2,45 \\
\hline
\end{tabular}

Fonte: Elaboração própria a partir dos dados do IBGE, 2015. 


\subsection{A REGIÃO DA AMAZÔNIA OCIDENTAL E O DESMATAMENTO ACUMULADO}

Os últimos dados referentes ao desmatamento acumulado na região amazônica publicadas pelo INPE, a partir do Projeto de Monitoramento do Desflorestamento da Amazônia Legal PRODES, foi da ordem de 777.170,6 $\mathrm{km}^{2}$ até 2016, um aumento de $29 \%$ em relação a 2015. Na Amazônia Ocidental, todos os estados apresentaram aumento nas taxas de desmatamento. O estado que mais desmata na taxa acumulada é Rondônia, juntamente com Pará e Mato grosso, os estados são responsáveis por $75 \%$ do total desmatado em números absolutos. Porém, o desmatamento nos estados do Acre e Amazonas apresentaram taxas altas em relação ao período anterior, no Amazonas houve um aumento de 54\% enquanto o Acre apresentou um aumento de $47 \%$.

Quadro 2. Comparativo da taxa de desmatamento entre 2015 e 2016 nos estados da Amazônia Ocidental

\begin{tabular}{|c|c|c|}
\hline Estados & PRODES 2015 $(\mathrm{km} 2)$ & PRODES 2016 $(\mathrm{km} 2)$ \\
\hline Acre & 264 & 389 \\
\hline Amazonas & 712 & 1099 \\
\hline Rondônia & 1.030 & 1394 \\
\hline Roraima & 156 & 209 \\
\hline Am. Ocidental & 2.162 & 3091 \\
\hline
\end{tabular}

O Sul do Amazonas, onde encontra-se o Arco do desmatamento, foi a região que teve a maior área desmatada no estado, de acordo com o Prodes 2016, com destaque para os municípios de Lábrea, Boca do Acre, Apuí e Manicoré. E o sudeste do Acre, onde também há o avanço da fronteira, passam há algumas décadas por esse processo de modificação das suas paisagens devido, principalmente 0 avanço das atividades agropecuárias na região. O desmatamento e a queima da vegetação por atividades humanas foram as grandes transformadoras das paisagens acreanas e continuam a crescer muito nas últimas décadas (Silva e Ribeiro, 2004).

O aumento na taxa de desmatamento no Amazonas contrapõe pesquisadores da área ao afirmarem que a existência do Polo Industrial de Manaus (PIM) é determinante para a preservação no estado, ou seja, o custo ambiental em termos de desmatamento seria menor em decorrência do Modelo Zona
Franca (Rivas et al. 2008). O Amazonas responsável por preservar $98 \%$ da floresta, destaca-se por desmatar 35\% do total observado no ano de 2016 (Gráfico 1). O avanço do Arco do desmatamento pelo sul do Amazonas e sudeste do Acre torna-se preocupante a medida que põe em risco o avanço obtido na redução do desmatamento entre 2005 e 2012.

O desmatamento na Amazônia brasileira tem como principais causas diretas a pecuária, a agricultura de larga escala e a agricultura de corte e queima. Dessas causas, a expansão da pecuária bovina é a mais importante (Rivero et al, 2009). A criação bovina destacase como umas das principais formas de uso do solo na região, tal fato evidencia-se no estado Rondônia, que possui o maior rebanho da Amazônia Ocidental e consequentemente, apresenta as maiores taxas de desmatamento na região, sendo responsável por $45 \%$ do total desmatado. 
Gráfico 1. Participação por estado no total do desmatamento na Amazônia Ocidental

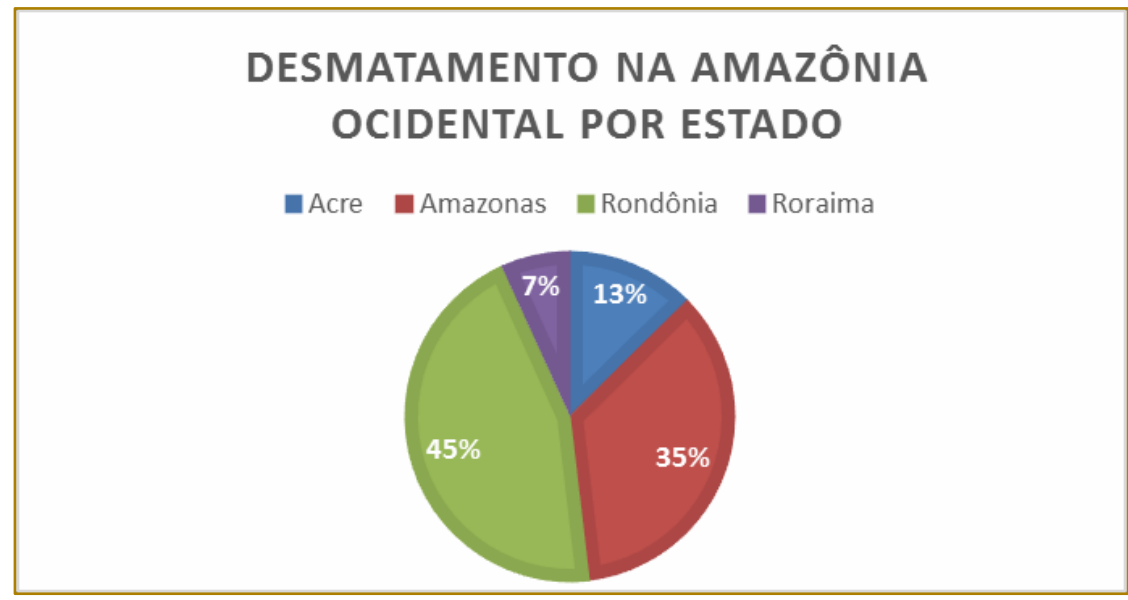

Fonte: INPE - PRODES (2016) - elaboração própria

A forte presença da bancada ruralista no congresso também contribui para o avanço do desmatamento, a exemplo da aprovação do novo Código Florestal, que anistiou aqueles que desmataram ilegalmente até 2008. A dificuldade de fiscalização e fortalecimento das políticas de comando e controle diante do grande território em que a região se encontra dificulta a inibição do desmatamento ilegal.

Dentre as principais consequências do desmatamento na região está a perda de biodiversidade e processos de esgotamento do solo, Segundo Fearnside (2003, p. 45), o uso da terra e a mudança do uso da terra na Amazônia contribuem para mudanças climáticas globais de diversas maneiras, em especial pelo aumento na emissão de gás carbônico oriundos das queimadas, que intensifica processos como o Efeito Estufa e causa sérias mudanças nos regimes de chuva.

\section{PROCEDIMENTOS METODOLÓGICOS}

\subsection{CORRELAÇÃO LINEAR}

O primeiro passo, em qualquer análise empírica é a formulação cuidadosa da questão de interesse, a qual pode ser a de testar efeitos de uma política governamental ou, até mesmo, de testar hipóteses e teorias. Em sua maioria, tem-se como procedimento inicial, testar o grau de correlação entre as variáveis para verificar se existe alguma relação forte ou fraca entre as mesmas. Para tanto usa-se o calculo do coeficiente linear de
Pearson (r). De acordo com a fórmula do calculo do coeficiente de Person, se $r$ é próximo de +1 , dizemos que há correlação positiva, o que indica que os pontos estão muito próximos da reta e/ou que as variáveis caminham em um mesmo sentido. Se $r$ é próximo de -1 , dizemos há entre as variáveis uma forte correlação linear negativa, o que indica que os pontos também estão muito próximos da reta, porém as variáveis caminham em sentido oposto. Por fim se $r$ se aproxima de 0 (zero), dizemos que há entre as variáveis uma fraca correlação linear e se $r$ for igual a 0 (zero) dizemos que não existe correlação linear.

\subsection{O MODELO DE REGRESSÃO LINEAR POR MÍNIMOS QUADRADOS ORDINÁRIOS (MQO),}

O modelo de regressão linear assim como o coeficiente linear, possui a preocupação de medir o grau de associação entre as variáveis, porém é uma técnica de análise mais robusta, já que, além de medir a interrelação entre as variáveis, também estima o padrão de causalidade entre as mesmas.

O modelo de regressão linear tem como exigência a determinação da forma funcional a qual pretende-se trabalhar a relação entre as variáveis. Para este estudo, a escolha recaiu sobre o modelo log $\rightarrow$ log pela facilidade de interpretação (em termos percentuais) e pelo melhor ajuste das variáveis. 
No que tange o método dos Mínimos Quadrados Ordinários (MQO) optou-se por esta técnica, visto que boa parte dos trabalhos na área de econometria, adotam este modelo por ser mais prático e por otimizar o ajuste do modelo através da minimização da soma dos quadrados das diferenças entre o valor estimado e os dados observados.

\subsection{MODELO TEÓRICO DE ANÁLISE}

Um conjunto de dados de corte transversal consiste em uma amostra de uma unidade de análise, tomada em um determinado ponto no tempo. Esses dados são muito utilizados em economia e por outras ciências como a biologia e a medicina. Analisar dados em um determinado ponto no tempo para testar e avaliar politicas e/ou verificar o comportamento de certas variáveis em um determinado momento no tempo.

Para tento, adotou-se a análise cross-section (dados em corte transversal), que consiste em mostrar uma "fotografia" do fenômeno estudado (o desmatamento) a partir de uma amostra de variáveis socioeconômicas tomada em um determinado ponto no tempo. Isto é relevante porque permitirá testar as prováveis hipóteses causadoras do desmatamento, em curso, na região da Amazônia Ocidental. Para o presente estudo pretende-se utilizar um modelo de regressão para estimar o comportamento da taxa de desmatamento em relação às variáveis selecionadas com a utilização do método de MQO (Mínimos Quadrados Ordinários). Para tal análise será utilizada o modelo proposto a seguir: $\ln (\mathrm{TXD}) \mathrm{ij}=\alpha+\beta 1 \ln (\mathrm{PPij})+\beta 2 \ln (\mathrm{IDHij})+\beta 3$
$\ln ($ GADij $)+\varepsilon$

Onde:

$\ln (T X D) i j=$ logaritmo natural da taxa de desmatamento do município (i) no Estado (j);

In(PPij) = logaritmo natural do PIB per capta do município (i) no Estado (j);

$\ln (I D H i j)=$ logaritmo natural do Índice de Desenvolvimento Humano do município (i) no Estado (j);

$\ln (G A D i j)=$ logaritmo natural da produção de gado do município (i) no Estado (j);

$\alpha=$ coeficiente linear;

$\varepsilon=$ termo de erro estocástico.

Na maioria dos casos, a análise econométrica começa pela especificação de um modelo econométrico, sem consideração de detalhes da criação de um modelo econômico. Entretanto, para este estudo em questão testamos a correlação entre as variáveis, PIB per capita, Índice de Desenvolvimento Humano (IDH) e produção de gado como variáveis explicativas do desmatamento na região Amazônica. O modelo de dados de corte transversal (croos section) foi preferível em virtude da dificuldade de obtenção dos dados e por dispor de menos rigor estatístico que modelos mais robustos como o de dados em painel e série temporal. A seguir no Quadro 1 as variáveis que pretende-se trabalhar neste estudo.

Quadro 3. Descrição das variáveis utilizadas.

\begin{tabular}{|c|c|c|c|}
\hline Variável & Descrição & Sinal esperado & Fonte \\
\hline Taxa de Desmatamento & Ln(TXD) & - & INPE(2016) \\
\hline Produto Interno Bruto & IBGE(2015) \\
\hline População & Ln(PP) & + & IBGE(2015) \\
\hline Índice de Desenvolvimento Humano & Ln(GAD) & + & IBGE(2010) \\
\hline Produção de Gado & + & \\
\hline
\end{tabular}

Fonte: elaboração própria.

Os dados da pesquisa são microdados secundários provenientes do Instituto Brasileiro de Geografia e Estatística (IBGE), Departamento de Contas Regionais. Os dados são relativos aos estados que compõem a região da Amazônia Ocidental: Amazonas, Acre, Rondônia e Roraima. Também trabalhou-se com os dados de desmatamento do Sistema Prodes (INPE). 


\section{RESULTADOS E DISCUSSÕES}

Para alguns autores o desenvolvimento da Região Amazônica e a expansão de atividades produtivas e não sustentáveis provocaram o desmatamento de sua floresta. Pode-se dizer que um dos trabalhos precursores e específico sobre o desmatamento é o de Tardin et al. (1979). Após este trabalho, surgiram outros, indicando as razões para o desmatamento. Embora alguns apontem enfaticamente para fatores específicos, como a construção e pavimentação de estradas ou outras melhorias em infraestrutura (LAURANCE et al., 2004; SOARES FILHO et al., 2005; WEINHOLD; REIS, 2003), o avanço da pecuária (MARGULIS, 2003) para atender os mercados internacionais (KAIMOWITZ et al., 2004) e da soja (BRANDÃO; REZENDE; MARQUES, 2005; FEARNSIDE, 2006) ou até mesmo o crescimento populacional, pode-se constatar que todos estão plenamente relacionados ao desmatamento.

Diante de problemas que o desmatamento traz ao meio ambiente, surgem trabalhos que visam oferecer sustentabilidade ambiental para as atividades econômicas na região (REYDON, 1997) e, numa escala mais ampla, que propõem o zoneamento ecológico econômico da região (HOMMA, 2006). Para este estudo adotou-se a análise em corte transversal para se obter uma fotografia do momento do desmatamento na Amazônia Ocidental, através de modelagem econométrica testando como variável dependente as taxas de desmatamento de 2016 e variáveis independente o PIB per capta (2015); Índice de Desenvolvimento Humano (IDH, 2010) e quantidade produzida de cabeças de gado (2016) nos Estados do Amazonas, Acre, Rondônia e Roraima que compõem a Amazônia Ocidental.

Inicialmente testou-se o grau de correlação entre as variáveis para analisar a relação linear entre seus valores de forma que sempre serão entre +1 e -1 . O sinal indica a direção, se a correlação é positiva ou negativa, e o tamanho da variável indica a força da correlação (Tabela 1). Cabe observar que, como o coeficiente é concebido a partir do ajuste linear, então a fórmula não contém informações do ajuste, ou seja, é composta apenas dos dados.

Tabela 1. Resultados do teste de correlação de Pearson com variáveis em nível.

\begin{tabular}{|c|c|c|c|c|}
\hline & TXD & $\mathrm{PP}$ & $\mathrm{IDH}$ & GAD \\
\hline TXD & 1 & & & \\
\hline PP & 0,3013 & 1 & & \\
\hline $\mathrm{IDH}$ & 0,3438 & 0,6842 & 1 & \\
\hline GAD & 0,280 & 0,3118 & 0,3321 & 1 \\
\hline
\end{tabular}

Fonte: elaborado a partir dos dados da pesquisa.

Inicialmente testou-se a correlação das variáveis em nível. Podemos perceber que as variáveis apresentaram correlação linear fraca. A seguir apresentaremos os dados referentes a estimação do modelo de corte transversal por MQO com variáveis em nível (Tabela 1).

Tabela 2. Resultado da análise de regressão com dados em corte transversal e variáveis em nível.

\begin{tabular}{|c|c|c|c|c|c|}
\hline TXD & \multicolumn{1}{|c|}{ Coef. } & $t$ & $p>|t|$ & Número de observações & 151 \\
\hline PP & 25,34366 & 0,91 & $37 \%$ & $f(3,147)$ & 8,94 \\
\hline IDH & 5448,242 & 2,09 & $4 \%$ & Prob. $>f$ & 0,0000 \\
\hline GAD & 0,001785 & 2,18 & $3 \%$ & R2 & 0,1544 \\
\hline- & - & - & - & R2 - Ajustado & 0,1371 \\
\hline
\end{tabular}

Fonte: elaborado a partir dos dados da pesquisa. 
O modelo adotado foi o de corte transversal (cross-section) para o ano de 2016 pois foi o ano mais recente com dados de taxa de desmatamento para os Estados da Amazônia Ocidental. Podemos notar que utilizou 151 observações, a estatística $F$ foi de 8,94 superior a 5 e pelo teste $F$ (prob. > f) rejeitamos estatisticamente a hipótese de que todos os coeficientes são estatisticamente iguais a 0 (zero) a $1 \%$ de significância. 0 teste R2 mostra que $15,44 \%$ das variações da Taxa de Desmatamento (TXD) são explicados pelas variáveis conjuntamente e 0 R2 - Ajustado foi de 13,71\%. Ambos os testes mostram que as variáveis são fracas para explicar o modelo, carecendo de mais variáveis explicativas ou um melhor ajustamento do modelo de regressão.
No que tange as variáveis, podemos evidenciar que apenas as variáveis Indice de Desenvolvimento Humano (IDH) e produção de gado (GAD) foram significativas a $4 \%$ e as $3 \%$, a variável Pib per capta (PP) não foi significativa. Diante do resultado apresentado, logaritimizou-se as variáveis, e mais uma vez testou-se a correlação de Person. Os resultados do modelo estão apresentados na Tabela 3 a seguir.

Os resultados da Tabela 3 mostram que as variáveis apresentaram novos resultados, sendo que a variável In(GAD) apresentou maior grau de correlação linear $(0,6277)$ e as demais variáveis apresentaram valores maiores e positivos.

Tabela 3. Resultados do teste de correlação de Pearson com variáveis logaritimizadas.

\begin{tabular}{|c|c|c|c|c|}
\hline & $\ln (T X D)$ & $\ln (\mathrm{PP})$ & $\ln (\mathrm{IDH})$ & $\ln (G A D)$ \\
\hline $\ln (T X D)$ & 1 & & & \\
\hline $\ln (\mathrm{PP})$ & 0,4673 & 1 & & \\
\hline $\ln (\mathrm{IDH})$ & 0,5135 & 0,6834 & 1 & \\
\hline $\ln (G A D)$ & 0,6277 & 0,5491 & 0,5194 & 1 \\
\hline
\end{tabular}

Fonte: elaborado a partir dos dados da pesquisa.

Um coeficiente de correlação mede o grau pelo qual duas variáveis tendem a mudar juntas. O coeficiente descreve a força e a direção da relação. Agora veremos o resultado da análise de regressão do modelo empírico proposto com variáveis em logaritmo (Tabela 4).

Tabela 4. Resultado da análise de regressão com dados em corte transversal com variáveis em logaritmo.

\begin{tabular}{|c|c|c|c|c|c|}
\hline $\ln (T X D)$ & Coef. & $t$ & $p>|t|$ & Número de observações & 151 \\
\hline $\ln (\mathrm{PP})$ & $11 \%$ & 0,48 & $0,6 \%$ & $f(3,147)$ & 38,97 \\
\hline $\ln (\mathrm{IDH})$ & $248 \%$ & 2,69 & $0,8 \%$ & Prob. $>f$ & 0,0000 \\
\hline $\ln (\mathrm{GAD})$ & $24 \%$ & 6,37 & $0,01 \%$ & $\mathrm{R} 2$ & 0,4430 \\
\hline- & - & - & - & $\mathrm{R} 2-$ Ajustado & 0,4316 \\
\hline
\end{tabular}

Fonte: elaborado a partir dos dados da pesquisa.

O resultado do modelo mostra que as variáveis obtiveram um melhor ajustamento. $\mathrm{A}$ $1 \%$ de confiança rejeitamos a hipótese de que todos os coeficientes são iguais a 0 (zero) (Prob. > f). A estatística R2 foi de 44,30\% bem maior que do modelo anterior e a estatística R2 - Ajustado foi de 43,16\% igualmente maior que no modelo anterior.
No que tange a estatística $T$ de Student as variáveis $\ln (I D H)$ e $\ln (G A D)$ foram significativas a $1 \%$ de significância, porém a variável In(PP) não foi significativa. A seguir apresentaremos os resultados de alguns testes normalidade do modelo. 


\subsection{TESTE DE MULTICOLINEARIDADE (VIF)}

Uma estatística pouco usual para detecção da presença de multicolinearidade, mas de fácil cálculo e interpretação, é o Fator de Inflação de Variância (FIV), que mede o quanto da variância de cada coeficiente de regressão do modelo estatístico se encontra inflado em relação à situação em que as variáveis independentes não estão correlacionadas (Tabela 5).

Tabela 5. Resultado do teste do Fator de Inflação de Variância (VIF)

\begin{tabular}{|c|c|c|}
\hline Variável & VIF & $1 / \mathrm{NIF}$ \\
\hline $\ln (P P)$ & 2,08 & 0,481293 \\
\hline $\ln (\mathrm{IDH})$ & 1,99 & 0,503193 \\
\hline $\ln (G A D)$ & 1,52 & 0,659521 \\
\hline
\end{tabular}

Fonte: elaborado a partir dos dados da pesquisa.

De acordo com os dados presentados na Tabela 5, podemos notar que as variáveis não apresentam multicolinearidade, pois os valores da estatística VIF são inferiores a 10 e a estatística TOL que é o inverso do VIF apresentam valores próximos de 1. Logo o modelo não apresenta multicolinearidade. Veremos a seguir o resultado dos testes de Heterocedasticidade.

\subsection{TESTE DE HETEROCEDASTICIDADE (WHITE)}

Em econometria, um teste extremamente comum para heterocedasticidade é o teste branco (White), o qual começa por verificar se o processo de heterocedasticidade ocorre em uma função de uma ou mais, das suas variáveis independentes. É semelhante ao teste de Breusch-Pagan, mas o teste White permite que a variável independente para ter um efeito não- linear e interativa sobre a variância do erro.

Normalmente, você aplicar o teste de White, assumindo que heterocedasticidade pode ser uma função linear de todas as variáveis independentes, em função dos seus valores quadrados, e uma função de seus produtos transversais.

No modelo em análise podemos verificar que o resultado do teste mostra que a estatística P-value $=0,0113$, ou seja o teste de White foi de $1,13 \%$ logo aceitamos a hipótese nula de homocedasticidade pois não podemos rejeitá- la a $1 \%$ de significância $(1,13 \%>1 \%)$ logo o modelo não apresenta Heterocedasticidade.

\subsection{TESTE DE HETEROCEDASTICIDADE (BREUSCH-PAGAN) \\ O teste de Breusch-Pagan (BP) é um dos testes mais comuns para} heterocedasticidade. Começa-se por permitir que o processo heterocedasticidade para ser uma função de uma ou mais das suas variáveis independentes, e é normalmente aplicada por heterocedasticidade assumindo que pode ser uma função linear de todas as variáveis independentes do modelo.

Os graus de liberdade para o F-teste são iguais a 1 e no numerador $n-2$ no denominador. Os graus de liberdade para o teste qui-quadrado é igual a 1. Se qualquer uma dessas estatísticas de teste é significativo, então você tem evidências de heteroscedasticidade. Se não, você não rejeitar a hipótese nula de homocedasticidade.

O resultado do teste para o modelo em análise mostra que a estatística BreuschPagan foi de Prob > chi2 $=0,9718$ ou seja aceitamos a $97,18 \%$ a hipótese nula de que o modelo apresenta homocedasticidade, e rejeitamos a hipótese alternativa de heterocedasticidade logo o modelo não possui heterocedasticidade. 


\subsection{INTERPRETAÇÃO DOS RESULTADOS}

Após o resultado dos testes de normalidade do modelo, podemos agora então apresentar a forma funcional do modelo proposto e sua interpretação:

$\ln (\mathrm{TXD})=\alpha+\beta 22,47 \%+\beta 30,24 \%+\varepsilon$

De acordo com o modelo matemático, uma variação de $1 \%$ no IDH dos municípios da Amazônia Ocidental, provoca um aumento de $2,47 \%$ na Taxa de Desmatamento. Se a produção de gado aumentar em 1\% a Taxa de Desmatamento anual aumenta em 0,24\%. No que tange a variável PIB per capta (PP) ela não foi estatisticamente significativa neste modelo sendo que sobre ela nada podemos inferir.

\section{CONCLUSÃO}

A Amazônia sempre foi motivo de grande preocupação sendo assim projetos e politicas desenvolvidas para alavancar o crescimento econômico da região aumentaram a devastação ambiental e a degradação de suas florestas. Diante desta situação, problemática este estudo se propôs a estimar um modelo de regressão em corte transversal (cross-section) para testar algumas variáveis e suas influencias sobre as taxas de desmatamento na Amazônia Ocidental.

No que tange a metodologia, adotou-se a análise de dados em corte transversal, que consiste em mostrar uma "fotografia" do fenômeno estudado (o desmatamento) a partir de uma amostra de variáveis já testadas em outros estudos que obtiveram um resultado positivo para a variável de interesse, tomada em um determinado ponto no tempo. Acredita-se que o modelo é relevante porque permitiu testar as prováveis hipóteses causadoras do desmatamento, em curso, na região da Amazônia Ocidental.

Desta forma este estudo utilizou um modelo de regressão em corte transversal, para estimar o comportamento da taxa de desmatamento em relação às variáveis PIB

\section{REFERÊNCIAS}

[1]. ALENCAR, Ane. et. al. Desmatamento na Amazônia: indo além da emergência crônica. Instituto de Pesquisa Ambiental da Amazônia (IPAM): Belém, 2004. per capta, IDH e Produção de Gado, através do método de MQO (Mínimos Quadrados Ordinários).

Os resultados aferidos mostram que as variáveis IDH e produção de gado foram altamente significativas (1\% de significância), porém a variável PIB per capta não foi significativa e sobre ela nada se pode dizer. Quando o IDH aumenta em $1 \%$ a taxa de desmatamento cresce $2,47 \%$ e quando a produção de gado aumenta em 1\% a taxa de desmatamento cresce $0,24 \%$, sendo assim pode-se concluir que o aumento no nível da qualidade de vida das pessoas que vivem nos municípios da Amazônia Ocidental impacta muito mais a taxa de desmatamento do que a produção de gado.

Vale ressaltar que o modelo em questão carece de mais variáveis por apresentar uma estatística R2 inferior a 50\%. Outro fato importante a ser ressaltado é que o estudo utilizou um modelo estático que é na verdade um corte temporal, requerendo posteriormente um aprofundamento com um modelo mais robusto e que utiliza um espaço temporal maior para tornar a análise mais dinâmica. Porém os resultados corroboram os obtidos por outros autores que estudam as relações entre o crescimento econômico e o desmatamento na Amazônia.

\section{NOTAS}

1 - Análise de correspondência é uma técnica de análise exploratória de dados adequada para analisar tabelas de duas entradas ou tabelas de múltiplas entradas, levando em conta algumas medidas de correspondência entre linhas e colunas; mostra como as variáveis dispostas em linhas e colunas estão relacionadas e não somente se a relação existe.

2 - O autor explica que o conceito de causalidade do sentido de Granger está relacionado com a capacidade de uma variável ajudar na previsão do comportamento de outra variável de interesse

[2]. BECKER, Bertha K. Geopolítica da Amazônia: a nova fronteira de recursos. Rio de Janeiro: Zahar Editores, 1982.

[3]. BENCHIMOL, Samuel. Amazônia: um pouco-antes e além-depois. Editora Umberto Calderado: Manaus, 1977. 841 p. 
[4]. BRANDÃO, A. S. P.; REZENDE, G. C.; MARQUES, R. W. C. Agricultural growth in the period 1999-2004, outburst in soybeans area and environmental impacts in Brazil. Rio de Janeiro: Ipea, 2005. 35p. (Texto para Discussão, 1062).

[5]. DINIZ, Marcelo; OLIVEIRA JR, José. Causalidades, clubes de convergência e análise quantílica. IN: RIVAS, Alexandre et. al. (Orgs.). Instrumentos Econômicos para a Preservação da Amazônia: a experiência do Polo Industrial de Manaus. 1를 Ed. Curitiba: Editora CRV, 2009. 207 p.

[6]. FEARNSIDE, P. M. Desmatamento e desenvolvimento agrícola na Amazônia brasileira Amazônia: a fronteira agrícola 20 anos depois. Belém: Museu Paraense Emílio Goeldi, 1991. 363p.

[7]. FEARNSIDE, Philip M. A floresta amazônica nas mudanças globais. Manaus: INPA, 2003. $134 \mathrm{p}$.

[8]. FREITAS, Carlos; NASCIMENTO, Fabíola. Uma análise de correspondência do desmatamento no Estado do Amazonas. IN: RIVAS, Alexandre. et. al. (Orgs.). Instrumentos Econômicos para a Preservação da Amazônia: a experiência do Pólo Industrial de Manaus. 1aㅡ ed. Curitiba: Editora CRV, 2009. 207 p.

[9]. HIGUCHI, Niro. et. al. Governos locais amazônicos e as questões climáticas. Manaus: Edição dos autores, 2009. 103 p.

[10]. HOMMA, A. K. O. Agricultura familiar na Amazônia: a modernização da agricultura itinerante. In: SOUSA, I. S. F. (Ed.). Agricultura familiar na dinâmica da pesquisa agropecuária. Brasília: Embrapa Informação Tecnológica, 2006. p. 33-60

[11]. IANNI, Octavio. Ditadura e Agricultura: O desenvolvimento do capitalismo na Amazônia: 1964-1978. $2^{\underline{a}}$ ed. Rio de Janeiro: Civilização Brasileira, 1986. 249 p.

[12]. IPEA. Rede Básica e Transportes da Amazônia. Brasília, 1998.

[13]. KAIMOWITZ, D.; MERTENS, B.; WUNDER, S.; PACHECO, P. A conexão hambúrguer alimenta a destruição da Amazônia: desmatamento e pecuária na Amazônia. Jakarta: CIFOR, 2004. Disponível em: http://www.cifor.cgiar.org/publications/pdf_files/me dia/ Amazon- Portugese.pdf. Acesso em: 02 abr. 2018.

[14]. LAURANCE, W. F.; AlBeRnAZ, A. K. M.; FEARNSIDE, P. M.; VASCONCELOS, H. L.;

[15]. FERREIRA, L. V. Deforestation in Amazonia. Science, Washington, n. 304, p. 11091111, 2004.
[16]. MAHAR, Dennis J. Desenvolvimento Econômico da Amazônia: uma análise das políticas governamentais. Rio de Janeiro: IPEA, 1978.

[17]. MARGULIS, S. Causas do desmatamento da Amazônia brasileira. 1. ed. Brasília: Banco Mundial, 2003. 100p.

[18]. NOBRE, Carlos. Amazônia: fonte ou sumidouro de carbono? IN: Brasil. Ministério do Meio Ambiente. Causas e dinâmica do desmatamento na Amazônia. Ministério do Meio Ambiente, Brasília: MMA, 2001. 435 p.

[19]. REYDON, B. P. Agricultura sustentável: uma agenda para o desenvolvimento de produção economicamente viável para a Região Amazônica. In: ROMEIRO, A. R.; REYDON, B. P.; LEONARDI, M. L. A. (Org.). Economia do meio ambiente: teoria, políticas e a gestão de espaços regionais. Campinas, SP: Unicamp, Instituto de Economia-IE, 1997. p. 299-309.

[20]. RIVAS, Alexandre; MOURÃO, Renata R.; FURTADO, Beatriz. O efeito do polo industrial de Manaus para evitar o desmatamento no estado do amazonas. Valoração e Instrumentos Econômicos Aplicados ao Meio Ambiente: Alternativas para Proteger a Amazônia, v. 69053, p. 95, 2008.

[21]. RIVERO, Sérgio, et al. "Pecuária e desmatamento: uma análise das principais causas diretas do desmatamento na Amazônia." Nova economia 19.1 (2009): 41-66.

[22]. SILVA, Rubicleis Gomes da e RIBEIRO, Claudiney Guimarães. Análise da degradação ambiental na Amazônia Ocidental: um estudo de caso dos municípios do Acre. Rev. Econ. Sociol. Rural [online]. 2004, vol.42, n.1, pp.91-110. ISSN 0103-2003.

[23]. SOARES-FILHO, B. S.; NEPSTAD, D.C.; CURRAN, L. Cenários de desmatamento para a Amazônia. Estudos Avançados, São Paulo, v. 19, n. 54, p. 137-152, 2005.

[24]. TARDIN, A. T.; SANTOS, A. P.; LEE, D. C. L.; MAIA, F. C. S.; MENDONÇA, F. J.;

[25]. ASSUNÇÃO, G. V.; RODRIGUES, J. E.; ABDON, M. M.; NOVAES, R. A.; CHEN, S. C.;

[26]. DUARTE, V.; SHIMABUKURO, Y. E. Levantamento de áreas de desmatamento na Amazônia Legal através de imagens do Satélite LANDSAT. São José dos Campos: Inpe, 1979. $142 p$.

[27]. WEINHOLD, D.; REIS, E. Land use and transportation costs in the Brazilian Amazon. Rio de Janeiro: Ipea, 2003. 31p. 


\section{Capítulo 5}

\section{INDICE DE DESENVOLVIMENTO MUNICIPIOS DO ESTADO DO PARÁ}

\section{Marcus Vinicius Mendonça}

Adriano Nascimento da Paixão

Nilton Marques de Oliveira

Rodolfo Alves da Luz

Resumo: O artigo tem o objetivo de construir um índice de desenvolvimento rural para os municípios do estado do Pará. Para o cálculo do índice utilizou-se o método de análise fatorial. As variáveis utilizadas foram obtidas junto aos Censos Demográficos do IBGE (2000 e 2010), Atlas do Desenvolvimento Humano no Brasil do PNUD (2013) e Censo Agropecuário do IBGE (2006). Os resultados revelam uma prevalência de municípios com baixos índices de desenvolvimento rural no estado. A infraestrutura das áreas rurais dos municípios do interior do estado é mais precária quanto maior é a dificuldade de acesso e o grau de isolamento destas áreas. A colonização de regiões distantes não foi acompanhada de investimentos em obras e serviços adequados ao provimento de qualidade de vida tanto de populações tradicionais quanto da população migrante que se instalou nas áreas rurais do estado.

Palavras-chave: análise fatorial; desenvolvimento local; desenvolvimento territorial; desenvolvimento regional; Amazônia. 


\section{INTRODUÇÃO}

Este artigo tem o objetivo de construir um índice de desenvolvimento rural para os municípios do estado do Pará e desta forma conhecer as diferenças locais e regionais que determinam este desenvolvimento a partir de variáveis que possam dimensionar causas, características e possíveis consequências de um desenvolvimento desigual.

De acordo com Delgado (2001), o desenvolvimento do setor agropecuário brasileiro passou por três fases distintas. Após a segunda guerra e, principalmente entre 1964 e 1980, conhecido como "modernização conservadora", por um lado estimulou-se a adoção de pacotes tecnológicos da "Revolução Verde" e o aumento da produção a partir de financiamento ao latifúndio e, por outro lado, o aprofundamento da heterogeneidade da agricultura brasileira. Após o fim do regime militar ocorre o retorno da questão agrária ao debate político e econômico na década de 1980, assim como uma relativa estagnação industrial.

A expressão desenvolvimento rural e a melhoria do bem-estar das populações rurais mais pobres, surge na década de 1970, associando o aumento da renda familiar resultado de mudança do processo produtivo na agricultura, com o desenvolvimento rural (NAVARRO, 2001).

$\mathrm{Na}$ década de 1990 estudiosos do tema redimensionam o significado do que é o "rural". O rural deixou de ser um espaço exclusivamente agrícola. Segundo Wanderley (2000), a crise produtivista de modernização agrícola e transformações recentes no meio rural nos países avançados apontam para a "emergência de uma nova ruralidade". Isso se deve a descentralização econômica de atividades industriais e comerciais para espaços rurais, a "paridade" econômica e social entre a população rural que obteve acesso tanto a bens e serviços modernos quanto a níveis de renda mais próximos aos dos habitats das cidades, o crescimento demográfico em razão da redução dos fluxos migratórios do campo para as cidades e a atração para o meio rural de outras categorias sociais.

Segundo Veiga (2000), não existe o desenvolvimento rural como fenômeno concreto e separado do desenvolvimento urbano. Para Figueroa (1997 apud KAGEYAMA, 2008) a economia rural está sempre integrada a uma cidade, e a economia regional é o contexto adequado para compreender o desenvolvimento rural.

De acordo com Kageyama (2004), há um certo consenso sobre a definição de rural: rural não é sinônimo de e nem tem exclusividade sobre o agrícola; o rural é multissetorial (pluriatividade) e multifuncional (funções produtiva, ambiental, ecológica, social); as áreas rurais têm densidade populacional relativamente baixa; não há um isolamento absoluto entre os espaços rurais e as áreas urbanas.

Isto posto, este artigo está divido em cinco partes. Além desta introdução, a segunda aborda resumidamente algumas considerações sobre o desenvolvimento rural. A terceira, a metodologia, assim como a área de estudo, análise fatorial e as descrições das variáveis. Na quarta, discute-se os principais resultados, e por fim, as considerações finais sumarizam o artigo.

\section{BREVE CONSIDERAÇÃO SOBRE DESENVOLVIMENTO RURAL}

Para Van der Ploeg et al. (2000) o paradigma da modernização da agricultura, que dominou a teoria, as práticas e as políticas, como a principal ferramenta para elevar a renda e levar o desenvolvimento as comunidade rurais, vem sendo substituído por um novo paradigma, o do desenvolvimento rural, buscando um novo modelo para o setor agrícola, com novos objetivos, como a produção de bens públicos (paisagem), sinergias com os ecossistemas locais, a maior valorização das economias de escopo em relação às economias de escala, e a pluriatividade das famílias rurais.

Ploeg et al. (2000) consideram o desenvolvimento rural em cinco níveis: o crescente inter-relacionamento da agricultura com a sociedade, fazendo com que esta perceba que o rural pode fornecer muito mais do que alimentos e matérias-primas; uma necessidade urgente em definir um novo modelo agrícola, capaz de valorizar as sinergias e a coesão no meio rural entre atividades agrícolas e não-agrícolas, ecossistemas locais e regionais, permitindo convivência de iniciativas e atividades diversificadas; um desenvolvimento rural capaz de redefinir as relações entre indivíduos, famílias e suas identidades, atribuindo um novo papel aos centros 
urbanos e a combinação de atividades multiocupacionais; um modelo que redefina o sentido de comunidade rural e as relações entre os atores locais; um desenvolvimento rural que leve em conta a necessidade de novas ações de políticas públicas e o papel das instituições.

Schneider (2004) acrescenta um sexto nível: é preciso um novo modelo que leve em consideração as múltiplas facetas ambientais, buscando garantir o uso sustentável e o manejo adequado dos recursos.

Segundo Ploeg et al. (2000), o cenário complexo das instituições participantes do desenvolvimento rural torna esse processo dependente de múltiplos atores, os quais estão envolvidos em relações locais e entre as localidades e a economia global. Para os autores, o desenvolvimento é ainda multifacetado, pois se desdobra em uma grande variedade de novas atividades, como administração da paisagem, conservação da natureza, agroturismo, agricultura orgânica, produção de especialidades regionais, vendas diretas, etc.

Conforme aponta Veiga (2001), na perspectiva de expansão das capacidades individuais e melhoria dos funcionamentos, preconizado na definição de Sen (2000) sobre o desenvolvimento, os elementos fundamentais do processo de desenvolvimento rural sustentável do Brasil são a valorização e o fortalecimento da agricultura familiar, a diversificação das economias dos territórios, o estímulo ao empreendedorismo local, o "empurrão" que viria do Estado para a formação de arranjos institucionais locais, além da menor desigualdade do acesso à terra e à educação.

O desenvolvimento rural é visto, portanto, como um processo que envolve a dimensões econômica, sociocultural, político-institucional e ambiental (KAGEYAMA, 2004 e 2008; CONTERATO, 2008; STEGE; PARRÉ, 2011) e não apenas como um processo de crescimento econômico medido unicamente pelo produto ou renda per capita.

\section{METODOLOGIA}

\section{1 ÁREA DE ESTUDO}

O Estado do Pará é o segundo maior estado do país com extensão territorial de 1.247.689,515 quilômetros quadrados ou
14,66\% do território nacional (PARÁ, 2010). De acordo com o Censo do IBGE de 2010 são 7.581 .051 habitantes, sendo $31,5 \%$ residentes na zona rural. O estado possui 144 municípios distribuídos em 12 regiões de integração (PARÁ, 2010).

Segundo Castro (1993) e Hébbet (2004), citados por Silva (2012), a política de Integração Nacional implementada na Amazônia após a década de 1970 levou o Pará a tornar-se o principal território de exploração de recursos naturais não renováveis, com o objetivo de integração das principais áreas mineradoras à economia internacional como forma de aumentar a pauta de exportações (COSTA, 1987 apud ibid., p. 116). Grandes projetos como a construção da Usina Hidrelétrica de Tucuruí, a Mineração Rio do Norte, a Albrás e Alunorte e o Projeto Ferro Carajás geraram novas regiões no Estado (CASTRO, 2009 apud SANTOS, 2015).

Silva (2012) revela as mudanças de características da dinâmica regional no estado do Pará. Esses investimentos produziram o crescimento econômico estadual e promoveram o deslocamento da dinâmica socioeconômica estadual da mesorregião Metropolitana de Belém para outros subespaços regionais, a partir da década de 1980. Algumas cidades passaram a compartilhar com Belém a dinâmica socioeconômica estadual como Ananindeua, Barcarena, Marabá, Parauapebas, Tucuruí e Redenção.

É preciso verificar quais os impactos que estas diferentes trajetórias regionais tiveram para o mundo rural do estado do Pará, tendo em vista a importância que o campo tem para a economia do estado. O uso de um índice de desenvolvimento rural é uma forma encontrada para comparar a realidade em diferentes municípios, de maneira a apontar similaridades e distorções nos processos de desenvolvimento.

\section{2 ÍNDICE DE DESENVOLVIMENTO RURAL}

Um indicador é um instrumento que possibilita medir aspectos de um determinado conceito, certa realidade, fenômeno ou um problema, e seu objetivo principal é "... traduzir de forma mensurável determinado aspecto de uma realidade dada (situação social) ou construída (ação de governo)" (Brasil, 2010 apud STEGE; PARRÉ, 2011, p. 4). 
Neste sentido, os trabalhos de Kageyama (2004 e 2008), Melo e Parré (2007), Waquil et al. (2010), Conterato (2008), Stege e Parré (2011) propõem um indicador para unidades e focos diferentes. Kageyama (2004) e Melo e Parré (2007), possuem como unidade de análise o rural municipal e elaboram um Índice de Desenvolvimento Rural para os municípios de São Paulo e Paraná, respectivamente. Waquil et al. (2007) desenvolveu um Indicador de Desenvolvimento Sustentável para quatro territórios rurais, definidos pelo Ministério do Desenvolvimento Agrário. Kageyama (2008) elabora um Índice de Desenvolvimento Rural para os estados brasileiros, enquanto Stege e Parré (2011) constroem um Índice de Desenvolvimento Rural sintético para todas as microrregiões brasileiras.

Muitos trabalhos foram realizados procurando construir índices de desenvolvimento rural municipal para diferentes estados da federação. Nestes trabalhos são utilizados dois métodos principais, sendo um baseado em média ponderada utilizado por Kageyama (2004), e o outro, em estatística multivariada desenvolvido por Melo e Parré (2007).

Neste artigo pretende-se apresentar um Índice de Desenvolvimento Rural dos municípios do estado do Pará, utilizando-se estatística multivariada. Destaca-se que outros trabalhos foram realizados no estado do Pará com o mesmo intuito, utilizando, no entanto, a metodologia adotada por Kageyama (2004), como o de Souza (2014) que caracteriza os municípios do estado e Santos (2015) que faz a abordagem a partir das diferentes regiões do estado.

\subsection{A ANÁLISE FATORIAL}

A análise fatorial se refere a uma variedade de técnicas da estatística multivariada cujo objetivo é representar um conjunto de variáveis em termos de um menor número de variáveis hipotéticas (KIM; MUELLER, 1978 apud STEGE; PARRÉ, 2011). As variáveis hipotéticas recebem o nome de fatores comuns e vão estar relacionadas com as variáveis originais através de um modelo linear (MINGOTI, 2005). De acordo com Rezende e Parré (2004 apud MELO; PARRÉ, 2007) esta técnica permite extrair um número reduzido de fatores, que são combinações lineares das variáveis originais, perdendo o mínimo de informações.

O método de análise fatorial pode ser expresso na forma matemática através de uma combinação linear entre as variáveis $\left(X_{i}\right)$ e K fatores comuns $(F)$ :

$$
X_{i}=A_{i 1} F_{1}+A_{i 2} F_{2}+\cdots+A_{i k} F_{k}+U_{i}+E_{i}
$$

Onde: $A_{i k}$ - Cargas fatoriais, usadas para combinar linearmente os fatores comuns.

$F_{1}, F_{2}, \ldots, F_{k}$ - Fatores comuns.

$U_{i}$ - Fator único

$E_{i}$ - Fator de erro

As cargas fatoriais indicam a intensidade das relações entre as variáveis normalizadas $X_{i}$ e os fatores. Quanto maior uma carga fatorial, mais associada com o fator se encontra a variável. A variância comum $h_{i}^{2}$, ou comunalidade, representa quanto da variância total de $X_{i}$ é reproduzida pelos fatores comuns, sendo calculada a partir do somatório ao quadrado das cargas fatoriais. A variância única $U_{i}$ é a parte da variância total que não se associa com a variância das outras variáveis. $O$ termo $E_{i}$ representa o erro de observação, de mensuração ou de especificação do modelo.

A medida denominada de autovalor, ou raiz característica, expressa a variância total do modelo explicada por cada fator. De acordo com Ferreira Junior, Baptista e Lima (2003 apud MELO; PARRÉ, 2007, p. 336), o seu valor é o somatório dos quadrados das cargas fatoriais de cada variável associada ao fator específico e refletem a importância relativa de cada fator, bem como a variância de cada um deles. É através desse valor que se define quantos fatores serão retidos. A quantidade de fatores retidos será igual ao número de autovalores maiores ou igual a 1 , a fim de manter no sistema novas dimensões que representem pelo menos a informação de variância de uma variável original (MINGOTI, 2005). O autovalor divido pelo número de variáveis $\left(X_{i}\right)$ determina a proporção da 
variância total explicada pelo fator. Esse valor irá revelar o quanto cada fator consegue captar da variabilidade original das variáveis.

Para facilitar a interpretação destes fatores é realizada uma rotação ortogonal pelo método varimax, que procura minimizar o número de variáveis fortemente relacionadas com cada fator, permitindo, assim, obter fatores mais facilmente interpretáveis (MELO; PARRÉ, op. cit., p. 336).

Através da utilização do software Stata (versão MP 13), foram obtidos os fatores e selecionados os que apresentaram valores maiores que 1. Identificados os fatores, é feita a estimação do escore fatorial, por meio do método semelhante ao da regressão. O escore para cada observação (município) é resultado da multiplicação do valor (padronizado) das variáveis pelo coeficiente do escore fatorial correspondente, sendo a expressão geral para estimação do j-ésimo fator $F_{j}$ dada por:

$$
F_{j}=W_{j 1} X_{1}+W_{j 2} X_{2}+W_{j 3} X_{3}+\cdots+W_{j p} X_{p}
$$

em que os W_ij são os coeficientes dos escores fatoriais e p é o número de variáveis.

Os escores fatoriais de cada fator possuem distribuição normal, com média zero e variância unitária e, desse modo, podem ser utilizadas para indicar a posição relativa de cada observação relativamente ao conceito expresso pelo fator. Assim, a partir da matriz dos escores fatoriais, é possível construir um índice para hierarquizar as observações (MONTEIRO; PINHEIRO, 2004 apud ibid., p. 337).

A verificação do grau de desenvolvimento de cada município paraense foi feita através dos escores fatoriais, ou seja, dos valores dos fatores para cada uma das 143 observações (municípios). Através da equação 3 , obtevese o Índice Bruto de Desenvolvimento, por meio do cálculo da média dos fatores (ponderada pela variância) pertencentes a cada município. Como procedeu-se à análise fatorial pelo método de componentes principais (que faz com que o primeiro fator contenha o maior percentual de explicação da variância total das variáveis da amostra, o segundo fator contenha o segundo maior percentual, e assim por diante) (FERREIRA JUNIOR; BAPTISTA; LIMA, 2003 apud ibid, p. 338), a ponderação pela proporção de explicação da variância total exprime a importância relativa de cada fator (MELO; PARRÉ, loc. cit.). A análise dos valores de cada um dos fatores que compõem o índice (Tabela 4 - Anexo) pode contribuir para focar alguma característica específica.

$$
I B=\frac{\sum_{i=1}^{5}\left(w_{i} F_{i}\right)}{\sum_{i=1}^{5} w_{i}}
$$

Sendo: IB = Índice bruto (média ponderada dos escores fatoriais)

$w_{i}=$ Proporção da variância explicada por cada fator

$F_{i}=$ Escores fatoriais

A partir daí, interpola-se os resultados, considerando-se o maior valor como 100 e o menor como zero, obtendo o Índice de Desenvolvimento Rural (IDR) para cada município. Foram considerados como grau de desenvolvimento muitíssimo alto (MMA) aqueles que apresentaram resultados com três desvios-padrão acima da média; muito alto (MA) aqueles com resultados entre dois e três desvios-padrão acima da média; alto $(A)$, aqueles com valores entre um e dois desviospadrão acima da média; médio ( $M$ ), os que apresentaram resultado entre a média e um desvio-padrão acima da média; baixo (B), aqueles com resultados no intervalo entre a média e um desvio-padrão abaixo da média; 
muito baixo (MB), aqueles que tiveram resultados entre um e dois desvios-padrão abaixo da média; muitíssimo baixo (MMB), os que tiveram resultados no intervalo entre dois e três desvios-padrão abaixo da média (MELO; PARRÉ, loc. cit.).

Para verificar a adequabilidade do modelo é utilizada a estatística de Kaiser-Meyer-Olkin (KMO) e o teste de esfericidade de Barlett.

\subsection{DESCRIÇÃO DAS VARIÁVEIS}

A análise do desenvolvimento rural como um todo vai além do domínio da economia, identificado pelo progresso econômico. Engloba um conjunto de indicadores que interagem entre si, reunindo aspectos sociais, demográficos, econômicos e ambientais, ou seja, trata-se de um fenômeno multidimensional. Utilizando estas quatro dimensões é possível encontrar variáveis que podem ser utilizadas para tentar explicar a "causa" do desenvolvimento.

As variáveis utilizadas neste trabalho foram extraídas da dissertação de Santos (2015). Segue Quadro 1 com cada uma das variáveis e suas fontes de dados.

Quadro 1. Variáveis selecionadas para o cálculo do IDR.

\begin{tabular}{|c|c|c|c|c|}
\hline Dimensão & $\begin{array}{c}\text { Variável e sua relação com o } \\
\text { desenvolvimento: positiva (+) ou } \\
\text { negativa (-) }\end{array}$ & Forma de Cálculo & Unidade & Fonte de Dados \\
\hline \multirow{4}{*}{ 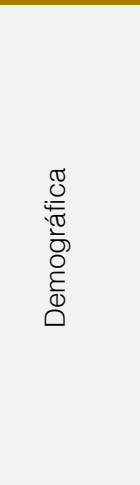 } & $\begin{array}{l}\text { X1) Densidade demográfica } \\
(\text { padronizada })^{\star}(+)\end{array}$ & $\begin{array}{l}\text { Proporção de habitantes (total) do } \\
\text { município em relação a sua área }\end{array}$ & $\begin{array}{l}\mathrm{hab} / \\
\mathrm{km}^{2}\end{array}$ & $\begin{array}{l}\text { Censo } \\
\text { Demográfico IBGE } \\
\text { (2010) }\end{array}$ \\
\hline & 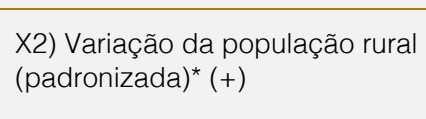 & $\begin{array}{l}\text { Taxa de crescimento da } \\
\text { população rural entre os anos de } \\
2010 \text { e } 2000\end{array}$ & $\%$ & $\begin{array}{l}\text { Censo } \\
\text { Demográfico IBGE } \\
(2000 \text { e 2010) }\end{array}$ \\
\hline & $\begin{array}{l}\text { X3) Proporção de população } \\
\text { rural do município (+) }\end{array}$ & $\begin{array}{l}\text { Proporção da população rural do } \\
\text { município pela sua população total }\end{array}$ & $\%$ & $\begin{array}{l}\text { Censo } \\
\text { Demográfico IBGE } \\
(2010)\end{array}$ \\
\hline & $\begin{array}{l}\text { X4) Proporção de população de } \\
\text { migrantes (+) }\end{array}$ & $\begin{array}{l}\text { Proporção da população que não } \\
\text { morou sempre no município pela } \\
\text { sua população total }\end{array}$ & $\%$ & $\begin{array}{l}\text { Censo } \\
\text { demográfico IBGE } \\
(2010)\end{array}$ \\
\hline \multirow{6}{*}{$\begin{array}{l}\frac{\bar{\pi}}{\mathrm{O}} \\
\stackrel{\leftrightarrow}{\infty}\end{array}$} & $\begin{array}{l}\text { X5) Índice de Desenvolvimento } \\
\text { Humano (IDH) - Longevidade } \\
(+)\end{array}$ & Esperança de vida ao nascer & Escala $(0-1)$ & $\begin{array}{l}\text { ADH - Atlas do } \\
\text { Desenvolvimento } \\
\text { Humano no Brasil } \\
(2013)\end{array}$ \\
\hline & X6) Taxa de alfabetização (+) & $\begin{array}{l}\text { População rural alfabetizada em } \\
\text { relação à população rural }\end{array}$ & $\%$ & $\begin{array}{l}\text { Censo } \\
\text { Demográfico IBGE } \\
(2010)\end{array}$ \\
\hline & X7) Intensidade de pobreza* ${ }^{*}(-)$ & $\begin{array}{l}\text { Distância que separa a renda } \\
\text { domiciliar per capita média dos } \\
\text { indivíduos pobres do valor da } \\
\text { linha de pobreza, medida em } \\
\text { termos de percentual do valor } \\
\text { dessa linha de pobreza }\end{array}$ & $\%$ & $\begin{array}{l}\text { ADH - Atlas de } \\
\text { Desenvolvimento } \\
\text { Humano no Brasil } \\
\text { (2013) }\end{array}$ \\
\hline & $\begin{array}{l}\text { X8) Domicílios rurais com } \\
\text { abastecimento de água } \\
\text { proveniente da rede geral (+) }\end{array}$ & $\begin{array}{l}\text { Proporção dos domicílios rurais } \\
\text { servido de água proveniente de } \\
\text { uma rede geral de abastecimento } \\
\text { pelo total de domicílios rurais }\end{array}$ & $\%$ & $\begin{array}{l}\text { Censo } \\
\text { Demográfico IBGE } \\
(2010)\end{array}$ \\
\hline & $\begin{array}{l}\text { X9) Domicílios rurais com } \\
\text { instalação de energia elétrica } \\
\text { de companhia distribuidora (+) }\end{array}$ & $\begin{array}{l}\text { Proporção dos domicílios rurais } \\
\text { que possuem energia elétrica pelo } \\
\text { total de domicílios rurais }\end{array}$ & $\%$ & $\begin{array}{l}\text { Censo } \\
\text { Demográfico IBGE } \\
(2010)\end{array}$ \\
\hline & $\begin{array}{l}\text { X10) Domicílios rurais com } \\
\text { esgoto sanitário - fossa séptica } \\
(+)\end{array}$ & $\begin{array}{l}\text { Proporção de domicílios rurais } \\
\text { com esgoto sanitário - fossa } \\
\text { séptica pelo total de domicílios } \\
\text { rurais }\end{array}$ & $\%$ & $\begin{array}{l}\text { Censo } \\
\text { Demográfico IBGE } \\
(2010)\end{array}$ \\
\hline
\end{tabular}


(continuação...)

\begin{tabular}{|c|c|c|c|c|}
\hline Dimensão & $\begin{array}{c}\text { Variável e sua relação com o } \\
\text { desenvolvimento: positiva (+) ou } \\
\text { negativa (-) }\end{array}$ & Forma de Cálculo & Unidade & Fonte de Dados \\
\hline \multirow{3}{*}{ 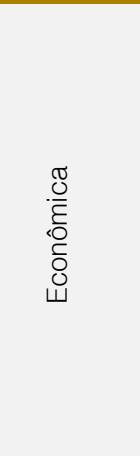 } & $\begin{array}{l}\text { X11) Índice de Desenvolvimento } \\
\text { Humano (IDH) - Renda (+) }\end{array}$ & $\begin{array}{l}\text { Soma da renda de todos os } \\
\text { residentes dividido pelo número } \\
\text { de pessoas que moram no } \\
\text { município }\end{array}$ & Escala (0-1) & $\begin{array}{l}\text { ADH - Atlas do } \\
\text { Desenvolvimento } \\
\text { Humano no Brasil } \\
\text { (2013) }\end{array}$ \\
\hline & $\begin{array}{l}\text { X12) Valor bruto de produção } \\
\text { por estabelecimento } \\
\text { agropecuário (padronizado) } \\
(+)\end{array}$ & $\begin{array}{l}\text { Valor bruto da produção } \\
\text { agropecuária pelo número de } \\
\text { estabelecimentos agropecuários }\end{array}$ & $R \$$ & $\begin{array}{l}\text { Censo } \\
\text { Agropecuário } \\
\text { IBGE (2006) }\end{array}$ \\
\hline & $\begin{array}{l}\text { X13) Valor bruto de produção } \\
\text { por pessoa ocupada na } \\
\text { agropecuária (padronizado) } \\
(+)\end{array}$ & $\begin{array}{l}\text { Valor bruto da produção } \\
\text { agropecuária pelo número de } \\
\text { pessoas ocupadas nos } \\
\text { estabelecimentos agropecuários }\end{array}$ & $R \$$ & $\begin{array}{l}\text { Censo } \\
\text { Agropecuário } \\
\text { IBGE (2006) }\end{array}$ \\
\hline \multirow{5}{*}{$\begin{array}{l}\frac{\pi}{\pi} \\
\frac{0}{0} \\
\frac{0}{2} \\
\frac{1}{4}\end{array}$} & $\begin{array}{l}\text { X14) Estabelecimentos com } \\
\text { práticas de conservação (+) }\end{array}$ & $\begin{array}{l}\text { Proporção de estabelecimentos } \\
\text { que praticam a conservação do } \\
\text { solo somado aos que não fazem } \\
\text { queimadas pelo total }\end{array}$ & $\%$ & $\begin{array}{l}\text { Censo } \\
\text { Agropecuário } \\
\text { IBGE (2006) }\end{array}$ \\
\hline & $\begin{array}{l}\text { X15) Matas naturais e plantadas } \\
(+)\end{array}$ & $\begin{array}{l}\text { Proporção de matas naturais e } \\
\text { plantadas pela área total }\end{array}$ & $\%$ & $\begin{array}{l}\text { Censo } \\
\text { Agropecuário } \\
\text { IBGE (2006) }\end{array}$ \\
\hline & $\begin{array}{l}\text { X16) Estabelecimentos que } \\
\text { utilizam agrotóxico*^ }(-)\end{array}$ & $\begin{array}{l}\text { Proporção de estabelecimentos } \\
\text { rurais que fazem uso de } \\
\text { agrotóxicos pelo total }\end{array}$ & $\%$ & $\begin{array}{l}\text { Censo } \\
\text { Agropecuário } \\
\text { IBGE (2006) }\end{array}$ \\
\hline & $\begin{array}{l}\text { X17) Estabelecimentos com uso } \\
\text { de adubação orgânica (+) }\end{array}$ & $\begin{array}{l}\text { Proporção de estabelecimentos } \\
\text { rurais que fazem uso de adubação } \\
\text { orgânica pelo total }\end{array}$ & $\% \%$ & $\begin{array}{l}\text { Censo } \\
\text { Agropecuário } \\
\text { IBGE (2006) }\end{array}$ \\
\hline & $\begin{array}{l}\text { X18) Proporção de domicílios } \\
\text { rurais com coleta de lixo - } \\
\text { coletado por serviço de limpeza } \\
\text { e caçamba de serviço de } \\
\text { limpeza (+) }\end{array}$ & $\begin{array}{l}\text { Proporção dos domicílios rurais } \\
\text { que possuem lixo coletado pelo } \\
\text { total de domicílios rurais }\end{array}$ & $\% \%$ & $\begin{array}{l}\text { Censo } \\
\text { Demográfico IBGE } \\
\text { (2010) }\end{array}$ \\
\hline
\end{tabular}

Fonte: Elaboração própria.

* Segundo Kageyama (2004) a padronização consiste em uma transformação algébrica para que o índice varie no intervalo de zero a um. Essa transformação é feita da seguinte forma: (valor da variável - mínimo) / (máximo - mínimo).

** Quando uma variável é negativa (-) em relação ao desenvolvimento, ela é invertida, ou seja, é subtraída uma unidade do resultado.

Os indicadores demográficos (X1 a $\mathrm{X} 4)$ procuram medir o dinamismo populacional que deveria favorecer o desenvolvimento rural. Segundo Kageyama (2004 e 2008), uma densidade demográfica elevada indica menor isolamento das áreas rurais, o que significa maior diversificação, multifuncionalidade e progresso social; uma grande população rural e seu crescimento na década indica maior capacidade da área rural de reter população; a migração de pessoas de outros municípios reforça a capacidade de atração daquele município na região.

As variáveis $\mathrm{X} 5$ a $\mathrm{X} 10$ são indicadores sociais de bem-estar dos residentes nas áreas rurais e demonstram se as pessoas ali residentes desfrutam de melhor qualidade de vida ou não. A variável Índice de Desenvolvimento Humano (IDH) - Longevidade representa a esperança de vida ao nascer para o município como um todo, refletindo assim as condições de saúde e de salubridade no local. Quanto a taxa de alfabetização rural, é um indicador educacional que tem correspondência positiva com o IDR.

A intensidade de pobreza é um indicador que permite obter informações pelo desvio médio entre a renda dos pobres e o valor da linha de pobreza e que mede a distribuição média da renda dos pobres no que se refere à linha de pobreza, ou seja, auxilia a identificar os mais pobres dos pobres (MELO, 2005). A variável tem uma correspondência negativa com o IDR e, portanto, utilizou-se um índice de 
intensidade de não-pobreza. As variáveis relacionadas às condições de infraestrutura dos domicílios rurais (instalação sanitária, água encanada e energia elétrica) estão ligadas a qualidade de vida e afetam positivamente o IDR (STEGE; PARRÉ, 2011).

As variáveis $\mathrm{X} 11$ a $\mathrm{X} 13$ são indicadores de desempenho econômico relacionados ao valor do setor agropecuário no município. A variável Índice de Desenvolvimento Humano (IDH) - Renda revela melhoria no sistema e tem relação positiva com o desenvolvimento rural (CONTERATO et al., 2009).

As variáveis relacionadas a produtividade dos fatores de produção afetam de forma positiva o desenvolvimento rural (STEGE; PARRÉ, 2011). A produtividade do trabalho na agricultura é medida pelo quociente entre o Valor Bruto da Produção Agropecuária (VBP) e o pessoal ocupado na agropecuária (população ocupada na agricultura, pecuária, silvicultura, exploração florestal e pesca).

As variáveis X14 a X18 destacam a influência das questões ambientais na conservação do meio rural e seu desenvolvimento. Segundo Kageyama (2004), os indicadores de meio ambiente procuram contrapor a presença dos efeitos nocivos do modelo de modernização agrícola com os efeitos compensadores de práticas de conservação do solo.

O uso de agrotóxicos possui uma relação negativa com o IDR e este indicador é transformado em não uso de agrotóxicos. A existência de matas naturais ou plantadas é um atributo importante para que, através da conservação da natureza, as áreas rurais cumpram a função de provedora de serviços ambientais e de bens públicos.

\section{RESULTADOS E DISCUSSÃO}

A análise aplicada ao modelo possibilitou a extração de seis fatores com raiz característica maior que a unidade e que sintetizam as contidas nas 18 variáveis originais. Após a rotação, os seis fatores selecionados explicam, em conjunto, $68,77 \%$ da variância total das variáveis selecionadas, conforme Tabela 1. O uso da variância de $68,77 \%$ é justificado por Hair et al. (2009), pois, segundo o autor, obter uma variância acumulada de $60 \%$ é satisfatório nas ciências sociais.

Tabela 1 - Raiz característica, percentual explicado por cada fator e variância acumulada

\begin{tabular}{|c|c|c|c|}
\hline Fator & Raiz característica & $\begin{array}{c}\text { Variância explicada pelo } \\
\text { fator (\%) }\end{array}$ & Variância acumulada (\%) \\
\hline F1 & 3,10379 & 17,24 & 17,24 \\
\hline F2 & 3,03841 & 16,88 & 34,12 \\
\hline F3 & 2,08767 & 11,60 & 45,72 \\
\hline F4 & 1,63675 & 9,09 & 54,81 \\
\hline F5 & 1,33650 & 7,43 & 62,24 \\
\hline F6 & 1,17482 & 6,53 & 68,77 \\
\hline
\end{tabular}

Fonte: Resultados da pesquisa

O teste de Bartlett mostrou-se significativo, rejeitando a hipótese nula de que a matriz de correlação é uma matriz identidade. O teste de KMO, para análise da adequabilidade da amostra apresentou valor de 0,6981, indicando que a amostra é passível de ser analisada pelas técnicas de análise fatorial.

A Tabela 2 apresenta as cargas fatoriais e as comunalidades para os fatores considerados.
Para sua interpretação foram consideradas apenas as cargas fatoriais com valores superiores a 0,50 (em negrito), buscando evidenciar os indicadores mais fortemente associados a determinado fator. Os valores encontrados para as comunalidades revelam que praticamente todas as variáveis têm sua variabilidade captada e representada pelos seis fatores. 
Tabela 2 - Cargas fatoriais e comunalidades

\begin{tabular}{|c|c|c|c|c|c|c|c|}
\hline \multirow{2}{*}{ Indicadores } & \multicolumn{6}{|c|}{ Cargas Fatoriais } & \multirow{2}{*}{ Comunalidades } \\
\hline & $\mathrm{F} 1$ & F2 & F3 & $\mathrm{F} 4$ & F5 & F6 & \\
\hline $\mathrm{X} 1$ & $-0,0358$ & 0,6194 & $-0,1681$ & 0,3461 & 0,3584 & $-0,0334$ & 0,6626 \\
\hline$x 2$ & 0,1968 & $-0,1141$ & 0,4174 & 0,5798 & $-0,1309$ & $-0,0279$ & 0,5801 \\
\hline$x 3$ & $-0,0903$ & $-0,7978$ & $-0,0711$ & 0,1988 & $-0,1435$ & $-0,0023$ & 0,7098 \\
\hline X4 & 0,0476 & 0,4602 & 0,1659 & $-0,5625$ & $-0,0391$ & 0,2136 & 0,6052 \\
\hline$x 5$ & 0,0384 & 0,6906 & $-0,0136$ & 0,0149 & $-0,3818$ & $-0,1139$ & 0,6375 \\
\hline$x 6$ & 0,6589 & 0,2774 & $-0,0459$ & 0,1708 & $-0,0551$ & 0,0594 & 0,5489 \\
\hline X7 & 0,3747 & 0,6397 & 0,1686 & $-0,0821$ & 0,2755 & $-0,1983$ & 0,6999 \\
\hline X8 & 0,7954 & $-0,1858$ & $-0,0003$ & 0,0907 & 0,1814 & $-0,0894$ & 0,7162 \\
\hline X9 & 0,7208 & 0,1674 & 0,0352 & $-0,2660$ & 0,2921 & $-0,0112$ & 0,7049 \\
\hline $\mathrm{X} 10$ & 0,6563 & 0,0417 & $-0,1034$ & $-0,1167$ & $-0,0939$ & 0,0870 & 0,4732 \\
\hline $\mathrm{X} 11$ & 0,2147 & 0,8238 & 0,2220 & $-0,2605$ & $-0,0220$ & 0,1228 & 0,8574 \\
\hline $\mathrm{X} 12$ & $-0,0189$ & 0,0838 & 0,9288 & $-0,0149$ & 0,0513 & 0,0431 & 0,8748 \\
\hline $\mathrm{X} 13$ & $-0,0408$ & 0,1338 & 0,9148 & $-0,0994$ & 0,0948 & $-0,0563$ & 0,8785 \\
\hline $\mathrm{X} 14$ & 0,1145 & 0,0558 & 0,1191 & $-0,1776$ & 0,7913 & 0,0669 & 0,6925 \\
\hline $\mathrm{X} 15$ & $-0,0909$ & $-0,0501$ & $-0,1538$ & 0,7147 & $-0,1170$ & 0,2444 & 0,6186 \\
\hline $\mathrm{X} 16$ & $-0,0501$ & $-0,0260$ & $-0,0082$ & 0,1024 & 0,0645 & 0,9189 & 0,8622 \\
\hline $\mathrm{X} 17$ & 0,5297 & 0,1323 & $-0,0106$ & 0,2554 & 0,4012 & $-0,3314$ & 0,6342 \\
\hline $\mathrm{X} 18$ & 0,7362 & 0,1969 & 0,1518 & $-0,0095$ & $-0,0110$ & $-0,1314$ & 0,6213 \\
\hline
\end{tabular}

Percebe-se que o fator F1 está positiva e fortemente relacionado com 0 indicador X6, que expressa a taxa de alfabetização rural; com as variáveis $X 8, X 9$ e $X 10$, proporção de domicílios rurais com abastecimento de água, com energia elétrica e com esgoto sanitário/fossa séptica, respectivamente, ou seja, variáveis ligadas a infraestrutura no meio rural; com a variável $X 17$, estabelecimento com o uso de adubação orgânica; e X18, que refere-se a domicílios rurais com coleta de lixo, ligado a serviço fornecido ao meio rural; ambos relacionados a qualidade ambiental. $\mathrm{O}$ fator 1 explica $17,24 \%$ do total da variância acumulada e está ligado as instalações e serviços fornecidos as populações e aos domicílios rurais, o que Kageyama (2008) trata como condições de bem estar nos domicílios rurais.

O fator F2 é positivamente relacionado com as variáveis $X 1$, de densidade demográfica; X5, X11 e X7, ou seja, IDH - Longevidade, IDH - Renda e intensidade de não pobres, respectivamente. Entretanto, o fator F2 é negativamente relacionado a variável $\mathrm{X} 3$, a proporção de população rural no município. $O$ fator dá ênfase a indicadores de ordem social para o município como um todo, que podem revelar municípios com maior qualidade de vida. Além disso, pode demonstrar que municípios com maior crescimento urbano, de maior densidade demográfica, proporcionam maior desenvolvimento rural e, por outro lado, municípios com maior população rural comparada a urbana, estão negativamente associados aos indicadores sociais. Este fator responde por $16,88 \%$ da variância acumulada e corresponde a condicionantes demográficas que podem explicar a relação intrínseca entre crescimento urbano e indicadores sociais de desenvolvimento.

$\mathrm{O}$ fator F3 possui uma relação forte com as variáveis X12 e X13, ou seja, o valor bruto da produção por estabelecimento agropecuário e por pessoa ocupada na agropecuária, respectivamente. É um fator ligado aos indicadores de desempenho econômico derivados da produção e produtividade agropecuária, característicos do modelo de produção agropecuário moderno.

O fator F4 está relacionado com as variáveis X2 e X15 que correspondem ao crescimento da população rural no período medido e a cobertura de matas naturais ou plantadas, respectivamente. Por outro lado, há uma relação negativa com a variável $\mathrm{X} 4$, a 
população de migrantes. Ou seja, este fator revela uma forte relação do crescimento populacional rural naqueles municípios de maior riqueza de recursos naturais, o que revela uma correlação entre o desenvolvimento rural e a abundância de recursos naturais. Por outro lado, há uma correspondência entre este desenvolvimento e a característica da população local (migrante ou nativa). O aumento da taxa de crescimento da população rural medido neste período está associado aos municípios com menor população migrante, e vice-versa.

O fator F5 possui uma relação com a variável $\mathrm{X} 14$, que abrange os estabelecimentos com práticas de conservação. É um fator que leva em consideração exclusivamente o aspecto ambiental do modelo de produção.

O fator F6 também possui uma relação com outro indicador ambiental relativo ao modelo de produção, a variável X16, indicador ambiental que revela estabelecimentos que não utilizam agrotóxico.
Uma vez verificadas as cargas fatoriais, o passo seguinte é observar os escores fatoriais, ou seja, o valor do fator para cada município do estado. A análise do fator deve ser feita levando em conta que seus escores originais, quando considerados todos os municípios em conjunto, são variáveis com média e desvio padrão igual a 1. Portanto, pode-se interpretar que os escores com valores próximos de zero indicam nível de desenvolvimento médio e, quanto maior em relação a zero for o fator, mais avançado será o município, no que se refere ao significado do fator em consideração. A Tabela 4, em anexo, apresenta os resultados por município.

O IDR médio situou-se em 41,64. A partir daí, foram definidas as categorias de desenvolvimento rural. Pode-se então construir um mapa que melhor visualiza como está a distribuição do desenvolvimento rural dentro do estado, apresentado na Figura 1.

Figura 1 - Mapa do Índice de Desenvolvimento Rural dos municípios do Pará

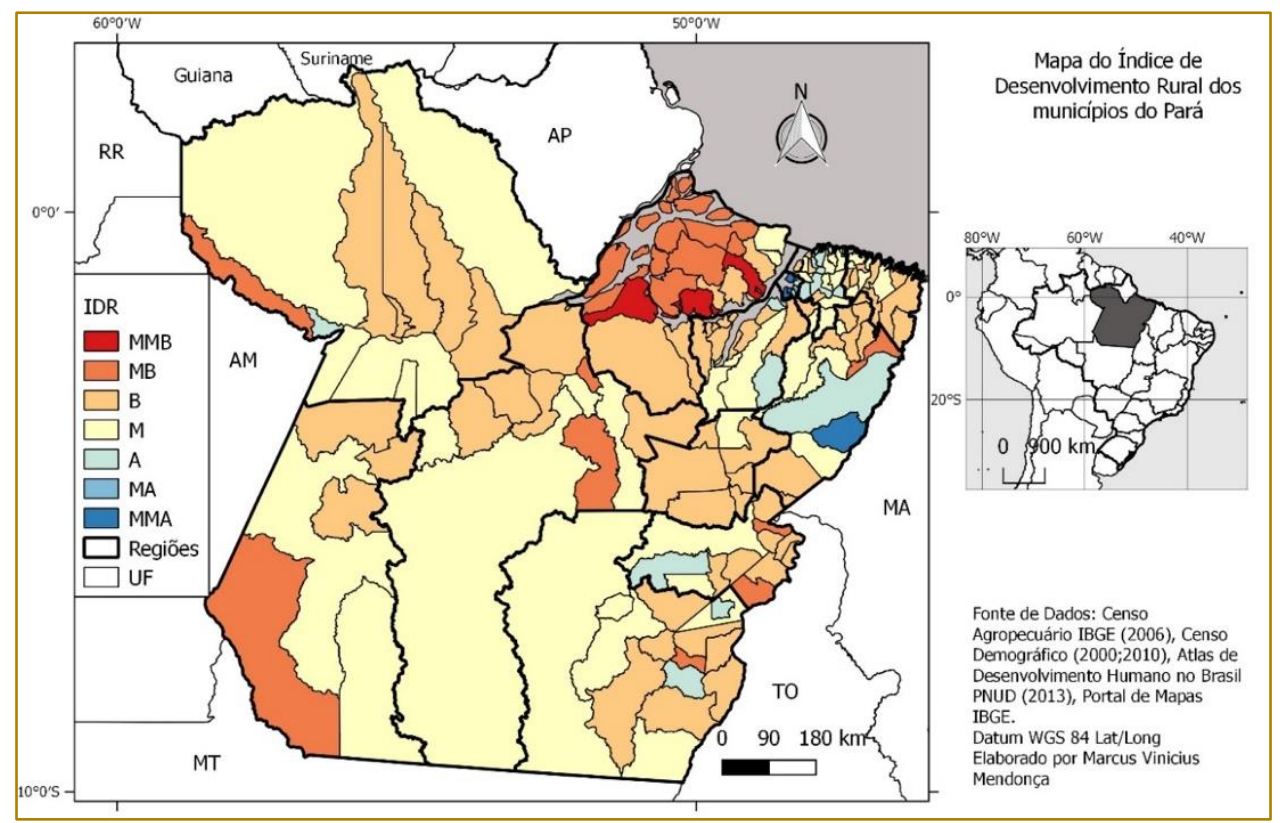

Fonte: Elaboração própria, 2017, a partir dos dados obtidos

Os municípios do estado são agrupados de acordo com a sua localização através da divisão administrativa que adota 12 regiões de integração, conforme a Figura 2. 
Figura 2 - Mapa das Regiões de Integração do Estado do Pará

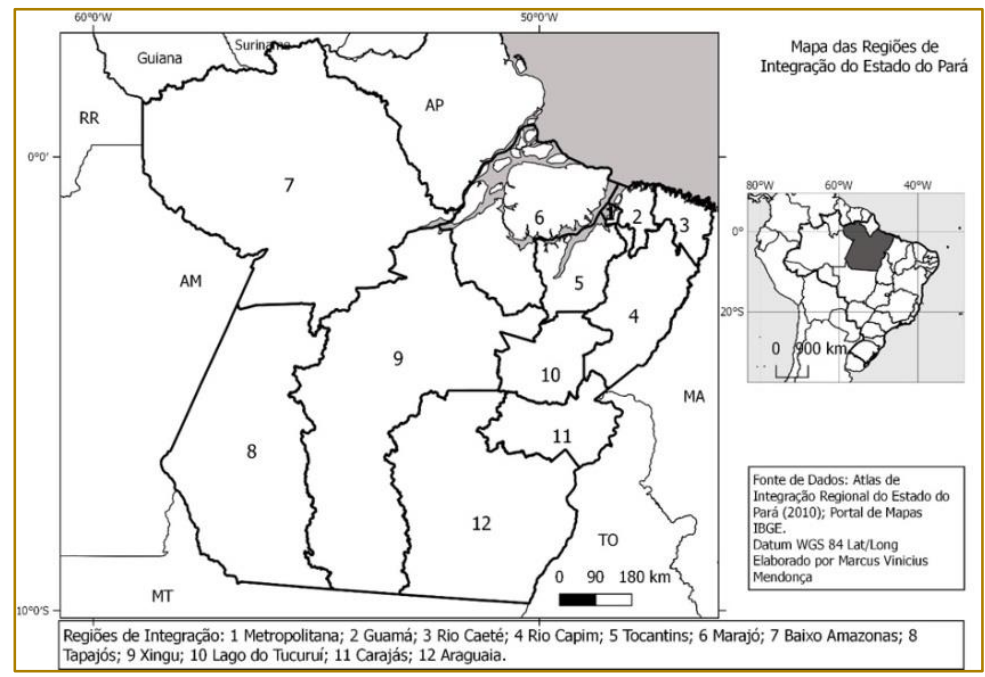

Fonte: Elaboração própria, 2018.

A Tabela 3 mostra que, de acordo com a classificação, as regiões Metropolitana e Rio Capim possuem quatro municípios com grau de IDR muitíssimo alto e muito alto (MMA e MA). Na categoria de alto desenvolvimento (A) não há municípios das regiões Lago de Tucuruí, Marajó, Tapajós e Xingu. Tanto na categoria de médio desenvolvimento (M) quanto na de baixo desenvolvimento (B) são registrados municípios de todas as regiões, com exceção da Metropolitana. Na categoria de desenvolvimento muito baixo (MB) há municípios das regiões do Araguaia, Baixo Amazonas, Carajás, Marajó, Rio Capim, Tapajós e Xingu. A região Marajó tem três municípios na mais baixa categoria de desenvolvimento (MMB).

Tabela 3 - Grau de desenvolvimento rural dos municípios paraenses

\begin{tabular}{|l|c|c|c|c|c|c|c|}
\multicolumn{1}{c}{} & \multicolumn{9}{c}{ Região } & \multicolumn{7}{c}{ Número do Municípios por grau de desenvolvimento } \\
\hline Araguaia & MMA & MA & A & M & B & MB & MMB \\
\hline Baixo Amazonas & 0 & 0 & 2 & 5 & 7 & 1 & 0 \\
\hline Carajás & 0 & 0 & 1 & 5 & 5 & 1 & 0 \\
\hline Guamá & 0 & 0 & 1 & 2 & 7 & 2 & 0 \\
\hline Lago de Tucuruí & 0 & 0 & 6 & 9 & 3 & 0 & 0 \\
\hline Marajó & 0 & 0 & 0 & 1 & 6 & 0 & 0 \\
\hline Metropolitana & 0 & 0 & 0 & 2 & 5 & 6 & 3 \\
\hline Rio Caeté & 2 & 1 & 2 & 0 & 0 & 0 & 0 \\
\hline Rio Capim & 0 & 0 & 1 & 6 & 8 & 0 & 0 \\
\hline Tapajós & 1 & 0 & 1 & 5 & 8 & 1 & 0 \\
\hline Tocantins & 0 & 0 & 0 & 2 & 3 & 1 & 0 \\
\hline Xingu & 0 & 0 & 2 & 3 & 6 & 0 & 0 \\
\hline
\end{tabular}

Fonte: Resultados da pesquisa

Somando-se os municípios abaixo da linha de médio desenvolvimento chega-se ao total de 79 ou $55,24 \%$ dos municípios, ou seja, mais da metade dos municípios do estado do Pará encontra-se com baixo grau de desenvolvimento.

A região Metropolitana é a única que apresenta todos os municípios classificados entre graus de desenvolvimento alto e muitíssimo alto. A região ainda concentrava 45\% do PIB estadual no ano de 2005 (SILVA, 2012). A elevada concentração de população urbana proporciona maior mercado consumidor para os produtos provenientes das áreas rurais, estimulando a diversificação da produção. Belém, Ananindeua e Marituba apresentam melhores indicadores sociais. Benevides, Marituba e Santa Bárbara do Pará apresentam maior acesso a infraestrutura e serviços no meio rural. Há um aumento da população rural em municípios de grande porte como Belém e Ananindeua. Conforme explica Silva (1997), nas regiões metropolitanas as populações são atraídas 
por empregos gerados por indústrias e agroindústrias instaladas nas áreas rurais, a expansão de condomínios rurais e zonas suburbanas e atividades ligadas a preservação ambiental.

O Guamá é a segunda região em proporção de municípios com maior desenvolvimento rural. A região beneficia-se da proximidade com a área metropolitana e o acesso ao seu mercado consumidor. O principal município da região é Castanhal que, segundo o Atlas de Integração Regional do Estado do Pará (PARÁ, 2010), possui uma importante produção industrial e funciona como um centro comercial fornecedor de insumos e equipamentos para a agricultura. A população rural é beneficiada pelo acesso a infraestrutura e serviços em todos os municípios. Os indicadores sociais, todavia, ainda são desiguais entre os municípios. O município de São João da Ponta destaca-se pela alta produção por estabelecimento e por pessoa ocupada na agropecuária, sendo o seu principal produto a mandioca.

Conforme Costa (2000) e Hébette (2004), citados por Silva (2012), os municípios da região Rio Caeté estão em sua maioria classificados com IDR abaixo da média do estado. A maior parte dos municípios desta região, conhecida anteriormente como Bragantina, teve grande participação na riqueza estadual nos séculos passados, porém se distanciou da rota dos investimentos dos interesses do capital privado e dos interesses governamentais, em especial, porque tinha uma produção mais restrita à capital Belém.

Em geral, a maioria dos municípios do Rio Caeté apresentou melhorias nos indicadores de acesso a infraestrutura e serviços pelos domicílios rurais. Entretanto, os indicadores sociais da grande maioria são baixos. Destacam-se os municípios de Salinópolis, que possui o turismo como importante atividade econômica, e Capanema com bons indicadores sociais. Bragança é o município mais populoso da região (PARÁ, 2010).

A região Rio Capim, chamada anteriormente de Guajarina, começou a ser colonizada entre a década de 1940 e 1950, com orientação ao abastecimento do mercado de Belém (SILVA, 2012). Apresenta maior variabilidade na classificação dos municípios quanto ao IDR. A maioria dos municípios está entre médio e baixo IDR. Em geral, apresentam indicadores razoáveis de acesso a infraestrutura e serviços pela população rural, mas baixos indicadores sociais. O município de Nova Esperança do Piriá é o de mais baixo desenvolvimento na região. Entretanto há um município com grau de desenvolvimento muito alto, Ulianópolis, e outro com grau de desenvolvimento alto, Paragominas.

Ulianópolis e Paragominas destacam-se com índices econômicos de produção por estabelecimento e por pessoa ocupada na agropecuária. Em Ulianópolis desenvolve-se uma agricultura altamente tecnificada através do plantio de cana para produção de açúcar. Este município, porém, apresenta infraestrutura e indicadores sociais piores que vários municípios da região. O município de Paragominas apresenta maior destaque na região, constituindo-se como um provedor de serviços, máquinas e equipamentos. No setor agropecuário também destaca-se através da produção de grãos e pecuária.

Na região Tocantins ocorre uma característica que diferencia estes municípios entre si que é o meio de transporte. Parte deles são atravessados pelo rio Tocantins e os principais acessos são pelos rios. Em outros os acessos principais são por estradas. Municípios como Barcarena e Tailândia apresentam um alto IDR, com bons resultados para infraestrutura e serviços na área rural e indicadores sociais. Em Barcarena está presente o projeto Albrás-Alunorte onde ficam as maiores fábricas de alumínio do país, constituindo-se em um polo na região. Moju e Tailândia apresentaram alta produtividade rural, sendo municípios produtores de óleo de dendê. Porém, os indicadores sociais de Moju são baixos. Os municípios atravessados por rios mantêm uma boa cobertura florestal e apresentam um aumento da população rural. Estes municípios possuem baixa quantidade de população migrante, o que pode associar o desenvolvimento rural a característica cultural da população nativa. Ou seja, a população nativa amazônica explora os recursos naturais de forma menos destrutiva. Por outro lado, os indicadores sociais e de infraestrutura e serviços para o meio rural para esses municípios são baixos.

Os municípios da região Marajó são aqueles que apresentam os piores indicadores de desenvolvimento rural. Sete municípios da região figuram entre os dez piores IDR do estado. A região apresenta baixa densidade demográfica, com elevada proporção de população rural, o que traduz pouco desenvolvimento urbano e indicadores sociais 
baixos. Os indicadores de bem estar dos domicílios rurais são os piores do estado, devido à pouca infraestrutura e serviços fornecidos a população rural. Soure e Salvaterra apresentaram IDR dentro da média estadual, com melhores indicadores de infraestrutura para o meio rural. Breves é o município mais populoso da região (PARÁ, 2010). A ausência de dados para alguns indicadores ambientais de alguns desses municípios (como pode ser observado na Tabela 4) pode ter rebaixado um pouco o índice final do IDR, sem entretanto alterar substancialmente a tabela de classificação. Melgaço é o município com o pior IDR do estado, o que tem correspondência com a classificação de pior IDH do país em 2010 (PNUD, 2013), com destaque para as altas taxas de analfabetismo.

$\mathrm{Na}$ região Baixo Amazonas destaca-se 0 município de Terra Santa com alto IDR, com bons indicadores de bem estar para os domicílios rurais. Santarém possui os melhores indicadores sociais e é o município mais populoso da região e provedor de serviços administrativos, educacionais e de outras ordens na região. Os municípios de Oriximiná e Alenquer, onde se encontra instalado o projeto de mineração de bauxita Rio do Norte, apresentaram médio e baixo IDR. Ou seja, a implantação de grandes projetos minerais na região não trouxeram impactos muito positivos nas áreas rurais. Faro possui o mais baixo IDR na região.

Os municípios da região Tapajós apresentam baixo IDR em geral. A densidade demográfica é baixa, com elevada proporção de população rural. Os melhores indicadores sociais encontram-se em Novo Progresso e Itaituba que apresentam IDR médio. Itaituba é o município mais populoso da região (PARÁ, 2010). Entretanto, os indicadores de bem estar para os domicílios rurais são baixos. Jacareacanga é o município com mais baixo IDR na região, com indicadores de cobertura de infraestrutura e serviços rurais muito baixos.

Na região Xingu, Altamira é o município polo. A região apresenta bons indicadores sociais, entretanto, com indicadores baixos de bem estar para os domicílios rurais, assim como todos os demais municípios da região. Assim como a região Tapajós, esta é uma região de ocupação mais recente, a partir da implantação da rodovia Transamazônica na década de 1970, e com precária infraestrutura rural. O município de Senador
José Porfírio apresentou o IDR mais baixo da região.

Os municípios da região do Lago do Tucuruí em geral apresentaram baixo IDR. Apenas Breu Branco apresentou IDR médio. Tucuruí, onde está implantada a hidrelétrica de Tucuruí, apresenta os melhores indicadores sociais. Entretanto, praticamente todos os municípios da região apresentam indicadores de infraestrutura e serviços para a área rural baixos.

Na região Carajás ocorre um município com alto IDR, Parauapebas, onde está instalado o projeto de extração de minério de ferro de Carajás desde a década de 1980. Marabá, município que centraliza equipamentos e serviços na região, apresenta somente um médio IDR. Canaã dos Carajás, onde está instalado outro grande projeto de mineração também apresenta médio IDR. Os demais municípios apresentam baixos indicadores sociais $e$ de infraestrutura para 0 desenvolvimento rural. Nota-se uma redução generalizada da população rural nos municípios desta região durante o período estudado. Uma das hipóteses é que estes municípios tenham perdido população rural para áreas urbanas dos municípios mineradores dentro da própria região, tendo em vista a grande expansão populacional nestes últimos.

Pode ser verificada uma correlação entre a redução da população rural e a reduzida proporção de áreas de mata nativa nesta região (F4). Isto pode ser explicado devido a atividade pecuária bovina ser a principal forma de exploração agropecuária na região. A expansão da pecuária ocorre com o avanço em áreas de floresta e, em pequenas áreas, isso leva ao que é chamado de "crise da capoeira", devido ao aumento desproporcional das pastagens e a uma "crise técnica" da pecuária devido à sobrelotação (HURTIENNE, 2005). As áreas antigas tornam-se improdutivas e com a redução das áreas florestais, o agricultor não encontra novas reservas para dar continuidade a sua produção e a "estratégia de fronteira", descrita por REYNAL et al. (1996 apud HURTIENNE, 2005), pode estar sendo prejudicada.

Na região Araguaia o município de Sapucaia apresentou alto IDR, devido aos componentes econômicos produtividade por estabelecimento e por pessoa ocupada na agropecuária. No município há grandes 
fazendas de criação de rebanho bovino com maior uso de tecnologia. Com bons indicadores sociais, Redenção também apresenta alto IDR, destacando-se como um provedor de serviços para o setor agropecuário na região, apesar de não se destacar tanto pela concentração populacional. Em geral, os municípios da região apresentam bons indicadores sociais, porém com baixos indicadores de bem estar para os domicílios rurais. O pior IDR foi registrado para o município de Pau D'Arco. Boa parte destes municípios apresentou o mesmo fenômeno de redução da população rural que a região de Carajás. Neste caso, a pecuária também é um componente muito importante no crescimento do PIB nesta região (SILVA, 2012). Tanto a região de Carajás quanto a Araguaia possuem grande população migrante, o que pode associar as características do desenvolvimento rural a cultura local.

\section{CONSIDERAÇÕES FINAIS}

O desenvolvimento rural é um fator relacionado a múltiplos aspectos da vida no campo. O estado do Pará destaca-se na região Amazônica pela marcante presença de populações rurais. Os grandes projetos na Amazônia e as políticas de colonização da região levaram a ocupação de praticamente todo território paraense. Este fluxo em tão pouco espaço de tempo foi feito de forma desordenada, tendo impactos sociais e ambientais. Procurando dimensionar as diferenças nas áreas rurais, classificou-se os municípios do estado em diferentes graus de desenvolvimento, a partir da análise fatorial.

A região Metropolitana aparece ainda como a maior propulsora de desenvolvimento e o maior número de municípios com alto desenvolvimento rural nas suas proximidades. Nela concentram-se investimentos estaduais, infraestruturas administrativas e serviços que atraem a população e geram melhores condições de vida, apesar do crescimento de áreas periféricas com moradias precárias em áreas urbanas.

Os grandes projetos levaram a descentralização econômica na geração de riqueza dentro do estado. Entretanto, essa descentralização privilegiou mais determinadas regiões do estado em detrimento de outras. Mesmo no interior das regiões marcadas pelos projetos minerais, os indicadores sociais melhoraram especialmente naqueles municípios onde se instalaram. Este comportamento dos indicadores é replicado também para o rural. Não houve uma política de regionalização dos benefícios oriundos da mineração, o que contribui para um fluxo interno dentro destas regiões em direção aos municípios mineradores.

A infraestrutura das áreas rurais dos municípios do interior do estado é mais precária de acordo com a dificuldade de acesso e grau de isolamento destas áreas. A ilha do Marajó, onde concentram os municípios com os piores índices de desenvolvimento rural, sofre com o isolamento apesar da maior proximidade geográfica com a capital. A região Tapajós é impactada pela dificuldade de acesso, principalmente em determinadas épocas do ano, devido a precariedade da rodovia Transamazônica, cujo asfaltamento não foi concluído.

O desenvolvimento regional mostra-se um desafio para um estado das dimensões do Pará. A colonização de regiões distantes não foi acompanhada de investimentos em obras e serviços adequados ao provimento de qualidade de vida as populações tradicionais que já habitavam e aquelas que migraram com o objetivo de possuir um pedaço de chão para cultivar.

Destaca-se que o modelo de desenvolvimento adotado nas regiões de maior crescimento baseado na exploração mineral e na pecuária extensiva pode levar a um colapso das riquezas naturais em um curto espaço de tempo, o que deve ser alvo de preocupação para a implantação de políticas públicas que revertam esta tendência e garantam um presente e um futuro para a população paraense.

Consideramos importante a continuidade das análises a respeito dos indicadores de desenvolvimento rural para que seja observado se as tendências encontradas na última década estão sendo mantidas ou se sofreram alguma alteração. Sugerimos a captação de variáveis ambientais mais adequadas que possam também estabelecer uma melhor análise entre o modelo de desenvolvimento agrário e agrícola com a qualidade do uso dos recursos naturais, como por exemplo, a quantidade de agrotóxico consumido no município. 


\section{NOTAS}

1 - Não foi incluído o município de Mojuí dos Campos nesta análise, pois no período de pesquisas realizadas pelo IBGE, de 2000 a 2010, o mesmo ainda pertencia ao município de Santarém.

2 - Mais informações ver Mingoti (2005, p. 137).

3 Mais informações ver Mingoti (2005, p. 138).

4 - O Atlas de Desenvolvimento Humano considerou para o ano de 2010 a linha de pobreza no valor de $R \$ 140,00$ de renda familiar per capita de pobres. O cálculo da Intensidade de Pobreza também considerou este mesmo valor de linha de pobreza $(\mathrm{R} \$$ 140,00). Portanto, a Intensidade de Pobreza é a diferença da renda domiciliar per capita média dos indivíduos pobres (renda domiciliar per capita inferior à $R \$ 140,00)$ do valor de $R \$ 140,00$, dividido por $R \$ 140,00$ e multiplicado por 100.

5 - Para determinar os estabelecimentos com práticas de conservação somaram-se os

\section{REFERÊNCIAS}

[1]. CONTERATO, M. A. Dinâmicas regionais do desenvolvimento rural e estilos de agricultura familiar: uma análise a partir do Rio Grande do Sul. Porto Alegre. 2008. 288 p. Tese (Doutorado em Desenvolvimento Rural) - Programa de PósGraduação em Desenvolvimento Rural, Faculdade de Ciências Econômicas, Universidade Federal do Rio Grande do Sul, Porto Alegre, 2008. Disponível em:

<https://lume.ufrgs.br/bitstream/handle/10183/1562 4/000661531. pdf?sequence $=1$ \&isAllowed $=y>$. Acesso em: 8 out. 2017.

[2]. CONTERATO, M. A.; SCHNEIDER, S.; WAQUIL, P. D. Desigualdades regionais de desenvolvimento rural do Rio Grande do Sul: uma proposta de análise multidimensional a partir de três microrregiões. Ensaios FEE, Porto Alegre, v. 30, p. 615-654, out. 2009. Número Especial. Disponível em: $<$ https://revistas.fee.tche.br/index.php/ensaios/artic le/view/2307/2685>. Acesso em: 8 out. 2017.

[3]. DELGADO, G. C. Expansão e modernização do setor agropecuário no pósguerra: um estudo da reflexão agrária. Estudos Avançados, São Paulo, v. 15, n. 43, p. 157-172, 2001. Disponível em: <http://www.scielo.br/scielo.php?script=sci_arttext \&pid=S0103-40142001000300013 >. Acesso em: 8 out. 2017. estabelecimentos que não praticam atos de conservação do solo com os que praticam queimadas, e subtraiu do total de estabelecimentos.

6 - Para a variável matas naturais e plantadas foram consideradas as áreas de matas e/ou florestas naturais destinadas à preservação permanente ou reserva legal; as áreas de matas e/ou florestas naturais (exclusive área de preservação permanente e as áreas em sistemas agroflorestais) e a área cultivada com espécies florestais também usadas para lavouras e pastejo de animais.

7 - Foram considerados como estabelecimentos que utilizam agrotóxico a soma dos que utilizam, mais os que utilizam mas não precisaram utilizar em 2006.

8 - Estabelecimentos com uso de adubação orgânica é o resultado da soma de esterco e/ou urina animal + adubação verde + vinhaça + húmus de minhoca + biofertilizantes + inoculantes + composto orgânico

[4]. HAIR JR., J. F. et al. Análise multivariada de dados. 5 ed. Porto Alegre: Bookman, 2005. 593 p.

[5]. HURTIENNE, T. P. Agricultura familiar e desenvolvimento rural sustentável na Amazônia. Novos Cadernos NAEA, Belém, v. 8, n. 1, p. 19-71, jun. $2005 . \quad$ Disponível em: <https://periodicos.ufpa.br/index.php/ncn/article/vi ew/47/42>. Acesso em: 16 out. 2017.

[6]. IBGE. Portal de Mapas. Disponível em: <https://portaldemapas.ibge.gov.br/portal.php\#ho mepage>. Acesso em: 20 nov. 2017.

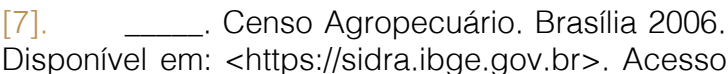
em: 10 nov. 2017.

[8] Censo Demográfico. Brasília 2010. Disponível em: <https://sidra.ibge.gov.br>. Acesso em: 10 nov. 2017.

[9]. KAGEYAMA, A. Desenvolvimento rural: conceito e medida. Cadernos de Ciência \& Tecnologia, Brasília, v. 21, n. 3, p. 379-408, set./dez. 2004. Disponível em: <https://seer.sct.embrapa.br/index.php/cct/article/v iew/8702/4887 >. Acesso em: 4 abr. 2017.

[10]

Desenvolvimento rural: conceitos e aplicação no caso brasileiro. Porto Alegre: Editora da UFRGS, 2008. 240 p.

MINGOTI, S. A. Análise de dados através de métodos de estatística multivariada: uma 
abordagem aplicada. Belo Horizonte: Editora UFMG, 2005. 297 p.

[12]. MELO, C. O. de; PARRÉ, J. L. Índice de desenvolvimento rural dos municípios paranaenses: determinantes e hierarquização. Revista de Economia e Sociologia Rural, Rio de Janeiro, v. 45, n. 2, p. 329-365, abr./jun. 2007. Disponível em: $<$ https://ageconsearch.umn.edu/bitstream/161395/ 2/05.pdf>. Acesso em: 8 out. 2017.

[13]. MELO, R. F. de. Análise do desenvolvimento rural na região do Triângulo Mineiro e Alto Paranaíba: caracterização dos municípios com base em indicadores populacionais, econômicos, ambientais e de bemestar social. Uberlândia. 2005. 138 p. Dissertação (Mestrado em Economia) - Programa de PósGraduação em Economia, Instituto de Economia, Universidade Federal de Uberlândia, Uberlândia, 2005. Disponível em: < https://repositorio.ufu.br/bitstream/123456789/1354 2/1/RFMeloDISSPRT.pdf>. Acesso em: 8 out. 2017.

[14]. NAVARRO, Z. Desenvolvimento rural no Brasil: os limites do passado e os caminhos do futuro. Estudos Avançados, São Paulo, v. 15, n. 43, p. 83-100, set./dez. 2001. Disponível em: <http://www.scielo.br/scielo.php?script=sci_arttext \&pid=S0103-40142001000300009>. Acesso em: 16 out. 2017.

[15]. PARÁ. Atlas de Integração Regional do Estado do Pará. Belém, PA: Secretaria de Estado de Integração Regional, 2010. 347 p.

[16]. PROGRAMA DAS NAÇÕES UNIDAS PARA O DESENVOLVIMENTO (PNUD). Atlas do Desenvolvimento Humano no Brasil. 2013. Disponível em: <http://atlasbrasil.org.br/2013>. Acesso em: 10 nov. 2017.

[17]. SANTOS, N. C. A. dos. Indicador de desenvolvimento rural para as regiões de integração do estado do Pará. Salvador. 2015. 140 p. Dissertação (Mestrado em Economia) Programa de Pós-Graduação em Economia, Faculdade de Economia, Universidade Federal do Bahia, Salvador, 2015. Disponível em: <https://repositorio.ufba.br/ri/bitstream/ri/18716/1/N ANETY\%20CRISTINA\%20ALVES\%20DOS\%20SAN TOS.pdf>. Acesso em: 30 ago. 2017.

[18]. SCHNEIDER, S. et al. A abordagem territorial do desenvolvimento rural e suas articulações externas. Sociologias, Porto Alegre, v. 6, n. 11, p. 88-125, jan./jun. 2004. Disponível em: <http://www.scielo.br/pdf/soc/n11/n11a06>. Acesso em: 16 out. 2017.

[19]. SEN, A. Desenvolvimento como liberdade. São Paulo: Companhia das Letras, 2000, 409 p.

[20]. SILVA, J. G. da. O Novo Rural Brasileiro. Revista Nova economia, Belo Horizonte, v. 7 , n. 1, p. 43-81, mai. 1997. Disponível em: <http://revistas.face.ufmg.br/index.php/novaecono mia/article/view/2253/1193>. Acesso em: 16 out. 2017.

[21]. SILVA, L. de J. M. da. A relação entre crescimento econômico e desenvolvimento sustentável: a Região do Araguaia no contexto regional paraense. Belém. 2012. 229 f. Tese (Doutorado em Desenvolvimento Sustentável do Trópico Úmido) - Núcleo de Altos Estudos da Amazônia, Universidade Federal do Pará, Belém, $2012 . \quad$ Disponível em: <http://repositorio.ufpa.br/jspui/bitstream/2011/296 3/7/Tese_RelacaoCrescimentoEconomico.pdf>. Acesso em: 15 ago. 2017.

[22]. SOUZA, P. de P. L. R. de. Desenvolvimento rural no contexto amazônico: uma análise multidimensional do estado do Pará. Porto Alegre. 2014. 91 f. Dissertação (Mestrado em Economia do Desenvolvimento) - Pontifícia Universidade Católica do Rio Grande do Sul, Porto Alegre, 2014. Disponível em: <https://www.alice.cnptia.embrapa.br/alice/bitstrea m/doc/1012342/1/dissertacaopledoux.pdf >. Acesso em: 30 ago. 2017.

[23]. STEGE, A. L.; PARRÉ, J. L. Desenvolvimento rural nas microrregiões do Brasil: um estudo multidimensional. Revista Teoria e Evidência Econômica, Passo Fundo, v. 17, n. 37, p. 160-193, jun./dez. 2011. Disponível em: <http://seer.upf.br/index.php/rtee/article/view/4227/ 2717>. Acesso em: 16 ago. 2017.

[24]. VAN DER PLOEG, J. D. et al. Rural development: from practices and policies towards theory. Sociologia Ruralis, Oxford, v. 40, n. 4, p. 391-408, out. 2000. Disponível em: <https://onlinelibrary.wiley.com/doi/epdf/10.1111/14 67-9523.00156>. Acesso em: 05 jun. 2018.

[25]. VEIGA, J. E. da. A face rural do desenvolvimento: natureza, território e agricultura. Porto Alegre: Editora da UFRGS, 2000. 197 p.

[26]. VEIGA, J. E. da. O Brasil rural ainda não encontrou seu eixo de desenvolvimento. Estudos Avançados, São Paulo, v. 15, n. 43, p. 101-119, set./dez. 2001. Disponível em: <http://www.scielo.br/pdf/ea/v15n43/v15n43a10.pd $f>$ Acesso em: 15 jun. 2018.

[27]. WANDERLEY, M. de N. B. A emergência de uma nova ruralidade nas sociedades modernas avançadas-o "rural" como espaço singular e ator coletivo. Estudos sociedade e agricultura, Rio de Janeiro, v. 8, n. 15, p. 87-145, out. 2000. Disponível em:

<https://revistaesa.com/ojs/index.php/esa/article/vi ew/178/174> . Acesso em: 16 out. 2017.

[28]. WAQUIL, P. et al. Avaliação de desenvolvimento territorial em quatro territórios rurais no Brasil. Redes, Santa Cruz do Sul, v. 15, n. 1, p. 104-127, jan./abr. 2010. Disponível em: $<$ https://online.unisc.br/seer/index.php/redes/article /view/48/1467>. Acesso em: 29 ago. 2017. 


\section{ANEXO}

Tabela 4 - Fatores (F), índice de desenvolvimento rural (IDR) e grau de desenvolvimento (GD) dos municípios paranaenses, por ordem de classificação no Estado.

\begin{tabular}{|c|c|c|c|c|c|c|c|c|c|}
\hline Municípios & Região & $\mathrm{F} 1$ & F2 & F3 & $\mathrm{F} 4$ & F5 & F6 & IDR & GD \\
\hline Ulianópolis & Rio Capim & $-0,32593$ & $-0,07600$ & 8,83565 & 1,03194 & 0,38853 & 1,15588 & 100,00 & MMA \\
\hline Ananindeua & Metropolitana & $-2,21164$ & 5,34514 & $-1,60807$ & 3,49059 & 4,23609 & 0,00246 & 90,52 & MMA \\
\hline Belém & Metropolitana & 0,23124 & 4,13734 & $-0,81500$ & 2,96506 & 0,26667 & 0,02843 & 88,92 & MMA \\
\hline Benevides & Metropolitana & 2,38342 & 0,94713 & 1,16288 & 0,76669 & 1,15383 & $-1,46530$ & 80,35 & MA \\
\hline Salinópolis & Rio Caeté & 1,68895 & 1,44428 & $-0,59376$ & 1,19751 & $-1,29013$ & 1,36676 & 70,38 & A \\
\hline Tailândia & Tocantins & 0,96962 & 0,69743 & 1,39782 & 1,31085 & $-0,82166$ & 0,46216 & 68,71 & A \\
\hline Santa Isabel do Pará & Guamá & 0,76080 & 1,11893 & 1,09720 & 0,83803 & 1,38031 & $-1,44398$ & 68,53 & A \\
\hline Barcarena & Tocantins & 2,09518 & 0,47607 & 0,61532 & 0,29409 & $-0,84157$ & 0,78509 & 68,36 & A \\
\hline Marituba & Metropolitana & 1,58978 & 2,51639 & $-1,06584$ & $-0,90569$ & 0,68958 & $-0,40564$ & 67,81 & A \\
\hline Curuçá & Guamá & 2,42848 & $-0,93968$ & 0,16888 & 1,55834 & 1,01105 & $-0,39909$ & 65,42 & A \\
\hline Paragominas & Rio Capim & 0,96585 & 0,91478 & 1,51815 & $-0,31128$ & 0,31506 & $-0,36428$ & 65,32 & A \\
\hline Castanhal & Guamá & 1,15120 & 1,43141 & 0,21976 & 0,41225 & 1,01014 & $-2,07935$ & 64,01 & A \\
\hline Parauapebas & Carajás & 1,90327 & 1,45802 & 0,04058 & $-1,27165$ & $-0,54396$ & 0,17975 & 63,62 & A \\
\hline Santa Maria do Pará & Guamá & 1,33010 & $-0,25085$ & 0,57746 & 0,37429 & 2,25211 & $-0,77533$ & 62,10 & A \\
\hline Sapucaia & Araguaia & 0,35365 & 0,83199 & 2,14643 & $-0,42832$ & $-0,84193$ & 0,32315 & 60,35 & A \\
\hline São João da Ponta & Guamá & $-0,85387$ & $-0,15303$ & 3,92032 & $-0,43102$ & 1,77911 & $-0,71267$ & 58,23 & A \\
\hline Santa Bárbara do Pará & Metropolitana & 1,94587 & $-0,18134$ & 0,57640 & 0,20237 & $-0,20140$ & $-0,73681$ & 58,18 & A \\
\hline Terra Santa & B. Amazonas & 1,21353 & 0,10754 & 0,55830 & 1,11252 & $-1,05662$ & 0,17329 & 58,13 & A \\
\hline Redenção & Araguaia & $-0,49704$ & 1,74853 & 0,95451 & $-0,63698$ & 0,79290 & $-0,12489$ & 57,47 & A \\
\hline Terra Alta & Guamá & 1,17587 & 0,16714 & $-0,19547$ & 0,17321 & 1,45283 & $-0,43329$ & 56,99 & A \\
\hline Novo Progresso & Tapajós & 0,19423 & 2,15739 & 0,35930 & $-1,20354$ & $-1,41772$ & 0,76776 & 55,53 & M \\
\hline São Miguel do Guamá & Guamá & 1,55999 & $-0,71471$ & $-0,24724$ & 0,57746 & 1,43922 & $-0,13454$ & 55,30 & M \\
\hline Magalhães Barata & Guamá & 1,94756 & $-0,48865$ & $-0,95848$ & 0,93051 & $-0,48983$ & 1,14146 & 55,03 & M \\
\hline Vigia & Guamá & 0,89650 & 0,17976 & 0,17434 & 0,14138 & 0,63058 & $-0,43138$ & 53,61 & $\mathrm{M}$ \\
\hline Dom Eliseu & Rio Capim & 0,85629 & 0,18824 & 0,51932 & $-0,75035$ & 0,36761 & 0,29191 & 52,65 & M \\
\hline Santo Antônio do Tauá & Guamá & 1,09245 & $-0,38500$ & $-0,55698$ & 0,65712 & 1,35689 & $-0,05586$ & 52,54 & M \\
\hline Xinguara & Araguaia & 0,86577 & 1,43002 & 0,46327 & $-1,48114$ & $-1,24084$ & $-0,28418$ & 51,70 & M \\
\hline Marabá & Carajás & 0,57003 & 0,94006 & 0,47534 & $-0,77670$ & $-1,09144$ & 0,14167 & 50,22 & M \\
\hline Santarém & B. Amazonas & 0,23303 & 1,12450 & $-0,46451$ & 0,66140 & $-1,14821$ & 0,28302 & 50,20 & $\mathrm{M}$ \\
\hline Itaituba & Tapajós & 0,45175 & 1,07497 & $-0,43401$ & $-0,27434$ & $-1,02973$ & 0,88921 & 50,01 & M \\
\hline São Domingos do Capim & Guamá & 1,85266 & $-0,25548$ & $-0,40907$ & $-0,10488$ & $-0,13320$ & $-0,71298$ & 49,87 & M \\
\hline Canaã dos Carajás & Carajás & 0,79364 & 1,07051 & 0,32115 & $-2,26349$ & 0,30478 & $-0,24773$ & 49,50 & M \\
\hline São Francisco do Pará & Guamá & 2,60624 & $-1,32024$ & 0,19517 & 0,26278 & $-0,98776$ & $-0,79962$ & 49,09 & M \\
\hline Salvaterra & Marajó & 0,81408 & $-0,09431$ & $-0,24130$ & $-0,19810$ & 0,64154 & 0,31873 & 49,07 & M \\
\hline Mãe do Rio & Rio Capim & 1,66809 & 0,30054 & $-0,84636$ & $-1,41280$ & $-0,32085$ & 0,75870 & 48,59 & M \\
\hline Moju & Tocantins & $-0,43120$ & $-0,60349$ & 1,50791 & 0,29426 & 0,93495 & 0,62836 & 48,51 & M \\
\hline Capanema & Rio Caeté & 0,67518 & 0,66059 & $-0,64287$ & $-0,30929$ & 0,16559 & $-0,07707$ & 48,34 & M \\
\hline São Félix do Xingu & Araguaia & $-0,22587$ & 0,40948 & 0,46185 & 1,12111 & $-1,44888$ & 0,66402 & 47,78 & $\mathrm{M}$ \\
\hline Marapanim & Guamá & 1,06991 & $-0,51712$ & $-0,54245$ & $-0,04788$ & 1,27156 & $-0,06519$ & 47,71 & $\mathrm{M}$ \\
\hline Santana do Araguaia & Araguaia & 0,10421 & 0,29676 & 0,61168 & 0,58802 & $-1,33942$ & 0,40011 & 47,66 & M \\
\hline Tomé-Açu & Rio Capim & 0,16101 & 0,78096 & $-0,25366$ & 0,82189 & $-0,14188$ & $-1,17108$ & 47,60 & $M$ \\
\hline Concórdia do Pará & Rio Capim & $-0,15088$ & $-0,27271$ & 0,06037 & 0,50274 & 1,59587 & 0,25225 & 47,49 & M \\
\hline
\end{tabular}


(continuação...)

\begin{tabular}{|c|c|c|c|c|c|c|c|c|c|}
\hline Municípios & Região & $\mathrm{F} 1$ & F2 & F3 & $\mathrm{F} 4$ & F5 & F6 & IDR & GD \\
\hline Baião & Tocantins & 0,31148 & $-0,34721$ & $-0,04917$ & 1,74395 & 0,72607 & $-1,32306$ & 47,48 & M \\
\hline Belterra & B. Amazonas & 0,80990 & $-0,33652$ & $-0,52881$ & 0,89863 & $-0,86216$ & 1,15231 & 47,42 & $M$ \\
\hline Igarapé-Açu & Guamá & 0,51353 & $-0,38908$ & 0,10065 & 0,03037 & 1,40141 & $-0,60050$ & 46,81 & $M$ \\
\hline Maracanã & Guamá & 1,22002 & $-0,68002$ & $-0,74741$ & 0,85077 & $-0,23631$ & 0,47647 & 46,68 & $M$ \\
\hline Juruti & B. Amazonas & 0,63081 & $-0,80088$ & $-0,20218$ & 1,14143 & $-0,12738$ & 0,80714 & 46,55 & $M$ \\
\hline Soure & Marajó & 0,63633 & 0,23474 & 0,11736 & $-0,88372$ & $-0,07701$ & 0,16128 & 46,06 & $M$ \\
\hline Ourilândia do Norte & Araguaia & $-0,05414$ & 1,14352 & 0,17228 & $-0,99292$ & $-1,11404$ & 0,84256 & 45,97 & M \\
\hline Mocajuba & Tocantins & $-0,23855$ & 0,00445 & $-0,21431$ & 1,01605 & 1,18591 & $-0,46249$ & 45,94 & $M$ \\
\hline Tucumã & Araguaia & $-0,30701$ & 1,58509 & 0,00556 & $-1,72045$ & $-0,05664$ & 0,44304 & 45,87 & M \\
\hline Santarém Novo & Rio Caeté & 2,26255 & $-1,09511$ & $-0,36801$ & 0,09717 & $-0,00607$ & $-1,58181$ & 45,06 & M \\
\hline Placas & Xingu & $-0,04974$ & $-0,31005$ & 0,19805 & 1,37143 & $-0,89454$ & 0,62548 & 44,73 & $M$ \\
\hline Almeirim & B. Amazonas & $-0,18579$ & 1,06604 & $-0,49520$ & 0,53541 & $-1,57869$ & 0,56182 & 44,60 & $M$ \\
\hline Vitória do Xingu & Xingu & 0,09473 & 0,10215 & $-0,25388$ & $-0,42325$ & 0,90914 & 0,13966 & 43,78 & $M$ \\
\hline Bragança & Rio Caeté & $-0,14612$ & $-0,05464$ & $-0,41017$ & $-0,19359$ & 1,41206 & 0,56195 & 43,76 & M \\
\hline Altamira & Xingu & $-0,84579$ & 1,57649 & $-0,32331$ & 0,21668 & $-1,09705$ & 0,25947 & 43,56 & $M$ \\
\hline Oriximiná & B. Amazonas & $-0,46532$ & 0,32237 & $-0,31055$ & 0,88107 & $-0,16408$ & 0,43872 & 43,39 & $M$ \\
\hline São João de Pirabas & Rio Caeté & 0,13988 & $-0,68347$ & $-0,38331$ & 0,63217 & 0,90483 & 0,65349 & 43,24 & M \\
\hline Quatipuru & Rio Caeté & 1,11692 & $-1,10952$ & $-0,30391$ & $-0,87816$ & 1,04932 & 0,96335 & 43,21 & M \\
\hline Breu Branco & L. de Tucuruí & 0,14507 & 0,13913 & 0,00064 & $-0,25684$ & $-0,60039$ & 0,48173 & 42,25 & $M$ \\
\hline Bonito & Rio Caeté & 0,81277 & $-0,84569$ & $-0,26771$ & 0,34353 & $-0,06657$ & 0,27581 & 42,17 & $M$ \\
\hline Anapu & Xingu & $-0,56446$ & 0,35432 & 0,19171 & 0,82213 & $-1,49103$ & 0,92565 & 42,10 & $M$ \\
\hline Ipixuna do Pará & Rio Capim & 0,89636 & $-1,52303$ & 0,29820 & 0,70681 & $-0,15671$ & 0,24011 & 41,65 & $M$ \\
\hline Rio Maria & Araguaia & $-0,69434$ & 1,39838 & 0,64204 & $-1,32502$ & $-0,17411$ & $-0,92355$ & 41,49 & B \\
\hline Ourém & Rio Capim & 0,74004 & $-1,05942$ & $-0,30173$ & $-0,30621$ & 0,84603 & 0,72330 & 41,44 & $\mathrm{~B}$ \\
\hline Abel Figueiredo & Rio Capim & $-0,67701$ & 1,52314 & 0,18500 & $-1,40247$ & $-0,66167$ & 0,16037 & 41,42 & $\mathrm{~B}$ \\
\hline Nova Timboteua & Rio Caeté & 0,96591 & $-0,26314$ & $-0,32911$ & 0,24473 & $-0,86288$ & $-0,81500$ & 41,07 & $\mathrm{~B}$ \\
\hline Colares & Guamá & 0,84442 & $-0,85282$ & $-0,65359$ & 0,25658 & $-0,03678$ & 0,63304 & 41,02 & B \\
\hline Bom Jesus do Tocantins & Carajás & 0,21056 & 0,29484 & $-0,08035$ & $-1,05080$ & $-0,35594$ & 0,26634 & 40,23 & $\mathrm{~B}$ \\
\hline Trairão & Tapajós & $-0,32537$ & $-0,01957$ & $-0,17638$ & 0,39521 & $-0,77375$ & 1,12378 & 40,22 & $\mathrm{~B}$ \\
\hline Inhangapi & Guamá & 0,54124 & $-0,89717$ & 0,04225 & 0,16451 & 0,16394 & $-0,07411$ & 40,07 & B \\
\hline Palestina do Pará & Carajás & $-0,60502$ & $-0,41312$ & $-0,30655$ & $-1,76924$ & 3,52679 & 1,12218 & 39,86 & $B$ \\
\hline Abaetetuba & Tocantins & $-0,60414$ & 0,70286 & $-0,46081$ & 0,61836 & $-0,65122$ & $-0,08999$ & 39,77 & B \\
\hline Rondon do Pará & Rio Capim & $-0,83155$ & 0,79342 & 0,09406 & $-0,26054$ & $-0,66342$ & 0,31984 & 39,08 & B \\
\hline Rurópolis & Tapajós & $-0,56008$ & $-0,13724$ & $-0,12096$ & 1,04425 & $-0,75943$ & 0,64771 & 38,96 & $\mathrm{~B}$ \\
\hline Bujaru & Rio Capim & $-0,24342$ & $-0,44761$ & $-0,51349$ & 1,49526 & $-0,75829$ & 0,64903 & 38,85 & B \\
\hline Irituia & Rio Capim & 0,35531 & $-1,13640$ & 0,28100 & 0,00764 & 0,11111 & 0,23668 & 37,92 & $\mathrm{~B}$ \\
\hline Óbidos & B. Amazonas & $-0,48446$ & $-0,34439$ & $-0,42060$ & 0,53983 & 0,39893 & 0,46610 & 37,53 & $\mathrm{~B}$ \\
\hline São Sebastião da Boa Vista & Marajó & $-1,11503$ & $-0,07784$ & $-0,48685$ & 1,98707 & $-0,62672$ & 0,70296 & 37,50 & $\mathrm{~B}$ \\
\hline Curionópolis & Carajás & $-0,64183$ & 0,81420 & 1,36862 & $-1,36709$ & $-0,92970$ & $-1,14149$ & 37,47 & $\mathrm{~B}$ \\
\hline Cametá & Tocantins & $-0,30724$ & $-0,47420$ & $-0,52631$ & 0,93608 & $-0,06197$ & 0,29404 & 36,86 & $\mathrm{~B}$ \\
\hline Brejo Grande do Araguaia & Carajás & $-0,11182$ & $-0,42843$ & 0,11499 & $-1,49130$ & 0,81798 & 0,89369 & 36,85 & $\mathrm{~B}$ \\
\hline Bagre & Marajó & $-1,74675$ & $-0,49543$ & 1,67317 & 0,83721 & 0,34701 & $-0,25325$ & 36,31 & B \\
\hline Tracuateua & Rio Caeté & $-0,15071$ & $-0,75948$ & $-0,64519$ & 0,68546 & 1,79551 & $-1,11656$ & 36,27 & $\mathrm{~B}$ \\
\hline Cumaru do Norte & Araguaia & $-0,89711$ & 0,06206 & 0,78367 & 0,06406 & $-1,37255$ & 0,65838 & 36,25 & $\mathrm{~B}$ \\
\hline Jacundá & L. de Tucuruí & $-0,67474$ & 0,78759 & $-0,39026$ & $-1,21157$ & 0,25811 & 0,15473 & 36,10 & $B$ \\
\hline
\end{tabular}


(continuação...)

\begin{tabular}{|c|c|c|c|c|c|c|c|c|c|}
\hline Municípios & Região & $\mathrm{F} 1$ & F2 & F3 & $\mathrm{F} 4$ & F5 & F6 & IDR & GD \\
\hline Porto de Moz & Xingu & $-1,19773$ & $-0,43062$ & $-0,18242$ & 1,68620 & $-0,10391$ & 0,62354 & 35,87 & B \\
\hline Novo Repartimento & L. de Tucuruí & $-0,17599$ & $-0,60085$ & $-0,10777$ & $-0,44793$ & 0,09649 & 0,97531 & 35,87 & B \\
\hline Primavera & Rio Caeté & 0,47533 & $-0,56048$ & $-0,54408$ & $-0,55634$ & $-0,15798$ & 0,34516 & 35,79 & $B$ \\
\hline Tucuruí & L. de Tucuruí & $-0,89965$ & 1,89763 & $-0,82027$ & $-1,34366$ & 0,14863 & $-1,17926$ & 35,67 & $\mathrm{~B}$ \\
\hline Capitão Poço & Rio Capim & 0,03681 & $-0,77612$ & $-0,02476$ & $-0,48048$ & 1,37855 & $-0,77155$ & 35,61 & $B$ \\
\hline Conceição do Araguaia & Araguaia & $-0,60391$ & 0,68528 & $-0,41773$ & $-1,02182$ & 0,08028 & 0,06110 & 35,58 & B \\
\hline Aveiro & Tapajós & $-0,22096$ & $-1,23676$ & $-0,70217$ & 1,31844 & 0,17721 & 1,11595 & 35,45 & $\mathrm{~B}$ \\
\hline Medicilândia & Xingu & $-0,11602$ & 0,26633 & $-0,33591$ & $-0,27617$ & $-1,36153$ & 0,15418 & 35,05 & B \\
\hline Augusto Corrêa & Rio Caeté & 0,02808 & $-0,87436$ & $-0,75390$ & 0,97258 & $-0,15145$ & 0,31729 & 34,95 & B \\
\hline Curuá & B. Amazonas & $-0,25856$ & $-0,59171$ & $-0,71718$ & 0,22374 & 0,41507 & 0,63535 & 34,81 & B \\
\hline Peixe-Boi & Rio Caeté & 0,27065 & $-0,80100$ & $-0,31615$ & $-0,32019$ & 0,12413 & 0,12782 & 34,72 & $B$ \\
\hline Oeiras do Pará & Tocantins & $-0,78820$ & $-0,56035$ & $-0,39630$ & 1,30648 & $-0,30110$ & 0,61227 & 34,55 & B \\
\hline Goianésia do Pará & L. de Tucuruí & $-0,67504$ & $-0,06194$ & $-0,03255$ & $-0,93770$ & 0,34763 & 0,75221 & 34,51 & B \\
\hline Muaná & Marajó & $-0,83476$ & $-0,04587$ & $-0,47413$ & 0,77283 & $-0,32834$ & 0,26069 & 34,37 & $\mathrm{~B}$ \\
\hline Bannach & Araguaia & $-0,56614$ & 0,43307 & 0,43083 & $-1,37703$ & $-1,08094$ & 0,45337 & 34,03 & B \\
\hline Água Azul do Norte & Araguaia & 0,40971 & $-0,37519$ & $-0,09198$ & $-0,82564$ & $-1,37639$ & 0,27133 & 33,40 & $B$ \\
\hline Uruará & Xingu & $-0,80470$ & 0,74500 & $-0,59393$ & $-0,35588$ & $-1,16730$ & 0,54372 & 33,27 & B \\
\hline Alenquer & B. Amazonas & $-0,74821$ & $-0,22739$ & $-0,27449$ & 0,89146 & $-0,69623$ & 0,04714 & 33,20 & $\mathrm{~B}$ \\
\hline Monte Alegre & B. Amazonas & $-0,08012$ & $-0,59559$ & $-0,89151$ & 0,04009 & 0,34236 & 0,32823 & 33,18 & $B$ \\
\hline Brasil Novo & Xingu & $-0,49250$ & 0,61812 & $-0,46976$ & $-0,80379$ & $-1,36770$ & 0,39239 & 32,33 & $B$ \\
\hline São Domingos do Araguaia & Carajás & $-0,40564$ & 0,13147 & $-0,28358$ & $-1,49193$ & 0,59445 & $-0,20000$ & 32,27 & B \\
\hline Acará & Tocantins & $-0,57392$ & $-0,88077$ & $-0,32981$ & 0,39423 & 0,76004 & 0,07252 & 32,09 & $\mathrm{~B}$ \\
\hline Prainha & B. Amazonas & $-0,40717$ & $-0,61672$ & $-0,61442$ & 0,89765 & $-0,75909$ & 0,44092 & 31,95 & B \\
\hline Santa Maria das Barreiras & Araguaia & $-0,17445$ & $-0,18756$ & $-0,08791$ & $-1,10501$ & $-1,11366$ & 0,92927 & 31,80 & B \\
\hline São Caetano de Odivelas & Guamá & $-0,07410$ & $-1,04470$ & $-0,29915$ & 0,13577 & 0,04636 & 0,20527 & 31,79 & B \\
\hline Viseu & Rio Caeté & 0,02183 & $-1,18299$ & $-0,18810$ & $-0,14738$ & 0,03905 & 0,37214 & 31,32 & B \\
\hline Portel & Marajó & $-1,89628$ & $-0,77658$ & 1,36970 & 0,89943 & $-0,07927$ & 0,17213 & 30,92 & B \\
\hline Floresta do Araguaia & Araguaia & $-1,07958$ & 0,14825 & $-0,11003$ & $-1,15911$ & 0,80700 & 0,07227 & 30,79 & $B$ \\
\hline Nova Ipixuna & L. de Tucuruí & $-0,55970$ & 0,34230 & $-0,23597$ & $-1,38197$ & $-0,34353$ & $-0,01561$ & 30,60 & B \\
\hline São Geraldo do Araguaia & Carajás & $-0,23693$ & 0,54405 & $-0,19769$ & $-1,65501$ & $-0,06857$ & $-1,45842$ & 30,37 & B \\
\hline Pacajá & Xingu & $-0,51330$ & $-0,81967$ & $-0,17627$ & $-0,26711$ & $-0,33342$ & 1,10750 & 30,31 & $\mathrm{~B}$ \\
\hline Cachoeira do Arari & Marajó & 0,33950 & $-0,89881$ & $-0,49222$ & $-0,39004$ & $-1,10843$ & 0,48077 & 29,67 & B \\
\hline Igarapé-Miri & Tocantins & $-1,10510$ & $-0,53501$ & $-0,04086$ & $-0,00508$ & 0,68828 & $-0,03982$ & 29,63 & B \\
\hline Eldorado dos Carajás & Carajás & $-0,49433$ & $-0,16332$ & $-0,36041$ & $-1,69837$ & 0,51872 & 0,48048 & 29,55 & B \\
\hline Itupiranga & L. de Tucuruí & $-0,43784$ & $-0,81886$ & $-0,30933$ & $-1,24794$ & 0,97628 & 0,75965 & 29,46 & $\mathrm{~B}$ \\
\hline Limoeiro do Ajuru & Tocantins & $-0,93439$ & $-0,75929$ & $-0,53915$ & 1,29840 & $-0,66515$ & 0,52562 & 29,05 & $B$ \\
\hline Aurora do Pará & Rio Capim & $-0,04202$ & $-1,00320$ & $-0,18226$ & $-0,05458$ & $-0,40486$ & $-0,25809$ & 29,01 & B \\
\hline Santa Luzia do Pará & Rio Caeté & $-0,41123$ & $-1,24482$ & $-0,40573$ & $-1,32776$ & 2,06244 & 0,32996 & 27,78 & B \\
\hline Cachoeira do Piriá & Rio Caeté & $-1,06130$ & $-1,04184$ & 0,60309 & 0,95626 & $-0,93851$ & $-0,03641$ & 27,78 & B \\
\hline Garrafão do Norte & Rio Capim & $-0,61773$ & $-0,60968$ & $-0,42218$ & $-0,52943$ & 0,67226 & $-0,54496$ & 26,86 & B \\
\hline São João do Araguaia & Carajás & $-0,23916$ & $-1,27557$ & 0,07181 & $-1,23473$ & 0,49973 & 0,33769 & 26,40 & MB \\
\hline Senador José Porfírio & Xingu & $-1,59795$ & $-0,23164$ & $-0,67210$ & $-0,70419$ & 1,84095 & 0,10789 & 25,82 & MB \\
\hline Pau D'Arco & Araguaia & $-0,92458$ & $-0,24278$ & $-0,46967$ & $-1,64581$ & 0,80743 & 0,34598 & 25,36 & $\mathrm{MB}$ \\
\hline Breves & Marajó & $-1,67981$ & $-0,23437$ & $-0,21036$ & 0,45655 & $-0,14854$ & $-0,06658$ & 25,08 & MB \\
\hline Piçarra & Carajás & $-0,48106$ & $-0,15455$ & $-0,12531$ & $-1,58944$ & $-0,51738$ & $-0,42841$ & 24,72 & MB \\
\hline
\end{tabular}


(continuação...)

\begin{tabular}{|l|c|c|c|c|c|c|c|c|c|c|}
\multicolumn{2}{c}{ Municípios } & Região & \multicolumn{2}{c}{ F1 F2 } & \multicolumn{1}{c}{ F3 } & F4 & F5 & F6 IDR & GD \\
\hline Gurupá & Marajó & $-1,40974$ & $-0,55775$ & $-0,26134$ & 0,82450 & $-0,85328$ & 0,05687 & 23,82 & MB \\
\hline Nova Esperança do Piriá & Rio Capim & $-0,75119$ & $-0,95306$ & $-0,13068$ & $-0,64553$ & 0,34748 & $-0,42497$ & 23,12 & MB \\
\hline Faro & B. Amazonas & $-0,92473$ & $-0,24810$ & $-1,14126$ & $-0,63182$ & $-0,31209$ & 0,09979 & 21,02 & MB \\
\hline Afuá & Marajó & $-1,67532$ & $-1,05972$ & 0,07020 & 0,38858 & $-0,10486$ & 0,16963 & 20,35 & MB \\
\hline Santa Cruz do Arari & Marajó & 1,25977 & $-0,94322$ & $-0,10312$ & $-0,56279$ & $-1,34609$ & $-4,95602$ & 19,95 & MB \\
\hline Anajás & Marajó & $-1,93176$ & $-0,81289$ & 0,40719 & $-0,12490$ & 0,09762 & $-0,30132$ & 19,04 & MB \\
\hline Chaves & Marajó & $-1,19045$ & $-1,28565$ & $-0,18550$ & 0,09435 & $-0,77182$ & 0,00683 & 16,75 & MB \\
\hline Jacareacanga & Tapajós & $-1,66209$ & $-0,55445$ & $-0,45652$ & $-1,32311$ & 0,16765 & 0,00311 & 14,29 & MB \\
\hline Ponta de Pedras & Marajó & $-0,56565$ & $-0,32788$ & $-0,39224$ & $-0,03024$ & $-1,65308$ & $-4,30467$ & 11,04 & MMB \\
\hline Curralinho & Marajó & $-1,69571$ & $-0,38560$ & $-0,45166$ & 0,84607 & $-1,21555$ & $-4,31379$ & 5,99 & MMB \\
\hline Melgaço & Marajó & $-2,24824$ & $-0,84885$ & 0,00558 & 0,78661 & $-0,89289$ & $-4,56772$ & 0,00 & MMB \\
\hline
\end{tabular}




\section{Bapítulo 6}

\section{COMERCIO INTERNACIONAL E DESENVOLVIMENTO REGIONAL: AS EXPORTACOÕES DOS SETORES DE UVA E DE MANGA DO ESTADO DE PERNAMBUCO}

\section{Maria Raiza Vicente da Silva}

\section{Maria Gilca Pinto Xavier}

Resumo: Devido às políticas de desenvolvimento regional implementadas desde a metade do século XX, o Vale do São Francisco experimentou nos últimos anos expressivo crescimento de sua fruticultura, sendo hoje um grande exportador de manga e uva, abrangendo os estados de Pernambuco e Bahia. O objetivo deste trabalho consiste em analisar a ocorrência de vantagens comparativas nos setores de exportação de uva e de manga na economia de Pernambuco frente a outros setores exportadores e sua importância no crescimento nos municípios pernambucanos da região no período entre 2010 e 2017. A concepção de vantagem comparativa aqui trabalhada compara as vantagens de diferentes produtos numa mesma região. O método utilizado para medi-la foi o cálculo do Índice de Contribuição ao Saldo Comercial que busca identificar a especialização das exportações de uma região ou país. Para medir o crescimento econômico, foram estudados os principais indicadores socioeconômicos. Os resultados mostraram que tanto o setor de uvas como o de mangas tem vantagens comparativas e apesar da uva ter perdido espaço para outros setores exportadores do estado, ambos os setores permanecem como importantes fatores de geração de crescimento da economia regional.

Palavras-chave: Desenvolvimento Regional, Vantagens Comparativas; Exportação; Uvas; Manga.

*Artigo apresentado no $56^{\circ}$ Congresso da Sociedade Brasileira de Economia, Administração e Sociologia Rural (SOBER), ocorrido na UNICAMP de 29/07 a 01/08 de 2018 


\section{INTRODUÇÃO}

Abrangendo municípios do sertão dos Estados da Bahia e de Pernambuco, o Vale do São Francisco é hoje uma das regiões frutícolas mais importantes para a economia dos dois Estados, com cerca de $90 \%$ de sua produção exportada para outros países (Araújo \& Silva, 2013). Suas maiores cidades, Petrolina (PE) e Juazeiro (BA), experimentaram expressivo desenvolvimento, passando respectivamente de um Índice de Desenvolvimento Humano Municipal (IDHM) de 0,471 e 0,396 em 1991, para 0,697 e 0,677 em 2010, ou seja, passando de um IDHM muito baixo para médio em 19 anos, de acordo com o Atlas de Desenvolvimento Humano do Brasil (2010).

Apesar de semiárida, a região do Vale do São Francisco cultiva manga e uva durante todo o ano. Isso ocorre devido a um processo histórico de políticas públicas focadas no desenvolvimento da região (ZUZA, 2008) que, dentre outras ações, implantou diversos perímetros irrigados e promoveu outros estímulos, como concessão de crédito e financiamentos para o setor agropecuário (CORREIA, ARAUJO \& CAVALCANTI, 2001).

As articulações sociais e políticas para desenvolvimento da região não são recentes, iniciaram-se com a criação da estatal Companhia Hidrelétrica do São Francisco (CHESF) em 1945, cujo objetivo era fornecer energia elétrica para o Nordeste e, com a Constituição de 1946, que determinou que 1\% do orçamento da União seria destinado à integração dos mercados internos e externos do Vale por 20 anos (ZUZA, 2008).

Nos anos seguintes vieram os primeiros empreendimentos públicos voltados para os pequenos e médios produtores da região. $A$ Comissão do Vale do São Francisco (CVSF), em 1948, foi criada para promover o aproveitamento dos recursos naturais da região. Substituída pela Superintendência do Vale São Francisco em 1967, posteriormente, denominada Companhia de Desenvolvimento dos Vales do São Francisco e do Parnaíba (CODEVASF) em 1974, foi responsável pelas primeiras práticas de cultivo, fornecendo suporte técnico para produtores e comerciantes (HORA, 2014).

A Superintendência de Desenvolvimento do Nordeste (SUDENE) também deu grande impulso à economia local, instalando na região entre os anos de 1968 a 1971, os Campos Experimentais, que iniciaram trabalhos experimentais com videiras. Já em 1975, foi criado o Centro de Pesquisa Agropecuária do Trópico Semiárido, da Empresa Brasileira de Pesquisa Agropecuária (Embrapa/CPATSA) que fundamentou a base técnica para melhoria na qualidade $e$ aumento na produção de uva e manga na região (SOARES \& LEÃO, 2009).

A tecnologia introduzida pelas organizações públicas, como a Embrapa e os Campos Experimentais da SUDENE, possibilitou melhorias nas técnicas de irrigação, manejo e cultivo de novas variedades, levando a uma produção de melhor qualidade. Desse modo, a produção de uva e manga ganhou destaque na região, e muitos produtores começaram a produzir safras aptas a satisfazer as exigências do mercado externo.

A política de desenvolvimento do Vale também atuou no escoamento dessa produção, com a construção da ponte Presidente Dutra entre Petrolina e Juazeiro, o asfaltamento de rodovias e a inauguração do Aeroporto Nilo Coelho, que facilitou o envio dessa produção para fora do país. Hoje, o aeroporto é o principal modal para exportação, que também segue pelos portos de Salvador (BA) e Pecém (CE) para os Estados Unidos e países da Europa e Ásia (JC ONLINE, 1015).

Em consequência, o comércio internacional vem provocando ganhos de escala para a região, ampliando seu crescimento econômico. Na verdade, o acesso a um mercado mais amplo pode estimular a produtividade e trazer vantagens competitivas para a economia (ARAUJO \& SOARES, 2011). Diante do exposto, este artigo tem como objetivo analisar a ocorrência de vantagem comparativa nos setores de exportação de uva e da manga de Pernambuco frente a outros setores exportadores e verificar sua importância no crescimento nos municípios pernambucanos da região do Vale Submédio São Francisco, no período entre 2010 a 2017. Como método, foi utilizado o Índice de Contribuição ao Saldo Comercial (ICSC), que busca identificar a especialização das exportações de uma região ou país.

Este artigo foi dividido em cinco sessões: a primeira contextualiza as principais políticas de desenvolvimento da região do Vale do São Francisco, enquanto a segunda parte traz uma revisão de literatura sobre a correlação do comércio internacional com o crescimento regional. A terceira sessão traz o método 
utilizado e as fontes dos dados, já a quarta traz os resultados da pesquisa e por fim, a quinta sessão traz as considerações finais do trabalho.

\section{REVISÃO DE LITERATURA}

Entre os séculos XVI e XVIII, o comércio internacional é marcado pelo pensamento mercantilista, que defende que o principal meio de enriquecimento das nações é a acumulação de metais preciosos, e por isso as importações não seriam benéficas à economia por representarem saída de recursos, resultando em fortes medidas protecionistas (XAVIER, 2013).

Já a teoria econômica clássica surgiu nos séculos XVIII e XIX. Seus principais representantes, Adam Smith e David Ricardo, defendiam que o comércio internacional, ao contrário da visão mercantilista anterior, poderia ser benéfico para as nações. Enquanto Adam Smith se baseou no conceito de vantagens absolutas, David Ricardo desenvolveu o conceito das Vantagens Comparativas, que foi a base para diversas vertentes de teorias de comércio internacional. Seu pensamento baseava-se nos custos de produção dos vinhos de Portugal e tecidos da Inglaterra levando em conta o fator mão de obra. Segundo a teoria, Portugal possuía menores custos na fabricação do vinho em relação ao tecido, enquanto a Inglaterra possuía menores custos na produção de tecidos do que de vinhos. Isso levaria a uma especialização dos países nos produtos de maior vantagem comparativa interna (XAVIER, 2013, RICARDO, 1817).

Porém outros fatores de produção, protecionismo e o elevado custo de transporte de mercadorias que podem levar um país à autossuficiência interna, eram fatores não considerados no modelo de Ricardo. Mais tarde surgiu a Teoria de Heckscher-Ohlin, que difere do modelo de Ricardo em dois pontos principais: os dois únicos fatores de produção eram o capital e o trabalho e as tecnologias de produção dos dois países da transação eram iguais (KOSHIYAMA, 2008). Nesse modelo, o comércio internacional se desenvolvia devido às diferenças de recursos entre os países, ou seja, o país tende a exportar o fator de produção mais abundante e importar as mercadorias cujo fator de produção é menos abundante (KRUGMAN \& OBSTELD, 2005).
Ao considerar que a concorrência é perfeita, as tecnologias são constantes e não levam em conta as economias de escala, essas teorias não conseguem explicar o mercado atual. Esses fatores foram abordados por Michael Porter, cuja teoria diz que a vantagem competitiva era uma questão como as empresas e países melhoram a qualidade dos fatores e aumentam a produtividade. O aspecto qualitativo é mais importante que o quantitativo (PORTER, 1993).

Ao estudar as relações entre duas regiões, devemos ainda clarear as diferenças entre competitividade e vantagens comparativas. Lafay (1990 apud XAVIER, 2013) diz que a primeira compara os custos de um mesmo produto em diferentes mercados, enquanto a última compara diferentes produtos numa mesma região.

Com base nos estudos de David Ricardo, Balassa foi um dos escritores que mais contribuíram na elaboração de índices mais precisos acerca do tema, afirmando que o mercado externo seria capaz de revelar as vantagens comparativas de uma região. Para ele, quanto melhor o desempenho de uma região no mercado mundial, maiores as suas vantagens comparativas. Assim, em 1965 propôs o Índice de Vantagem Comparativa Revelada (VCR), que buscava identificar quais produtos os países ou estados possuíam vantagem comparativa (XAVIER, 2013). Do mesmo modo, Lafay propôs em 1990 o Índice de Contribuição ao Saldo Comercial (ICSC), que propunha identificar a especialização das exportações de uma região (SILVA, LERMAN, SILVA, \& CORONEL, 2016).

A relação causal entre comércio internacional sobre o crescimento econômico ainda não é um consenso pelos pesquisadores, tendo em vista que o contrário também pode ocorrer. Para Metzdorff (2015), países com maior atividade externa conseguem maiores ganhos e consecutivamente exibem maior crescimento. Para Guan e Hong (2012, apud METZDORFF, 2015), existe uma relação bidirecional entre exportações e PIB, mas não para importações e PIB, ou seja, as exportações podem gerar crescimento econômico, mas restringir as importações não tem o mesmo efeito.

Uma das primeiras teorias correlacionando comércio internacional e crescimento regional foi a Teoria da Base Exportadora, em que o produto e emprego regional cresce com a 
demanda pelas exportações dessa região. Nela o crescimento não decorre somente das vendas diretas. $O$ crescimento das exportações gera um aumento da renda resultando num aumento adicional das demandas locais, que por consequência leva a um crescimento adicional na renda regional. Porém essa teoria recebeu críticas por pressupor que é a exportação que induz às atividades do mercado interno, e por não explicar o crescimento econômico quando a região se industrializa e cresce de tamanho (KOSHIYAMA, 2008).

A teoria de base exportadora tem mais influência em pequenas economias regionais dominada por poucos setores e é válida em um curto prazo. Em regiões maiores e de economia diversificada, os setores não exportadores são mais importantes para o crescimento regional, pois seriam esses que influenciam os tipos de indústria que a região atrai (KOSHIYAMA, 2008). Porém, apesar de ser válida em economias menores, é importante salientar que, sem determinados serviços e uma infraestrutura urbana e logística básica, não é possível desenvolver nenhuma atividade de exportação.

\section{METODOLOGIA}

Para medir a vantagem comparativa do setor da uva em relação aos outros setores exportadores da economia de Pernambuco, foi utilizado o Índice de Contribuição ao Saldo Comercial (ICSC) proposto por Lafay em 1990 (apud GONÇALVEZ \& PAULILLO, 2016), que compara a balança comercial de um produto com o saldo comercial teórico desse mesmo produto. O índice é obtido de acordo com a equação a seguir:

$$
I C S C=\left\{\frac{100}{\frac{(X g+M g)}{2}}\right\}\left\{\left[(X v-M v)-(X g-M g) \frac{(X v+M v)}{(X g+M g)}\right]\right\}
$$

Em que:

ICSC é o Índice de Contribuição ao Saldo Comercial;

Xv é a exportação de um produto i numa região;

Mv é a importação de um produto i numa região;

Xg é exportação total da região;

e Mg é a importação total da região.

O primeiro termo da equação, entre colchetes, representa a balança comercial da uva e da manga (produto i), enquanto o segundo termo representa a balança comercial teórica. Quando o saldo comercial é maior que o saldo comercial teórico (ICSC $>0$ ), o produto possui vantagem comparativa revelada, caso contrário, para valores negativos $(\mathrm{ICSC}<0)$, o produto apresenta desvantagem (SOARES \& SILVA, 2013).

Em relação aos dados utilizados, a exportação de uva, de manga e a exportação total do estado de Pernambuco foram coletadas no Sistema de Análise das Informações de Comércio Exterior (ALICE Web) em valores FreeonBoard (FOB), abrangeram o período de 2010 a 2017. Os dados referentes ao setor de uvas frescas são representados na Nomenclatura Comum do
Sul(NCM) pelo código 08061000 e o de mangas frescas ou secas pelo código 08045020, a periodicidade das variáveis é anual. Os dados foram rodados no programa Matlab.

Para medir o crescimento econômico regional, foram utilizadas as variáveis Produto Interno Bruto (PIB) per capita e o Índice de Desenvolvimento Humano Municipal (IDHM) para as cidades pernambucanas de Petrolina, Lagoa Grande, Santa Maria e Orocó. O IDHM é um indicador socioeconômico que leva em consideração no seu cálculo, três dimensões: longevidade, educação e renda (ATLAS, 2010). Os dados do PIB per capita se referem aos anos de 2010 e 2014 e foram coletados no IBGE Cidades, enquanto os valores do IDHM se referem aos anos de 2000 e 2010 e foram coletados no Atlas do Desenvolvimento Humano no Brasil. 


\section{ANÁLISE DOS RESULTADOS}

No período estudado, a exportação de uvas pernambucanas teve forte queda, atingindo seu pico em 2011 e só voltando a crescer em 2017. Já os números de exportação da manga começaram mais modestos no período estudado, sofrendo oscilações nos primeiros anos e passando a crescer a partir de 2013, como mostra o Gráfico 1 em valores FOB.

Gráfico 1: Exportações de Manga e Uva de 2010 a 2017.

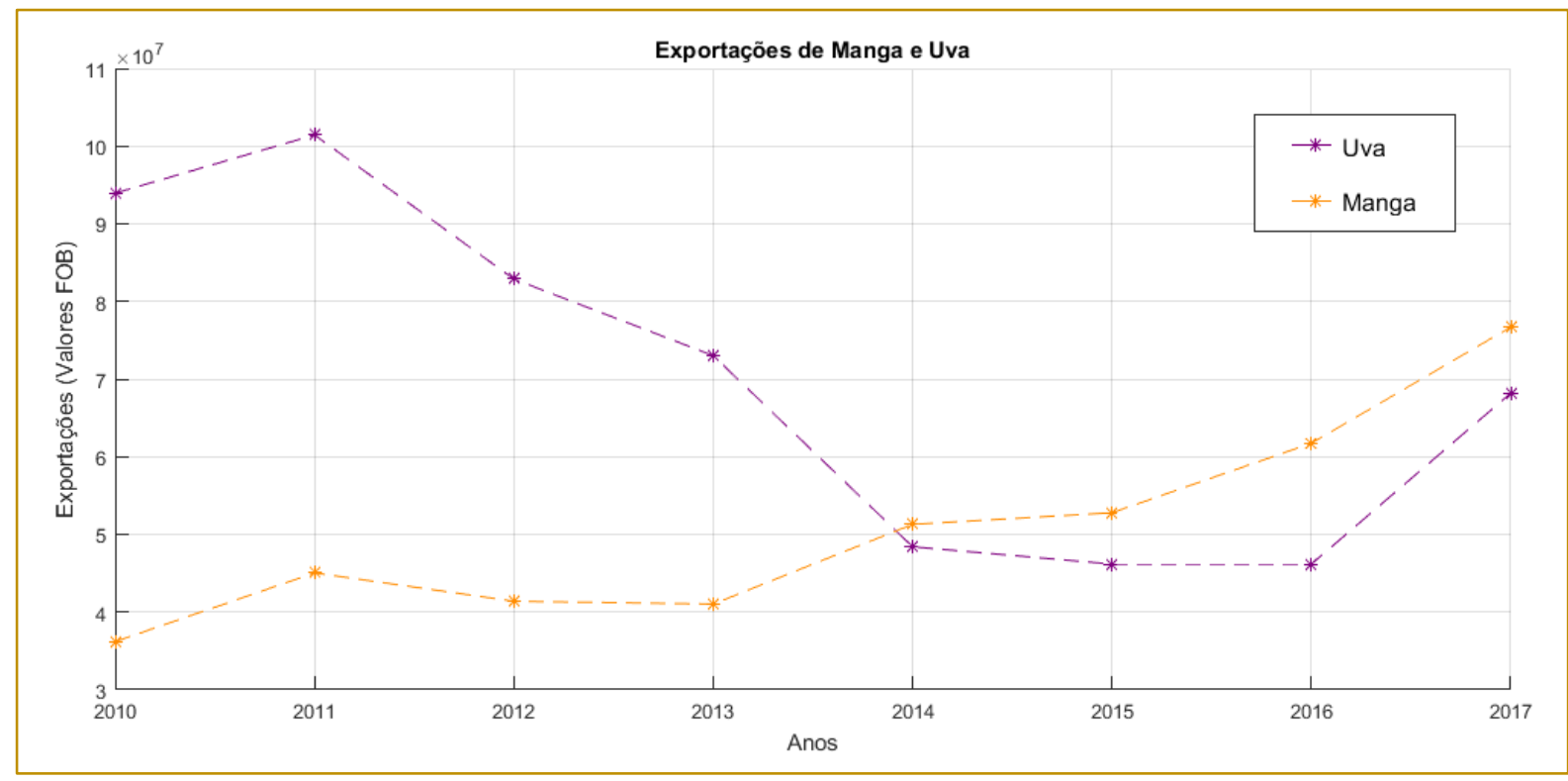

Fonte: AliceWeb

Dentre as variedades de videiras cultivadas no perímetro irrigado da região do Vale do São Francisco, estão a Benitaka, Benitaka Brasil, Itália comum, Itália melhorada, Patrícia, Ribier, RedGlobe, Crimssom, Festival e Thompsom (EMBRAPA, 2010). Quanto a manga as principais variedades na região são a Espada, Rosa, Haden, Keitt, Kent, Tommy Atkins, Palmer, Van dyke (EMBRAPA, 2004). Os principais produtores de uva são os municípios de Petrolina e Lagoa Grande, enquanto os de manga são os municípios de Petrolina e Santa Maria da Boa vista respectivamente.

Para identificar se os setores de uvas e de manga tiveram vantagem comparativa entre os outros setores de exportação do estado de Pernambuco, foi calculado o Índice de Contribuição para o Saldo Comercial de cada setor, representados visualmente no Gráfico 2. Nele é possível visualizar que todos os valores deram positivos para ambas culturas, indicando que tanto o setor de uvas como o de mangas possuem destaque na economia pernambucana, com vantagem comparativa em relação aos outros setores exportadores.

Porém percebe-se que o ICSC da uva apresentou considerável queda no período estudado, passando de 2,21 em 2010 para 0,56 em 2016, indicando que o setor diminuiu suas exportações pernambucanas ao longo do período, embora permaneça com vantagens comparativas em relação a outros setores exportadores.

Já o setor de mangas apresentou uma pequena queda nos primeiros anos, voltando a crescer a partir de 2013, tendo inclusive, passado o setor de uvas em representatividade dentro das exportações pernambucanas no ano seguinte e permanecendo com o ICSC maior que a uva desde então. 
Gráfico 2: Índice de Contribuição ao Saldo Comercial da Manga e da Uva de 2010 a 2017.

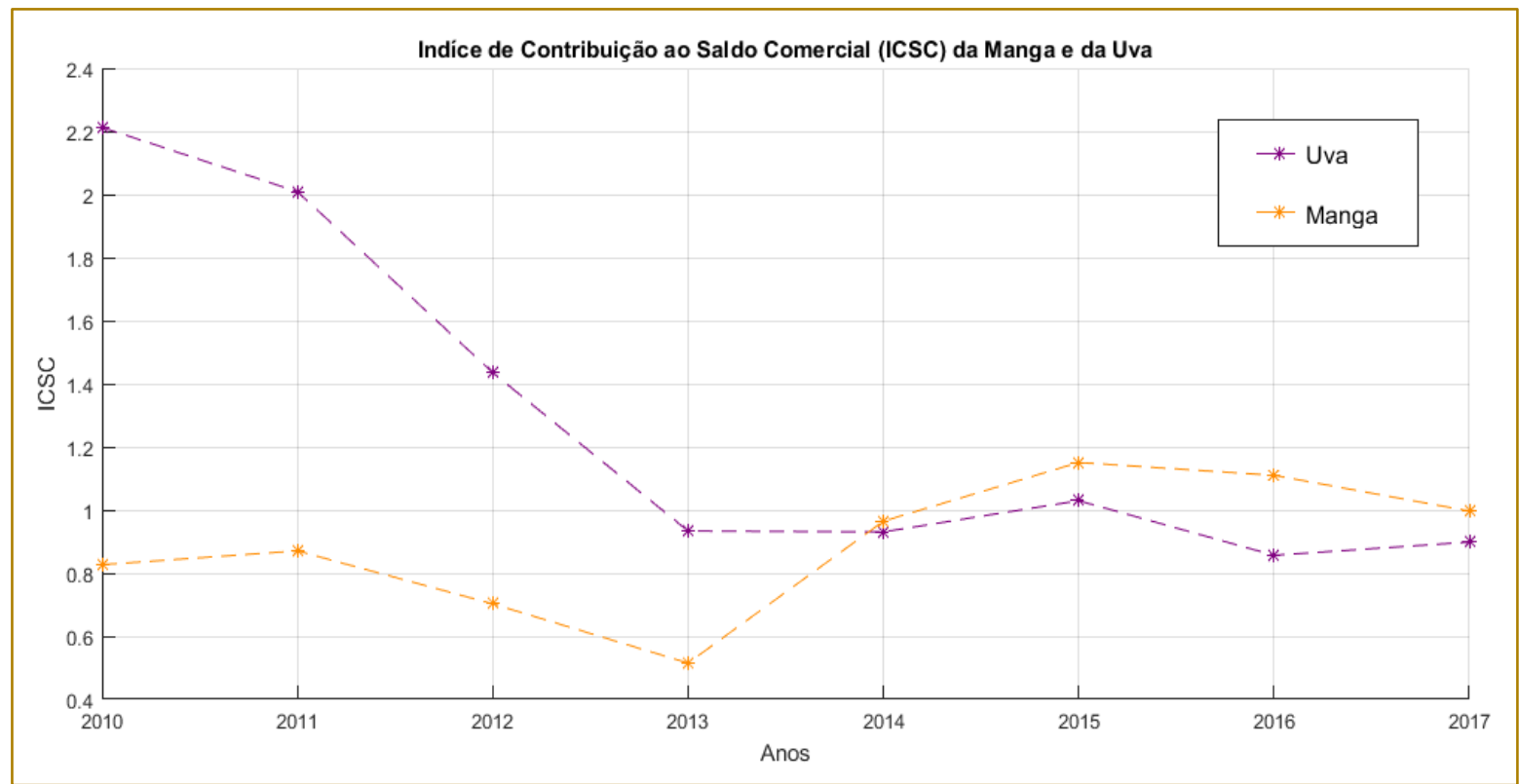

Fonte: Dados da pesquisa.

Segundo Isabella Ornellas (2014), a queda nas exportações de uva ocorreu porque o valor da fruta no mercado interno estava mais atrativo do que o do mercado externo. Com o dólar baixo, o preço praticado no Brasil era bem parecido com o praticado fora, e como exportar envolve vários riscos, os produtores preferiram vender a produção dentro do país. A região sudeste é a maior consumidora de uvas de mesa, absorvendo cerca de $46 \%$ da produção nacional e tendo o estado de São Paulo como principal mercado consumidor. Já o Nordeste, apesar de ser uma importante região produtora, corresponde a apenas $23,7 \%$ do consumo nacional (EMBRAPA, 2010).

O período entre 2014 e 2015 também experimentou uma queda na produção de uvas, gerando consecutivamente uma diminuição dos valores exportados. Edis Matsumoto em entrevista ao jornal G1 Petrolina (2014), apontou como principal causa da diminuição da produção, uma baixa na fertilidade das plantas devido ao clima do ciclo anterior, o que ocasionou uma diminuição de cachos. Já Freddo (2015) pontua o aumento nos juros das linhas de crédito, o que dificultou o custeio da safra pelos viticultores da região.

Mas, já no segundo semestre de 2016, os produtores começaram a esperar uma melhora das exportações. A alta do dólar em relação aos últimos quatro anos e a qualidade das frutas, com uma maior concentração de brix, que a faz mais doce, dá preferência aos consumidores de fora. O preço médio de uma caixa de $5 \mathrm{~kg}$ da variedade Seibel, cujo sabor é bastante apreciado por europeus, pode sair por até 10 euros, tornando a exportação mais vantajosa para o produtor (G1 PETROLINA, 2016).

Já a manga apresentou crescimento contínuo das exportações ao longo dos últimos anos. Tal fato ocorreu devido principalmente a cotação favorável do dólar, os novos mercados dentro dos Estados Unidos e os preços favoráveis para exportação, cuja caixa de manga chegou a ser vendida a US $\$ 12,00$ em 2016, enquanto que em anos anteriores não chegava nem a US\$10,00 (JC ONLINE, 2016).

A manga do Vale do São Francisco também ganhou novos mercados na Ásia, mas especificamente Seul, capital da Coreia do Sul. Fruto de uma negociação que já vinha há alguns anos, cerca de duas mil toneladas da fruta foram exportadas para o país no final de 2017, ampliando os mercados consumidores. Para o país seguiram três variedades: Tommy, Palmer e Kent, com a caixa de quatro quilos sendo vendida a 29 dólares (G1 PETROLINA, 2017).

O crescimento do PIB per capita dos municípios produtores indica que a economia da região também cresceu nos últimos anos. $\mathrm{Na}$ Tabela 2, nota-se que a maior alteração 
positiva de PIB per capita ocorreu em Petrolina, sendo ela a maior cidade pernambucana da região. $O$ crescimento menos expressivo nesse indicador foi o do município de Orocó. Outro dado que chama atenção é o município de Petrolândia, que, ao contrário dos outros, teve uma queda em seu PIB per capita, mas mesmo assim, continuou com o maior índice entre os municípios.

Tabela 1 Produto Interno Bruto per capita $(\mathrm{R} \$)$

\begin{tabular}{|c|c|c|c|c|c|c|}
\hline \multicolumn{7}{|c|}{ Produto Interno Bruto per capita (R\$) } \\
\hline \multirow{2}{*}{ PIB } & Petrolina & $\begin{array}{c}\text { Lagoa } \\
\text { Grande }\end{array}$ & Santa Maria & Orocó & $\begin{array}{c}\text { Belém do São } \\
\text { Francisco }\end{array}$ & Petrolândia \\
\hline 2010 & $11.677,58$ & $7.982,39$ & $7.232,83$ & $8.512,36$ & $4.932,80$ & $28.700,80$ \\
\hline 2014 & $16.043,56$ & $11.853,39$ & $11.130,02$ & $10.574,72$ & $7.936,93$ & $16.595,53$ \\
\hline
\end{tabular}

Fonte: IBGE Cidades.

Ao analisar o IDHM, indicador socioeconômico que leva em consideração aspectos da longevidade, educação e renda, percebe-se que houve significativa mudança na qualidade de vida dos municípios da região. Na Tabela 3 pode-se notar que no ano 2000 as cidades de Lagoa Grande, Santa Maria, Orocó e Belém do São Francisco possuíam IDHM Muito Baixo, enquanto Petrolina e Petrolândia IDHM Baixo. Num espaço de tempo de dez anos, o IDHM das cidades evoluiu, enquanto Lagoa Grande e Santa Maria ficaram na faixa Baixo, todas as outras passaram para a faixa Médio, sendo que Petrolina está bem próxima de passar para a próxima faixa.

Tabela 2 Índice de Desenvolvimento Humano Municipal

\begin{tabular}{|c|c|c|c|c|c|c|}
\hline \multicolumn{7}{|c|}{ Índice de Desenvolvimento Humano Municipal } \\
\hline IDHM & Petrolina & Lagoa Grande & Santa Maria & Orocó & $\begin{array}{c}\text { Belém do São } \\
\text { Francisco }\end{array}$ & Petrolândia \\
\hline 2000 & 0,580 & 0,441 & 0,468 & 0,474 & 0,482 & 0,527 \\
\hline 2010 & 0,697 & 0,597 & 0,590 & 0,610 & 0,642 & 0,623 \\
\hline
\end{tabular}

\section{CONSIDERAÇÕES FINAIS}

A história da fruticultura no Vale do São Francisco mostra que, através do empenho entre governo e sociedade, é possível vencer barreiras geográficas e históricas, como a seca, e prosperar uma região. O crescimento do mercado da uva e da manga nesse polo se mostrou importante não só para a economia local, mas para toda a economia do estado de Pernambuco.

A política de desenvolvimento regional iniciada ainda na década de 40, e que ao longo dos anos envolveu ações de investimento em inovações tecnológicas, implementação de órgãos técnicos e de articulação com empresas privadas, melhorias de infraestrutura e concessão de créditos e financiamentos, possibilitou a expansão da região, seu desenvolvimento social e econômico.

Apesar dos mercados da uva e da manga terem vantagens comparativas reveladas em relação a outros setores exportadores do estado de Pernambuco, houve uma expressiva diminuição nas exportações de uva nos últimos anos, consequência de uma taxa cambial pouco atrativa frente aos riscos de exportação, mostrando as influências do câmbio nas transações comerciais entre países. Porém, alta do dólar dos últimos anos e alta dos preços tem aumentado o interesse do produtor de uva de voltar a exportar. Enquanto isso, a manga teve crescimento constante, com preços mais vantajosos e atingindo novos mercados nos Estados Unidos e na Ásia, devido principalmente a qualidade da sua produção. 


\section{REFERÊNCIAS}

[1]. ARAUJO, R. A., SOARES, C. Export Led Growth' x 'Growth Led Exports': What Matters for the Brazilian Growth Experience after Trade Liberalization? MunichPersonalRePEcArchive. 2011. Disponível em: <https://mpra.ub.unimuenchen.de/30562/1/MPRA_paper_30562.pdf>. Acesso em 21 mar 2017.

[2]. ATLAS de Desenvolvimento Humano do Brasil. 2010. Disponível em: <http://www.atlasbrasil.org.br>. Acesso em 20 mar. 2017.

[3]. CORREIA, R. C.; ARAUJO, J. L. P.; CAVALCANTI, E. de B. In: Anais do Congresso Brasileiro de Economia e Sociologia Rural, Recife,2001.

[4]. EMBRAPA. (2004). Cultivo da Manga. Disponível em: <http://www.cpatsa.embrapa.br:8080/sistema_prod ucao/spmanga/cultivares.htm>. Acesso em 25 mar. 2018.

[5]. EMBRAPA. (2014). Levantamento dados de produção: culturas anuais, semi-perenes e perenes.

[6]. EMBRAPA. (2010). Cultivo da Videira. Disponível em: <http://www.cpatsa.embrapa.br:8080/sistema_prod ucao/spuva/comercializacao.html>. Acesso em 20 mar. 2017.

[7]. FREDDO, Ana Rita Lopes Farias. Conjuntura Mensal Uva e Derivados. CONAB. Disponível em <http://www.conab.gov.br/OlalaCMS/uploads/arqui vos/15_07_21_15_08_17_

[8]. G1 PETROLINA. (2014). Exportações de Frutas no Vale São Francisco sofrem queda em $2014 . \quad$ Disponível em: $<$ http://g1.globo.com/pe/petrolinaregiao/noticia/2014/11/exportacoes-de-frutas-novale-do-sao-francisco-sofrem-queda-em2014.html>. Acesso em 20 mar. 2017.

[9]. G1 PETROLINA. (2016). Produtores do Vale do São Francisco esperam alta na exportação de frutas. Disponivel em: <http://g1.globo.com/pe/petrolinaregiao/noticia/201 6/08/produtores-do-vale-do-sao-franciscoesperam-alta-na-exportacao-de-frutas.html>. Acesso em 20 mar. 2017

[10]. G1 PETROLINA. (2017). Mangas do Vale do São Francisco serão exportadas para Coreia do Sul. Disponível em: $<$ https://g1.globo.com/pe/petrolinaregiao/noticia/mangas-do-vale-do-sao-franciscoserao-exportadas-para-a-coreia-do-sul.ghtml>. Acesso em 25 mar. 2018

[11]. GONÇALVES, K. P. dos A.; PAULILLO, L. F. DE O. e. Competitividade do Agronegócio nos Estados Brasileiros: Evolução de Indicadores de Comércio Internacional entre 1997 e 2014. Anais do $54^{\circ}$ Congresso da Sociedade de Economia,
Administração e Sociologia Rural. João Pessoa, PB. 2015

[12]. HORA, G. B. Análise do processo de inovação no APL da vitivinicultura do vale do Submédio São Francisco 2001-2012. Recife, 2014.

[13]. JC ONLINE. Porto de Suape tenta atrair exportação de frutas do Vale do São Francisco. $2015 . \quad$ Disponível em: <http://jconline.ne10.uol.com.br/canal/economia/pe rnambuco/noticia/2015/10/10/porto-de-suape-tentaatrair-exportacao-de-frutas-do-vale-do-saofrancisco-203093.php>. Acesso em 30 jan. 2016.

[14]. JC ONLINE. Exportações de manga do Vale do São Francisco crescem 20\%. 2016. Disponível em: <http://jconline.ne10.uol.com.br/canal/economia/pe rnambuco/noticia/2016/05

[15]. /27/exportacoes-de-manga-do-vale-dosao-francisco-crescem-20_porcento-237621. php>. Acesso em 25 mar. 2018.

[16]. KRUGMAN, P.; OBSTFELD, M. Economía Internacional. 7. ed. Madrid: Pearson Addison Wesley, 2006, 768 p.

[17]. ORNELLAS, Isabella. (2014). Vale do São Francisco deve sofrer retração nas exportações. G1 Petrolina. Disponível em: <http://g1.globo.com/pe/petrolinaregiao/noticia/2014/09/vale-do-sao-francisco-devesofrer-retracao-nas-exportacoes-de-frutas.html>. Acesso em 20 mar. 2017.

[18]. PORTER, M. A vantagem competitiva das nações. Rio de Janeiro: Editora Campus, 1993.

[19]. RICARDO, DAVID. Princípios de Economia Política e Tributação. São Paulo: Editora Nova Cultural. 1817. $318 \mathrm{p}$

[20]. SILVA, M. L. da; LERMEN, N. G.; SILVA, R. A.; CORONEL, D. A. Análise da competitividade do setor vinícola do Rio Grande do Sul. Revista Qualitas. V.17 n.1 jan./mar. 2016.

[21]. SOARES, J. M.; LEÃO, P. C. de S. A Vitivinicultura no Semiárido Brasileiro - Brasília, DF: Embrapa Informação Tecnológica; Petrolina: Embrapa Semiárido, 2009.

[22]. SOARES, N. S.; SILVA, M. L. Competitividade brasileira no comércio internacional de produtos extrativos vegetais. Econ. NE, Fortaleza, v. 44, n. 4, p. 879-893, out/dez 2013. [23]. uvajunho2015.pdf>. Acesso em 20 mar. 2017. (errado na FONTE)

[24]. XAVIER, L. F. Exportações entre Brasil e China: uma análise sobre o aproveitamento de oportunidades comerciais. UFPE, Recife. 2013.

[25]. ZUZA, J. V. C. F. Apolítica econômica regional do Vale do São Francisco: uma busca do desenvolvimento do interior brasileiro. Revista Estudos Sociais, Mato Grosso. ano 10, n. 20, v. 2. 2008. 


\section{Capítulo 7}

\section{PRONAF, CAPITAL SOCIAL E EMPREENDEDORISMO RURAL: MODELO CONCEITUAL PARA DESENVOLVIMENTO DA AGRICULTURA FAMILIAR}

\section{Leonardo Guimarães Medeiros}

Resumo: O desenvolvimento rural pode ser entendido como ações articuladas previamente pretendendo induzir mudanças em um determinado ambiente rural. Destaca-se a melhoria do bem-estar das populações rurais como objetivo final desse desenvolvimento. Recentemente, políticas públicas para a agricultura familiar têm sido encaradas como o fator estratégico para se alcançar esse propósito. Após revisão da literatura e verificação do estado da arte, este artigo teórico apresenta um modelo conceitual composto por quatro dimensões que devem estar alinhadas para o alcance do desenvolvimento rural: PRONAF, capital social, perfil do empreendedor rural e formação do empreendedorismo rural. Com isso, são apresentadas proposições de pesquisa para serem testadas por futuros estudos empíricos que desejem responder a seguinte questão: quais as relações existentes entre PRONAF, capital social e empreendedorismo para desenvolvimento rural da agricultura familiar? O teste das proposições sugeridas neste texto pode revelar, dentre outros resultados, aspectos intrínsecos e possíveis falhas que o PRONAF apresenta em relação a sua contribuição à formação do empreendedorismo rural no Brasil, as principais dificuldades encontradas quanto a formação do capital social nos territórios e as características peculiares da agricultura familiar que podem ser fator chave no processo empreendedor.

Palavras-chave: Desenvolvimento rural, agricultura familiar, PRONAF, capital social, empreendedorismo rural. 


\section{INTRODUÇÃO}

No Brasil, o setor agropecuário se apresenta de forma bastante dinâmica, mostrando grupos de produtores que diferem muito entre si. Fatores como posse de terra, capital, mão de obra e destino da produção são bastante heterogêneos. Diante disso, em um contexto macro, existem no Brasil basicamente dois tipos de unidades produtivas: a agricultura patronal e a agricultura familiar (FAUTH, 2008).

A agricultura familiar, contudo, se define como uma unidade produtiva possuindo a utilização da mão de obra familiar, a moradia é no próprio estabelecimento e sua renda advém das atividades desenvolvidas por estes agricultores, podendo ser agrícola ou não, independente da sua extensão de terra (FAUTH, 2008). Porém, a Lei 11.326/2006, que estabelece conceito e princípios para a agricultura familiar, veio limitar a extensão de terras do empreendimento familiar rural em quatro módulos fiscais.

A agricultura familiar possui grande importância na produção agrícola brasileira, produzindo grande diversidade de produtos agropecuários (LEITE et al, 2004). Nesse sentido, todos esses produtos vão colaborar, seja para alimentação da própria família, seja para obtenção de renda (através da comercialização). Entretanto, percebe-se que essas famílias possuem características essenciais que as proporcionam ter um perfil empreendedor.

É fato que o principal responsável pela comida que chega às mesas das famílias brasileiras advém da agricultura familiar, a qual, responde por boa parte da produção dos alimentos consumidos em todo o país (BRASIL, 2015). Diante dessa responsabilidade, esses estabelecimentos familiares se diferenciam muito da agricultura comercial (constituída principalmente de médios e grandes fundiários). A agricultura familiar vem ganhando notoriedade no espaço econômico e sendo encarada como um setor estratégico da economia.

Neste sentido, surge a questão sobre o desenvolvimento rural, objeto de estudo de várias pesquisas (ABRAMOVAY, 2000; NAVARRO, 2001; SCHNEIDER, 2010; VEIGA, 2001; WANDERLEY, 2001), gerando volumosos debates à medida que há 0 crescimento populacional e aumento das práticas agrícolas. No Brasil, porém, percebese uma desproporcionalidade de políticas públicas voltadas para o desenvolvimento do meio rural e do meio urbano em relação a sua importância no contexto nacional. Em consequência disso, a pobreza no campo ainda continua alta.

O PRONAF é a principal política pública destinada a este segmento de agricultores. Iniciado no ano de 1995, o PRONAF se constitui no fornecimento de crédito subsidiado. Segundo Guanziroli (2007), o principal argumento para sua criação, era de que os agricultores familiares, descapitalizados e com baixa produtividade, não estariam em condições de tomar recursos a taxas de mercado para realizar investimentos em modernização e elevação da produtividade. Vinte e dois anos se passaram desde sua criação, e mesmo assim, os índices pobreza no campo ainda continuam relativamente altos, colocando em discussão a efetividade do PRONAF.

No entanto, considerando que as relações em comunidades de agricultores familiares são tecidas coletivamente e baseadas na reciprocidade (ABRAMOVAY, 1998), o crédito fornecido pelo PRONAF pode não ser eficientemente empregado caso não haja a existência de um outro recurso, o capital social. Esse recurso compreende a sociabilidade de um grupo humano, com os aspectos que permitem a colaboração e o seu uso. Os sociólogos sublinham que o capital social é formado pelas redes sociais, pela confiança mútua e pelas normas internas. De um modo geral, essa sociabilidade assume o termo capital por ser considerada um recurso que contribui para aumentar a eficiência da sociedade, facilitando as ações coordenadas (ABRAMOVAY, 2000). O capital social dentro das abordagens modernas sobre empreendedorismo pode ser considerado um ativo essencial para a solidificação do processo empreendedor.

O empreendedorismo rural pode ser entendido como o envolvimento de pessoas e processos que, em conjunto leva a transformação de ideias e oportunidades em negócios de sucesso no meio rural. E O empreendedor é o sujeito que detecta essa oportunidade e cria um negócio para capitalizar sobre ela, assumindo assim, riscos calculados e inovando continuamente (DORNELAS, 2012).

A importância de se estudar este tema se deve ao fato de existir estudos isolados que 
abordam tais subtemas e inexistir estudos, que abordam de forma relacionada na agricultura familiar, O PRONAF, O capital social e o empreendedorismo rural para o alcance do desenvolvimento rural.

Nesse contexto, após revisão da literatura, esse texto tem por objetivo apresentar um modelo teórico composto por proposições de pesquisa para serem testados por futuros estudos empíricos que desejem responder à seguinte questão: quais as relações existentes entre PRONAF, capital social e empreendedorismo para desenvolvimento rural da agricultura familiar? Espera-se que os testes das proposições sugeridas neste texto possam revelar, dentre outros resultados, a efetividade do PRONAF, o nível do capital social e a importância da formação do perfil empreendedor no meio rural.

\section{FUNDAMENTAÇÃO TEÓRICA \\ 2.1 PRONAF}

Antes da década de 1990 as políticas públicas para o meio rural estavam voltadas principalmente para a modernização e desenvolvimento de novas tecnologias para o campo. Isso privilegiaria somente os médios e grandes fundiários, principais produtores de commodities para exportação (WANDERLEY, 2014).

Nesse sentido, a figura do agricultor familiar estava marginalizada frente aos benefícios decorrentes da política agrícola na época, contidas essencialmente no crédito rural, nos preços mínimos, e no seguro agrícola. Juntando se a isso os agricultores familiares estavam descapitalizados e com baixa produtividade advinda de processos arcaicos de produção. Esses agricultores muitas vezes estavam passando por situação de pobreza extrema, gerando assim, o êxodo rural (MATTEI, 2015).

Um dos acontecimentos mais marcantes no que diz respeito às políticas públicas para o meio rural foi a criação do Programa Nacional de Fortalecimento da Agricultura Familiar (PRONAF). A criação desse programa veio reconhecer e legitimar o papel do Estado para especificidades de uma nova categoria social, os agricultores familiares, que até esse momento eram designados como pequenos produtores, produtores familiares, produtores de baixa renda ou agricultores de subsistência (SCHNEIDER et al. 2004).
Conforme Mattei (2005, p.2):

Com a criação do PRONAF atendeu-se a uma antiga reivindicação dos trabalhadores rurais, que colocava a necessidade da formulação e implementação de políticas de desenvolvimento rural especificas para o segmento numericamente mais importante, porém $\mathrm{O}$ mais fragilizado a agricultura brasileira, tanto em termos de capacidade técnica como de inserção nos mercados agropecuários

Contudo, destaca-se a contribuição de dois fatores importantes que impulsionaram a criação do programa. O primeiro deles se deve ao fato do reconhecimento institucional da agricultura familiar, originarias a partir de estudos da Food And Agriculture Organization (FAO) e do Instituto de Colonização e Reforma Agrária (INCRA) no início da década de 1990. A partir desse momento, o segmento de agricultores familiares ganhou visibilidade e importância no contexto nacional (AZEVEDO; PESSÔA, 2011).

Segundo Mattei (2015), outro fator que contribuiu para isso são os movimentos sindicais, principalmente, através das reivindicações dos trabalhadores rurais, onde ganharam destaque nas chamadas "Jornadas Nacionais de Luta" na primeira metade da década de 1990, nos estados da região sul do Brasil.

O programa como se conhece hoje é resultado de diversas modificações institucionais no decorrer dos anos. Cronologicamente, o embrião do PRONAF foi - Programa de Valorização da Pequena Produção Rural (PROVAP), criado no então governo do presidente Itamar Franco. O PROVAP operava basicamente com recursos oriundos do Banco Nacional de Desenvolvimento (BNDES), vale destacar que esse programa obteve resultados tímidos do ponto de vista dos recursos destinados aos agricultores, entretanto foi o precursor de uma transição de políticas públicas diferenciadas destinadas a agricultores familiares. Já em 1995, no governo de Fernando Henrique Cardoso, O PROVAP foi totalmente reformulado, dando origem em 1996 ao PRONAF, cuja institucionalização ocorreu através do Decreto presidencial $\mathrm{n}$ - 1.996, datado de 28/07/1996. Desse momento em diante o PRONAF é tido como a principal política pública do Governo Federal para os agricultores familiares (SCHNEIDER et al, 2004). 
De acordo com Brasil (1996), o programa visa o fortalecimento da agricultura familiar mediante o apoio técnico e financeiro, para promover o desenvolvimento rural sustentável, possuindo como objetivo central fortalecer a capacidade produtiva da agricultura familiar, contribuir para a geração de emprego e renda nas áreas rurais e melhorar a qualidade de vida dos agricultores familiares. O programa possui diferentes categorias de beneficiários, onde estão organizados em grupos de acordo com suas características sociais, econômicas e culturais.

Nesses 20 anos de existência do PRONAF seus números são animadores, foram aplicados aproximadamente $\mathrm{R} \$ 160$ bilhões em mais de 26 milhões de contratos, nas suas diferentes modalidades e para diferentes tipologias de agricultores familiares. Para se ter uma noção dessa dimensão, somente na linha "Mais Alimentos" foram financiados 50.000 tratores nos últimos 7 anos e $\mathrm{R} \$ 5,6$ bilhões foram destinados em investimentos em agricultores situavam-se abaixo da linha da pobreza. Em função da magnitude e importância desse programa ele é referência para o mundo em se tratando de política pública para agricultores familiares (BIANCHINI, 2015).

De acordo com Guanziroli (2007), para que o PRONAF não perca sua característica original de proteger esse segmento de agricultores duramente castigados antes da década de 1990, é necessário que o programa seja permanentemente revisto, avaliado e aperfeiçoado sob a perspectiva de que esses recursos sejam usados de maneira eficiente, produzindo resultados efetivos para 0 desenvolvimento rural.

\subsection{CAPITAL SOCIAL}

Em torno do desenvolvimento rural, não se deve ater ao apontamento de vantagens ou obstáculos geográficos de localização e sim, estudar a montagem das "redes", das "convenções", ou seja, das instituições que permitem ações cooperativas - que incluem, evidentemente, a conquista de bens públicos como educação, saúde, informação capazes de enriquecer o tecido social de uma certa localidade. Este processo de enriquecimento, - muito influente nas organizações internacionais de desenvolvimento - chamado, com base nos trabalhos de Coleman (1988) e Putmam (1996), de capital social, refere-se às "[...] características da organização social, como confiança, normas e sistemas, que contribuem para aumentar a eficiência da sociedade, facilitando as ações coordenadas" (ABRAMOVAY, 2000).

Capital social emergiu como um dos conceitos mais salientes das ciências sociais e é visto a partir de pontos de vista divergentes, sendo os estudos utilizando a perspectiva teórica impulsionada com base na publicação dos trabalhos de Coleman (1988) e Putnam (1996.). Para Coleman (1988), capital social pode ser definido como o conjunto de aspectos da estrutura social, que facilitam certas ações comuns dos agentes dentro de uma estrutura. Nesse ponto de vista, a ausência de capital social impossibilita certas ações e o alcance de objetivos que estariam acessíveis com a sua presença. Por sua vez, Putnam (1993) apresenta o capital social como um conjunto de aspectos das organizações sociais. Dentre esses aspectos, tem-se: redes de relacionamento, normas e confiança que permitem a ação e a cooperação para o benefício mútuo.

Para Putnam (1993), o capital social gera condições para a instalação e fortalecimento da democracia e melhores resultados econômicos. O capital social aumenta a participação popular em todo o processo político, promove relações horizontais de reciprocidade e cooperação - ao invés de relações verticais de autoridade e dependência - cria redes de solidariedade, confiança e tolerância, e possibilita elevados níveis de participação nas associações.

Em sua perspectiva, o cerne do capital social são as relações de confiança e cooperação existentes entre os indivíduos de determinada região. As relações de confiança objetivam a promoção da cooperação ou atuam ampliando a probabilidade de maior ocorrência. O estoque de capital social é criado a partir de um ciclo virtuoso de confiança e cooperação entre os indivíduos (PUTNAM, 1996).

Putnam $(1993,1996)$ levanta a hipótese de que os níveis de engajamento cívico e do associativismo poderiam proporcionar condições de melhoria do bem-estar da comunidade. O associativismo horizontal, fruto de confiança, normas e redes de solidariedade, produziria relações cívicas virtuosas. Enquanto que o associativismo vertical, no qual predominaria a desconfiança, 
ausência de normas transparentes, faccionismo, isolamento etc., produziria obstrução da ação coletiva.

\subsection{EMPREENDEDORISMO RURAL}

Em um primeiro momento parece impossível relacionar à palavra empreendedorismo a agricultura familiar, pois se imagina no senso comum, que este agricultor não possua uma visão inovadora, devido principalmente a sua infraestrutura inadequada, baixo nível de escolaridade, baixa qualificação, baixa renda e uma cultura que não incentiva a capacidade de assumir riscos em suas atividades (TOMEI; LIMA, 2014).

Entretanto, o que se observa na prática contradiz isso, observa-se cada vez mais que a família assentada está agregando valor a sua produção com processos de produção eficientes, além do beneficiamento e embalagem de seus produtos, se utilizando de ideias inovadoras. Com isso, Veiga (2002) afirma que as chances de desenvolvimento rural brasileiro estão estritamente relacionadas à capacidade de empreendedorismo da população local, na qual, possibilita a geração de emprego e renda.

O termo empreendedorismo muito difundido nos dias atuais é visto por muitos autores como uma transformação que mudará a forma das organizações no mundo, assim como foi a Primeira Revolução Industrial ocorrida no século XVIII e Segunda Revolução Industrial no Século XIX. No Brasil e nos países em desenvolvimento, esse termo muitas vezes está estritamente relacionando a momentos de crise na economia, uma vez que, é nesse momento onde encontra se as melhores oportunidades de negócio e há um aumento do chamado empreendedorismo de necessidade devidos aos altos índices de desemprego (DORNELAS, 2012).

Não há uma definição absoluta de empreendedorismo, vários autores o atribuíam a diferentes abordagens, contudo, define-se genericamente empreendedorismo sendo o envolvimento das pessoas e processos que, no contexto geral, levam a transformação de ideias em oportunidades. E o empreendedor é o sujeito que detecta essa oportunidade e cria um negócio para capitalizar sobre ela, assumindo assim, riscos calculados (DORNELAS, 2012).
Segundo Fillion (1999) embora tenha sido estudado vários séculos antes, foi somente no século XX que o empreendedorismo recebeu atenção especial. Várias vertentes de estudo se originaram nesse século, dentre elas, se destaca a vertente comportamentalista, na qual será utilizada mais adiante para estabelecer uma relação entre o comportamento da família assentada e sua capacidade de empreender utilizando recursos do PRONAF.

A escola comportamentalista (behavorista) assim como foi chamada, tinha o objetivo de definir basicamente o que significava ser um empreendedor e quais características o mesmo deveria possuir (McCLELLAND, 1971).

Vários são os fatores que influenciam o comportamento do empreendedor. Sobre isso Fillion (1999, p.10) descreve:

Uma amostragem de empreendedores que entraram no mercado há dois anos não dará o mesmo perfil de outros empreendedores que se lançaram 20 anos atrás. Treinamento e emprego anteriores também terão certo impacto, assim como religião, valores da comunidade educacional e cultura familiar, entre outros

Ao se fazer uma pesquisa na literatura sobre o termo empreendedorismo rural, pouco se encontra sobre esse assunto seja no Brasil ou em outros lugares no mundo. $O$ que pode ser visto, porém, são alguns artigos, dissertações, estudos de caso, cartilhas e alguns programas voltados para essa vertente advindas de organizações como o Serviço Brasileiro de Apoio ás Micro e Pequenas Empresas (SEBRAE), Serviço Nacional de Aprendizagem Rural (SENAR) e Fundação Educacional para o Desenvolvimento Rural (FUNAR) e, mesmo assim, somente em alguns estados brasileiros.

Percebe-se que, ao demonstrar anteriormente o conceito de empreendedorismo que, o mesmo não possui uma definição absoluta. Diante disso Tomei; Lima (2014, p.110) discorrem sobre o empreendedorismo rural:

Essa falta de convergência sobre quem seria o empreendedor e o que seria rural talvez seja um indicativo da razão de se ter uma literatura tão escassa sobre quem seria, portanto, o empreendedor rural. Combinar dois temas polêmicos não é uma tarefa simples e poderá suscitar uma discussão ainda maior. 
Entretanto, apesar dessas discussões, é possível identificar a importância do empreendedorismo no meio rural, especialmente para a agricultura familiar e sua contribuição para o desenvolvimento rural. Sobre isso, Veiga (2002) afirma que as chances de desenvolvimento rural brasileira estão estritamente relacionadas à capacidade de empreendedorismo da população local, na qual, possibilita a geração de emprego e renda.

\subsection{DESENVOLVIMENTO RURAL}

Pretende-se propor neste estudo, proposições de estudo de como ocorre o desenvolvimento rural em um local que possui hipoteticamente população empreendedora, capital social e recursos disponibilizados pelo PRONAF. Para isso, se faz necessário sua compreensão. De acordo com Schneider et al (2004), a definição de desenvolvimento rural pode ser encarada semelhante a de desenvolvimento econômico apenas com o viés voltado para o meio rural, ou seja, são ações articuladas visando induzir mudanças socioeconômicas e ambientais no ambiente rural para melhorar a renda, a qualidade de vida e o bem estar dessas populações.

Diante dessa perspectiva, se em um determinado espaço rural ocorrer um aumento substancial da produção agropecuária devido a utilização de tecnologias e melhoramento do processo, entretanto se esse mesmo crescimento não vier acompanhado de aumento de renda, qualidade de vida e bem estar, pode se dizer que houve apenas o crescimento desse setor, mas não o desenvolvimento do espaço rural.

Veiga (2001) ao analisar os estudos da professora Joan Robison da Universidade de Cambridge, complementa essa definição abordando a ampliação das liberdades. O desenvolvimento corresponde ampliação das possibilidades de escolha diante de mais opções, sobretudo das oportunidades de expansão das potencialidades humanas que, nesse momento depende dos fatores descritos anteriormente que garantam a qualidade de vida e bem estar como saúde, educação, comunicação, direito e liberdade. Dessa forma, em países desenvolvidos, as pessoas possuem muito mais chances e opções do que no restante do mundo.

O desenvolvimento rural no Brasil se apresenta de forma dinâmica entre as décadas de 1950 e 1980, o crescimento demonstrado no espaço rural era orientado através de políticas públicas que favoreciam a modernização da agricultura e a aplicação de novas tecnologias no campo, nas quais, tinham como alvo os médios e grandes fundiários. Isso acarretou no aumento da pobreza no campo e êxodo rural, diante da crise desse modelo de desenvolvimento, na década de 1990 houve uma reformulação das políticas públicas para o desenvolvimento rural. A partir desse momento, o agricultor familiar que antes estava marginalizado, passou a ser o foco de políticas públicas especificas (GRACIANO, 2016).

Outro aspecto que também deve ser considerado como parte do contexto emergente do desenvolvimento rural na década de 1990, é o fato de ter ressurgidos organizações e movimentos sociais que haviam sido oprimidos durante o período da ditadura militar. Esses movimentos sociais e organizações passaram a exercer uma atitude proativa e propositiva, fazendo com que a sociedade civil ampliasse a diversidade de formas de expressões. Nesse contexto, houve um aumento significativo de organizações não governamentais (ONGs), associações, cooperativas, entre outras (SCHNEIDER, 2010).

Entretanto, desenvolvimento rural não se restringe tão somente população rural, mas compreende todas as mudanças sociais, as quais se tem por limite o município, pois podem se estender para horizontes territoriais mais extensos (NAVARRO, 2001).

Contudo, Graciano (2016) afirma que o meio rural deve ser interpretado de modo geral, pois há uma diversidade enorme de atores, instituições, funções, perspectivas culturais, sociais e ambientais. E para que haja um desenvolvimento rural de forma efetiva é necessário equilibrar todos esses atores em consonância com o desenvolvimento econômico e proteção ambiental.

\section{PROPOSIÇÕES DE PESQUISA E MODELO CONCEITUAL}

As proposições de pesquisas estão agrupadas para cada uma das dimensões propostas neste estudo.

\subsection{PROPOSIÇÕES LIGADAS AO PRONAF}

O Pronaf foi um marco na história das políticas públicas brasileiras exatamente por 
associar o acesso do agricultor familiar a um ativo fundamental para empreender na sua propriedade: O crédito. (ABRAMOVAY; VEIGA, 1999).

Tendo em vista que Marioni et al. (2016) apontam que a região sul recebeu o maior volume de recursos do PRONAF entre 2000 e 2012, e que essa região tem alto índice de desenvolvimento em termos de empreendimento rural (Miyazaki at al, 2008; Weber et al, 2016), é plausível supor que existe relação direta entre volume de crédito do Pronaf e a formação do empreendedor rural no Brasil, levando à primeira proposição deste estudo:

Proposição 1: Quanto maior o volume de crédito obtido pelo agricultor familiar, maior a influencia na formação do empreendedor rural.

Medina (2016) aborda sobre o número de contratos efetivados pelo PRONAF, concluindo que, embora o valor disponibilizado pelo Plano Safra da Agricultura Familiar aumente a cada ano, o número de agricultores familiares beneficiados com o PRONAF, permanece o mesmo, aumentando, consequentemente, a concentração dos recursos para uma parcela distinta de produtores familiares, possivelmente agricultores mais desenvolvidos. No contexto nacional, a expansão do crédito vem se baseando exclusivamente no aumento do tamanho médio dos contratos e na crescente participação de estados com agricultura mais capitalizada em sua distribuição, principalmente a região sul do Brasil (SOUZA et $\mathrm{al}$, 2013). Diante dessas evidencias empírica, é apresentada a segunda proposição:

Proposição 2: A frequência com que 0 agricultor familiar recorre aos recursos do PRONAF afeta positivamente a formação do empreendedor rural.

Em relação ao uso dos recursos do PRONAF, foi observado que no estado de Goiás a liberação do crédito é realizada de forma concentrada para as atividades tradicionais. Conforme Medina (2016), as instituições financeiras facilitam a liberação de recursos para financiar atividades já consolidadas na região, como é o caso da bovinocultura de leite em Goiás. Mesmo que o programa possua linhas de crédito para outras atividades, o agricultor é forçado requerer o crédito para atividades tradicionais, sendo seu uso não condizente com a principal finalidade da linha de crédito.

No estudo realizado por Mera e Didonet (2010), para descrever a aplicação dos recursos do PRONAF no município de Cruz Alta - RS, chegou-se à conclusão que 39,35\% dos agricultores familiares utilizam 0 financiamento para quitar dívidas fora do PRONAF e adquirir bens de consumo duráveis e não duráveis. Considerando tais evidencias, formula-se a terceira proposição:

Proposição 3: O uso dos recursos do Pronaf na prática não condiz com a obtenção do crédito inicialmente, prejudicando a formação do empreendedor rural.

\subsection{PROPOSIÇÕES LIGADAS AO CAPITAL SOCIAL}

Pesquisas (ABRAMOVAY, 2000; COSTA; GALINA, 2016; MIYAZAKI et al. 2008) defendem o fortalecimento do capital como mecanismo de desenvolvimento de territórios. Informações chave no processo empreendedor são transmitidas por pessoas de confiança do empreendedor, como amigos de longa data e familiares próximos (GRANOVETTER, 1973; JULIEN, 2000). A confiança torna essas pessoas fontes de consulta da maior parte dos empreendedores quanto à avaliação e decisão de aproveitar ou não oportunidades de negócios (DAVIDSSON; HONIG, 2003). Considerando que confiança é um elemento central do capital social (VEIGA, 2005), isto é, a ideia segunda a qual é a existência de um mínimo de confiança coletiva que condiciona a reação de um território ao esgotamento de atividades lucrativas que até então garantiam seu progresso, formula-se a quarta proposição:

Proposição 4: O capital social proporciona ao agricultor familiar acesso a informações e ideias com potencial de serem oportunidades de negócio.

Proposição 5: Capital social afeta positivamente a formação do empreendedor rural.

\subsection{PROPOSIÇÕES LIGADA AO PERFIL EMPREENDEDOR}

Empreendedorismo rural é constituído pelo envolvimento de pessoas e processos que, em conjunto, transformam ideias $e$ 
oportunidades em negócios de sucesso no meio rural. Machado et al. (2003), em estudo que investiga o perfil gerencial de mulheres empreendedoras no Brasil, Canadá e França, indicam que, em média, o tempo de experiência profissional é de nove anos. Adicionalmente, Faia et al. (2014), em estudo com empreendedores de vários segmentos econômicos brasileiros, mostram que a experiência profissional, geradora conhecimentos tácitos que facilitam a integração e acumulação de novos conhecimentos, também concorre para a adaptação às novas situações. Considerando estes argumentos, a quinta proposição é formulada:

Proposição 6: A experiência na atividade produtiva de agricultores familiares afeta positivamente a formação do empreendedor rural.

Outro aspecto fundamental são as características do perfil empreendedor que o agricultor familiar deve possuir. O estudo de Tomei e Lima (2014) evidenciou que as barreiras para a formação do empreendedorismo rural estavam associadas à ausência de liderança e capacidade de assumir riscos; e enfatizou a importância da família, redes sociais e da educação formal no desenvolvimento da agricultura familiar. Weber et al (2016) abordam que os agricultores familiares costumam preservar a cultura nos métodos de produção não buscando inovação. Neste sentido, a sétima proposição é estabelecida:

Proposição 7: Características presentes no agricultor familiar como liderança, capacidade de assumir riscos e inovação afeta positivamente a sua formação de empreendedor rural.

O conhecimento do mercado é um dos aspectos formativos do perfil empreendedor, relacionando-se com o nível de informações que o empreendedor possui do mercado em que atua. Greatti (2005) identificou que o conhecimento do ramo é um dos aspectos que mais influenciam o sucesso do negócio no início de suas atividades em micro e pequenas empresas da cidade de Maringá/PR. Conhecimento do mercado e do ramo em que se pretende atuar é essencial para se perceber as chances de sucessos e prevenir-se em relação aos imprevistos
(GREATTI, 205). No entanto, no contexto da agricultura familiar, Weber et al. (2016) mostram que esse aspecto é um ponto fraco, pois, muitas vezes, a distância de centros urbanos e o baixo acesso aos meios de comunicação, são barreiras a um maior nível de informações mercadológicas de agricultores familiares. Conforme esses argumentos, formula-se a oitava proposição:

Proposição 8: Agricultores familiares com maior conhecimento de mercado possuem melhor formação em termos de empreendedorismo rural do que aqueles em situação contrária.

\subsection{PROPOSIÇÃO LIGADA AO DESENVOLVIMENTO RURAL}

Sugere-se que um procedimento mais adequado para testar a teoria proposta aqui seria analisar se as dimensões estão corretamente selecionadas de acordo com a teoria, e, então, comparar o nível de desenvolvimento rural dos agricultores familiares.

O conceito de desenvolvimento rural depende da melhoria de variáveis socioculturais, como saúde, educação, qualidade de vida e bemestar, mas sobretudo, na ampliação das possibilidades de escolha (VEIGA, 2001). As variáveis descritas apresentam o nível de desenvolvimento rural que determinada família possui. Diante do exposto e das abordagens teóricas utilizadas, formula-se a seguinte proposição:

Proposição 9: As famílias cuja formação do empreendedor rural está alinhada ao modelo teórico proposto neste estudo, terão, em média, melhor desenvolvimento do que as famílias cuja formação do empreendedor rural não esteja alinhada com o modelo.

\subsection{MODELO CONCEITUAL}

O modelo conceitual tem como finalidade criar um sistema coerente de objetos, propriedades e relações claramente mapeados para o domínio da tarefa que se propõe, neste caso o alcance do objetivo geral do estudo. Após a formulação das proposições de pesquisa, apresenta-se o modelo conceitual na Figura 1 a seguir: 
Figura 1: Modelo conceitual com as proposições

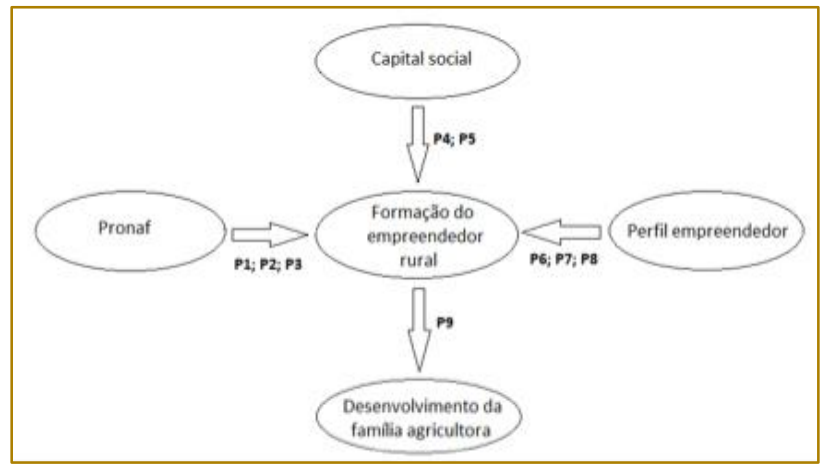

Fonte: elaboração do autor, 2017.

\section{DISCUSSÕES E NOTAS FINAIS}

Visando contribuir com o avanço da literatura que tem examinado as relações entre PRONAF, capital social e empreendedorismo rural, este texto teve por objetivo apresentar um modelo conceitual composto por proposições de pesquisas para serem testados por futuros trabalhos empíricos que desejem explorar o fenômeno na agricultura familiar brasileira.

Baseado em trabalhos anteriores, foi proposto que o desenvolvimento rural seja mensurado através de níveis de saúde, educação, renda, qualidade de vida e ampliação das liberdades. Testando a proposição 9 , será possível identificar se realmente o modelo conceitual proposto, estando todas suas dimensões alinhadas, alcança o desenvolvimento da agricultura familiar.

No Brasil, a criação do Pronaf teve o propósito de fornecer acesso do agricultor familiar a um ativo essencial ao processo empreendedor: o crédito. Diante disso, vislumbra-se a necessidade de estudar 0 papel deste crédito para a formação do empreendedor rural. O teste das proposições 1,2 e 3 poderão demonstrar aspectos intrínsecos e possíveis falhas que o programa apresenta em relação a sua contribuição à formação do empreendedorismo rural no Brasil.

Outra questão bem consolidada é a relação existente entre empreendedorismo rural e capital social. Não resta dúvida de que existe uma relação virtuosa entre estes termos. Abramovay (2000) e Veiga (2002), percussores do estudo do empreendedorismo no meio rural, já defendia o fortalecimento do capital social dos territórios como forma de desenvolve-los. Costa e Galina (2016) e Miyazaki et al. (2008) continuaram nessa linha acerca desta relação. Testando as proposições 4 e 5, futuros estudos podem identificar as principais dificuldades encontradas quanto a formação do capital social nos territórios.

Acerca do perfil do empreendedor rural, grande parte dos estudos observados dedicou-se a apresentar as características empreendedoras presentes (ou faltantes) no agricultor familiar, bem como as barreiras que dificultam o desenvolvimento de um perfil empreendedor adequado. É o caso, por exemplo dos estudos de Tomei e Lima (2014), Villanueva et al. (2012) e Weber et al. (2016). Testando as proposições 6,7 e 8 será possível verificar, que além das características básicas identificadas por autores clássicos do tema empreendedorismo, há características peculiares da agricultura familiar que podem ser fatores chaves no processo empreendedor.

Trabalhos empíricos ao testar as proposições aqui sugeridas podem expandir a articulação teórica incorporando discussões relativas ao desenvolvimento rural. Isso o enriquecerá do ponto de vista conceitual, além de permitir discussões teóricas mais aprofundadas dos resultados.

Este artigo descreveu relações entre construtos teóricos a partir de uma revisão de literatura sistematizada acerca dos subtemas abordados. Consequentemente, possui como limitação, a impossibilidade de estender os resultados obtidos para todos os agricultores familiares localizadas em todo território brasileiro, ou para outros tipos de organização. 


\section{REFERÊNCIAS}

[1]. ABRAMOVAY, Ricardo. Paradigmas do capitalismo agrário em questão. 2.ed. Campinas: Hucitec, 1998.

[2]. ABRAMOVAY, Ricardo. O capital social dos territórios: repensando o desenvolvimento rural. Economia Aplicada - volume 4, $\mathrm{n}^{\circ} 2$, abril/junho 2000.

[3]. ABRAMOVAY, Ricardo; VEIGA, José Eli da. Novas instituições para o desenvolvimento rural: o caso do Programa Nacional de Fortalecimento da Agricultura Familiar (PRONAF). IPEA, Texto para discussão 끄 641, 1999.

[4]. AZEVEDO, Francisco Fransualdo; PESSÔA, Vera Lúcia Salazar. O programa nacional de fortalecimento da agricultura familiar no Brasil: uma análise sobre a distribuição regional e setorial dos recursos. Sociedade e Natureza, Uberlândia, v.23, n.3, setembro-dezembro, 2011.

[5]. BIANCHINI, Valter. Vinte anos de PRONAF, 1995 - 2015: avanços e desafios. Brasília: Secretaria da Agricultura Familiar/Ministério do Desenvolvimento Agrário, 2015, 113p.

[6]. BRASIL, Ministério da Agricultura e do Abastecimento. Manual Operacional do PRONAF Programa Nacional de Fortalecimento da Agricultura Familiar, 1996.

[7]. BRASIL, Portal. Agricultura familiar produz $70 \%$ dos alimentos consumidos por brasileiro. Brasília, 2015. Disponível em: <http://www.brasil.gov.br/economia-eemprego/2015/07/agricultura-familiar-produz-70dos-alimentos-consumidos-por-brasileiro>. Acesso em: 22 fev. 2018

[8]. BRASIL. Lei no 11.326, de 24 de julho de 2006. Estabelece as diretrizes para a formulação da Política Nacional da Agricultura Familiar e Empreendimentos Familiares Rurais.

[9]. COLEMAN, James. Social Capital in the creation of Human Capital. The American Journal of Sociology, and Supplement: Organizations and Institutions: Sociological and Economic Approaches to the Analysis of Social Structure. Vol. 94 (1988), pp. S95-S120

[10]. COSTA, Teresa; GALINA, Simone. A relação virtuosa entre empreendedorismo e capital social: um estudo em empreendimentos de turismo em espaço rural em Portugal e no Brasil. Tourism \& Management Studies, Algarve-Portugal.., vol.12, n.2, pp.57-69, 2016. Disponível em:< http://www.scielo.mec.pt/scielo.php?script=sci_abs tract\&pid=S2182-

$84582016000200007 \& \operatorname{lng}=$ pt\&nrm=iso $>$ Acesso em: 20 fev. 2018.

[11]. DAVIDSSON, Per; HONIG, Benson. The role of social and human capital among nascent entrepreneurs. Journal of Business Venturing, 18(3), 301-331, 2003. Disponível em: < https://eprints.qut.edu.au/5832/>. Acesso em: 12 mar. 2018.

[12]. DORNELAS, José Carlos Assis. Empreendedorismo: transformando ideias em negócios. 4 ed. 2aㅡ reimpressão. Rio de Janeiro: Elsevier, 2012.

[13]. FAIA, Valter da Silva; ROSA, Marco Aurélio Garcia; MACHADO, Hilka Pelizza Vier. Alerta Empreendedor e as Abordagens Causation e Effectuation sobre Empreendedorismo. Revista de Administração Contemporânea. Rio de Janeiro, v. 18, n. 2, art. 5, pp. 196-216, Mar./Abr. 2014.

[14]. FAUTH, Eva Maria. Agricultura familiar: evolução favorável em anos recentes. Indicadores Econômicos FEE, Porto Alegre, v.35, n.4, p.51-60, 2008.

[15]. FILION, Louis Jacques. Empreendedorismo: Empreendedores e Proprietários - Gerentes de Pequenos Negócios. Revista de Administração, São Paulo v. 34, n. 2, p. 5-28, abril-junho, 1999.

[16]. GÓMEZ-ARAUJO,

Eduardo; BAYON, Manoj Chandra. Fatores socioculturais e o empreendedorismo dos jovens nas regiões rurais. Revista brasileira de gestão de negócios, São Paulo-SP, vol.19, n.64, pp.200-218, 2016. Disponível <http://www.scielo.br/scielo.php?pid=S1806$48922017000200200 \&$ script=sci_abstract\&tlng=pt >. Acesso em: 20 fev. 2018

[17]. GRACIANO, Monyele Camargo. Políticas públicas e desenvolvimento rural sustentável: uma análise do Programa Bolsa Verde no Assentamento Canudos em Goiás. Goiânia, 2016.101f. Dissertação (Mestrado em Agronegócios) - Escola de Agronomia, Universidade Federal de Goiás.

[18]. GRANOVETTER, Mark. The strenght of weak ties. American Journal of Sociology. ChicagoIL, V. 78, n. 6, maio, 1973. Disponível em: < https://www.journals.uchicago.edu/doi/abs/10.1086 /225469>. Acesso em: 12 mar. 2018.

[19]. GREATTI, Ligia. Perfis empreendedores: análise comparativa das trajetórias de sucesso e do fracasso empresarial no município de MaringáPR. Revista FACEF Pesquisa, Desenvolvimento e Gestão. França -SP, v.8 - n.1- 2005.

[20]. GUANZIROLI, Carlos E. PRONAF dez anos depois: resultados e perspectivas para 0 desenvolvimento rural. Revista de Economia e Sociologia Rural, Brasília, v.45, n.2, abril-junho, 2007.

[21]. JULIEN, Pierre-André. L'entrepreneuriat au Québec - pour une révolution tranquille entrepreneurial 1980-2005. Montreal: Transcontinental/Fondation de I'Entrepreneurship, 2000 . 
[22]. LEITE, Sergio et al. Impactos dos assentamentos: um estudo sobre o meio rural Brasileiro. São Paulo: Unesp, 2004.

[23]. MACHADO, Hilka Vier; ST-CYR, Louise; MIONE, Anne; ALVES, Marcia Cristina Moita. O processo de criação de empresas por mulheres. Revista de Administração de Empresas -eletrônica. São Paulo. v. 2, n. 2, jul-dez/2003.

[24]. MARIONI, Larissa da Silva; VALE, Vinicius de Almeida; PEROBELLI, Fernando Salgueiro; FREGUGLIA, Ricardo da Silva. Uma Aplicação de Regressão Quantílica para Dados em Painel do PIB e do Pronaf. Revista de Economia e Sociologia Rural. Brasília. vol.54 n.2. Abr./Jun 2016.

[25]. MATTEI, Lauro. Programa Nacional de Fortalecimento da Agricultura Familiar (PRONAF): concepção, abrangência e limites observados. Disponível em: $<$ https://www.researchgate.net/publication/2375255 51> Acesso em: 28 fev.2018.

[26]. McCLELLAND, David Clarence. Entrepreneurship and Achievement Motivation: Approaches to the Science of Socio-economic Development. In: Lengyel, P. (ed.) Paris, UNESCO, 1971.

[27]. MEDINA, Gabriel. Agricultura familiar em Goiás: lições para o assessoramento técnico. 3. ed. Goiânia: Editora UFG, 2016.

[28]. MERA, Claudia Prudêncio de; DIDONET, Graciela Beck. Aplicação dos recursos do PRONAF pelos agricultores familiares do município de Cruz Alta (RS). Perspectiva Econômica. São Leopoldo - RS. v.6, n. 2:45-58, jul./dez. 2010

[29]. MIYAZAKI, Juliane; VILAS BOAS, Paulo Alberto; RAIZEL, Tiago. Capital social e empreendedorismo rural: a agricultura familiar no oeste do Paraná. Resultados preliminares do projeto: Gestão das unidades artesanais, 2008.

[30]. NAVARRO, Zander. Desenvolvimento rural no Brasil: os limites do passado e os caminhos do futuro. Estudos Avançados. São Paulo, v.15, n.43, setembro-dezembro, 2001. Disponível em: < http://www.scielo.br/pdf/ea/v15n43/v15n43a09.pdf > Acesso em: 24 ago.2017.

[31]. PUTNAM, R. D. Comunidade e democracia: a experiência da Itália moderna. Tradução de: Luiz Alberto Monjardim. Rio de Janeiro: FGV, 1996.

[32]. PUTNAM, R. Making democracy work: civic traditions in modern Italy. Princeton: Princeton University, 1993.

[33]. SACCOL, Amarolinda Zanela. Um retorno ao básico: compreendendo os paradigmas de pesquisa e sua aplicação na pesquisa em administração. Revista de Administração da UFSM, v. 2, n. 2, p. 250-269, 2009.
[34]. SCHNEIDER, Sérgio. Situando o desenvolvimento rural no Brasil: o contexto e as questões em debate. Revista de Economia Política. São Paulo, v.30, n.3, julho-setembro, 2010.

[35]. SCHNEIDER, Sérgio; MATTEI, Lauro; CAZELLA, Ademir Antonio. Histórico, caracterização e dinâmica recente do PRONAFPrograma Nacional de Fortalecimento da Agricultura Familiar. Políticas públicas e Participação Social no Brasil Rural. 1.ed.Porto Alegre: UFRGS, v. 1, 2004.

[36]. TOMEI, Patrícia Amélia; LIMA, Daniela Arantes Alves. Análise das barreiras que dificultam a transformação do agricultor familiar em empreendedor rural no contexto brasileiro. Revista Ibero Americana de Estratégia, São Paulo, v.30, n.3, p.107-122, julho-setembro, 2014.

[37]. VEIGA, Jose Eli da. O Brasil rural ainda não encontrou seu eixo de desenvolvimento. Estudos Avançados, São Paulo, v. 15, n.43, 2001.

[38]. VEIGA, José Eli da. Do crescimento agrícola ao desenvolvimento rural. In: Desenvolvimento em Debate (vol. II), org. Ana Célia Castro, Rio de Janeiro, p. 383-409. 2002.

[39]. VEIGA, José Eli da. Empreendedorismo e desenvolvimento no Brasil rural.

[40]. VILLANUEVA, José Luis Jaramillo; GARRIDO, José Sergio Escobedo; JIMÉNEZ, Juan Morales; CASTRO, José Guadalupe Ramos. Perfil emprendedor de los pequeños empresarios agropecuarios en El Valle de Puebla, México. Entramado, Cali, Colombia vol.8, n.1, pp.44-57, 2012. Disponível em:< http://www.scielo.org.co/scielo.php?pid=S1900 38032012000100004\&script=sci_abstract\&tlng=pt >. Acesso em: 25 set. 2017.

[41]. WEBER, Josiane; MORGAN, Andressa; WINCK, César Augustus. Empreendedorismo rural sustentável no contexto do oeste catarinense: um estudo de caso no munícipio de Guatambu. Encontro de estudos sobre empreendedorismo e gestão de pequenas empresas, Passo Fundo, 2016. Disponível em: < http://www.egepe.org.br/2016/artigosegepe/440.pdf>. Acesso em: 25 set. 2017.

[42]. WANDERLEY, Maria de Nazareth Baudel. A ruralidade no Brasil moderno. Por um pacto social pelo desenvolvimento rural. Una nueva ruralidad en América Latina?. Buenos Aires: CLACSO, Consejo Latinoamericano de Ciencias Sociales, 2001. Disponível em: < http://bibliotecavirtual.clacso.org.ar/clacso/gt/2010 0929125458/giarraca.pdf>. Acesso em: 14 mar. 2018.

[43]. WANDERLEY, Maria de Nazareth Baudel. O campesinato brasileiro: uma história de resistência. Revista de Economia e Sociologia Rural. Brasília, v.52, n.2, 2014. 


\section{Capítulo 8}

\section{A ARMAZENAGEM DE GRÃOS NO BRASIL: EVOLUÇÃO E PERSPECTIVAS}

\section{Tatiana Silva Fontoura de Barcellos Giacobbo \\ Junior Giacobbo}

Resumo: Este artigo apresenta a recente evolução da capacidade de armazenagem de grãos no Brasil visando a verificar se há efetividade nas políticas de incentivos governamentais para o setor, feitas através do Banco Nacional de Desenvolvimento Econômico e Social, atualmente (2013-2018) realizadas por meio do programa de fomento à construção e ampliação de armazéns (PCA Armazéns). A partir de uma análise conjuntural e empírica, pretende-se detectar se o país terá capacidade para suprir demanda de estocagem nos próximos anos (2018-2026). Para realizar tal análise, parte-se da contextualização da importância do setor de grãos na economia brasileira e sua evolução a partir de 2000, para, então, elaborar uma estimativa de demanda por estocagem para o mercado brasileiro, realizada através de um estudo de séries temporais, com dados do Ministério da Agricultura, Pecuária e Abastecimento (MAPA) e da Companhia Nacional de Abastecimento (CONAB). Os resultados sugeriram que a política governamental de fomento ao setor de grãos é efetivamente necessária e importante para o Brasil ter competitividade no mercado internacional e precisará ser ampliada para os anos 2018-2026, uma vez que a produção de grãos se expandirá ainda mais ao longo dos anos analisados, gerando uma carência de estocagem ainda maior do que a já existente.

Palavras-chave: armazenagem de grãos, políticas de desenvolvimento econômico, agronegócio. 


\section{INTRODUÇÃO}

O Brasil é destaque no comércio internacional como exportador de commodities agrícolas, sendo um dos países mais competitivos do mundo na produção de commodities. (JANK et $\mathrm{al}, 2005)$. A concorrência no mercado internacional requer, entretanto, que os produtos brasileiros exportados sejam de alta qualidade e com preços competitivos. Salienta-se, porém, que o preço precisa cobrir os custos de toda a cadeia produtiva do setor, o que não ocorre quando o produtor precisa escoar a produção rapidamente, por não ter local para estocá-la. Nesse contexto, a capacidade instalada de armazenamento nas zonas de produção de grãos é fundamental, devido às peculiaridades da produção agrícola, como sazonalidade e dependência de fatores climáticos.

Dentre os estados brasileiros que mais produzem grãos, segundo dados da Companhia Nacional de Abastecimento (Conab, 2018), destacam-se Mato Grosso, Goiás, Rio Grande do Sul e Paraná, sendo que os dois primeiros apresentam maior déficit em capacidade de armazenamento e estão em áreas distantes dos portos, dificultando sua comercialização imediata.

A produção de grãos vem crescendo desde o início do período analisado nesse estudo, que abrange o período de 2000 a 2018, além de estar aumentando a área plantada, tendência que tem como consequência que a cada ano tem-se uma safra recorde no país. Em contrapartida, a capacidade instalada para estocagem que já era aquém do necessário, embora esteja crescendo, permanece bastante inferior à necessidade do setor.

Segundo orientação da Organização das Nações Unidas para a Alimentação e a Agricultura (FAO), o ideal é que a capacidade estática de um país seja 1,2 vez a produção de grãos. Para atender a esse requisito a capacidade estática de armazenagem brasileira deveria ser, em 2017, de 285 milhões de toneladas, porém na última safra, 2016/2017, foi de 162 milhões de toneladas, correspondendo a uma relação de 0,68 vez a produção de grãos, ou seja, está 43,3\% abaixo do patamar desejado.

Tendo em vista esse cenário, o governo federal, através do Banco Nacional de Desenvolvimento Econômico e Social (BNDES), lançou, em agosto de 2013, um programa de fomento específico ao setor de armazenagem de grãos, disponibilizando aos produtores financiamentos de longo prazo com taxas inferiores à taxa básica de juros (taxa Selic) para a aquisição de silos e infraestrutura para a estocagem. No ano de 2018 tal programa de fomento à construção e ampliação de armazéns (PCA), está operando com taxas de juros de $6,5 \%$ ao ano e prazo para amortização de até 15 anos para aquisição de silos.

Diante desse contexto, o objetivo desse estudo é realizar uma análise da linha de financiamento à armazenagem do BNDES PCA Armazéns e sua efetividade enquanto política governamental de fomento ao setor primário, tendo em vista a relação da produtividade brasileira de grãos com a capacidade de armazenamento necessária para que o país possa negociar preços no mercado internacional.

$\mathrm{O}$ argumento fundamental deste trabalho é o de que o BNDES atua com uma política de subsídios adequada para o setor de armazenagem de grãos, podendo ser propulsor do desenvolvimento econômico do setor agrícola. A hipótese principal que se busca investigar e testar é se a adoção das taxas de juros subsidiadas auxilia o Brasil a ter a sua capacidade de armazenagem de grãos mais elevada.

Assim, este artigo tratará de uma análise temporal e conjuntural do setor de armazenagem de grãos e, como desfecho, verificará a possibilidade ou não de eficácia do programa lançado pelo governo, na tentativa de ampliar a capacidade instalada do país, de acordo com a necessidade de tal mercado.

\section{A ARMAZENAGEM DE GRÃOS: O MERCADO E A EVOLUÇÃO NO BRASIL DE 2000 A 2017}

Para Aguiar (1992), o armazenamento é uma atividade empresarial e que está inserida dentro do conjunto de atividades econômicas, com custo e receitas associadas, podendo assim ser analisada sob o enfoque da teoria econômica. Para melhor compreender este ramo de atividade e inseri-lo na análise econômica, é importante compreender o funcionamento do mercado de armazenagem de grãos.

A armazenagem é o processo de guardar o produto, associada a uma sequência de operações, tais como limpeza, secagem, tratamento fitossanitário, transporte e 
classificação, com o intuito de preservar as qualidades físicas e químicas da colheita, até o abastecimento. Após essas operações, os grãos devem obter uma série de qualidades desejáveis como baixo teor de umidade, alto peso específico, baixa degradação de componentes nutritivos, baixa susceptibilidade à quebra, baixa porcentagem de grãos danificados, alta viabilidade de sementes e ausência de pragas, fungos ou bactérias. (ELIAS, 2003).

Segundo Elias (2003) a rede de armazéns é composta por unidades armazenadoras que possuem estrutura adequada às suas finalidades especificas e devem ser localizadas e dimensionadas de acordo com as características de operação, estabelecendo um fluxo lógico, tal qual sugere a logística, de atendimento ao escoamento da safra, com preservação da qualidade dos grãos, até que esses produtos cheguem ao consumidor final, conservando a qualidade, controlando perdas e estocando o excedente que não foi comercializado.
Tendo em vista tais especificidades deste setor agrícola, evidencia-se a indispensável necessidade da armazenagem para 0 mercado de grãos, pois ao cumprir os requisitos de qualidade o valor do produto será majorado, aumentando lucro e receita da atividade. No mercado mundial, o Brasil tem vantagens comparativas na produção de soja em relação aos outros produtores mundiais, contudo perde em aspectos logísticos. (PONTES et al., 2009).

O mercado de grãos está em constante ascensão no Brasil, conforme mostram os dados da produção estática de grãos no gráfico 1 demonstrado a seguir. Nessa medida, tornam-se necessárias melhorias na infraestrutura, tendo em vista que algumas das maiores empresas exportadoras da soja brasileira indicam que suas principais restrições para aumento do volume exportado estão relacionadas aos custos e às incertezas inerentes ao processo de escoamento da produção da soja (MEREGE e ASSUMPÇÃO, 2002).

Gráfico 1: Evolução da produção agrícola de grãos e capacidade de armazenamento no Brasil

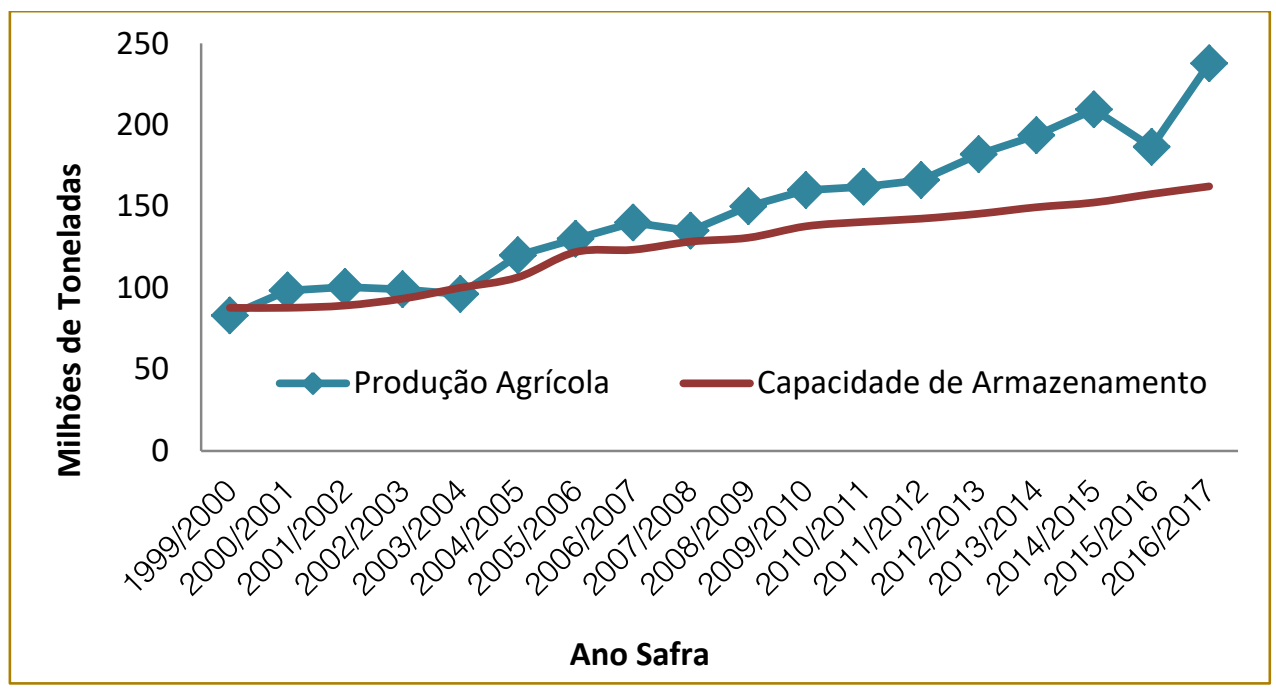

Fonte: elaboração própria, dados CONAB (2018) e MAPA (2018).

A produção estática de grãos no Brasil, conforme demonstrado no gráfico 1, cresceu 81 , $\%$ entre as safras 1999/2000 e 2012/2013, passando de 100,5 milhões toneladas para 182 milhões de toneladas. Em alguns anossafra (2001/02, 2004/05, 2008/09) houve uma pequena queda em relação ao ano-safra anterior, decorrentes de quebra de safra, por motivos climáticos que impediram o aproveitamento dos grãos plantados. Apesar disso, a tendência evidenciada é a de aumento extremamente significativo ao longo do período analisado.

A partir da análise do gráfico 1, verifica-se, também, que entre os anos de 2013 e 2017, a capacidade estática de armazenagem cresceu $11,5 \%$, ao passo que a produção de grãos avançou 30,6\% no mesmo intervalo. Em face deste crescimento da produção brasileira de grãos, está o crescimento da capacidade estática de estocagem do país. O Brasil aumentou significativamente a 
capacidade estática para armazenar sua produção no período entre 2000 e 2017, passando de 82,9 milhões de toneladas em 2000 para 162,3 milhões de toneladas em 2017.

Apesar do crescimento dos armazéns verificado pela capacidade estática de estocagem, os dados apresentados evidenciam que a produção de grãos está crescendo mais do que a estrutura de armazenagem. Portanto, o setor de estocagem, que tem capacidade aquém da produção de grãos brasileira está se tornando cada vez menos capaz de suprir a demanda de armazenamento.

\section{A ARMAZENAGEM DE GRÃOS NO BRASIL} APÓS A IMPLANTAÇÃO DO PROGRAMA DO BNDES PCA ARMAZÉNS: CONJUNTURA DE 2013 A 2018 E PERSPECTIVAS PARA O FUTURO

Tendo em vista o descompasso entre oferta e demanda de grãos, que gera um sistema de escoamento fortemente centrado em caminhões para tal finalidade, o governo federal criou em 2013 um programa de incentivo ao setor. O PCA Armazéns é um programa de financiamento do Banco Nacional de Desenvolvimento Econômico e Social, com a finalidade de fomentar investimentos individuais ou coletivos, referentes exclusivamente a projetos para ampliação, modernização, reforma e construção de armazéns destinados à guarda de grãos, frutas, tubérculos, bulbos, hortaliças, fibras e açúcar.

Assim, segundo dados do BNDES, verifica-se que o programa está efetivamente fomentando o setor, pois entre o período de 2013 e fevereiro de 2018, foram registradas 1.420 operações, para as quais o BNDES desembolsou aproximadamente $R \$ 3,3$ bilhões, conforme a evolução destacada na tabela 1.

De acordo com o preço médio praticado no mercado brasileiro para a construção de uma planta de armazenagem, de $\mathrm{R} \$ 400,00$ por tonelada, o BNDES fomentou, desde 2013 até fevereiro de 2018, pelo PCA 844,3 mil toneladas de capacidade de armazenagem. Tendo em vista que a capacidade estática aumentou cerca de 13 milhões de toneladas nesse período, é possível inferir que o BNDES esteve presente menos de $7 \%$ dos investimentos.

Tabela 1: Número de desembolsos e valores desembolsados anualmente pelo PCA- Armazéns

\begin{tabular}{|c|c|c|}
\hline \multirow{2}{*}{ Ano } & \multicolumn{2}{c|}{ Liberações PCA (R\$) } \\
\hline 2013 & 38.475 .754 & 100 \\
\hline 2014 & 725.982 .752 & 363 \\
\hline 2015 & 917.154 .116 & 240 \\
\hline 2016 & 824.427 .398 & 352 \\
\hline 2017 & 803.976 .245 & 351 \\
\hline 2018 & 67.140 .837 & 14 \\
\hline Soma: & 3.377 .157 .102 & 1.420 \\
\hline
\end{tabular}

Fonte: elaboração própria, dados BNDES (2018).

Segundo Souza e Veríssimo (2013), a década de 2000 foi caracterizada por um desempenho expressivo das exportações brasileiras de commodities, fato que configurou um ambiente favorável à um processo de especialização no manejo e cultivo de grãos. Dessa forma, se a capacidade de armazenagem de grãos crescer no país, a tendência é que melhore ainda mais o desempenho das exportações de commodities brasileiras, uma vez que é possível armazenar grãos e negociar melhores preços de venda, sem a necessidade de escoar a produção imediatamente.

Salienta-se, não obstante aos incentivos governamentais, que há entraves governamentais neste mercado. Para que o produtor rural consiga instituir a infraestrutura 
de armazenagem em suas terras, é necessário ter licença ambiental e tal licença é condição indispensável para a obtenção de financiamento junto ao BNDES e demais instituições financeiras que repassam seus recursos. Tendo em vista que as concessões de licenças deste tipo são de difícil obtenção e normalmente bastante demoradas, este se torna um entrave significante neste mercado.

Apesar desse contexto, a fim de se verificar empiricamente a necessidade e efetividade de uma política governamental de subsídios no setor de armazenagem, realizou-se uma previsão de demanda dos níveis de produção de grãos nacional e do crescimento da capacidade de estocagem. Para realizar tal previsão, utilizaram-se as séries temporais do período da safra 1999/2000 a 2016/2017 e fez-se uma previsão até 2025/2026, cujo resultado está apresentado no gráfico 2, abaixo.

Gráfico 2: Projeção da produção agrícola de grãos e capacidade de armazenamento no Brasil para os próximos anos safra.

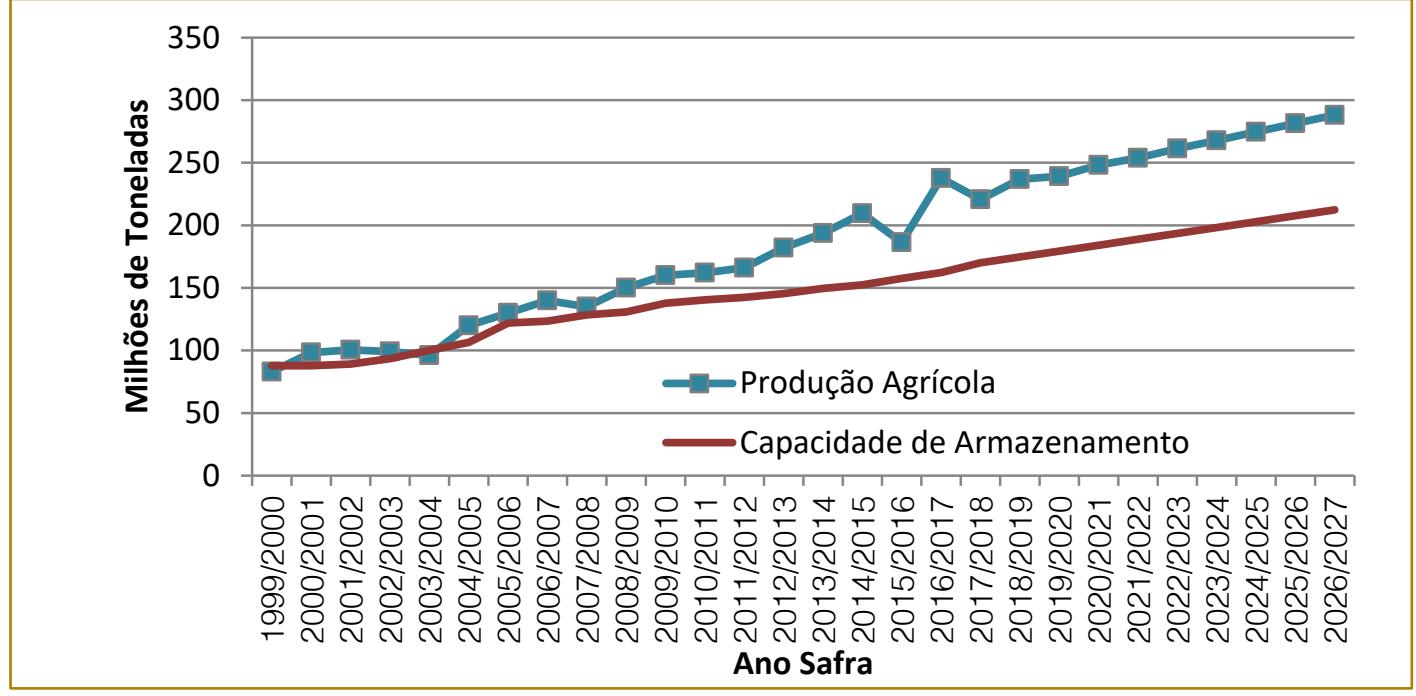

Fonte: elaboração própria, dados MAPA (2018)

O crescimento da capacidade de armazenamento foi projetado pela aproximação linear baseado nos dados históricos (série), através da técnica de previsão de média móvel. A estimativa da produção de grãos levou em conta dados do MAPA (2018).

A insuficiência da armazenagem no Brasil já existente desde a safra 2008/2009 fica ainda mais evidente ano a ano ao projetarmos até a safra 2025/2026, levando em conta expectativa média nas projeções e mantendo o ritmo histórico no avanço da capacidade estática de armazenagem. Dessa forma, fica evidenciada a assertividade de uma política de fomento ao setor e necessidade de um aporte de recursos ainda maior, para que esse distanciamento entre as duas curvas diminua e, consequentemente, o Brasil possa ser mais competitivo no mercado externo.

\section{CONSIDERAÇÕES FINAIS}

O objetivo desse estudo foi realizar uma análise da linha de financiamento à armazenagem do BNDES - PCA Armazéns e sua efetividade enquanto política governamental de fomento ao setor primário, tendo em vista a relação da produtividade brasileira de grãos com a capacidade de armazenamento necessária para que o país possa negociar preços no mercado internacional. O fato de que há carência no setor primário brasileiro para a estocagem dos grãos produzidos foi verificado, tanto pela revisão da literatura realizada, como através da análise de dados da capacidade brasileira de armazenagem, disponibilizados pelo MAPA e pela Conab, para o período analisado, de 2000 a 2017.

Para analisar a capacidade de armazenamento do mercado de grãos brasileiro, partiu-se de uma perspectiva histórica, demonstrando a evolução da 
capacidade de armazenamento desde o ano de 2000 até o ano de 2017. Através dessa análise, verificou-se que o Brasil aumentou significativamente a capacidade estática para armazenar sua produção no período entre 2000 e 2017, passando de 82,9 milhões de toneladas em 2000 para 162,3 milhões de toneladas em 2017.

A seguir, apresentou-se o programa de fomento governamental ao setor de armazenagem de grãos, PCA Armazéns, operacionalizado pelo BNDES desde julho de 2013 e ainda vigente, em que foram registradas 1.420 operações, para as quais 0 BNDES desembolsou aproximadamente 3,3 bilhões de reais. Em seguida, fez-se uma previsão de demanda para as safras de grãos e capacidade de estocagem dos próximos anos, levando-se em conta o crescimento da capacidade de armazenamento estática desde 2000 até 2017 e projetando-se o mesmo crescimento para 2025/2026. O resultado projetado apresenta um déficit absoluto de 76 milhões de toneladas para a safra 2025/2026, verificando-se que para se adequar à capacidade sugerida pela $\mathrm{FAO}$, o Brasil deveria aumentar em 183 milhões de toneladas a capacidade de armazenagem na próxima década.

Nesse sentido, a política de fomento ao setor de armazenagem de grãos instituída pelo governo federal, através do BNDES, está sendo executada em um mercado que realmente precisa crescer, e se não fosse o subsídio da linha a situação poderia estaria ainda mais agravada.

$\mathrm{O}$ argumento fundamental deste trabalho foi o de que o BNDES atua com uma política de subsídios adequada para o setor de armazenagem de grãos, podendo ser propulsor do desenvolvimento econômico do setor agrícola. A hipótese principal que se buscou investigar e testar é se a adoção das

\section{REFERÊNCIAS}

[1]. AGUIAR, A.L. A armazenagem sob condições de incerteza: o caso do arroz no Brasil. 1992. 134 p. Dissertação (Mestrado em Economia Aplicada) - Escola Superior de Agricultura "Luiz de Queiroz", Universidade de São Paulo, Piracicaba, 1992.

[2]. ARMSTRONG, J. S. Principles of Forecasting: A handbook for Researchers and Practitioners. Boston: Kluwer Academic Publishers, 2001. taxas de juros subsidiadas auxilia o Brasil a ter a sua capacidade de armazenagem de grãos mais elevada, o que de fato pôde ser inferido através dos resultados obtidos pela previsão de demanda realizada através da utilização do instrumento estatístico de séries temporais.

Sob o ponto de vista das exigências governamentais, como foi mencionado, há muitos entraves para que o produtor de cereais consiga o financiamento para a aquisição de silos e equipamentos de infraestrutura, sendo o mais relevante a dificuldade e o tempo de espera para a obtenção de licença ambiental. Dessa forma, cabe enfatizar que para que os programas de incentivos sejam ainda mais efetivos, é necessário melhorar os processos administrativos e burocráticos do setor público.

Dito isso, percebe-se que a tendência que se apresenta é a de que o país continue em um processo de crescimento na atividade de produção de grãos e aumento de produtividade em seus processos, permitindo um avanço ainda maior neste mercado, salvo fatores exógenos, como variações climáticas. Assim, maiores investimentos em estocagem de grãos também devem ser consequência natural deste processo de crescimento do setor.

Destaca-se, dessa forma, que o programa de fomento ao estoque de grãos do setor primário, PCA Armazéns, operado pelo Banco Nacional de Desenvolvimento Econômico e Social se mostrou uma política acertada e efetiva e pela tendência projetada, o governo federal deve fomentar ainda mais esse setor nos próximos anos. Observa-se, porém, que o setor carece de incentivos ainda maiores do que os atuais para que seja possível escoar a produção brasileira de grãos.

[3]. BNDES - Banco Nacional de Desenvolvimento Econômico e Social. Base de dados. Disponível em <http://www.bndes.gov.br>. Acesso em: agosto de 2018.

[4]. BOPP, A. E. On Combining Forecasts: Some Extensions and Results. Management Science, v. 31, 1492-1498, 1985.

[5]. CALSING, L. C. Previsão de demanda combinada a partir de métodos quantitativos e 
opinião de especialistas. Porto Alegre: UFRGS, 2015. Dissertação (Mestrado em Engenharia) Universidade Federal do Rio Grande do Sul, Brasil, Porto Alegre, 2015.

[6]. CONAB - Companhia Nacional de Abastecimento. Base de dados. Disponível em $<$ http://www.conab.gov.br>. Acesso em: março de 2018 .

[7]. ELIAS, Moacir Cardoso. Armazenamento e Conservação de Grãos. Material Didático. Universidade Federal de Pelotas, Pelotas, 2003. Disponível em

$<$ http://pt.scribd.com/doc/62562346/ARMAZENAME NTO-E-ONSERVACAO-DE-GRAOS-TEXTODIDATICO-2003.> Acesso em março de 2018.

[8]. JANK, Marcos Sawaya; NASSAR, André Meloni; TACHINARDI, Maria Helena. Agronegócio e Comércio Exterior Brasileiro. Revista USP, São Paulo, n.64, p. 14-27, 2004/2005.

[9]. MAPA - Ministério da Agricultura, Pecurária e Abastecimento. Publicações de Política Agrícola. Disponível em: < http://www.agricultura.gov.br/assuntos/politicaagricola/todas-publicacoes-de-politicaagricola/projecoes-do-agronegocio/projecoes-doagronegocio-2017-a-2027-versao-preliminar-25-0717. pdf >._Acesso em março de 2018.
[10]. MEREGE, A. A; ASSUMPÇÃO, M. R. P. Logística para exportação da soja paranaense. XXII Encontro Nacional de Engenharia de Produção - ENEGEP. Curitiba: Paraná, 2002.

[11]. OJIMA, A. L. R. O.; ROCHA, M,B. Desempenho logístico e inserção econômica do agronegócio da soja: as transformações no escoamento da safra. XLIII Congresso da SOBER Sociedade Brasileira de Economia e Sociologia Rural, Ribeirão Preto, 2005.

[12]. OMETTO, J. G. S. Os gargalos da agroindústria. O Estado de São Paulo, 22 de maio 2006 .

[13]. PONTES, H.L.J.; CARMO, B.B.T.; PORTO, A.J.V. Problemas logísticos na exportação brasileira da soja em grão. Sistemas \& Gestão, Niterói, v.4, n.2, p.155-181, maio a agosto de 2009.

[14]. ROESSING, A. C.; SANTOS, A. B. Descrição sucinta da cadeia produtiva da soja na região Sul do Brasil. EMBRAPA - CNPSO, Londrina, 1997

[15]. SOUZA, Túlio Assis; VERÍSSIMO, Michele Poline. O papel das commodities para o desempenho exportador brasileiro. Indicadores Econômicos. FEE, v. 40, n. 2, p. 79-94, Porto Alegre, 2013. 


\section{Bapítulo 9}

\section{NIVEL DE EFICIENCIA DO PROGRAMA BOLSA FLORESTA NAS UNIDADES DE CONSERVACÃO DO AMAZONAS: UMA ANÁLISE ENVOLTÓRIA DE DADOS}

\section{Loiseane Santos Correia Pinto}

\section{Elane Conceição de Oliveira}

Neuler André Soares de Almeida

Resumo: Este trabalho tem como objetivo analisar a eficiência socioeconômica do Programa Bolsa Floresta (PBF) desenvolvida nas Unidades de Conservação (UC's) do estado do Amazonas, no período de 2014 a 2017. E para isto utiliza-se o método Análise Envoltória de Dados (Data Envelopment Analysis - DEA) com retornos constantes de escala. Entende que a escolha do modelo é porque qualquer variação nas entradas (inputs) produzirá variação proporcional nas saídas (outputs). Isto porque um dos resultados esperados pelo PBF é promover o desenvolvimento sustentável e o bem-estar dos homens da florestal de forma proporcional aos recursos empregados nas UC's. Os resultados mostraram que das 11 UC's do tipo Reserva de desenvolvimento Sustentável (RDS) analisadas apenas 5 obtiveram 100\% de eficiência no sentido de pareto. Ademais, apesar de 4 UC's apresentaram resultados satisfatórios no sentido de reduzir o desmatamento, apenas 2 delas apresentaram 100\% de eficiência ou fronteira de pareto eficiente (RDS Piagaçu-Purus e Uatumã). O PBF representa uma política potente para promover a conservação das florestas e o desenvolvimento sustentável no AM, mas somente seguido de uma gestão eficiente.

Palavras-chave: Programa Bolsa Floresta; Análise Envoltória de Dados; Amazonas.

${ }^{*}$ Artigo apresentado no $56^{\circ}$ Congresso da Sociedade Brasileira de Economia, Administração e Sociologia Rural (SOBER) 


\section{INTRODUÇÃO}

Com relação ao crescente aumento no nível de desmatamento na Amazônia, Alencar et al.(2004) e Higuchi et al.(2009) apontam diversos fatores responsáveis por esse fenômeno na região ocasionado por diferentes usos do solo, como: agropecuária, extração madeireira, produção de energia (hidrelétricas, petróleo e gás natural), exploração mineral, incêndios florestais. No caso do bioma Amazônia, Veríssimo e Pereira (2014) apontam que o desflorestamento, em meados do ano de 2012, já tinha atingido 19\% dessa região.

Essa tendência do crescimento das taxas de desmatamento, no entanto, não é homogênea entre os Estados que compõem a região Amazônica. E mais recentemente, Estados que não tinham uma tendência alarmante do crescimento das suas taxas tem tido taxas em crescimento. O estado do Amazonas (AM), por exemplo, de acordo com o INPE (2017), os dados do Prodes Monitoramento da Floresta Amazônica Brasileira por Satélite mostram que a taxa de 2016 para 2017 desacelerou em $-15 \%$, muito embora ela tenha tido um crescimento de 54\%, de 2015 para 2016

Nesse escopo, três questões merecem destaque: a) o AM pertence à região Norte do país, possui 62 municípios e uma área territorial de 1.559 mil km2, o que corresponde a $18,45 \%$ da área total brasileira, $40,76 \%$ da área da região Norte e 30,87\% da área territorial da região Amazônica; b) as florestas do AM estão quase totalmente preservadas; dados do Sistema de Monitoramento da Floresta Amazônica Brasileira por Satélite (PRODES) mostram que, até 2011, o Estado tinha desmatado apenas $2,37 \%$ de sua cobertura florestal, o que caracteriza um indicador de preservação da ordem de 97,63\% de florestas nativas; e, c) o AM é detentor de um dos grandes programas brasileiro voltado para a disseminação do desenvolvimento sustentável nas comunidades interioranas dos municípios amazonenses - o Programa Bolsa Floresta (PBF).

Para Oliveira (2008) e Almeida (2015), o surgimento do PBF no AM deveu-se, sobretudo, à importância da floresta para os ribeirinhos na nossa região, uma vez que os recursos provenientes da floresta ainda constituem um dos principais meios de sobrevivência para os homens da floresta.
Tanto é que, segundo Viana (2008) o PBF implementa uma série de atividades pioneiras no campo da conservação ambiental e desenvolvimento sustentável na Amazônia; e sua concepção se insere no contexto das mudanças climáticas globais e de redução do desmatamento, com especial ênfase para as comunidades tradicionais da "Amazônia profunda". Juridicamente, a criação do PBF foi interposta pela Lei $n$ 은 3.135 de 05/06/2007 que diz respeito a políticas sobre mudanças climáticas, conservação ambiental e desenvolvimento Sustentável no Estado do Amazonas; e pela Lei Complementar $n^{\circ} 53$ de 05/06/2007 que se refere à institucionalização do Sistema Estadual de Unidades de Conservação (SEUC).

Hoje, o PBF é um dos maiores programas de Pagamento por Serviços Ambientais (PSA) do mundo, com mais de 35 mil pessoas atendidas em 15 UC's no AM, englobando uma área total de 10 milhões de hectares (FAS, 2016). O objetivo do PBF é de compensar, por meio de investimentos em geração de renda e desenvolvimento social, as populações tradicionais pela disposição em conservar as florestas, de forma a garantir a oferta de Serviços Ambientais local e globalmente, afirma a Fundação Amazônia Sustentável. Sua estrutura dar-se em quatro bolsas: Renda, Social, Familiar e Associação, nas quais objetivam oferecer suporte econômico e social, usando as bolsas como incentivos, às comunidades ribeirinhas que residem nas UC do AM por meio da valoração da floresta, cabendo a este último fator, um benefício ambiental (FAZ, 2015).

Em face disto, tornar-se indispensável estudos e análises sobre a eficiência das políticas públicas intergovernamentais implementadas na região, cujo fim de algumas dessas iniciativas, conforme Rivas (2014), é aliar qualidade de vida e conservação ambiental. E, nesse particular, avaliar a eficiência da gestão de recursos em Unidades de Conservação (UC's) surge como um objeto ímpar nesse tipo de análise, em geral, para a Amazônia e, em especial, para o estado do Amazonas (AM).

Muitos trabalhos tem analisado a eficiência do ponto de vista de várias temáticas, como: programas governamentais, saúde, educação, atividades produtivas, comércio, meio ambiente, entre outras temáticas, utilizando o modelo Análise Envoltória de Dados (Data Envelopment Analysis - DEA), que é uma ferramenta matemática para a 
medida de eficiência relativa das unidades tomadoras de decisão (Decision Making Units - DMU's), como são chamadas as unidades analisadas ou as unidades tomadoras de decisão ou unidades produtivas.

Brambilla e Carvalho (2017) analisaram a eficiência da gestão do Programa Bolsa Família nos municípios do Paraná no ano de 2013. Os autores ao utilizarem o modelo DEA, com retornos variáveis à escala orientado a output, tiveram como resultados que três dos 399 municípios paranaenses foram eficientes; e que o indicador que mais contribui para a gestão do PBF foi o de cobertura de cadastro no Cadastro Único.

Barbosa e Souza (2014) analisaram a eficiência técnica e de escala do setor agropecuário nos municípios cearenses por meio do DEA, obtendo como resultados que os municípios cearenses podem diminuir, em média, os custos com insumos em $45 \%$ e $35 \%$, respectivamente, nos modelos com retornos constantes e variáveis, sem reduzir o valor da produção.

Mello et al. (2003) avalia a eficiência das companhias aéreas brasileiras, usando o DEA com os retornos de escala, através da comparação de cada companhia com as que operam em escala semelhante.

Quanto a este trabalho, o objetivo é analisar a eficiência socioeconômica do Programa Bolsa Floresta desenvolvida nas Unidades de Conservação do estado do Amazonas, no período de 2014 a 2017. E para isto utiliza-se o modelo DEA com retornos constantes de escala. Entende que a escolha do modelo é porque qualquer variação nas entradas (inputs) produzirá variação proporcional nas saídas (outputs), uma vez que a intensão dos recursos injetados nas comunidades das UC's onde o bolsa floresta atua é produzir benefícios socioeconômicos e ambientais na mesma proporção ou razoavelmente superior.

\section{PROCEDIMENTOS METODOLÓGICOS}

\subsection{MODELO TEÓRICO DE ANÁLISE}

De acordo com Mello et al. (2016; 2003), Pindyck e Robisfield (2005), Tupy e Yamaguchi (1998), o estudo de análise de eficiência produtiva em economia baseia-se nos princípios da teoria da produção, especificamente no conceito de função de produção, que indica a relação técnica entre a produção máxima obtida em determinada unidade de tempo e os insumos utilizados no processo de produção.

Dessa base conceitual deriva-se o desenvolvimento da técnica Data Envelopment Analysis (DEA) para análise de eficiência relativa de unidades. O método DEA é baseado no trabalho proposto por Farrell (1957), generalizado por Charnes et al. (1978), em que foram incluídos múltiplos insumos (inputs) e produtos (outputs). Essa técnica permite analisar a eficiência de unidades produtivas (decision making units DMUs) com múltiplos insumos e múltiplos produtos através da construção de uma fronteira de eficiência.

De acordo com Mello (2016), para estimar e analisar a eficiência relativa das DMUs, a DEA utiliza a definição de ótimo de Pareto, segundo o qual nenhum produto pode ter sua produção aumentada sem que sejam aumentados os seus insumos ou diminuída a produção de outro produto, e, de forma alternativa, quando nenhum insumo pode ser diminuído sem ter que diminuir a produção de algum produto. A eficiência é analisada, relativamente, entre as unidades.

As funções de produção são à base da análise de eficiência conforme afirma Barbosa e Souza (2014). As considerações em torno dessas funções visam definir uma relação entre insumos e produtos. As hipóteses que são consideradas para a relação entre insumos e produtos determinam que haja retornos constantes, crescentes ou decrescentes à escala. A função apresenta retornos constantes à escala se, ao aumentar os fatores de produção, a produção aumentar na mesma proporção. Haverá retornos crescentes quando o aumento na produção for mais do que proporcional ao aumento nos fatores; caso contrário, haverá retornos decrescentes.

Para Charnes et al. (1994) a DEA pode ser definida com orientação-insumo ou orientação-produto. Com orientação-insumo caracteriza-se a tecnologia de produção pela minimização proporcional (contração) do vetor insumo, dado um vetor de produto, enquanto a DEA com orientação-produto caracteriza-se a tecnologia de produção pela maximização proporcional do vetor produto, dado um vetor de insumo. Ou melhor, podese usar um modelo orientado a outputs, no qual se obtém o máximo nível de outputs mantendo os inputs fixos (modelo BCC); ou usar um modelo orientado a inputs, que visa a 
obter um menor uso de inputs dado o nível dos outputs (modelo CCR). Para este estudo adotamos o modelo orientado a inputs.

\subsection{MODELO CCR (RETORNOS CONSTANTES DE ESCALA).}

O modelo CCR, apresentado originalmente por Charnes et al. (1978), constrói uma superfície linear por partes, não paramétrica, envolvendo os dados. Trabalha com retornos constantes de escala, isto é, qualquer variação nas entradas (inputs) produz variação proporcional nas saídas (outputs). Esse modelo é igualmente conhecido como modelo CRS - Constant Returns to Scale.

De acordo com Angulo Meza (2002) Este modelo determina a eficiência pela otimização

$$
\operatorname{MAXEff_{0}}=\left(\frac{\sum_{j=1}^{s} u_{j} y_{j 0}}{\sum_{i=1}^{r} v_{i} x_{i 0}}\right)
$$

Sujeito a:

$\frac{\sum_{j=1}^{s} u_{j} y_{j k}}{\sum_{i=1}^{r} v_{i} x_{i k}} \leq 1, \forall k$

$v_{i}, u_{j} \geq 0, \forall i, j$

Segundo Lins e Silva (2001) o problema apresentado é de programação fracionária, que deve ser resolvido para cada uma das DMUs e pode ser transformado em um problema de programação linear (PPL). Para tal, obriga-se que o denominador da função

$$
\operatorname{MAXEff_{0}}=\sum_{j=1}^{s} u_{j} v_{j 0}
$$

objetivo deva ser igual a uma constante, normalmente igual à unidade. A formulação do modelo CCR é, então, apresentada em (2). Nesse modelo as variáveis de decisão são os pesos vi e uj.

Sujeito a:

$\sum_{i=1}^{r} v_{i} x_{i 0}=1$

$\sum_{j=1}^{s} u_{j} v_{j k}-\sum_{i=1}^{r} v_{i} x_{i k} \leq 0, \forall k$

$v_{i}, u_{j} \geq 0, \forall i, j$

Conforme apresentado no modelo anterior, podemos evidenciar que a estrutura matemática do modelo, permite que uma DMU seja considerada eficiente a partir de vários conjuntos de pesos. De certa forma podemos atribuir peso zero a alguns inputs e outputs, o que significa que essa variável em

questão foi desconsiderada na avaliação do modelo.

A primeira etapa do modelo DEA é definir o que se quer medir com as DMU's. Nessa pesquisa, as DMU's serão:

DMU's 1 = UC's RDS. 
DMU's 2 = comunidades beneficiadas dentro dessas UC's.

DMU's 3 = modalidades de bolsas florestas por comunidades ou por UC's.

A eficiência é analisada, relativamente, entre as unidades das DMU's. Para avaliar a eficiência, as DMU's devem realizar tarefas similares, de modo que a comparação entre elas faça sentido. Além disso, uma característica da técnica DEA é que os inputs (insumos) e outputs (produtos) sejam iguais, variando apenas na quantidade.

As variáveis necessárias para a pesquisa são variáveis de cunho social, econômico e ambiental, geradas em virtude da implementação do PBF nas comunidades das UC's do estado do Amazonas, especialmente as RDS:

Input 1: INV UC = valor dos investimentos com infraestrutura e bens por RDS (R\$).

Input 2. INV BF = valor dos investimentos totais realizados por tipo de bolsa floresta $(\mathrm{R} \$)$.

Input 3: FAT UC = Faturamento bruto médio por família $\mathrm{p} / \mathrm{RDS}(\mathrm{R} \$)$.

Output 1: FAM ATEN $=n^{\circ}$ de famílias atendidas (un).

Output 2. DESEV COM = taxa de desmatamento evitado por RDS (\%).

Para o desenvolvimento da análise será utilizado o Software Frontier Analyst 4.0 que é uma ferramenta de análise de eficiência baseada, que usa a técnica chamada Data Envelopment Analysis (DEA) para examinar o desempenho relativo das unidades organizacionais, que desempenham funções similares. É, portanto, adequado para uso em organizações que operam através de um sistema de pontos de venda (como lojas de varejo, bancos, franquias, etc.) e para uso com organizações do setor público ou "sem fins lucrativos", como hospitais, escolas e outras organizações do setor público "baseadas em unidades". A técnica DEA evoluiu no setor público, onde medidas diferentes de medidas puramente financeiras eram necessárias para avaliar o desempenho.

\section{3 ÁREA DE ESTUDO DA PESQUISA}

A área de estudo para essa pesquisa será as UCs' do tipo RDS e RESEX localizadas no Estado do Amazonas (Figura 1). Uma Reserva de Desenvolvimento Sustentável (RDS) segundo Almeida (2015) é uma área natural que abriga populações tradicionais que vivem em sistemas de exploração sustentável dos recursos naturais.

Ao proteger o uso do ambiente desenvolvido ao longo de gerações e adaptado às condições ecológicas locais, esta categoria de unidade de conservação de uso sustentável contribui para a proteção da natureza e para a manutenção da diversidade biológica.

De acordo com a FAS (2016), as Reservas de Desenvolvimento Sustentável foram criadas pela Lei 9.985/00, o Sistema Nacional de Unidades de Conservação da Natureza (SNUC), que, por sua vez, é regulado pelo Decreto no 4.340/02.

Segundo o Cadastro Nacional de Unidades de Conservação - CNUC (MMA, 2018), até o início de março de 2018, existem 39 RDS no país: 2 nacionais, 32 estaduais e 5 municipais. São exemplos: a Reserva de Desenvolvimento Sustentável Mamirauá (AM), a Reserva de Desenvolvimento Sustentável Veredas do Acari (MG), a Reserva de Desenvolvimento Sustentável Estadual Ponta do Tubarão (RN) e a Reserva de Desenvolvimento Sustentável do Rio Negro (AM). 
Figura 1. Unidades de Conservação do Estado do Amazonas.

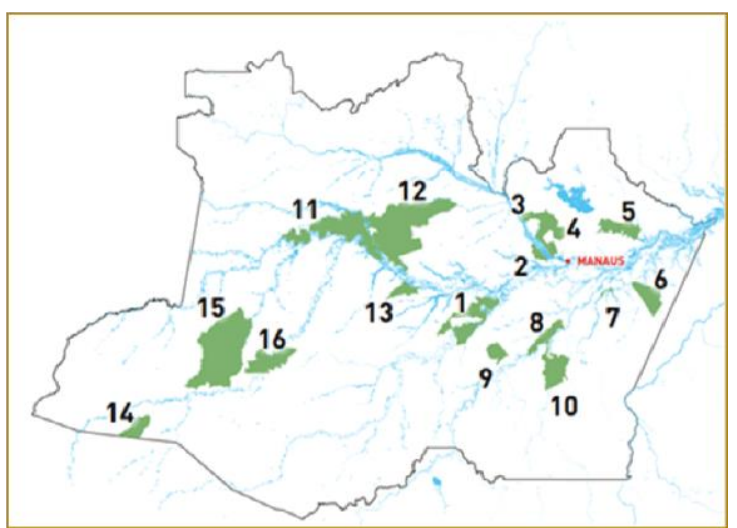

Fonte: Fundação Amazonas Sustentável, 2018.

\subsection{FLUXOGRAMA OPERACIONAL DA} PESQUISA.

O Fluxograma 1 mostra o caminho para melhor entender a pesquisa. A partir do conhecimento do PBF, é delimitado as UC's que estão localizadas no Estado do Amazonas que são do tipo RDS. Muito embora exista outras UC's em regiões, por exemplo, críticas de desmatamento1. As UC's RDS possuem muitas comunidades que são amparadas pelo PBF nas suas diversas modalidades de bolsas (renda, social, familiar, associação). Nesse ponto, a pesquisa se apropria das DMU's (RDS, comunidades e bolsas florestas), na linha tracejada, para realizar a análise de eficiência. Mas, as DMU's dependem totalmente das variáveis inputs e outputs que são geradas automaticamente, quando das aplicações das bolsas florestas nas comunidades das RDS. É necessário observar que possivelmente uma comunidade pode ser beneficiada simultaneamente por todas as modalidades de bolsa floresta como também por apenas uma ou duas, e assim sucessivamente. À medida que essas comunidades recebem recursos financeiros, com o fim de promover qualidade de vida com proteção ambiental, é gerado diversos dados como resultados da aplicação desses recursos.

Figura 2. Fluxograma operacional da pesquisa.

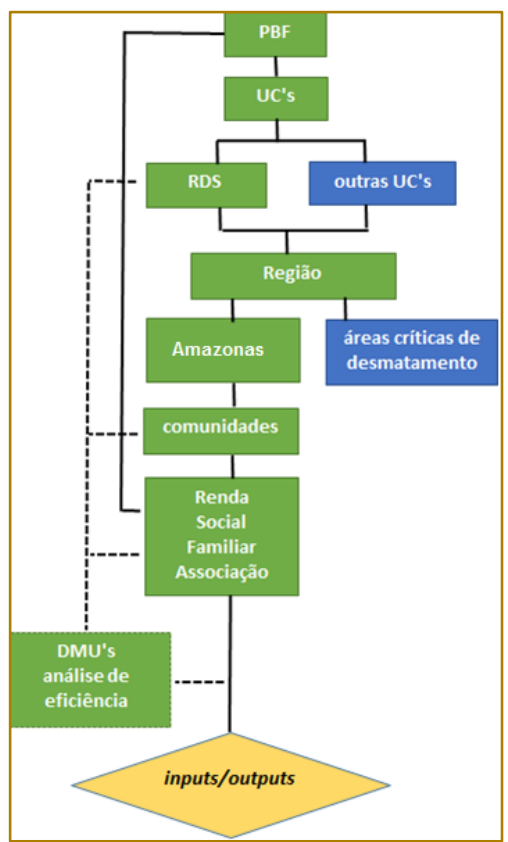

Fonte: Elaboração própria. 
Visando atender aos objetivos delineados por esta pesquisa, o presente estudo utilizará dados secundários obtidos junto aos Relatórios de Gestão da Fundação Amazonas Sustentável (FAZ) do ano de 2016 em vista deste ter sido o último ano de publicação disponível.

Também far-se-á uso de dados obtidos juntos a Instituto Brasileiro de Geografia e Estatística (IBGE) sobre renda, população e produção agropecuária, bem como os dados de desmatamento de 2015 à 2016 do Sistema de Monitoramento da Floresta Amazônica Brasileira por Satélite (PRODES) do Instituto Nacional de Pesquisas Espaciais (INPE) e também informações acerca dos municípios que fazem parte das referidas unidades de conservação através do anuário estatístico do Amazonas e Condensado dos municípios relatório este disponibilizado pela Secretaria de Estado de Planejamento, Desenvolvimento, Ciência, Tecnologia e Inovação (SEPLANCTI).

\section{RESULTADOS E DISCUSSÕES}

O primeiro passo da pesquisa foi levantar as Unidades de Conservação (UCs) do Estado do Amazonas, conforme apresentado na Tabela $\quad 1 \quad$ a seguir.

Tabela 1. Unidades de Conservação do Amazonas, área(há), famílias e localidades

\begin{tabular}{|c|c|c|c|}
\hline UC & Área(ha) & Famílias & Localidades \\
\hline RDS Piagaçu-Purus & 1.008 .167 & 999 & 64 \\
RDS do Rio Negro & 102.979 & 693 & 19 \\
APA do Rio Negro & 611.008 & 220 & 10 \\
RDS Puranga Conquista & 76.936 & 346 & 12 \\
RDS do Uatumã & 424.430 & 337 & 20 \\
Floresta Estadual de Maués & 438.440 & 740 & 16 \\
RDS Canumã & 22.355 & 316 & 52 \\
RDS do Rio Madeira & 283.117 & 1.069 & 10 \\
RDS do Rio Amapá & 216.109 & 411 & 38 \\
RDS do Juma & 589.611 & 476 & 184 \\
RDS Mamirauá & 1.124 .000 & 2.332 & 817 \\
RDS Amanã & 2.350 .000 & 817 & 13 \\
Resex Catuá-Ipixuna & 217.486 & 234 & 27 \\
Resex do Rio Gregório & 427.004 & 210 & 2 \\
RDS Cujubim & 2.450 .380 & 48 & 30 \\
RDS de Uacari & 632.949 & 349 & \\
\hline
\end{tabular}

Fonte: Relatório de Gestão da Fundação Amazonas Sustentável (2016).

De acordo com dados apresentados na Tabela 1, podemos notar que no Amazonas existem 12 Reservas de Desenvolvimento Sustentável (RDSs); 2 Reservas Extrativistas (RESEX); 1 Floresta Estadual e 1 Área de Proteção Ambiental (APA). A RDS Cujubim é a Unidade de Conservação que possui a maior área por hectare (2.450.380). A RDS de Mamirauá é a Unidade de Conservação que possui o maior número de famílias (2.332) e por fim a RDS de Anamã é a que possui o maior número de localidades (817).

O segundo passo foi levantar o tipo de produção por unidade de conservação, produção por safra e o faturamento bruto médio das famílias. Nesta etapa, priorizaramse somente as Unidades de Conservação (UCs) do tipo RDS, pois partimos do princípio que apenas estas unidades possuem atividade produtiva voltada para 0 desenvolvimento local, apesar de que na Unidade de Conservação Floresta Estadual de Maués e Reservas Extrativistas, possuírem atividade econômica voltada para a produção de guaraná e farinha.

Os dados apresentados na Tabela 2, nos mostram que das 12 Unidades de Conservação do tipo RDS a produção de farinha é dominante (5 unidades produzem farinha) seguido por 3 unidades que produzem pirarucu fresco e 1 unidade cada produz castanha, madeira e banana. Não foi possível obter dados de faturamento bruto médio por famílias da RDS Puranga Conquista. 
Tabela 2. Reservas de Desenvolvimento Sustentável do Amazonas, produção por safra, faturamento bruto médio por família.

\begin{tabular}{|c|c|c|}
\hline UC & $\begin{array}{c}\text { Produção por } \\
\text { safra }\end{array}$ & $\begin{array}{c}\text { Fatur. bruto } \\
\text { Médio p/Família } \\
\text { (R\$) }\end{array}$ \\
\hline RDS Piagaçu-Purus & castanha & 2.533 \\
RDS do Rio Negro & madeira & 6.223 \\
RDS Puranga Conquista & Farinha & - \\
RDS do Uatumã & Farinha & 2.973 \\
RDS Canumã & Farinha & 1.297 \\
RDS do Rio Madeira & cacau & 1.375 \\
RDS do Rio Amapá & banana & 2.735 \\
RDS do Juma & Farinha & 2.579 \\
RDS Mamirauá & pirarucu & 2.994 \\
RDS Amanã & pirarucu & 1.996 \\
RDS Cujubim & Farinha & 1.098 \\
RDS de Uacari & pirarucu & 2.095 \\
\hline
\end{tabular}

Fonte: Relatório de Gestão da Fundação Amazonas Sustentável (2016).

Os dados nos mostram que a atividade que proporciona um maior faturamento bruto médio por família e a produção de madeira sustentável ( $R \$$ 6.223). A seguir os dados referentes a valor dos investimentos totais por bolsa em cada uma das unidades de conservação em análise.

Gráfico 1. Investimentos totais por bolsa em cada Reserva de Desenvolvimento (RDS) em $\mathrm{R} \$ 1.000,00$.

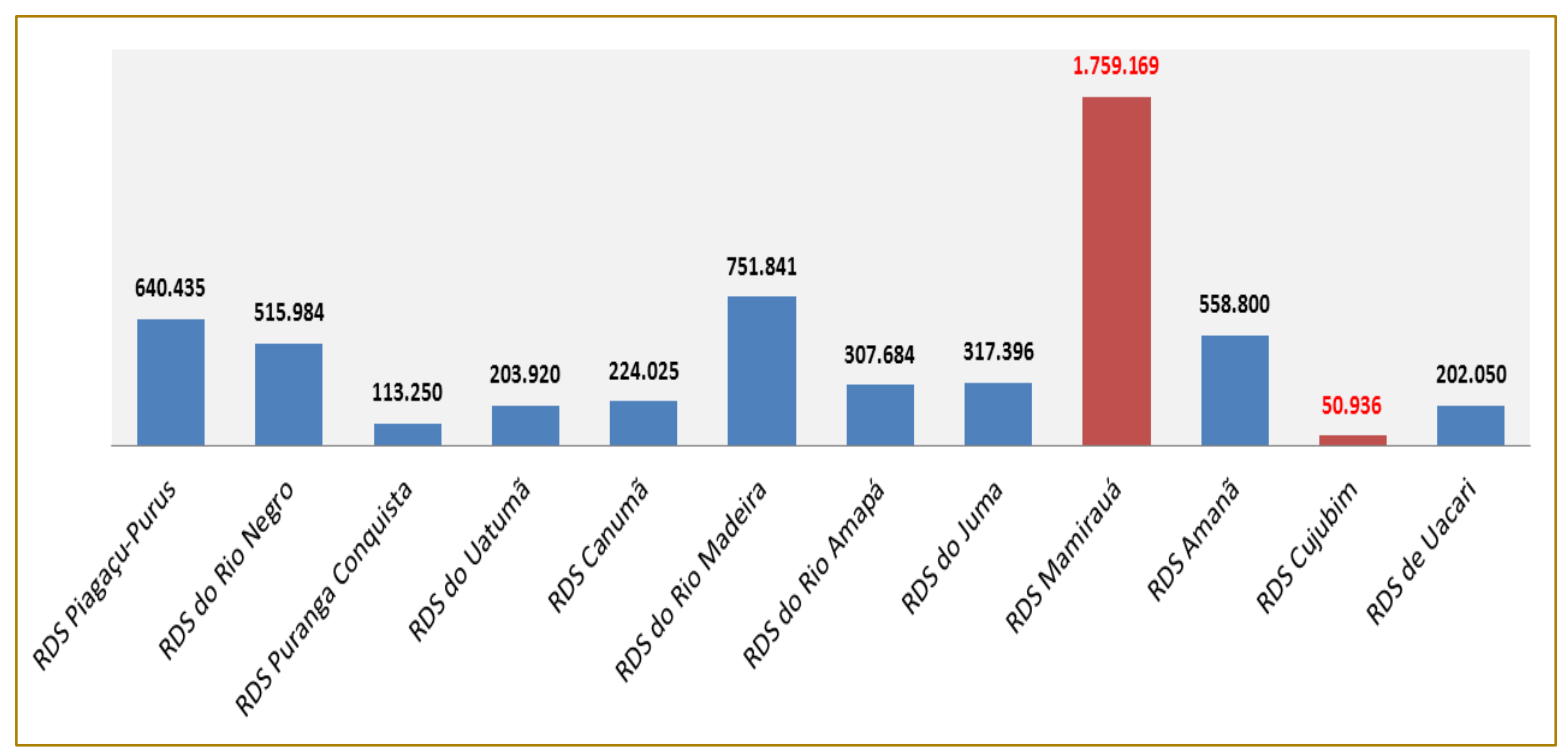

Fonte: Relatório de Gestão da Fundação Amazonas Sustentável (2016).

$\left(^{*}\right)$ Estes valores são as somas dos 4 componentes bolsa floresta (familiar, associação, renda e social).

Os dados do Gráfico 1 fazem referência ao somatório de todos os valores em Bolsa Floresta investidos nas RDS. Podemos notar que a RDS Mamirauá obteve um valor expressivo de investimentos da ordem de $\mathrm{R} \$ 1.759 .169$ muito superior a todas as demais. Em parte, este resultado se deve pelo fato de que esta RDS possuir o maior número de famílias beneficiadas pelo programa. No Gráfico 2 a seguir veremos o comportamento das taxas de desmatamento de 2015 a 2016. 
Gráfico 2. Taxa de desmatamento por Reserva de Desenvolvimento (RDS) de 2015 a 2016.

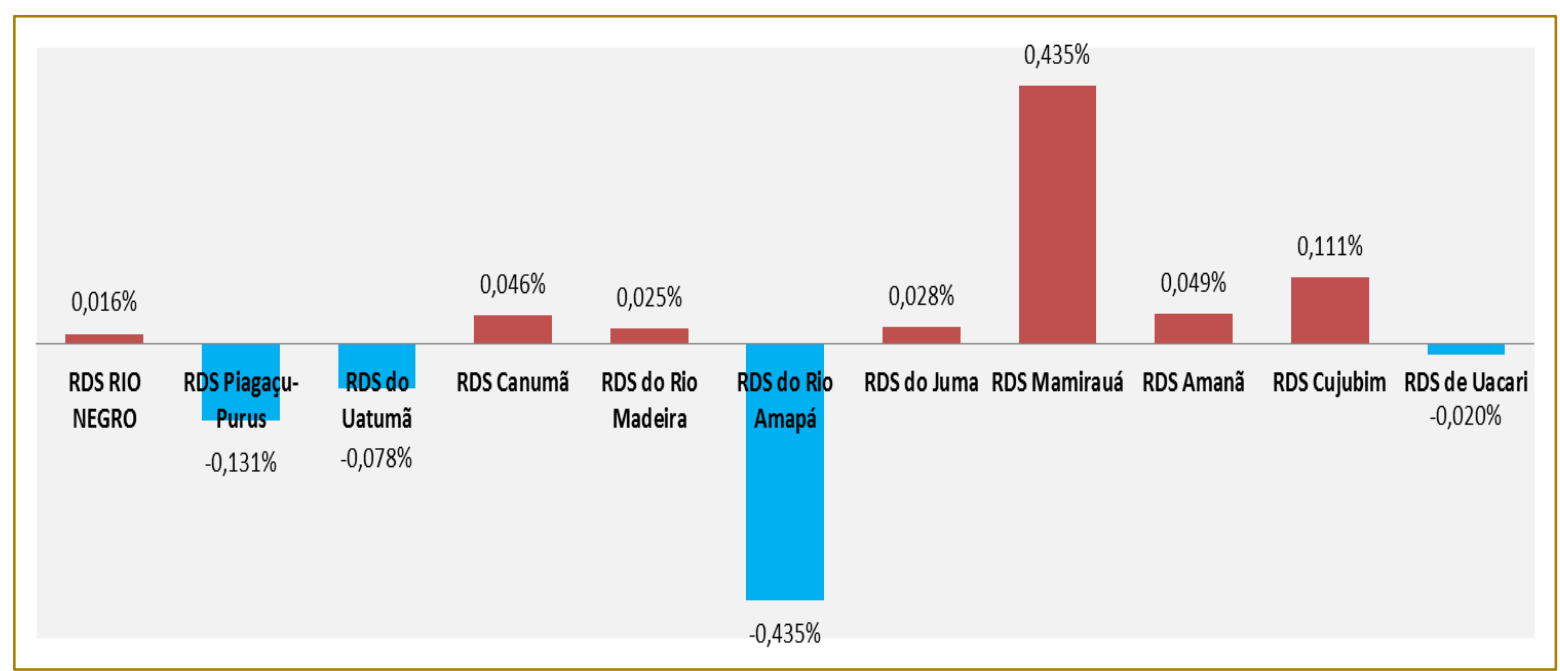

Fonte: PRODES/INPE (2018).

De acordo com os dados do Gráfico 2 podemos evidenciar que das 11 Unidades de Conservação do tipo RDS apenas 4 obtiveram taxa de desmatamento evitado no período em análise. As demais RDS's tiveram crescimento na taxa de desmatamento, sendo a RDS Mamirauá a que obteve a maior taxa $(0,435 \%)$. Agora apresentaremos os dados obtidos pelo método DEA utilizando o Software Frontier Analyst 4.0 para verificar O grau de eficiência obtido pelo Programa Bolsa Floresta em 2016 nas RDS selecionadas.

\subsection{RESULTADO DA ANÁLISE ENVOLTÓRIA DE DADOS (DEA)}

Inicialmente tínhamos 12 Reservas de Desenvolvimento Sustentável (RDS) para analisar, entretanto dados às limitações do Software Frontier Analyst 4.0 só poderíamos analisar no máximo 11 DMU's, sendo assim optou-se por excluir da análise a RDS Puranga Conquista, pois a mesma não apresentou dados de faturamento bruto médio por famílias segundo a Tabela 2. Desta forma organizaram-se os dados conforme Tabela 3 a seguir.

Tabela 3. Tabulações dos dados para análise.

\begin{tabular}{|c|c|c|c|c|}
\hline \multirow{2}{*}{ UC } & \multicolumn{3}{|c|}{ INPUTS } & OUTPUTS \\
\cline { 2 - 5 } & $\begin{array}{c}\text { Fatur. bruto } \\
\text { Médio p/Família } \\
\text { (R\$̦) }\end{array}$ & $\begin{array}{c}\text { Investimento com } \\
\text { Infraestrutura e } \\
\text { bens (R\$) }\end{array}$ & $\begin{array}{c}\text { Investimentos } \\
\text { totais por bolsa } \\
\text { em cada UC (R\$̦) }\end{array}$ & $\begin{array}{c}\text { N de familías } \\
\text { benefeciadas }\end{array}$ \\
\hline RDS Piagaçu-Purus & 2.533 & 208.938 & 640.435 & 999 \\
RDS do Rio Negro & 6.223 & 131.787 & $515.983,55$ & 693 \\
RDS do Uatumã & 2.973 & 55.077 & $203.920,40$ & 337 \\
RDS Canumã & 1.297 & 72.433 & $224.025,05$ & 316 \\
RDS do Rio Madeira & 1.375 & 245.057 & $751.840,92$ & 1069 \\
RDS do Rio Amapá & 2.735 & 105.755 & $307.684,33$ & 411 \\
RDS do Juma & 2.579 & 50.364 & $317.396,20$ & 476 \\
RDS Mamirauá & 2.994 & 590.892 & $1.759 .168,54$ & 2332 \\
RDS Amanã & 1.996 & 187.986 & $558.800,00$ & 817 \\
RDS Cujubim & 1.098 & 43.225 & $50.935,93$ & 48 \\
RDS de Uacari & 2.095 & 37.591 & $202.050,00$ & 349 \\
\hline
\end{tabular}

Fonte: Elaboração própria

Desta forma trabalhou-se apenas com 11 RDS cujo, os dados de eficiência pelo método CCR (Retornos Constantes de Escala) apresentam-se na Tabela 4.
No primeiro momento utilizando as variáveis: faturamento bruto médio por família, investimentos com infraestrutura e bens, investimento total por bolsa em cada Unidade de Conservação do tipo Reserva de 
Desenvolvimento Sustentável (UC/RDS) como input e tendo como output o número de famílias beneficiadas, tentou-se verificar o nível de eficiência do Programa Bolsa Floresta
(PBF) no sentido de melhorar a qualidade de vidas das famílias que vivem e dependem do programa.

Tabela 4. Resultado da Análise Envoltória de Dados pelo método CCR.

\begin{tabular}{|c|c|c|c|}
\hline \multicolumn{2}{|c|}{ DMU's } & Resultado & Condição \\
\hline Descrição & Percentual (\%) & - & Fracamente eficiente \\
\hline RDS Amanã & 95,2 & - & Ineficiente \\
\hline RDS Canumã & 87,7 & - & Ineficiente \\
\hline RDS Cujubim & 54,6 & Eficiente & Pareto eficiente \\
\hline RDS Mamirauá & 100,0 & Eficiente & Pareto eficiente \\
\hline RDS Piaguaçu-Purus & 100,0 & Eficiente & Pareto eficiente \\
\hline RDS de Uacari & 100,0 & Eficiente & Pareto eficiente \\
\hline RDS do Juma & 100,0 & - & Ineficiente \\
\hline RDS do Rio Amapá & 79,1 & Eficiente & Pareto eficiente \\
\hline RDS do Rio Madeira & 100,0 & - & Ineficiente \\
\hline RDS do Rio Negro & 77,8 & - & Fracamente eficiente \\
\hline RDS do Uatumã & 95,7 & - & - \\
\hline
\end{tabular}

Fonte: Elaboração própria a partir do Software Frontier Analyst 4.0.

De acordo com os dados da Tabela 4 podemos perceber que das 11 RDS's apenas 5 obtiveram $100 \%$ de eficiência no resultado. Em outras palavras qualquer variação nas entradas (inputs) produz variação proporcional nas saídas (outputs).

Podemos dizer que as RDS's que apresentaram resultados eficientes tiveram condição eficiente no sentido de pareto ou fortemente eficientes dado que, um aumento de $10 \%$ nos insumos provocou um aumento proporcional no produto. Por outro lado, as DMU's que apresentaram resultado sem caracterização tiveram condição consideradas fronteira fracamente eficiente e por fim as DMU's que apresentaram percentual ente $70-90 \%$ e condição ineficientes podemos considerar como fronteira não pareto eficiente ou simplesmente ineficientes.

Levando em conta que a filosofia do PBF é de compensar, por meio de investimentos em geração de renda e pagamento por serviços ambientais as pessoas que vivem $e$ dependem da floresta para sua sobrevivência, cujo entendimento é que estas pessoas são os verdadeiros guardiões da floresta, tendo em vista que o programa, também busca, dotar as famílias atendidas de uma alternativa econômica que as possibilite produzir e gerar renda sem degradar o meio ambiente e destruir a floresta, foi que a pesquisa utilizou as mesmas variáveis para analisar a relação dos inputs (faturamento bruto médio por família, investimentos com infraestrutura e bens e investimento total por bolsa floresta) com as taxas de desmatamento evitado de 2015 a 2016 (outputs).

Para esta análise, não se levou em consideração o total de Reservas de Desenvolvimento Sustentável (RDS's), pois segundo os dados apresentados no Gráfico 2 apenas 4 unidades obtiveram redução na taxa de desmatamento no período de 2015 a 2016. 
Tabela 5. Organização dos dados tendo como Output a Taxa de desmatamento evitado.

\begin{tabular}{|c|c|c|c|c|}
\hline UC & $\begin{array}{c}\text { Fatur. bruto } \\
\text { Médio } \mathbf{p} / \text { Família } \\
\text { (R\$S) }\end{array}$ & $\begin{array}{c}\text { Investimento com } \\
\text { Infraestrutura e } \\
\text { bens (R\$̦) }\end{array}$ & $\begin{array}{c}\text { Investimentos } \\
\text { totais por bolsa } \\
\text { em cada UC (RȘ) }\end{array}$ & $\begin{array}{c}\text { TX desmatamento } \\
\text { evitado 2015-2016 }\end{array}$ \\
\hline RDS Piagaçu-Purus & 2.533 & 208.938 & 640.435 & 0,06 \\
RDS do Uatumã & 2.973 & 55.077 & $203.920,40$ & 0,05 \\
RDS do Rio Amapá & 2.735 & 105.755 & $307.684,33$ & 0,01 \\
RDS de Uacari & 2.095 & 37.591 & $202.050,00$ & 0,01 \\
\hline
\end{tabular}

Fonte: Elaboração própria.

Sendo assim levou-se em consideração na análise apenas as RDS's Piagaçu-Purus;
Uatumã; Rio Amapá e Uacari. O resultado é apresentado na Tabela 6.

Tabela 6. Resultado da Análise Envoltória de Dados pelo método CCR tendo como Outputa Taxa de desmatamento evitado.

\begin{tabular}{|c|c|c|c|}
\hline \multicolumn{2}{|c|}{ DMU's } & \multicolumn{2}{c|}{ Resultados comparados } \\
\hline Descrição & Percentual (\%) & Resultado & Condição \\
\hline RDS Piaguaçu-Purus & 100,0 & Eficiente & Ineficiente \\
\hline RDS de Uacari & 29,3 & - & Ineficiente \\
\hline RDS do Rio Amapá & 19,8 & - & Pareto eficiente \\
\hline RDS do Uatumã & 100,0 & Eficiente \\
\hline
\end{tabular}

Fonte: Elaboração própria a partir do Software Frontier Analyst 4.0.

De acordo com os dados apresentados na Tabela 6, podemos evidenciar que apesar de que 4 Unidades de Conservação (UC's) terem apresentado um resultado satisfatório no sentido de reduzir o desmatamento, apenas 2 delas apresentaram 100\% de eficiência, ou como podemos dizer fronteira de pareto eficiente (RDS Piagaçu-Purus e Uatumã). As demais foram ineficientes no sentido de pareto (isto é, apesar de se dobrar os insumos o produto obtido não foi na mesma proporção).

\section{CONSIDERAÇÕES FINAIS}

Uma das maiores inquietações mundiais a respeito da crise ambiental que se instaurou são as previsões catastróficas da mudança climática global, cujos efeitos indicam ser demasiadamente prejudicial para a humanidade, porém de forma diferenciada em diversas regiões do planeta. O mundo todo sofrerá com os impactos negativos da mudança do clima; mas nos países pobres, onde há grande incidência de fome, guerrilhas, subnutrição e falta geral de recursos de todas as ordens, esses impactos serão mais graves e catastrófico.

Em termos de bioma Amazônia, o ritmo de desmatamento e das queimadas na região causa preocupação em nível mundial e nacional. Isto porque preservar a floresta é importante para todos: o estado de equilíbrio dinâmico atual da atmosfera sobre a região amazônica depende do tipo de cobertura vegetal existente, ou seja, depende da floresta. Grandes alterações da cobertura vegetal poderão levar a alterações climáticas.

Recentemente, os Órgãos responsáveis pelo controle e monitoramento do desmatamento da região registraram taxas altíssimas se comparadas aos controles de outrora. Isto caracteriza àquela velha tendência do modelo de desenvolvimento na região - perda de florestas para produção agropecuária, entre outras atividades.

Políticas estratégicas de desenvolvimento que venham simultaneamente oferecer algum benefício à sociedade local e ao clima mundial - em cada sub-região da Amazônia é o grande desafio do governo brasileiro. E as políticas ambientais - que defendem recursos 
financeiros destinados a fomentar políticas de desenvolvimento a partir do desmatamento evitado ou conservação de florestas parecem contribuir bastante para um dos grandes objetivos da Convenção do Clima, que é a responsabilidade comum, porém diferenciada dos países.

Assim, o PBF está inserido na Lei de Mudanças Climáticas, Conservação Ambiental e Desenvolvimento Sustentável do Amazonas, sendo construído de forma participativa, com ampla discussão tanto nas comunidades quanto com instituições governamentais e não governamentais em Manaus. Além disso, o PBF é considerado um programa de Governo do Estado do Amazonas, que busca a interiorização do desenvolvimento a partir da compensação, da valorização e do reconhecimento dos povos da floresta como um fator ímpar na luta a favor do equilíbrio mundial do clima, da manutenção da floresta em pé e do desmatamento zero.

O PBF é um conjunto positivo de ações que tem como objetivo oferecer uma compensação financeira para os serviços prestados pelas populações tradicionais e indígenas do Amazonas, ou seja, uma recompensa aos guardiões da floresta que se comprometem com a conservação ambiental e o desenvolvimento sustentável nas UC's do Estado do Amazonas. É o primeiro programa brasileiro de pagamento de serviços ambientais feito diretamente para as comunidades que residem nas UC's.

Ao analisar a eficiência socioeconômica e ambiental do PBF do AM, no primeiro momento utilizou-se como variável o faturamento bruto médio por família,

\section{REFERÊNCIAS}

[1]. ALENCAR, Ane. et. al. Desmatamento na Amazônia: indo além da emergência crônica. Instituto de Pesquisa Ambiental da Amazônia (IPAM): Belém, 2004.

[2]. ALMEIDA, André Soares de. A dinâmica do desenvolvimento econômico: Desafios e Perspectivas. - Manaus EDUA, 2015.

[3]. ANGULO MEZA, L. Um enfoque multiobjectivo para os modelos de determinação de alvos na Análise Envoltória de Dados. 2002. Tese (Doutorado em Engenharia de Produção) COPPE, Universidade Federal do Rio de Janeiro, Rio de Janeiro. investimentos com infraestrutura e bens, investimento total por bolsa em cada UC do tipo RDS como input e tendo como output o número de famílias beneficiadas. E assim, buscou-se verificar o nível de eficiência do PBF no sentido de melhorar a qualidade de vidas das famílias que vivem e dependem do programa. Os resultados apontaram que das 11 RDS's apenas 5 obtiveram 100\% de eficiência no resultado, ou seja, qualquer variação nas entradas (inputs) produz variação proporcional nas saídas (outputs). Pôde-se avaliar que as RDS's que apresentaram resultados eficientes tiveram condição eficiente no sentido de pareto ou fortemente eficientes dado que, um aumento de $10 \%$ nos insumos provocou um aumento proporcional no produto. Por outro lado, as DMU's que apresentaram resultado sem caracterização tiveram condição consideradas fronteira fracamente eficiente e por fim as DMU's que apresentaram percentual ente $70-90 \%$ e condição ineficientes podemos considerar como fronteira não pareto eficiente ou simplesmente ineficientes.

Ao analisar o desmatamento evitados nessas RDS por conta do PBF, considerou-se apenas as RDS's Piagaçu-Purus; Uatumã; Rio Amapá e Uacari. No resultado, apesar de que 4 (UC's) terem apresentado um resultado satisfatório no sentido de reduzir o desmatamento, apenas 2 delas apresentaram $100 \%$ de eficiência, ou como podemos dizer fronteira de pareto eficiente (RDS PiagaçuPurus e Uatumã). As demais foram ineficientes no sentido de pareto (isto é, apesar de se dobrar os insumos o produto obtido não foi na mesma proporção).

[4]. BARBOSA, W.; SOUZA, E.P. S. Eficiência técnica e de escala da agropecuária no estado do Ceará. Cadernos de Ciências Sociais Aplicadas. Vitória da Conquista-BA n. 17 p. 153-185 2014.

[5]. BRAMBILLA, M.A.; CARVALHO, S.C.C. Análise da eficiência da gestão do programa bolsa família nos municípios do paraná. Revista Brasileira de Estudos Regionais e Urbanos, vol. 11, n. 4, pp. 537-556, 2017.

[6]. CHARNES, A., COOPER, W.W., LEWIN, A.Y., SEIFORD, L.M. Data envelopment analysis: theory, methodology, and application. Dordrecht: Kluwer Academic, 1994. 
[7]. FAS. Disponível em: http://fasamazonas.org/

[8]. FAS, Fundação Amazonas Sustentável. Relatório de Gestão 2015. Disponível em: http://fasamazonas.org Acessado em: 23/01/2018.

[9]. FAS, Fundação Amazonas Sustentável. Relatório de Gestão 2016. Disponível em: http://fasamazonas.org Acessado em: 12/02/2018.

[10]. HIGUCHI, Niro. Governos locais amazônicos e as questões climáticas globais. Manaus: Edição dos autores, 2009.

[11]. INSTITUTO NACIONAL DE PESQUISAS ESPACIAL (INPE). Projeto PRODES Monitoramento da Floresta Amazônica por Satélite. Desmatamento nos Municípios (Amazonas). Disponível em http://www.dpi.inpe.br/prodesdigital/prodesmunicip al.php. Acesso em: 15/3/2017.

[12]. IPEADATA. Região Metropolitana de Manaus. Disponível em: http://www.ipea.gov.br/agencia/images/stories/PDF s/livros/livros/141125_atlas_manaus. Acesso em 10 set de 2017

[13]. LINS, M.P.E.; SILVA, A.C.M. Evitando a inviabilidade em modelos DEA com restrições aos pesos. Relatório Técnico EP03/01-PO, Programa de Engenharia de Produção/COPPE/UFRJ, Rio de Janeiro, 2001.

[14]. MELLO, J. C. B. S; et al. Análise de envoltória de dados no estudo da eficiência e dos benchmarks para companhias aéreas brasileiras. Pesqui. Oper., Rio de Janeiro, v. 23, n. 2, p. 325345, Aug. 2003.

[15]. MELLO, João Carlos Correia Baptista Soares de; et al. Curso de Análise Envoltória de Dados. XXXVII Simpósio Brasileiro de Pesquisa
Operacional e o Desenvolvimento Sustentável. Gramado, RS, 27 a 30/09/2005. Disponível em: www.uff.br/decisao/sbpo2005_curso.pdf. Acesso em: 15. Out. 2016

[16]. OLIVEIRA, Elane Conceição de. Desmatamento evitado: o caso do programa bolsa floresta do Estado do Amazonas como política ambiental para mitigar os gases de efeito estufa. Universidade de Brasília, Centro de desenvolvimento. DINTER CDS/UNB-UEA. Dezembro, 2008.

[17]. OLIVEIRA, Elane Conceição de; et al. Deficit social e pobreza absoluta na Região Metropolitana de Manaus: governança para o desenvolvimento da região. IN: BARBOSA, Evandro; et al. Governança na Amazônia: socioeconômica, meio ambiente, segurança e defesa. Manaus: BK Editora, 2011.

[18]. PINDYCK, Robert S.; RUBINFELD, Daniel L. Microeconomia. 6 ${ }^{\underline{a}}$ ed. São Paulo: Pearson Prentice Hall, 2005.

[19]. RIVAS. Alexandre. Economia e valoração de serviços ambientais utilizando técnicas de preferências declaradas. / - Manaus. EDUA, 2014.

[20]. TUPY, Oscar; YAMAGUCHI, Luis Carlos T. Eficiência e Produtividade: conceitos e medição. Agricultura em São Paulo, v. 45, n.2, p. 39-41, 1998.

[21]. VERÍSSIMO, A.; PEREIRA, Denys. Produção na Amazônia Florestal: características, desafios e oportunidades. Parc. Estrat. Brasília-DF, v. 19, n. 38, p. 13-44, jan-jun, 2014.

[22]. VIANA, V. M.. Bolsa Floresta: Um instrumento inovador para a promoção da saúde em comunidades tradicionais da Amazônia. Estudos Avançados, 22(6), pp. 1-11, 2008. 


\section{Gapítulo 10}

\section{OS IMPACTOS DA SECA NA ECONOMIA FAMILIAR NORDESTINA}

\section{Maricelia Almeida da Silva}

\section{Lucas Ferreira Lima}

Resumo: Os nordestinos sofrem com grandes períodos de seca, muito já se foi proposto para resolver os problemas causados pela, a transposição de um dos mais importantes rios do Brasil, o rio São Francisco. O projeto de transposição do rio São Francisco vem sendo executado desde 2007 e promete trazer água ao sertão, atender a população sertaneja que sofre com o difícil acesso a água e trazer desenvolvimento a região, criando empregos e novas oportunidades para o aumento da renda do povo nordestino. Porem muitos pesquisadores e especialistas na área mostra que o projeto, que tem custos muito elevados não cumprirá a promessa feita por seus idealizadores, além de ser uma ameaça para o rio São Francisco e seus afluentes, já tem tirado a fonte de renda de famílias que viviam da agricultura familiar e da criação de animais e que tiveram que sair de suas propriedades, muitas vezes tirando dela o pouco de água que tem reservada e o modo como podem reservar melhor essa água. Tirando a esperança dessas pessoas. A transposição é, segundo seus idealizadores, uma solução para a seca, mas quem é contra o projeto, cobra do governo a busca por outras soluções possíveis. A transposição vai beneficiar, principalmente, o agronegócio, deixando assim de atender a maior parte da população, fortificando ainda mais, a indústria da seca, formada por grandes empresários do agronegócio que tem posses sobre as reservas de água que estão no sertão nordestino e não sofrem com a seca como os sertanejos. A redistribuição dessas reservas é uma das soluções para resolver os problemas causados pela seca e para acabar com a indústria da seca.

Palavras-chave: transposição, sertão, indústria da seca. 


\section{INTRODUÇÃO}

A região Nordeste do Brasil sofre com grandes períodos de seca, onde geralmente ocorrem períodos longos de seca seguidos por períodos muito curtos de chuvas. A última grande seca que atingiu o Nordeste teve inicio no ano de 2011 e já dura sete anos. A renda da população mais carente do sertão nordestino é formada principalmente pela agricultura familiar, mas também se dá através da prestação de serviços à grandes fazendeiros e empresários da região.

Além do grande problema da seca que impacta diretamente na renda do povo nordestino há na região problemas como falta de infraestrutura, educação e saúde causados, principalmente, pela falta de investimentos públicos. É importante salientar que os problemas causados pela falta de investimento público são encontrados também em outras regiões do país, mas devido à estrutura socioeconômica estão acentuados no Nordeste.

A pergunta que se faz importante abordar é: a seca é a grande causa dos problemas socioeconômicos do sertão nordestino? Isto é, ao se resolver o problema seca, todos os outros problemas encontrados no sertão serão facilmente resolvidos?

Grande parte dos problemas, principalmente em relação à renda, são causados pelos longos períodos de seca, entretanto, o grande problema nordestino é o descaso público e a presença dos grandes empresários (latifundiários) que se aproveitam da seca para ampliarem seu poder e riqueza, além de se beneficiarem das reservas de água que deveriam ser destinadas à produção familiar para continuarem produzindo e fortalecendo a indústria da seca.

Vários projetos e instituições foram criadas com o objetivo de resolver o problema da seca no Nordeste, tais como a SUDENE (Superintendência do Desenvolvimento do Nordeste) durante o Plano de Metas, no governo do presidente Juscelino Kubitschek. Um dos principais interlocutores e coordenador da SUDENE foi o professor Celso Furtado, economista que agia sempre em beneficio do Nordeste, apoiado por outros economistas nordestinos, tais como Francisco de Oliveira e Tânia Barcelar, que direcionavam seus estudos para superação dos entraves socioeconômicos da economia nordestina.
Com grande maioria de economistas nordestinos, a SUDENE quando criada elaborou um grande estudo com os principais pontos de estrangulamento da economia nordestina e, elaborou ações em prol do desenvolvimento para esta região. Esse grupo da SUDENE pouco pode fazer pelo Nordeste, devido à conjuntura política e social do período e devido à entraves e disputas com os latifundiários que lucravam com a indústria da seca.

Muitas ações foram propostas para resolver $\mathrm{O}$ problema a seca no Nordeste, como a criação de programas sociais que construíam cisternas para a população armazenar água, o Programa Cisternas (O Programa Nacional de Apoio à Captação de Água de Chuva e outras Tecnologias Sociais), criado pelo Ministério do Desenvolvimento Social, até obras grandiosas, como a transposição do rio São Francisco.

A transposição do rio São Francisco é um projeto que foi proposto inicialmente durante o segundo reinado, quando Dom Pedro II apresentou a transposição do rio São Francisco como a solução para a seca no Nordeste e, desde então, houve muitos projetos de transposição, até que o presidente Lula decidiu tirar o projeto do papel e deu inicio em 2007 à essa obra.

O projeto prometeu levar água para o povo sertanejo que sofre com a seca, mas estudos sobre o projeto mostram que a maior parte da água fornecida através da transposição está sendo destinada para o agronegócio (monocultura e latifúndio) e para a indústria, tendo assim uma pequena parte destinada à produção agrícola familiar e à população. Além da controversa relação da ideia central do projeto e o destino real (final) da água, a transposição tirou muitos moradores das regiões onde passa, afetando a vida desses moradores que tiveram que deixar suas terras, plantações e, em muitos casos, perderam a única terra que tinham para manter suas criações em troca de uma indenização baixa.

O assunto transposição é muito discutido entre estudiosos que defendem ou não a transposição, mas poucos estudos têm sido feitos sobre os reais impactos para a população nordestina. A possibilidade de ter acesso mais facilitado à água pode fazer com que a população mais pobre do sertão, que é a maior parte da população, deposite suas esperanças na transposição mesmo sem 
saber se o projeto atenderá a demanda por água.

Outras opções para levar água ao sertanejo e que tivessem um menor impacto social e ambiental em relação à transposição já foram propostas por especialistas, mas os governos continuaram optando pela transposição. Ou seja, há outros meios de reduzir os problemas com a seca, principalmente no Nordeste brasileiro, a região semiárida com maior reserva de água do mundo. Entretanto, na visão dos autores, os problemas nessa região vão além da seca.

Este artigo é formado por sete capítulo, este primeiro capítulo introdutório. Um segundo capítulo que apresenta a região do semiárido através de grandes autores nordestinos, que descrevem a região como uma terra seca e de gente sofrida, como acontece na obra de Graciliano Ramos (1892 - 1953), Vida Secas (1938). Já em um terceiro capítulo são apresentados alguns números que representam o nordeste com a quantidade de municípios que se encontra em estados de emergência pela seca, e também apresenta características geográficas da região, como os estados que a formam e sua hidrografia, além de mensurar os prejuízos que a seca tem causado na economia nordestina. O quarto capítulo cita alguns projetos propostos desde o Brasil império para realizar a transposição do rio São Francisco até o momento em que o projeto sai do papel durante o governo do presidente Lula em 2007. Em um quinto capitulo, o projeto é descrito com seu orçamento inicial, mostrando como o projeto impacta a vida do sertanejo e questionando se vale a pena a população pagar um preço tão alto para que o projeto seja realizado. O sexto capitulo apresenta um pouco do que é falado sobre o projeto transposição, citando algumas personalidades e instituições que defendem o projeto e alguns especialistas que apresentam argumentos contra o projeto. $\mathrm{O}$ sétimo capítulo, que fecha o artigo mostram que outras soluções foram propostas e algumas poderiam ter sido estudas pelo governo como uma alternativa com menor impacto sobre a economia e o ecossistema da região em relação ao projeto de transposição.

\section{A HISTÓRIA DO NORDESTE}

Ao dizer: "venderei até a última joia da coroa, mas solucionarei o problema da seca no
Nordeste!", Dom Pedro II já demonstrava que - problema da seca preocupava os governantes no Brasil desde o Brasil império.

Autores que dedicaram grande parte de seus estudos para analisar e descrever a vida do povo nordestino, como o mineiro Darcy Ribeiro (1922 - 1997), que era antropólogo, escritor e político brasileiro, descreveu em seu livro "O Povo Brasileiro" (1995), que o Nordeste se caracteriza como uma terra de vegetação pobre, formada por pastos naturais e ralos. A economia nordestina se caracteriza como uma economia pastoril baseada no fornecimento de carne, couro, que durante o auge da cana-de-açúcar, eram fornecidos principalmente para os engenhos que ficavam no litoral nordestino.

A economia pastoril e a agricultura familiar são as principais atividades econômicas do sertão, pois quem trabalhava em grandes fazendas muitas vezes recebia parte do excedente e produtos de origem secundária à produção (sistema de meeiros), como os produtos de origem animal como o leite e o couro, além de terem uma pequena parte de terra para morar e montarem suas próprias plantações.

Devido à falta de demanda por gado para ser utilizado nas plantações de cana de açúcar no litoral e, com o excedente das pequenas criações, começaram a se formar grandes feiras locais que incluíam manifestações culturais, tais como as festas religiosas. Essas características, já citadas neste capitulo, são descritas por Darcy Ribeiro também em "O Povo Brasileiro" (1995).

O desespero causado pela seca levou por várias vezes o povo sertanejo a ter esperança de que um salvador os tiraria da miséria em que viviam e da seca no sertão. Sendo assim, há uma tendência ao messianismo, algo muito presente na cultura do sertanejo. Um exemplo dessa tendência ao messianismo foi 0 Massacre de Canudos, onde muitos morreram ao ver nas palavras de um homem a esperança de sair da miséria e da seca, este homem era "Antonio Conselheiro". Seus seguidores se rebelaram contra o governo, que ordenou o ataque ao vilarejo, onde cerca de 25 mil pessoas foram mortas, destruindo todo o povoado. Esse massacre aconteceu no dia 06 de outubro de 1897, com a queima de todo o povoado e o assassinato da população de Canudos, no dia anterior Antonio Conselheiro e mais três defensores de seus ideais foram assassinados. Euclides da 
Cunha faz relatos sofre a tragédia em Canudos e sobre o fanatismo no vilarejo em seu livro "Os Sertões" de 1902.

O sofrimento do povo sertanejo era apresentado em muitas obras de grandes autores brasileiros, como no livro "Vidas Secas" (1938), do alagoano Graciliano Ramos (1892 - 1953). O livro do alagoano descreve o sofrimento de um sertanejo solitário que vive no sertão, retratando a vida sofrida do sertanejo através de seus personagens. $O$ romance representa a situação social do nordestino, onde através de relatos da vida de um retirante representa o sofrimento com a seca e com os abusos de poder dos latifundiários.

Graciliano Ramos, nordestino, viveu grande parte de sua vida no sofrido sertão ao morar com seus pais em Buíque, Pernambuco. Sebastião Ramos, seu pai, comprou uma fazenda, mas teve o gado morto pela seca, impactando toda a família.

O que tem em comum nessas obras é a imagem da acentuada desigualdade social no sertão nordestino. Essa grande desigualdade cresce com a ajuda da indústria da seca, muitas vezes beneficiada por governantes que aceitam trabalhar para que obras públicas e recursos públicos sejam direcionados aos grandes empresários da região. Grande parte desses políticos utiliza de seus cargos públicos para crescimento de suas empresas e de empresas de seus conhecidos.

O pernambucano Francisco de Oliveira, integrante do grupo que formou a SUDENE junto com Celso Furtado, mostra em sua obra "Critica a razão dualista" (2003), que um grande problema do nordeste é a relação centro periferia que há entre a região sudeste e a região nordeste. Assim A população nordestina além de ter grande parte da sua PEA (população economicamente ativa) migrando para região sudeste e assim produzindo e consumindo na região sudeste deixando de colaborar com a dinâmica econômica nordestina, a população nordestina passa a consumir muitos produtos produzidos na região sudeste por não encontrar os mesmos produtos de produção local, transferindo assim a renda obtida na região nordeste para a região sudeste.

O mesmo acontece com algum investimento, quando o empresário nordestino deixa de investir na região nordeste pelo alto custo de produção, causado principalmente pelo difícil acesso a água e pelo alto custo de matérias primas que muitas vezes tem que vir de longe, há também o problema de logística que encarece o produto. Assim o empresário nordestino que obteve capital na região nordeste passa a investir na região sudeste, tendo assim uma transferência de investimentos da região nordeste para a região sudeste. $\mathrm{O}$ faz com que o multiplicador econômico que deveria favorecer a região onde surgiriam essas empresas deixe de dar dinamismo a economia nordestina e estimule a economia do nordeste.

Para resolver os problemas da seca e evitar que problemas envolvendo políticos e empresários (indústria da seca) acontecessem, foi criado o DNOCS (Departamento Nacional de Obras Contra a Seca) em 1909. Órgão que foi corrompido pelo clientelismo e, sendo assim, pouco eficiente para resolver os problemas dos sertanejos, o que favoreceu os grandes latifundiários.

Com o passar dos anos, foi necessário que outro órgão fosse criado para entender e executar obras com o objetivo de melhorar a vida do povo nordestino. Esse novo órgão foi a SUDENE (Superintendência do Desenvolvimento do Nordeste), criada em 1959 pelo governo JK, e liderada pelo economista paraibano Celso Furtado (1920 2004). A SUDENE tinha como principal objetivo gerar desenvolvimento para 0 Nordeste, entretanto grande parte dos projetos criados na SUDENE foi interrompida após o Golpe Militar de 1964 por causa dos interesses de quem pertencia à indústria da seca.

\section{O NORDESTE EM NÚMEROS}

A caatinga é o bioma predominante na região Nordeste, predominante em regiões semiáridas como o sertão nordestino. Segundo dados da SUDENE, essa região possui aproximadamente 53 milhões de habitantes, cerca de $57,7 \%$ da população nacional.

Quatro grandes bacias hidrográficas fazem parte da região: a bacia do Rio São Francisco, passando por cinco estados: Minas Gerais, Bahia, Pernambuco, Sergipe e Alagoas; a bacia do Rio Tocantins que passa pelo Maranhão e pela Bahia; e os grupos de bacias do Atlântico Norte/Sul e Atlântico Leste, composto por rios de menor porte. 
O IDHM (Índice de Desenvolvimento Humano Municipal) aponta três importantes dimensões do desenvolvimento econômico: a oportunidade de viver uma vida longa e saudável, o acesso ao conhecimento e um padrão de vida que garanta as necessidades básicas, representadas pela saúde, educação e renda. Antes dos anos 2000, o Nordeste apresentava um IDHM em faixas consideradas muito baixas $(0-0,499)$ e baixas $(0,500-0,599)$, o que representava as grandes dificuldades de se viver bem e em ter seus direitos preservados, como acesso à educação.

O Nordeste é a região com menor IDHM do país, mas entre os anos 2000 e 2010 a situação do IDHM nordestino passou para o nível médio $(0,600$ - 0,699), representando uma pequena melhora no nível de desenvolvimento e acesso à educação. A classificação do IDHM é feita pelo Atlas do Desenvolvimento Humano, elaborado pelo PNUD Brasil (Programa das Nações Unidas para o Desenvolvimento no Brasil).

Um IDHM, ainda em níveis considerados baixos, mostra como a região do sertão nordestino precisa da atenção do governo para trazer desenvolvimento a região $e$ garantir à população direitos básicos como educação, saúde e alimentação. Mas, por mais que o governo envie recursos para serem investidos nessa região, há também a necessidade de uma rigorosa fiscalização que garanta que os recursos destinados ao semiárido sejam, realmente, destinadas à garantia dos direitos básicos dos nordestinos.

A SUDENE atualmente é um grupo vinculado ao ministério da integração, que acompanha a região do semiárido, coletando dados, agindo como uma autarquia especial, administrativa e financeiramente autônoma, integrante do Sistema de Planejamento e de Orçamento Federal, assim agindo com base na Lei Complementar no 125 , de 03/01/2007, que descreve onde e como a SUDENE deve atuar.

A atuação da SUDENE abrange os estados Maranhão, Piauí, Ceará, Rio Grande do Norte, Paraíba, Pernambuco, Alagoas, Sergipe, Bahia, e os municípios: Águas Formosas, Angelândia, Aricanduva, Arinos, Ataléia, Bertópolis, Campanário, Carlos Chagas, Catuji, Crisólita, Formoso, Franciscópolis, Frei Gaspar, Fronteira dos Vales, Itaipé, Itambacuri, Jenipapo de Minas, José Gonçalves de Minas, Ladainha, Leme do Prado, Maxacalis, Monte Formoso, Nanuque, Novo Charlo Oriente de Minas, Ouro Verde de Minas, Pavão, Pescador, Ponto dos Volantes, Poté, Riachinho, Santa Fé de Minas, Santa Helena de Minas, São Romão, Serra dos Aimorés, Setubinha, Teófilo Otoni, Umburatiba e Veredinha, todos em Minas Gerais, e o município de Governador Lindemberg, no Espírito Santo. A região do semiárido acompanhada pela SUDENE é que sofre muito com a seca está representada no mapa abaixo.

Figura 1 - Área de Atuação da SUDENE

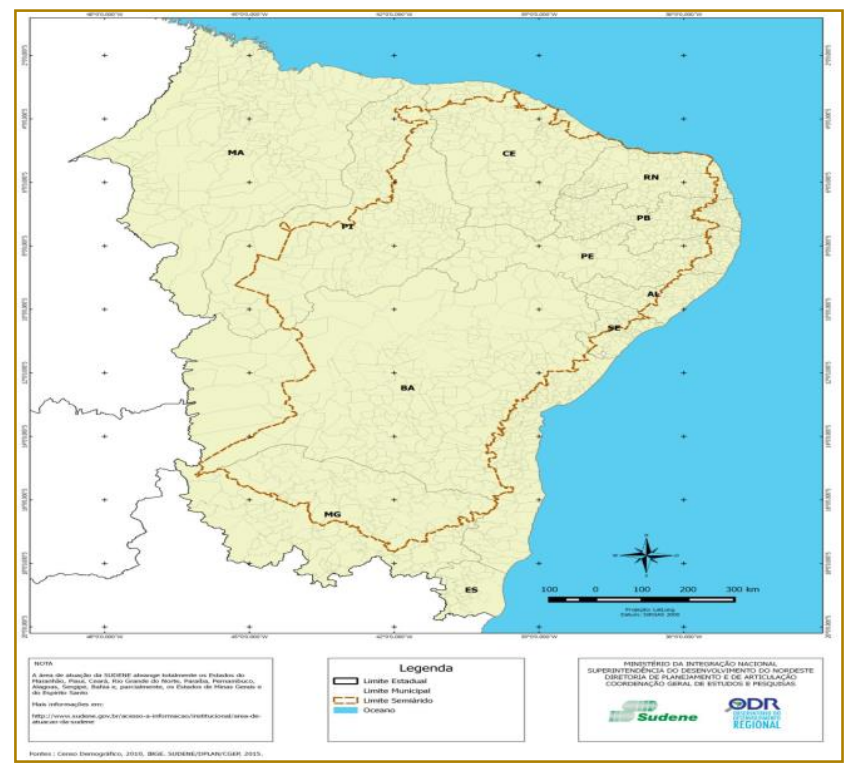

Fonte: SUDENE 
Outro índice que mostra uma pequena melhora na região é a Taxa Bruta de mortalidade, que segundo o Ministério da Saúde foi decrescente em - 0,7\% entre 2010 e 2011. Além disso, o Ministério da Saúde também apresenta dados que demonstram que a região apresenta uma redução de 2,1\% na taxa de natalidade, o que mostra que mesmo com a queda na mortalidade, inclusive a mortalidade infantil, a população nordestina tem crescido cada vez menos, grande parte dessa queda na natalidade se dá pela migração de parte da população nordestina para as regiões centro-sul do Brasil em busca de melhores condições de vida. A migração faz com que novas famílias que deveriam se formar no Nordeste passem a se formar em outras regiões do Brasil, o que também faz com que a população economicamente ativa se reduza e que seja cada vez menor também em relação ao número de aposentados na região, isto é, há redução da PEA na região.

Grande parte da população nordestina que vive, atualmente, de aposentadorias é alta, isto é, muitas famílias têm como principal ou única renda uma aposentadoria. Essa situação é cada vez mais comum na região por causa da seca. Com baixa produção, os agricultores familiares e de pequenas criações tem que recorrer a pequenos auxílios que o governo dá para a população de baixa renda, e assim muitas famílias por não tem como cultivar suas pequenas plantações $e$ perdem cada vez mais rápido seus animais. Essa população passa a viver de auxílios como o Programa Bolsa Família e aposentadorias. Essa população deixa de produzir, o que faz com que a economia nordestina fique estagnada e que $\mathrm{o}$ multiplicador econômico, que poderia dinamizar a economia da região através do aumento de renda e do crescimento no comércio seja pouco expressivo.

Outro fator que faz com que a economia nordestina tenha grande queda é a queda na indústria que acontece porque muitas empresas se vêm obrigadas a sair da região por ter um aumento significativo no custo de produção causado pelo difícil acesso a água, desempregando assim grande parte da população, colaborando assim para que não tenha um multiplicador econômico na região.

Segundo um levantamento feito pela Secretaria Nacional da Defesa Civil, o número de pessoas afetadas pela seca é de 8.354.092 em 1.089 municípios. Número alto de famílias que em grande parte, viviam da agricultura familiar e de pequenas criações e que perderam tudo e passaram a viver com muito pouco, passando muitas vezes, até mesmo fome e sede. Essa população que já sofre com serviços públicos de baixa qualidade e, em muitos casos, tendo que esperar muito para ter acesso a um serviço público de direito, aumentando o sofrimento do nordestino.

Tabela 1 - População afetada pela seca no Nordeste

\begin{tabular}{|c|c|c|}
\hline \multicolumn{1}{|c|}{ Estado } & \multicolumn{1}{c|}{$\begin{array}{c}\text { Pessoas } \\
\text { afetadas* }\end{array}$} & $\begin{array}{c}\text { Municípios em } \\
\text { emergência** }\end{array}$ \\
\hline AL & 458.222 & 36 \\
\hline BA & 2.737 .256 & 254 \\
\hline CE & 1.978 .232 & 172 \\
\hline MA & - & 5 \\
\hline PB & 554.222 & 195 \\
\hline PE & 1.150 .540 & 112 \\
\hline PI & 871.411 & 155 \\
\hline RN & 500.000 & 142 \\
\hline SE & 104.209 & 18 \\
\hline NORDESTE & 8.354 .092 & 1089 \\
\hline
\end{tabular}

Fonte: * Defesas civis estaduais; ${ }^{\star \star}$ Secretaria Nacional de Defesa Civil 
Segundo dados do IBGE (Instituto Brasileiro de Geografia e Estatística), em 2013, os prejuízos causados pela seca na agricultura nordestina já chegavam a $R \$ 3,6$ bilhões, mas com a queda no setor varejista proveniente da continuação do período de seca, entre 2013 e 2015, o prejuízo passou a ser de $R \$ 105,3$ bilhões.
Esse prejuízo atingiu os setores da agricultura e pecuária e assim diminui a renda do sertanejo que diminui seu consumo, causando assim uma queda em cadeia em outros setores como o varejista e o setor de serviços na região. Deixando assim a economia nordestina no vermelho.

Figura 2 - Prejuízos da seca

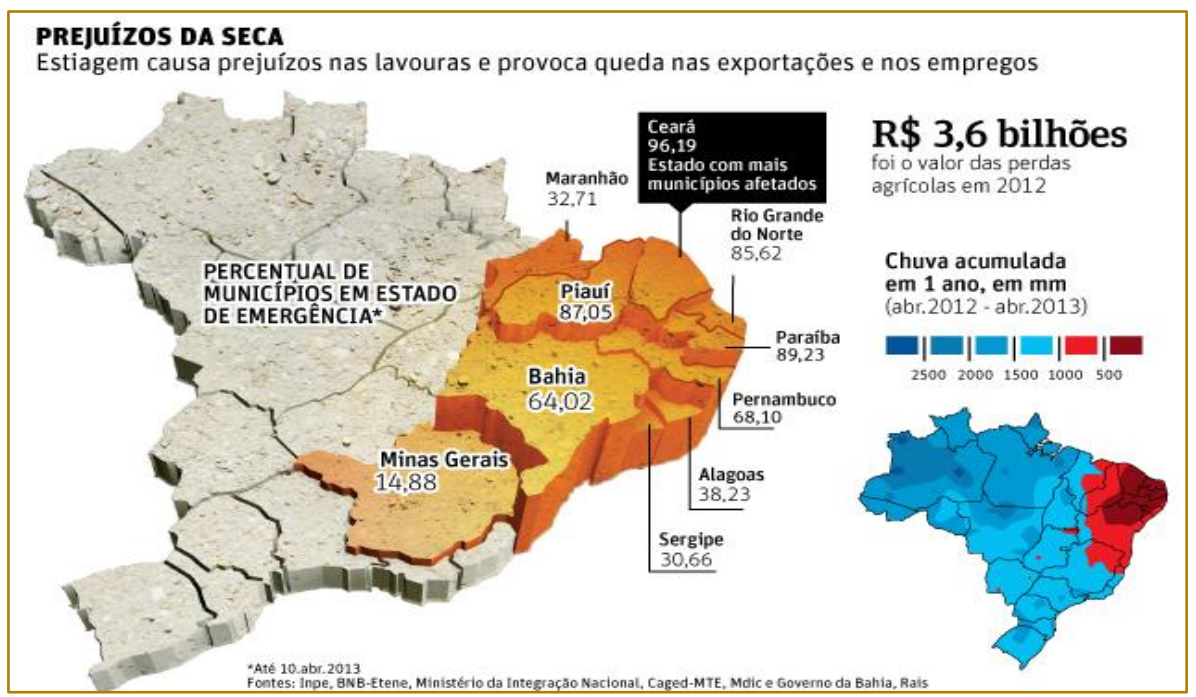

Fontes: INPE, BNB-Etene, Ministério da Integração Nacional, Caged-MTE, Mdic e Governo da Bahia, Raís.

\section{TRANSPOSIÇÃO DO SÃO FRANCISCO, UM PROJETO DESDE O BRASIL IMPÉRIO.}

A seca no Nordeste brasileiro tem sido uma preocupação para o governo desde a época do império. Com uma seca que atingiu a região durante o período de 1844 a 1845, o intendente da comarca do Crato, no Ceará, Marcos Antônio de Macedo propôs a criação de um canal que partiria de Cabrobó, em Pernambuco, em direção ao rio Jaguaribe, um dos principais rios do Ceará, levando assim água do São Francisco ao estado. Mas o projeto não foi realizado por falta de recursos. Sendo assim, o primeiro projeto de transposição do rio São Francisco se deu em 1847.

Ainda durante o reinado de Dom Pedro II, em 1856, uma comissão cientifica liderada pelo Barão de Capanema, estudou o problema de seca e propôs um canal que levasse água do rio São Francisco para o rio Jaguaribe. Em 1886, o engenheiro cearense, Tristão Franklin Alencar retomou o tema, mas os projetos de um canal que levasse água do rio São Francisco ao rio Jaguaribe sugeridos no período do Brasil Império não saíram do papel.

Em 1909, o tema transposição do São Francisco volta a ser discutido durante o governo do presidente Afonso Pena, com a criação da IOCS (Inspetoria de Obras Contra a Seca), o primeiro órgão especialmente criado para estudar os problemas da seca no Brasil. O IOCS tinha a transposição como um de seus principais projetos, mas teve que arquiva-lo por causa da elevação de 160 metros na área da Chapada do Araripe, que interromperia o curso das águas.

Já em 1919, durante o governo do presidente Epitáfio Pessoa, houve um projeto para a criação de açudes que seriam alimentados pelas águas do São Francisco. Mas, com uma fiscalização chefiada por Cândido Mariano da Silva Rondon, conhecida como 'Relatório Rondon', constatou, em 1922, um desvio de recursos nas obras e o projeto foi interrompido.

Durante o período da ditadura militar, o $1^{\circ}$ Grupamento de Engenharia, instalados em João Pessoal (PB), liderados pelo Coronel 
Mário Andreazza, criou um projeto de transposição que demoraria 40 anos para ser finalizado, mas devido à problemas climáticos e políticos, os militares acabaram desistindo do projeto.

Em 1993, durante o governo Itamar Franco, uma grande seca atingiu o semiárido durante dois anos e uma pequena obra emergencial de transposição do São Francisco foi proposta prelo Ministro da Administração e da Integração Regional, Aluízio Alves, porém a seca terminou em 1994 e o projeto não foi realizado.

Em 2007 o então presidente Lula, dá inicio às obras ainda não concluídas, da transposição do Rio São Francisco. Prometendo levar água ao Nordeste e melhorar a vida do sertanejo.

\section{TRANSPOSIÇÃO: VALE A PENA PAGAR TÃO CARO POR ELA?}

A transposição que era a promessa de levar água para o povo nordestino, trouxe vários problemas causados pela execução e pela escolha do trajeto da obra, trazendo prejuízos para a população que estivesse em seu caminho.

A obra tirou vários moradores de suas casas, os indenizando com valores baixos em relação ao valor real de suas propriedades, perdendo não só suas casas, mas também suas fontes de renda por haver, em muitas dessas propriedades desapropriadas, pequenas plantações (agricultura familiar), o que em grande parte das vezes não são possíveis em alojamentos cedidos pelo governo ou nos lugares para onde esses moradores são deslocados. Essas ações geraram problemas para quem vivia da agricultura familiar e que residia no trecho da obra, induzindo-os a procurar uma nova fonte de renda, em grande parte das vezes menos rentável.

Equipes da CPT (Comissão Pastoral da Terra Nordeste II) de Pernambuco realizaram um encontro sobre impactos dos 'grandes projetos' nas comunidades camponesas, em uma visita ao lote 12 da transposição do rio São Francisco, localizado em Sertânea, no sertão pernambucano. Nessa visita, entrevistaram o sr. Francisco, um trabalhador rural de 65 anos que vivia desde menino na região. Francisco teve que deixar sua propriedade em razão da obra de transposição, recebendo $\mathrm{R} \$ 5.000,00$ de indenização, sendo que na propriedade havia um hectare de terra, uma casa e uma cisterna. Como havia cisterna, Francisco tinha como armazenar água para consumo próprio e para seus animais e cultivo agrícola familiar. Entretanto, ao sair de sua propriedade, Francisco passou a ter que ir buscar água em uma região próxima, com água de qualidade inferior e lamacenta. Esse foi apenas um dos relatos colhidos por muitas das equipes de ONGs e instituições que estão preocupadas em como a transposição afeta a vida dos sertanejos.

Além de afetar quem teve de sair de suas propriedades, as obras também afetaram os serviços básicos de alguns municípios e povoados, pois alguns desses terrenos a serem desapropriados são usados no serviço à população, como postos de saúde. Como é o caso de um posto de saúde no assentamento Serra Negra, distante $65 \mathrm{~km}$ do centro de Floresta (PE), que está no trajeto da transposição e será destruído pela obra. Edilene Alves, uma agente de saúde que trabalha no posto, contou a Eduardo Bresciani e Wilson Pedrosa, enviados especiais do jornal Estadão, que 400 famílias estão cadastradas no posto saúde e que será um caos se o posto tiver que ser transferido da região.

Além disso, os moradores do assentamento ainda sofrem como problemas estruturais em suas casas, causados pela obra que passa muito perto de suas casas.

Todos esses sertanejos afetados pelas obras da transposição e muitos outros que sofrem com os grandes períodos de seca no Nordeste, sempre tiveram a esperança de que a transposição poderia dar um fim ao problema, mas essa esperança vem se reduzindo, pois, grande parte da população nordestina vê a obra tirando o pouco que têm, além de começarem a perceber que a água que passará pela obra não chegará facilmente às suas torneiras.

Pesquisadores nordestinos da Fundação Joaquim Nabuco, como João Suassuna e Clóvis Cavalcanti, mencionam que essa água não terá como principal objetivo atender a população sertaneja. Segundo Suassuna, as águas da transposição serão distribuídas de forma que $70 \%$ será destinada para irrigação do agronegócio, 26\% destinado ao setor industrial e urbano e apenas 4\% para abastecimento humano e da agricultura familiar. Ou seja, a parcela destinada à população do semiárido é tão pequena, 
atingirá poucas pessoas e terá um preço muito alto para grande parte da população do sertão nordestino.

Ademais, com relação à questão financeira, o preço da água à população nordestina será elevado. Segundo Suassuna, enquanto é cobrado cerca de $\mathrm{R} \$ 0,01$ a $\mathrm{R} \$ 0,02$ por mil litros de água consumida de outras bacias hidrografias no país, para uso da água proveniente da transposição do São Francisco será cobrado o valor de $R \$ 0,13$ por mil litros. Com um valor tão alto, cobrado de uma população que sofre com grandes problemas sociais e que tem um dos índices mais altos de pobreza do país, a transposição, com certeza, não trará vantagens. Além disso, é necessário conscientizar os entes públicos sobre a necessidade de políticas destinadas a atender os sertanejos que não possuem recursos para pagar pela água.

Além do alto valor da água da transposição e dos prejuízos sociais e ambientais trazidos para a população sertaneja através da desapropriação de suas propriedades e dos danos estruturais e sociais causados pela obra, a transposição tem se mostrado um projeto muito caro. O projeto de transposição do rio São Francisco tinha um orçamento inicial de $R \$ 4,5$ bilhões, esse orçamento teve um crescimento de $113 \%$ no decorrer da obra, chegando a $\mathrm{R} \$$ 9,6 bilhões, valor que deve ser maior ao fim da obra, afinal as obras da transposição que se iniciaram em 2007 deveriam ter sido entregues em 2012, mas ainda não estão concluídas.

O atraso nas obras, segundo o Ministério da Integração Nacional, é justificado pela grandiosidade da obra. A obra foi e continua sendo interrompida por muito tempo em muitas regiões.

\section{O QUE É FALADO SOBRE TRANSPOSIÇÃO DO RIO SÃO FRANCISCO}

O projeto de transposição do rio São Francisco foi uma proposta de governo do presidente Lula, que se iniciou em 2007. O então presidente tinha com o projeto levar água ao sertão nordestino e, assim, gerar desenvolvimento na região. Lula prometeu fazer a transposição sem esquecer da preocupação com a recuperação do rio São Francisco e seus afluentes. Numa visita ao Retiro de Itaci da CNBB (Conferencia dos
Bispos do Brasil) em Indaiatuba-SP, Lula disse:

"eu sempre me recusei a discutir a transposição das águas do jeito que muita gente queria discutir, sem antes discutir como recuperar o rio São Francisco, como recuperar seus afluentes, como recuperar a sua cabeceira. Houve nota de protesto e de repúdio contra mim, em plena eleição, na Paraíba, no Rio Grande do Norte, no Ceará. E serei eu - prestem atenção ao que eu estou dizendo, e eu não posso mentir na frente de tantos bispos e cardeais aqui -, serei exatamente eu, que nunca assumi um compromisso, que vou fazer a transposição das águas para o Nordeste brasileiro" (Lula, 2007).

O Professor da área de Recursos Hídricos da UFRN (Universidade Federal do Rio Grande do Norte), José Abner, mostra, através do exemplo do Mar de Aral, na Ásia Central, como o uso intenso das águas de um rio sem que haja um retorno proporcional pode fazer com que o rio e seus afluentes enfraqueçam, como aconteceu no Mar de Aral, um mar que um dia já foi o quarto maior do mundo, que começou a secar rapidamente e enfraquecer assim como seus afluentes. Assim os professores José Abner, como outros especialistas no assunto, chama atenção para o mal que a transposição pode fazer ao rio São Francisco e seus afluentes.

O PAC (Programa de Aceleração do Crescimento), diz que o projeto de transposição vai levar água ao semiárido além de criar muitos empregos na região e defende que:

"O empreendimento, além de recuperar 23 açudes da região, construirá outros 27 reservatórios, além de 4 túneis, 14 aquedutos e 9 estações de bombeamento, em 477 quilômetros de extensão em dois eixos (Norte e Leste) de transferência de água do rio São Francisco. A obra beneficiará um total estimado de 12 milhões de pessoas nos estados de Pernambuco, Ceará, Paraíba e Rio Grande do Norte. Além de água, a obra leva também emprego e renda, promovendo inclusão social às comunidades" (PAC Ministério do Planejamento, 2017).

Já o ambientalista Apolo Heringer Lisboa, do projeto Manuelzão da UFMG (Universidade Federal de Minas Gerais) e integrante da Caravana do São Francisco, afirma que o projeto de transposição é apenas uma promessa e que é ineficiente ao dizer que " $a$ 
transposição não vai começar; se começar não vai continuar; se continuar não vai terminar; se terminar não vai funcionar. Tratase de uma grande mentira" (Apolo Lisboa, 2005)

Muitos pesquisadores como Marco Antonio Coelho, jornalista do site Observatório da Imprensa, apontam a transposição como apenas mais uma propaganda política.

Já o compositor Plácido Júnior, da Comissão Pastoral da Terra Nordeste II, mostra através do poema apresentado abaixo como a transposição é a promessa de trazer água mas que tem tirado as reservas de água do povo nordestino através da destruição de muitas cisternas.

\section{DESTRUIÇÃO DAS CISTERNAS}

Como podes nos dar água

Se destróis nossas cisternas?

Como trazes benefícios

Se nos aparta dos baixios?

Rasgar a terra só se for para juntar água
Rasgar a terra só se for para o plantio

A gente não queria ter saído

Dos nossos pedacinhos de terra!

A gente não queria ter deixado

Nossas águas e os baixios

Essa tal transposição foi quem fez isso com a gente

Como ficam as famílias, as plantações e os bichinhos?

Poema de Plácido Júnior, da Comissão Pastoral da Terra Nordeste II

Outro ponto forte na luta pelo desenvolvimento do Nordeste e que deve ser ressaltado é a atuação dos movimentos que lutam pelo povo sertanejo, além do posicionamento de instituições de ensino e religiosas, como a CPT (Comissão Pastoral da Terra), a OAB (Ordem dos Advogados do Brasil) que mostrou que o projeto pode ser inconstitucional, a ASA (Articulação no Semiárido Brasileiro), entre outros.

Figura 3 - Os números da transposição

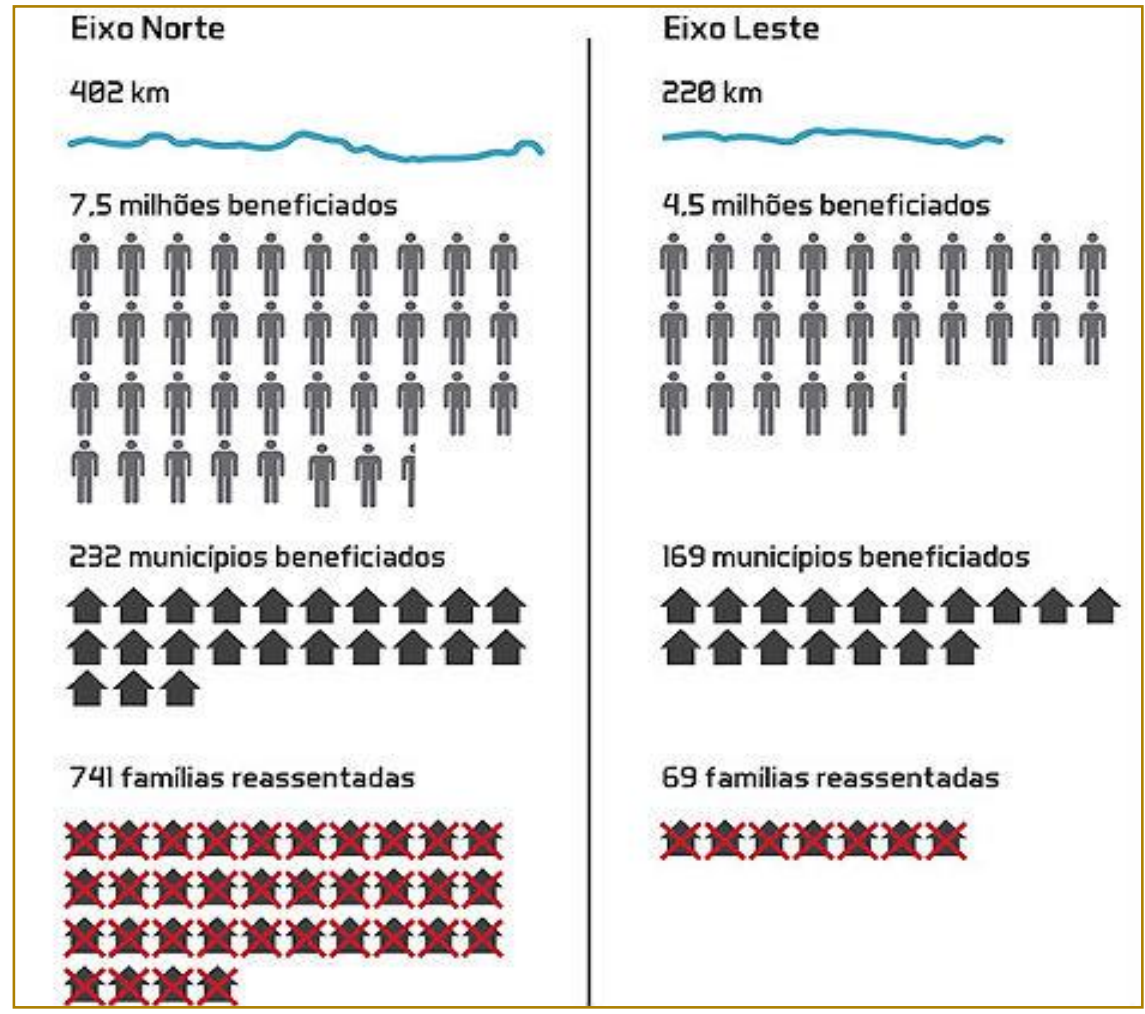

Fonte: Ministério da Integração, Agência de Jornalismo Investigativo 
A imagem acima mostra o alto número que o projeto pretende atender, que segundo os dados apresentados pelo Ministério da Integração, é um número alto em relação ao número de famílias reassentadas, diretamente afetadas, famílias que passam a perder por muitas vezes suas fontes de renda, que apesar de serem assistidas pelo governos e que possam receber algum auxilio do governo, não conseguem retomar a mesma renda e qualidade de vida que tinham antes da passagem da obra em suas terras, além de receber um valor como indenização que não corresponde ao valor de suas propriedades desapropriadas.

Figura 4 - Impactos da transposição do São Francisco

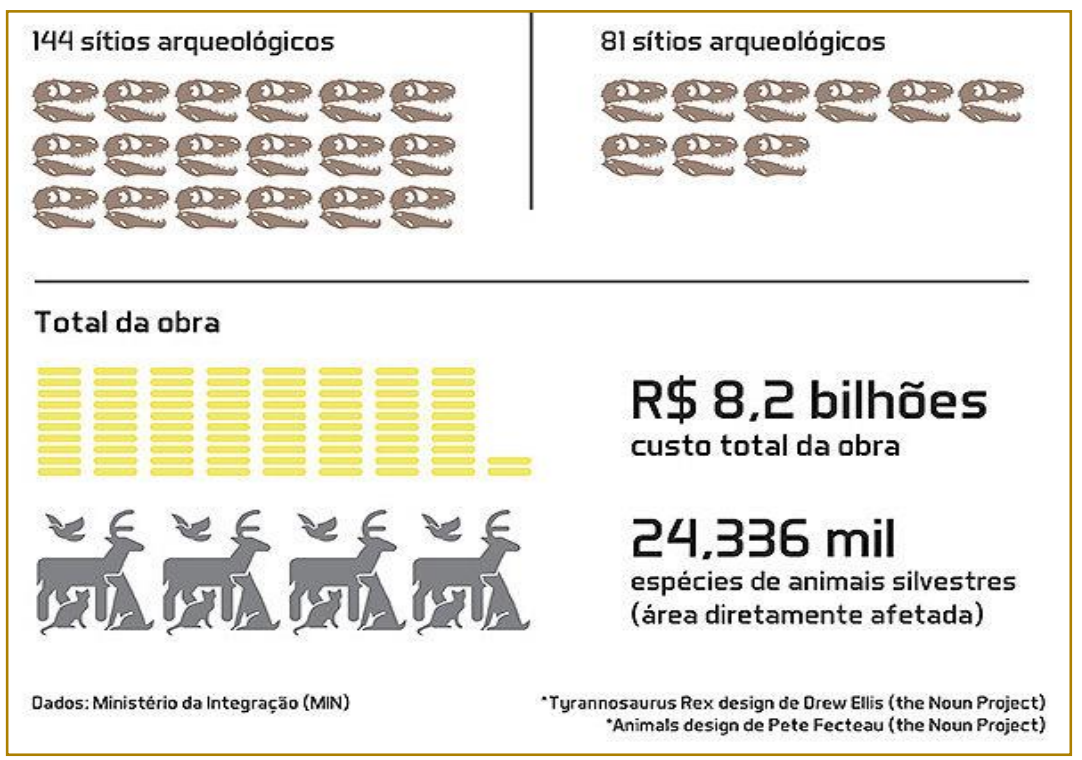

Fonte: Agência de Jornalismo Investigativo.

A imagem acima mostra o grande impacto ambiental que a obra trás para a região. Além de ter um custo altíssimo, a obra irá atingir um grande número de sítios arqueológicos, trazendo um grande prejuízo para a arqueologia brasileira e tornando impossível a descoberta de achados arqueológicos importantíssimos para a ciência. Além de colocar em risco um grande número de espécies de animais silvestres, que podem diminuir suas população ou até mesmos correm o risco de entrar em processo de extinção, por terem seu meio ambiente modificado pela obra, reduzindo as regiões de mata ou até mesmo inundando algumas regiões e afetando não só a vida dos animais silvestres, mas também modificando toda a vegetação típica da região, colocando também em risco de extinção espécies de plantas típicas da região por onde a transposição passar.

\section{HÁ OUTRA SAÍDA?}

No livro Seca e poder: entrevista com Celso Furtado (1998), Furtado descreve o Nordeste como uma região com alto potencial produtivo, porém essa riqueza potencial é mal distribuída, isto é, e uma pequena parte da população formada por empresários e políticos tem grande poder sobre a região e, através da indústria da seca, barra o desenvolvimento de toda a região.

Nessa entrevista, Celso Furtado chama atenção para o plano do governo Fernando Henrique Cardoso de produzir álcool na região Nordeste para consumo interno e exportações, e dá o exemplo da Zona da Mata na Bahia, onde a produção para exportação foi estimulada, porém muitos moradores passam fome, nessa região que não sofre tanto com as secas. Ademais, Furtado chama a atenção para a necessidade de produzir para o consumo interno, produzindo alimentos, com o objetivo de matar a fome da população da região.

Mas as sugestões de Celso Furtado, que ameaçavam os interesses dos grandes empresários, latifundiários e políticos que se beneficiam da indústria da seca, não tiveram forças para serem executadas, por desafiar o status quo local. 
O pesquisador João Suassuna (1999) mostra que o governo prometeu buscar outras soluções para resolver os problemas causados pela seca que não fossem tão caros e com tantos impactos negativos para a população e o ecossistema local, afinal, as obras além de ameaçarem o rio São Francisco e seus afluentes, ainda tiraram as pessoas e até mesmo povoados inteiros de suas propriedades, excluindo a renda de quem vivia nessas terras.

João Suassuna chama atenção para o fato de semiárido brasileiro ter uma oferta de água de 37 bilhões de $\mathrm{m}^{3}$, sendo o semiárido que tem o maior volume de água represada no mundo. Segundo Manoel Bomfim Ribeiro (2008), engenheiro civil e ex-diretor regional do DNOCS (Departamento Nacional de Obras Contra a Seca), existem 70.000 reservatórios superficiais na região, tendo um açude a cada $14 \mathrm{~km}^{2}$ por toda a superfície do Polígono das Secas. Mostrando que o volume de água presente nos açudes do Nordeste é grande em relação a outras regiões semiáridas do mundo, a pergunta que se levanta nesse momento é: porque levar água de um dos principais rios do país para regiões onde já há água?

O problema na verdade não é a falta de água, porque estudos da região mostram que há grandes reservas de água, mas sim o acesso restrito a água. Afinal, quem tem acesso às águas represadas no sertão? O problema é que a maior parte dessas reservas está em

\section{NOTAS}

1 - O Plano de Metas proposto pelo presidente Juscelino Kubitscheck, eleito em 1955, tinha como objetivo principal fazer com que o país se desenvolvesse rapidamente (50 anos em 5). Nesse período, foram executadas grandes mudanças no país, incluindo a meta síntese de construção de uma nova capital, Brasília. Além disso, foram elaborados vários projetos de desenvolvimento setoriais para o país, tais como o incentivo ao setor industrial e um plano de desenvolvimento para o Nordeste, criando assim a SUDENE, com o professor Celso Furtado à frente deste projeto.

2 - Programa Nacional de Apoio à Captação de Água de Chuva e outras Tecnologias Sociais, instituído pela Lei № 12.873/2013 e regulamentado pelo Decreto $N^{\circ}$ 8.038/2013, financiado pelo MDS (Ministério do Desenvolvimento Social), que tem como principal objetivo amenizar os problemas da terrenos particulares, principalmente de grandes fazendeiros. Ou seja, a água hoje presente no sertão nordestino faz parte da indústria da seca, onde quem tem acesso à água é quem possui dinheiro e poder local. Essa água que deveria ser usada para o consumo humano é utilizada nas criações e cultivos de grandes fazendeiros, isto é, a água do sertão pertence ao agronegócio, enquanto a população muito próxima a essas reservas morre de sede e fome, devido à baixíssima produção agrícola familiar.

O governo deveria estudar e propor outras saídas para os problemas da seca que não a transposição do rio São Francisco. A utilização da água presente nessas reservas, para grande parte dos especialistas, é a forma mais viável de resorver o problema no sertão. Porém, isso vai contra os objetivos dos grandes empresários do agronegócio, que lucram com a seca, utilizando a água dos reservatórios de forma quase exclusiva, além de muitas vezes vender água a preços altos para que não tem acesso.

Com a transposição, a indústria da seca ficará mais forte, pois agora além da água dos açudes, terão também acesso a maior parte da água quem vem da transposição. Portanto, a redistribuição das reservas de água, além de ser a solução para com os problemas da sede e fome do povo nordestino, pode aumentar renda do sertanejo que vive da agricultura familiar.

seca com a construção de cisternas de acordo com a necessidade da população, construindo cisternas em vilarejos, hospitais e escolas das regiões mais atingidas pela seca.

3 - A relação centro periferia é uma relação de dependência entre um centro que fornece produtos e emprego a população da periferia, assim a periferia além de fornecer mão de obra também transfere renda ao centro, criando assim uma dependência da periferia ao centro, a periferia passa a colaborar com a economia do centro, estagnando sua economia e ajudando a dinamizar a economia do centro.

4 - O DNOCS (Departamento Nacional de Obras contra a Seca) foi criado em 1909 através do Decreto 7.619 de 21 de outubro de 1909, durante o governo do presidente Nilo Peçanha, inicialmente chamada de IOCS (Inspetoria de Obras Contra a Seca), já em 1919 recebeu o nome de IFOCS (Inspetoria 
Federal de Obras Contra a Seca), até passar a ser denominado como DNOCS em 1945, se transformando em autarquia federal em 1963 através da Lei n 4229, de 01/06/1963.

5 - A caatinga é um bioma exclusivamente brasileiro, caracterizado pela vegetação resistente ao clima quente e seco, com longos períodos de seca.

6 - O IDHM (Índice de Desenvolvimento Humano Municipal) considera três dimensões do desenvolvimento humano: longevidade, educação e renda. Variado de 0 a 1. Os dados são coletados e o calculo é feito pelo

\section{REFERÊNCIAS}

[1]. ANDRADE, Manuel Correia de; TAVARES, Maria da Conceição e PEREIRA, Raimundo. Seca e Poder: Entrevista com Celso Furtado. São Paulo. Fundação Perseu Abramo. 1998.

[2]. BRASIL. Governo anuncia investimentos para combate a seca. Disponível em: <http://www.brasil.gov.br/infraestrutura/2016/12/go verno-anuncia-investimentos-para-combater-aseca>. Acesso em 23 mar 2018.

[3]. BRASIL. Lei Complementar no 125, de 03/01/2007 - DOU 04/01/2007. Disponível em: $<$ http://www.sintese.com/norma_integra.asp?id=43 98> . Acesso em 25 mar 2018.

[4]. BRASIL. Ministério da Integração. Programa Água para Todos. Disponível em: <http://www.mi.gov.br/agua-para-todos> . Acesso em 23 mar 2018.

[5]. BRASIL. Ministério da Integração. Projeto São Francisco. Disponível em: <http://www.mi.gov.br/web/projeto-sao-francisco>. Acesso em 23 mar 2018.

[6]. BRASIL. Ministério da Saúde. Taxa Bruta de Mortalidade. Disponível em: <http://tabnet.datasus.gov.br/cgi/idb2012/a10b.htm $>$. Acesso em 23 mar 2018

[7]. BRASIL. Ministério da Saúde. Taxa de Natalidade. Disponível em: <http://tabnet.datasus.gov.br/cgi/idb2011/a07b.htm >. Acesso em 23 mar 2018.

[8]. BRASIL. Ministério do Desenvolvimento Social. Programa Cisternas. Disponível em: $<$ http://mds.gov.br/assuntos/segurancaalimentar/acesso-a-agua-1/programa-cisternas $>$. Acesso em 23 mar 2018.

[9]. CARTA CAPITAL. A seca extrema avança no Nordeste.. Disponível em: <http://www.cartacapital.com.br/revista/929/aseca-extrema-avanca-no-Nordeste> . Acesso em 23 mar 2018.

[10]. CPT (Comissão Pastoral da Terra Nordeste II). Transposição do Rio São Francisco:
PNUD (Programa das Nações Unidas para o Desenvolvimento), IPEA (Instituto de Pesquisa Econômica Aplicada) e Fundação João Pinheiro.

7 - A PEA (População Economicamente Ativa) indica a população inserida no mercado de trabalho, os dados da PEA são colhido pelo IBGE (Instituto Brasileiro de Geografia e Estatística).

8 - Entrevista de Celso Furtado feita por Manuel Correia de Andrade, Maria da Conceição Tavares e Raimundo Pereira, economistas e historiadores.

As perguntas de Seu Chico. Disponível em: $<$ https://www.cptne2.org.br/index.php/publicacoes/ noticias/grandes-projetos/2835-transposicao-dorio-sao-francisco-perguntas-de-seu-chico>. Acesso em 23 mar 2018.

[11]. CUNHA, Euclides da. Os Sertões. Rio de Janeiro. Laemmert. 1902.

[12]. DIÁRIO DO NORDESTE. Transposição: Em Quase 10 Anos, Custo Saltou 113\%. <http://diariodoNordeste.verdesmares.com.br/cade rnos/negocios/transposicao-em-quase-10-anoscusto-saltou-113-1.1650881>. Acesso em 25 mar 2018.

[13]. DNOCS, Departamento Nacional de Obras Contra a Seca. Disponível em: <http://www.dnocs.gov.br/php/comunicacao/registr os.php?f_registro=2\&>. Acesso em 25 mar. 2018.

[14]. ECODEBATE. Após Transposição água do Rio São Francisco Será a Mais Cara.. Disponível em:

<https://www.ecodebate.com.br/2010/11/24/apostransposicao-agua-do-rio-sao-francisco-sera-amais-cara/> . Acesso em 23 mar. 2018.

[15]. ECODEBATE. Transposição: uma análise cartesiana, estudo de Manoel Bomfim Ribeiro ( 23/12/1930 e + 03/12/2012). Disponível em: <https://www.ecodebate.com.br/2014/12/04/transp osicao-uma-analise-cartesiana-estudo-de-manoelbomfim-ribeiro-23121930-e-03122012/> . Acesso em 28 mar 2018.

[16]. ESTADÃO. Na Rota do Canal, posto de saúde e Assentamento. <http://politica.estadao.com.br/noticias/geral,narota-do-canal-posto-de-saude-eassentamento,806316> . Acesso em 23 mar 2018.

[17]. FURTADO, Celso. A operação Nordeste. Rio de Janeiro. Instituto Superior de Estudos Brasileiros. 1959.

[18]. FURTADO, Celso. Formação Econômica do Brasil. 34 ed. Rio de Janeiro. Companhia da Letras. 1959. 
[19]. LIMA, Lucas Ferreira. Processo Sóciotécnico MACBETH de Apoio Multicritério à Decisão e a Organização de Comunidades Tradicionais: O caso da Comunidade do Marujá no Vale do Ribeira - SP. 195 p. Dissertação (Mestrado) - Instituto de Economia, Universidade Estadual de Campinas, Campinas, [Brasil], 2012.

[20]. LISBOA, Apolo Henringer. Transposição do São Francisco. Disponível em: <http://www.fundaj.gov.br/images/stories/observafu ndaj/transposicao-rio-artigo-apolo.pdf >. Acesso em 25 mar 2018.

[21]. OLIVEIRA, Francisco de. Critica a razão dualista. Rio de Janeiro. Boitempo, 2003.

[22]. RAMOS, Graciliano. Vidas Secas. Rio de Janeiro. Record. 1998.

[23]. RIBEIRO, Darcy. O Povo Brasileiro. Rio de Janeiro. Companhia das Letras. 1995.

[24]. ROMEIRO, A. R. Desenvolvimento sustentável: uma perspectiva econômicoecológica. Estudos Avançados, v. 26, n. 74, p. 6592, 2012.
[25]. ROMEIRO, Ademar Ribeiro. "Economia ou economia política da sustentabilidade". Em: MAY, Peter H.; LUSTOSA, Maria Cecília; VINHA, Valéria da (orgs.). Economia do meio ambiente: teoria e prática. Rio de Janeiro: EcoEco/Campus, 2003.

[26]. ROMEIRO, Ademar Ribeiro; REYDON, Bastian Philip; LEONARDI, Maria Lucia Azevedo (orgs.). Economia do meio ambiente: teoria, políticas e a gestão de espaços regionais. Campinas: Unicamp/IE, 1996.

[27]. SACHS, Ignacy. Caminhos para o desenvolvimento sustentável. Rio de Janeiro: Garamond, 2002.

[28]. SUASSUNA, João. Indignações Sobre a Transposição do Rio São Francisco. Disponível em: <http://remabrasil.org:8080/virtual/r/remaatlantico.o $\mathrm{rg} / \mathrm{sul} /$ Members/suassuna/campanhas/indignacoes -sobre-a-transposicao-do-rio-sao-francisco>.

Acesso em 23 mar 2018.

[29]. UVAGP. A Importância do Projeto de Transposição do Rio São Francisco. <https://uvagpclass.wordpress.com/2017/04/04/aimportancia-do-projeto-de-transposicao-do-rio-saofrancisco/>. Acesso em 23 mar. 2018. 


\section{Capítulo 11}

\section{O SISTEMA AGROINDUSTRIAL MICRORREGIÃO DE DRACENA-SP}

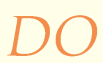

Wagner Luiz Lourenzani

Evandro Jardim dos Santos

Ana Elisa Bressan Smith Lourenzani

Resumo: Esse trabalho objetivou compreender o Sistema Agroindustrial (SAG) do urucum na Microrregião de Dracena, estado de São Paulo. A justificativa de estudo na região se dá pela representatividade geográfica nacional, pela importância mercadológica e socioeconômica desse objeto de estudo. Por meio de um estudo exploratório de caráter qualitativo, a metodologia envolveu uma revisão bibliográfica e uma pesquisa de campo. Foram realizadas 20 entrevistas junto aos agentes chaves dos SAG do urucum na região em estudo. Os resultados revelam que essa é uma atividade característica da pequena produção e adotada, em sua maioria, por produtores caracterizados pela agricultura familiar. Esse trabalho contribui com informações sobre o mercado e a organização da produção agrícola do urucum, especialmente na região delimitada.

Palavras-chave: Urucum, Corantes Naturais, Sistema Agroindustrial

*Artigo apresentado no 56ํㅡㄹ Congresso da Sociedade Brasileira de Economia, Administração e Sociologia Rural (SOBER - 2018) Campinas SP 


\section{INTRODUÇÃO}

O urucum (Bixa orellana) é uma espécie de arbusto originário da América Central e da América do Sul. Pertencente ao sistema agroflorestal semi-arbóreo, recebe o nome de urucuzeiro ou urucueiro (Netto, 2009). Seu nome popular vem da palavra tupi "uru-ku", que significa "vermelho" devido à cor predominante de suas sementes. Essa cor é resultado do corante bixina, do grupo dos carotenoides, que formam um dos grupos de pigmentos mais conhecidos na natureza (Corlett et al., 2007).

A classificação botânica do urucum é: a) Subdivisão: Angiosperma; b) Classe: Dicotiledoneae; c) Ordem: Parietales; d) Subordem: Cistianeae; e) Família: Bixaceae; f) Gênero: Bixa; g) Espécies: Bixa orellana L., Bixa arborea, Bixa americana, Bixa urucurana, Bixa upatensis, Bixa tinetoria e Bixa oviedi. A espécie mais cultivada é a Bixa orellana $L$. (Franco et al., 2002).

As cachopas do urucuzeiro produzem sementes, que são moídas para a extração de coloríficos, bem como para a produção dos corantes bixina, norbixina e nobixato (Fabri \& Teramoto, 2015). Tais pigmentos são largamente utilizados nas indústrias alimentícias (Mendes et al., 2006), mas também adotados nas indústrias farmacêutica, cosmética, têxtil e de tintas. O urucum ainda é muito cultivado como planta ornamental, pela beleza e exuberância de suas flores (Anselmo et al., 2008; Torres \& Bezerra Neto, 2009). Os estudos científicos têm focado nesses aspectos, enquanto são raros os estudos voltados ao mercado e à organização do seu Sistema Agroindustrial (SAG) no Brasil.

O conceito de SAG está relacionado a uma abordagem ampla em que a indústria de insumos, a produção agropecuária, a indústrias de processamento e o sistema de distribuição apresentam relações de interdependência (Souza \& Avelhan, 2009). O SAG do urucum, cuja semente é utilizada para a produção de corante natural e seus derivados industriais, pode ser compreendido a partir de um encadeamento de relações existentes entres os agentes que o compõem. Encontram-se presentes os fornecedores de insumos agrícolas, os produtores de urucum, os intermediários e as indústrias de processamento, as quais comercializam seus produtos em mercados nacionais e internacionais.
A importância e a justificativa desse trabalho baseiam-se em duas principais dimensões: uma mercadológica e outra, socioeconômica. Enquanto a importância mercadológica diz respeito às tendências de crescimento da demanda do urucum e do aumento dos critérios de qualidade, a justificativa socioeconômica se dá pela importância dessa atividade na região de análise. Nesse contexto, esse trabalho tem como objetivo analisar o SAG do urucum, caracterizando o mercado e a produção desse produto agrícola na Microrregião de Dracena-SP.

\section{METODOLOGIA}

O desenvolvimento dessa pesquisa se deu por meio de um estudo exploratório de caráter qualitativo. A pesquisa exploratória envolve uma maior familiaridade com o problema, tornando-o mais explícito para a construção de hipóteses (Gil, 2002). A flexibilidade é uma característica fundamental para análise do objeto de estudo e, geralmente, envolvem entrevistas com pessoas que tiveram experiências práticas. Tal tipo de pesquisa mostrou-se adequado devido à escassez de trabalhos científicos sobre o assunto. Essa pesquisa teve uma abordagem qualitativa, cuja característica é dar ênfase ao contexto e ao comportamento dos indivíduos sobre as experiências vividas (Dalfovo et al., 2008).

A coleta de dados envolveu duas etapas. Primeiramente, foi realizada uma pesquisa bibliográfica para a obtenção de dados secundários em artigos de periódicos, capítulos de livros, relatórios técnicos, dissertações e teses, entre outros, que tratassem sobre o mercado e a produção do urucum. Em seguida, esse trabalhou utilizouse de pesquisa de campo para coleta de dados primários. Trata-se de um método focado especificamente em comunidades, seja de trabalho, lazer, estudos ou qualquer outra forma organizacional. A partir da observação direta das atividades do grupo estudado, e/ou das pesquisas das amostras selecionadas dentro do universo pesquisado, objetiva-se buscar informações do que ocorre no grupo (Gil, 2002; Lakatos \& Marconi,2003).

Para operacionalizar a pesquisa de campo, foram aplicados formulários na forma de entrevista, já que é um eficiente instrumento de pesquisa a ser utilizado para coleta de dados em estudos de campo (Duarte, 2004; Minayo, 2013). 
Ao todo foram realizadas 20 entrevistas, no período entre outubro e novembro de 2016, envolvendo representantes do setor de insumos, de produção, um agente intermediário e de instituições de apoio. A seleção e a definição do número de agentes participantes dessa pesquisa se deram de forma intencional, a partir da indicação de agentes envolvidos nesse SAG, bem como pelo aceite dos agentes em participar da pesquisa.

Esse trabalho parte de um recorte geográfico definido pela região denominada de Microrregião de Dracena - SP, pois é considerada a maior região produtora de urucum do Brasil em termos de área plantada e quantidade produzida. Essa região é composta por dez municípios de pequeno porte, com uma população média de cerca de 12.500 habitantes, sendo o setor da agricultura uma das principais bases econômicas desses municípios (IBGE, 2016a; ATLAS BRASIL, 2016). Fazem parte dessa região os municípios de Monte Castelo, São João do Pau d'Alho, Tupi Paulista, Junqueirópolis, Ouro Verde, Nova Guataporanga, Paulicéia, Dracena, Santa Mercedes e Panorama (IBGE, 2016a). Nessa região, os municípios de Monte Castelo e São João de Pau D'Alho destacam-se na produção regional, apresentando o maior número de unidades produtoras, bem com o maior número de plantas de urucum (IBGE, 2016b; CATI, 2008).

\section{SISTEMA AGROINDUSTRIAL (SAG)}

A atividade agrícola passou por um intenso processo de especialização devido aos novos modelos sociais e econômicos que surgiram a partir da primeira metade do século 20. Acontecimentos como intensificação tecnológica, êxodo rural e especialização produtiva, romperam as barreiras agrícolas de produção de subsistência, envolvendo os agentes agrícolas em modernas e complexas formas de produção. Essa nova rede de relações comerciais entre firmas se deu pela limitação de cada uma das partes em produzir e distribuir sua produção de forma individual (HOFF et al., 2007).
Para Zylbersztajn (1995), o período pósguerra impulsionou a produção de alimentos processados, que passaram a ser adquiridos via mercado. Isto demandou atividades de armazenagem, processamento e distribuição muito mais complexas que a formatação da produção e consumo de períodos anteriores.

Nesse contexto, a partir da década de 1950, um novo panorama surge por meio de trabalhos e estudos de pesquisadores dedicados a compreender e explicar a dinâmica de funcionamento dessa rede agroalimentar. Surge o conceito de Sistema Agroindustrial (SAG), representando uma importante contribuição para o entendimento do setor.

Os estudos de Goldberg em 1957 e Davis e Goldberg em 1968 foram os responsáveis por disseminar a abordagem de Agribusiness System Approach (ASA) ou Commodity System Approach (CSA) (MENDES, FIGUEIREDO e MICHELS, 2009; ZYLBERSZTAJN e GIORDANO, 2015). Segundo Zylbersztajn e Giordano (2015), Goldberg rompe com os limites da unidade de produção agrícola e aborda em seus estudos todos os sistemas envolvidos na produção de produtos agropecuários ou outros produtos a partir deles, chegando até o consumidor final (mercado final).

Nesse contexto, a dinâmica de funcionamento do SAG vai além dos limites da firma. Considera elementos que envolvem a relação entre agentes engajados em determinadas atividades e muito além delas, uma vez que a complexidade inerente das atividades agrícolas pressionam estes agentes a se mobilizarem na busca de formas mais competitivas.

Lima, Esceveste e Ribeiro (2014) afirmam que um dos grandes obstáculos da atividade agroindustrial está relacionada com a sazonalidade da produção rural. Sua produtividade está intimamente ligada a fatores que não podem ser controlados, apenas previstos, atribuindo riscos e incertezas ao processo de produção agrícola e zootécnica. O Quadro 1 apresenta as principais características das atividades agroindustriais. 
Quadro 1: Características da produção agroindustrial

\begin{tabular}{|c|c|}
\hline \multicolumn{2}{|r|}{ Características da produção rural } \\
\hline $\begin{array}{l}\text { Dependência do } \\
\text { clima }\end{array}$ & $\begin{array}{l}\text { O clima é determinante para a realização da maioria das atividades e tratos culturais } \\
\text { como colheita, plantio e adubação. Esses fatores subordinam a produção agrícola às } \\
\text { condições da natureza. }\end{array}$ \\
\hline $\begin{array}{l}\text { Condições } \\
\text { biológicas }\end{array}$ & $\begin{array}{l}\text { O ciclo de produção é irreversível. Uma vez iniciado, o mesmo completará seu ciclo, } \\
\text { pois se trata de seres vivos plantas ou animais. }\end{array}$ \\
\hline $\begin{array}{lr}\text { Terra } & \text { como } \\
\text { participante } & \text { da } \\
\text { produção } & \end{array}$ & $\begin{array}{l}\text { Condições químicas, biológicas e topográficas definem a qualidade da terra e } \\
\text { consequentemente, a qualidade do que é produzido. }\end{array}$ \\
\hline $\begin{array}{l}\text { Sazonalidade da } \\
\text { produção }\end{array}$ & $\begin{array}{l}\text { A demanda por produtos agropecuários tende a ser regular; entretanto, a oferta não é } \\
\text { estável o ano todo, pois está condicionada às condições climáticas, biológicas e da } \\
\text { própria sazonalidade da produção dos produtos agrícolas. }\end{array}$ \\
\hline $\begin{array}{l}\text { Estacionalidade da } \\
\text { produção }\end{array}$ & $\begin{array}{l}\text { A produção é específica de locais definidos para o cultivo, não havendo a } \\
\text { possibilidade de realocação durante a fase de produção. }\end{array}$ \\
\hline $\begin{array}{l}\text { Incidência } \\
\text { riscos }\end{array}$ & $\begin{array}{l}\text { A vulnerabilidade a que se submete a produção agropecuária, como proliferação de } \\
\text { pragas e doenças, atribui altos riscos e incertezas às atividades rurais. A oscilação de } \\
\text { preços decorrentes da sazonalidade da demanda também atribui riscos e incertezas a } \\
\text { uma atividade com mercado futuro. }\end{array}$ \\
\hline $\begin{array}{l}\text { Produtos } \\
\text { uniformes }\end{array}$ & $\begin{array}{l}\text { A impossibilidade de padronização dos produtos agrícolas pode remeter certa parcela } \\
\text { da produção a não aceitação em determinados critérios de classificação. }\end{array}$ \\
\hline $\begin{array}{l}\text { Barreiras à entrada } \\
\text { e à saída }\end{array}$ & $\begin{array}{l}\text { Os altos investimentos iniciais referentes a certas atividades, ou mesmo a } \\
\text { impossibilidade de realocação de determinados ativos (ativos específicos), podem } \\
\text { dificultar ou mesmo restringir a entrada, realocação ou saída em determinados } \\
\text { negócios agropecuários. }\end{array}$ \\
\hline Perecibilidade & $\begin{array}{l}\text { A perecibilidade exige grande eficiência logística para o acondicionamento da } \\
\text { produção agrícola e sua distribuição às indústrias de processamento, uma vez que a } \\
\text { impossibilidade de estocagem pode comprometer sua produção. }\end{array}$ \\
\hline
\end{tabular}

Fonte: Desenvolvido a partir de Lima, Esceveste e Ribeiro (2014) e Azevedo (2007).

A disponibilidade de matéria-prima é subordinada a períodos de safra e entressafra e tem forte impacto no planejamento e controle da produção agroindustrial. A falta de uniformidade e variação na qualidade das matérias-primas também acarreta em profundos impactos na qualidade final dos produtos transformados (BATALHA e SILVA, 2007; AZEVEDO, 2007).

Para os autores, a perecibilidade característica de muitos produtos agrícolas impossibilita sua estocagem. A logística se torna um instrumento de eficiência no processo produtivo, já que o planejamento do transporte e aprovisionamento desses produtos pode significar perdas financeiras e ou de qualidade significantes. As oscilações na demanda por determinados produtos industrializados durante o ano exigem maior planejamento e controle da produção (ZYLBERSZTAJN e GIORDANO, 2015). Certos produtos, procurados apenas em datas específicas, faz com que plantas industriais trabalhem com grande ociosidade, se não houver possibilidades de realocação ou uso na produção de outros produtos.

De acordo com Batalha e Silva (2007), a perecibilidade dos produtos finais exige da logística uma grande eficiência em sua distribuição até os pontos de venda, para que sejam consumidos dentro dos prazos específicos e dentro da qualidade estipulada. O baixo valor unitário de determinados produtos também dificulta a diluição dos custos associados à sua produção. A vigilância acentuada do governo sobre os produtos também atribui um maior grau de complexidade ao gerenciamento dos processos de produção agroindustriais.

O impacto da tecnologia nas fases de produção agropecuária e de produtos agroindustriais deverá cada vez mais, servir como instrumento de comunicação e coordenação entre os agentes de um dado sistema agroindustrial (BATALHA e SILVA, 2007). 
Nestes aspectos, a globalização apresentou fortes influências sobre a forma de organização dos agentes. O entendimento dessa nova estrutura pode ser alcançada por meio de dois enfoques de análise: - 0 primeiro: tendo em Goldberg o principal expoente e com base na escola americana, considerou a coordenação do sistema de commodities (de montante a jusante) a partir dos conceitos de Agribusiness e Commodity System Approach (CSA) (ZYLBERSZTAJN, 1995; SOUZA e AVELHAN, 2009; ZYLBERSZTAJN e GIORDANO, 2015); - O segundo: com base na escola francesa e com ênfase nas relações tecnológicas, conceituou esse sistema como Filière, ou Cadeia de Produção Agroindustrial, a partir de uma análise de jusante a montante (BATALHA e SILVA, 2007; SOUZA e AVELHAN, 2009; NEVES e CALEMAN, 2015).

Embora apresentem pontos de partida de análises diferentes, ambos os conceitos se complementam, com o objetivo de explicar as relações nos sistemas agroindustriais a partir da noção de sucessão de etapas produtivas, assumindo a visão dinâmica do sistema e distanciando-se da análise tradicional de divisão setorial em agricultura, indústria e serviços (BATALHA e SILVA, 2007).

Segundo Batalha e Silva (2007), a abordagem de SAG permite um enfoque mesoanalítico, o qual permite preencher a lacuna de compreensão entre a micro e macro economia. Entre as principais características analisadas pelas teorias econômicas, existe uma carência de análise que se refere às formas de organização derivadas do trabalho em equipe e associação entre agentes. O que sugere uma abordagem sistêmica para compreensão da produção agroindustrial.

Verifica-se, ao longo dos anos, uma interpretação distorcida do conceito de agronegócio, sendo este considerado como sinônimo de produção de larga escala com uso de capital intensivo (ZYLBERSZTAJN e GIORDANO, 2015). O agronegócio também se refere a outras formas de produção, os quais estão fora dos limites impetrados pelos latifundiários, inserindo-se também os pequenos produtores e aqueles caracterizados pela agricultura familiar (ZYLBERSZTAJN, 1995; BATALHA e SILVA, 2007).

Segundo Batalha (1995) e Batalha e Silva (2007), esse sistema complexo é composto pelos setores de agricultura, pesca, indústrias agroalimentares, distribuição, consumo final, comércio internacional e indústria e serviço de apoio.

Além da abordagem de encadeamento produtivo, o conceito de SAG considera os elementos do ambiente institucional onde as firmas estão inseridas (ZYLBERSZTAJN, 1995; CALEMAN, 2006). Para Neves e Caleman (2015), o SAG pode ser caracterizado como um complexo sistema entre agentes econômicos, no qual possui como tema central a coordenação. Esse novo ambiente interfere na competitividade das firmas e exige tomada de decisões com uma visão sistêmica, devido ao caráter somatório das relações entre agentes que estreitam transações com vistas a reduzirem seus custos.

Sobre o conceito de SAG, Souza e Avelhan (2009) e Batalha e Silva (2007) atribuíram a essa abordagem a noção de conjunto, visão de todo, já que nenhuma firma que está disputando determinados mercados desenvolve suas atividades de forma isolada. Existe uma relação entre os agentes da indústria de insumos, produção agropecuária, indústrias de alimentos e os sistemas de distribuição, caracterizando estruturas de governança em suas transações para que todos possam atingir seus objetivos. Nesse contexto, o SAG pode ser representado por firmas que realizam diferentes tipos de transações. As instituições que compõem o ambiente estabelecem relacionamentos entre si na busca de seus objetivos (MENDES, FIGUEIREDO e MICHELS, 2009).

Para Saab, Neves e Cláudio (2009), o agronegócio é composto por vários sistemas agroindustriais associados aos principais produtos. Já o SAG trata-se de um recorte de um determinado produto dentro do Agronegócio. Essas empresas colaboram entre si, buscando objetivos comuns a partir da articulação de ações conjuntas, de forma que todos agentes compreendam as exigências impetradas pelo mercado sobre seus produtos.

Entre essas exigências, destacam-se as influências e restrições impostas pelo ambiente institucional, que é caracterizado por regras formais como mudanças na legislação e avanços tecnológicos e regras informais como tradições e costumes. As mudanças impetradas pelo ambiente institucional irão influenciar no comportamento dos agentes, porém não há condições de se 
prever como esses irão se comportar frente a tais mudanças (AZEVEDO, 2000; MENDES, 2011).

Também exercem influências sobre os agentes de um determinado SAG os aspectos relacionados ao ambiente organizacional, como comportamento dos concorrentes e outras formas de organização públicas e privadas (ZYLBERSZTAJN, 2005). Esses fatores, internos e externos, conferem grande complexidade na forma organizacional dos sistemas agroindustriais e seu fluxo de atividades, conforme pode ser visualizado na Figura 1.

Figura 1: Representação do Sistema Agroindustrial (SAG)

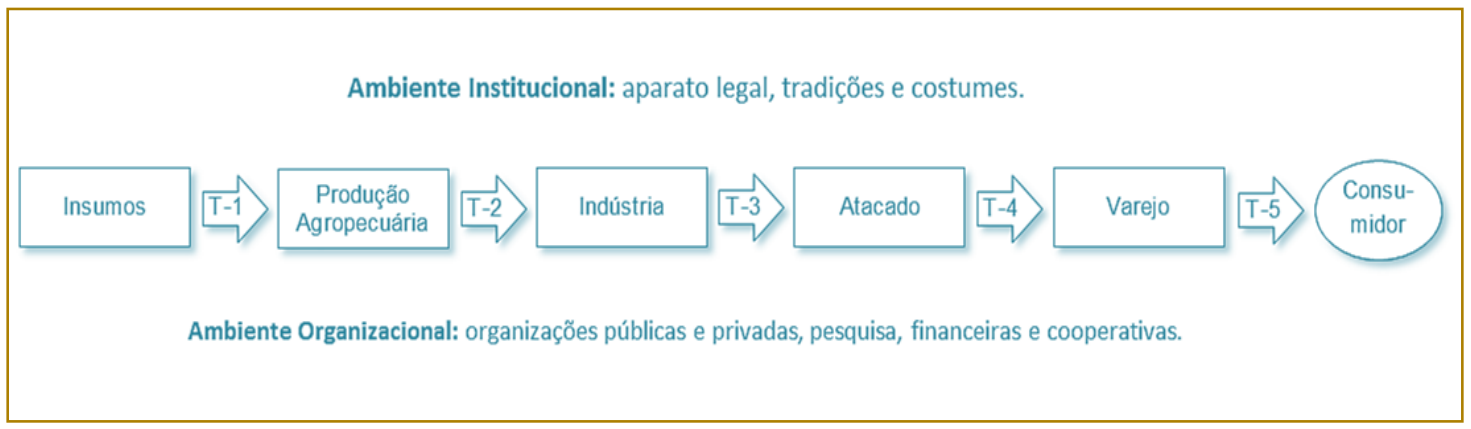

Fonte: baseado de Zylbersztajn (2005)

Verifica-se que os aspectos organizacionais e institucionais definem os limites das firmas envolvidas no sistema. A abordagem sistêmica considera o rompimento das fronteiras agrícolas sugerindo um sistema produtivo integrado entre diversos agentes ao longo da cadeia. A visão isolada não confere completude, não fazendo sentido derivar desse pensamento justificativas para estudos do agronegócio, o qual está inserido a meio a mudanças nos ambientes organizacional e institucional de forma contínua. Da mesma forma, a indústria de processamento deve lidar com a heterogeneidade e perecibilidade dos insumos de origem agropecuária em seu processo de transformação. Esses fatores aliados aos custos de produção e de transação definem a competitividade dos agentes.

Todas essas etapas da produção agropecuária visam suprir os desejos e necessidades dos consumidores que, procuram produtos ou serviços que melhor atendam suas expectativas derivadas de seus hábitos, poder aquisitivo e outros fatores que determinam suas escolhas.

Para Batalha (1995), uma economia forte e desenvolvida caracteriza-se pelo desenvolvimento harmonioso de todo um Sistema Agroindustrial. Esse fortalecimento está condicionado à eficiência das relações e transações entre os agentes que estão presentes tanto nas fases de produção, quanto de distribuição. Tais características determinam o grau de competitividade do setor devido à eficiência resultante da economia dos custos alcançados em suas transações.

Segundo Siffert Filho e Faveret Filho (1998), a competitividade das firmas se estabelece a partir de sua capacidade em conquistar e preservar parcelas de mercado. Para alcançar esse posicionamento, as firmas precisam maximizar as economias de escala e de escopo com vistas a minimizar os custos. Esses mecanismos de governança têm por finalidade lidar com a perecibilidade e a necessidade de um desenvolvimento harmonioso em todo sistema agroindustrial (BATALHA, 1995; SIFFERT FILHO e FAVERET FILHO, 1998).

Os produtos agroindustriais possuem, geralmente, natureza de commodity devido ao seu caráter primário ou semi processado, o que exige níveis eficientes de governança para se reduzir custos e maximizar resultados. Neste aspecto, as economias de escala se apresentam como uma relevante estratégia na busca de vantagem competitiva, para que a firma assuma posições no mercado e a mantenha níveis seguros de diferenciação (SIFFERT FILHO e FAVERET FILHO, 1998).

Os referidos autores também consideram o preço como fator de competitividade, uma vez que a fixação de preços de produtos primários ocorre basicamente de forma 
exógena em forma de preços de referência impetrados via mercado, exigindo das empresas alternativas de diferenciação de produtos com vistas a agregar maior valor e influenciar os preços.

Para Batalha (1995), administrar todas essas transações econômicas não é uma tarefa simples. A complexidade resultante dos sistemas agroindustriais se deve ao processo de integração das indústrias de insumos, distribuição e armazenamento bem como, mudança nos hábitos dos consumidores.

Nesses aspectos, na visão de Hoff et al. (2007), para se compreender a dinâmica presente nos sistemas agroindustriais é imprescindível reunir diversas áreas do conhecimento. Destacam-se disciplinas como biotecnologia, química, engenharia, veterinária, agronomia, economia, saúde, sociologia, gestão, logística e até mesmo a psicologia, com vistas a compreender as preferências dos consumidores e alinhar as estratégias empresariais às reais necessidades do mercado.

Dessa forma, visando a maior compreensão dos fenômenos econômicos a partir da nova realidade dos negócios agrícolas, tornou-se necessário a formação de quadros de profissionais capacitados para atuar em abordagens interdisciplinares (HOFF et al., 2007). A observação se torna mais completa quando um objeto de estudos é analisado por mais de um anglo de visão. Faz-se necessário reunir diversos saberes para que se possa entender novos fenômenos e novos comportamentos derivados da complexidade do agronegócio.

Os estudos de Zylbersztajn (1995) e de Zylbersztajn e Farina (1999) também consideram que o entendimento da dimensão e abrangência do SAG é imprescindível para o conhecimento do "mundo real" da agricultura e suas relações com a sociedade. Para os autores, conhecer as diferentes formas de organizações agrícolas e como se relacionam pode contribuir para a elaboração de estratégias que visem a maximização de valor ao longo da cadeia e da minimização dos custos envolvidos em suas transações. A coordenação entre agentes econômicos além da fronteira de preços permite abordar a complexidade dos sistemas agroindustriais de forma mais ampla, considerando elementos como integração vertical, alianças estratégicas e estudo dos contratos. A abordagem institucional permite uma compreensão mais detalhada das relações entre agentes envolvidos em um determinado SAG (ZYLBERSZTAJN e GIORDANO, 2015).

Para os autores outro aspecto analisado por Goldberg, dentro da visão de Agribusiness System Approach, é a parcela apropriada pelo setor agrícola em suas relações contratuais. Existe um jogo de forças desiguais no setor agrícola, onde a parcela proporcional ao setor "dentro da porteira" é inferior aos ganhos de outros agentes envolvidos nas transações devido a sua capacidade de poder de mercado. A celebração de contratos pode contribuir na garantia da apropriação das parcelas pertencentes a quem é de direito na disputa por mercados a partir de transações entre agentes.

Os novos estudos institucionais impulsionados por Ronald Coase, em 1937, complementaram a visão de firma analisada pela corrente neoclássica. A concepção de mercado era focada no mecanismo de preços como elementos suficientes para explicar os problemas de alocação dos recursos. Já essa nova visão produziu estudos necessários sobre a concepção de teorias de firma que deram ênfase em suas atividades internas e suas relações contratuais (ZYLBERSZTAJN e GIORDANO, 2015).

Farina (1999) reforça a presente concepção de SAG, afirmando que o desempenho não é entendido como resultado do esforço de uma firma individual e sim da eficiência dos agentes evolvidos dentro do sistema e o grau de dependência entre eles. Para a autora, é nesse ponto que se justifica a aplicação de teorias, como a Nova Economia Institucional (NEI) e seus desdobramentos a partir dos trabalhos de Ronald Coase (1937), para se entender integração da firma com a indústria (competitividade horizontal) e da indústria com a cadeia produtiva (competitividade vertical) (FARINA, 1999).

Enaltecendo a importância conferida aos contratos, Caleman (2015) relaciona a eficiência de um Sistema Agroindustrial à sua capacidade de criar, sustentar e distribuir valor a partir de mecanismos de coordenação. E que a inovação é o ponto central para a criação e apropriação deste valor dentro do SAG. Essa necessidade de gerenciamento de valor confere aos contratos um papel relevante enquanto instrumento de incentivo à alocação eficiente de recursos no agronegócio. 
Complementando essas proposições, Caleman e Zylbersztajn (2012) buscam referências nos estudos de Yoram Barzel, de 1997, afirmando que o processo de tomada de decisão se torna mais seguro e efetivo numa economia a partir da criação de um ambiente seguro, protegido por instrumentos legais que visam reduzir as incertezas. O ambiente competitivo criado por nexos de contratos confere às firmas maiores possibilidades de competitividade e permanência no mercado.

Já Mendes (2011) afirma que na tentativa de minimizar a dissipação de valor derivada das falhas contratuais, os agentes recorrem às garantias para a minimização das externalidades geradas pelo processo de troca. Complementa ainda que a necessidade de formas garantidoras advém da existência de variabilidade e incertezas ou ainda, da dificuldade de mensurar os atributos a baixo custo. O Estado tem a função de garantir o direito à propriedade privada em forma de direito legal, a partir de seu poder coercitivo. Este garante que os contratos sejam cumpridos, definindo sanções sobre o seu não cumprimento. Assim, confere-se ao Estado a permanente justificativa de intervenção na economia, regulamentando o ambiente institucional (MENDES, 2011).

Essas são as principais considerações acerca da concepção de Sistemas Agroindustriais, os quais foram elaboradas a partir de estudos seminais. Buscou-se compreender o comportamento das firmas diante das mudanças em curso no agronegócio, enaltecendo a importância das relações entre agentes econômicos para o alcance do objetivo de cada um. O ponto de convergência entre o conceito de SAG e a Nova Economia Institucional, a qual será discorrida a seguir, se dá pelo papel do ambiente institucional sobre a conduta das organizações e a importância das transações para a eficiência dos SAGs.

\section{CARACTERIZAÇÃO DO SAG DO URUCUM NA MICRORREGIẨO DE DRACENA}

O Sistema Agroindustrial do Urucum na Microrregião de Dracena, especificamente nos municípios de Monte Castelo e São João do Pau D'Alho, pode ser representado por um fluxo de produtos, serviços e informações. Desde o fornecimento de insumos agrícolas até o destino final do urucum, são verificados relacionamentos de interdependência entre diferentes agentes, as quais podem ser representadas por um fluxograma (Figura 2).

O SAG do Urucum pode ser compreendido a partir de um encadeamento de relações existentes entres os agentes que o compõem. Encontram-se presentes nesse SAG os fornecedores de insumos agrícolas, os produtores de urucum, sendo esses agricultores independentes ou associados, os intermediários (aqui representado pela empresa Urucum do Brasil) e as indústrias de processamento, que comercializam seus produtos em mercados nacionais e internacionais.

Figura 2: Representação do SAG do urucum no estado de São Paulo

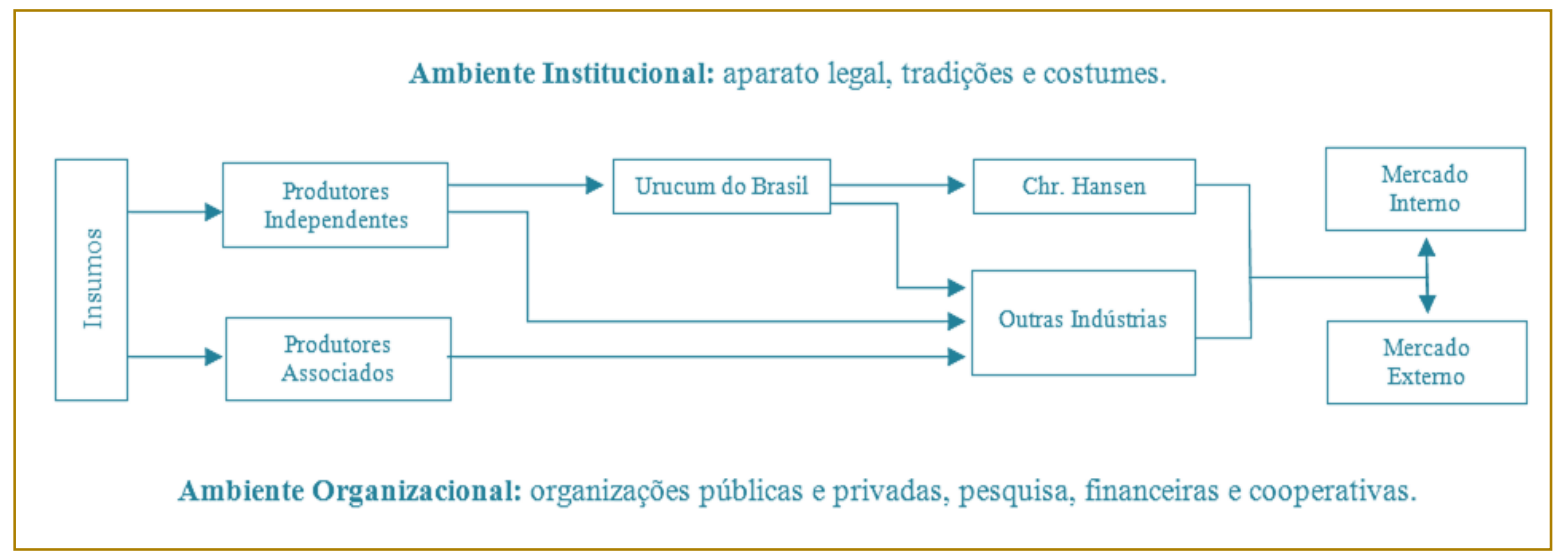

Fonte: os autores. 


\section{- Insumos}

O setor de insumos agrícolas do SAG do Urucum envolve aqueles insumos de produção necessários à obtenção da produção vegetal, tais como as mudas de plantas, as máquinas e os implementos agrícolas, bem como os produtos que garantam a nutrição e proteção das plantas. De acordo com as entrevistas realizadas, constata-se que, atualmente, não existem defensivos certificados e técnicas de combate às pragas consideradas sistematizadas e de uso aprovado pelo Ministério da Agricultura para a cultura do urucum.

Os entrevistados relatam a existência de esforços conjuntos do governo federal, estadual e municipal, aliados a iniciativa privada, em pesquisas e desenvolvimento de técnicas de manejo e colheita, bem como em investimentos no desenvolvimento de máquinas e implementos, em busca de maior eficiência produtiva.

Verifica-se na região em estudo a existência de três produtores de mudas de urucum, sendo um localizado no município de Tupi Paulista e os outros dois no município de Monte Castelo. Esses são os responsáveis pelo atendimento da demanda de mudas de plantios e replantios

O maior produtor de mudas de urucum da região, participante da pesquisa de campo, está localizado no município de Monte Castelo. Ele atua nessa atividade de geração de mudas há cerca de 10 anos, em uma propriedade de um alqueire, juntamente com mais três familiares. De acordo com o entrevistado, é o responsável direto pela padronização de mudas, estabelecida por critérios próprios, a partir de informações dos produtores, bem como das Casas da Agricultura de Monte Castelo e de São João do Pau D'Alho.

Esse produtor foi o pioneiro na atividade de produção de mudas e, atualmente, produz cerca de 300.000 mudas por ano. Devido a grande demanda, outros produtores se inseriram nessa atividade e, trabalhando em equipe, somam suas produções para atender à demanda dos estados de São Paulo, Mato Grosso e Minas Gerais.

Para a produção da muda de urucum são semeadas aproximadamente seis sementes por "tubete". A mão de obra aplicada na atividade deve possuir características específicas como delicadeza e detalhamento. Nessa etapa inicial é constante o uso da irrigação e o controle de pragas, que é muito frequente na fase de crescimento. As mudas denominadas "Anão" são pertencentes à variedade "Piave" e vendidas à $R \$ 0,20$ a unidade (dados obtidos em 2016).

Após o nascimento da planta, essa é submetida a uma técnica de "raleamento" (um profissional treinado pode ralear até 1.000 mudas/hora), com o objetivo de selecionar a planta com melhor desenvolvimento. Não existe formação de estoque, a demanda é orientada por encomenda, com um prazo de até 90 dias para entrega após o pedido.

Em suas atividades cotidianas, esse produtor de mudas recebe frequentemente assistência técnica da Casa da Agricultura, o que possibilita aprimorar suas ideias e suas técnicas de manejo e desenvolvimento de mudas. Frequentemente também recebe visita de compradores interessados em firmar acordos e separar lotes de mudas. Uma vez que não há contratos formais, a frequência das visitas e negociações, aliada a características das mudas (especificidade dos ativos), estreitam as relações comerciais entre os agentes.

Seguindo a constante busca por alternativas de tecnificação em todas as fases da cultura, foi desenvolvida por esse produtor uma máquina manual para plantio direto da muda. A muda é inserida na parte superior do equipamento e desliza até o fechamento na parte inferior. A mesma é inserida no solo quando acionado $\mathrm{o}$ gatilho de abertura. Segundo o entrevistado, o equipamento ainda está sendo testado por produtores e o feedback de seu desempenho é fundamental para melhorias do projeto, pois não visa interesses comerciais, mas sim, facilitar o plantio para que os produtores tenham maior desempenho e rapidez nessa fase da cadeia.

De acordo com as entrevistas realizadas, verifica-se que máquinas, implementos e técnicas de cultivo vêm sendo desenvolvidas por produtores da região que procuram melhores formas de cultivo e colheita. O espaçamento básico para o plantio dos arbustos é de $5 \times 2 m$ (vãos de 5 metros entre linhas 2 metros na linha) para a colheita manual. Em seguida é realizada a quebra das cachopas e as sementes são levadas por balaios até as cabeceiras das lavouras para o beneficiamento em máquina adaptada. Inicialmente essa máquina era utilizada para 
beneficiamento de feijão e de milho, sendo alimentada manualmente.

Recentemente, uma indústria do interior de São Paul fez adaptações na colhedeira de feijão para uso na colheita do urucum. Para sua utilização, entretanto, foi necessário o plantio com espaçamento específico $(7 \mathrm{~m} \times$ $3 \mathrm{~m})$, mais largo, para permitir a entrada e manobra do equipamento, que é tracionado por trator. Para essa tarefa as cachopas são enfileiradas no meio dos vãos da cultura.

Pode-se afirmar que há muito espaço para o aperfeiçoamento dos insumos de produção da cultura do urucum. Tais melhorias tendem a contribuir com o desempenho técnico dessa cultura, trazendo benefícios para produtores e compradores desse produto.

\section{- Produção do Urucum}

No que se refere à produção de urucum, a Microrregião de Dracena tem representado, em média, nos últimos anos, $80 \%$ da produção estadual, o que corresponde a cerca de $20 \%$ da produção nacional (Figura 3). Constata-se, dessa forma, que é a maior região produtora de urucum do estado de São Paulo e do Brasil, tanto em termos de área plantada quanto de quantidade produzida (IBGE, 2016; ATLAS BRASIL, 2016).

Essa região apresentava, em 2008, um total de 5.058 estabelecimentos voltados para a agropecuária; sendo, a maioria (84\%), estabelecimentos característicos da pequena produção e com menos de 50 ha (Tabela 1). Os municípios integrantes dessa microrregião apresentavam, em 2008, 280 estabelecimentos com produção de urucum, somando cerca de 1.700 hectares com essa cultura, ocupadas por pouco mais 900 mil plantas. Esse cenário representava $65,7 \%$ dos estabelecimentos, e $71,92 \%$ da área, com urucum no estado de São Paulo. Nesse contexto, percebe-se a grande concentração da produção no oeste do estado e, em especial, nos municípios de Monte Castelo e São João do Pau D’Alho (LUPA - CATI, 2008).

Figura 3: Área colhida (hectares) de urucum no estado de São Paulo e na Microrregião de Dracena, entre 1990 e 2014

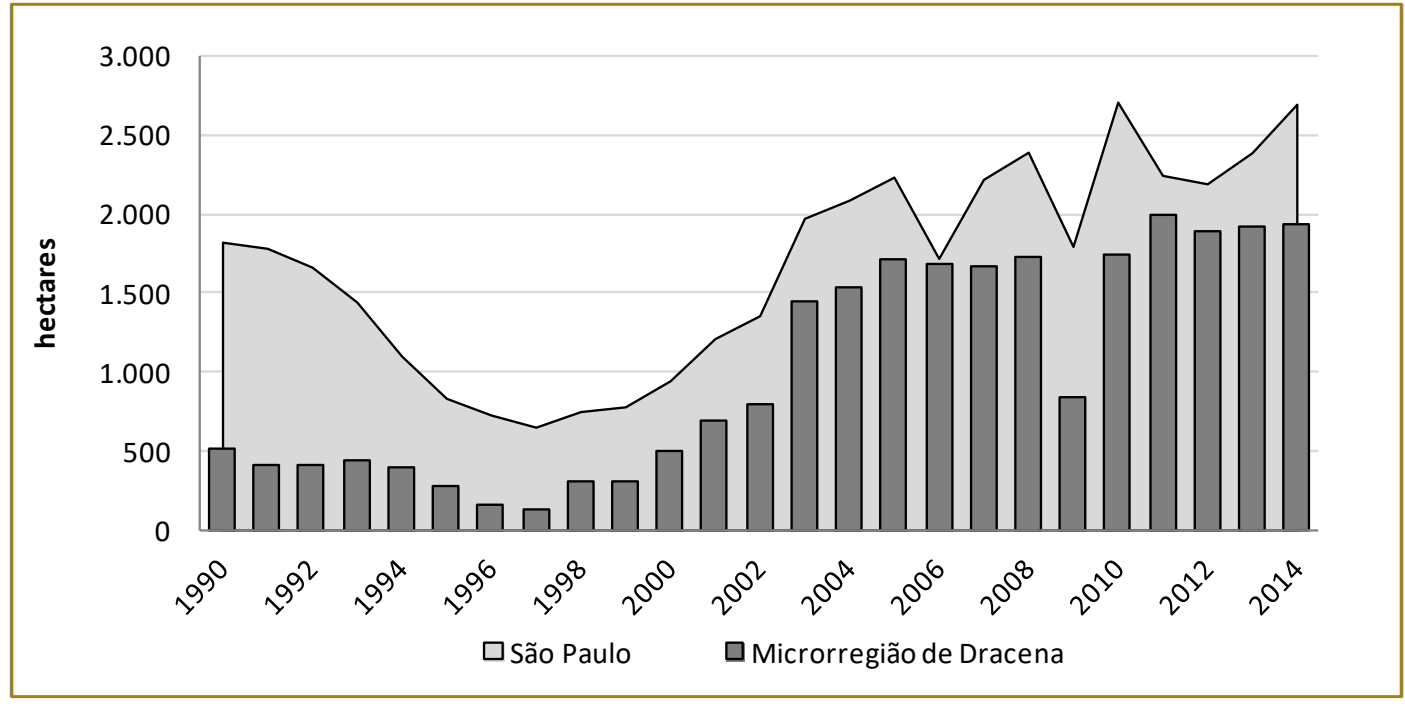

Fonte: IBGE (2016).

Dentro do Sistema Agroindustrial, os produtores de urucum são os agentes responsáveis pela produção da matériaprima. Na região estudada, verificaram-se duas formas de organização desses produtores. Verificou-se que os mesmos atuam de forma independente ou associada. 
Tabela 1: Características das Unidades Produtivas da Microrregião de Dracena, em 2008

\begin{tabular}{|c|c|c|c|c|c|c|c|c|}
\hline \multirow{2}{*}{ Município } & \multicolumn{3}{|c|}{ UPAs Total } & \multicolumn{2}{|c|}{ UPAs com Urucum } & \multicolumn{2}{|c|}{ Área com Urucum } & \multirow{2}{*}{$\begin{array}{l}\text { Número } \\
\text { Plantas }\end{array}$} \\
\hline & Núm. & $\begin{array}{l}\text { Até } 50 \\
\text { ha }\end{array}$ & $\%$ & Núm. & $\%{ }^{*}$ & ha & $\%{ }^{\star \star}$ & \\
\hline Monte Castelo & 466 & 393 & $84 \%$ & 99 & $23,2 \%$ & 786,3 & 33,17 & 439.200 \\
\hline $\begin{array}{l}\text { São João do Pau } \\
\text { d'Alho }\end{array}$ & 268 & 245 & $91 \%$ & 67 & $15,7 \%$ & 384,3 & 16,21 & 176.728 \\
\hline Tupi Paulista & 925 & 841 & $91 \%$ & 43 & $10,1 \%$ & 230,1 & 9,71 & 124.471 \\
\hline Junqueirópolis & 1.198 & 1.019 & $85 \%$ & 34 & $8,1 \%$ & 149,3 & 6,30 & 85.316 \\
\hline Ouro Verde & 346 & 267 & $77 \%$ & 5 & $1,2 \%$ & 61,2 & 2,58 & 23.900 \\
\hline $\begin{array}{l}\text { Nova } \\
\text { Guataporanga }\end{array}$ & 165 & 152 & $92 \%$ & 11 & $2,6 \%$ & 49,2 & 2,08 & 36.800 \\
\hline Paulicéia & 235 & 181 & $77 \%$ & 16 & $3,7 \%$ & 32,1 & 1,35 & 11.054 \\
\hline Dracena & 1.024 & 872 & $85 \%$ & 3 & $0,7 \%$ & 6,6 & 0,28 & 4.800 \\
\hline Santa Mercedes & 204 & 143 & $70 \%$ & 1 & $0,2 \%$ & 5,0 & 0,21 & 2.000 \\
\hline Panorama & 227 & 158 & $70 \%$ & 1 & $0,2 \%$ & 0,7 & 0,03 & 350 \\
\hline Total & 5.058 & 4.271 & $84 \%$ & 280 & $65,7 \%$ & $1.704,8$ & 71,92 & 904.619 \\
\hline
\end{tabular}

A produção independente é característica dos produtores do município de Monte Castelo; já em São João do Pau D’Alho, a predominância é de produtores associados. Enquanto os produtores associados se beneficiam do compartilhamento de informações, locação de máquinas e implementos agrícolas, os produtores independentes obtêm serviços semelhantes por meio da relação com uma empresa intermediária - a Urucum do Brasil.

Por meio das entrevistas realizadas, verificouse que tanto os produtores independentes de Monte Castelo, quanto os produtores associados de São João do Pau D'Alho, recebem assistência técnicas das Casas da Agricultura dos respectivos municípios. Destaca-se que, embora associados, os produtores de São João do Pau D'Alho comercializam suas safras de urucum de forma individual.

Com relação ao manejo, cultivo e colheita do urucum, foram identificados junto aos produtores entrevistados diversos gargalos que ainda limitam e dificultam a sua cultura. Um aspecto é a poda do arbusto do urucum, a qual é realizada de forma manual ou com uma roçadeira adaptada pelos próprios produtores. Ainda existem outros implementos destinados a esse manejo, porém devido aos custos de aquisição e ou alocação, buscamse formas alternativas de poda, tanto na parte superior quanto lateral.
O plantio de urucum com maior espaçamento $(3 \times 7 \mathrm{~m})$ possibilita a introdução e manobra da colhedeira móvel dentro dos vãos da cultura. Mesmo com a densidade alcançada pelos arbustos em fase adulta, com a técnica de poda superior e lateral, consegue-se manter os pés de urucum em um delineamento que permita a colheita mecanizada, bem como, alta produtividade por planta.

Considerando a nova realidade referente à colheita mecanizada móvel, especificamente no município de São João do Pau D'Alho, as culturas mais antigas - com mais de 5 anos são arrancadas para que sejam plantadas com o novo espaçamento. A renovação das lavouras também se dá pelo fato de que os arbustos apresentam uma queda significativa de produtividade ao longo do tempo e, a partir do quinto ano, percebe-se uma redução significativa de produção por arbusto.

\section{- Intermediário (Urucum do Brasil)}

Identificou-se no SAG do Urucum na Microrregião de Dracena a presença de uma organização que exerce 0 papel de intermediário, atuando entre os produtores de urucum e as indústrias processadoras.

Presente no município de Monte Castelo, a Urucum do Brasil, empresa de iniciativa privada, é responsável pela aquisição de grande parte do urucum daquele município. 
Ela é responsável pelo beneficiamento mais refinado das sementes de urucum e comercializa, predominantemente, para uma indústria específica de aditivos alimentares a denominada Chr. Hansen. A comercialização da empresa intermediária com essa indústria em específico se dá por meio de acordos prévios. Caso haja excedentes de mercadoria, além das metas pré-estabelecidas, a Urucum do Brasil comercializa para outras empresas processadoras.

O proprietário da Urucum do Brasil foi um dos entrevistados da pesquisa. Além de atuar como produtor, este tem 20 anos de atuação no comércio de urucum no município de Monte Castelo e, desde 2005, tem essa empresa (Comércio de Urucum Brasil Ltda.) formalizada.

De acordo com o entrevistado, houve na década de 1990, por iniciativa dele, a abertura de uma associação para agregar os produtores de urucum de Monte Castelo. Entretanto, essa organização não se mostrou efetiva, não havendo interesse dos produtores pela sua continuidade.

Mesmo assim, observando a necessidade de informações constantes sobre os tratos culturais do urucum, começou a desenvolver atividades semelhantes à de uma associação. Atualmente, a Urucum do Brasil oferece serviços de apoio ao produtor, assistência técnica em todas as fases da cultura. Realiza ainda a locação de máquinas e implementos próprios para os produtores e os incentiva a produzirem suas próprias mudas.

\section{- Processamento e distribuição do Urucum}

Os produtores rurais de urucum da Microrregião de Dracena comercializam suas produções para intermediários ou diretamente para as indústrias. Tais empresas atuam como processadoras e fornecedoras de produtos destinados aos setores alimentício, farmacêutico, cosmético e de nutrição animal. São organizações de grande porte e atuam em mercados nacionais e internacionais.
Tais empresas, por terem dificuldade de acesso direto aos pequenos produtores de urucum, recorrem a estratégias de intermediação por meio de representantes. Esses agentes têm o objetivo de realizar a compra de urucum em grandes quantidades, o que justifica sua presença constante nas propriedades. Para obter os volumes necessários de urucum beneficiado, essas empresas estão dispostas a pagar aos produtores preços, muitas vezes, acima dos preços de mercado.

O Quadro 2 lista as principais empresas compradoras apontadas pelos entrevistados, as quais possuem representantes competindo localmente pela compra da produção do urucum. Estes realizam visitas regulares nas lavouras mesmo antes da colheita, com o objetivo de firmar acordos e estreitar o relacionamento com os produtores.

Outros aspectos positivos apontados pelos produtores entrevistados são as valiosas informações que esses representantes fornecem sobre o mercado do urucum e as alternativas de preços que ofertam. Segundo os produtores, essa competição entre empresas compradoras ampliam as possibilidades de melhores acordos na negociação da produção de urucum, a partir de melhores preços por cada quilo produzido.

Compondo o rol de empresas compradoras presentes no SAG estudado, destaca-se a Chr. Hansen. Trata-se de uma empresa sediada na Dinamarca com atuação mundial e atua na região, por meio de uma empresa intermediária - a Urucum do Brasil. As transações entre essas duas empresas são disciplinadas por meio de contrato de fornecimento. A Chr. Hansen fornece ao mercado soluções para a indústria alimentícia produzindo corantes naturais, principalmente a base de urucum, probióticos, enzimas especiais para conservação de alimentos e tecnologias para engorda e sanidade de animais. Ainda fornece insumos para as indústrias farmacêutica e agrícola. 
Quadro 2: Principais empresas compradoras de urucum

\begin{tabular}{|c|c|c|c|}
\hline Empresa & Matriz & Atividade & Site \\
\hline Chr. Hansen & Dinamarca & $\begin{array}{l}\text { Soluções naturais para as indústrias } \\
\text { alimentar, nutricional, farmacêutica e } \\
\text { agrícola }\end{array}$ & http://www.chr-hansen.com \\
\hline Sensient & $\begin{array}{l}\text { Estados } \\
\text { Unidos da } \\
\text { América }\end{array}$ & $\begin{array}{l}\text { Corantes para alimentos, tecnologias } \\
\text { para cosméticos, indústria } \\
\text { farmacêutica, impressão, aromas e } \\
\text { fragrâncias, }\end{array}$ & http://www.sensient.com.br \\
\hline $\begin{array}{c}\text { GMS } \\
\text { alimentos }\end{array}$ & Baruerí/SP & $\begin{array}{l}\text { Condimentos, especiarias e produtos } \\
\text { naturais para alimentos }\end{array}$ & http://gmsalimentos.com.br \\
\hline $\begin{array}{c}\text { Kraki } \\
\text { Kienast e } \\
\text { Kratschmer }\end{array}$ & São Paulo/SP & $\begin{array}{l}\text { Aditivos e soluções personalizadas } \\
\text { para os mercados cárneo e lácteo. }\end{array}$ & http://www.kraki.com.br \\
\hline Sun foods & Itu/SP & $\begin{array}{l}\text { Processamentos de vegetais em } \\
\text { conserva, aromas doces e salgados, } \\
\text { corantes naturais e artificiais, } \\
\text { condimentos, molhos, polpa de frutas } \\
\text { em pó, picles, extratos vegetais entre } \\
\text { outros }\end{array}$ & http://www.sunfoods.com.br \\
\hline $\begin{array}{c}\text { Cori } \\
\text { ingredientes }\end{array}$ & Rio Claro/SP & $\begin{array}{l}\text { Ingredientes e produtos químicos para } \\
\text { a indústria de alimentos }\end{array}$ & http://www.coriingredientes.com.br \\
\hline Ibrac & Rio Claro/SP & Aditivos e condimentos para alimentos & http://www.ibrac.com.br \\
\hline Kratos & Rio Claro/SP & Corantes naturais para alimentos & $\begin{array}{l}\text { http://www.kratoscorantesnaturais.co } \\
\text { m.br }\end{array}$ \\
\hline Tecnocor & Matão/SP & $\begin{array}{l}\text { Condimentos e corantes naturais para } \\
\text { alimentos }\end{array}$ & http://www.tecnocor.ind.br \\
\hline Nex max & Americana/SP & $\begin{array}{l}\text { Aditivos, ingredientes e corantes } \\
\text { naturais para alimentos }\end{array}$ & http://www.newmaxindustrial.com.br \\
\hline Baculerê & Olímpia/SP & $\begin{array}{l}\text { Corantes naturais para indústrias } \\
\text { diversas }\end{array}$ & http://www.baculere.com.br \\
\hline
\end{tabular}

Fonte: baseado nas entrevistas da pesquisa de campo.

A empresa americana Sensient é fornecedora de tecnologias e soluções para os mais diversos ramos das atividades industriais. Está presente na região por meio de seus representantes, que realizam visitas frequentes aos produtores em todos os períodos da produção de urucum. A Sensient atua no ramo de bebidas e alimentos, produzindo corantes principalmente a base de urucum, aromatizantes, e toda linha para desidratados para fermentação. A empresa ainda fornece insumos para o setor farmacêutico, de cosméticos e tinta para impressão.

Além das duas multinacionais, existem outras indústrias processadoras de urucum nacionais que também atuam na região, utilizando-se de representantes que negociam diretamente com os produtores no mercado aberto. São empresas como GMS Alimentos, Kraki, Sun Foods, Ibrac, Kratos, Tecnocor, New Max e Baculerê.

\section{- Ambiente Organizacional: Instituição de apoio ao SAG do Urucum}

Além dos agentes que compõem o SAG do Urucum, é necessário caracterizar o seu ambiente organizacional. Compõem esse ambiente as organizações que apoiam e dão suporte ao funcionamento desse sistema. No caso específico desse estudo, destacam-se as Casas de Agricultura dos municípios de Monte Castelo e São João do Pau D'Alho, bem como a Associação de Produtores de Monte Castelo.

\section{CATI - Casa da agricultura de Monte Castelo}

Um dos agentes entrevistados nessa pesquisa foi o engenheiro agrônomo da Casa da Agricultura de Monte Castelo, o qual prestou valiosa contribuição para a realização dessa pesquisa. A atuação da Casa da Agricultura se dá por meio de convênio entre a Prefeitura Municipal e o governo do estado de São Paulo. As principais atividades desenvolvidas são referentes à agricultura e 
ao meio ambiente, por meio de serviços de assistência técnica, extensão rural e acompanhamento de todas as cadeias produtivas do município.

O entrevistado afirmou que um dos maiores desafios da agricultura do município é a estruturação organizacional dos produtores, como a formação de cooperativas e associações. Ele destaca a exigência do Estado por organismos formais de trabalho mútuo, para que haja a obtenção de incentivos e acesso à políticas públicas de fomento ao desenvolvimento do setor e ainda, para a obtenção de subsídios para aquisição de máquinas e implementos coletivos, adquiridos a partir de compras coletivas. Implementos esses que são de alto custo de aquisição e de manutenção, inviabilizando a aquisição individual ou mobilização de poucos indivíduos. Assim, a organização cooperativista e ou associativista pode garantir os requisitos para produtores usufruírem das políticas e programas públicos voltados à agricultura e à pecuária.

$\mathrm{Na}$ visão do responsável pela Casa da Agricultura, os produtores do município de Monte Castelo enfrentam dificuldades associadas à falta de pesquisa, a qual impulsionaria uma base de desenvolvimento mais sólido, e mais distante da "tentativa e erro" presente no cotidiano da cadeia do urucum. O entrevistado também afirma que a falta de certificações no setor contribui para a informalidade e adaptações no manejo. Neste aspecto destaca 0 importante trabalho desenvolvido pela pesquisadora Eliane Gomes Fabri, por suas relevantes pesquisas no setor, impulsionando e incentivando a cultura do urucum com publicações de informações técnicas em todas as fases da cultura, desde preparo e manejo de solos, plantio, adubação, colheita e pesquisa das oportunidades de mercado.

\section{CATI - Casa da agricultura de São João do Pau D'Alho}

No município de São João do Pau D'Alho também foi entrevistado o Engenheiro agrônomo responsável pela Casa da Agricultura do município. Análogo ao município de Monte Castelo, a Casa da Agricultura surgiu a partir de convênio entre Prefeitura Municipal e o governo do estado de São Paulo e, nos últimos anos, possui como principais ações o incentivo à mecanização e à redução de custos de produção.
O município de São João do Pau D'alho, em contraste com o município de Monte Castelo, conta com uma associação de produtores - a APRIMOR, a qual se revela atuante e com grande importância para a permanência e incentivo à cultura do urucum. Nesse contexto, entretanto, o entrevistado reforça que, apesar de todos os benefícios do sistema associativista, os produtores associados ainda demonstram resistência com relação à comercialização da produção em conjunto.

A adoção da estratégia de venda coletiva proporcionaria aos produtores usufruírem da escala de produção e barganha para se alcançar melhores preços e condições de pagamento. Outro aspecto abordado pelo entrevistado é a demanda pela construção de um barracão (galpão) para armazenagem do urucum em "bags", bem como a aquisição de caminhões para o transporte das propriedades até aos armazéns. Para o entrevistado outro benefício visualizado seria a aquisição de insumos agrícolas de forma coletiva, o que reduziria significativamente dos custos de aquisição.

Portanto, a Casa da Agricultura de São João do Pau D'alho tem como metas, em conjunto com a associação: a) realizar a compra de insumos e a venda da produção de urucum de forma coletiva; b) promover a modernização da cultura com vistas a alcançar o reconhecimento de pólo nacional produtor de urucum.

\section{APRIMOR - Associação dos Produtores Rurais, Industriais e Moradores de São João do Pau D'Alho}

O município de São João do Pau D'Alho possui uma Associação de produtores rurais. O presidente da APRIMOR também foi entrevistado nessa pesquisa. O responsável pela associação proporcionou informações valiosas para a compreensão do relacionamento entre os produtores rurais deste município.

A Associação foi criada em 1989, mesma época de declínio da cultura do café. Os produtores do município decidiram se mobilizar na busca de alternativas econômicas para a atividade agropecuária. Esse momento de fragilidade econômica foi um marco decisivo para que produtores optassem por unir forças em prol da continuidade de seus negócios. 
A APRIMOR possui, atualmente, cerca de 90 associados, os quais contribuem com a manutenção da instituição e pela locação das máquinas e implementos utilizados nas atividades agrícolas, pagando uma anuidade de $R \$ 90,00$.

A parceria com a Casa da Agricultura do município é fator chave para o sucesso e continuidade da associação e, possivelmente, pela adesão de novos produtores. Algumas conquistas só foram conseguidas devido à existência de uma associação formalizada. Exemplo disso é que, por meio da associação, em parceria com o programa de Microbacias II do estado de São Paulo, foram adquiridos um trator, um automóvel pick-up e duas colhedeiras para a cultura do urucum.

Além dessas conquistas, a associação ainda possui em seu imobilizado uma máquina de beneficiamento de café, uma completa fábrica de ração, seis tratores, linha completa de implementos agrícolas para a maioria das atividades agrícolas como preparo da terra, plantio, adubação e colheita.

Todos esses os equipamentos foram viabilizados a partir dos convênios firmados com o governo estadual, por meio de programas de incentivo a continuidade das pequenas propriedades rurais. Trata-se de máquinas de grande valor, as quais nem os produtores individuais, nem mesmo a APRIMOR, teriam condições financeiras para adquiri-las. A manutenção é realizada por recursos próprios da associação através da receita proveniente das anuidades e locação dos implementos aos membros associados.

A associação não desenvolve atividades comerciais de compra e venda de produtos agrícolas, apenas organiza as formas de trabalho. Os produtores são independentes com relação às formas de negociação de sua produção agrícola. Com relação à comercialização, para o entrevistado, os produtores de urucum poderiam obter melhores preços devido às condições de barganha com grandes volumes produzidos.

Todos os membros possuem o mesmo poder de decisão. Constantemente, os associados são informados sobre as reuniões ordinárias realizadas na sede da associação e outros encontros previstos em calendário para que participem, votem e contribuam com suas experiências e sugestões. Na ocorrência de imprevistos são organizadas reuniões e encontros extraordinários, com o objetivo de solucionar situações emergenciais.

\section{CONSIDERAÇÕES FINAIS}

Este trabalho teve como proposta compreender a estrutura e o funcionamento do Sistema Agroindustrial do urucum na Microrregião de Dracena. A escolha por esse SAG, especificamente nessa região, se deu respectivamente, pela falta de trabalhos científicos acerca desse produto, nessa abordagem, e pela sua representatividade geográfica nacional e estadual. Também contribuiu para o interesse no desenvolvimento da pesquisa a importância mercadológica e socioeconômica desse objeto de estudo.

O urucum é considerado um dos mais importantes corantes naturais, atuando não só como coloríficos, mas agregando propriedades nutricionais aos produtos que 0 utilizam. Em função de suas características físico-químicas, destacam-se ainda suas diferentes aplicações nas indústrias farmacêutica, de cosmético, têxtil, entre outras.

A constatação de concentração produtiva de urucum em uma pequena região do estado de São Paulo suscitou sobre a importância dessa atividade. Em um contexto socioeconômico, identificou-se que o cultivo do urucum é uma alternativa de produção agrícola para a Microrregião de Dracena. Trata-se de uma atividade característica da pequena produção e adotada, em sua maioria, por produtores caracterizados pela agricultura familiar.

A caracterização do SAG do urucum revelou a interdependência entre os agentes, desde o fornecimento de insumos agrícolas até o destino final do urucum. Ainda não explorado na literatura científica, esse trabalho contribuiu com informações sobre o mercado e a organização da produção agrícola do urucum, especialmente na região delimitada.

Grandes desafios associados ao sistema produtivo do urucum foram identificados nesse trabalho, dentre eles destacam-se: a falta de produtos defensivos aprovados para o urucum, a incipiência no desenvolvimento de máquinas e implementos específicos para a cultura, a oferta de mão de obra para o manejo e a colheita, bem como a preocupação com a continuidade da atividade agrícola das próximas gerações dos produtores rurais. 


\section{NOTAS}

1 - A mesoanálise pode ser definida como sendo a análise estrutural e funcional de subsistemas e de sua interdependência dentro de um sistema integrado (BATALHA e SILVA, 2007).

2 - Eliane Gomes Fabri é pesquisadora científica da Agência Paulista de Tecnologia dos Agronegócios (APTA), atuando junto ao Centro de Horticultura - Plantas Medicinais e Aromáticas do Instituto Agronômico Campinas-IAC (Extraído do currículo Lattes em 27/12/2016).

\section{REFERÊNCIAS}

[1]. ANSELMO, George Carlos S.; MATA, Mário Eduardo R. M. C.; RODRIGUES, Edson. Comportamento higroscópico do extrato seco de urucum (Bixa Orellana L). Ciências Agrotécnicas, Lavras, v. 32, n. 6, p. 18881892, dez. 2008.

[2]. ATLAS BRASIL. IDH-M - Ranking no estado de São Paulo. Disponível em: http://www.atlasbrasil.org.br/2013/pt/ranking. 2016. Acesso em 29/07/2016.

[3]. AZEVEDO, Paulo Furquim de. Comercialização de produtos agroindustriais. In: BATALHA, Mário Otávio (Coord.). Gestão Agroindustrial. São Paulo: Atlas. 2007, p. 63-112.

[4]. BATALHA, Mário Otávio. Gestão do sistema agroindustrial: A formação de recursos humanos para o Agribusiness brasileiro. Gestão \& Produção, v. 2, n. 3, p. 321-330, 1995

[5]. BATALHA, Mário Otávio; SILVA, Andrea Lago. Gerenciamento de sistemas agroindustriais: Definições, especificidades e correntes metodológicas. In: BATALHA, Mário Otávio (Coord.). Gestão Agroindustrial. São Paulo: Atlas. 2007, p. 1-62.

[6]. CALEMAN, Silvia M. Q. Contratos e coordenação. In: ZYLBERSZTAJN, Decio; NEVES, Marcos F.; CALEMAN, Silvia M. Q. (Org.). Gestão de sistemas de agronegócios. São Paulo: Atlas, 2015. p.71-87.

[7]. COORDENADORIA DE ASSISTÊNCIA TÉCNICA INTEGRAL (CATI). LUPA Levantamento censitário das unidades de produção agropecuária do estado de São Paulo. Distribuição geográfica da produção de urucum no estado de São Paulo, em 2007/2008. Disponível em: http://www.cati.sp.gov.br/projetolupa/. Acesso em 05/08/2016.

[8]. CORLETT, Francisco M. F.; BARROS, Antônio Carlos S. A.; VILLELA, Francisco A., Qualidade fisiológica de sementes de urucum armazenadas em diferentes ambientes e
3 - Projeto de Desenvolvimento Rural Sustentável - Microbacias II - Acesso ao Mercado, tem por objetivo ampliar a competitividade e proporcionar o acesso ao mercado aos agricultores familiares organizados em associações e cooperativas em todo o Estado de São Paulo, bem como organizações de produtores de comunidades tradicionais como quilombolas e indígenas. $\mathrm{O}$ Projeto pretende aumentar as oportunidades de emprego e renda, a inclusão social e promover a conservação dos recursos naturais (CATI, 2016).

embalagens. Rev. bras. sementes, Londrina, $v$. 29, n. 2, p. 148-158, 2007.

[9]. DALFOVO, Michael Samir; LANA, Rogério Adilson; SILVEIRA, Amélia. Métodos quantitativos e qualitativos: um resgate teórico. Revista Interdisciplinar Científica Aplicada, v.2, n.4, p.0113, 2008.

[10]. DUARTE, Rosália. Entrevistas em pesquisas qualitativas. Educ. rev., n. 24, p. 213225, 2004

[11]. FABRI, Eliane G.; TERAMOTO, Juliana R. S., Urucum: fonte de corantes naturais. Hortic. Bras., Vitória da Conquista, v. 33, n. 1, p. 140, Mar. 2015.

[12]. FARINA, Elizabeth M.M.Q. Competitividade e coordenação de sistemas agroindustriais: um ensaio conceitual. Gestão \& Produção. v. 6, n. 3, p.147-161,1999.

[13]. GIL, Antônio Carlos. Como elaborar projetos de pesquisa. 4. Ed. São Paulo: Atlas, 2002.

[14]. HOFF, Débora. N; DEWES, Homero; RATHMANN, Régis; BRUCH, Kelly L.; PADULA, Antônio D., Os desafios da pesquisa e ensinos interdisciplinares. Revista Brasileira de Pós Graduação, v. 4, n.7, p. 42-65, 2007.

[15]. INSTITUTO BRASILEIRO DE GEOGRAFIA E ESTATÍSTICA (IBGE). Cidades do estado de São Paulo. 2016. Disponível em: http://www.cidades.ibge.gov.br/xtras/uf.php?lang= \&coduf=35\&search=sao-paulo . Acesso em 01/08/2016a.

[16]. INSTITUTO BRASILEIRO DE GEOGRAFIA E ESTATÍSTICA (IBGE). Área destinada à colheita, área colhida, quantidade produzida, rendimento médio e valor da produção das lavouras permanentes. 2015. http://www.sidra.ibge.gov.br/bda/tabela/listabl.asp? $z=t \& c=1613$. Acesso em: 30/07/2016b. 
[17]. LAKATOS, Eva Maria; MARCONI, Marina de Andrade. Fundamentos de metodologia científica. 5. ed. São Paulo: Atlas, 2003.

[18]. LIMA, José D.; ESCEVESTE, Márcia E.S.; RIBEIRO, José Luis D. Fatores que subsidiam a tomada de decisão no âmbito da produção agrícola - um estudo de caso no Sudoeste do Paraná. Enciclopédia Biosfera. Centro Científico Conhecer. Goiânia, v. 10, n. 18, p. 1760-1780, 2014.

[19]. MENDES, Krisley; FIGUEIREDO, Jeovan C.; MICHELS Ido L. A Nova Economia Institucional e sua aplicação no estudo do agronegócio brasileiro. Revista de Economia e Agronegócio. v.6, n.3, p. 309-342. 2009

[20]. MINAYO, Maria Cecília de Souza (org.). O desafio da pesquisa social. In: MINAYO, Maria Cecília de Souza (org.). Pesquisa social: teoria, método e criatividade. 28 ed. Petrópolis, RJ: Vozes, 2009.

[21]. NEVES, Marcos F.; CALEMAN, Silvia M. Q., Metodologia para análise dos sistemas agroindustriais. In: ZYLBERSZTAJN, Decio; NEVES, Marcos F.; CALEMAN, Silvia M. Q.; (Org.). Gestão de sistemas de agronegócios. São Paulo: Atlas. 2015, p. 44-67.

[22]. SAAB, Maria Stella B. L. de Melo; NEVES, Marcos Fava; CLAUDIO, Leandro Del Grande. O desafio da coordenação e seus impactos sobre a competitividade de cadeias e sistemas agroindustriais. R. Bras. Zootec., v. 38, n. spe, p. 412-422, 2009.

[23]. SIFFERT FILHO, Nelson Fontes; FAVERET FILHO, Paulo. O Sistema agroindustrial de carnes: competitividade e estruturas de governança. Revista do BNDES, Rio de Janeiro, v. 5, n. 10, p. 265-297, dez. 1998.

[24]. SOUZA, José P.; AVELHAN, Bruna L., Aspectos conceituais relacionados à análise de sistemas agroindustriais. Caderno de Administração. Maringá. v. 17, n. 2, 2009.

[25]. TORRES, Salvador B; BEZERRA NETO, Francisco. Teste de envelhecimento acelerado para avaliação do potencial fisiológico de sementes de urucum. Hortic. Bras., Brasília, v. 27, n. 1, p. 55-58, 2009.

[26]. ZYLBERSZTAJN, Décio. Estrutura de governança e coordenação do agribusiness: uma aplicação da nova economia das instituições. 1995. 238 f. Tese (Livre-Docência) - Faculdade de Economia, Administração e Contabilidade, Universidade de São Paulo, São Paulo.

[27]. ZYLBERSZTAJN, Décio; GIORDANO, Samuel R., Coordenação e governança de sistemas agroindustriais. In: ZYLBERSZTAJN, Decio; NEVES, Marcos F.; CALEMAN, Silvia M. Q.; (Org.). Gestão de sistemas de agronegócios. São Paulo: Atlas. 2015, p.1-20. 


\section{Gapítulo 12}

\section{A ocUPAĊ̃o DAS tERRAS AGRICULTÁVEIS NOS ESTADOS DO MATOPIBA}

José de Ribamar Sá Silva

Ilnar Fernandes Feitoza

Benjamin Alvino de Mesquita

Resumo: Analisa-se a apropriação da terra pelos estabelecimentos rurais, nos estados do Maranhão, Tocantins, Piauí e Bahia, que abrangem uma extensa área de Cerrado recentemente denominada de Matopiba. O objetivo é ressaltar possíveis efeitos do avanço do agronegócio em relação à agricultura familiar no que se refere à ocupação do espaço. Inicialmente são explicitadas as referências teóricas a respeito do avanço das relações capitalistas para a agricultura, contextualizando a realidade brasileira. Em seguida, analisam-se dados referentes à evolução das lavouras temporárias, como arroz, feijão e mandioca, e das monoculturas de soja e eucalipto, no período 2006-2016. Com base nos levantamentos feitos, observa-se que área ocupada pelas atividades do agronegócio destinadas ao mercado externo avança significativamente, enquanto a área utilizada para produção de alimentos destinada ao mercado interno reduz-se em todas as unidades federativas consideradas.

Palavras-chave: Agronegócio; Agricultura familiar; Matopiba 


\section{INTRODUÇÃO}

A agricultura é o setor da economia, essencialmente, responsável pela produção de alimentos. De acordo com informações do próprio governo brasileiro (MDA, 2017), a agricultura familiar produz cerca de $2 / 3$ dos alimentos consumidos pela população interna, situação que a coloca na condição de imprescindível para a garantia da soberania alimentar e da segurança nutricional do país. Um dos grandes desafios desse segmento nos dias atuais é resistir e superar os impactos causados pelo avanço do agronegócio, uma vez que a monocultura demanda grandes áreas de terra. Constituindo-se em um arranjo empresarial, o agronegócio busca necessariamente a lucratividade, desarticulando as formas produtivas específicas praticadas pela população local.

Ao longo da história do nosso país, é possível observar que, por um lado, as atividades ligadas à produção dos alimentos destinados ao mercado interno têm recebido suporte estatal insuficiente para garantir seu fortalecimento e sua expansão de forma sustentada. Por outro lado, as atividades relacionadas ao agronegócio vêm sendo fomentadas de várias formas (infraestrutura, subsídios, crédito agrícola, perdão de dívidas, entre outras). O Estado brasileiro implementae fortalece as políticas públicas a fim de promover o agronegócio e garantir maior produção para atender a demanda externa.

Embora se reconheça que, sobretudo, ao longo da primeira década do presente século, tenha havido um esforço do governo visando ao fortalecimento da agricultura familiar, o fato é que, concomitantemente, houve um crescimento mais que proporcional dos investimentos que incentivam o agronegócio. Considerada a partir de um ponto de vista mais amplo, essa situação significa muito mais que uma recorrente opção de políticas agrícolas desfavoráveis à agricultura familiar. $\mathrm{Na}$ realidade, representa uma complexa trajetória de acesso à terra, oficialmente revelada pelo Censo Agropecuário de 2006 (IBGE, 2006), segundo o qual $15,6 \%$ do total dos estabelecimentos detêm $75,7 \%$ da área apropriada, enquanto os $84,6 \%$, caracterizados como sendo de agricultura familiar, dispõem de apenas $24,3 \%$ da área total.

Esses números nos fornecem uma breve indicação da complexidade que envolve a questão agrária não resolvida, ao longo da trajetória histórica de nossa sociedade, desde a época colonial até os dias de hoje. Assim, para compreender a atual situação da ocupação da terra entre grandes e pequenos estabelecimentosno contexto da expansão do agronegócio e de seus efeitos sobre a agricultura familiarna área denominada Matopiba, considera-se importante recorrer às explicações de alguns estudiosos da questão agrária e da modernização da agricultura no Brasil. Tendo o suporte dessas explicações e do debate sobre as definições de agronegócio e de agricultura familiar, podese, então, lançar um olhar sobre os dados referentes à evolução das lavouras temporárias, como arroz, feijão e mandioca, e das monoculturas de soja e eucalipto, no período 2006-2016, nos estados que compõem a citada área produtiva.

\section{BREVE CARACTERIZAÇÃO DO AVANÇO DO CAPITALISMO PARA A AGRICULTURA NO BRASIL}

Diversos autores têm procurado explicar o avanço das relações capitalistas no campo e as transformações na agricultura nesse processo. Entende-se que essa é uma discussão fundamental para que se possa, na atual fase neoliberal, contextualizar o sentido da ocupação das terras agricultáveis pelas empresas do agronegócio e pela agricultura familiar, ou, em outros termos, pelos grandes e pelos pequenos estabelecimentos.

Entre os principais estudiosos que se debruçaram sobre a questão agrária encontra-se Caio Prado Jr. (1979). Esse autor analisa uma série de elementos que impossibilitam o desenvolvimento material e social da massa dos trabalhadores rurais despossuídos da terra ou proprietários de pequenas propriedades no Brasil. Prado Júnior destaca que, no Brasil, a distribuição da terra foi sempre pautada na divisão de vantagens de localização ou de recursos naturais para as grandes propriedades. Por sua vez, as pequenas propriedades situam-se em condições menos favoráveis. O autor esclarece que existe no campo brasileiro uma massa de trabalhadores rurais dispostos a vender sua força de trabalho sem fazer qualquer tipo de exigência ou questionamento, porque não dispõem de poder de barganha. A forte concentração da propriedade fundiária impede a melhoria das 
condições de vida para a maior parte da população rural.

Para Prado Júnior (1979), o problema da terra no Brasil está, sobretudo, na desvalorização do homem e na valorização da produção para atender a demanda externa. Historicamente, o papel que coube à grande massa dos trabalhadores rurais brasileiros foi tão somente "fornecer mão-de-obra à minoria privilegiada" uma vez que para uma massa de camponeses "a terra e as atividades que nela exercem constituem a única fonte de subsistência para eles acessível" (PRADO JR., 1979, p. 22-25).

De acordo com o autor, a inserção da tecnologia para aumentar a produtividade rural é um elemento fundamental para se alcançar maior rentabilidade da grande exploração rural, mas ele observa que isso não tem relação direta com a melhoria das condições de trabalho, nem com acréscimos da remuneração. Ele destaca que, na realidade brasileira, o progresso técnico agrícola causa mais concentração da terra e da riqueza.

A função da terra no Brasil, na visão de Prado Jr. (1979) é, essencialmente, atender interesses comerciais e não sociais. Em cada região do país, a atividade agrária desenvolve-se para produzir algum gênero de grande valor comercial e exportável, enquanto que os produtos alimentícios necessários à vida dos trabalhadores ficam em segundo plano. Para o autor, a demanda dos mercados internacionais influencia significativamente na estrutura fundiária brasileira.

Por outro lado, a distribuição da terra em pequenas propriedades, que reflete o acesso à terra pela massa dos trabalhadores rurais, somente é possível quando as grandes explorações perdem a razão principal de existência, ou seja, quando a demanda dos produtos agrícolas está em retração. O autor destaca que, "a pequena propriedade, ao contrário da grande que tem a ampará-la a privilegiada exploração de larga escala, não oferece nenhuma resistência à partilha sucessória" (PRADO JR. 1979, p. 74).

Nessa direção, Silva (1981) esclarece que criação das pequenas propriedades, no Brasil, é dependente da subida e descida dos ciclos econômicos. Segundo o autor, as pequenas propriedades são reagrupadas quando há um maior desenvolvimento capitalista no campo, por isso, a grande propriedade do Brasil sempre tem seu crescimento maior do que as pequenas, "em resumo, nas épocas favoráveis de expansão da atividade econômica, o grande prospera e engole os pequenos a sua volta. Na 'crise', ao contrário, o grande se retrai” (SILVA, 1981, p. 13).

Ainda segundo esse autor, no Brasil, a terra é fonte de prestígio, de acesso a outras formas de riqueza, de aproximação com os poderes político, econômico e social. Essa circunstância explica o processo observado entre os anos de 1960 e 1970, quando a concentração fundiária se agravou com a presença das grandes multinacionais e implicou na perda da terra por milhares de pequenos posseiros, parceiros, arrendatários e pequenos proprietários, que foram obrigados a migrar para as cidades em busca de novas formas de sobrevivência. Como consequência, a reconcentração da terra teria, por um lado, implicado uma aceleração da urbanização e o crescimento do mercado interno para a indústria. Por outro lado, as grandes explorações rurais, com menos mão de obra, deixaram de produzir alimento e se dedicaram à comercialização de produtos exportáveis.

Outra contribuição para o debate é dada por Sorj (2008). O autor destaca que com a expansão do capitalismo para o campo, no Brasil, grande quantidade de latifundiários transformou-se em grandes empresas capitalistas. Na suavisão, a partir dos anos de 1990, a agricultura brasileira foi permeada por transformações nas relações produtivas, porém sem correspondente alteração da estrutura fundiária, com enriquecimento de alguns e empobrecimento da maioria da população envolvida. O capitalismo avança sobre a agricultura de forma diferenciada, de acordo com a região do país, porém, sendo essas diferenças ainda não totalmente aparentes. Todavia, observa que os grandes e pequenos agricultores capitalizados encontram-se mais nas regiões do Centro-Sul do país e os mais marginalizados e pauperizados, no Nordeste e no Norte.

A percepção de Sorj (2008) reaviva as interpretações de Prado Junior (1979) e de Silva (1981), ao destacar que a agricultura brasileira se expandiu nas últimas décadas com a manutenção de estrutura fundiária concentrada e, por isso, um pequeno grupo privilegiado controla a terra e os estabelecimentos rurais. Segundo seus pressupostos, há um padrão na expansão 
agrícola brasileira que "conjuga de forma original a expansão da pequena produção, e, portanto, um caminho distributivo, que permanentemente é quebrado pelo latifúndio que volta a afirmar um caminho concentracionistade organização fundiária" (SORJ, 2008, p. 12).

Diante do que foi resenhado, é possível depreender queos autores considerados apresentam teses que explicam as razões que mantém concentrada a estrutura fundiária do Brasil. Essa estrutura é, sem dúvida, um fator que viabilizou a rápida expansão das monoculturas de soja e de eucalipto, como observado após os anos de 1990. Nessa fase, - ciclo econômico dessas commodititesagropecuárias experimentou forte expansão devido à demanda global, especialmente da China.

Tendo em vista que os objetivos fundamentais da política econômica e agrária brasileira nunca sofreram alterações estruturais para buscar o atendimento das necessidades da população, em termos de garantia de trabalho e alimentos, observa-se que a ocupação das terras agricultáveis vem se destinando, cada vez mais, para as monoculturas de soja e eucalipto, especialmente nas áreas de Cerrado e na Pré-Amazônia.

Para serem rentáveis, essas atividades necessitam de extensas áreas de terra, além de mecanização avançada, em um movimento que, ao mesmo tempo, dispensa a mão de obra e expropria os antigos habitantes locais. Esse processo se repete na atualidade, confirmando o que observara Prado Júnior (1979), no que diz respeito aos prejuízos que o progresso tecnológico na agricultura impõe aos trabalhadores rurais. Em uma situação historicamente desfavorável aos trabalhadores, a manutenção do acesso à terra, como um meio de produção essencial, coloca-se na ordem do dia, não apenas em função da permanência dos agricultores familiares enquanto segmento social, mas também como um caminho estratégico para a segurança alimentar do conjunto da população.

\section{AGRICULTURA FAMILIAR E AGRONEGÓCIO NA FRONTEIRA AGRÍCOLA}

No campo brasileiro atual, pode-se observar um embate entre dois projetos distintos que correspondem a duas formas específicas de utilizar os recursos naturais e direcionar os resultados da produção: a agricultura familiar e o agronegócio. Por sua própria origem, essa situação permite distintas abordagens e muitos autores têm gerado contribuições importantes ao debate.

Em virtude de modificações conceituais e da atividade do pequeno produtor rural, especialmente nas últimas décadas, convém destacar as formulações de Wanderley (1996). Esta autora esclarece como se insere o pequeno produtor agrícola nas sociedades modernas, com entendimento de que as formas da agricultura familiar não camponesa multiplicaram-se por causa das transformações vivenciadas pela população rural devido à proximidade com as cidades, maior acesso à cultura urbana, predominância das demandas do mercado, globalização da economia entre outros.

A autora afirma que o pequeno produtor rural produz mercadoriascom o objetivo de obter recursos para sobreviver e que isso é o esperado pela lógica capitalista, pois "o pequeno produtor mercantil reage a qualquer diminuição de seu nível de vida com um acrescimento de seu esforço produtivo e em que toda intensificação deste gênero permite extrair uma mais valia crescente sobre seu trabalho" (WANDERLEY, 1996, p. 6).

Além desses aspectos, a autora esclarece que o pequeno produtor rural do Brasil ocupaum lugar secundário e subalterno na sociedade brasileira. Mesmo logrando pouco reconhecimento, o campesinato brasileiro caracteriza-se pelas "lutas para conseguir um espaço próprio na economia e na sociedade" (WANDERLEY, 1996, p. 8). Essas lutas são motivadas pela instabilidade que ameaçam a autonomia, precariedade nas conquistas da terra e acesso ao mercado, com dificuldade para construir um lugar familiar para viver e trabalhar. É sob a pressão do latifúndio que o camponês se move de um lugar para outro, servindo para abrir fronteiras, e nesse ponto a autora adverte, "seja como um lugar de refúgio e reconstrução, seja como um lugar de desilusão e fracasso, a fronteira é o lugar da utopia" (WANDERLEY, 1996, p. 12).

Assim, as colocações de Wanderley (1996) reafirmam as percepções de Prado Jr (1979), Silva (1999) e Sorj (2008), sobre as difíceis relações de produção para o trabalhador rural que, no Brasil, são ancoradas na concentração fundiária e no controle da terra pelo grupo rural dominante, que oprime e 
subjuga os despossuídos que dependem desse meio de produção para sobreviver.

Esses aspectos das relações de produção na atividade agrícola relacionam-se com o uso das terras brasileiras que, desde a colonização, foram exploradas com culturas agrícolas para atender demandadas do mercado externo por um pequeno grupo de ruralistas que dispunham de recursos econômicos e políticos. Em se tratando de momentos recentes, observa-se que, a partir da década de 1990, as monoculturas como soja e eucalipto ganharam expressividade para atender as demandas de outros países. E monoculturas necessitam de grandes áreas, portanto, são favorecidas por uma estrutura fundiária concentrada.

Diante de um cenário do capitalismo globalizado, a agricultura voltada para o atendimento de mercados estrangeiros passa a ser um dos suportes da balança comercial do Brasil. Essa circunstância impõe a necessidade de aumentar a produtividade das culturas exportáveis, utilizando-se de mais terras e tecnologia, modernizando-se a produção e, ao mesmo tempo, busca-se legitimidade interna com a mídia exercendo o papel de difusor das noções acerca do agronegócio ou agrobusiness para aliciar o imaginário da população.

Contribuindo com o debate, Delgado (2010) observa que a política brasileira de comércio exterior é alterada após os anos 1990, visando "gerar saldos (...) a qualquer custo, tendo em vista suprir o déficit da Conta Corrente". Dessa forma, o agronegócio passa a ser agenda prioritária da política macroeconômica combinada com a política agrícola do Brasil. Na visão do autor, após os anos 2000, ocorreu um crescimento global no mercado agrícola ou da demanda por commodities, especialmente, em virtude da rápida expansão da economia da China, que influenciaria a economia do Brasil. Devido a isso, "o Estado reestrutura suas políticas de crédito, de comercialização e de terras, tendo em vista fomentar a acumulação de capital no espaço ampliado das cadeias agroindustriais, mercado de terras e do sistema de crédito" (DELGADO, 2010, p. 119).

Outro aspecto que Delgado (2010) enfatiza é o crescimento da renda da terra, por ser o elemento crucial para a extração do lucro. Desse modo, a terra passa a ser ambicionada por um pequeno grupo de multinacionais, por se transformar numa forma vantajosa para acumular capital. O autor defende que haverá uma pressão dobrada para obter ganhos e produzir mais pela "a incorporação de novas áreas ao espaço econômico explorado", que inevitavelmente implicará na exigência de um consumo maior de outros recursos naturais como solo, água e biodiversidades (DELGADO, 2010, p. 121).

Diante das concepções de Delgado (2010) e Wanderley (1996), Prado Jr (1979), Silva (1999) e Sorj (2008), é possível ressaltar que o modo de produção capitalista avança para a agricultura com o aparato do Estado, intensificando a concentração fundiária, impondo mais exclusão e agravando as formas de sobrevivência do pequeno produtor no espaço rural. O agronegócio configura-se na forma moderna como o capital avança para a agricultura, com o suporte das políticas públicas, justificadas pelo discurso de o Estado buscar o equilíbrio da balança comercial. Contudo, o agronegócio é produção de mercadorias exportáveis e demanda uma quantidade elevada de recursos naturais que são limitados e esgotáveis como fertilidade do solo e água. Além disso, o agronegócio de exportação, diferente da agricultura familiar, não produz alimentos para o mercado doméstico, utilizase de alta tecnologia e mecanização, requer espaço para produção em alta escala por esses dois últimos fatores usurpa a terra e o trabalho de homens e mulheres que sobreviviam naqueles espaços.

E cada progresso da agricultura capitalista não é só um progresso na arte de saquear o trabalhador, mas ao mesmo tempo na arte de saquear o solo, pois cada progresso no aumento da fertilidade por certo período é simultaneamente um progresso na ruína das fontes permanentes dessa fertilidade (MARX, 1996, p. 113)

Marx (1996), há algum tempo, lançava esse alerta quanto aos impactos do avanço do capitalismo para a agricultura, aos diversos prejuízos sociais e ambientais, devido à subjugação da agricultura pelo capital, à lógica do mercado. Essa é uma situação inteiramente presente na agricultura brasileira dos dias atuais, sobretudo nas áreas de fronteira agrícola. 


\section{O PLANO DE DESENVOLVIMENETO DO MATOPIBA E O AGRONEGÓCIO}

A Empresa Brasileira de Agropecuária (EMBRAPA), através do Grupo de Inteligência Territorial Estratégica (GITE), elaborou o Plano de Desenvolvimento Agropecuário do Matopiba (PDA-MATOPIBA), para demarcação territorialmente nos estados do Maranhão, Tocantins, Piauí e Bahia (Matopiba), visando separar as áreas para promover o crescimento da produção.

De acordo com a EMBRAPA/GITE, o plano de desenvolvimento para esses estados busca orientar as políticas públicas e privadas para o desenvolvimento agrário e regional, por meio de inovações. Para a elaboração do plano, a instituição leva em consideração os aspectos natural, agrário, agrícola, social, ambiental e econômico, além da infraestrutura.

Nessa perspectiva, os técnicos entendem que existem milhares de hectares ocupados por uma agricultura de baixa produtividade $\mathrm{e}$ pouca rentabilidade. Além disso, o documento fornece informações dos estados do Matopiba acerca das unidades de conservação, terras indígenas, áreas quilombolas, projetos de regularização fundiária e assentamentos de reforma agrária, uma vez que a delimitação geográfica com informações precisas é fundamental para orientar as políticas públicas e privadas na região. O documento contém, ainda, informações sobre bacias hidrográficas e biomas. O objetivo declarado dessa demarcação é apoiar, monitorar e avaliar as políticas públicas e privadas na região.

Conforme se lê no artigo $1^{\circ}$ do Decreto no $8.447 / 2015$, o PDA-Matopiba "tem por finalidade promover e coordenar políticas públicas voltadas ao desenvolvimento econômico sustentável fundado nas atividades agrícolas e pecuárias que resultem na melhoria da qualidade de vida da população" (BRASIL, 2015, p.1).

Para o Maranhão, a demarcação territorial englobou 23.982.346 hectares, o que corresponde a $33 \%$ do território do estado e envolve 135 municípios: no Tocantins a área incorporada foi de 27.772.052 hectares, ou $38 \%$ da área total do Estado, abarcando 139 municípios. No Piauí, a área destinada foi de 8.204.588 hectares, o que representa $11 \%$ do total desse estado, incluindo 33 municípios. $\mathrm{Na}$ Bahia foram demarcados 13.214.499 hectares, o que equivale a $18 \%$ do território do Estado e abrange 30 municípios.

A delimitação territorial obtida e proposta para - MATOPIBA abrange 31 microrregiões geográficas do IBGE, reúne 337 municípios e uma área total de 73.173.485 ha. Ela engloba um universo com cerca de 324.326 mil estabelecimentos agrícolas. A repartição aproximada do MATOPIBA entre os quatro Estados é a seguinte: 33\% no Maranhão (15 microrregiões, 135 municípios, 23.982.346 ha); 38\% no Tocantins (8 microrregiões, 139 municípios e 27.772 .052 ha); $11 \%$ no Piauí (4 microrregiões, 13 municípios e 8.204.588 ha) e $18 \%$ na Bahia (4 microrregiões, 30 municípios e 13.214.499 ha) (EMBRAPA, 2014, p. 14).

O plano do Matopiba aponta as desigualdades sociais existentes nos Estados do Maranhão, Tocantins, Piauí e Bahia, como também destaca a concentração fundiária e de renda, apresenta dados do Produto Interno Bruto (PIB) e PIB per capita, e informações sobre os biomas dessas áreas e com definições de estratégias para o desenvolvimento regional, porém, numa visão mais estreita as estratégias são contraditórias. O eucalipto, todos sabem, é uma planta exótica que exige muita água para crescer, realizar reflorestamento com essa silvicultura em estados do Nordeste e Norte nos quais o índice pluviométrico já não é tão elevado é mais uma forma de secar as escassas fontes de água já existentes. Além disso, o eucalipto não substituirá as árvores frutíferas que eram utilizadas por muitos camponeses e povos tradicionais como fontes de alimentos, como é o caso do babaçu.

Nesse sentido, Buainain, Garcia e Vieira Filho (2017) ratificam o crescimento da produção agropecuária nos municípios integrantes do PDA-Matopiba, como pensado pela Embrapa: "Cabe destacar que apenas dez municípios concentravam $40 \%$ do produto interno bruto (PIB) da região (...), reflexo da histórica concentração e da desigualdade que marcam a região e o próprio país" (BUAINAIN; GARCIA; VIEIRA FILHO, 2017, p. 16).

Outro aspecto que levanta desconfiança é a capacidade do plano para promover o real desenvolvimento dos pequenos produtores e gerar oportunidade para os trabalhadores rurais nos municípios envolvidos. Monoculturas como soja e eucalipto ocupam extensas áreas agricultáveis, recursos naturais e são altamente mecanizadas, por 
isso dispensam mão de obra e concentram a terra. Pode-se prever que o plano elevará a produção e produtividade agropecuária em cada estado integrante do Matopiba, mas não implicará desenvolvimento socioeconômico para a população. Na visão deBuainain, Garcia e Vieira Filho (2017), o fomento da agropecuária nesses municípios provocará ainda mais disparidades socioeconômicas na região.

A economia e as estruturas vigentes no Matopiba ainda refletem pouco as transformações mais recentes, impulsionadas pela dinamização da agropecuária nas áreas de Cerrado. É possível que a principal manifestação do novo impulso seja a maior concentração na geração de renda em alguns municípios e o consequente aumento da desigualdade no interior da região (BUAINAIN; GARCIA; VIEIRA FILHO, 2017, p. 18).

Numa visão mais estreita é possível afirmar que o plano de desenvolvimento do Matopiba representa uma forma que o Estado encontrou para apoiar a expansão do capital para a agricultura naquela extensa área do Cerrado. E na lógica capitalista não há espaço para a contabilidade do desgaste do homem e da natureza, como bem alertou Marx (1996). A respeito da atuação do Estado para apoiar a expansão do capitalismo, Gramsci (2001) formula que o Estado cria o alicerce necessário para sustentar e revigorar o capitalismo. Nesse rumo, Harvey (2005, p.82)) assevera que "o Estado capitalista não pode ser outra coisa que instrumento de dominação de classe, pois se organiza para sustentar a relação básica entre capital e trabalho".Por sua vez, Foladori, Melazi e Kilpp (2016) ressaltam que uma das funções do Estado na economia é baratear o capital por meio de investimentos em obras de construção, manutenção de estradas, redes de água, energia etc. Estes autores afirmam que, no Brasil:

Os grandes projetos de apoio ao agronegócio, que the garante canais de irrigação e estradas desvios de rios, desvios de rios, como o projeto de transposição do São Francisco que, transvestidos de um interesse social, básico, objetiva atender, na verdade, aos interesses dos grandes capitais do setor agrícola (FOLADORI; MELAZI; KILPP, 2016, p. 235).
Pitta e Vega (2017) também preocupados com os prejuízos impostos aos camponeses e à Natureza devido à expansão capitalista para a agricultura, sustentam que uma das fortes maneiras utilizadas para legalizar a expansão da fronteira agrícola é o "discurso de que a região é 'atrasada', vem a pretensa solução para a região na forma de 'progresso' e 'desenvolvimento' que hoje está intimamente ligada à atuação do agronegócio" (PITTA; VEGA, 2017, p. 27). Para os autores, por trás da expansão dos espaços agrícolas e desenvolvimento do agronegócio na região do Matopiba, está a espoliação de camponeses e indígenas por causa dos recursos naturais, como a água, que estavam disponíveis em seus territórios.

A expansão financeirizada da agroindústria da soja para a Bahia, Maranhão, Piauí e Tocantins conduziu à expropriação de indígenas e camponeses das mais variadas formas. As áreas altas e planas das chapadas eram as áreas prioritárias a serem ocupadas. Ali, as produções podiam acessar um regime pluviométrico adequado, além de serem justamente os locais de cabeceira / nascentes dos rios do Cerrado na região (PITTA; VEGA, 2017, p. 39).

Nesse sentido, é relevante apresentar os dados referentes à ocupação das terras com a produção agrícola no Brasil e dos estados que compõem o Matopiba (Maranhão, Tocantins, Piauí e Bahia), nos anos de 20062016. Levantaram-se os dados das lavouras temporárias das culturas de arroz, feijão e mandioca que são utilizadas pela população como fonte alimentícia e produzidas, em sua maioria, pela agricultura familiar e as áreas ocupadas pelo monocultivo da soja, que é uma oleaginosa demandada pelo mercado externo, com pouco proveito pela maioria dos brasileiros.

Conforme dados do IBGE (2018), observa-se queda das áreas destinadas às lavouras de arroz e feijão em todos os estados integrantes do Matopiba, quando se compara os anos de 2006 e 2016, com relação aos plantios de feijão, com exceção do Tocantins que agregou área à cultura, nos demais estados também se verificam redução, por outro lado, a soja ocupa cada vez mais espaço. 
Tabela 1. Brasil e estados do Matopiba: evolução da área plantada (Ha) de arroz, mandioca, feijão e soja, 2006 e 2016.

\begin{tabular}{|l|c|c|c|c|c|c|c|c|}
\hline \multicolumn{3}{|c|}{2006} & Soja & Arroz & Feijão & Mandioca & Soja \\
\hline Localidades & Arroz & Feijão & Mandioca & Soja & & & & \\
\hline Brasil & 3.010 .169 & 4.243 .474 & 1.974 .419 & 22.082 .666 & 2.004 .643 & 2.946 .801 & 1.439 .754 & 33.309 .865 \\
\hline Tocantins & 124.643 & 12.821 & 19.975 & 329.220 & 110.974 & 16.979 & 15.035 & 845.745 \\
\hline Maranhão & 507.446 & 85.606 & 212.096 & 383.284 & 168.407 & 71.802 & 157.158 & 783.654 \\
\hline Piauí & 148.226 & 234.199 & 52.311 & 232.009 & 75.681 & 219.687 & 37.518 & 563.084 \\
\hline Bahia & 17.442 & 739.781 & 387.094 & 872.600 & 7.074 & 371.527 & 182.693 & 1.536 .678 \\
\hline
\end{tabular}

Fonte: IBGE - Produção Agrícola Municipal, 2018a

Assim, ao confrontar a área ocupada com a lavoura de arroz, constata-se que no Brasil houve retração de $33,4 \%$ (um milhão de hectares - ha), passando de 3 milhões de ha, em 2006, para 2 milhões, em 2016. No Tocantins, a retração foi de 13,6 mil ha (10,9\%), em 2006 a lavra foi de 124,6 mil (ha) e em 2016 de 110,9 mil. Dentre os estados considerados, as reduções mais expressivas, em termos absolutos, ocorreram no Maranhão de 339 mil ha (66,8\%), e no Piauí, de 72,5 mil ha $(48,9 \%)$, enquanto em 2006, no Maranhão plantaram 507,4 mil ha, em 2016 os plantios abrangeram 168,4 mil ha e no Piauí, a área saiu de 148,2 mil ha, em 2006, para 75,6 mil ha em 2016. Na Bahia, a área ocupada pela rizicultura caiu em $59,4 \%$ ou 10,3 mil hectares, indo de 17,4 mil ha para 7 mil, conforme tabelas 1 e 2 .

Em se tratando da lavoura de feijão, constatase que no Brasil a queda foi de 1,2 milhões de hectares $(30,5 \%)$, saindo de 4,2 milhões de hectares (ha), em 2006, para 2,9 milhões, em 2016. No Tocantins houve elevação da área em $32,4 \%$, partindo de 12,8 mil hectares, em 2006, para 16,9 mil (ha), em 2016. Dentre os estados considerados, a Bahia foi o estado que perdeu mais área de feijoeiro $(49,7 \%)$ ou 368 mil hectares, enquanto em 2006, foram plantadas 739,7 mil ha, em 2016, os plantios abrangeram 371,5 mil ha. No Maranhão e Piauí, as diminuições foram de 16,1\% (13,8 mil ha) e de $6,2 \%$ (14,5 mil ha), respectivamente.

Com relação à cultura da mandioca, no Brasil, a área plantada reduziu-se em 534,6 mil hectares (27\%), passando de 1,9 milhões de hectares, em 2006, para 1,4 milhões ha, em 2016. No Tocantins, a redução da área foi de 24,7\% (4,9 mil ha), partindo de 19,9 mil hectares, em 2006, para 15 mil (ha), em 2016. Dentre os estados considerados, a Bahia, também foi o que mais perdeu área da lavra de mandioca (52,8\%) ou 204,4 mil hectares, enquanto em 2006, plantaram 387 mil ha, em 2016 , os plantios abrangeram 182,6 mil ha. No Maranhão e Piauí, as diminuições foram de $25,9 \%$ (54,9 mil ha) e de $28,2 \%$ (14,7 mil ha), respectivamente.

Por outro lado, a soja aumentou em todos os estados, e as variações ficaram entre $76,1 \%$ e 156,8\%. No Brasil, a incorporação total da área pela monocultura foi de $50,8 \%$, ou seja, 11,2 milhões de hectares, saindo de 22 milhões de hectares em 2006, para 33,3 milhões em 2016. Entre os estados considerados, em termos absolutos, a Bahia foi quem mais destinou área para a oleaginosa, 664 mil hectares, passando de 872,6 mil ha para 1,5 mil, um acréscimo de $76,1 \%$. Em termos percentuais, o Tocantins foi campeão, acrescentou 156,8\% (516,5 mil ha) de plantios de soja, partindo de 329,2 mil hectares para 845,7 mil. O Maranhão e o Piauí acrescentaram, ao longo do período considerado, $104,4 \%$ e 142,7 respectivamente. Em 2006, no Maranhão, a soja era destinada 383,2 mil hectares e, em 2016, 783,6 mil há; no Piauí, a oleaginosa ocupava naquele ano 232 mil hectares, em 2016, os plantios apoderam-se de 563 mil hectares. 
Tabela 2. Variação absoluta e percentual da área de arroz, mandioca, feijão e soja (hectares) do Brasil, Maranhão, Tocantins, Piauí e Bahia, 2006 e 2016

\begin{tabular}{|c|c|c|c|c|c|c|c|c|}
\hline \multirow{2}{*}{ Localidades } & \multicolumn{4}{|c|}{ Variação hectares } & \multicolumn{4}{|c|}{ Variação percentual (\%) } \\
\hline & Arroz & Feijão & Mandioca & Soja & Arroz & Feijão & Mandioca & Soja \\
\hline Brasil & -1.005 .526 & -1.296 .673 & -534.665 & 11.227 .199 & $-33,4$ & $-30,5$ & -27 & 50,8 \\
\hline Tocantins & -13.669 & 4.158 & -4.940 & 516.525 & $-10,9$ & 32,4 & $-24,7$ & 156,8 \\
\hline Maranhão & -339.039 & -13.804 & -54.938 & 400.370 & $-66,8$ & $-16,1$ & $-25,9$ & 104,4 \\
\hline Piauí & -72.545 & -14.512 & -14.793 & 331.075 & $-48,9$ & $-6,2$ & $-28,2$ & 142,7 \\
\hline Bahia & -10.368 & -368.254 & -204.401 & 664.078 & $-59,4$ & $-49,7$ & $-52,0$ & 76,1 \\
\hline
\end{tabular}

Fonte: IBGE - Produção Agrícola Municipal, 2018a

Assim, observa-se que a soja abrange maiores espaços das terras agricultáveis do Brasil por ser uma cultura dotada de privilégios financeiros e comerciais como logística para exportação e isenção de imposto. Por outro lado, a área destinada às lavouras de arroz, feijão e mandioca, que são culturas utilizadas na alimentação da população interna, sofre retração. Verifica-se que a área dessas três culturas encolheu 2,8 milhões de hectares no Brasil, ou seja, 30,7\%. Os estados do Maranhão e Bahia perderam mais de $50 \%$ da área destinada ao arroz, feijão e mandioca, 407,7 mil hectares do primeiro e 583 mil hectares do segundo, entre 2006 e 2016. As quedas menores foram no Tocantins de 9,1\% (menos 14,4 mil ha) e no Piauí de 23,4\% (redução de 101,8 mil ha), conforme tabela 3.

Tabela 3. Variação absoluta (hectares) e percentual da área total de arroz, mandioca e feijão do Brasil, Maranhão, Tocantins, Piauí e Bahia, 2006 e 2016

\begin{tabular}{|c|c|c|} 
Localidades & $\begin{array}{c}\text { Arroz, Feijão e Mandioca } \\
\text { (hectares) }\end{array}$ & Arroz, Feijão e Mandioca, \% \\
\hline Brasil & -2.836 .864 & $-30,7$ \\
\hline Tocantins & -14.451 & $-9,1$ \\
\hline Maranhão & -407.781 & $-50,6$ \\
\hline Piauí & -101.850 & $-23,4$ \\
\hline Bahia & -583.023 & $-50,9$ \\
\hline \multicolumn{2}{|c|}{ Fonte: IBGE - Produção Agrícola Municipal, 2018a. } \\
\hline
\end{tabular}

Outros dados relevantes referem-se à área destinada aos plantios de eucalipto, no período considerado. Constata-se, na tabela 4, que no Brasil, a área ocupada por essa árvore passou de 3,5 milhões de hectares, em 2006, para 7,5 milhões, em 2016, um acréscimo de 3,9 milhões de hectares, ou seja, 112,5\%. Dos estados do Matopiba, o Maranhão foi o que mais destinou área para essa espécie da silvicultura (168,3 mil hectares), o que corresponde a uma elevação de 180,4\%, entre 2006 e 2016, passando de 93,2 mil hectares para 261,6 mil ha. Em 2006, o Tocantins ainda não havia iniciado o plantio do eucalipto, mas até 2016, havia cedido uma área de 134,7 mil hectares. Observa-se um forte avanço do eucalipto naquela unidade federativa. A Bahia incorporou mais $8,65 \%$, o que corresponde a 46,7 mil hectares, saindo de 540,1 mil ha em 2006 e atingindo 586,8 mil hectares, em 2016. 
Tabela 4. Variação absoluta (hectares) e percentual da área total de arroz, mandioca e feijão do Brasil, Maranhão, Tocantins, Piauí e Bahia, 2006 e 2016

\begin{tabular}{|c|c|c|c|c|}
\hline \multirow{2}{*}{ Localidades } & \multicolumn{2}{|c|}{2006} & 2016 & $\begin{array}{c}2006-2016 \\
\text { hectares }\end{array}$ \\
\hline Brasil & 3.549 .148 & 7.543 .707 & 3.994 .559 & 112,5 \\
\hline Tocantins & & 134.720 & 134.720 & \\
\hline Maranhão & 93.285 & 261.605 & 168.320 & 180,4 \\
\hline Piauí & - & 36.316 & 36.316 & \\
\hline Bahia & 540.172 & 586.889 & 46.717 & 8,6 \\
\hline
\end{tabular}

Fonte: IBGE - Produção da Extração Vegetal e da Silvicultura, 2018b, ABRAF, 2018.

Desse modo, é impossível admitir que os planos governamentais de desenvolvimento formulados para os estados do Maranhão, Piauí, Tocantins e Bahia (Matopiba) obtenham sucesso na perspectiva do desenvolvimento socioeconômico concebido pelas Nações Unidas. Os planos dos estados envolvidos não trazem ações que colaborem decisivamente para que haja desconcentração da terra, tão pouco prioriza a produção de alimentos para atender a demanda interna da população brasileira. Ao invés disso, elenca várias estratégias que vão ao encontro dos interesses dos empresários do agronegócio, acirrando ainda mais a disputa pelas terras agricultáveis desses estados.

Nos planoselaborados do Matopibaestão destacados dados socais e econômicos referentes às pessoas que moram nos municípios abrangidos na região, como renda per capita, índices de desenvolvimento humano, mas não destacam estratégias para melhorias dessas variáveis. Sabe-se que a expansão das monoculturas da soja e eucalipto para o espaço rural desses estados é o reflexo da expansão do capitalismo para a agricultura, em busca de acumulação de capital. Assim, os técnicos formuladores das políticas estatais deveriam antes de articular tais planos, compreender que o capitalismo desconsidera a diversidade da fauna e flora, a escassez dos recursos naturais, o esgotamento humano, e a necessidade da produção de alimentos, que são a fonte essencial da vida.

\section{CONSIDERAÇÕES FINAIS}

O avanço de uma lógica de produção tipicamente capitalista na agricultura brasileira torna-se mais intensa a partir do início dos anos de 1990. As atividades representativas do agronegócio expressas em um arranjo produtivo com características industriais, uso de técnicas de gestão empresarial, mecanização da produção e emprego de mão de obra específica, expandem-se para os últimos espaços de fronteira agrícola no país, que abrangem os estados do Maranhão, Piauí, Tocantins e Bahia (Matopiba).

Como suporte à efetivação desse processo está um conjunto de políticas públicas, concebidas em favor do agronegócio e que são apresentadas sobre a justificativa de promoção do desenvolvimento econômico, mas que secundarizam a agricultura familiar e o universo camponês. O setor agrícola passa a ter restringida sua função social de produtor de gêneros alimentícios e gerador de trabalho, transformando-se em produtor de commodities agrícolas com apoio do aparato estatal e planos governamentais que arregimentam argumentos, ideias e estratégias de desenvolvimento para determinados espaços, como são os planos do Matopiba.

Nesse contexto, as famílias camponesas que são essencialmente produtoras de alimentos, perdem visibilidade, emergindo a presença das grandes empresas, articuladas aos circuitos globais de reprodução do capital, e se torna dominante a produção regular de mercadorias. São incluídas nesses planos de desenvolvimento grandes extensões de terra, para atender a demanda de outros países, o que impõe maior concentração fundiária, com a consequente exclusão do pequeno produtor rural, desarticulando a produção de alimentos destinada ao mercado interno e, portanto, atingindo negativamente a segurança alimentar e nutricional da população. 
Contudo, mais uma vez, é necessário lembrar que "crescimento" e "desenvolvimento" econômico não são sinônimos. Há muito que suas distinções são debatidas e não há consenso em torno disso, porém, pode-se ressaltar que 0 primeiro se refere a um aumento na quantidade de mercadorias e serviços produzidos, enquanto o segundo pressupõe que esse aumento implique melhoria das condições de vida das pessoas, proporcionando, por exemplo, acesso aos serviços de saúde e educação, maior longevidade e mais renda. Para que se caminhe na direção do desenvolvimento neste país, é imprescindível o fortalecimento da agricultura familiar para geração de empregos, alimentos e desconcentração da terra, a fim de garantir acesso aos meios de produção e maior autonomia para 0 camponês, produtor de alimentos, ao invés de continuar a privilegiar econômica e politicamente os grandes produtores rurais.

No atual cenário da produção agrícola, o Brasil é visto como "o celeiro do mundo". Dados oficiais mostram uma forte expansão da área ocupada para produção de matérias primas destinada à exportação, como é o caso das plantações de soja e de eucalipto, especialmente a partir dos anos de 1990. No entanto, no contexto de construção de uma nação verdadeiramente soberana, haveria de esperar que as terras brasileiras fossem utilizadas, primordialmente, para suprir as necessidades internas de alimentos de toda a população e de trabalho dos camponeses.

Os estados do Maranhão, Piauí, Tocantins e Bahia possuem vasta extensão territorial e recursos naturais bastante diversificados, todavia seus indicadores socioeconômicos permanecem entre os mais baixos do país. Com a consolidação da fase neoliberal do capitalismo global e no âmbito do realinhamento das economias periféricas na divisão internacional do trabalho, parece caber a esses estados o papel de

\section{NOTAS}

1 -A expressão MATOPIBA resulta de um acrônimo criado com as iniciais dos estados do Maranhão, Tocantins, Piauí e Bahia. Essa expressão designa uma realidade geográfica que recobre parcialmente os quatro estados mencionados, caracterizada pela expansão de uma fronteira agrícola baseada em tecnologias modernas de alta produtividade (EMBRAPA. 2015). continuarem encampando a opção do governo federal de intensificar a exploração dos recursos naturais e dos espaços rurais, segundo a lógica de acumulação capitalista. As atividades do agronegócio vêm sendo fortalecidas, transformando-se grande parte do espaço rural em um "deserto verde", que avança sobre os espaços antes ocupados por uma diversidade de sujeitos do campo, incluindo pequenos produtores independentes, comunidades quilombolas e áreas indígenas, que vivem, produzem e se reproduzem na terra. Diferentemente da ação do agronegócio - cuja finalidade maior é produzir mercadorias e que, para isso, desconsidera a importância da diversidade de fauna, da flora e dos sujeitos para o equilíbrio do meio ambiente - a existência da agricultura em pequena escala pressupõe e necessita a utilização parcimoniosa dos recursos naturais, além de comportar uma larga diversidade de formas de exploração e de emprego de mão de obra.

A terra para o fortalecimento da agricultura familiar e para a exploração por camponeses cooperados poderia ou deveria ser a base das políticas agrícola e agrária no Brasil. Há que se admitir que melhores condições de produção e de vida nos espaços rurais implicariam melhoria no espaço urbano. A geração de alimentos saudáveis e de empregos no campo poderia reduzir a pressão populacional e a violência nas cidades. Esse tipo de opção de desenvolvimento, porém, não foi o que se mostrou dominante na trajetória recente do país e, em particular, dos estados do Matopiba (Maranhão, Tocantins, Piauí e Bahia), com a expansão da produção de commodities e suas implicações para a produção local de alimentos, para o desmatamento na região e, indiretamente, para as condições de vida nas cidades próximas aos locais onde se instalam os empreendimentos do agronegócio.

2 - Para o estado do Maranhão, por exemplo, o plano contém estratégias para a elevação da produção da pecuária, arroz irrigado, extrativismo do bacuri, reflorestamento com eucalipto, bambu e sabiá, além de apontar as necessidades de investimento em infraestrutura como poços, eixo da Ferrovia Carajás-Itaqui e energia.

3 - O conceito de desenvolvimento humano, bem como sua medida, o Índice de 
Desenvolvimento Humano, IDH, foram apresentados em 1990, no primeiro Relatório de Desenvolvimento Humano do Programa das Nações Unidas para o Desenvolvimento, idealizado pelo economista paquistanês MahbubulHaq e com a colaboração e inspiração no pensamento do economista Amartya Sen. A popularização da abordagem de desenvolvimento humano se deu com a criação e adoção do IDH como medida do grau de desenvolvimento humano de um país,

\section{REFERÊNCIAS}

[1]. ABRAF. Anuário Estatístico da ABRAF, 2007, ano base 2006. Disponível em <http://www.ipef.br/estatisticas/relatorios/anuarioABRAF-2007.pdf.> Acesso em: 10 mar. 2017.

[2]. BRASIL. Decreto-Lei no 8.447, de 6 de maio de 2015. Dispõe sobre o Plano de Desenvolvimento Agropecuário do Matopiba e a criação de seu Comitê Gestor. Disponível em: $<$ http://www.planalto.gov.br/ccivil_03/_ato20152018/2015/decreto/d8447.htm >. Acesso em: 20 mar. 2018.

[3]. BUAINAIN, A. M.; GARCIA, J. R.; VIEIRA FILHO, J. E. R. Dinâmica da economia e da agropecuária no Matopiba. Texto para Discussão 2.283, 2017 Disponível em: $<$ repositorio.ipea.gov.br/bitstream/11058/7574/1/TD _2283.PDF>. Acesso em: 5 mar. 2018.

[4]. DELGADO, G. C. Especialização primária como limite ao desenvolvimento. Desenvolvimento em debate, v. 1, n. 2, p. 111-125, 2010. Disponível em:

<http://desenvolvimentoemdebate.ie.ufrj.br/pdf/dd_ guilherme.pdf>. Acesso em: 3 fev. 2018.

[5]. EMBRAPA.Matopiba delimitação, caracterização, desafios e oportunidades para o desenvolvimento Piauí, 2015. Disponível em: $<$ https://www.embrapa.br/gite/projetos/ matopiba/150514_MATOPIBA_PI.pdfpdf>. Acesso em: 6 fev. 2018.

[6]. EMBRAPA. Matopiba delimitação, caracterização, desafios e oportunidades para o desenvolvimento. 2014. Disponível em: <https://www.embrapa.br/gite/publicacoes/ NT1_DelimitacaoMatopiba.pdf>. Acesso em: $6 \mathrm{fev}$. 2018 .

[7]. EMBRAPA. Matopiba delimitação, caracterização, desafios e oportunidades para o desenvolvimento Maranhão 2015. Disponível em:<https://www.embrapa.br/gite/

projetos/matopiba/150514_MATOPIBA_MA.pdf>. Acesso em: 6 fev. 2018.

[8]. EMBRAPA. Matopiba delimitação, caracterização, desafios e oportunidades para o desenvolvimento Bahia. 2015. Disponível em: <https://www.embrapa.br/gite/ em alternativa ao Produto Interno Bruto, hegemônico à época como medida de desenvolvimento. $\mathrm{O}$ IDH reúne três dos requisitos mais importantes para a expansão das liberdades das pessoas: a oportunidade de se levar uma vida longa e saudável saúde -, ter acesso ao conhecimento educação - e poder desfrutar de um padrão de vida digno - renda " (PNUD; IPEA; FJP, 2013 p. 27).

projetos/matopiba/150515_MATOPIBA_BA.pdf. Acesso em: 6 fev. 2018.

[9]. EMBRAPA. Matopiba delimitação, caracterização, desafios e oportunidades para o desenvolvimento Tocantins. 2015. Disponível em: <https://www.embrapa.br/gite/ projetos/matopiba/150513_MATOPIBA_TO.pdf>. Acesso em: 6 fev. 2018.

[10]. FOLADORI, G.; MELAZZI, G.; KILPP, P. A economia da sociedade capitalista e suas crises recorrentes. São Paulo: Outras expressões, 2016.

[11]. GRAMSCI, A. Cadernos do cárcere. Rio de Janeiro: Civilização Brasileira, v. 2, 2 ed., 2001.

[12]. HARVEY, D. A produção capitalista do espaço. São Paulo: Annablume, 2005.

[13]. IBGE. Censo agropecuário 2006.

[14]. IBGE. Produção Agrícola Municipal. 2018a. Disponível em: <https:// https://sidra.ibge.gov.br/Tabela/1612. Acesso em 8 set. 2017.

[15]. IBGE. Produção da extração vegetal e da silvicultura. 2018b. Disponível em: <https://sidra.ibge.gov.br/tabela/5930>. Acesso em: 8 set. 2017 .

[16]. LAMARCHE, H. (coord.). A agricultura familiar: comparação internacional. v. 1. Campinas: Editora da Unicamp, 1993

[17]. MARX, K. O 18 de Brumário de Luís Bonaparte. São Paulo: Boitempo, 2008.

[18]. . O capital: crítica da economia política. São Paulo: Nova Cultural, 1996.

[19]. MDA. Brasil: 70\% dos alimentos que vão à mesa dos brasileiros são da agricultura familiar, $2017 . \quad$ Disponível em: <http://www.mda.gov.br/sitemda/noticias/brasil-70dos-alimentos-que-vão-à-mesa-dos-brasileiros-sãoda-agricultura-familiar>. Acesso em 25 mar. 2018.

[20]. PITTA. F. T.; VEGA. G. C. Impactos da expansão do agronegócio no Matopiba: comunidade e meio ambiente. Rio de Janeiro: [s.n.], 2017.Disponível em: <https://www.tratamentodeagua.com.br/wp- 
content/uploads/2017/09/expansao-agronegociomatopiba.pdf>. Acesso em: 2 mar. 2017.

[21]. PNUD; IPEA; FJP. Atlas de desenvolvimento humano do Brasil de 2013. 2013. Disponível em: <www.atlasbrasil.org.br/2013/data/rawData/idhmdo-brasil.pdf>. Acesso em: 5 mai. 2015.

[22]. PRADO JR., C. A. Questão Agrária. 4.ed. São Paulo: Brasiliense, 1979.

[23]. SILVA, H. O. Agricultura Familiar: Diversidade e adaptabilidade. Revista de Sociologia e Política, Curitiba, n. 12, p. 161-167 1999. Disponível em: <http://www.redalyc.org/articulo.oa?id=23801212>. Acesso em: 2 fev. 2018.
[24]. SILVA, J. G. O que é questão agrária. 4 ed. São Paulo: Ed. Brasiliense, 1981.

[25]. SORJ, B. Estado e classes sociais na agricultura brasileira. Rio de Janeiro: Centro Edelstein de Pesquisas Sociais, 2008.

[26]. WANDERLEY, M. N. B. Raízes históricas do campesinato brasileiro. In: XX Encontro Anual da ANPOCS, 1996, Caxambu - MG. Disponível em: <http://www.reformaagrariaemdados.org.br/sites/d efault/files/Raízes\%20Historicas\%20do\%20Campes inato\%20Brasileiro\%20-

\%20Maria\%20de\%20Nazareth\%20Baudel\%20Wan derley\%20-\%201996.pdf>. Acesso em: 2 fev. 2018. 


\section{Bapítulo 13}

\section{A FORMAÇÃO DO PREÇO DAS COMMODITIES ARROZ, MILHO E SOJA NO BRASIL}

\section{Elizangela Beckmann}

Antônio Cordeiro de Santana

Resumo: No Brasil, commodities agrícolas como arroz, milho e soja têm importância tanto no abastecimento do mercado interno, quanto no equilíbrio da balança comercial do país. O mercado de commodities é comumente visto sob as características da concorrência perfeita, o que torna o produtor rural um tomador de preço. Portanto, informações sobre o comportamento destes preços são determinantes para as decisões dos agricultores. Assim, o objetivo desta pesquisa foi identificar as funções de demanda, oferta e preço dessas commodities considerando as variáveis tradicionais, adicionadas das tecnologias (biológicas, técnicas de cultivo, máquinas e equipamentos de precisão) para explicitar o mercado. Nos modelos tradicionais, o preço aparece como variável única e, neste trabalho, tem-se um modelo simultâneo. Os resultados indicam que demanda e oferta de commodities são inelásticas a preço e, no caso da função de peço de equilíbrio, a variável tecnologia teve forte influência negativa sobre os preços das commodities no país. Conclui-se que é importante considerar variáveis modernas na formação das funções de demanda, oferta e preço de mercado das commodities, uma vez que estas se mostraram significativas e com efeito representativo, principalmente no caso do preço, que normalmente não é calculado como função separada da oferta e da demanda. Um modelo com maior número de variáveis tende a ser mais completo e auxiliar de maneira mais eficiente na tomada de decisão, na medida que fornece mais informações aos interessados no mercado de commodities nacional.

Palavras-chave: Agricultura. Equações Simultâneas. Tecnologia. 


\section{INTRODUÇÃO}

O Brasil está entre os maiores produtores e/ou exportadores das commodities arroz, milho e soja no mundo. Conforme dados da FAO (2016) o país está entre as 10 maiores economias do mundo, sendo o setor agrícola de suma importância para tal. A produção de soja, milho e arroz em 2016 está prevista em mais de 192 milhões de toneladas, das quais 82 milhões de toneladas são para exportação, sendo a soja o produto de maior destaque, com produção de 100,1 milhões de toneladas, tendo mais de 50\% como destino as exportações. A agricultura brasileira é vista por analistas, governos, instituições e parte da sociedade como uma referência de sucesso para outros países.

Nesta perspectiva, Vieira Filho (2014) menciona que a fronteira agrícola no País se expandiu em duas fases: a primeira resultou dos elevados investimentos realizados nas décadas de 1960 e 1970, que levaram o Centro-Oeste a se transformar na região maior produtora de grãos do Brasil na década de 1980; e a segunda ocorreu a partir da década de 1990, em direção da região MAPITOBA (Maranhão, Piauí, Tocantins e Bahia), que contribuiu para a produção brasileira (da soja, por exemplo) em 2012 igualar-se à produção norte-americana.

A agricultura brasileira destaca-se pela modernização tecnológica, que se acelerou a partir da década de 1960 e teve como alicerce os princípios estabelecidos na Revolução Verde, que produziu mudanças no sistema de produção agrícola, baseado no melhoramento genético das plantas, uso intensivo de fertilizantes e de defensivos agrícolas, atrelados a novas técnicas de cultivo que redefiniram a forma de organização e gestão desse sistema produtivo. Assim, a produção agrícola evoluiu nas últimas décadas com a influência de empresas multinacionais que atuaram junto aos produtores para utilizarem "pacotes tecnológicos", que incluem desde a venda de insumos para produção até a compra do produto final da lavoura (GONÇALVES; LEMOS, 2011; VIEIRA FILHO, 2014).

Conforme dados da Companhia Nacional de Abastecimento (CONAB, 2015), entre as safras 1979/1980 e 2007/2008, a produção de soja aumentou $300 \%$, a de milho $200 \%$ e a de arroz $25 \%$, sendo a cultura menos expressiva dentre os grãos produzidos, podendo ser justificada pelo menor valor da produção deste cultivo, não sendo atrativo aos grandes produtores ( SANTOS, 2010). Em 2015, a safra de soja colhida foi de 99 milhões de toneladas, ou seja, em sete anos aumentou a produção em $60 \%$. O milho teve a produção incrementada em 44,4\%, sendo produzidas mais de 84 milhões de toneladas. Quanto ao arroz, o incremento foi de $3 \%$, cerca de 12 milhões de toneladas.

Além da expansão da produção, a área cultivada de soja, milho e arroz apresentou uma evolução relativamente modesta, incrementando de 27 milhões para 38 milhões de hectares entre 1980 e 2008 (incremento de $40 \%$ ). Em 2015, a área das três lavouras somou 53 milhões de hectares. O rendimento médio da produção destes grãos, por sua vez, saltou de 1,5 t/ha para 3,5 t/ha, destacando-se como principal fator responsável pela expansão da produção (CONAB, 2015).

O rendimento de soja por hectare foi maior em 66\% entre as safras 1979/1980 e $2007 / 2008$, o de milho aumento $120 \%$ e o de arroz 182\%. Em 2015, o rendimento médio da soja foi cerca de 3 toneladas por hectare, para o milho 5,3 e para o arroz 5,4 toneladas por hectare cultivado. As informações confirmam que o peso maior do incremento da produção deve-se ao efeito rendimento da terra relativamente à expansão de área cultivada (CONAB, 2015).

O aumento do rendimento pode ser atribuído a fatores como qualificação da mão de obra, uso mais eficiente das máquinas e equipamentos, uso de cultivares mais resistentes e adaptadas, uso de sementes geneticamente modificadas, além de investimentos em novas práticas. Melhorias neste sentido vem de encontro com as novas leis ambientais, cujo foco está em reduzir a abertura de novas áreas, pois como afirmado em Buainain et al. (2014), na década de 2000 o crescimento da produção agrícola brasileira pela expansão de área foi sendo lentamente substituído pela elevação da produtividade total dos fatores, calcada no uso intensivo de tecnologia. Logo, o aumento da produção tem ocorrido em virtude da tecnologia aplicada nos cultivos, a fim de garantir a segurança alimentar do país.

Observa-se que o aumento da produtividade, devido a inovações tecnológicas (plantas adaptadas para novos climas e resistentes às pragas, novas técnicas de cultivo, máquinas e equipamento de precisão), acarretou 
aumentos na produção e, por consequência, queda nos preços das commodities. Mesmo diante desta queda de preços, a oferta continuou aumentando, o que contraria a lei da oferta. Isto está ocorrendo porque o deslocamento da oferta ocorre pelo incremento da produtividade que gera redução nos custos unitários superiores às quedas de preço, mantendo e/ou incrementando a receita líquida dos produtores.

A série de dados sobre preço e rendimento das commodities de 1980 a 2008 se comportam com nítida assimetria, com queda no preço e aumento do rendimento (Figura 1).

Este efeito nos preços causado pelo incremento na produtividade mostra que não se pode analisar somente o preço de mercado das commodities por meio dos métodos tradicionais, mas incorporando metodologias que incluam as informações que definem demanda, oferta e preços de forma simultânea, sendo esta a originalidade deste trabalho. Assim, é relevante entender se as variáveis consideradas não tradicionais interferem na demanda, oferta e preços das commodities.

Figura 1: Preço e Rendimento das commodities arroz, milho e soja no Brasil entre 1980 e 2008

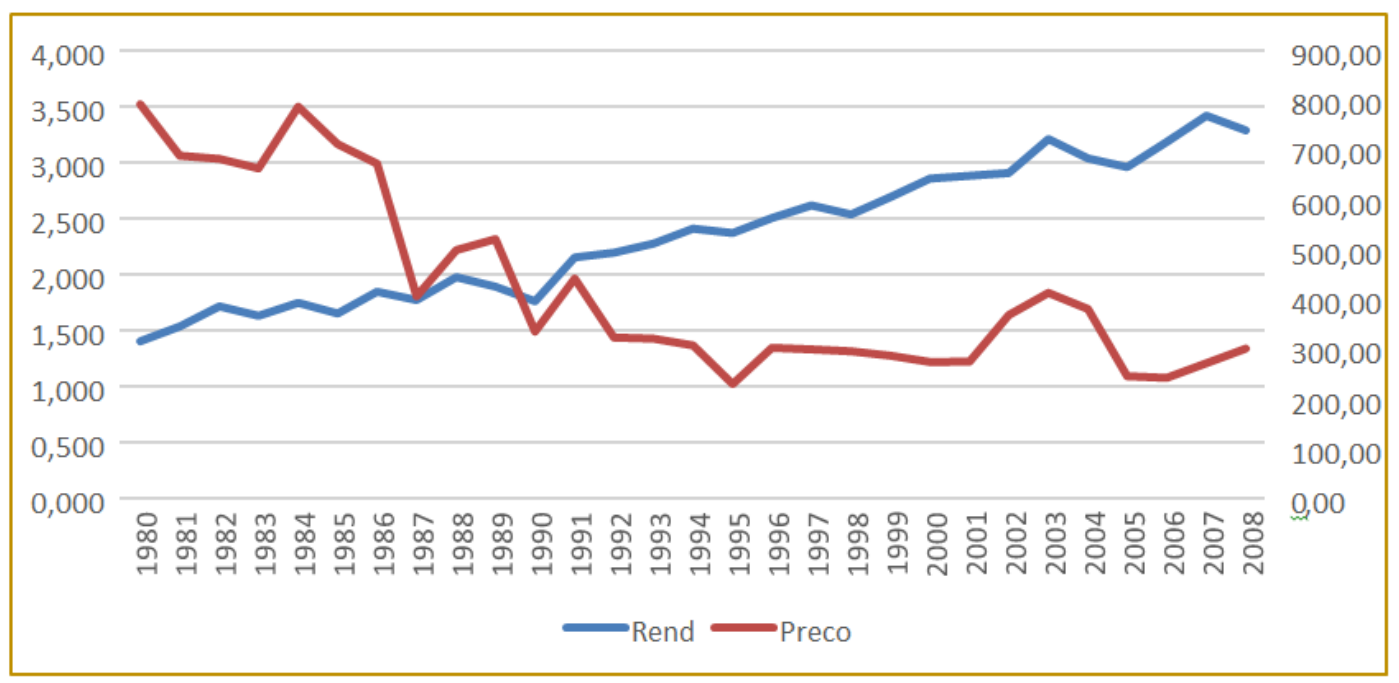

Fonte: Dados da Pesquisa. Elaborada pela autora com base em IBGE (2015).

Não se tem registros de estimação da equação de preços neste formato. O caso comum ocorre nos trabalhos que estudam a transmissão de preços de alguns produtos agrícolas por meio de modelos univariados, que relacionam os preços com o mercado externo, câmbio, taxa de juros e mercado futuro. Assume-se que, no setor agrícola quem orienta as decisões é o preço, ainda mais quando se tem dificuldade de mão de obra e, quando a tecnologia se torna ainda mais importante. Assim, o produtor obriga-se a utilizar as novas tecnologias, caso queira continuar no mercado. Logo, considerar o efeito de variáveis definidoras das tecnologias modernas utilizadas é uma contribuição para a tomada de decisão dos agentes que atuam no setor de commodities.

Entre os estudos já realizados para o mercado de grãos, destaca-se o de Pino e
Rocha (1994), que estima a influência das cotações dos contratos futuros da Bolsa de Chicago (Chicago Board of Trade - CBOT) sobre os preços da soja. Lovadine e Bacchi (2005), que analisam a causalidade e a transmissão de preços dos produtos do complexo da soja (grão, farelo e óleo) entre os mercados brasileiro e internacional, no período de janeiro de 1999 a janeiro de 2004. Margarido, Turolla e Fernandes (2001), que analisaram a elasticidade da transmissão de preços no mercado de grão de soja entre o Porto de Rotterdam e o Brasil, entre julho de 1994 e setembro de 2000, a partir de um modelo baseado em Mundlack e Larson (1992), o qual mostra como variações nos preços externos refletem-se em variações nos preços internos, tendo como base a Lei do Preço Único. Com este modelo, pode-se escrever o preço doméstico do produto agrícola como função do preço internacional 
da commodity agrícola, da taxa de câmbio nominal e da política comercial adotada. E, Mafioletti (2000) estudou a formação e transmissão de preços no complexo da soja ao produtor, no atacado e no varejo, considerando os mercados interno e externo.

Para o arroz e o milho, não há a mesma disponibilidade de estudos. Caldarelli e Bacchi (2010) fizeram a análise simultânea da oferta, demanda e preço do milho, sendo o preço deste estimado com influência apenas do variável preço da soja. Libera (2009) em seu estudo sobre transmissão de preços entre os mercados físico a nível de produtor e futuro para as commodities milho e soja no Brasil, concluiu que há transmissão de preços entre os mercados físico da soja e futuro do milho. Santos et al. (2007) estudaram a causalidade entre o preço internacional do milho e o recebido pelo produtor brasileiro entre 1996 e 2006. No mesmo sentido, Block et al. (2012), concluíram que o etanol hidratado influencia o preço da cana de açúcar e do açúcar no Estado de São Paulo. E ainda se tem na literatura trabalhos de transmissão de preços para trigo, café e algodão (SOUSA; CAMPUS, 2009; CORONEL et al., 2010; CUNHA, 2008).

Estes modelos, entretanto, não captam os efeitos das variáveis que induzem as mudanças estruturais no sistema de produção e que causam as dinâmicas de evolução da produção. Ou seja, as decisões são incompletas por conta de um problema de mensuração do cenário oferecido para a tomada de decisão por parte dos agentes, sobretudo os produtores que compõem o elo mais fraco da cadeia. Portanto, o nível de conhecimento oferecido para a tomada de decisão dos agentes que participam destas atividades é limitado e pode levar a decisões enviesadas sobre a realidade do mercado.

Os modelos tradicionais de transmissão de preços especificados a partir de séries temporais univariadas geram informações limitadas para orientar a formulação de estratégias competitivas e para a tomada de decisão dos agentes. Para atenuar este problema, utilizou-se a especificação de um modelo simultâneo, em que as funções de demanda, oferta e preço são estimadas simultaneamente e com maior número de variáveis, inclusive considerando o erro para captar as demais variáveis (biotecnológicas, climáticas, técnicas de plantio, máquinas e equipamentos) não demonstradas, dando base melhor para explicar o comportamento do preço das commodities.
A hipótese estabelecida neste trabalho $\left(\mathrm{H}_{1}\right)$ foi de que o rendimento das lavouras comerciais produz deslocamentos sistemáticos na curva de oferta, a ponto de produzir um comportamento em longo prazo que resulta em uma trajetória inversa entre preços de equilíbrio e quantidade produzida, pois o rendimento das lavouras, mesmo com preços em queda, é cada vez maior. A causa fundamental do aumento de produtividade destas lavouras está na utilização de tecnologias biológicas de melhoramento genético das plantas, que propicia a combinação de um maior adensamento de plantas por unidade de área, resistência a pragas e doenças, adequação às condições climáticas e a incorporação de informações e resultados de pesquisas.

Assim, o objetivo da pesquisa foi estimar as funções de demanda, oferta e preço das commodities arroz, milho e soja para o Brasil, visando contribuir para uma tomada de decisão dos agentes com base no conhecimento dos efeitos das variáveis consideradas nos modelos tradicionais (preço, renda) e como diferencial, das variáveis área cultivada, fertilizantes e tecnologias. As variáveis quantidade e preço também são incluídas com defasagem, para especificar o modelo na forma dinâmica e permitir a estimação dos parâmetros das equações de longo prazo. No presente trabalho, pensa-se no setor agrícola como concorrencial, sendo uma contribuição pioneira ao estudo de mercado das commodities nacional, uma vez que se faz uma análise da equação de equilíbrio de preços separadamente à demanda e a oferta.

\section{MATERIAL E MÉTODOS}

Especificou-se um modelo de equações simultâneas, contemplando as equações de demanda, oferta e preço das commodities. Os dados utilizados na pesquisa referem-se às três principais commodities cultivadas no Brasil: soja, milho e arroz, para o período de 1980 e 2008. A base de dados foi obtida no Instituto Brasileiro de Geografia e Estatística (IBGE, 2015).

A identificação da influência da tecnologia de produção sobre o rendimento (Rend) das commodities no Brasil compreende o passo inicial do trabalho. Assume-se, portanto, que a variável Rend é determinada pelo uso de fertilizante (Fert) e o efeito das demais variáveis que compõe a tecnologia (biológica, 
novas técnicas de cultivo, máquinas $e$ equipamentos) que será captado pelo termo de erro aleatório $\left(\varepsilon_{t}\right)$ da equação (1), para o período de tempo da análise 1980-2008. A especificação da equação de rendimento, na forma logarítmica é a seguinte:

$$
\operatorname{lnRend}_{t}=\beta_{0}+\beta_{1} \operatorname{lnFert} t+\varepsilon_{t}
$$

O termo de erro da equação (1), incorpora a influência de outras variáveis como as condições climáticas que propiciam a otimização do impacto do fertilizante e de defensivos agrícolas sobre o rendimento, o câmbio, assistência técnica e a sozonalidade. O modelo não incorpora o efeito do clima sobre o rendimento das lavouras de grãos como variável direta, por falta de informações. Cabe ressaltar que com condições climáticas favoráveis (precipitações pluviométricas no período normal e com distribuição dentro da média esperada para as lavouras, juntamente com ventos e calor), tem-se o máximo da contribuição do fertilizante e controle fitossanitário para o rendimento. Condições fora desse padrão causam efeitos negativos sobre o rendimento.
A seguir, procurou-se identificar esse efeito da tecnologia $\left(\varepsilon_{t}\right)$ sobre a estrutura de formação do preço das lavouras de grãos no Brasil. A teoria econômica define que, em livre concorrência de mercado, os preços são formados com base em uma estrutura de oferta e demanda do produto (MARSHALL, 1982 apud SANTANA; SANTANA; CAMPOS, 2011).

Nesse contexto, as principais variáveis relacionadas à demanda de um produto são o preço de mercado $\left(P_{t}\right)$ e a renda do consumidor $\left(R_{t}\right)$. A quantidade demandada do produto $\left(\mathrm{Q}_{\mathrm{td}}\right)$ pode ser especificada na forma logarítmica:

$$
\ln Q_{t}^{d}=\alpha_{0}+\alpha_{1} \ln P_{t}+\alpha_{2} \ln R_{t}+\mu_{t}
$$

Em que, $\alpha_{\mathrm{i}}(\mathrm{i}=0,1,2)$ representa, respectivamente, o intercepto, a influência do preço e da renda na quantidade demandada e $\mu$ o termo de erro aleatório.
A quantidade ofertada $\left(\mathrm{Q}_{\mathrm{ts}}\right)$ é o produto da área plantada (Area) pelo rendimento (Rend). Ou seja:

$$
Q_{t}{ }^{s}=\operatorname{Area}_{t} \varphi^{\varphi^{1}} \operatorname{Rend}_{t} \varphi^{\varphi^{2}}
$$

Em que $\varphi_{1}$ e $\varphi_{2}$ são, respectivamente, a participação da área plantada e do rendimento na produção total de cultivos de grãos no Brasil.

Aplicando logaritmo na equação (3), tem-se: 
E substituindo (1) em (4), tem-se:

$$
\ln Q_{t}{ }^{s}=\varphi_{1} \ln \text { Area }_{t}+\varphi_{2} \beta_{0}+\varphi_{2} \beta_{1} \ln \operatorname{Fert}_{t}+\varphi_{2} \varepsilon_{t}
$$

A situação de equilíbrio obtém-se igualando as equações de oferta e demanda, ou seja, as equações (2) e (5):

$$
\varphi_{1} \ln \text { Area }_{t}+\varphi_{2} \beta_{0}+\varphi_{2} \beta_{1} \operatorname{lnFert} t_{t}+\varphi_{2} \varepsilon_{t}=\alpha_{0}+\alpha_{1} \ln P_{t}+\alpha_{2} \ln R_{t}+\mu_{t}(6)
$$

Isolando a variável preço da equação (6), assumida como variável endógena no sistema de mercado, tem-se a equação (7).

$$
\ln P t=\varphi \underline{2} \beta \alpha \underline{0} 1-\alpha \underline{0}+\varphi \alpha \underline{1} \ln A r e a t+\varphi \alpha \underline{2} \beta 1 \underline{1} \ln F e r t t-\alpha \alpha \underline{2} 1 \ln R t+\varphi \alpha 1 \underline{2} \varepsilon t-\alpha-11 \mu t
$$

A equação (7) indica a formação do preço nacional das lavouras de grãos em função da condição de equilíbrio entre oferta e demanda no mercado brasileiro.

Além disso, se houver presença de autocorrelação serial de primeira ordem no modelo, adiciona-se o preço defasado $(t-1)$ das commodities na equação (7), obtendo-se o seguinte modelo:

$\ln P t=\varphi \underline{2 \beta} \alpha \underline{0} 1-\alpha \underline{0}+\varphi \alpha 1 \underline{1} \ln A r e a t+\varphi \alpha \underline{2} \beta 1 \underline{1} \ln F e r t t-\alpha \alpha 1 \underline{\ln R t}+\varphi \alpha 1 \underline{2} \varepsilon t+\theta 1 \ln P t-1-\alpha-11 \mu t$

O primeiro termo à direita da igualdade da equação 8 é a constante. Dado que a quantidade demandada é inversamente relacionada com o preço, tem-se que $\square_{1}$ deve apresentar sinal negativo e os demais coeficientes sinais positivos. Portanto, esperam-se valores negativos para as elasticidades de transmissão sobre o preço 
nacional das commodities em relação às variáveis: Area ${ }_{t}$, Ferti $_{t}$ e $\varepsilon_{\tau}$.

A razão disso é que uma variação positiva nestas variáveis tende a aumentar a oferta dos grãos, o que provoca reduções nos preços de equilíbrio do mercado. Um sinal positivo é esperado para a variável $R_{t}$ e um sinal negativo para a variável $P_{t-1}$. No caso da renda, isto se justifica porque um aumento nesta variável (tudo o mais constante) tende a produzir um deslocamento da demanda, influenciando positivamente o preço de equilíbrio. E, o sinal negativo esperado para a variável $P_{t-1}$, geralmente se verifica em função da correlação temporal descendente da série de preços das commodities brasileiras, em função da trajetória de mudanças tecnológicas que resultaram em sucessivos incrementos de produtividade ao longo do tempo.

A fim de constatar a efetividade dos pressupostos a serem alcançados na pesquisa de melhoramento genético de plantas, por meio da produção contínua de sementes de alta produtividade e resistentes a pragas e doenças, espera-se um coeficiente negativo e significativo para a variável $\boldsymbol{\varepsilon}_{\tau}$ e um coeficiente positivo e significativo para Area ${ }_{t}$.

\subsection{MODELO ECONOMÉTRICO}

O modelo econométrico estrutural é especificado por um sistema de equações simultâneas envolvendo a demanda, oferta e preço das commodities.

$$
\begin{aligned}
& \ln Q_{t}^{d}=\alpha_{0}+\alpha_{1} \ln P_{t}+\alpha_{2} \ln R_{t}+\mu_{1 t} \\
& \quad \ln Q_{t}^{s}=\beta_{0}+\beta_{1} \ln \text { Area }_{t}+\beta_{2} \ln F e r t_{t}+\beta_{3} \ln P_{t-1}+\beta_{4} \ln Q_{t-1}+\mu_{2 t} \\
& \ln P_{t}=\phi_{0}+\phi_{1} \ln F e r t_{t}+\phi_{2} \ln R_{t}+\phi_{3} \varepsilon_{t}+\mu_{3 t}
\end{aligned}
$$

Variáveis Endógenas:

$\angle n Q_{t}=$ logaritmo natural da quantidade demandada e ofertada das commodities arroz, milho e soja no período de 1980 a 2008, em toneladas;

$L n P_{t}=$ logaritmo natural do índice de preços das commodities arroz, milho e soja no período de 1980 a 2008, em $\mathrm{R} \$ / \mathrm{t}$;

Variáveis Exógenas e Instrumentais:

$L n Q_{t-1}=$ logaritmo natural da quantidade produzida das commodities arroz, milho e soja defasada de um período (1979-2007);

$L n P_{t-1}=$ logaritmo natural do índice de preços das commodities arroz, milho e soja defasado de um período (1979-2007);
$L n R_{t}=$ logaritmo natural da renda, representada pelo PIB per capita do Brasil, no período de 1980 a 2008, em $\mathrm{R} \$$;

$L n$ Area $_{t}=$ logaritmo natural da área colhida das commodities arroz, milho e soja do

Brasil no período de 1980 a 2008, em hectares;

Area $_{t-1}=$ área defasada de um período como variável instrumental (1979-2007);

$\mathrm{LnFert}_{t}=$ logaritmo natural da quantidade de fertilizantes utilizada nas commodities arroz, milho e soja no período 1980 a 2008, em t/ha; $\varepsilon_{\mathrm{t}}=$ efeito das variáveis que compõe a tecnologia (biológica, técnicas de cultivo, máquinas e equipamentos);

$\mu_{1,2,3}=$ termos de erro das equações. 
Os parâmetros do modelo foram estimados pelo método generalizado dos momentos (MGM), que conforme mencionado em Santana, Santana e Santos (2011) tem vantagens em relação a outros métodos generalizados de estimação de sistemas de equações por permitir incorporar variáveis instrumentais defasadas, para que se possa captar seus efeitos dinâmicos sobre o modelo estrutural. A estimação do modelo foi realizada por meio do software Eviews 6.0.

Para testar a adequação do sistema de equações por MGM, assim como em Santana, Santana e Santos (2011), utilizou-se o teste j de Hansen, sendo que com a obtenção de um valor próximo de zero para este teste, confirmam-se que as condições de momentos sobreidenficadoras foram satisfeitas.

Considerando que o mercado das commodities arroz, milho e soja funciona como concorrencial e desconsiderando a atuação das tradings, cuja estrutura se aproxima de um oligopólio na formação dos preços, tem-se que é grande o número de produtores e compradores de grãos, sendo que cada um transaciona uma pequena parcela da oferta de grãos. A escala de cada produtor é pequena em relação à demanda de grãos, ou seja, o produtor é tomador de preço.

Outras características definidas claramente na teoria econômica (VARIAN, 2012; PINDYCCK; RUBINFELD, 2010) que aproximam este mercado da concorrência perfeita são o fato de o produto ser homogêneo, ou seja, a soja, o milho e o arroz comercializados por um produtor são iguais aos dos demais. São substitutos perfeitos, logo não há preferência por um fornecedor, os agentes conhecem o preço, custos, frete, transporte e há mobilidade de fatores entre as atividades e as regiões produtoras, devido a novas oportunidades e por fim, não existem barreiras impedindo a entrada e saída dos agentes do mercado de commodities.

Sendo que a produção de grãos ocorre em todos os estados brasileiros, este estudo pode servir de base para a tomada de decisão e o estabelecimento dos preços das commodities a nível nacional. Com base na teoria microeconômica e especificamente na realidade do mercado de commodities nacional, a demanda foi estimada em função do preço e da renda. Espera-se uma relação inversa entre preço e quantidade demandada, ou seja, a cada aumento nos preços haverá redução na demanda e, uma relação direta entre renda e demanda, uma vez que aumento na renda faz com que a demanda aumente, ceteris paribus.

A oferta de commodities é realizada tanto por pequenos agricultores quanto por latifundiários. De acordo com a teoria da firma espera-se uma relação positiva entre oferta e área colhida de commodities, uma vez que quando se aumenta a área há aumento na produção de grãos. Quanto a variável fertilizantes, considerado como influenciador no aumento da produção, também se espera que tenha sinal positivo para oferta.

A variável preço, que foi considerada com defasagem de um período, espera-se que tenha sinal negativo, pois um aumento de preços atuais faz com que a oferta atual aumente, o que reflete em redução de preço no ano seguinte e consequente queda na oferta do ano seguinte. Já para quantidade defasada de um período, espera-se um sinal positivo, pois com aumento na produção de commodities no ano atual, mediante o uso intensivo de tecnologias e devido à baixa mobilidade de fatores do setor agrícola, a produção do ano seguinte ainda continuará aumentando.

No sistema está inclusa a equação de preço das commodities, pois afirma-se não ser apenas uma variável explicativa da demanda e da oferta, mas uma variável endógena a ser explicada pelo uso de fertilizantes e da tecnologia (captando o efeito da oferta) e pela renda (captando o efeito da demanda). Neste caso, espera-se que o preço seja influenciado negativamente pelo uso de fertilizantes, ou seja, quanto mais fertilizantes, mais se produz e menor será o preço das commodities. Quanto a renda, espera-se uma relação positiva, ou seja, um aumento na renda desloca positivamente a demanda, o que aumenta o preço dos grãos. $E$, quanto a tecnologia, espera-se um coeficiente negativo, pois na medida que se usam mais tecnologias nos cultivos, maior a produção e menor o preço dos grãos.

As variáveis instrumentais defasadas de um período foram incluídas para adicionar mais informação ao modelo e torná-lo mais bem especificado a luz da teoria e das condições reais em que o mercado opera. As estimativas dos parâmetros da oferta e da demanda são interpretadas como elasticidades, sendo a medida da sensibilidade de uma variável em relação a outra (PINDYCK; RUBINFELD,2010) 
uma vez que as equações foram especificadas na forma logarítmica. E, os coeficientes associados às variáveis que explicam o comportamento do preço são analisados como flexibilidade-preço, dado que a equação está na forma inversa.

\section{RESULTADOS E DISCUSSÃO}

Os parâmetros estimados se comportaram de acordo com o esperado. A estatística "j" indicou que o modelo foi adequadamente especificado. Assim, o modelo de demanda e oferta de commodities apresentou valor de $\mathrm{j}=$ 0,300038, sinalizando que as condições de momento foram satisfeitas e os parâmetros estimados são robustos. Para todas as funções foram utilizadas como variáveis instrumentais preço, quantidade e área defasadas de um período, renda, fertilizantes, área e rendimento.

Os sinais dos parâmetros do sistema de equações estão de acordo com o esperado segundo a teoria e se apresentam significativos a $1 \%$ de probabilidade, exceto a variável preço na equação de demanda que foi significativa a 3,44\%. Ou seja, as variáveis explicativas, em conjunto, validam os resultados das equações de demanda, oferta e preço das commodities arroz, milho e soja no Brasil.

Os resultados para equação da demanda são evidenciados na Tabela 1. Estes resultados mostram que $84,57 \%$ das variações na quantidade demandada de commodities são explicadas diretamente por variações simultâneas no preço e na renda e indiretamente pelas variáveis instrumentais. 0 coeficiente associado ao preço apresentou sinal negativo, indicando uma relação inversa com a quantidade demandada e a renda apresentou sinal positivo, mostrando que aumentos na renda causam incremento na demanda por commodities.

Tabela 1: Resultados da equação de demanda por commodities no Brasil.

\begin{tabular}{|l|c|c|c|c|}
\hline \multicolumn{2}{|c|}{ Variável dependente: LnQd } \\
\hline Variável & Coeficiente & Desvio padrão & Estatística-t & Probabilidades \\
\hline Constante & 0,655103 & 0,766825 & 0,854305 & 0,3957 \\
\hline LnP & $-0,088841$ & 0,041227 & $-2,154.948$ & 0,0344 \\
\hline LnRenda & 1,285438 & 0,063453 & $2,025.805$ & 0,0000 \\
\hline R-quadrado & 0,845767 & & & \\
\hline R-quadrado ajustado & 0,833903 & & & \\
\hline
\end{tabular}

Fonte: Dados da pesquisa.

A elasticidade-preço da demanda por commodities no Brasil, igual a - 0,088841, indica que a quantidade demandada tende a cair $0,88 \%$ a cada aumento de $10 \%$ no preço das commodities, ceteris paribus. Este resultado revela que a demanda é inelástica a preço e isso ocorre devido à ausência de substitutos dos grãos considerados (soja, milho e arroz) e devido a alta perecibilidade do produto, que para mantê-lo em estoque torna-se caro e aumenta o risco.

A elasticidade-renda da demanda é igual a 1,285438 e, mostra que a cada incremento de $10 \%$ na renda, representada pelo PIB per capita, tem-se um aumento de $12,8 \%$ na demanda de grãos do país, ceteris paribus, sendo então a demanda por commodities elástica a variações na renda da população. Isto indica que com aumento no PIB per capita, a demanda por tais commodities tende a aumentar mais que proporcionalmente, sobretudo pelo aumento no consumo de carnes, ovos e óleos que dependem fortemente destes produtos em seu processo produtivo.

Pelo lado da demanda, o que é característico dos bens agropecuários, mesmo quando se trata dos processados, há uma baixa elasticidade-preço da demanda. Isso quer dizer que variações de preços podem se traduzir em variações maiores nos gastos realizados na aquisição do produto (RAMOS, 2007).

Conforme Ramos (2007) a produção destas commodities é influenciada pelas condições naturais, ou seja, depende da disponibilidade de água e da regularidade das chuvas, 
fertilidade do solo, variações climáticas anuais normais (temperatura, ventos, umidade), por isso a produção está sujeita a riscos e incertezas maiores do que as atividades industriais não agrícolas.

Os resultados obtidos para equação de oferta estão coerentes com o esperado (Tabela 2). As variações na quantidade ofertada de commodities foram explicadas em 97,61\% pelas variações simultâneas no preço defasado de um período, nos fertilizantes, na área colhida e na quantidade defasada de um período e, indiretamente pela variável instrumental.

A estimativa do preço com defasagem de um período foi de $-0,133375$ e, indica que cada
$10 \%$ de aumento no preço das commodities faz com que a quantidade ofertada se reduza em $1,33 \%$ no ano seguinte, ceteris paribus. Essa influência negativa do preço atual na oferta do ano seguinte, ocorre porque um aumento no preço hoje nem sempre será seguido de maior produção no ano seguinte, pois o investimento é alto e exige preparação, seja financeira ou em infraestrutura. Este fenômeno pode também estar atrelado ao fato de que é o aumento da produtividade que move a produção destas commodities no Brasil. Logo,se o aumento da produtividade não baixar os custos em proporção maior do que a queda nos preços, a produção tende a diminuir.

Tabela 2: Resultados da equação de oferta por commodities no Brasil.

\begin{tabular}{|l|c|c|c|c|}
\hline \multicolumn{1}{|c|}{ Variável dependente: LnQs } \\
\hline Variável & Coeficiente & Desvio padrão & Estatística-t & Probabilidades \\
\hline Constante & $-4,116407$ & 0,321980 & $-1,278467$ & 0,0000 \\
\hline LnPt-1 & $-0,133375$ & 0,013280 & $-1,004336$ & 0,0000 \\
\hline LnFert & 0,357743 & 0,087738 & 4,077417 & 0,0001 \\
\hline LnArea & 0,985394 & 0,053922 & 1,827427 & 0,0000 \\
\hline LnQt-1 & 0,248989 & 0,058860 & 4,230177 & 0,0001 \\
\hline R-quadrado & 0,976121 & & & \\
\hline R-quadrado ajustado & 0,972141 & Fonte: Dados da pesquisa. \\
\hline
\end{tabular}

A elasticidade cruzada da oferta (variação na quantidade ofertada de um bem em relação a variação de outro bem) em relação aos fertilizantes foi de 0,357743 , o que indica que um incremento de $10 \%$ no uso de fertilizantes nas terras em que se cultivam commodities aumenta a oferta em $3,57 \%$, ou seja, com uso destes produtos a produção agrícola é elevada e mais que contrabalança o efeitopreço. Este resultado confirma a realidade da agricultura brasileira, em que se tem expansão da fronteira agrícola para terras de relevo plano, caso do Cerrado, mas de baixa qualidade de solos, o que exige um uso intenso de fertilizantes, que como consequência permitem aumento da produção. Segundo Gasques et al. (2014), entre 1970 e 2006, os custos com adubos, energia e defensivos agrícolas aumentaram de $12 \%$ para $34 \%$ no Brasil.

A variável área, cuja elasticidade cruzada foi de 0,985394 indica que com aumento de 10\% na área, a oferta de commodities irá aumentar em $9,85 \%$. Esta informação remete a ideia de que o aumento da oferta de arroz, milho e soja no Brasil ainda tem alta influência da expansão da área, o que pode refletir negativamente no futuro, seja considerando questões ambientais, ou até mesmo a decadência da atividade agrícola nacional em função do esgotamento dos solos, o que seria prejudicial, na medida que o país ainda é dependente das divisas geradas no setor primário.

A variável quantidade com defasagem de um período apresentou sinal positivo, com valor de 0,248989, ou seja, o aumento da quantidade cultivada no período atual em $10 \%$, interfere em $2,48 \%$ na oferta de commodities no ano seguinte. Isso ocorre porque a produção de um período é comercializada no período seguinte ou na entre safra, na busca por preços mais competitivos.

Os resultados da equação de preço são apresentados na Tabela 3. Os coeficientes de todas as variáveis foram significativos a $1 \%$ e 
as variações no preço das commodities foram explicadas em $69,82 \%$ pelas variações conjuntas nos fertilizantes, no rendimento e na tecnologia utilizada $e$, indiretamente pelas variáveis instrumentais. Por se tratar de uma equação especificada na forma inversa, tendo os preços como variável endógena, os parâmetros foram interpretados como flexibilidade.

Tabela 3: Resultados da equação reduzida do preço das commodities no Brasil.

\begin{tabular}{|l|c|c|c|c|}
\multicolumn{5}{|c}{ Variável dependente: LnP } \\
\cline { 2 - 5 } Variável & Coeficiente & Desvio padrão & Estatística-t & Probabilidades \\
\hline Constante & 50,38244 & 4,900291 & 1,028152 & 0,0000 \\
\hline LnFert & $-5,583476$ & 0,632176 & $-8,832155$ & 0,0000 \\
\hline LnR & 5,553885 & 0,779584 & 7,124162 & 0,0000 \\
\hline Ert & $-2,887713$ & 0,347099 & $-8,319559$ & 0,0000 \\
\hline R-quadrado & 0,698253 & & & \\
\hline R-quadrado ajustado & 0,662043 & & \\
\hline
\end{tabular}

O coeficiente da variável indicadora do uso de fertilizantes teve como valor -5,583476, indicando que um aumento de $10 \%$ no uso de fertilizantes transmite uma queda de $55,83 \%$ para o preço das commodities, pelo forte impacto no incremento da produção que desloca a oferta e gera preços de equilíbrio mais baixos. Ou seja, o consumo de fertilizantes na agricultura tem alta influência sobre o comportamento do preço das commodities, uma vez que o custo elevado destes produtos tende, diante da queda no preço dos grãos, a ser compensado pelo aumento da produtividade.

A variável renda, que apresentou valor de 5,553885 indica que um aumento de $10 \%$ na renda do consumidor, ceteris paribus, transmite para o preço das commodities um aumento de $55,53 \%$. Isso ocorre porque o aumento de renda desloca a demanda de grãos positivamente, fazendo com que o novo preço de equilíbrio seja maior. Portanto, o efeito nas variações da renda tende a neutralizar o efeito de variações no uso de fertilizantes sobre os preços das commodities.

Por último, a variável que representa o uso de tecnologias na agricultura apresentou sinal negativo, com valor igual a $-2,887713$. Assim, a cada $10 \%$ de aumento no uso de tecnologias transmite-se para os preços das commodities uma queda de $28,87 \%$, justamente pelo fato de que ao realizar pesquisas na melhoria genética dos insumos do agronegócio, ao ter condições climáticas favoráveis e com uso de técnicas e máquinas inovadoras, amplia-se a quantidade produzida, o que desloca a curva de oferta positivamente e o preço de equilíbrio tende a cair.

Assim, pode-se afirmar que o aumento da produtividade dos grãos reduz a renda dos produtores, pois as variáveis relacionadas ao rendimento das commodities e incluídas na equação de equilíbrio de preço (fertilizantes e uso da tecnologia) tem influência negativa sobre o mesmo, o que induz à queda na renda do produtor rural.

Um estudo sobre a tendência histórica de preços pagos ao produtor na agricultura de grãos do Rio Grande do Sul, indica que um dos motivos para a tendência de queda dos preços agrícolas é justamente o incremento da adoção de tecnologia no campo, que contribuíram para o aumento considerável da produção e produtividade das culturas (SOUZA; VIANA, 2007).

Os avanços tecnológicos modificam a agricultura tradicional e trazem consequências em termos de perda de competitividade, maior dependência tecnológica, desemprego ou insegurança alimentar, devido ao domínio de mercado por poucas empresas (GONÇALVES; LEMOS, 2011). Deve-se atentar ao fato de que as tecnologias de ponta na agricultura estão sob domínio de multinacionais, como é o caso das sementes de soja transgênica, por exemplo, enquanto as empresas públicas brasileiras, como Embrapa (Empresa Brasileira de Pesquisa Agropecuária) dominam cultivares 
tradicionais, como mencionam Costa e Santana (2013).

Outro aspecto considerado por Costa e Santana (2013), quando se tratam de tecnologias de sementes de cultivares como soja e milho, é o domínio de mercado e a formação de preços por empresas com controle mundial da informação, forçando o produtor a aumentar a produção para manter sua capitalização. Os autores concluem ainda que a instabilidade na renda do produtor "compromete diretamente a utilização de métodos de produção mitigadores de impactos ambientais e intensivos no uso de mão de obra" (COSTA; SANTANA, 2013, p.66).

Silva (2008) também mostra que o aumento da produtividade dos grãos pode reduzir o lucro real dos produtores rurais, devido ao poder de oligopólio das empresas fornecedoras de insumos para o setor, citando também o caso das empresas de sementes transgênicas que possuem a propriedade intelectual do material genético comercializado no mercado brasileiro.

Por fim, as projeções com base na demanda visam auxiliar a evitar um déficit ou superávit de commodities no mercado, permitindo conhecer a sensibilidade das variáveis do modelo. A oferta oferece suporte para a obtenção da produção necessária para abastecer e garantir o crescimento econômico. E o preço, que é o principal fator de orientação das decisões dos agentes que operam o mercado de commodities, especificado como variável endógena e com as variáveis de maior relevância para explicar as dinâmicas do setor, tende a contribuir para aperfeiçoar a tomada de decisão.

\section{CONCLUSÃO}

A estimação do modelo simultâneo para equações de demanda, oferta e preço de

\section{REFERÊNCIAS}

[1]. BUAINAIN, A.M.; PEDROSO, M.T.M.; VIEIRA JÚNIOR, P.A.; SILVEIRA, R.L.F.; NAVARRO, $Z$. Quais os riscos mais relevantes nas atividades agropecuárias? In:

[2]. BUAINAIN, A.M.; ALVES, E.; SILVEIRA, J.M.; NAVARRO, Z. O mundo rural no Brasil do século 21: a formação de um novo padrão agrário e agrícola. Brasília, DF: Embrapa, 2014. 1182 p.. equilíbrio para as commodities agrícolas arroz, milho e soja no Brasil teve parâmetros de acordo com o esperado, atingindo o objetivo do artigo. Em resposta ao problema de pesquisa, concluise que de fato variáveis não tradicionais, como biotecnologia, clima, fertilizantes, etc, interferem na demanda, oferta e preço das commodities no Brasil.

Os resultados permitem concluir que a demanda e a oferta de commodities no Brasil são inelásticas a preço, o que torna o valor da produção instável diante de variações nos preços. A demanda é menos inelástica a preços do que a oferta $(0,88 \%$ e $1,33 \%)$. Isso significa que um aumento no preço gera um impacto maior sobre a receita dos produtores do que sobre a renda dos demandantes de commodities no Brasil. E ainda, a demanda se mostrou elástica a alterações na renda. $\mathrm{Na}$ função de preço de equilíbrio a variável renda interferiu positivamente enquanto as variáveis tecnologia e fertilizantes tiveram sinais negativos e, os efeitos da variável renda são neutralizados pelos efeitos dos fertilizantes, dado que tiveram sinais opostos e valores dos parâmetros parecidos. Assim, pode-se concluir que os efeitos das tecnologias químicas, mecânicas e biológicas mais que contrabalançam os efeitos das variáveis que retraem a oferta e expandem a demanda.

Por se tratar de um modelo inovador $e$ original, as equações estimadas permitem aos agentes econômicos tomarem decisões mais coerentes, na medida que outros modelos não incluem tais variáveis como fatores influentes no preço das commodities. $E$, considerando que o rendimento é um impedimento forte no mercado de commodities, se o produtor não atender a este quesito, incorporando tecnologia, a tendência é que saia do mercado, dado a queda de preços registrada nas séries históricas.

[3]. BLOCK, A. S.; CORONEL, D. A.; VELOSO, G. Análise da transmissão de preços no setor sucroalcooleiro brasileiro. Revista Eletrônica de Estratégia \& Negócios, v. 5, p. 120-137, 2012.

[4]. CALDARELLI, C.E; BACCHI, M.P. Fatores de influência no preço do milho no Brasil. Nova Economia, v. 22, n. 1, p. 141-164. 2012

[5]. COMPANHIA NACIONAL DE ABASTECIMENTO- CONAB. Séries históricas. 
Disponível

em: $<$ http://www.conab.gov.br/conteudos.php?a=1252\&t =2>. Acesso em: 21 dez 2015.

[6]. CORONEL, D.A.; AMORIM. A.L; de SOUSA, L.P.; de LIMA, J. E. Integração e transmissão de preços entre os mercados de trigo argentino e internacional. Pesquisa \& debate,v. 21, n. 2, p. 279-305. 2010.

COSTA, N.L.; SANTANA, A.C. Poder de mercado e desenvolvimento de novas cultivares de soja transgênicas e convencionais: análise da experiência brasileira. Revista de Ciências Agrárias, v. 56, n. 1, p. 61-68, jan./mar. 2013. Disponível em:

http://doi.editoracubo.com.br/10.4322/rca.2013.003 >. Acesso em: 17 jan 2016.

[8]. CUNHA, D.A. A integração de preços no mercado internacional de café. 2008. Dissertação (Mestrado em Economia Aplicada). 2008. Universidade de Viçosa. Minas Gerais: 2008.

[9]. Food and Agriculture Organization - FAO. Agricultural Outlook. Disponível em: , http://stats.oecd.org/viewhtml. aspx?Queryld=71240 $\& v h=0000 \& v f=0 \& \mid \& i l=\& l a n g=e n>$. Acesso em: 31 ago 2016.

[10]. GASQUES, J.G.; BASTOS, E.T.; VALDES, C; BACCHI, M.R.P. C.; Produtividade da agricultura: resultados para o Brasil e estados selecionados. Revista Política Agrícola, Brasília, DF, Ano XXIII, n. 3, jul. /ago. /Set, 2014.

[11]. GONÇALVES, E.; LEMOS, M. B. Padrão de inovação tecnológica na indústria de defensivos agrícolas brasileira. Revista de Economia e Agronegócio, v. 9, n. 1, p. 1-28, jan./abr., 2011.

[12]. INSTITUTO BRASILEIRO DE GEOGRAFIA E ESTATÍSTICA - IBGE. Disponível em: <http://www.ibge.gov.br>. Acesso em:20 jan 2015.

[13]. LIBERA, A.A.D. Integração entre os mercados de milho e soja: uma análise através da transmissão de preços. Dissertação (Mestrado em Agronegócios) Universidade Federal do Rio Grande do Sul. Programa de Pós-Graduação em Agronegócio. 2009.

[14]. LOVADINE, D.; BACCHI, M. R. P. Causalidade e Transmissão de Preços entre mercado interno e internacional para produtos do complexo soja. CONGRESSO SOBER, 2005. Disponível em :< http://www.sober.org.br/palestra/2/463.pdf.>. Acesso em: 01 jan 2016.

[15]. MAFIOLETTI, R.L. Formação de preços na cadeia agroindustrial da soja na década de 90. Piracicaba, 2000. 95p. Dissertação (Mestrado em Ciências). Escola Superior de Agricultura "Luiz de Queiroz", Universidade de São Paulo.

[16]. MARGARIDO, M. A.; TUROLLA, F. A.; FERNANDES, J. M. Análise da Elasticidade de Transmissão de Preços no Mercado Internacional de Soja. Pesquisa \& Debate, SP, volume 12, $\mathrm{n}$.
2(20), p. 5-40, 2001. Disponível em: <http://revistas.pucsp.br/index.php/rpe/article/view File/12012/8702>. Acesso em: 28 jan 2016.

[17]. MUNDLACK, Y.; LARSON, D. F. On the transmission of world agricultural prices. The World Bank Economic Review, v. 6, n. 1, p.399-422, 1992.

[18]. PINDYCK, R.S.; RUBINFELD, D.L. Microeconomia. 7ª . ed. São Paulo: Pearson Education do Brasil, 2010.

[19]. PINO, F. A.; ROCHA, M. B. Transmissão de preços de soja no Brasil. Revista de Economia e Sociologia Rural, Brasília, v.32, n.4, p.345-361, out./dez. 1994.

[20]. RAMOS, P. (Org.). Dimensões do agronegócio brasileiro: políticas, instituições e perspectivas. Brasília: MDA, 2007. 360p. Nead Estudos.

Disponível em:<http://www.mda.gov.br/sitemda/sites/sitemda/f iles/user_arquivos_64/pageflip-420422974145It_Dimenses_do_Agronegci-2731160.pdf.>. Acesso em: 18 jan 2016.

[21]. SANTANA, A.C.; CAMPOS, P.S.S.; RAMOS, T.J. N.; GALATE, R.S; MOTA, A.V. O Mercado de Frutas no Estado do Pará: 1985 a 2005. Revista de Estudos Sociais, n. 26, v. 13., 2011. Disponível em:< http://periodicoscientificos.ufmt.br/index.php/res/iss ue/view/171>. Acesso em: 15 jan 2016.

[22]. SANTANA, A.C.; SANTANA, A. L.; SANTOS, M.A.S. Influência do desmatamento no mercado de madeira em tora da região MamuruArapiuns, Sudoeste do Pará. Revista de

[23]. Ciências Agrárias, v.54, n.1, p.42-51, Jan/Abr 2011. Disponível em: < https://periodicos.ufra.edu.br/index.php?journal=aj aes\&page $=$ article\&op=view\&path[] $=281>$. Acesso em: 15 jan 2016

[24]. SANTOS, V.F.; PEREIRA, M, W. G; VIEIRA, W. C. Transmissão de preços do milho entre os mercados externos e Internos. In: CONGRESSO BRASILEIRO DE ECONOMIA E SOCIOLOGIA RURAL, 45. Londrina, 2007. Anais.... Brasília: SOBER, 2007.

[25]. SANTOS, G.R. Agricultura e Políticas Públicas: uma interpretação das diferenças regionais no cultivo do arroz. Radar. Instituto de Pesquisa Econômica Aplicada - IPEA.2010. Disponível

em:<http://www.ipea.gov.br/agencia/images/stories /PDFs/radar/100428_radar07_cap3.pdf>. Acesso em: 29 ago.2016.

[26]. SILVA, J. M. Impactos macroeconômicos do desempenho agropecuário. Revista de Economia e Agronegócio, v.6, n.3, p.283-308, set./dez. 2008

[27]. SOUZA, E.P.; CAMPOS, A.C. Efeitos de acordos comerciais sobre a integração de preços do algodão nos mercados interno e externo. 
Revista de economia e Agronegócio, v. 7, n 2, 2009.

[28]. SOUZA, R.S.; VIANA, J.G.A. Tendência histórica de preços pagos ao produtor na agricultura de grãos do Rio Grande do Sul, Brasil. Ciência Rural, v.37, n.4, jul-ago, 2007. Disponível em:<

http://www.scielo.br/scielo.php?script=sci_arttext\& pid=S010384782010005000122\&lng=pt\&nrm=iso\& tlng=pt>. Acesso em: 20 jan 2016 .
[29]. VARIAN, H. R. Microeconomia: Princípios básicos. 7aㅡ ed. Rio de Janeiro: Campus, 2012.

[30]. VIEIRA FILHO, J.E.R. Transformação histórica e padrões tecnológicos da agricultura brasileira. In: BUAINAIN, A.M.; ALVES, E.; SILVEIRA, J.M.; NAVARRO, Z. O mundo rural no Brasil do século 21: a formação de um novo padrão agrário e agrícola. Brasília, DF: Embrapa, 2014. 1182 p. 


\section{Gapítulo 14}

\section{CAROÇO DE ALGODÃO INTEGRAL NA DIETA DE CORDEIROS CONFINADOS: UMA ANÁLISE PRODUTIVA E ECONOMMICA NA REGIÃO SUDESTE DO MATO GROSSO, BRASIL.}

Miller de Jesus Teodoro

Henrique Leal Perez

Geovanne Ferreira Rebouças

Matheus Sodré Ferreira

Poliana Fernandes de Almeida

Affonso Amaral Dalla Libera

Resumo: O objetivo deste trabalho foi verificar o efeito da inclusão de $20 \%$ do caroço de algodão integral na dieta de cordeiros confinados, identificando o efeito sobre o desempenho animal e a performance econômica da atividade. O experimento foi realizado no setor de ovinocultura do Instituto Federal de Educação, Ciências e Tecnologia de Mato Grosso, Campus São Vicente, o qual possui baias individuais para cordeiros de $1,5 \mathrm{~m}^{2}$ de piso cimentado. Foram utilizados 16 cordeiros contemporâneos não castrados, com aproximadamente 80 dias de idade, peso corporal médio de 19,37 kg e oriundos de um rebanho cruzado comercial das raças Santa Inês e Dorper. As dietas foram isoprotéicas e a proporção volumoso: concentrado foi de 15:85. Foi utilizado o delineamento inteiramente casualizado. Os parâmetros analisados consistiram em indicadores de desempenho produtivo dos animais, características quantitativas das carcaças e indicadores econômicos de produção. As análises de variância foram realizadas adotando o PROC GLM e verificada a significância do teste $F(P<0,05)$. A inclusão de caroço de algodão em $20 \%$ na dieta de cordeiros confinados apresentou valor presente líquido de $22,82 \%$ superior e elevação na taxa interna de retorno de $14 \%$ quando comparado a dieta convencional. Para análise de desempenho animal não ocorreu diferença significativa.

Palavras-chave: alimento alternativo, análise econômica, confinamento, ovino. 


\section{INTRODUÇÃO}

A ovinocultura é uma atividade que acompanha a humanidade desde o início da domesticação dos animais no âmbito alimentício (10.000 ac.). Esta atividade se tornou popular em quase todos os continentes e é explorada até os dias atuais, nos diversos ramos, como produção de pele, leite e, principalmente, carne e lã. Países tradicionais na produção de ovinos, como Austrália e Nova Zelândia por exemplo, desenvolveram e aplicaram tecnologias à criação para aperfeiçoar os índices zootécnicos através do uso de técnicas de manejo, estudos nutricionais e programas de melhoramento genético animal, visando melhorar as características das raças de acordo com os objetivos econômicos da criação. Porém, países com menor tradição na atividade, como o Brasil, não acompanharam o desenvolvimento tecnológico obtido, sendo a ovinocultura caracterizada por ser uma atividade de subsistência e baixa exploração econômica.

Os primeiros ovinos a chegarem no Brasil datam do início da colonização portuguesa, a mais de 500 anos. Todavia, aspectos culturais bem como a relação de substituição observada com a bovinocultura em termos de demanda quando do provimento de proteína animal para consumo humano, tem feito da produção de carne ovina uma atividade pouco desenvolvida e com pouca expressão econômica dentro do agronegócio brasileiro (ZIGUER et al., 2011; VIANA \& SILVEIRA, 2008; ALVES et al., 2003). Desta forma, a ovinocultura ao longo dos anos, foi sendo deixada de lado, desenvolvendo-se lentamente no território nacional.

Devido aos baixos índices zootécnicos nacionais observados quando comparados a países que apresentam tradição na produção de ovinos, a atividade não costuma receber atenção devida da pesquisa para ampliação do sistema. Assim, a maioria das criações continuam ligadas a baixos níveis tecnológicos, como a criação em sistema extensivo em áreas de pastagens com baixas disponibilidades quantitativas e qualitativas (BARROS, 2015; BARROS, 2008).

Nos últimos anos o Brasil tem ocupado a 17aㅗ posição no ranking mundial em número de animais, com aproximadamente 18,4 milhões de cabeças, sendo 0 rebanho geograficamente distribuído principalmente na Região Nordeste - 57,5\% - e Região Sul -
29,3\% (FAO, 2016; GOMES, 2014). A demanda de carne ovina, no Brasil, demonstra expressivo crescimento nos últimos anos, principalmente nos grandes centros urbanos, impulsionado pelo crescimento demográfico e consequentemente, impulsionando a produção de animais para o abate (VIANA, 2015; FAO, 2013; CUNHA et al., 2008a). Mesmo diante deste cenário, a observação do consumo per capta do produto demonstra que culturalmente $\mathrm{o}$ brasileiro não tem $\mathrm{o}$ costume de consumo quando comparado a outras carnes. O consumo de carnes per capta por ano nacional é de $65 \mathrm{Kg}$ (URANO et al., 2006), enquanto o consumo de carne ovina encontra-se na ordem de 0,7 kg per capta (CABRAL, 2008). Pelo lado da oferta, nota-se que se faz necessário importar carne ovina para atender à crescente demanda nacional (VIANA, 2015).

A Região Sudeste do estado de Mato Grosso apresenta como principal atividade econômica sistemas agrícolas caracterizados pela ocorrência de duas safras por ano: primeira safra e segunda safra (LIBERA, 2016). A cultura da soja consiste na principal cultura em primeira safra, enquanto as culturas do milho e do algodão competem por área na segunda safra, apresentando uma explicita relação de substituição em termos de oferta para os agricultores que optam entre uma ou outra cultura de acordo com a atratividade econômica das mesmas. Esta possibilidade de realização de dois cultivos na região torna-se possível devido a ocorrência de duas estações climáticas bem definidas: a estação de chuvas, que se inicia em outubro e se estende até início de abril, e, a estação de seca, que se inicia em abril e estende-se até o final de setembro.

O elevado custo da terra verificado na Região Sudeste de Mato Grosso torna o confinamento de ovinos uma estratégia com potencial para satisfazer tanto 0 produtor quanto 0 consumidor. Este sistema de produção permite reduzir o ciclo de produção e disponibilizar ao mercado carcaças de animais jovens e de melhor qualidade (URANO et al., 2006). Contudo, em criações confinadas os custos de produção se elevam comparados aos demais sistemas de produção, principalmente pelos custos com infraestrutura, manutenção e os custos com a dieta (REGO et al., 2015; GALVANI, 2011; BARROS et al., 2009). Neste sentido, uma maneira de diminuir o custo com a dieta 
consiste no uso de insumos alternativos, que possam permitir um bom desempenho animal e a melhoraria dos resultados financeiros do negócio.

O desenvolvimento da ovinocultura em uma das principais regiões produtoras de algodão do país permite a possibilidade de substituição de farelo de soja por caroço de algodão na dieta de ovinos. Sementes de oleaginosas, como é o caso do caroço de algodão, são ricas em lipídeos e apresentam elevado teor de proteína bruta (URANO et al., 2006), apresentando baixo custo durante o período da safra do produto. Este fato torna o caroço de algodão insumo interessante para formulação de rações, tendo em vista a redução do custo da dieta de ovinos em confinamento.

O objetivo deste trabalho foi verificar o efeito da inclusão de $20 \%$ do caroço de algodão integral na dieta de cordeiros confinados, identificando o efeito sobre o desempenho animal e a performance econômica da atividade.

Além da presença de uma agricultura comercial constituída por sistemas de produção formados pela rotação de culturas com soja, milho e algodão, há uma significativa presença de agricultores familiares resultante de assentamentos de reforma agrária na região. Neste sentido, a ovinocultura constitui-se em atividade que necessita de menor espaço por cabeça para seu desenvolvimento, bem como demanda mão de obra de uma maneira intensiva. Sendo assim, a atividade adequa-se as possibilidades deste tipo de agricultura, surgindo como uma alternativa a diversificação de risco e fonte de renda para agricultores familiares.

\section{REFERENCIAL TEÓRICO}

A ovinocultura é uma das primeiras atividades humana relacionada a exploração econômica de animais, estando destinada principalmente a subsistência das famílias de zonas rurais no Brasil. Está presente em praticamente todos os continentes, sedo que sua ampla difusão ocorreu principalmente devido ao seu poder de adaptação a diferentes climas, relevos e vegetações. Os maiores rebanhos estão distribuídos pelos países pertencentes à Ásia, África e Oceania, onde a China se destaca como sendo o país com maior número de animais, seguido da Austrália, Índia, Irã e Nigéria (FAO, 2016).

Segundo Barros (2008), a criação de ovinos no Brasil frequentemente é praticada com baixo nível tecnológico e sem o devido suporte de técnicos especializado, sendo considerada como hobby para alguns criadores. Em muitas propriedades, a ovinocultura apresenta-se como atividade secundária, praticada em sistemas extensivos, dotados de nula ou quase nula aplicação de técnicas e conhecimentos no ciclo de produção.

O Brasil possui grande extensão de terras e área destinadas para o cultivo de pastagens, apresentando potencial relevante para produção de ruminantes. Porém, investimentos em adubação, recuperação e implantação de pastagens ainda são escassos, principalmente nas áreas destinadas a ovinocultura. Como resultado, tem-se uma produção baixa de matéria verde de boa qualidade e poucas unidades animal por hectare. A produção nacional caracterizase pela criação de subsistência, através de um sistema em pastejo, com baixos índices zootécnicos, acarretando em menor produção por hectare e menor giro de capital na propriedade (SOUZA, 2014; BARROS, 2008; VIDAL et al., 2006).

Com o crescimento populacional mundial e o aumento da demanda por alimentos, faz-se necessária a intensificação de sistemas de produção de ruminantes, nos quais a produção de proteína de origem animal assume grande importância. A ovinocultura desempenha um papel produtivo fundamental neste contexto, pois transforma plantas forrageiras em proteína alimentar de elevado valor biológico, contribuindo para combater a fome e assumindo um papel relevante frente ao crescimento das populações (CARVALHO et al., 2007; PEREZ, 2015). Além da intensificação do sistema de produção de ovinos, a mudança dos consumidores direciona os produtores a se preocuparem cada vez mais com aspectos sanitário, éticos e de qualidade do produto (PEREZ, 2015).

Recorrentemente encontra-se na literatura pertinente relatos de problemas atrelados ao sistema de produção de ovinos associados a ocorrência de nematoides no pasto (MACEDO et al., 2000). Em regiões tropicais, com altos índices pluviométricos e altas temperaturas, os helmintos parasitas têm grandes chances de desenvolvimento nas pastagens, tornando- 
se prejudiciais à produção de cordeiros, já que esses animais são susceptíveis a diversos helmintos, elevando o custo de produção pelo uso de anti-helmínticos para controle da carga parasitária do animal.

Dentre os diversos sistemas de criação e tecnologias implantadas na produção, uma que vem ganhando espaço mundialmente nas últimas décadas é o sistema de criação de animais confinados. Este sistema de produção permite reduzir o ciclo de produção e disponibilizar ao mercado carcaças de animais jovens $e$ de melhor qualidade (URANO et al., 2006), em consonância com as exigências do mercado consumidor.

Diversos autores apontam que o confinamento de ruminantes apresenta vantagens sobre os sistemas extensivos, pois favorece a oferta de carne ovina de qualidade durante o ano inteiro, o tempo para abate é encurtado, diminui a quantidade de área destinada para produção, melhora e padroniza o acabamento de carcaça, explora a máxima capacidade produtiva do animal, melhora o aproveitamento de insumos, aumenta o giro de capital, diminui o contato dos animais com helmintos, menor mortalidade devido a verminoses e constituise em alternativa para a época da seca (PEREZ, 2015; SOUZA, 2014, GERON et al., 2011; BARROS, 2008; CARVALHO et al., 2007; MACEDO et al., 2000). Em contrapartida, o confinamento de ovinos apresenta duas desvantagens principais: o aumento do custo de produção e a maior demanda por investimentos em infraestrutura.

Uma opção para diminuir os custos do sistema de confinamento diz respeito a busca por insumos alternativos capazes de disponibilizar fatores nutricionais semelhantes aos convencionais e de menor custo de aquisição. Com isso, o caroço de algodão tem se mostrado uma boa escolha para integrar a dieta de ruminantes, já que possui alto valor energético e proteico, apresentando $90,1 \%$ de matéria seca, $23,5 \%$ de proteína bruta, $50,30 \%$ de fibra em detergente neutro, 40,1\% de fibra em detergente ácido, 12,9\% de lignina, 4,2\% de matéria natural e 19,3\% de extrato etéreo (NRC, 1996).

Cunha et al. (2008b) verificaram os índices da produção com inclusão de caroço de algodão na dieta de cordeiros confinados, sendo 0 , 20, 30 e 40\% de inclusão, associada com a palma forrageira e o feno de tifton 85 como volumoso. Os autores não encontraram diferenças estatísticas entre os tratamentos para consumo de matéria seca, além de observarem que o caroço melhorou a digestibilidade da FDN. Entretanto, verificouse redução nos valores de ganho de peso e conversão alimentar de acordo com o crescimento do percentual de caroço de algodão incluído na dieta.

Cunha et al. (2008a) observaram os efeitos da inclusão do caroço de algodão em dietas de ovinos em sistema de confinamento e verificaram que a inclusão deste insumo na dieta não diferiu entre os tratamentos $(0,20$, 30 e $40 \%$ de inclusão) para os parâmetros de rendimentos de corte e características da carcaça, podendo ser incluído em dietas de terminação. O aumento da produção de carne ovina para atendimento da demanda potencial deverá estar acompanhado por técnicas que propiciem a apresentação de carcaças de alta qualidade (MACEDO et al., 2000). Desta forma, afirma-se que o caroço de algodão pode ser utilizado na dieta de ruminantes, já que está disponível em abundância no estado de Mato Grosso a um custo menor do que os grãos convencionais.

Para Silva e Pires (2000), as características quantitativas e qualitativas da carcaça são de fundamental importância, pois estão diretamente relacionadas ao produto final. No entanto, para a melhoria da produção e da produtividade, o conhecimento do potencial do animal em produzir carne é fundamental, e, entre as formas para avaliar essa capacidade, está o rendimento de carcaça. No estudo de carcaças ovinas, o rendimento é, geralmente, o primeiro índice a ser considerado, expressando a relação percentual entre os pesos da carcaça e do animal (ALVES et al., 2003). O nível nutricional a que o animal está submetido exerce grande influência sobre o rendimento da carcaça e de seus cortes e a proporção dos tecidos musculares (CUNHA et al., 2008a).

O uso do caroço de algodão na alimentação de ruminantes pode contribuir para fornecer energia ao rúmen nas primeiras horas após a alimentação e a proteína do caroço de algodão apresenta alta degradabilidade ruminal (ARIELI, 2008; PEREZ, 2015). Entretanto, alguns fatores limitam a utilização do caroço de algodão na alimentação dos animais. Para ruminantes destinados ao abate, o principal fator limitante é o teor de óleo que, dependendo do percentual na dieta, prejudica a digestibilidade da fibra e causa alterações na produção dos ácidos 
graxos voláteis. Outro aspecto que pode limitar o seu uso é que animais alimentados com caroço de algodão podem apresentar alteração no sabor da carne (SOUZA, 2014). Desta forma, o uso indiscriminado do caroço de algodão na dieta de ruminantes pode afetar diretamente a qualidade do produto final.

\section{METODOLOGIA DE PESQUISA}

O experimento foi conduzido no setor de ovinocultura do Instituto Federal de Educação, Ciência e Tecnologia de Mato Grosso, Campus São Vicente, localizado no município de Cuiabá - Mato Grosso. Os cordeiros foram alojados em baias individuais cobertas de $1,5 \mathrm{~m}^{2}$. O galpão das baias é construído em alvenaria com $30 \mathrm{~m}^{2}$, piso cimentado e cada baia dispunha de comedouro e bebedouro.

Foram utilizados 16 cordeiros de mesmo grupo de contemporâneos, não castrados, cruzados (Santa Inês x Dorper) com aproximadamente 80 dias de idade, peso corporal médio de $18,83 \mathrm{~kg}$ e oriundos de um rebanho comercial. Os animais foram distribuídos em delineamento inteiramente casualizado, com 2 tratamentos e 8 repetições.

Inicialmente, os cordeiros foram identificados com colares, pesados em jejum, everminados, vacinados contra clostridioses (2mL/animal) e receberam suplementação de vitaminas $A, D$ e E. Utilizou-se de um período pré-experimental de 15 dias com o objetivo de adaptação dos animais à dieta, sendo que o fornecimento foi iniciado em 3,5\% com relação ao peso vivo dos animais, com aumento escalonado da proporção de concentrado, a cada 3 dias, sendo 0,50, 60, 70 e $85 \%$, onde cada tratamento possuía seu concentrado específico.

Os animais foram pesados ao final da adaptação para o início do período experimental, obtendo o peso médio de 19,37 $\mathrm{kg}$. O manejo diário consistia em duas refeições, às 7 horas e às 17 horas, com controle da quantidade fornecida e pesagem das sobras para determinação do consumo de matéria seca, com ajuste de $5 \%$ do fornecido em relação as sobras do dia anterior. Os animais tiveram livre acesso a água. As pesagens foram realizadas a cada 20 dias para controle do desenvolvimento dos animais, e atingindo aproximadamente $34 \mathrm{~kg}$, o animal foi retirado do ensaio.

As dietas isoprotéicas foram formuladas atendendo os requerimentos nutricionais em proteína e energia para cordeiros confinados com base no NRC (2007) considerando ganho de $0,250 \mathrm{~kg} / \mathrm{dia}$ e contendo quantidades de fibras o mais homogêneo possível. A proporção volumoso:concentrado utilizada foi de 15:85. Como volumoso foi utilizada silagem de milho. Os concentrados utilizados são compostos por milho, farelo de soja, ureia e mistura mineral. A diferenciação do concentrado controle para o desafio consiste na inclusão do caroço de algodão em $20 \%$ da dieta (Tabela 1 ).

Tabela 1. Composição percentual e nutricional das dietas experimentais.

\begin{tabular}{|c|c|c|}
\hline Ingredientes & \multicolumn{2}{|c|}{ Composição percentual (\%MS) das dietas } \\
Silagem de Milho & Sem Caroço & 15,00 \\
\hline Milho moído & 15,00 & 55,10 \\
\hline Farelo de Soja & 66,50 & 5,00 \\
\hline Caroço de Algodão & 13,50 & 20,00 \\
Ureia & 0,00 & 0,90 \\
\hline Mistura Mineral ${ }^{1}$ & 1,00 & 4,00 \\
\hline MS & 4,00 & Composição nutricional \\
PB & & 81,09 \\
EE & 80,90 & 15,82 \\
FDN & 15,95 & 6,62 \\
FDA & 3,41 & 21,30 \\
NDT & 14,50 & 13,77 \\
\hline
\end{tabular}

${ }^{1}$ Mistura mineral comercial para ovinos - níveis de garantia por kg de produto: $200-225 \mathrm{~g}$ de cálcio; $75 \mathrm{~g}$ de sódio; $90 \mathrm{~g}$ de enxofre; $10 \mathrm{~g}$ de magnésio; 5000mg de ferro; 1848mg de manganês; 3060mg de zinco; 40mg de iodo; $20 \mathrm{mg}$ de cobalto; $24 \mathrm{mg}$ de selênio; $312500 \mathrm{Ul}$ de vitamina A; 50000Ul de vitamina D3; 437UI de vitamina E. Matéria Seca (MS), proteína bruta (PB), extrato etéreo (EE), fibras em detergente neutro (FDN), fibras em detergente ácido (FDA) e nutrientes digestíveis totais (NDT). 
Os ingredientes, milho moído e farelo de soja, foram triturados em moinho com peneira apresentando crivos de $5 \mathrm{~mm}$. Posteriormente as dietas foram misturadas a ureia, ao sal mineral, em misturador vertical nas suas devidas proporções (Tabela 1). Porém, diferente dos anteriores, o caroço de algodão foi triturado, mas não passou pela peneira para que não ocorressem problemas mecânicos no equipamento devido a presença de fibras (linter) em volta do caroço. Com isso, pôde-se realizar um processo melhor de mistura dos insumos. Para o fornecimento da dieta, as quantidades de silagem de milho e de concentrado, previamente pesados, eram misturados antes do fornecimento, homogeneizando a dieta de forma a evitar a seleção de ingredientes pelos animais.

O consumo da dieta foi determinado descontando-se as sobras diárias do total fornecido. Durante a fase experimental, foram colhidas amostras semanais dos alimentos fornecidos (silagem e concentrado) e amostras diárias de $10 \%$ das sobras por animal, sendo as mesmas mantidas em congelador a $-20^{\circ} \mathrm{C}$.

Foram determinados ao final do ensaio o ganho de peso médio total, a conversão alimentar, eficiência alimentar, consumo de matéria seca e dias de confinamento. Os dados referentes ao ganho de peso médio diário foram obtidos dividindo-se o ganho de peso pelo número total de dias de confinamento. A conversão alimentar dividindo a quantidade total da dieta consumida pelo ganho total de peso, a eficiência alimentar dividindo a quantidade total de ganho de peso pela quantidade de dieta consumida e os dias de confinamento contabilizando os dias que o animal levou para chegar aos $35 \mathrm{~kg}$ de peso vivo.

Ao atingir $35 \mathrm{~kg}$ de peso corporal, os animais foram abatidos, passando por jejum de dieta sólida de 16 horas e pesados (peso vivo ao abate). Em seguida, ocorreu o atordoamento com pistola de dardo sem penetração e posterior degola e sangria. Foram obtidos os pesos de carcaça quente, e o rendimento de carcaça foi obtido pela relação entre o peso de carcaça quente e o peso de abate, expresso em porcentagem. Com o rendimento de carcaça quente a conversão alimentar do peso vivo foi calculada e transformada para conversão alimentar da carcaça quente, ou seja, a quantidade de matéria seca ingerida para ganhar 1 quilo de carcaça. Após o resfriamento por 24 horas em câmara frigorífica a $4^{\circ} \mathrm{C}$, as carcaças foram novamente pesadas para a obtenção do peso de carcaça fria e respectivo rendimento de carcaça fria.

Para o estudo dos indicadores econômicos dos tratamentos, realizou-se $\mathrm{o}$ uso dos coeficientes obtidos no experimento para simular um módulo de produção de cordeiros confinados, com 480 animais, onde ocorriam 6 ciclos produtivos por ano. Além disto, os indicadores calculados foram: valor presente líquido (VPL), taxa interna de retorno (TIR), lucratividade e rentabilidade. A TIR representa a taxa de desconto que iguala 0 VPL a zero, ou seja, onde as entradas em caixa são iguais as saídas. O valor presente líquido é utilizado para calcular o valor presente de uma série de pagamentos futuros descontado a uma taxa mínima de atratividade. A Equação 1 apresenta a fórmula de cálculo do VPL.

$$
V P L=F C_{0}+\sum_{t=1}^{N} \frac{F C t}{(1+T M A)^{t}}
$$

Onde;

$\mathrm{FC}_{0}$ representa o fluxo de caixa no período 0 (investimento inicial); $\mathrm{FC}_{\mathrm{t}}$ os respectivos fluxos de caixa a cada período t e TMA consiste na taxa mínima de atratividade, ou seja, taxa que representa o mínimo de retorno que o executor do projeto deseja obter. Para esta análise foi utilizada uma TMA de $7,5 \%$.

Para a verificação da TIR, iguala-se o VPL a zero e obtemos a seguinte estrutura de cálculo, conforme Equação 2. 


$$
0=F C_{0}+\sum_{t=1}^{N} \frac{F C t}{(1+T I R)^{t}}
$$

Onde;

$\mathrm{FC}_{0}$ representa o fluxo de caixa no período 0 (investimento inicial); $\mathrm{FC}_{\mathrm{t}}$ os respectivos fluxos de caixa a cada período t e TIR consiste na taxa interna de retorno.

A Lucratividade foi calculada conforme Equação 3 e representa os ganhos imediatos do negócio em um período específico, isto é, indica o ganho obtido sobre as vendas realizadas.

$$
\text { Lucratividade }=\frac{\text { Lucro Líquido }}{\text { Renda Bruta }} * 100
$$

Já a rentabilidade indica o retorno sobre o investimento que foi feito em longo prazo, ou seja, indica o percentual de retorno do investimento realizado. A rentabilidade é obtida conforme Equação 4.

$$
\text { Rentabilidade }=\frac{\text { Lucro Líquido }}{\text { Investimento Total }} * 100
$$

Os valores do preço médio do quilo da carne de cordeiro foram pesquisados nos comércios da região de Campo Verde - MT. O valor do quilo da ração foi calculado a partir dos preços dos ingredientes no período experimental e suas respectivas quantidades utilizadas.

A pressuposição de normalidade dos dados foi testada através do comando proc univariate opção normal, ao nível de significância de 5\%. As análises de variância serão realizadas adotando o PROC GLM (SAS, 2001). Verificada a significância do teste $F \quad(P<0,05)$, as médias das dietas experimentais foram comparadas utilizando $\mathrm{O}$ teste de Tukey $(P<0,05)$.

\section{RESULTADOS E DISCUSSÕES}

A partir dos dados apresentados na Tabela 2, verifica-se que não houveram diferenças significativas $(p<0,05)$ para os parâmetros de desempenho animal, ganho diário médio, conversão alimentar em peso vivo, conversão alimentar de carcaça quente, eficiência alimentar, consumo de matéria seca e dias de confinamento. Os valores encontrados para ganho médio diário, foram de acordo com os propostos por NRC (2007) para cordeiros em terminação, de 200 à 400g/dia.

Pesquisas com a inclusão de caroço de algodão em dieta de ruminantes apontam que a FDN da dieta aumenta, escalonadamente, de acordo com os níveis de caroço de algodão (CUNHA, 2008b; RUFINO JUNIOR et al., 2015). Este fato ocorre, pois, o caroço possui grande quantidade de fibra (linter) em sua composição, o que pode implicar na alteração da taxa de ruminação e da taxa de passagem do bolo alimentar. Observando a formulação das dietas (Tabela 1), é possível verificar maiores concentrações de EE, FDN e FDA quando se inclui o caroço de algodão.

Por não haver diferença significativa no consumo de matéria seca, suspeita-se que a diferença da FDN nos tratamentos não influenciou a taxa de passagem e ruminação do bolo alimentar. Solaiman (2007), não encontrou diferenças $(p<0,05)$ para CMS e GMD entre tratamentos com inclusão de até $30 \%$ de caroço de algodão para caprinos. Outro fator capaz de contribuir com os 
resultados observados de ganho de peso, conversão alimentar, eficiência alimentar $e$ dias de confinamento está ligado a quantidade de EE na dieta, o qual no tratamento com caroço foi superior $(93,57 \%$ a mais que o sem caroço). Os lipídeos disponíveis na dieta resultaram em maior energia líquida para os animais, permitindo que não houvesse diferença significativa para o ganho de peso dos cordeiros. Estes resultados são semelhantes aos encontrados por Cunha et al., (2008b) e Rufino Junior et al. (2015), que não observaram diferença significativa no desempenho animal com inclusão de até $40 \%$ de caroço de algodão para cordeiros confinados.

Tabela 2. Peso inicial, peso final, ganho diário médio (GMD), conversão alimentar (CA), conversão alimentar de carcaça quente (CACQ), eficiência alimentar (EA), consumo de matéria seca (CMS) e dias de confinamento (DC).

\begin{tabular}{|c|c|c|c|}
\multicolumn{1}{|c|}{ Variáveis } & \multicolumn{3}{c|}{ Tratamentos } \\
\hline & 19,36 & Com Caroço & CV (\%) \\
\hline Peso Inicial (kg) & 34,64 & 19,37 & 8,88 \\
Peso Final (kg) & 0,319 & 35,13 & 3,36 \\
GMD (kg) CA (MS) & 4,19 & 0,347 & 14,32 \\
CACQ (MS) & 8,61 & 3,91 & 10,30 \\
EA (\%) & 24,19 & 8,34 & 9,90 \\
CMS (kg) & 1,388 & 25,64 & 9,31 \\
DC & 48,25 & 1,355 & 16,37 \\
& & 46,12 & 9,68 \\
\hline
\end{tabular}

Na Tabela 3 são apresentados os resultados encontrados para os parâmetros quantitativos de carcaça analisados. É possível verificar que as dietas não interferiram no peso de carcaça quente, peso de carcaça fria e perda ao resfriamento. Estes resultados demonstram que a inclusão de caroço de algodão em $20 \%$ não altera as características da carcaça, que estão relacionadas com o rendimento de carcaça. Ademais, os achados deste experimento estão alinhados aos resultados encontrados por Barros et al. (2015) e Perez (2015), que avaliando dietas para cordeiros com alta densidade energética não encontraram diferenças significativas entre os tratamentos experimentais.

Verificou-se diferenças estatisticamente significativas $(P>0,05)$ entre os tratamentos no rendimento de carcaça quente, onde o tratamento experimental com caroço de algodão apresentou menor rendimento. Este resultado pode estar ligado ao volume e tamanho do trato digestivo dos animais que receberam esta dieta, pois apresenta maior quantidade de fibras, o que leva ao aumento dos compartimentos estomacais. Estes dados são semelhantes aos encontrados por Carvalho et al. (2007), que verificando diferentes proporções de volumoso:concentrado, observaram efeito depressivo para rendimento de carcaça quente quando aumenta a quantidade de FDN na dieta, isso devido a dieta com maior quantidade de fibra apresentar maior conteúdo digestivo nos cordeiros, no momento do abate, resultando em menor porção de material comestível. Estes resultados são diferentes dos encontrados por Alves et al. (2003), Barros et al. (2015) e Perez (2015), que não verificaram efeito significativo nas diferentes dietas contendo altos valores energéticos. 
Tabela 3. Peso vivo ao abate (PVA), peso de carcaça quente (PCQ), peso de carcaça fria (PCF), perda ao resfriamento (PR) e rendimento de carcaça quente (RCQ).

\begin{tabular}{|c|c|c|c|}
\multicolumn{3}{c}{ Variáveis } & \multicolumn{3}{c|}{ Tratamentos } \\
& Sem Caroço & Com Caroço & CV (\%) \\
\hline PVA (kg) & 34,65 & 35,13 & 3,36 \\
PCQ (kg) & 16,85 & 16,47 & 3,84 \\
PCF (kg) & 16,47 & 16,09 & 3,67 \\
PR (MS) & 2,30 & 2,33 & 21,74 \\
RCQ (MS) & $48,68^{\text {a }}$ & $46,89^{\mathrm{b}}$ & 3,36 \\
\hline
\end{tabular}

Médias seguidas por letras distintas na mesma linha diferem pelo teste de Tukey $(P<0,05)$.

Os resultados da análise econômica afirmam a viabilidade do experimento avaliado. Utilizando um módulo com 480 cordeiros é possível evidenciar os ganhos de escala. Barros (2009), avaliando diferentes sistemas de criação de cordeiros, apontou que dentre os 12 sistemas estudados, o confinamento apresenta o maior investimento inicial, onde, mesmo possuindo menores custos com terra, apresenta maior investimento com benfeitorias. Os custos anuais também foram maiores no confinamento devido aos custos com conservação e depreciação das benfeitorias e alimentação dos cordeiros.
Conforme a Tabela 4, é possível verificar que a inclusão de $20 \%$ de caroço de algodão na dieta é capaz de elevar o valor presente líquido em $22,82 \%$, a taxa interna de retorno em $14 \%$, a lucratividade em $13,54 \%$ e a rentabilidade em $15,02 \%$. Esses dados são suficientes para aumentar a atratividade da ovinocultura sob sistemas confinados e provam o motivo deste sistema estar sendo utilizado em ovinos. Desta forma, se torna imprescindível a utilização de alimentos alternativos para diminuir os custos de produção e aumentar os lucros em uma propriedade sob sistemas confinado.

Tabela 4. Indicadores financeiros em módulo com 480 cordeiros e 6 ciclos produtivos por ano.

\begin{tabular}{|c|c|c|}
\hline Variáveis & \multicolumn{2}{|c|}{ Tratamento } \\
\hline Valor Presente Líquido (R\$) & Sem Caroço & $198.126,13$ \\
Taxa Interna de Retorno (\%) & $161.304,78$ & 62,10 \\
Lucratividade (\%) & 54,47 & 10,73 \\
Rentabilidade (\%) & 9,45 & 66,39 \\
\hline
\end{tabular}

É possível observar que mesmo com resultado inferior do rendimento de carcaça do tratamento com caroço de algodão (Tabela 4), o mesmo obteve maior lucratividade por $\mathrm{kg}$ de produto. Isto se deve ao fato de que a lucratividade do negócio se destaca pela redução dos custos com a dieta, alcançando maior resultado por quilo de produto (Tabela 5). 
Tabela 5. Indicadores econômicos de produção e custo.

\begin{tabular}{|c|c|c|}
\hline \multirow{2}{*}{ Itens (R\$) } & \multicolumn{2}{|c|}{ Tratamento } \\
\hline & Sem caroço & Com caroço \\
\hline Custo por kg de dieta & 0,74 & 0,67 \\
\hline Custo por kg de peso vivo & 3,10 & 2,62 \\
\hline Custo por kg de carcaça fria & 6,37 & 5,58 \\
\hline Custo por animal/dia & 1,54 & 1,40 \\
\hline Lucro por kg de produto & 7,06 & 8,21 \\
\hline
\end{tabular}

A Figura 1 expõe que dentre os custos variáveis da produção de cordeiros sob sistemas confinados, a aquisição dos animais ocupa o maior investimento (80\%). Desta forma, possivelmente uma maneira de diminuir os custos de produção, e indiretamente aumentar o lucro da propriedade, consiste na aquisição de cordeiros em mercados mais competitivos, a fim de diminuir o preço de compra, ou a adesão ao sistema de criação de ovinos completo, ou seja, a cria, para obtenção dos cordeiros para engorda, e a terminação, para a comercialização da carcaça.

Figura 1. Custos variáveis na produção de cordeiros confinados.

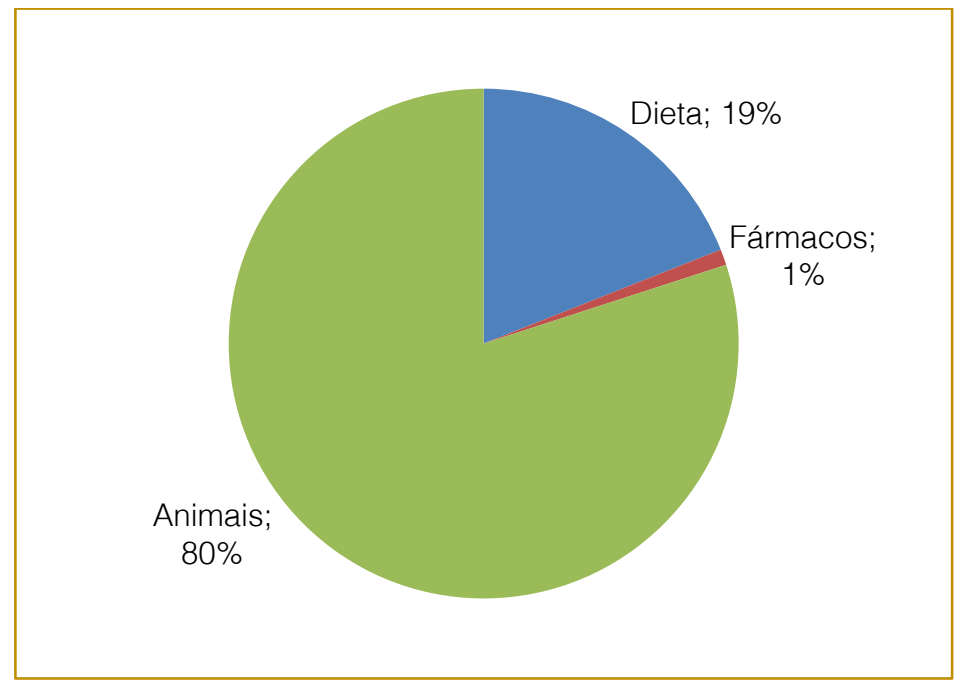

\section{CONSIDERAÇÕES FINAIS}

A inclusão de $20 \%$ de caroço de algodão na dieta de cordeiros confinados apresenta resultados interessantes para a produção de ovinos confinados, já que os indicadores de desempenho animal não se alteram significativamente e o custo diário por animal diminui em 9,1\%. Como principal efeito, temse o aumento da lucratividade por quilo do produto em $16,28 \%$, constituindo-se o caroço de algodão em uma boa alternativa de insumo. Pode-se ainda recomendar pesquisas complementares com relação a viabilidade econômica da exploração do segmento de cria na propriedade, pois assim tem-se a possibilidade de redução dos custos com aquisição dos cordeiros desmamados para terminação e a consequente ampliação dos lucros da atividade na propriedade.

\section{AGRADECIMENTOS}

Nosso especial agradecimento a FAPEMAT pelo auxílio financiero, fundamental para a execução deste estudo, e ao IFMT - Campus São Vicente, pela disponibilização da infraestrutura, onde foi realizado o experimento. 


\section{REFERÊNCIAS}

[1]. ABRAPA - Associação brasileira dos produtores de algodão. 2016. Produção mundial de algodão 2016 [online]. Disponível em: < http://www.abrapa.com.br/Paginas/dados/produca omundialalgodao_backup2017.aspx>. Acesso em: 22 de maio de 2017

[2]. ALVES, K. S., CARVALHO, F. F. R., FERREIRA, M. A. Níveis de Energia em Dietas para Ovinos Santa Inês: Características de Carcaça e Constituintes Corporais. Revista Brasileira de Zootecnia, v.32, n.6, p.1927-1936, 2003.

[3]. ARIELI, A. Whole cottonseed in dairy cattle feeding: a review. Animal Feed Science and Technology, v.72. n.1-2, p.97-110. 1998.

[4]. BARROS, C. S. Análise econômica de sistemas de produção de ovinos para carne. Dissertação (Mestrado em Ciências Veterinárias) Setor de Ciências Agrárias, 145f. Universidade Federal do Paraná, Curitiba - PR, 2008.

[5]. BARROS, M. C. C., MARQUES, J. A., SILVA, F. F. Glicerina bruta na dieta de ovinos confinados: consumo, digestibilidade, desempenho, medidas morfométricas da carcaça e características da carne. Semina: Ciências Agrárias, Londrina, v. 36, n. 1, p. 453-466, jan./fev. 2015.

[6]. BARROS, C. S., et al. Rentabilidade da produção de ovinos de corte em pastagem e em confinamento. Revista Brasileira de Zootecnia, v. 38, n.11, p. 2270-2279, 2009.

[7]. CABRAL, L. S., et al. Estimativas dos requisitos nutricionais de ovinos em condições brasileiras. Revista Brasileira de Saúde e Produção Animal, v.9, n.3, p. 529-542, jul/set, 2008.

[8]. CARVALHO, S., et al. Desempenho e avaliação econômica da alimentação de cordeiros confinados com dietas contendo diferentes relações volumoso:concentrado. Ciência Rural, v.37, n.5, set-out, 2007.

[9]. CUNHA, M. G. G., et al. Características quantitativas de carcaça de ovinos Santa Inês confinados alimentados com rações contendo diferentes níveis de caroço de algodão integral. Revista Brasileira de Zootecnia, v.37, n.6, p.11121120, 2008a.

[10]. CUNHA, M. G. G., et al. Desempenho e digestibilidade aparente em ovinos confinados alimentados com dietas contendo níveis crescentes de caroço de algodão integral. Revista Brasileira de Zootecnia, v.37, n.6, p.1103-1111, 2008b.

[11]. FOOD AND AGRICULTURE ORGANIZATION - FAO. Organização das Nações Unidas para a Agricultura e Alimentação. Estatísticas FAO, 2013.

[12]. FOOD AND AGRICULTURE ORGANIZATION - FAO. Organização das Nações
Unidas para a Agricultura e Alimentação. Estatísticas FAO, 2016.

[13]. GALVANI, D. B. Exigências e eficiência energética e proteica de ovinos Dorper x Santa Inês alimentados com dietas contendo volumosos de valor nutricional distinto. Tese (Doutorado em Ciência Animal e Pastagens), 111 p. - Escola Superior de Agricultura "Luiz de Queiroz", 2011.

[14]. GERON, L. J. V., et al. Inclusão do caroço de algodão em rações de alto concentrado constituído de co-produtos agroindustriais sobre o desempenho animal em tourinhos confinados. Archives of Veterinary Science, v.16, n.3, p.14-24, 2011.

[15]. GOMES, B. V. Conjuntura trimestral caprino-ovinocultura Pernambuco. Companhia Nacional de Abastecimento (CONAB), Nota Técnica - no 1. abril de 2016.

[16]. LIBERA, A. A. D. Dinâmica tecnológica e aprendizagem agrícola em Mato Grosso: uma abordagem evolucionária. Tese (Doutorado em Desenvolvimento Econômico). Universidade Estadual de Campinas, UNICAMP, Brasil, 2016.

[17]. MACEDO, F. A. F., SIQUEIRA, E. R., MARTINS, E. N. Análise econômica da produção de carne de cordeiros sob dois sistemas de terminação: pastagem e confinamento. Ciência Rural, Santa Maria, v. 30, n.4, p.677-680. 2000.

[18]. MACEDO, F. A. F., et al. Qualidade de Carcaças de Cordeiros Corriedale, Bergamácia $x$ Corriedale e Hampshire Down x Corriedale, Terminados em Pastagem e Confinamento. Revista Brasileira de Zootecnia, 29(5):1520-1527, 2000.

[19]. NATIONAL RESEARCH COUNCIL - NRC. 1996. Nutrient requirements of beef cattle. 7th ed. Washington, D.C. 242 p.

[20]. NATIONAL RESEARCH COUNCIL - NRC. 2007. Nutrient Requirements of Small Ruminants. WashingtonUSA: National Academy Press, 362p.

[21]. PEREZ, H. L. Milho, amido ou caroço de algodão associados a glicerina bruta em dietas para ovinos. Tese (Doutorado em Zootecnia), 87p. Universidade Estadual Paulista, Faculdade de Ciências Agrárias e Veterinárias, Jaboticabal - SP, 2015.

[22]. PINHEIRO, R. S. B., et al. Qualidade de carnes provenientes de cortes da carcaça de cordeiros e de ovinos adultos. Revista Brasileira de Zootecnia, v.38, n.9, p.1790-1796, 2009.

[23]. REGO, F. C. A., et al. Development, economic viability and attributes of lamb carcass from confined animals fed on different amounts of crude glycerin. Semina: Ciências Agrárias, Londrina, v. 36, n. 5, p. 3445-3454, set./out. 2015. 
[24]. SAS - Statistical Analysis Systems Institute, 2001. SAS users guide: Statistics Version SAS, Cary, N.C. 2001.

[25]. SILVA, L. F., PIRES, C. C. Avaliações Quantitativas e Predição das Proporções de Osso, Músculo e Gordura da Carcaça em Ovinos. Revista brasileira de zootecnia, 29(4):12531260, 2000.

[26]. SILVA SOBRINHO, et al. Características de Qualidade da Carne de Ovinos de Diferentes Genótipos e Idades ao Abate. Revista Brasileira de Zootecnia, v.34, n.3, p.1070-1078, 2005.

[27]. SILVA SOBRINHO, A.G., SILVA, A.M.A. Produção de carne ovina. Revista Nacional da Carne, n.285, p.32-44, 2000.

[28]. SOLAIMAN, S. G. Feeding value of whole cottonseed for goats. Notes on Goats. Tchnical Paper No. 07-08, August, 2007.

[29]. SOUZA, R. A. Caroço de algodão moído na alimentação de cordeiros(as) em confinamento. Dissertação (Mestrado em Zootecnia), 102p. Escola Superior de Agricultura "Luis de Queiroz", Piracicaba - SP, 2014

[30]. URANO, F. S., et al. Desempenho e característica da carcaça de cordeiros confinados alimentados com grãos de soja. Pesquisa
Agropecuária Brasileira, Brasília, v.41, n.10, p.1525-1530, out. 2006.

[31]. VIANA, J. G. A. Panorama Geral da Ovinocultura no Mundo e no Brasil. Revista Ovinos, Ano 4, No 12, Porto Alegre, março de 2008.

[32]. VIANA, J. G. A., MORAES, M. R. E. \& DORNELES, J. P. Dinâmica das importações de carne ovina no Brasil: análise dos componentes temporais. Semina: Ciências Agrárias, Londrina, v. 36, n. 3, suplemento 1, p. 2223-2234, 2015

[33]. VIANA, J. G. A. \& SILVEIRA, V. C. P. Análise econômica da ovinocultura: estudo de caso na Metade Sul do Rio Grande do Sul, Brasil. Ciência Rural, Santa Maria, Online, 2008.

[34]. VIDAL, M. F., et al. Análise econômica da produção de ovinos em lotação rotativa em pastagem de capim tanzânia (Panicum maximum (Jacq)). Revista de Economia e Sociologia Rural, Rio de Janeiro, vol. 44, no 04, p. 801-818, out/dez 2006.

[35]. ZIGUER, E. A., et al. Resultados econômicos da produção de cordeiros em confinamento utilizando na dieta casca de soja associada a quatro fontes de nitrogênio nãoproteico. Revista Brasileira de Zootecnia, v.40, n.9, p.2058-2065, 2011. 


\section{Bapítulo 15}

\section{DETERMINANTES DO TEMPO TOTAL DE APROVACÃO DE EVENTOS GM DE ALGODÃO, MILHO E SOJA NA UNIÃO EUROPEIA}

\section{Maurício Benedeti Rosa}

\section{Diego Sarti de Souza}

\section{Dallas Kelson Francisco de Souza \\ Rosane Nunes de Faria}

Resumo: O tempo total de aprovação de eventos geneticamente modificados (GM) desempenha papel importante no comércio internacional, haja vista que exportações e importações de culturas transgênicas dependem da aprovação dos eventos GM. O objetivo deste artigo é avaliar quais são os principais determinantes do tempo total de aprovação de eventos GM na União Europeia considerando algodão, milho e soja. Para tanto, faz-se uso de um estimador de mínimos quadrados ordinários a partir de dados de 48 eventos já concluídos. Os resultados mostram que o tempo de aprovação técnica tem impacto significativo no tempo total e representa a maior parte do tempo gasto no processo de aprovação, descaracterizando o viés político que é comumente atribuído ao processo de aprovação europeu. Além disso, empresas europeias têm seus eventos aprovados mais rapidamente, o que também ocorre com eventos GM de soja, ressaltando a necessidade da UE quanto à commoditye seus derivados.

Palavras-chave: eventos GM, regulamentos GM; tempo de aprovação; União Europeia

*Trabalho realizado no Núcleo de Estudos em Economia Aplicada (NEA) - UFSCar campus Sorocaba. 


\section{INTRODUÇÃO}

As culturas geneticamente modificadas (GM) tiveram sua comercialização iniciada em 1996, e desde então a área mundial cultivada tem crescido significativamente, atingindo 185,1 milhões de hectares em 2016, ante 1,7 milhões de hectares cultivados em 1996. As três commodities mais relevantes no contexto do comércio internacional de transgênicos são milho, algodão e soja, as quais têm, respectivamente, $33 \%, 64 \%$ e $78 \%$ de taxa de adoção global (JAMES, 2016).

Em países que já estabeleceram seus regulamentos para comercialização de produtos geneticamente modificados, a condição básica para a comercialização de um novo evento GM no mercado doméstico é sua aprovação prévia para cultivo e/ou comercialização como alimento humano e animal (VIGANI e OLPER, 2013). Quando um evento GM é aprovado comercialmente em um país exportador, mas o mesmo não acontece no país importador, principalmente devido a diferenças temporais na aprovação de eventos GM para uso comercial, cria-se uma situação conhecida como aprovação assíncrona (AA), ou seja, ela se caracteriza pela aprovação de um novo evento GM que não acontece simultaneamente entre países importadores e exportadores (STEIN e RODRÍGUEZ-CEREZO, 2010).

A aprovação assíncrona aliada à impossibilidade de segregar totalmente eventos aprovados de não aprovados pode fazer com que países importadores recebam traços de eventos GM ainda não aprovados em seu território, fato denominado "Low Level Presence" (LLP). Dessa maneira, a aprovação assíncrona associada a políticas restritivas de LLP pode levar a alteração e/ou ruptura do comércio internacional de commodities (BACKUS et al., 2008; KALAITZANDONAKES, 2011).

A literatura tem mostrado que a aprovação assíncrona pode ter impactos significativos no comércio internacional de produtos GM. Backus et al. (2008) investigaram os possíveis impactos econômicos da combinação entre assincronia dos procedimentos de aprovação e a política de tolerância zero da União Europeia (EU) para milho e soja. Os autores concluíram que as rupturas comerciais poderiam se tornar mais frequentes $\mathrm{e}$ impactariam setores dependentes de importações com elevação de custos e perda de competitividade. Kalaitzandonakes,
Kaufman e Miller (2014) avaliaram impactos econômicos de possíveis rupturas entre a UE e seus principais exportadores de soja e derivados de soja utilizando um modelo de equilíbrio espacial, e estimaram que a UE gastaria entre $200 \%$ e $220 \%$ mais com os produtos em caso de ruptura no comércio.

Faria e Wieck (2015) mensuraram a extensão e a restritividade da aprovação assíncrona entre 40 países, dentre eles a UE, para algodão, milho e soja. Os resultados mostraram que, em média, a aprovação assíncrona aumentou entre os anos de 2000 e 2012 e afetou negativamente o comércio internacional dessas commodities.

A UE se destaca por ser grande importador de produtos GM de diversas partes do mundo (EUROPABIO, 2015) e ter especial dependência à importação de soja em grãos e farelo de soja (DE VISSER, SCHREUDER e STODDARD, 2014). Além disso, a União Europeia possui uma das mais rígidas regulamentações para a aprovação comercial de culturas transgênicas no mundo (a diretiva Dir. 2001/18/EC e os regulamentos Reg. EC 1829/2003 e Reg. EC 1830/2003), o que faz com que o processo de aprovação seja lento. Portanto diferenças temporais entre a UE e seus principais exportadores no momento de aprovar eventos GM são passíveis de acontecer, ocasionando o surgimento da aprovação assíncrona que, aliada à política de tolerância zero (limite $0.0 \%$ ) para a presença adventícia de traços de eventos GM, pode impactar negativamente o fluxo de comércio internacional de produtos GM.

A literatura tem mostrado existir uma grande heterogeneidade de regulamentação GM entre países, especialmente no que diz respeito ao processo de aprovação de novos eventos GM. Isso pode ser exemplificado pelas diferenças entre os tempos médios de aprovação de novos eventos em diferentes países, os quais variam de um ano nos EUA, dois anos no Japão, dois a três anos na China, e de dois a quatro anos na União Europeia (EBATA, PUNT e WESSELER, 2013; GILMOUR, DANG e WANG, 2015; WAGER e MCHUGHEN, 2010).

Nesse contexto, o tempo necessário para aprovação de eventos GM na UE desempenha papel importante no comércio internacional de produtos transgênicos. Por um lado, as importações de transgênicos na UE são diretamente influenciadas pela demora nos processos de aprovação de 
eventos GM. Por outro lado, países exportadores de commodities GM que têm a UE como um de seus principais importadores também dependem da rapidez com que novos eventos GM são aprovados para que suas exportações não sejam afetadas.

Considerando que trabalhos que analisem diferenças temporais nos processos de aprovação de eventos GM na UE ainda são incipientes na literatura, torna-se importante avaliar quais são os determinantes do tempo de aprovação de eventos GM na UE, de forma a tentar harmonizar o processo de aprovação, e, consequentemente, minimizar a aprovação assíncrona. Smart, Blum e Wesseler (2017) analisaram de forma abrangente o tempo gasto nos processos de aprovação de GM na UE, utilizando amostra com eventos de diversas commodities para verificar o impacto das características de cada processo no tempo de cada etapa de aprovação e também no tempo total.

Diferentemente de Smart, Blum e Wesseler (2017), no presente trabalho, consideram-se apenas as commodities mais relevantes no contexto GM, algodão, milho e soja, e ainda é incluída a etapa de análise técnica para explicar o tempo total de aprovação na UE, dado que o mesmo é constantemente caracterizado como "político". Dessa maneira, o objetivo deste artigo é avaliar quais são os principais determinantes do tempo total de aprovação de eventos GM na União Europeia considerando as commodities transgênicas mais relevantes no comércio internacional: algodão, milho e soja.

Este trabalho está subdividido, em complemento à introdução, da seguinte forma: as seções 2 e 3 apresentam uma breve revisão da literatura associada à discussão do processo de aprovação de eventos GM na UE. Em seguida, discorre-se sobre o modelo empírico e os dados nas seções 4 e 5 . Os resultados são discutidos na seção 6 e as conclusões são apresentadas na seção 7.

\section{REVISÃO DE LITERATURA}

São poucos os trabalhos na literatura que buscam analisar mais detalhadamente os processos de aprovação de eventos GM em diferentes países, bem como quais características influenciam o tempo gasto em cada etapa específica de aprovação. Por outro lado, muitos trabalhos têm analisado a heterogeneidade de regulamentação GM, interpretando-a no âmbito das medidas não tarifárias (NTMs), e relacionando-a a alterações no comércio internacional (FARIA e WIECK, 2015; VIGANI e OLPER, 2013).

Segundo Baldwin (2000), as medidas não tarifárias têm como principal objetivo corrigir externalidades associadas ao consumo e/ou produção de modo a garantir a saúde, segurança e bem estar das pessoas, animais e meio ambiente. No entanto, a principal dificuldade está em determinar se essas servem a interesses da sociedade ou a interesses protecionistas, quando ambos normalmente estão combinados. No contexto de produtos GM, a regulamentação imposta para a utilização e comercialização dos mesmos, tal como rotulagem obrigatória e rastreabilidade, pode ser interpretada como uma NTM e ainda possuir características protecionistas (KREIPE, 2010).

Países que adotam o princípio da precaução (União Europeia é a principal representante) apresentam regulamentos mais rigorosos quanto às aprovações de eventos GM já que, por esse princípio, qualquer produto GM está sujeito à regulamentação específica, pois podem existir riscos ainda não avaliados cientificamente (FALKNER e GUPTA, 2009). Segundo Tait (2011), o princípio da precaução defende restrições ao desenvolvimento quando o mesmo provoca a suspeita de possíveis danos ambientais, sem a necessidade da existência de provas científicas. Dessa maneira, ao não considerar custos e benefícios, a abordagem poderia paralisar 0 desenvolvimento de novas tecnologias, motivo pelo qual são impostas algumas limitações à mesma.

Dentre os estudos que avaliaram as motivações para imposição de regulamentos GM, Victor (2001) discorre sobre os limites da tênue relação entre proteção (no sentido de segurança alimentar, saúde humana, animal e vegetal e minimização de riscos ambientais) e protecionismo comercial na utilização do princípio da precaução para regulamentação de organismos geneticamente modificados. Vigani e Olper (2013) afirmam que regulamentos podem ser vistos como "proteção disfarçada" para substituição de tarifas. Evidência empírica dessa situação pode ser observada no trabalho de Anderson, Damania e Jackson (2004), no qual a desvantagem comparativa da UE em relação aos EUA, na produção de GM, propiciou a formulação de políticas mais restritivas na regulamentação de eventos GM. 
Dentre os principais impactos causados pelas diferenças entre regulamentos GM em diferentes países, destacam-se as variações temporais para a completude dos processos de aprovação. Bayer, Norton e Falck-Zepeda (2010) apontam que atrasos associados à regulamentação têm grande potencial para restringir o comércio, enquanto Faria e Wieck (2015), de forma semelhante, concluem que diferenças temporais entre a aprovação de eventos GM em diferentes países, a aprovação assíncrona, tem impacto negativo sobre 0 comércio internacional. Adicionalmente, Kalaitzandonakes, Alston e Bradford (2007) associam processos de aprovação lentos e custosos às dificuldades de desenvolver e comercializar novas culturas transgênicas.

Especificamente com relação à UE, alguns autores analisaram os processos de aprovação de eventos GM no bloco, e como os mesmos são influenciados tanto técnica quanto politicamente. Mühlböck e Tosun (2015) analisaram o comportamento de votação da Comissão Europeia em vários processos de autorização de eventos GM, para encontrar padrões de votação e determinar as principais características de voto tanto no Conselho quanto no Parlamento Europeu. Os autores reiteram a biotecnologia como um assunto controverso, o qual tem gerado comportamentos de votação pouco convencionais, ou seja, nas votações dificilmente consegue-se uma maioria. Além disso, os padrões de votação dos países membros do bloco, individualmente, são voláteis.

Smart, Blum e Wesseler (2015), além de avaliar o comportamento de votação dos Estados Membros da UE nos processos de aprovação de eventos GM, investigaram se as características dos eventos e sua utilização influenciam os padrões de voto. Segundo os autores, dentre os eventos previamente aprovados tecnicamente, nunca se obteve uma maioria qualificada nos processos de votação do Conselho Europeu, comportamento que provavelmente se mantenha, a menos que grandes players, como Alemanha, França e Itália, mudem suas posições conjuntamente. Ainda, os autores concluem que as características dos eventos ou sua utilização não explicam os padrões de votação dos países membros, mas que tais comportamentos são consequência de efeitos fixos individuais, ou seja, fatores endógenos associados a cada país membro.
Smart, Blum e Wesseler (2017) investigaram tendências para o tempo gasto nos processos de aprovação de eventos GM nos EUA e na UE, e também como as características de cada processo influenciam o tempo de aprovação. Os autores concluem que o tempo de aprovação nos EUA apresentou tendência de redução entre 1988 e 1997, mas após esse período se manteve aproximadamente inalterado. $\mathrm{Na}$ UE, surpreendentemente, por existir notável resistência dos consumidores em relação aos transgênicos, o tempo de aprovação, entre 1996 e 2015, manteve uma tendência de queda com o passar do tempo. Os autores ainda determinam como algumas características dos processos de aprovação impactam cada etapa do mesmo, bem como o tempo total, com destaque para o tipo de commodity.

\section{PROCESSO DE APROVAÇÃO DE EVENTOS GM NA UNIÃO EUROPEIA}

O processo de autorização para a comercialização de eventos GM para alimentação, tanto humana quanto animal, na União Europeia está regulamentado pelo Regulamento (CE) 1829/2003 e pela Diretiva 2001/18/CE. O processo decisório quanto à aprovação de eventos GM na UE é composto pelas etapas detalhadas na Figura 1.

As aplicações de novos eventos para alimentação humana e animal são feitas pelas empresas fabricantes dos eventos GM, em algum dos Estados Membros do bloco, seguindo a regulamentação 1829/2003 e enviadas a Autoridade Europeia para Segurança dos Alimentos (EFSA), órgão responsável por fazer uma avaliação dos riscos inerentes ao evento. Em seguida, a EFSA emite um relatório científico no qual pode considerar o evento GM tão seguro quanto o seu semelhante não transgênico, através da avaliação quanto a efeitos potenciais na saúde humana, animal e no meio ambiente.

$\mathrm{Na}$ etapa de análise pela EFSA, denominada doravante de avaliação técnica, a autoridade deve tentar respeitar um prazo de seis meses para emitir o seu parecer final, contados a partir do recebimento de um pedido válido. Tal prazo pode ser estendido caso a autoridade solicite informações adicionais ao requerente da aprovação. Dentre as etapas que a autoridade deve concluir para emissão do parecer final, destacam-se: verificar conformidade das informações e 
documentação fornecida pelo requerente; enviar ao laboratório de referência informações que possibilitem teste e validação dos métodos de detecção e identificação utilizados; comparar as características da nova variedade GM e seu equivalente tradicional, levando em conta os limites aceitáveis de variação.

A autoridade, durante o processo, pode solicitar aos órgãos competentes avaliações quanto à segurança do gênero alimentício e de possíveis riscos ambientais. São aplicáveis, ainda, aos próprios eventos GM e aos alimentos que contenham ou sejam constituídos por GM, avaliações quanto aos requisitos de segurança ambiental conforme Diretiva 20011/18/CE. Nesse caso a EFSA deve consultar a autoridade nacional competente de cada Estado Membro, a qual dispõe de três meses após a solicitação para dar o seu parecer.

A avaliação técnica, então, é enviada à Comissão Europeia, a qual decidirá, de forma preliminar, por aprovar ou não o evento GM nos Estados Membros do bloco, num processo de gerenciamento de riscos notadamente "político". A Comissão Europeia, em sequência, envia sua decisão preliminar ao comitê composto por representantes dos Estados Membros do bloco e do Comitê Permanente da Cadeia Alimentar e da Saúde Animal (SCFCAH), os quais decidirão a respeito da aprovação através de votação por maioria qualificada. Caso exista maioria e haja aprovação, o processo é finalizado nesse ponto

Figura 1 - Processo decisório relacionado à aprovação de eventos GM para alimentação humana e animal na União Europeia

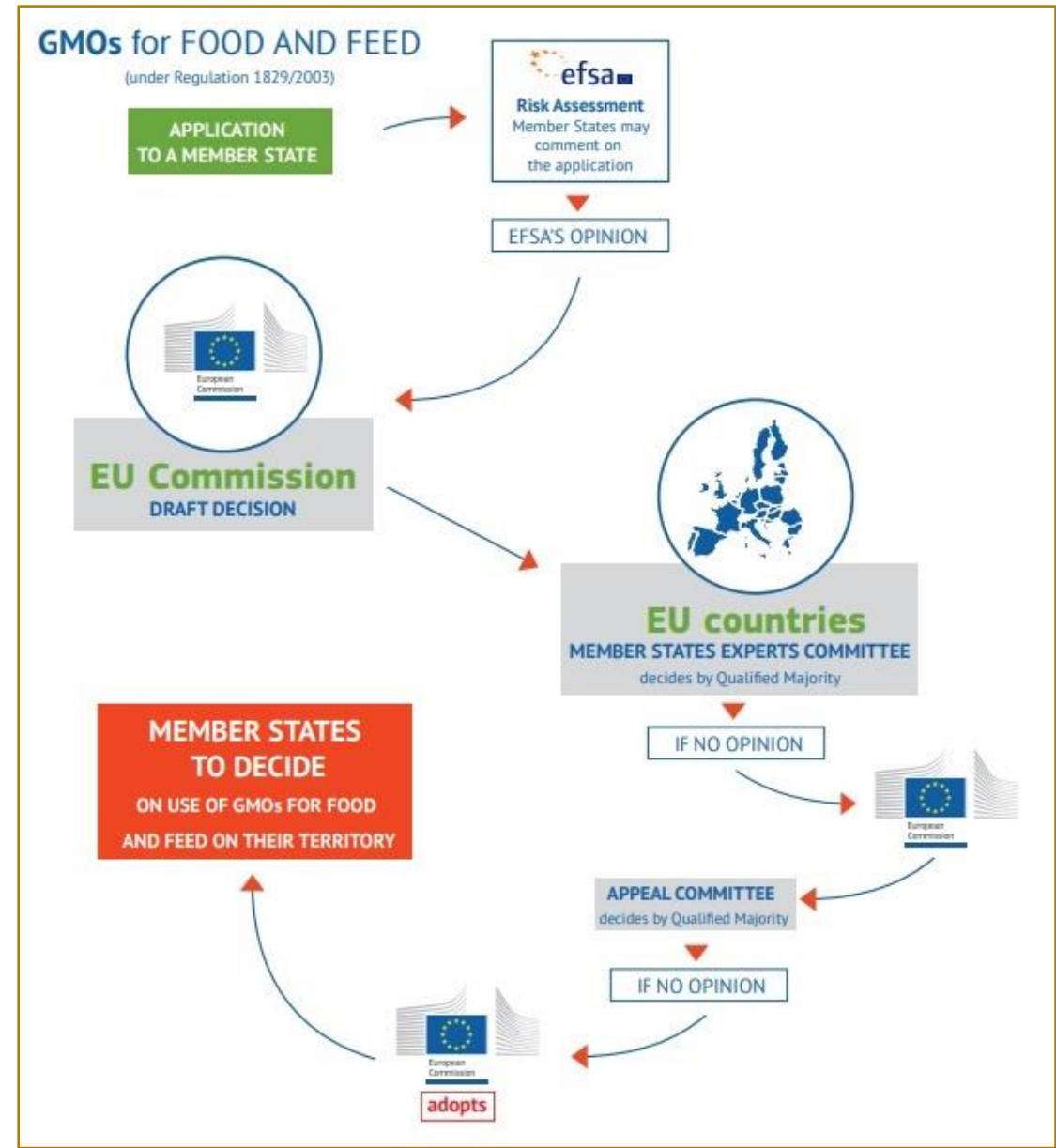

Fonte: Elaboração própria com informações da Comissão Europeia.

No caso de não aprovação, ou ausência de opinião por parte do comitê, ou seja, não foi atingida uma maioria qualificada, o processo retorna a Comissão Europeia, a qual envia o mesmo a um Comitê de Apelação, o qual, juntamente com representantes dos Estados 
Membros, também decidirá através de votação por maioria qualificada. Caso esse Comitê conclua por "ausência de opinião" quanto ao evento, a Comissão Europeia pode conceder a aprovação e cada um dos Estados Membros do bloco optará pelo uso do evento GM em seu território.

\section{MODELO EMPÍRICO}

O modelo econométrico para estimar os determinantes do tempo total de aprovação de eventos GM na UE tem a seguinte forma:

$$
T_{-} \text {Total }_{i}=\beta_{1}+\beta_{2} T_{-} \text {EFSA }_{i}+\beta_{3} \text { Origem }_{i}+\beta_{4} \text { Soja }_{i}+\beta_{5} \text { Milho }_{i}+u_{i}
$$

onde:

T_Total: Variável que denota o tempo total, em anos, necessário para aprovação do evento GM ( /) na União Europeia;

T_EFSA: Variável que denota o tempo necessário, em anos, para o evento GM ( $/$ ) ser aprovado tecnicamente pela EFSA;

Origem: Variável binária que indica o país ou bloco de origem da empresa que solicita a aprovação do evento GM (I). União Europeia (1) e EUA (0);

Soja: Variável binária que assume o valor 1 se o evento GM (I) for referente à commodity soja e 0 em caso contrário;

Milho: Variável binária que assume o valor 1 se o evento GM ( $l$ ) for referente à commodity milho e 0 em caso contrário.

O algodão é a variável de referência.

Foi utilizado o método de Mínimos Quadrados Ordinários (MQO) para estimar a equação (1). Para verificar a hipótese de heterocedasticia utilizou-se o teste de Breusch-Pagan. Para verificar se existe multicolinearidade no modelo foi utilizada a estatística do Variance Inflation Factor (VIF).

\section{DADOS}

As informações foram retiradas da base de dados GMO Compass, que disponibiliza detalhes de todos os processos de aprovação de eventos GM da União Europeia, tanto os que ainda estão em fase de análise quanto os que já foram concluídos. Para cada evento
GM, as principais informações fornecidas são: Nome do evento (Ex: MON531 x MON1445), commodity à qual se refere (Ex: Algodão); escopo da aprovação (Ex: Alimentação humana e animal; importação e processamento; cultivo), tipo de melhoramento (Ex: Resistência a insetos; tolerância a herbicidas), empresa solicitante (Ex: Monsanto; Syngenta), país no qual foi submetida a solicitação de aprovação do evento GM (Ex: Reino Unido; Holanda), data na qual foi solicitada a aprovação, data da validação técnica do evento GM pela EFSA (European Food Safety Authority) e a data de validação final pela comissão europeia.

As empresas que compõem a amostra são: Monsanto, Dow AgroSciences e Pioneer, originárias dos EUA, além de BASF, Bayer CropScience e Syngenta com origem na União Europeia.

Para este trabalho, foram considerados eventos GM com autorização válida, oriundos de processos de criação (não foram considerados processos de renovação de eventos GM) na União Europeia para as commodities algodão, milho e soja, processos esses finalizados entre 2006 e 2015. Dessa maneira, 48 eventos GM foram analisados. Para estimar a regressão, foi utilizado o software Stata/SE 12.0.

\section{RESULTADOS}

Inicialmente, a Tabela 1 apresenta a análise descritiva das variáveis associadas às commodities e a origem das empresas solicitantes. 
Tabela 1 - Análise descritiva das variáveis

\begin{tabular}{|l|c|c|c|c|c|} 
& \multicolumn{3}{c}{ Commodities } & \multicolumn{2}{c|}{$\begin{array}{c}\text { Origem da Empresa } \\
\text { Solicitante }\end{array}$} \\
& \multicolumn{2}{|c|}{ Algodão } & Milho & Soja & EUA \\
\hline Eventos & 7 & 30 & 11 & 34 & 14 \\
\hline Tempo Médio (Anos) & 6,9 & 4,5 & 4,4 & 5,1 & 4,2 \\
\hline Mais Longo (Anos) & 10,4 & 9,7 & 7,9 & 10,4 & 8 \\
\hline Mais Curto (Anos) & 3,7 & 2,3 & 1,8 & 1,8 & 2,3 \\
\hline
\end{tabular}

Fonte: Elaboração própria com dados do GMO-Compass.

Com relação à quantidade de eventos, a commodity mais representativa foi o milho, com 30 eventos dentre o total de 48 coletados. Quanto à origem da empresa solicitante, 34 dos 48 eventos tiveram sua solicitação feita por empresas estadunidenses. O tempo total de aprovação de eventos variou entre 1,8 e 10,4 anos, o

Tabela 2 exibe o tempo médio de cada etapa do processo de aprovação, entre os anos de 2006 e 2015, com exceção de 2014, ano no qual não houve finalização de processos. No período analisado, os processos finalizados no ano de 2012 representam o único caso em que o tempo médio de aprovação técnica foi mais curto e o mais longo, respectivamente. Por sua vez, o tempo médio de aprovação foi inferior para empresas europeias, quando comparadas às estadunidenses, além de inferior também para eventos GM de soja e milho, quando comparados aos eventos GM de algodão.

A

superior ao tempo médio de aprovação política. Em todos os outros anos da amostra, a etapa de aprovação técnica consumiu mais tempo, de tal forma que, dentre todos os processos, gastou-se, em média, 3,3 anos para obtenção da aprovação técnica, e 1,5, em média, para finalização da etapa complementar.

Tabela 2 - Tempo médio gasto em cada etapa do processo de aprovação

\begin{tabular}{|c|c|c|}
\hline $\begin{array}{c}\text { Ano de Aprovação dos } \\
\text { Eventos GM }\end{array}$ & $\begin{array}{c}\text { Média de Tempo da Aprovação } \\
\text { Técnica (Anos) }\end{array}$ & $\begin{array}{c}\text { Média de Tempo da Aprovação } \\
\text { Política (Anos) }\end{array}$ \\
\hline 2006 & 2,9 & 1,4 \\
\hline 2007 & 1,9 & 1,2 \\
\hline 2008 & 2,0 & 0,9 \\
\hline 2009 & 3,4 & 0,7 \\
\hline 2010 & 2,6 & 2,1 \\
\hline 2011 & 3,1 & 1,5 \\
\hline 2012 & 2,6 & 0,5 \\
\hline 2013 & 1,8 & 3,1 \\
\hline 2015 & 5,0 & 1,7 \\
\hline Total Geral & 3,3 & 1,5 \\
\hline
\end{tabular}

Fonte: Elaboração própria com dados do GMO-Compass. 
Tal comportamento vai ao encontro dos resultados de Smart, Blum e Wesseler (2017), os quais, ao analisarem as tendências no tempo necessário para concluir cada uma das etapas do processo de aprovação, encontraram tendência crescente para a etapa técnica e decrescente para a etapa política. Dessa forma, ressalta-se a importância do processo de aprovação técnica como possível fator de lentidão do processo de aprovação da UE.

Os resultados referentes à estimação econométrica são exibidos na Tabela 3. O teste de Breusch-Pagan resultou na não rejeição da hipótese nula de homocedasticidade, e a estatística Variance Inflation Factor (VIF) de 1,86 indica ausência de multicolinearidade no modelo.

Tabela 3 - Resultados da estimação.

\begin{tabular}{|c|c|}
\hline Variável & Coeficiente \\
\hline Tempo de Aprovação Técnica & $\begin{array}{l}0,87^{* * *} \\
(0,09)\end{array}$ \\
\hline Origem UE & $\begin{array}{c}-0,63^{* *} \\
(0,28)\end{array}$ \\
\hline Origem EUA & referência \\
\hline Soja & $\begin{array}{c}-0,87^{* *} \\
(0,36)\end{array}$ \\
\hline Milho & $\begin{array}{l}-0,33 \\
(0,38)\end{array}$ \\
\hline Algodão & referência \\
\hline Constante & $\begin{array}{l}2,51^{* \star *} \\
(0,54)\end{array}$ \\
\hline Observações & 48 \\
\hline $\mathrm{R} 2$ & 0,71 \\
\hline
\end{tabular}

A partir do teste $\mathrm{F}$ rejeitou-se a hipótese nula de que todos os coeficientes são estatisticamente iguais a zero com significância de 1\%. Analisando os resultados da estimação, verifica-se que os coeficientes associados ao tempo de aprovação técnica, e às variáveis binárias para empresas de origem europeia e para a commodity soja são estatisticamente significativos a $1 \%$ e $5 \%$, respectivamente. A variável explicativa binária associada ao milho não foi estatisticamente diferente de zero.

O tempo necessário para aprovação técnica, referente à EFSA, apresentou coeficiente positivo estatisticamente significativo e igual a 0,87 . Dado que o tempo total de aprovação depende diretamente do tempo de aprovação técnica, ou seja, se o tempo para aprovação técnica for longo, isso irá impactar diretamente o tempo total, pode parecer óbvia relação encontrada. Porém, dada a intensa caracterização do processo de aprovação da UE como "político", a relação acima mencionada nos permite supor que para acelerar os processos europeus, seria interessante propor melhorias quanto à análise técnica da EFSA, dado que a mesma leva mais de duas vezes o tempo gasto, em média, pela etapa política do processo. Smart, Blum e Wesseler (2017), além de confirmar uma tendência positiva na qual os processos de análise técnica tem se tornado cada vez mais longos, sugerem investigação detalhada para propor maneiras de acelerar a análise da EFSA, além da tentativa de encurtar ou mesmo eliminar a etapa de análise "política" dos processos, tornando-os mais rápidos.

Os resultados indicam que, em média, empresas europeias têm seus eventos aprovados mais rapidamente em relação às empresas estrangeiras. No período, pode-se dizer que, em média, as empresas com origem na UE necessitaram 0,63 anos a menos para aprovar eventos GM. No trabalho de Smart, Blum e Wesseler (2017), os 
resultados foram semelhantes e apontaram relação negativa entre a submissão do processo por uma empresa europeia e o tempo necessário para completar o processo de aprovação.

Com relação às commodities, o coeficiente associado ao milho não tem significância estatística. Por sua vez, o coeficiente da commodity soja, estatisticamente significativo ao nível de significância de 5\%, demonstra que os processos de aprovação da mesma, em média, são 0,87 anos mais rápidos em comparação ao tempo médio da aprovação do algodão. Considerando a dependência da UE na importação de soja, a necessidade da mesma parece agilizar os seus processos de aprovação, mesmo sendo o mercado europeu notadamente restritivo a aprovação de GM.

É possível traçar um paralelo entre a maior rapidez na aprovação de eventos GM associados à soja aos menores níveis de aprovação assíncrona da mesma na União Europeia exibidos no trabalho de Faria e Wieck (2015). Segundo as autoras, o índice de protecionismo $(\mathrm{PI})^{1}$ para soja diminuiu continuamente entre 2000, 2009 e 2012. Porém, tal comportamento contrastou significativamente com os valores de PI para as outras commodities, algodão e milho. Para ambas, a aprovação assíncrona aumentou (aproximadamente 25\%) entre 2000 e 2009 e decresceu ligeiramente (aproximadamente $6 \%$ ) entre 2009 e 2012. O decrescimento contínuo do índice nos três anos mencionados é exclusivo para processos de aprovação de soja, e corrobora um dos resultados desse trabalho, o qual sugere que a dependência do bloco para com a soja e seus derivados acelera os seus processos de aprovação.

\section{CONCLUSÕES E SUGESTÕES PARA TRABALHOS FUTUROS}

${ }^{1} \mathrm{O} \mathrm{Pl}$ é definido de forma bilateral, através da comparação do status de aprovação para um evento GM de países importadores e exportadores. O PI varia no intervalo ]0,e], no qual o valor unitário indica que existe o mesmo status de aprovação entre importador e exportador, enquanto que valores superiores (inferiores) a 1 indicam que 0 status de aprovação do país importador é mais (menos) restritivo quando comparado ao país exportador.
Esse trabalho busca avaliar as ligações entre as características dos processos de aprovação de eventos GM na União Europeia e o tempo total para sua completude, considerando as commodities GM algodão, milho e soja, de forma a relacioná-las as divergências temporais que originam a aprovação assíncrona entre países e que tem impactado diretamente o comércio internacional de GM.

O tempo de aprovação técnica é um importante determinante do tempo total de aprovação, pois representa, em média, quase $70 \%$ do tempo necessário referente ao processo de aprovação na União Europeia. Isso ilustra a rigorosidade técnica implementada pela UE na aprovação de eventos GM (adoção do princípio da precaução), ou seja, a rigidez relacionada ao parecer técnico, que avalia, dentre outros, os possíveis riscos associados à utilização de GM no contexto de saúde humana, animal e meio ambiente. Apesar de diversos trabalhos darem ênfase ao processo político de aprovação de eventos GM da UE (NAVAH, VERSLUIS e VAN ASSELT, 2013; MÜHLBÖCK e TOSUN, 2015; SMART, BLUM e WESSELER, 2015; SMART, BLUM e WESSELER, 2017), assim associando maior rapidez do processo a melhorias na etapa política, nossos resultados sugerem que medidas mais eficientes para tornar o processo de aprovação mais ágil estão relacionadas a mudanças na etapa de análise técnica da EFSA. Compreender quais são os principais gargalos dentro do processo de avaliação de risco da EFSA é uma das principais necessidades a fim de diminuir o tempo total de aprovação.

De forma complementar, as empresas europeias conseguem aprovação de eventos GM em intervalos de tempo inferiores às empresas estrangeiras, 0 que pode caracterizar viés protecionista no processo de aprovação. Por fim, processos de aprovação associados à commodity soja acontecem em menores intervalos de tempo, o que evidencia a dependência do bloco para com a mesma, e acelera os seus processos de aprovação.

Como sugestões para trabalhos futuros estão às inclusões de eventos GM de outras commodities e do tipo de melhoramento genético como variáveis explicativas no modelo econométrico. 


\section{REFERÊNCIAS}

[1]. ANDERSON, K.; DAMANIA, R.; JACKSON, $\mathrm{L}$. Trade, standards, and the political economy of genetically modified food. World Bank Policy Research Working Paper 3395, 2004.

[2]. BACKUS, G.B.C.; BERKHOLT, P.; EATON, D.J.F.; FRANKE, L.; DE KLEIJN, A.J.; LOTZ, B.; VAN MIL; E.M., ROZA, P.; UFFELMANN, W. EU policy on GMOs: A quick scan of the economic consequences. p. 79, 2008.

[3]. BALDWIN, R.E. Regulatory Protectionism, Developing Nations, and a Two-Tier World Trade System. Brookings Trade Forum, n. 1, p. 237-280, 2000.

[4]. BAYER, J.C.; NORTON, G.W.; FALCKZEPEDA, J.B. Cost of Compliance with Biotechnology Regulation in the Philippines: Implications for Developing Countries, AgBioForum, v. 13, n. 1, p. 53-62, 2010.

[5]. DE VISSER, C.L.M.; SCHREUDER, R.; STODDARD, F. The EU's dependency on soya bean import for the animal feed industry and potential for EU produced alternatives. OCL, v. 21, n. 4, p. D407, 2014.

[6]. EBATA, A.; PUNT, M.; WESSELER, J. For the approval process of GMOs: The Japanese case. AgBioForum, v. 16, n. 2, p. 140-160, 2013.

[7]. EUROPABIO. Disponível em: $<$ http://www.europabio.org/sites/default/files/qa_0.p df>. Acesso em: 5 jan. 2018.

[8]. FALKNER, R.; GUPTA, A. The limits of regulatory convergence: Globalization and GMO politics in the south. International Environmental Agreements: Politics, Law and Economics, v. 9, n. 2, p. 113-133, 2009

[9]. FARIA, R.N. DE; WIECK, C. Empirical evidence on the trade impact of asynchronous regulatory approval of new GMO events. Food Policy, v. 53, p. 22-32, 2015.

[10]. GILMOUR, B.; DANG, H.; WANG, X. China's Agri-Biotech Policy, Regulation, and Governance. AgBioForum, v. 18, n. 1, p. 72-86, 2015.

[11]. JAMES, C. Global Status of Commercialized Biotech/GM Crops. ISAAA brief, v. 51, 2016

[12]. KALAITZANDONAKES, N. The economic impacts of asynchronous authorizations and low level presence: an overview. Position Paper, October, 2011.

[13]. KALAITZANDONAKES, N.; ALSTON, J.M.; BRADFORD, K.J. Compliance costs for regulatory approval of new biotech crops. Nature biotechnology, v. 25, n. 5, p. 509-511, 2007.

[14]. KALAITZANDONAKES, N.; KAUFMAN, J.; MILLER, D. Potential economic impacts of zero thresholds for unapproved GMOs: The EU case. Food Policy, v. 45, p. 146-157, 2014.

[15]. KREIPE, M. Genetically Modified Food: Trade Regulation in View of Environmental Policy Objectives. Diplomica Verlag, 2010.

[16]. MÜHLBÖCK, M.; TOSUN, J. Deciding over controversial issues: Voting behavior in the Council and the European Parliament on genetically modified organisms. In: Seventh International Conference on Coexistence between Genetically Modified (GM) and non-GM based Agricultural Supply Chains (GMCC-15), Amsterdam. 2015

[17]. NAVAH, M.; VERSLUIS, E.; VAN ASSELT, M.B. The politics of risk decision making the voting behaviour of the EU member. Balancing between trade and risk: integrating legal and social science perspectives, p. 128-146, 2013

[18]. SMART, R.D.; BLUM, M.; WESSELER, J. EU member states' voting for authorizing genetically engineered crops. German Journal of Agricultural Economics, v. 64, n. 4, p. 244-262, 2015

[19]. SMART, R.D.; BLUM, M.; WESSELER, J. Trends in approval times for genetically engineered crops in the United States and the European Union. Journal of Agricultural Economics, v. 68, n. 1, p. 182-198, 2017.

[20]. STEIN, A.J.; RODRÍGUEZ-CEREZO, E. International trade and the global pipeline of new GM crops. Nature biotechnology, v. 28, n. 1, p. 2325, 2010.

[21]. TAIT, J. More Faust than Frankenstein : the European debate about the precautionary principle and risk regulation for genetically modified crops. Journal of Risk Research, v. 4, n. 2, p. 175-189, 2011.

[22]. VICTOR, M. Precaution or Protectionism-The Precautionary Principle, Genetically Modified Organsims, and Allowing Unfounded Fear to Undermine Free Trade. Transnat'l Law, v. 14, p. 295, 2001.

[23]. VIGANI, M.; OLPER, A. GMO standards, endogenous policy and the market for information. Food Policy, v. 43, p. 32-43, 2013.

[24]. WAGER, R.; MCHUGHEN, A. Zero sense in European approach to GM. EMBO reports, v. 11, n. 4 , p. 258-262, 2010 


\section{Gapítulo 16}

\section{ANÁLISE DA VIABILIDADE DO RETORNO ECONÔMICO- FINANCEIRO DAS ATIVIDADES LEITEIRA E AVICOLA}

Silvana Dalmutt Kruger

Mauricio Antônio Bottini

Fabio José Diel

Vanderlei Gollo

Resumo: O estudo teve por objetivo comparar a viabilidade econômica e financeira das atividades avícola e leiteira, desenvolvidas em uma propriedade rural do município de Águas de Chapecó-SC. Quanto à metodologia, a pesquisa é caracterizada como descritiva, realizada por meio de um estudo de caso, com análise de cunho qualitativo. A partir do levantamento patrimonial e dos custos das atividades leiteira e avícola (no período de 18 meses - julho/2016 a dezembro/2017), elaborou-se a demonstração de resultados das atividades. Posteriormente foram analisados os investimentos com os seguintes métodos de avaliação: Valor Presente Líquido, Taxa Interna de Retorno e payback simples e descontado. Os resultados evidenciam que a atividade leiteira gerou resultado médio mensal foi de $\mathrm{R} \$ 11.180,12$, com margem líquida de 63,76\%, financeiramente o tempo de retorno dos investimentos é de 1 ano e 7 meses, com a TIR de 48,73\%. Já a atividade avícola gerou uma margem líquida de 67,15\%, considerando a análise de oito lotes produzidos no período observado, com lucro médio de $R \$ 4.225,54$ por lote, totalizando lucro de $R \$ 33.804,29$. Na atividade avícola, o tempo de retorno dos investimentos é de 7 anos e 6 meses pelo payback descontado, com a TIR de $11,12 \%$. Os resultados evidenciam que, financeiramente a atividade leiteira gera retorno dos investimentos em menor tempo, em relação a atividade avícola, economicamente ambas são viáveis nesta realidade. De modo geral, destaca-se a importância da utilização da contabilidade no meio rural para subsidiar a análise do desempenho das atividades desenvolvidas.

Palavras-chave: Atividade leiteira. Atividade avícola. Contabilidade rural

*Artigo aprovado e apresentado no XXV Congresso Brasileiro de Custos - Vitória, ES, Brasil, 12 a 14 de novembro de 2018 


\section{INTRODUÇÃO}

A participação do agronegócio na economia brasileira é representativa e importante para inúmeras atividades a ele relacionadas. Apesar do cenário de restrição econômica, o agronegócio apresentou um aumento de 1,0\% no Produto Interno Bruto (PIB) do Brasil em 2016, superando todos os outros setores da economia brasileira conforme dados do Instituto Brasileiro de Geografia e Estatística IBGE (2017). O agronegócio brasileiro se caracteriza como um conjunto de operações que contemplam a extração vegetal, as atividades zootécnicas, até a comercialização e transportes desses produtos ao consumidor final (DAL MAGRO et al., 2016). A agricultura familiar também tem a sua participação na produção e movimentação do agronegócio brasileiro. Conforme dados do IBGE (2017), a agricultura familiar é responsável pela produção de mais de dois terços dos alimentos consumidos no Brasil.

Para Mior (2005), o desenvolvimento rural no Brasil deve ter a agricultura familiar como estratégia dos governantes, tendo em vista a geração de receita econômica e empregos. Destaca-se a participação da agricultura familiar em várias atividades, entre elas a criação de suínos, aves e a atividade leiteira, realizadas muitas vezes em forma de parceria, entre produtor rural e agroindústrias.

A atividade leiteira é destaque no contexto da agricultura familiar do Estado de Santa Catarina, assim como a avicultura de acordo com dados do Instituto de Planejamento e Economia Agrícola de Santa Catarina (ICEPA, 2017). Ambas as atividades econômicas, contribuem com a geração de renda e empregos diretos $e$ indiretos. Conforme dados da EPAGRI (2018), a atividade leiteira é desenvolvida em cerca de 80 mil propriedades rurais no Estado Catarinense, destas cerca de 74\% estão localizadas na região Oeste. Em relação a avicultura, o Estado detém $20 \%$ da produção nacional de aves, atende a $65 \%$ do mercado interno e participa com $75 \%$ das exportações brasileiras de carne de frango (DECKER; GOMES, 2016; EPAGRI, 2018).

No contexto do desenvolvimento das atividades rurais, o controle e o planejamento dos investimentos e gastos, tornam-se instrumentos de gestão rural. A contabilidade aplicada no meio rural serve de apoio para a mensuração, controle e planejamento das atividades desenvolvidas no meio rural, visando atingir seu objetivo de controlar o patrimônio e possibilitar o planejamento e acompanhamento dos resultados das atividades rurais, bem como a análise dos investimentos realizados (MARION, 2012; KRUGER et al., 2015).

A análise da situação econômica e financeira das propriedades rurais, bem como a viabilidade dos investimentos realizados no meio rural, permite aos gestores identificar o tempo de retorno dos valores investidos, a geração prevista de fluxo de caixa e comparar o desempenho entre as atividades desenvolvidas. A exemplo de qualquer negócio ou empreendimento, no meio rural a viabilidade e o menor tempo de retorno do capital investido, devem ser fatores de análise dos gestores (NASCIMENTO, 2011; KRUGER et al., 2017).

Diante da relevância das atividades desenvolvidas no meio rural, surge o problema da pesquisa: Qual a viabilidade econômica e financeira entre as atividades leiteira e avícola desenvolvidas numa propriedade rural no município de Águas de Chapecó - SC? Como objetivo, tenciona-se comparar a viabilidade econômica e financeira entre as atividades leiteira e avícola desenvolvidas numa propriedade rural no município de Águas de Chapecó - SC.

Destaca-se a relevância econômica dos empreendimentos rurais, considerando-se a geração de empregos e renda proporcionada pelos estabelecimentos rurais, especialmente na região Oeste Catarinense. Justifica-se neste sentido a relevância do estudo, no intuito de analisar o uso das informações contábeis como instrumento de apoio ao processo decisório pelos estabelecimentos rurais, visando evidenciar a importância do controle e planejamento das atividades desenvolvidas no meio rural, bem como da mensuração e da análise dos resultados econômicos e do tempo de retorno dos investimentos.

\section{REVISÃO DA LITERATURA}

Nesta seção aborda-se a importância da contabilidade quando aplicada nas propriedades rurais, para fins de análise dos resultados e dos investimentos realizados, bem como destacam-se estudos relacionados ao assunto pesquisado. 


\subsection{CONTABILIDADE RURAL}

O objeto de estudo da contabilidade é o patrimônio das entidades, independente se ele for resultado de consolidação ou da subdivisão em parcelas menores que mereçam um acompanhamento nas suas variações e mutações, e ainda se é de pessoa física ou jurídica (IUDíCIBUS; MARION; FARIA, 2009). Segundo Marion (2012), a contabilidade tem a finalidade de examinar, fiscalizar, planejar e controlar o patrimônio das entidades, mediante registro e análise dos fatos ocorridos, bem como da apuração do lucro ou prejuízo obtido.

Mazzioni et al. (2011) salientam que a contabilidade é importante aliada na tomada de decisões e na gestão de negócios, sendo aplicável tanto para pessoas jurídicas, como para as pessoas físicas. A contabilidade voltada ao meio rural visa auxiliar na mensuração, controle e planejamento, com o objetivo de controlar o patrimônio das entidades rurais e possibilitar a análise dos resultados (KRUGER et al., 2014; KRUGER et al., 2015).

Entre as finalidades da contabilidade rural, pode-se destacar a orientação das operações realizadas no meio rural; a possibilidade de medir o desempenho de cada atividade produtiva individualmente; o apoio no processo de decisões sobre investimentos, ou sobre a necessidade de recursos; o controle das transações financeiras, a análise comparativa de resultados e auxílio no controle das despesas pessoais e nas informações para o imposto de renda (CREPALDI, 2011). Conforme Zanin et al. (2015) e Kruger et al. (2014), a contabilidade aplicada no meio rural é importante instrumento de controle e planejamento, sendo elementar seu uso e reconhecimento por parte dos gestores das unidades produtivas rurais.

O planejamento é parte essencial da gestão das entidades rurais, bem como deve-se considerar três fatores de produção relacionados aos negócios rurais: a terra, o capital e o trabalho. Na terra é onde se aplicam os recursos e se trabalha para obter a produção; o capital é o conjunto de bens aplicados sobre a terra com a intenção de aumentar sua produtividade; e o trabalho é conjunto de atividades desempenhadas pelo homem. Nesse conjunto deve-se obter resultados satisfatórios para remunerar o capital e o trabalho (CREPALDI, 2011).
No desenvolvimento das atividades rurais, especialmente naquelas entidades com estrutura familiar, o dono da propriedade rural é também o seu administrador, torna-se relevante o princípio contábil da entidade, visando a separação dos gastos da família daqueles da empresa (DAL MAGRO et al., 2016). No intuito de possibilitar a análise do desempenho individual das atividades desenvolvidas, a comparação dos resultados econômicos e financeiras gerados e o retorno dos investimentos realizados.

Destaca-se no contexto das atividades rurais, a importância da gestão contábil, tanto para a identificação dos resultados econômicos entre as atividades, quanto para a análise financeira do retorno sobre os investimentos realizados, especialmente se a análise pudesse ocorrer de forma preditiva a aplicação dos resultados nas atividades. Nestes aspectos a análise dos custos e dos resultados individualmente por atividade, torna-se diferencial de apoio a gestão rural (KRUGER et al., 2017).

\subsection{ANÁLISE DE RESULTADOS NO MEIO RURAL}

A observação da situação econômica e financeira das propriedades rurais é importante para que os gestores tenham conhecimento dos resultados e da situação financeira, em relação a geração de caixa e quanto ao tempo de retorno dos investimentos nas atividades rurais que desenvolvem (NASCIMENTO, 2011). Segundo Assaf Neto e Lima (2009), entre os métodos de avaliação de desempenho utilizados, estão o Valor Presente Líquido (VPL), a Taxa Interna de Retorno (TIR) e o prazo de retorno indicado pelo método payback.

A TIR "é uma taxa de juros implícita numa série de recebimentos (entradas) e pagamentos (saídas), que tem a função de descontar um valor futuro ou o fator de juros sobre um valor presente" (HOJI, 2003, p. 81). Ainda, o conceito de TIR é utilizado para calcular a taxa 'i' quando existe mais de um pagamento e mais de um recebimento, independente das parcelas serem ou não uniformes (HOJI, 2003).

Para Groppelli e Nikbakht (2005), a TIR é um dos métodos mais utilizados no orçamento da propriedade. Além disso, pode-se dizer que a TIR é uma taxa de desconto que iguala o VPL a zero. No entanto, para analisar se a TIR é 
viável, ou seja, se o investimento proporciona um percentual aceitável de retorno, a TIR deve ser comparada com uma Taxa Mínima de Atratividade (TMA), como forma de identificar o retorno desejado com o alcançado (GROPPELLI; NIKBAKHT, 2005).

No que concerne ao VPL, ele possibilita identificar "a soma das entradas e saídas de um fluxo de caixa na data inicial" (HOJI, 2003, p. 85). Neste sentido para que o investimento seja viável financeiramente, o valor presente do fluxo de caixa futuro deve ser maior que o custo inicial. Neste sentido, a análise do VPL evidencia se o investimento é viável (VPL maior que que custo), ou se é inviável (VPL menor que o custo), ainda, destaca-se a importância desta análise que permite $\mathrm{o}$ reconhecimento do dinheiro no tempo (GROPPELLI; NIKBAKHT, 2005).

E ainda, quanto a análise do prazo de retorno dos investimentos, o método payback, permite a identificação do período necessário para recuperar um determinado investimento (Hoji (2003). A partir do payback simples ou descontado é possível auferir a viabilidade financeira do recurso investido. Neste contexto é possível verificar que "a análise da estrutura econômica e financeira propicia o conhecimento do nível de solidez financeira da empresa" (HOJI, 2003, p. 131). O Quadro 1 apresenta o conceito e as finalidades dos métodos de análise de retorno de investimentos: TIR, VPL e payback.

Quadro 1: Conceitos e finalidades da análise de investimentos

\begin{tabular}{|c|c|c|}
\hline Conceito & Finalidade & Fórmula \\
\hline $\begin{array}{l}\text { TIR: É uma taxa de desconto } \\
\text { hipotética que, quando } \\
\text { aplicada a um fluxo de caixa, } \\
\text { faz com que os valores das } \\
\text { despesas, trazidos ao valor } \\
\text { presente, seja igual aos valores } \\
\text { dos retornos dos investimentos, } \\
\text { também trazidos ao valor } \\
\text { presente }\end{array}$ & $\begin{array}{l}\text { É utilizada para calcular a taxa de } \\
\text { desconto que teria um } \\
\text { determinado fluxo de caixa para } \\
\text { igualar a zero seu Valor Presente } \\
\text { Líquido. Em outras palavras, seria } \\
\text { a taxa de retorno do investimento } \\
\text { em questão. }\end{array}$ & $\begin{array}{l}V P L=0=\text { Investimento inicial }+\sum_{t=1}^{N} \frac{F_{t}}{(1+T I R)^{t}} \\
\text { no qual 'F' significa o fluxo de caixa de cada } \\
\text { período e 't' é o período em questão. Assim, cada } \\
\text { fluxo de caixa deve ser dividido pela TIR elevada } \\
\text { ao seu respectivo período, visto que os juros, } \\
\text { neste caso, são compostos. E tudo isso deve ser } \\
\text { igual a zero. }\end{array}$ \\
\hline $\begin{array}{l}\text { VPL: Também conhecido } \\
\text { como valor atual líquido } \\
\text { (VAL) ou método do valor } \\
\text { atual. }\end{array}$ & $\begin{array}{l}\text { É a fórmula capaz de } \\
\text { determinar o valor presente } \\
\text { de pagamentos futuros } \\
\text { descontados a uma taxa de } \\
\text { juros apropriada, menos o } \\
\text { custo do investimento inicial. }\end{array}$ & $\begin{array}{l}V P L=F C_{1}+\frac{F C_{2}}{(1+i)^{j+1}}+\frac{F C_{3}}{(1+i)^{j+2}}+\frac{F C_{6}}{(1+i)^{j+5}} \\
\text { no qual 'FC' significa o fluxo de caixa de cada } \\
\text { período, 'i' é a taxa de desconto escolhida e 'j' } \\
\text { 1. Assim, cada fluxo de caixa é dividido pela taxa } \\
\text { de desconto elevada ao seu respectivo período, } \\
\text { visto que os juros, neste caso, são compostos. }\end{array}$ \\
\hline $\begin{array}{l}\text { Payback simples: Utilizada nas } \\
\text { empresas e propriedades rurais } \\
\text { para análise do prazo de } \\
\text { retorno do investimento em um } \\
\text { projeto. }\end{array}$ & $\begin{array}{l}\text { Tempo de retorno do investimento } \\
\text { inicial até o momento no qual o } \\
\text { ganho acumulado se iguala ao } \\
\text { valor deste investimento. }\end{array}$ & $\begin{array}{l}\text { Payback = Investimento inicial } \\
\text { Ganho no período }\end{array}$ \\
\hline $\begin{array}{l}\text { Payback descontado: é o } \\
\text { tempo necessário para } \\
\text { recuperar o investimento, } \\
\text { avaliando-se os fluxos de } \\
\text { caixa descontados, ou seja, } \\
\text { considerando-se o valor do } \\
\text { dinheiro no tempo. }\end{array}$ & $\begin{array}{l}\text { É quase o mesmo que o } \\
\text { payback simples, mas antes } \\
\text { de calculá-lo, é descontado } \\
\text { seu fluxo de caixa; reduz os } \\
\text { pagamentos futuros pelo seu } \\
\text { custo de capital atual. Dessa } \\
\text { forma considera-se o valor } \\
\text { presente para identificá-lo. }\end{array}$ & $\begin{array}{l}\text { O payback descontado é um método um } \\
\text { pouco mais complexo, pois ele envolve a } \\
\text { mesma lógica do cálculo do VPL, mas com } \\
\text { o intuito de montar um fluxo mais preciso } \\
\text { economicamente. Nele, considera-se o valor } \\
\text { presente dos fluxos de caixa futuros. Assim, } \\
\text { mostra o valor do dinheiro ao longo do } \\
\text { tempo. }\end{array}$ \\
\hline
\end{tabular}

Fonte: Adaptado de ASSAF NETO; LIMA (2009); HOJI (2003). 
Observa-se, no Quadro 1, os conceitos aplicáveis de cada processo para a análise dos investimentos realizados no meio rural, bem como para identificar o retorno de cada atividade desenvolvida, possibilitando a avaliação dos investimentos.

A partir da análise econômica pode-se comparar resultados e a capacidade de geração de caixa das atividades rurais. A análise financeira possibilita avaliar as decisões de investimentos e o retorno sobre o capital aplicado nas atividades desenvolvidas no meio rural. Neste sentido a análise econômico-financeira dos investimentos, realizada com critérios e métodos adequados, tornam-se instrumento de auxílio ao processo de tomada de decisão, inclusive para a gestão dos negócios rurais.

\subsection{ESTUDOS CORRELATOS}

Os estudos correlatos evidenciam a utilização e importância da contabilidade no meio rural, a exemplo das pesquisas de Fischer et al. (2012), Dal Magro et al. (2013), Kruger et al. (2014), Zanin et al. (2014), Vogado et al. (2016) e Seramim e Rojo (2016). As referidas pesquisas apresentam contribuições e melhorias para a gestão das propriedades rurais.

A pesquisa de Fischer et al. (2012), analisou a produção leiteira dos principais produtores mundiais e bacias produtoras de leite no Brasil a partir de sítios de pesquisa oficiais relacionados aos negócios lácteos. A análise indica que as propriedades rurais com até vinte hectares respondem por mais de $70 \%$ da produção de leite, revelando a importância da pecuária leiteira para a economia e para a geração de empregos, especialmente no meio rural.

Dal Magro et al. (2013), analisou os resultados das atividades leiteira e avícola de uma propriedade rural localizada na região Oeste de Santa Catarina, visando identificar à rentabilidade de cada atividade. No estudo de caso realizado a atividade leiteira produz maior rentabilidade quando comparada à atividade avícola; no entanto concluem que a atividade avícola apresentou maior giro, pois sua receita líquida é maior que o resultado da leiteira.

Kruger et al. (2014) identificou o uso da contabilidade como instrumento de gestão das propriedades rurais. A pesquisa foi aplicada com questionários para 150 produtores rurais no município de Erval Grande - RS. Os resultados destacam a carência da utilização da contabilidade como um instrumento de apoio à gestão, inclusive na separação dos gastos das atividades rurais com as despesas da família, o que prejudica a análise dos custos efetivos com as atividades rurais desenvolvidas.

O estudo de Zanin et al. (2014), analisou a estrutura de gestão das propriedades rurais do Oeste de Santa Catarina por meio de questionários aplicados a 210 propriedades rurais. Os resultados evidenciam a carência da utilização da contabilidade no meio rural, bem como as fragilidades quanto à estrutura organizacional destas propriedades, ainda, destacam a preocupação com o processo de continuidade ou sucessão familiar destas propriedades rurais, tendo em vista a falta de interesse dos filhos na continuidade.

A pesquisa realizada por Vogado et al. (2016), avaliou a evolução da avicultura, considerando a produção e a tendência ao consumo no Brasil e no mundo. Os resultados revelaram que um dos principais fatores que fundamentaram a evolução da avicultura brasileira foi a integração dos diversos elos da cadeia de produção, formando, portanto, um complexo agroindustrial altamente interligado que permite o planejamento da atividade e a diminuição dos custos de produção. Os investimentos em genética e as características de eficiência alimentar (desenvolvidos pelas agroindústrias), também são fatores de destaque no contexto da produção avícola.

O estudo de Seramim e Rojo (2016), compara os custos de produção em duas propriedades rurais, a análise é realizada por meio de planilhas eletrônicas de controle da atividade leiteira, visando oportunizar melhorias no processo de gestão financeira nas entidades. Os resultados identificaram os custos em ambas as propriedades, permitindo verificar diferenças como a relação do índice de lucro e os investimentos realizados. Constataram que na propriedade menor (com menos investimento), o índice de lucratividade foi maior

Kruger et al. (2017), comparou a viabilidade entre as atividades leiteira e avícola desenvolvidas em uma propriedade rural no município de Coronel Freitas - SC. A partir dos resultados dos estudos de caso, observaram o patrimônio e os custos das atividades, permitindo identificar os investimentos e o 
resultado de cada atividade. Os resultados destacaram que economicamente e financeiramente a atividade leiteira gerou melhor resultado, em comparação com os investimentos e resultados da atividade avícola, embora ambas as atividades sejam viáveis do ponto de vista do retorno do capital investido.

De forma geral, os estudos anteriores evidenciam a percepção da fragilidade da gestão rural, a carência do uso da contabilidade e das informações de custos no processo de administração das propriedades rurais, tanto para o acompanhamento dos resultados, quanto para a análise de retorno dos investimentos. Neste sentido, destaca-se a importância da contabilidade rural para auxiliar no planejamento das atividades desenvolvidas e com controles de apoio a análise de resultados e no processo decisório.

\section{PROCEDIMENTOS METODOLÓGICOS}

Discorre-se, nesta seção, acerca dos procedimentos metodológicos adotados na presente pesquisa, a qual se caracteriza, no que tange aos objetivos, como descritiva, quanto aos procedimentos é um estudo de caso, e no que concerne à abordagem do problema, como qualitativa.

A pesquisa caracterizada como descritiva, segundo Raupp e Beuren (2004), preocupase em observar os fatos, registrá-los, analisálos, classificá-los e interpretá-los, sem a interferência do pesquisador. Neste sentido o estudo de caso realizado numa propriedade rural do município de Águas de Chapecó-SC, com objetivo de comparar a viabilidade econômica e financeira das atividades avícola e leiteira, foi desenvolvido a partir da identificação do patrimônio e dos custos das atividades.

Conforme destaca Gil (2010), "o estudo de caso é caracterizado pelo estudo profundo e exaustivo de um ou de poucos objetos, de maneira a permitir conhecimentos amplos e detalhados do mesmo". Neste sentido, apresentam-se as etapas e procedimentos metodológicos que justificam a pesquisa como um estudo de caso (YIN, 2015). O estudo de caso deve atender às características de triangulação de dados para a análise realizada:

(a) Visitas ao ambiente de pesquisa e conversas informais com o gestor para conhecer o caso: a propriedade rural objeto do estudo está localizada no Município de Águas de Chapecó (SC), tem uma área em torno de 18,6 há. A mão de obra é familiar, são 3 pessoas que realizam as atividades, eventualmente contratam alguém para auxiliar nos afazeres. Possui, na atividade leiteira, 71 matrizes e sua alimentação é baseada em sal, pastagens temporárias, silagem e ração. Para o processo da avicultura, a propriedade possui um aviário. A atividade avícola tem o processo de parceria, onde a empresa parceira fornece as aves, assistência técnica e alimentação enquanto o produtor é o responsável pelo desenvolvimento da atividade, mão de obra e instalações.

(b) Informações e coleta de dados: empregou-se conversas formais, entrevistas para obter as informações de tempo das atividades e dos procedimentos para identificar as receitas, os custos, bem como demais gastos e despesas de cada atividade.

(c) Análise dos resultados: após as etapas de coleta e tratamento dos resultados, as informações foram organizadas em Tabelas considerando: levantamento patrimonial, identificação e análise de custos, demonstração de resultados e a análise da viabilidade econômica e financeira. O modelo de coleta e análise dos resultados foi adaptado do estudo de Kruger et al. (2017).

Quanto a abordagem do problema, o estudo se caracteriza como de análise qualitativa, ponderando as características do estudo de caso. Conforme Raupp e Beuren (2004), a análise qualitativa busca descrever a complexidade de determinado problema, analisá-lo, sem a pretensão de generalizar seus resultados. Neste aspecto destaca-se a limitação da pesquisa, tendo em vista que os dados e resultados são específicos deste ambiente de pesquisa, não cabem generalizações acerca dos resultados, embora destaca-se a possibilidade de comparação, e a adaptação do modelo utilizado possa servir para outras entidades rurais.

Os resultados do estudo contemplam o período temporal de 18 meses, sendo de junho/2016 a dezembro/2017, considerando 18 meses de análise da atividade leiteira (apurada mensalmente), e 8 lotes de produção avícola (média de 65 dias por lote). Para a análise da viabilidade econômica considerou-se a média do resultado das atividades mensais, enquanto para a análise 
da viabilidade financeira considerou-se o retorno sobre o capital investido e o fluxo de caixa líquido das atividades.

\section{ANÁLISE E INTERPRETAÇÃO DOS RESULTADOS}

Nesta seção apresenta-se o levantamento patrimonial dos bens da propriedade rural estudada, sendo: bens patrimoniais em geral, instalações, máquinas, equipamentos e a terra, além dos bens utilizados na atividade avícola e na atividade leiteira. A Tabela 1 demonstra o levantamento patrimonial dos bens da propriedade rural estudada.
$\mathrm{Na}$ Tabela 1, observa-se a depreciação mensal e acumulada dos bens, a vida útil estimada dos bens, a base para depreciação, o valor de mercado segundo a avaliação do próprio gestor, o valor residual estimado (que seria o valor de venda após a expectativa de vida útil, considerando a data de aquisição dos bens e o tempo de uso estimado). Sendo assim, apurou-se a depreciação mensal dos bens patrimoniais gerais, no valor de $\mathrm{R} \$ 441,94$, a atividade avícola possui uma depreciação mensal de $\mathrm{R} \$ 259,44$ e a atividade leiteira tem depreciação mensal de bens no valor de $\mathrm{R} \$ 84,17$.

Tabela 1 - Levantamento patrimonial

\begin{tabular}{|c|c|c|c|c|c|c|c|c|}
\hline \multicolumn{9}{|c|}{ 1) Bens patrimoniais gerais } \\
\hline $\begin{array}{l}\text { Descrição do } \\
\text { bem }\end{array}$ & $\begin{array}{l}\text { Data de } \\
\text { aquisição }\end{array}$ & $\begin{array}{c}\text { Valor de } \\
\text { Aquisição } \\
\text { R\$ }\end{array}$ & $\begin{array}{c}\text { Valor de } \\
\text { Mercado } \mathrm{R} \$\end{array}$ & $\begin{array}{c}\text { Valor } \\
\text { Residual } \mathrm{R} \$\end{array}$ & $\begin{array}{c}\text { Base p/ } \\
\text { Depreciar } \\
\mathrm{R} \$\end{array}$ & $\begin{array}{l}\text { Vida Útil } \\
\text { - Anos }\end{array}$ & $\begin{array}{c}\text { Dep. } \\
\text { Mensal R } \$\end{array}$ & $\begin{array}{l}\text { Depreciação } \\
\text { Acumulada }\end{array}$ \\
\hline Terra & 08/06/1981 & $350.000,00$ & $1.300 .000,00$ & $1.300 .000,00$ & - & - & - & - \\
\hline Trator & $17 / 06 / 2010$ & $12.000,00$ & $15.000,00$ & $7.000,00$ & $5.000,00$ & 10 & 41,67 & $3.750,00$ \\
\hline Trator & $23 / 03 / 2013$ & $105.000,00$ & $105.000,00$ & $20.000,00$ & $85.000,00$ & 20 & 354,2 & $20.187,50$ \\
\hline Carretão & $22 / 02 / 2004$ & $5.000,00$ & $5.200,00$ & $2.500,00$ & $2.500,00$ & 15 & 13,89 & $2.138,89$ \\
\hline Carretão & 05/06/2007 & $6.500,00$ & $7.500,00$ & $3.500,00$ & $3.000,00$ & 15 & 16,67 & $1.900,00$ \\
\hline Carretão & $29 / 07 / 2001$ & $4.300,00$ & $5.000,00$ & $1.500,00$ & $2.800,00$ & 15 & 15,56 & $2.877,78$ \\
\hline Total & - & $482.800,00$ & $1.437 .700,00$ & $1.334 .500,00$ & $98.300,00$ & - & 441,94 & $30.854,17$ \\
\hline \multicolumn{9}{|c|}{ 2) Bens patrimoniais - Ativida de avícola } \\
\hline Aviário & $06 / 05 / 2004$ & $90.000,00$ & $110.000,00$ & $20.000,00$ & $70.000,00$ & 35 & 166,67 & $25.166,67$ \\
\hline Silo/Comedouro & $17 / 03 / 2008$ & $18.000,00$ & $23.000,00$ & $4.000,00$ & $14.000,00$ & 25 & 46,67 & $4.900,00$ \\
\hline Nebulizador & $20 / 06 / 2004$ & $6.000,00$ & $7.000,00$ & 500 & $5.500,00$ & 25 & 18,33 & $2.750,00$ \\
\hline Ventiladores & $20 / 06 / 2004$ & $2.800,00$ & $3.500,00$ & $1.500,00$ & $1.300,00$ & 15 & 7,22 & $1.083,33$ \\
\hline Bebedouro & $17 / 05 / 2007$ & $5.200,00$ & $8.000,00$ & $3.000,00$ & $2.200,00$ & 15 & 12,22 & $1.405,56$ \\
\hline Aquecedor & $20 / 06 / 2004$ & $2.000,00$ & $2.300,00$ & 500 & $1.500,00$ & 15 & 8,33 & $1.250,00$ \\
\hline Total & - & $124.000,00$ & $153.800,00$ & $29.500,00$ & $94.500,00$ & - & 259,44 & $36.555,56$ \\
\hline \multicolumn{9}{|c|}{ 3) Bens patrimoniais - Atividade leiteira } \\
\hline $\begin{array}{l}\text { Sala de } \\
\text { Ordenha }\end{array}$ & 01/04/1998 & $20.000,00$ & $28.000,00$ & $6.000,00$ & $14.000,00$ & 25 & 46,67 & $10.453,33$ \\
\hline Resfriador & $10 / 02 / 2005$ & $6.500,00$ & $8.000,00$ & $2.000,00$ & $4.500,00$ & 15 & 25 & $3.550,00$ \\
\hline Ordenhadeira & 02/03/2001 & $4.200,00$ & $3.500,00$ & $1.200,00$ & $3.000,00$ & 20 & 12,5 & $2.362,50$ \\
\hline Total & - & $30.700,00$ & $39.500,00$ & $9.200,00$ & $21.500,00$ & - & 84,17 & $16.365,83$ \\
\hline
\end{tabular}

Fonte: Dados da pesquisa.

Observa-se em relação a atividade avícola e leiteira que os bens já possuem mais de 10 anos de uso em sua maioria, e embora alguns destes tenham expectativa de uso de mais de 20 anos, o gestor rural não considera a depreciação como item de custo, mas reconhece que haverá necessidade de novos investimentos em relação as atividades, visando atender principalmente as exigências das agroindústrias. Neste aspecto, a 
necessidade de troca ou melhorias nas instalações (especialmente quanto ao aviário climatizado), exigirá recursos e desembolso de caixa por parte do gestor rural, neste aspecto torna-se relevante a análise da viabilidade dos investimentos, considerando o fluxo de caixa gerado pelas atividades.

\subsection{ATIVIDADE AVÍCOLA}

$\mathrm{Na}$ atividade avícola, as aves ficam em média 50 dias no aviário, para posteriormente entrega para o abate, a atividade é desenvolvida no sistema de parceria. O alojamento de outras aves ocorre em média após um intervalo de 15 dias, sendo o tempo necessário para o gestor fazer o processo de limpeza e a organização do aviário. A Tabela 2 apresenta a demonstração do resultado do exercício da atividade avícola, elaborada após o levantamento dos custos de produção do período analisado.
A Tabela 2 apresenta o resultado da atividade avícola, após a identificação dos custos de produção do período. A receita líquida por lote totalizou $\mathrm{R} \$ 6.292,99$, os custos dos lotes entregues totalizaram em média $R \$ 2.067,45$, incluindo-se as depreciações, a mão de obra, maravalha, lenha e a energia elétrica, gerando um resultado líquido médio mensal de $\mathrm{R} \$ 4.225,54$, com margem líquida de $67,15 \%$ sobre a receita líquida. Destaca-se que no sistema de parceria o produtor recebe as aves com um dia de vida, a alimentação e assistência técnica são gastos da agroindústria. No início do recebimento das aves, os lotes exigem maiores cuidados e depois apenas a manutenção e acompanhamento da alimentação e temperatura. Para a limpeza geral do aviário, o gestor faz o processo anualmente, fazendo a lavagem e retirada de todo o adubo do aviário, o qual é utilizado nas pastagens da própria entidade rural.

Tabela 2 - Demonstração do resultado do exercício da atividade avícola DEMONSTRAÇÃO DO RESULTADO DO EXERCícIO DE JULHO/2016 A DEZEMBRO/2017

Atividade Avícola - Propriedade Silva

Descrição $\mathrm{R} \$$ Média por lote $\mathrm{R} \$$

Análise Vertical

\begin{tabular}{|l|c|c|c|}
\hline $1(=)$ Receita bruta de vendas & $51.529,06$ & $6.441,13$ & - \\
\hline 2(-) Deduções das receitas & $1.185,17$ & 148,15 & - \\
\hline (-) Funrural - 2,3\% & $1.185,17$ & 148,15 & $100,00 \%$ \\
\hline $3(=)$ Receita operacional líquida & $50.343,89$ & $6.292,99$ & $32,85 \%$ \\
\hline $4(-)$ Custo de produção -aves engorda & $16.539,60$ & $2.067,45$ & $6,16 \%$ \\
\hline Energia elétrica & $3.100,00$ & 387,50 & $3,67 \%$ \\
\hline Lenha & $1.850,00$ & 231,25 & $13,63 \%$ \\
\hline Mão de obra & $6.860,00$ & 857,50 & $3,10 \%$ \\
\hline Maravalha (lote) & $1.560,00$ & 195,00 & $4,95 \%$ \\
\hline Máquinas (lote) & 680,00 & 85,00 & $67,15 \%$ \\
\hline Depreciações instalações & $2.489,60$ & 311,20 & $100,00 \%$ \\
\hline $5(=)$ Resultado líquido do exercício & $33.804,29$ & $4.225,54$ & - \\
\hline Receita líquida média por ave & 0,85 & 0,85 & $32,85 \%$ \\
\hline Total de aves & 59.550 & $7.443,75$ & $67,15 \%$ \\
\hline Custo médio por ave & 0,28 & 0,28 & 0,57 \\
\hline Lucro médio por ave & 0,57 & & - \\
\hline
\end{tabular}

Fonte: Dados da pesquisa. 
A mão de obra foi calculada durante os 18 meses estudados, considerando-se o tempo que o proprietário rural gasta em média no trato da atividade, em média são duas horas diárias no cuidado e trato das aves. A lenha utilizada no aviário é comprada pelo gestor rural, para atender a necessidade de aquecimento das instalações, especialmente nos primeiros dias de recebimento das aves, e no inverno. Entre os custos da atividade avícola, a mão-de-obra com 13,63\% e a energia elétrica com $6,16 \%$, são os custos mais representativos para o gestor rural durante o período estudado, conforme demonstra na Tabela 2. Observa-se que a média de custo por ave foi de $R \$ 0,28$ e o lucro de $\mathrm{R} \$ 0,57$.

\subsection{ATIVIDADE LEITEIRA}

A atividade leiteira é composta por um plantel formado por 71 matrizes. Na Tabela 3 apresenta-se o levantamento das matrizes leiteiras da propriedade rural estudada, com a especificidade de que o gestor não adquire animais de terceiros, todas as matrizes são recrias do seu próprio plantel.

Tabela 3 - Plantel - Matrizes

\begin{tabular}{|c|c|c|c|c|c|c|c|}
\hline \multicolumn{8}{|c|}{ Plantel - Matrizes - Holandesas - Gersey } \\
\hline $\begin{array}{l}\text { Descrição das } \\
\text { Matrizes }\end{array}$ & Quant. & $\begin{array}{l}\text { Valor } \\
\text { médio } \\
\text { unitário }\end{array}$ & $\begin{array}{l}\text { Valor de } \\
\text { Mercado R\$ }\end{array}$ & $\begin{array}{c}\text { Valor } \\
\text { Residual } R \$\end{array}$ & $\begin{array}{c}\text { Base } p / \\
\text { Depreciar } \\
\mathrm{R} \$\end{array}$ & $\begin{array}{l}\text { Vida } \\
\text { Útil }\end{array}$ & $\begin{array}{c}\text { Dep. } \\
\text { Mensal R\$ }\end{array}$ \\
\hline Matrizes até $12 \mathrm{~m}$ & 11 & $4.000,00$ & $44.000,00$ & $7.150,00$ & $36.850,00$ & 9 & 227,47 \\
\hline Matrizes $12 / 24 m$ & 11 & $3.800,00$ & $41.800,00$ & $7.150,00$ & $34.650,00$ & 9 & 213,89 \\
\hline Matrizes 24/36m & 6 & $3.550,00$ & $21.300,00$ & $7.150,00$ & $14.150,00$ & 9 & 87,35 \\
\hline Matrizes $36 / 48 m$ & 10 & $3.300,00$ & $33.000,00$ & $7.150,00$ & $25.850,00$ & 9 & 159,57 \\
\hline Matrizes $48 / 60 \mathrm{~m}$ & 6 & $3.100,00$ & $18.600,00$ & $7.150,00$ & $11.450,00$ & 9 & 70,68 \\
\hline Matrizes $60 / 72 \mathrm{~m}$ & 3 & $2.900,00$ & $8.700,00$ & $7.150,00$ & $1.550,00$ & 9 & 9,57 \\
\hline Matrizes 72/84m & 4 & $2.500,00$ & $10.000,00$ & $7.150,00$ & $2.850,00$ & 9 & 17,59 \\
\hline Matrizes 84/96m & 9 & $2.300,00$ & $20.700,00$ & $7.150,00$ & $13.550,00$ & 9 & 83,64 \\
\hline Matrizes acima 96 & 11 & $1.900,00$ & $20.900,00$ & $7.150,00$ & $13.750,00$ & 9 & 84,88 \\
\hline Total & 71 & $27.350,00$ & $219.000,00$ & $64.350,00$ & $154.650,00$ & - & 954,63 \\
\hline
\end{tabular}

Fonte: Dados da pesquisa.

Diante dos dados apresentados na Tabela 3, observa-se o levantamento do plantel de matrizes leiteiras, as quais foram agrupadas por idade de produção (de 12 meses a 9 anos). Observa-se o valor médio unitário de cada matriz, o valor residual estimado na venda das matrizes (geralmente para um abatedouro da região), e posteriormente identificou-se a base para depreciar. A vida útil estimada do plantel é de 9 anos em média. O levantamento realizado permitiu identificar a depreciação mensal do plantel, que irá compor o custo do leite.

Após a identificação do plantel composto por 71 matrizes leiteiras, identificou-se os custos de produção do período analisado, e elaborou-se a demonstração do resultado do exercício da atividade leiteira, conforme apresenta-se na Tabela 4. Observa-se na Tabela 4 a receita bruta mensal de $\mathrm{R} \$ 17.947,78$, que após a dedução do Funrural de $R \$ 412,80$, obteve uma receita líquida no total de $R \$ 17.534,98$. Na apuração dos custos do leite vendido, considerou-se a pastagem (capim sudão e aveia de verão) e a silagem (parte produzida na entidade rural e parte adquirida de terceiros, no inverno).

Observa-se na Tabela 4 o resultado líquido do exercício, o qual totalizou $63,76 \%$ da receita líquida, representando um valor médio mensal de $R \$ 11.180,12$ de lucro. A receita bruta por litro de leite produzido é de, aproximadamente, $R \$ 1,19$. A média mensal comercializada é de 14.761 litros a um custo de $R \$ 0,43$ ao litro, com lucro de $R \$ 0,76$. Entre os custos da atividade leiteira, a 
depreciação das matrizes representou $18,84 \%$ dos custos, e a alimentação com $4,09 \%$, são os custos mais representativos do período de 18 meses analisado.

A mão de obra é familiar e foi calculada durante os 18 meses estudados, considerando-se a média de tempo dedicado para os processos de ordenha, trato e demais cuidados com o plantel. Os resultados demonstram a representatividade econômica da atividade leiteira na geração de caixa para a propriedade rural estudada, bem como demonstram a eficiência nos processos de produção, tendo em vista o lucro gerado por litro de leite entregue e a média de resultado obtido atividade.

Tabela 4 - Demonstração do Resultado do Exercício da Atividade Leiteira

\begin{tabular}{|c|c|c|c|}
\hline DEMONSTRAÇÃO DO RESULTADO & EXERCÍCIO & LHO/2016 A DEZE & $\mathrm{RO} / 2017$ \\
\hline Atividade & ira - Proprie & Silva & \\
\hline DESCRIÇÃO & $R \$$ & Média Mensal R\$ & Análise Vertical \\
\hline 1(=) Receita bruta de vendas & $323.059,97$ & $17.947,78$ & - \\
\hline 2(-) Deduções das receitas & $7.430,38$ & 412,80 & - \\
\hline (-) Funrural 2,3\% & $7.430,38$ & 412,80 & - \\
\hline 3(=) Receita operacional líquida & $315.629,59$ & $17.534,98$ & $100,00 \%$ \\
\hline 4(-) Custo do leite vendido & $114.387,52$ & $6.354,86$ & $36,24 \%$ \\
\hline Pastagem temporária: silagem & $9.260,00$ & 514,44 & $2,93 \%$ \\
\hline Pastagem temporária: capim/aveia de verão & $6.360,00$ & 353,33 & $2,02 \%$ \\
\hline Depreciação de máquinas e equipamentos & $1.515,06$ & 84,17 & $0,48 \%$ \\
\hline Depreciação das matrizes & $59.462,46$ & $3.303,47$ & $18,84 \%$ \\
\hline Energia elétrica & $9.900,00$ & 550,00 & $3,14 \%$ \\
\hline Alimentação (ração e sal) & $12.900,00$ & 716,67 & $4,09 \%$ \\
\hline Medicamentos & $4.850,00$ & 269,44 & $1,54 \%$ \\
\hline Mão de obra & $9.340,00$ & 518,89 & $2,96 \%$ \\
\hline Outros custos & 800,00 & 44,44 & $0,25 \%$ \\
\hline 5 (=) Resultado líquido do exercício & $201.242,07$ & $11.180,12$ & $63,76 \%$ \\
\hline Receita líquida média por litro & 1,19 & 1,19 & $100 \%$ \\
\hline Total de litros vendidos & 265.692 & 14.761 & - \\
\hline Custo por litro & 0,43 & 0,43 & $36,24 \%$ \\
\hline Lucro por litro & 0,76 & 0,76 & $63,76 \%$ \\
\hline
\end{tabular}

Fonte: Dados da pesquisa.

Observa-se na Tabela 4 o resultado geral do período analisado (18 meses), e a média mensal obtida. Os resultados coadunam com a pesquisa de Dal Magro et al. (2013), destacando que a análise e os resultados da atividade leiteira proporcionam margem líquida satisfatória, evidenciando-se como geradora de caixa e lucratividade para as propriedades rurais.
4.3 ANÁLISE COMPARATIVA DOS RESULTADOS ENTRE AS ATIVIDADES AVÍCOLA E LEITEIRA

A Tabela 5 apresenta o comparativo entre as atividades avícola e leiteira, a partir da receita, dos custos de produção e dos resultados apresentados anteriormente. 
Tabela 5 - Comparativo entre a atividade avícola e atividade leiteira

\begin{tabular}{|c|c|c|c|c|}
\hline \multicolumn{5}{|c|}{$\begin{array}{c}\text { DEMONSTRAÇÃO DO RESULTADO - COMPARATIVO JULHO/2016 } \\
\text { Atividade Avícola e Leiteira - Propriedade Silva } \\
\text { Atividade I eiteira }\end{array}$} \\
\hline DESCRIÇÃO & $\begin{array}{c}\text { Média mensal } \\
\qquad \$\end{array}$ & $\begin{array}{c}\text { Análise } \\
\text { Vertical \% }\end{array}$ & $\begin{array}{c}\text { Média } \\
\text { mensal R\$ }\end{array}$ & $\begin{array}{c}\text { Análise } \\
\text { Vertical \% }\end{array}$ \\
\hline 1 (=) Receita bruta de vendas & $17.947,78$ & - & $2.862,73$ & - \\
\hline 2 (-) Deduções das receitas & 412,80 & - & 65,84 & - \\
\hline (-) Funrural 2,3\% & 412,80 & - & 65,84 & - \\
\hline 3 (=) Receita operacional líquida & $17.534,98$ & $100,00 \%$ & $2.796,89$ & $100,00 \%$ \\
\hline 4 (-) Custo dos produtos vendidos & $6.354,86$ & $36,24 \%$ & 918,87 & $32,85 \%$ \\
\hline 5 (=) Resultado líquido do exercício & $11.180,12$ & $63,76 \%$ & $1.878,02$ & $67,15 \%$ \\
\hline
\end{tabular}

Fonte: Dados da pesquisa.

De forma comparativa, observa-se na Tabela 5 que a atividade leiteira e a atividade avícola apresentaram retorno econômico para o produtor rural, embora do ponto de vista da geração de caixa mensal, a atividade leiteira gera melhor resultado de caixa, destacando por agregar renda mensal para a família rural.

\subsection{ANÁLISE DOS INVESTIMENTOS}

Entre os métodos de avaliação de investimentos, destacam-se o prazo de retorno medido pelo payback, a TIR e o VPL (ASSAF NETO; LIMA, 2009). A Tabela 6 apresenta os resultados da análise dos investimentos realizados na atividade avícola, considerando-se o fluxo de caixa líquido gerado e os investimentos patrimoniais na propriedade rural analisada.

$\mathrm{Na}$ Tabela 6 observa-se que a atividade avícola apresentou como retorno do investimento, pelo payback simples o prazo de aproximadamente 5 anos e 1 mês, e pelo payback descontado o prazo de retorno é de 7 anos e 6 meses. O fluxo de caixa indicado é resultado da identificação do resultado econômico somada a depreciação (que não representa desembolso).

Tabela 6 - Métodos de avaliação da atividade avícola

\begin{tabular}{|c|c|c|c|c|}
\hline Período & VF & SALDO VP & VP & SALDO VF \\
\hline 0 & $-124.000,00$ & $-124.000,00$ & $-124.000,00$ & $-124.000,00$ \\
\hline 1 & $24.195,93$ & $-99.804,07$ & $21.996,30$ & $-102.003,70$ \\
\hline 2 & $24.195,93$ & $-75.608,14$ & $19.996,64$ & $-82.007,06$ \\
\hline 3 & $24.195,93$ & $-51.412,21$ & $18.178,76$ & $-63.828,30$ \\
\hline 4 & $24.195,93$ & $-27.216,28$ & $16.526,15$ & $-47.302,16$ \\
\hline 5 & $24.195,93$ & $-3.020,35$ & $15.023,77$ & $-32.278,39$ \\
\hline 6 & $24.195,93$ & $21.175,58$ & $13.657,97$ & $-18.620,42$ \\
\hline 7 & $24.195,93$ & $45.371,51$ & $12.416,34$ & $-6.204,08$ \\
\hline 8 & $24.195,93$ & $69.567,44$ & $11.287,58$ & $5.083,50$ \\
\hline TIR & \multicolumn{4}{|c|}{$11,12 \%$} \\
\hline VPL & \multicolumn{4}{|c|}{$\mathrm{R} \$ 5.083,50$} \\
\hline Payback simples & 5,12 & \multicolumn{3}{|c|}{ Retorno em 5 anos e 1 mês } \\
\hline Payback descontado & 7,55 & \multicolumn{3}{|c|}{ Retorno em 7 anos e 6 meses } \\
\hline
\end{tabular}


A taxa mínima foi baseada na expectativa do rendimento de um determinado investimento, se optasse por uma aplicação financeira por exemplo. Sendo que a TMA desejada é de $10 \%$ ao ano. Observa-se que a TIR do projeto é de $11,12 \%$, ou seja, maior que a TMA de $10 \%$ ao ano. O VPL apresentou resultado positivo de $R \$ 5.083,50$, representando outro indicativo para a aceitação do investimento. Considerando-se a avaliação dos três métodos sugeridos, pode-se avaliar o investimento como viável, atendendo aos pressupostos teóricos da área de finanças, conforme evidenciados por Assaf Neto e Lima (2009).

A Tabela 7 apresenta os métodos de avaliação dos investimentos da atividade leiteira. De forma comparativa a Tabela 7 evidencia que a atividade leiteira apresentou retorno mais satisfatório que o da atividade avícola, o payback simples apontou um prazo de 1 ano e 4 meses e o payback descontado um prazo de 1 ano e 7 meses para recuperar o investido realizado, a partir das projeções de fluxo de caixa estimados. O investimento da atividade leiteira é a soma dos bens patrimoniais da atividade e do plantel de matrizes leiteiras. O fluxo de caixa indicado é resultado da identificação do resultado econômico da produção leiteira, somadas as depreciações (que não representam desembolso de caixa).

Observa-se que a TIR também é considerada atraente, sendo de $48,73 \%$, ou seja, muito superior que a TMA desejada de 10\%. O VPL também é positivo de $\mathrm{R} \$ 185.034,21$, evidenciando a viabilidade do investimento na entidade rural estudada.

Tabela 7 - Métodos de avaliação da atividade leiteira

\begin{tabular}{|c|c|c|c|c|}
\hline Período & VF & SALDO VP & VP & $-249.700,00$ \\
\hline 0 & $-249.700,00$ & $-249.700,00$ & $-249.700,00$ & $-90.779,04$ \\
\hline 1 & $174.813,06$ & $-74.886,94$ & $158.920,96$ & $53.694,57$ \\
\hline 2 & $174.813,06$ & $99.926,12$ & $144.473,60$ & $185.034,21$ \\
\hline 3 & $174.813,06$ & $274.739,18$ & $131.339,64$ & \\
\hline TIR & $48,73 \%$ & & & \\
\hline VPL & $185.034,21$ & & Retorno em 1 ano e 4 meses \\
\hline Payback simples & 1,43 & \multicolumn{3}{|c|}{ Retorno em 1 ano e 7 meses } \\
\hline Payback descontado & 1,63 & \multicolumn{3}{|c|}{} \\
\hline
\end{tabular}

Fonte: Dados da pesquisa.

Conforme a Tabela 7, quanto ao resultado financeiro, a atividade leiteira apresentou um retorno em menor tempo em relação à atividade avícola. Em relação ao resultado econômico, a atividade avícola apresentou melhor desempenho e margem líquida maior em relação a atividade leiteira, porém financeiramente a atividade leiteira se sobressaiu em relação a geração de caixa. Observa-se que ambas as atividades desenvolvidas na propriedade rural estudada, são economicamente e financeiramente viáveis, embora a atividade avícola apresentou resultado financeiro mais demorado em relação a atividade leiteira.

A comparação dos resultados e a análise da viabilidade econômica e financeira dos investimentos, possibilita o planejamento de curto e longo prazo, permitindo o processo decisório a partir dos resultados. Os resultados corroboram com o estudo de Kruger et al. (2017), evidenciando que economicamente e financeiramente a atividade leiteira também gerou melhor resultado para a entidade rural. Os achados vão ao encontro da pesquisa de Kruger et al. (2014), destacando a importância da separação dos gastos das atividades rurais e da análise dos custos efetivos com as atividades rurais desenvolvidas. Bem como, enfatizam a preocupação com o processo de continuidade das propriedades rurais, a partir da viabilidade das atividades desenvolvidas, conforme salienta Zanin et al. (2014).

De modo geral, os resultados encontrados destacam a importância do uso da contabilidade como instrumento de controle 
para a análise dos resultados das atividades desenvolvidas no meio rural.

\section{CONCLUSÕES E PESQUISAS FUTURAS}

O estudo teve por propósito analisar de forma comparativa a viabilidade econômica e financeira das atividades avícola e leiteira, desenvolvidas em uma propriedade rural no município de Águas de Chapecó - SC. Para atender a esse propósito, primeiramente apurou-se o patrimônio da entidade e aqueles relacionados as atividades avícola e leiteira. Após a identificação dos bens patrimoniais relacionados a cada atividade, realizou-se o levantamento do plantel das matrizes leiteiras e dos custos de produção de ambas as atividades desenvolvidas, possibilitando a apuração dos resultados e a elaboração da demonstração do resultado de cada atividade desenvolvida na propriedade rural estudada, considerando o período de 18 meses.

A partir da análise da demonstração de resultado do exercício da propriedade, verificou-se que a atividade avícola obteve margem líquida de $67,15 \%$, enquanto a atividade leiteira atingiu $63,76 \%$ de margem líquida. A atividade avícola demonstrou maior margem líquida em relação a atividade leiteira, porém financeiramente pela geração de caixa e tempo de retorno do investimento, a atividade leiteira apresenta melhor desempenho, com menor tempo de retorno do investimento realizado.

Entre os custos das atividades durante o período estudado, observou-se que na atividade avícola a mão-de-obra e a energia elétrica são os custos mais representativos, enquanto que na atividade leiteira a depreciação das matrizes e a alimentação do plantel, são os custos mais representativos para o gestor rural. Essa diferença ocorre em função da característica das atividades, na atividade avícola existe uma parceria, e o gestor recebe a alimentação e as aves, já na atividade leiteira o contrato é de apenas o recolhimento do produto, então os custos com alimentação e a manutenção do plantel são gastos da entidade rural. Além dos custos citados, destaca-se a dificuldade de mensuração da mão de obra das atividades, tendo em vista que são dois membros da família que as executam, e não há um valor fixo mensal para cada membro que trabalha (marido e esposa), logo o cálculo foi baseado na média de gastos e retiradas de caixa que a família realizou.
Após a identificação dos custos, foi possível conduzir e analisar os investimentos. Verificou-se que a atividade leiteira gera retorno do investimento em menos tempo, conforme apuração pelo método do payback simples e descontado, o resultado da TIR e do VPL também destacam a viabilidade financeira de ambas as atividades desenvolvidas. Embora a atividade leiteira tenha apresentado retorno dos investimentos num prazo de 1 ano e 7, pelo payback descontado e TIR de 48,73\%. Comparativamente a atividade avícola apresentou retorno 7 anos e 6 meses pelo payback descontado e TIR de 11,12\%.

A análise dos resultados evidencia a importância da utilização da contabilidade no meio rural, possibilitando a comparabilidade dos resultados das atividades desenvolvidas e a análise do tempo de retorno entre as atividades, bem como da viabilidade dos investimentos. Estas informações são diferenciais no planejamento de novos investimentos ou na expansão dos negócios. Salienta-se neste contexto, a relevância da utilização das informações geradas pela contabilidade, como instrumento de apoio à gestão das propriedades rurais, visando identificar os resultados por cada atividade realizada e conduzir o processo decisório.

De forma específica ao estudo de caso, sugere-se para os gestores rurais a continuidade do acompanhamento e do controle dos custos de produção das atividades, bem como, a separação dos gastos com cada atividade desenvolvida, daqueles outros gastos da família. Ainda, é recomendável para o acompanhamento dos custos, dos resultados e no planejamento de novos investimentos, a análise contábil realizada por um profissional contábil, de forma contínua observando os ciclos de produção da entidade.

Para novas pesquisas, recomenda-se, a análise da viabilidade econômica e financeira para novos investimentos, utilizando a informação de forma preditiva aos investimentos. Bem como, a análise de maior período temporal, visando reduzir dúvidas em relação a períodos sazonais que podem interferir nos resultados.

De forma geral, destaca-se a relevância das informações contábeis no apoio ao processo de tomada de decisão no meio rural, a análise dos custos e dos resultados por atividade tornam-se diferenciais, possibilitando de 
forma comparativa o acompanhamento do desempenho econômico e financeiro das atividades rurais.

\section{REFERÊNCIAS}

[1]. ASSAF NETO, A.; LIMA, F. G. Curso de administração financeira. São Paulo: Atlas, 2009.

[2]. CREPALDI, Silvio Aparecido. Contabilidade rural: uma abordagem decisorial. 6. ed. São Paulo: Atlas, 2011.

[3]. DAL MAGRO, Cristian Baú; DI DOMENICO, Daniela; KLANN, Roberto Carlos; ZANIN, Antônio. Contabilidade rural: comparativo na rentabilidade das atividades leiteira e avícola. Custos e agronegócio online, v. 9, n. 1, p. 2-22, 2013.

[4]. DAL MAGRO, Cristian Baú; VOGT, Mara; DEGENHART, Larissa; CUNHA, Leila Chaves; ROSA, Fabricia Silva da. Contabilidade rural e de custos aplicada à atividade leiteira: um estudo de caso em uma propriedade rural do Oeste de Santa Catarina. ABCustos: Associação Brasileira de Custos, v. 11, n. 2, p. 94-123, 2016.

[5]. DECKER, Sérgio Renato Ferreira; GOMES, Mario Conill. Análise do desempenho e participação da agricultura familiar na avicultura de corte na região Sul do Rio Grande do Sul/Brasil. Revista Brasileira de Agropecuária Sustentável, v. 6, n. 1, p. 15-25, 2016.

[6]. EPAGRI. EMPRESA DE PESQUISA AGROPECUÁRIA E EXTENSÃO RURAL DE SANTA CATARINA. Síntese Anual da Agricultura Familiar de SC 2016-2017. Disponível em: <http://docweb.epagri.sc.gov.br/website_cepa/pub licacoes/Sintese-Anual-da-AgriculturaSC_2016_17.pdf> Acesso 01 fev. 2018.

[7]. FISCHER, Augusto; JUNIOR, Silvio Santos; SEHNEM, Simone; BERNARDI, Ismael. Produção e produtividade de leite do Oeste catarinense. RACE-Revista de Administração, Contabilidade e Economia, v. 10, n. 2, p. 337-362, 2012.

[8]. GIL, A. C. Como elaborar projetos de pesquisa. 5. ed. São Paulo: Atlas, 2010.

[9]. GROPPELLI, A. A; NIKBAKHT, E. Administração financeira. 2. ed. São Paulo: Saraiva, 2005.

[10]. HOJI, Masakazu. Administração financeira uma abordagem prática. 4. ed. São Paulo: Atlas, 2003.

[11]. IBGE. INSTITUTO BRASILEIRO DE GEOGRAFIA E ESTATÍSTICA. Estatística da Produção Agrícola 2017. Disponível em: $<$ https://biblioteca.ibge.gov.br/visualizacao/periodi cos/2415/epag_2017_ago.pdf>. Acesso em 09 set. 2017 .
[12]. IBGE. INSTITUTO BRASILEIRO DE GEOGRAFIA E ESTATÍSTICA. Contas Nacionais Trimestrais. Disponível em:

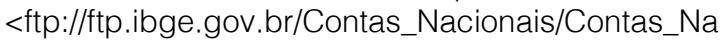
cionais_Trimestrais/Fasciculo_Indicadores_IBGE/pi b-vol-val_201604caderno.pdf>. Acesso em 19 out. 2017.

[13]. INSTITUTO DE PLANEJAMENTO E ECONOMICA AGRÍCOLA DE SANTA CATARINA ICEPA. Aspectos Agropecuários - 2017. Disponível em: <http://www.epagri.sc.gov.br/?page_id=19404. Acesso em 05 nov. 2017.

[14]. IUDíCIBUS, Sergio; MARION, José Carlos; DE FARIA, Ana Cristina. Introdução à teoria da contabilidade: para o nível de graduação. Atlas, 2009 .

[15]. KRUGER, Silvana Dalmutt; CECCATTO, Leticia; MAZZIONI, Sady; DI DOMENICO, Daniela; PETRI, Sérgio Murilo. Análise Comparativa da Viabilidade Econômica e Financeira das Atividades Avícola e Leiteira. Revista Ambiente Contábil, v. 9, n. 1, p. 37-55, 2017.

[16]. KRUGER, Silvana Dalmutt; GLUSTAK, Ediane; MAZZIONI, Sady; ZANIN, Antonio. Contabilidade como instrumento de gestão dos estabelecimentos rurais. REUNIR: Revista de Administração, Contabilidade e Sustentabilidade, v. 4, n. 2, p. 134-153, 2014.

[17]. KRUGER, Silvana Dalmut; ORTOLAN, Catiane; DIEL, Elisandra Henn; DIEL, Fabio Jose; MAZZIONI, Sady. Análise dos resultados da atividade leiteira: custo histórico versus valor justo dos ativos biológicos. Extensão Rural, v. 22, n. 3, p. 68-88, 2015.

[18]. MARION, J. C. Contabilidade rural: contabilidade agrícola, contabilidade da pecuária, imposto de renda - pessoa jurídica. 13. ed. São Paulo: Atlas, 2012.

[19]. RAUPP, F. M.; BEUREN, I. M. Metodologia da pesquisa aplicável às ciências sociais. In: BEUREN, I. M. (Org.). Como elaborar trabalhos monográficos em contabilidade: 2. ed. São Paulo: Atlas, 2004. p. 76-97.

[20]. SERAMIM, Ronaldo Jose; ROJO, Claudio Antonio. Gestão dos custos de produção da atividade leiteira na agricultura familiar. Revista Gestão \& Tecnologia, v. 16, n. 3, p. 244-260, 2016.

[21]. VOGADO, Gleissa Mayone Silva; VOGADO, Kalene Taty Silva; FONSECA, Weverton Jose Lima; OLIVEIRA, Augusto Matias; VOGADO, Willamy Fonseca; LUZ, Carlos Syllas Monteiro. 
Evolução da Avicultura Brasileira. Nucleus Animalium, v. 8, n. 1, p. 48-59, 2016.

[22]. YIN, Robert K. Estudo de Caso: planejamento e métodos. Bookman Editora, 2015.

[23]. ZANIN, Antônio; FAVRETTO, Jacir; POSSA, Angélica; MAZZIONI, Sady; ZONATTO, Vinicius Costa da Silva. Apuração de custos e resultado econômico no manejo da produção leiteira: uma análise comparativa entre o sistema tradicional e o sistema freestall. Organizações Rurais \& Agroindustriais, v. 17, n. 4, p. 431-444, 2015.

[24]. ZANIN, Antônio; OENNING, Vilmar; TRES, Naline; KRUGER, Silvana Dalmutt; GUBIANI, Clesia Ana. Gestão das propriedades rurais do Oeste de Santa Catarina: as fragilidades da estrutura organizacional e a necessidade do uso de controles contábeis. Revista Catarinense da Ciência Contábil, v. 13, n. 40, p. 09-19, 2014. 


\title{
Bapítulo 17
}

\section{PÓS-GRADUAÇÃO LATO SENSU NA MODALIDADE DE EDUCAÇ̃O A DISTÂNCIA: UM ESTUDO DE CASO EM UMA PARCERIA PÚBLICO/PRIVADA PARA OFERTA DO CURSO DE ESPECIALIZACÃO EM COOPERATIVISMO SOLIDÁRIO E CRÉDITO RURAL}

\author{
Simão Ternoski \\ Zoraide da Fonseca Costa \\ Felipe Polzin Druciaki \\ Maria Aparecida Crissi Knuppel
}

Resumo: O estudo trata dos resultados parciais de um Curso de Especialização em Cooperativismo Solidário e Crédito Rural, desenvolvido em parceria entre a Universidade Estadual do Centro-Oeste - UNICENTRO, a Cooperativa de Crédito Rural com Interação Solidária - Central Cresol Baser e o Instituto de Formação do Cooperativismo Solidário - Infocos. Diante da necessidade de qualificação profissional na sociedade contemporânea, bem como pela urgência em novos tempos para estudar e ainda, ampliar o acesso ao ensino superior: o problema da pesquisa questiona: Qual a eficácia da oferta de um curso de especialização lato sensu para a promoção da educação e profissionalização de pessoal? Como resposta admite-se que a educação a distância utilizada pela Cooperativa Cresol para profissionalização de seus colaboradores, é fundamental para atingir resultados amplos e eficazes no que diz respeito à promoção da educação e profissionalização de seus colaboradores em regiões com acesso restrito ao ensino superior. O objetivo geral consiste em analisar, por meio da metodologia de estudo de caso, o desenvolvimento de um curso de especialização, na temática do cooperativismo solidário e crédito rural, no intuito de verificar sua área de abrangência, interesse de demanda e reflexos na formação e capacitação dos envolvidos. Especificamente: 1) analisar a demanda dos candidatos em relação ao curso e a modalidade de ensino; 2) mensurar o índice de evasão e o grau de aproveitamento dos alunos em relação às disciplinas ofertadas; 3) identificar e quantificar 0 quantitativo de alunos em relação às matrículas por regiões geográficas. Como estudo de caso, a metodologia se apoia ainda na pesquisa exploratória e descritiva e apresenta natureza qualitativa e quantitativa. Os resultados indicam que a educação a distância foi primordial para atingir os objetivos de formação profissional dos colaboradores da Cooperativa, bem como ampliou o acesso de pessoas de diferentes regiões em oportunidades de estudos.

Palavras-chave: Formação de profissionais. Educação à distância. Parceria público-privada 


\section{INTRODUÇÃO}

$\mathrm{Na}$ contemporaneidade, a preocupação das pessoas com a formação em nível superior é constante e torna-se, na maioria das vezes, condição para inserção no mercado de trabalho. Aliado a esses fatores, muitas empresas já perceberam a relevância em formar seus quadros de colaboradores para se ter ganhos em produtividade.

Dados do Caged (2018) apontam a redução de postos de trabalho na economia brasileira, fator que pode estar relacionado com o período de crise econômica enfrentada nos últimos anos. De igual forma, a instabilidade no emprego frente a períodos de baixa atividade econômica exige uma maior capacitação dos indivíduos tendo em vista a manutenção de empregos plenos ou empregabilidade.

Contudo, o cenário da qualificação profissional nem sempre é o mais fácil. É comum tentativa dos trabalhadores em conciliar estudo com o trabalho, criando uma rotina diária exaustiva, principalmente quando é necessário o deslocamento para realizar esta formação. Este aspecto se agrava ainda mais em municípios pequenos que não dispõem de possibilidades de ofertas de estudo, principalmente em nível de graduação, ou ainda ofertas de aperfeiçoamento e especialização em níveis lato sensu e stricto sensu.

Aos profissionais que tentam melhorar sua qualificação só restam duas possibilidades: abandonar o sonho de uma formação ou aperfeiçoamento em nível superior; ou então realizar deslocamentos diários para cidades vizinhas, o que demanda uma rotina exaustiva para conciliar trabalho, viagens e estudos.

Nessa perspectiva, uma modalidade de ensino vem ganhando relevância no Brasil nos últimos anos quer na formação inicial ou na formação continuada. A educação a distância desponta como uma possibilidade de acesso à educação, mesmo em regiões distantes de escolas técnicas e universidades. O Instituto Nacional de Estudos e Pesquisas Educacionais Anísio Teixeira - INEP (2014) aponta um crescimento no número de alunos que procuram esta modalidade. No período de 2003 a 2013, o aumento foi de 50 mil para 1,1 milhões de alunos.

O fomento de cursos na modalidade a distância também é foco das políticas públicas. Um exemplo é a Universidade Aberta do Brasil - UAB, considerada o maior programa de educação a distância do Brasil. O Decreto 5800 de 2006, em seu Art. 01 define a finalidade da UAB: "expandir e interiorizar a oferta de cursos e programas de educação superior no País" (BRASIL. 2006). O Decreto destacado aponta como foco para a criação da UAB a necessidade da interiorização da educação superior no Brasil, reconhecendo a carência de cursos e modalidades de ensino em muitas regiões.

Além das iniciativas públicas, o setor privado também busca aperfeiçoar seus procedimentos e ações internas e destaca-se neste processo a formação de seus colaboradores. Um exemplo é a ação da Cooperativa de Crédito Rural com Interação Solidária - Central Cresol Baser.

Ternoski (2015a), Ternoski (2015b) e Ternoski (2016) em pesquisas anteriores apresentam a experiência de um curso de aperfeiçoamento - modalidade de extensão e outro de especialização, ofertados pela Universidade Estadual do Centro Oeste - UNICENTRO em parceria com a Central Cresol Baser no intuito de formação de seus colaboradores.

Dados do Sistema Cresol (2016) apontam 188.085 cooperados em 264 postos de atendimento espalhados por 9 estados brasileiros: Rondônia, Goiás, Minas Gerais, Espírito Santo, Rio de Janeiro, São Paulo, Paraná, Santa Catarina e Rio Grande do Sul, com a atuação de 1.490 colaboradores. Diante dos dados apresentados se percebe o desafio em capacitar e proporcionar formação aos colaboradores.

Neste aspecto e considerando a necessidade de formação de colaboradores e funcionários - problema da pesquisa questiona: Qual a eficácia da oferta de um curso de especialização para a promoção da educação e profissionalização de pessoal? Como resposta ao problema do estudo admite-se que a educação a distância utilizada pela Cooperativa Cresol para profissionalização de seus colaboradores é fundamental para atingir resultados amplos e eficazes, no que diz respeito à promoção da educação e profissionalização de seus colaboradores em regiões com acesso restrito ao ensino superior.

Para tanto, o objetivo geral da pesquisa centra-se em analisar o desenvolvimento e os resultados de um Curso de Especialização em Cooperativismo Solidário e Crédito Rural, 
em especial, para dimensionar área de abrangência, demanda e reflexos na formação e capacitação dos envolvidos. Especificamente: 1) analisar a demanda dos candidatos em relação ao curso e a modalidade de ensino; 2) mensurar o índice de evasão e o grau de aproveitamento dos alunos em relação às disciplinas ofertadas; 3) identificar e quantificar os alunos da atual oferta, em relação às regiões brasileiras em que estão inseridos.

Mesmo com o desenvolvimento do ensino superior nas últimas décadas no Brasil, ainda há muitas pessoas que não tem formação necessária para o trabalho que exercem ou que buscam exercer. A dificuldade de acesso se dá por diversos motivos, entre eles citamse a falta de infraestrutura para acessar as dependências acadêmicas, falta de recursos financeiros, escassez de tempo devido a outras atividades, entre outros.

A metodologia da pesquisa se pauta no estudo de caso, como uma possibilidade de investigação de uma ação realizada em parceria público-privada, visando à formação de pessoas, como uma das condições possíveis para a empregabilidade.

\section{O CAPITAL HUMANO E O ENSINO A DISTÂNCIA}

O desenvolvimento econômico e social de uma determinada região ou município é resultado de uma série de fatores estruturais e também intangíveis. Um desses aspectos, de grande relevância dentro do debate científico acerca do tema, é o investimento em capital humano, ou seja, atividades intelectuais de cunho educacional ou profissional que gerem uma tensão positiva na produtividade do indivíduo.

Por definição, capital é todo ativo que, investido em algo, poderá posteriormente render mais (FISHER, 1984). Para Shultz (1961) o termo 'capital está prescrito no alicerce de que há um gasto, ou sacrifício, que formará um estoque a ser utilizado a posteriori, relacionado ao período de tempo em que isso ocorre. O resultado deste investimento de tempo e unidades monetárias se consolidará sobre a forma de crescimento e desenvolvimento econômico.

Segundo Druciaki et al (2014), a Teoria do Capital Humano passou a ter posição de destaque a partir do início da década de 1960, com os trabalhos seminais de Jacob
Mincer (1958 e 1974) e Gery Becker (1962). O capital humano é o resultado inerente da educação formal e informal dos indivíduos, que desde o início da infância recebem educação sob tais prismas. Na vida adulta o investimento em capital humano se torna mais evidente, pois devido às escolhas laborais dos indivíduos, estes se especializam em determinadas áreas, passando mais tempo recebendo educação formal em instituições de ensino, bem como treinamento profissional. Essa trajetória traz em seu bojo uma relação de custo, pois para atingir determinado grau de produtividade um indivíduo terá investido em sua formação, e formará um "estoque de capital" (MINCER,1981).

O acúmulo de treinamento proporciona às pessoas melhor aproveitamento no seu ambiente de trabalho, seja seu labor intelectual ou físico. Em estudo sobre o tema, Barbosa et al (2015) afirma que o capital humano sob a forma de educação formal é o que mais reflete no aumento da produtividade dos fatores, mesmo em economias mais desenvolvidas.

Neste sentido Seguí Mas (2007) elaborou estudo sobre o papel do capital humano em ambientes cooperativos, mais precisamente em uma cooperativa de crédito na Europa e demonstra que o capital humano ou o investimento na educação formal e informal, no sistema cooperativo também traz retornos positivos, além de possuir características singulares devido aos valores cooperativos inerentes à cultura organizacional das mesmas. Além do mais, o autor faz constatações importantes acerca do rumo que o capital humano pode tomar para aperfeiçoar todo o sistema cooperativo.

\section{Parece interesante que la empresa opte por incluir la formación no presencial (e-learning) dentro de su oferta formativa. De este modo, se podría conseguir una mayor flexibilidad de la oferta (puesto que permite el acceso a los contenidos de forma asíncrona y desde cualquier parte del planeta). Además, la formación no presencial y el potencial ahorro que puede generar, permitiría ampliar la gama y la cantidad del catálogo de acciones formativas (SEGUÍ MAS, p.112, 2007).}

Dentre inúmeras formas de se agregar conhecimento ao intelecto humano, seja por meio de educação formal, profissional ou informal, destaca-se o dinamismo de uma forma diferenciada, que é a modalidade de 
educação à distância. Conforme exposto, anteriormente, nota-se que a flexibilidade da educação sob a forma não presencial pode ser um instrumento e possibilitar melhores e contínuos investimentos no capital humano de seus cooperados bem como aumentar ou melhorar sua produtividade no ambiente organizacional.

As cooperativas são como atores sociais, atuam no processo de tensionamento estrutural e colaboram no desenvolvimento de um município ou de todo um território (DRUCIAKI, 2018). Portanto, é imprescindível que esses atores sociais dediquem seus recursos à capacitação, treinamento e educação de seus colaboradores, para permitir que o desenvolvimento da cooperativa se expanda e auxilie no processo de melhoria de qualidade de vida da sociedade em geral.

Vale ressaltar, entretanto, que o investimento em capital humano por vezes é oneroso para as empresas, devido ao deslocamento e permanência de seus colaboradores em ambientes, por vezes, distantes do local de origem. Assim, a modalidade de educação à distância, com auxílio de tecnologias de informação e de comunicação, permite que haja investimento nos colaboradores de uma forma mais dinâmica e atual.

Os apontamentos teóricos apresentados indicam a educação à distância como uma das formas de expansão da educação, como aponta o Decreto 5800 de 8 de junho de 2006 que reconhece a necessidade de interiorização da educação por meio dessa modalidade, bem como nos escritos de Seguí Mas (2007) em relação a flexibilidade do modelo.

Quando se caracteriza a educação a distância como uma "modalidade educacional", como a modalidade educacional na qual aluno e professor estão separados, física ou temporalmente e, por isso, faz-se necessária à utilização de meios e tecnologias de informação e comunicação. (BRASIL, 2018) tem-se outra perspectiva da educação, ou seja, a EaD vai além do uso da tecnologia, o professor torna-se um mediador, incentivador que instiga os alunos na busca do conhecimento. A utilização de diferentes meios e tecnologias permitem a flexibilidade e a utilização de diversas mídias, sendo assim, vem sendo tratada como uma estratégia democrática para ampliação da educação, principalmente dando acesso a maior parte da sociedade brasileira.

Os dados do Censo da Educação Superior de 2016 de acordo com o INEP (2016) indicam o crescimento de ensino da modalidade a distância. Em 2006 eram 207.206 alunos matriculados em cursos à distância o que representava apenas 4,25\% aproximadamente do total de alunos matriculados no Brasil, enquanto que as matrículas do presencial somavam 4.676.646 e correspondiam a $95,75 \%$ do total de matriculados.

Em 2016 os dados indicam uma variação de $624,72 \%$ no número de matriculados em cursos à distância, chegando a 1.494 .418 alunos, enquanto que a variação no número de alunos do presencial do período foi de $40,15 \%$ apenas e fechou 2016 com 6.554.283. A educação a distância passou de $4,25 \%$ do número total de alunos para $18,57 \%$ (INEP, 2016). Todos estes dados consolidam a necessidade de se entender a formação de pessoas, por meio desta modalidade de ensino.

\section{PROCEDIMENTOS METODOLÓGICOS}

Este artigo se caracteriza como estudo de caso, por realizar uma investigação do desenvolvimento de um Curso de Especialização em Cooperativismo Solidário e Crédito Rural ofertado na segunda oferta que compreende o período de 2017 - 2018.

Michel (2009, p. 53) destaca que "o método estudo de caso consiste na investigação de casos isolados ou de pequenos grupos, com o propósito básico de entender fatos, fenômenos sociais." A investigação de estudo de caso como estratégia de pesquisa compreende um método que abrange tudo como a lógica de planejamento, e incorpora abordagem específica para a coleta de dados e para a análise de dados. É um estudo que permite uma verificação das características significantes de eventos vivenciados, tais como: processos organizacionais e administrativos, mudanças em geral (YIN, 2015).

Com o intuito de atingir o objetivo geral desta pesquisa empregaram-se também as pesquisas de ordem bibliográfica e descritiva. Quando se trata de pesquisa bibliográfica se buscam conceitos e teorias que identifiquem o caso analisado. Gil (1999) explica que a pesquisa bibliográfica é desenvolvida 
mediante material já elaborado, principalmente livros e artigos científicos.

A classificação da pesquisa quanto aos meios também é considerada no presente estudo, como exploratória, pois conforme Gil (1993, p.45) "visa proporcionar maior familiaridade como o problema, com vistas a torná-lo mais explícito ou a construir hipóteses." Quanto aos fins, é classificado como descritivo, ao detalhar características relevantes de um objeto de pesquisa, ou como pondera Kauark et al. (2010) no sentido dos estudos descritivos apresentam características de uma população ou fenômeno, compreendendo a relação de variáveis. A pesquisa descritiva, de forma mais geral tem como propósito analisar os fatos e fenômenos estudados, usando conexões entre os resultados encontrados e a teoria utilizada, para retratar o máximo possível o assunto estudado (TRIVIÑOS, 1987).

Importante pontuar que os resultados apresentados em relação ao curso são parciais visto que este estudo foi elaborado no momento em que os acadêmicos se encontram na etapa de elaboração do Trabalho de Conclusão de Curso - TCC. As defesas estão pré-agendadas para os dias 18 a 22 de junho de 2018 em três estados brasileiros: Paraná, Minas Gerais e Rondônia.

Quanto à abordagem se utiliza da análise quantitativa e qualitativa. A pesquisa qualitativa é tida como uma análise não numérica, não estruturada e exploratória, baseada em pequenas amostras. Para Minayo (2001) a pesquisa qualitativa trabalha com o universo de significados, motivos, aspirações, crenças, valores e atitudes, o que corresponde a um espaço mais profundo das relações, dos processos e dos fenômenos que não podem ser reduzidos à operacionalização de variáveis.

$$
i_{a}=\frac{n_{a p}}{n_{a m}}
$$

Onde:

$i_{a}=$ índice de aproveitamento, variando de 0 (zero) a 1 (um) sendo que 1 (um) reflete que todos os alunos que cursaram a disciplina foram aprovados, e 0 (zero) indica que todos os alunos que cursaram ficaram retidos;

$n_{a p}=$ número de alunos aptos na disciplina/curso;
Já a pesquisa quantitativa se centra na objetividade dos dados, sendo mais comumente representada de forma numérica, quantificado e analisado de forma matemática e estatística. Para Silveira e Córdova (2009, p 33) a pesquisa quantitativa "tem suas raízes no pensamento positivista lógico, tende a enfatizar o raciocínio dedutivo, as regras da lógica e os atributos mensuráveis da experiência humana". Cooper e Schindler (2011) ressaltam que os dados quantitativos costumam consistir em respostas de participantes que são codificadas, categorizadas e reduzidas a números para que esses dados possam ser manipulados por análise estatística.

Mesmo que as duas abordagens sejam diferentes elas não se excluem, podem se complementar, para uma análise mais aprofundada do estudo. Tendo um resultado com maior cientificidade possível. Quando utilizados os dois métodos em conjunto temse a definição de métodos "qualiquanti" ou "misto".

Os dados coletados se configuram como estudo de caso e serão analisados, tanto com o uso da estatística descritiva no sentido de analisar os dados quantitativos a respeito do número de alunos e aproveitamento das disciplinas, como de análise qualitativa, que envolvem as percepções em torno do aproveitamento e acompanhamento dos acadêmicos.

Por fim, o método empregado no sentido de verificar o aproveitamento das disciplinas por parte dos acadêmicos se deu na mensuração de um índice de aproveitamento, o qual consiste na relação entre os alunos aprovados na disciplina e o número de alunos total, conforme equação abaixo:

$n_{a m}=$ número de alunos matriculados na disciplina/curso.

O índice permitirá verificar o aproveitamento dos acadêmicos em relação às disciplinas. Vale pontuar que se consideram somente os alunos ativos no curso, excluindo aqueles que tenham solicitado formalmente 0 desligamento do curso. 
4 A EXPERIÊNCIA DA SEGUNDA OFERTA DO CURSO DE ESPECIALIZAÇÃO EM COOPERATIVISMO SOLIDÁRIO E CRÉDITO RURAL.

A proposta do curso se iniciou a partir de uma parceria entre a Central Cresol Baser, o Instituto de Formação do Cooperativismo Solidário - Infocos e a Universidade Estadual do Centro-Oeste - UNICENTRO, visando proporcionar oportunidades de estudos aos colaboradores da cooperativa espalhados pelos mais diferentes municípios brasileiros. A parceria iniciou em 23 de dezembro de 2013, por meio de instrumento específico.

$\mathrm{Na}$ oportunidade das negociações e da primeira oferta foram oferecidos dois cursos: cursos de aperfeiçoamento voltado aos alunos sem a formação superior; curso de especialização para alunos graduados. A proposta de curso de extensão foi aprovada por meio da Resolução $n^{\circ}$. 110PROEC/UNICENTRO, de 30 de maio de 2014, envolvendo a carga horária de 570 horas e compreendeu a oferta no período de 2014 a 2015.

Este curso inicial de aperfeiçoamento obteve 737 alunos inscritos como destaca Ternoski (2015a) e Ternoski (2015b). Paralelamente ao desenvolvimento do curso de aperfeiçoamento, ocorreu às negociações para a oferta do curso de especialização, devidamente aprovado pela Resolução no 18 CEPE/UNICENTRO, de 7 de julho de 2014, no qual foram inscritos 317 alunos. Assim na primeira oferta entre aperfeiçoamento e especialização a proposta atendeu 1054 alunos.

As avaliações destes dois cursos demonstraram conforme Ternoski (2016) que algumas lacunas deveriam ser superadas. Os dados indicaram evasão elevada principalmente entre os alunos do aperfeiçoamento, uma vez que o curso foi pensado para alunos graduados e adaptado aos alunos do ensino médio. Outro ponto de lacuna demonstrou que lapsos temporais, ou seja, recessos durante o curso elevaram a evasão.

Identificados os problemas da primeira oferta, no ano de 2017 iniciou-se uma segunda oferta, pensada a partir das dificuldades apontadas na edição anterior e que compreendeu apenas a oferta de um curso de especialização.

As principais alterações foram: adaptação da carga horária para 370 horas, início e término da oferta das disciplinas dentro do período letivo, vinculação do curso dentro do plano de cargos e salários da cooperativa, dentre outros ajustes.

O processo de seleção dos alunos para a oferta 2017 - 2018 compreendeu o período de 01 de janeiro de 2017 a 03 de fevereiro de 2017, num total de 243 inscritos. No entanto, foram selecionados 183, conforme se apresenta no Quadro 01.

Quadro 01 - Número de inscritos e quantidade total de alunos selecionados

\begin{tabular}{|c|c|}
\hline ETAPAS & QUANTIDADE \\
\hline Desclassificados primeira fase & 23 \\
\hline Desclassificados segunda fase & 37 \\
\hline Classificados & 183 \\
\hline Total de Inscritos & 243 \\
\hline
\end{tabular}

Fonte: Dados da Pesquisa

Percebe-se por meio do Quadro 01 que dentre os inscritos 23 candidatos foram desclassificados na primeira fase. O motivo da desclassificação decorreu do não envio de declaração, uma vez que para efetivação da inscrição era necessária apresentação de declaração de vínculo, assinada pelo presidente da Cooperativa Cresol a qual estava vinculado.
Contudo, pode se observar a inscrição de candidatos externos e sem vínculo com a instituição, reforçando novamente o interesse e a demanda pelo curso, o que em certo aspecto pode estar relacionado com a oferta do curso na modalidade de educação a distância. Outro aspecto da exigência da declaração decorre ao fato da necessidade da chefia imediata do candidato na Cresol, ter 
o conhecimento que o colaborador pretende realizar o curso.

Um segundo momento compreendeu a análise e recepção de documentos. Nesta fase, foram desclassificados mais 34 candidatos. Dentre os motivos $56 \%$ dos casos foram decorrentes de pessoas que não haviam feito a colação de grau em curso de graduação devidamente reconhecido. Essa situação gera uma reflexão sobre o período de seleção: se por um lado foi resolvido o problema dos lapsos de tempo durante a oferta das disciplinas que iniciaram e terminaram dentro do período letivo, por outro o período da seleção excluiu candidatos que ainda não haviam colado grau, uma vez que o início do ano é marcado na grande maioria das universidades pelas cerimônias de colação de grau.

Os demais casos desclassificados na segunda fase foram ocasionados pelo não envio de documentos solicitados em $23 \%$ dos casos, e pela desistência do processo de seleção, o que equivale a $21 \%$ do total de desclassificados. Os alunos que iniciaram o curso residem em diferentes municípios brasileiros, conforme pode ser observado na Figura 01.

Os dados representados na Figura 01 indicam que os inscritos estão distribuídos em 11 estados brasileiros: Alagoas (1), Bahia (14), Distrito Federal (2), Goiás (1), Minas Gerais (7), Paraná (100), Rio Grande do Sul (5), Rondônia (8), Santa Catarina (42), São Paulo (2) e Sergipe (1). Dentre os inscritos, o Estado do Paraná apresenta o maior número de alunos e estreita relação, de municípios num total de 41. A Figura 02 representa a distribuição dos alunos nos municípios paranaenses.

No que se refere ao Estado do Paraná, o município com maior número de alunos é Francisco Beltrão, com 27, seguido por Cascavel com 7. A grande quantidade de alunos em Francisco Beltrão pode ser explicada em decorrência da Central Cresol Baser ter sede neste município, além do que, a Cresol teve seu início no sudoeste paranaense, inclusive em Francisco Beltrão, ainda se atribui este número mais elevado às articulações do curso realizadas pela equipe do Infocos que tem sua sede neste município, facilitando o contato com os alunos.

Figura 01 - Mapa do quantitativo de alunos de acordo com a localização geográfica.

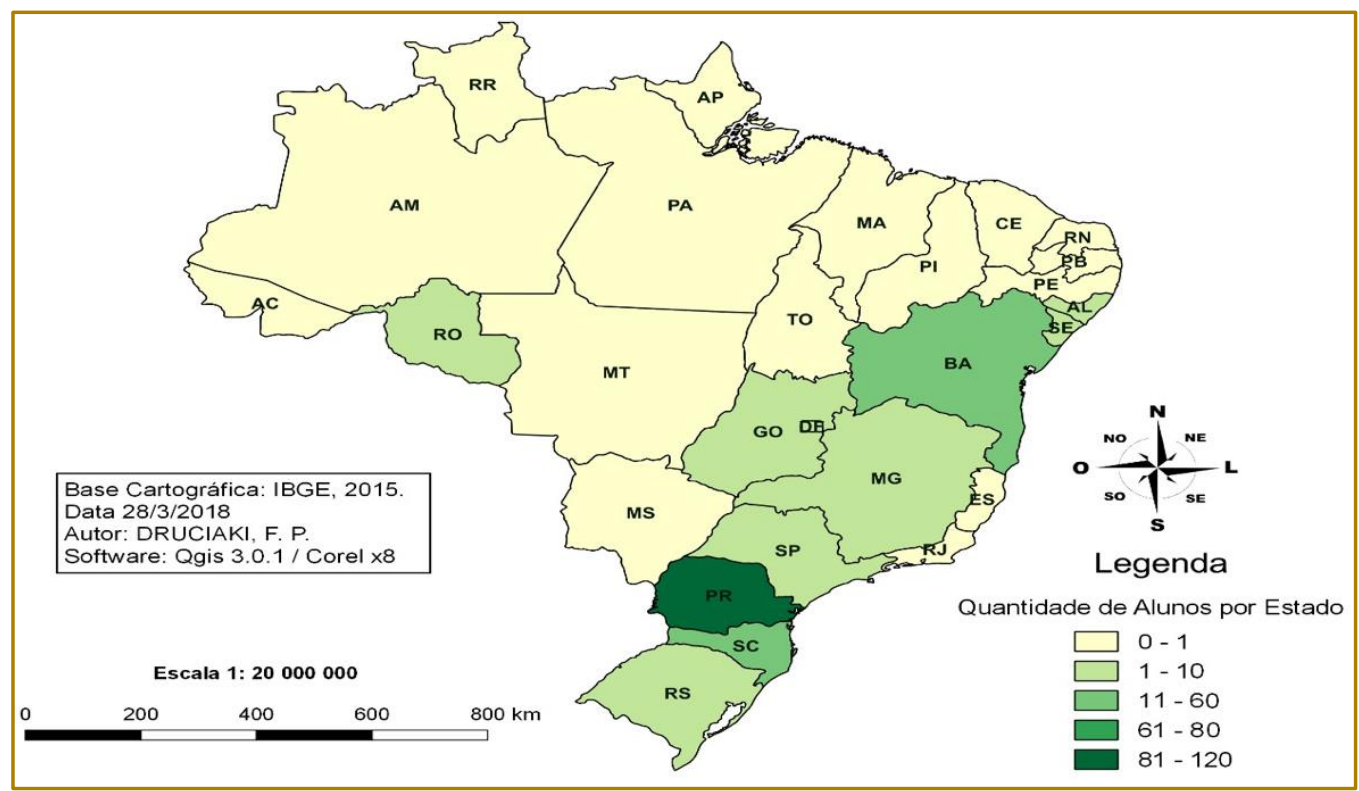

Fonte: Dados da Pesquisa

O segundo maior estado em número de alunos é Santa Catarina com 42 alunos e 25 municípios representados, conforme destaque na Figura 03. Os municípios catarinenses com maiores quantidades de alunos inscritos são Botuverá com 8 alunos e Brusque com 3 alunos no curso. 
Figura 02 - Mapa do quantitativo de alunos no Estado do Paraná de acordo com a localização geográfica.

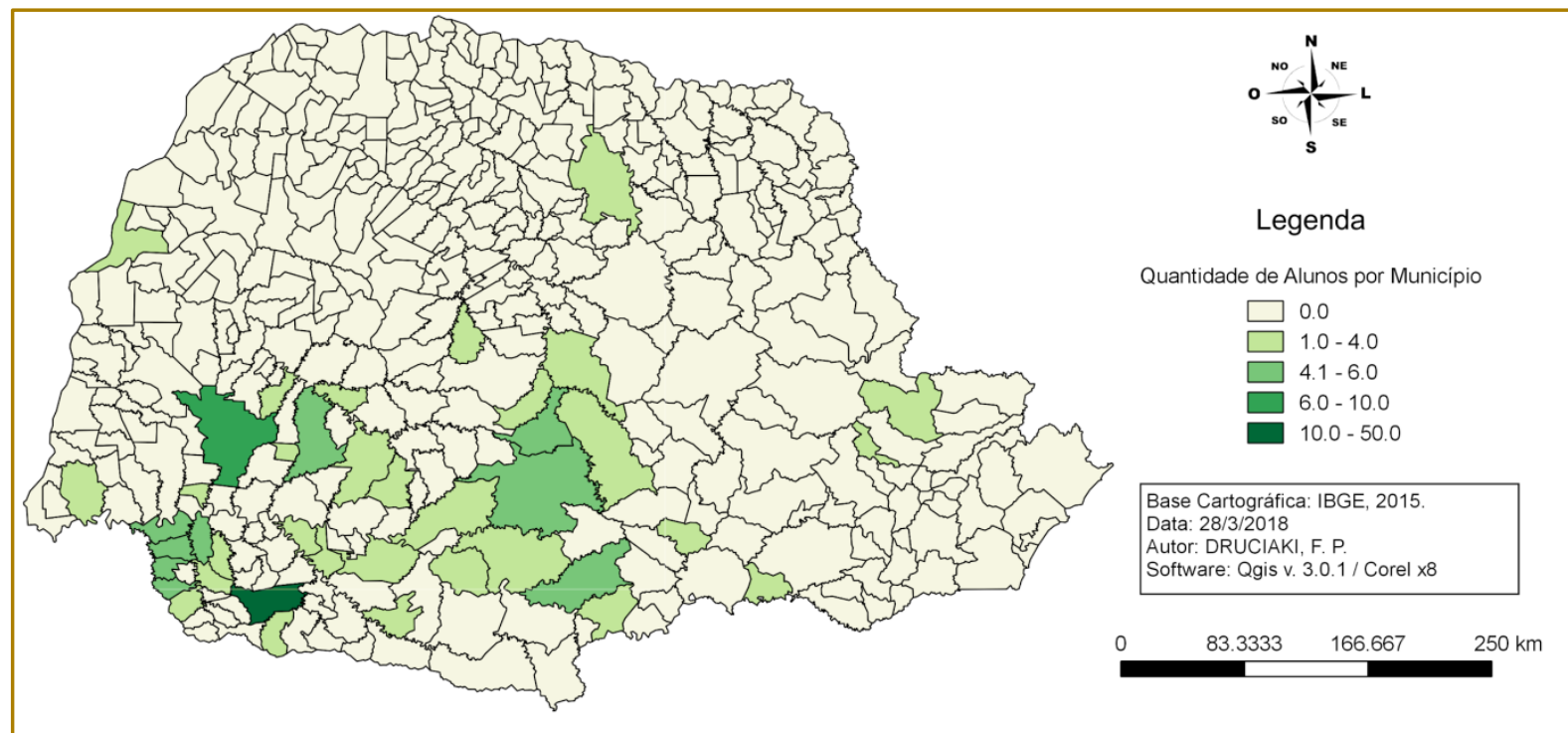

Fonte: Dados da Pesquisa

Seguindo em número de alunos aparece o Estado da Bahia com 14 alunos em 9 municípios: Araci (1), Barrocas (2), Biritinga (1), Conceição do Coité (1), Governador Mangabeira (1), Ichu (1), Ilhéus (1), Santaluz (2) e Serrinha (4).
Em quarto lugar em número de alunos encontra-se Rondônia com 8 alunos e 5 municípios, a saber: Alvorada D'Oeste (1), Governador Jorge Teixeira (1), Ji-Paraná (3), Ministro Andreazza (2) e Vilhena (1)

Figura 03 - Mapa do quantitativo de alunos do Estado de Santa Catarina de acordo com a localização geográfica municipal.

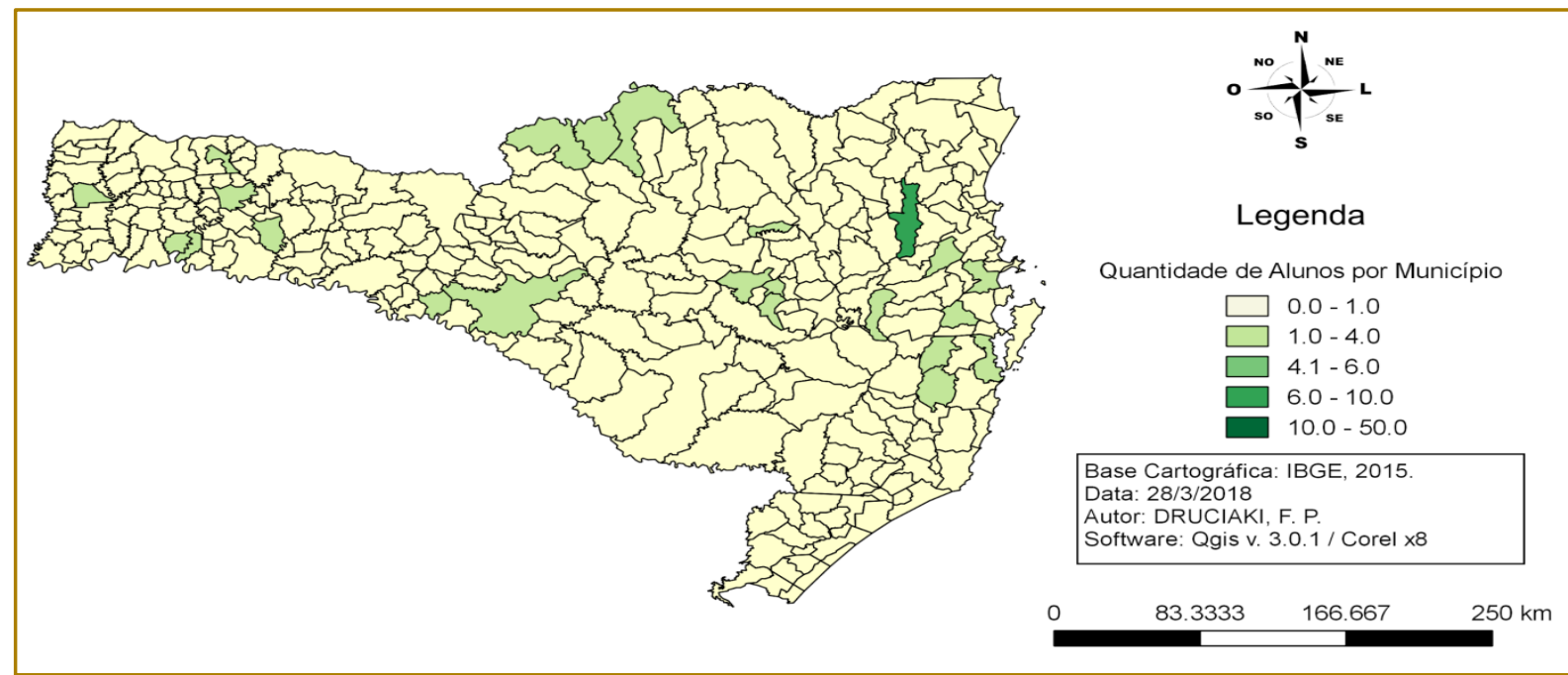

Fonte: Dados da Pesquisa

Minas Gerais aparece na quinta posição com 7 alunos em 6 municípios: Araponga (1), Carangola (1), Divino (1), Fervedouro (1), Muriaé (2) e Rosário da Limeira (1).
Na sequência o Estado do Rio Grande do Sul com 5 alunos em 4 municípios: Caseiros (1), Guarani da Missões (2), Ibiraiaras (1) e Viadutos (1) 
Posteriormente entre os estados com menor quantidade de alunos estão: São Paulo com 2 alunos no município de Capão Bonito; Distrito Federal com 2 alunos em Brasília; Sergipe com 1 aluno no município de Poço Verde; Goiás com 1 aluno em Orizona e Alagoas com
1 acadêmico no município de Pão de Açúcar. Os acadêmicos iniciaram o curso cumprindo uma carga horária total de 370 horas distribuídas em 10 disciplinas, conforme pode ser observado no Quadro 02.

Quadro 02 - Disciplinas e carga horária

\begin{tabular}{|c|c|}
\hline Nome da Disciplina & Carga Horária \\
\hline Introdução à Educação a Distância & 30 \\
\hline Fundamentação e desafios do Cooperativismo & 40 \\
\hline Estratégias Cooperativas & 60 \\
\hline Elaboração e Gestão de Projetos I & 20 \\
\hline Regulamentação e Normatização para Cooperativas de Crédito & 40 \\
\hline Crédito Rural & 40 \\
\hline Mercado Financeiro & 40 \\
\hline Matemática Financeira aplicada ao Cooperativismo de Crédito & 40 \\
\hline Análise de negócio e contratação de crédito & 40 \\
\hline Elaboração e Gestão de Projetos II & 20 \\
\hline Carga Horária Total do Curso & 370 \\
\hline
\end{tabular}

Fonte: Dados da Pesquisa

Importante destacar que de acordo com o Ministério da Educação, por meio da Resolução n. ${ }^{\circ}$, de 8 de junho de 2007, que trata do funcionamento dos cursos de pósgraduação lato sensu, exige-se o cumprimento de 360 horas de carga horária mínima. Vale pontuar que a Resolução n. ${ }^{\circ} 1$ estava vigente no momento da proposição do projeto da especialização.

Os cursos de pós-graduação lato sensu, em nível de especialização, têm duração mínima de 360 (trezentas e sessenta) horas, nestas não computado o tempo de estudo individual ou em grupo, sem assistência docente, e o reservado, obrigatoriamente, para elaboração individual de monografia ou trabalho de conclusão de curso (Art. $5^{\circ}$, RESOLUÇÃO n. ${ }^{\circ}$ 1, de 8 de junho de 2007).

Diante do que estabelece a Resolução n. ${ }^{\circ} 1$ verifica-se o cumprimento da carga horária mínima, de modo que além das 370 horas os acadêmicos deveriam cumprir mais 80 horas para realização do TCC. Ternoski (2015b) aponta que na primeira oferta a quantidade de horas foi de 570, mais 80 horas para o TCC, este fator ocasionou problemas na oferta da disciplina uma vez que o tempo de conclusão foi muito extenso, elevando o índice de evasão.

Durante a segunda oferta do Curso, a Cooperativa informou formalmente o desligamento de 26 alunos, reduzindo o número de alunos de 183 para 157. As desistências foram ocasionadas em parte pela demissão das pessoas que atuavam na Cooperativa.

Desse modo, considerando apenas os alunos ativos no curso, o aproveitamento dos alunos em relação às disciplinas, sem considerar a oportunidade do plano de estudos pode ser observado no Gráfico 01. 
Gráfico 01 - Percentual parcial de Aprovados antes do plano de estudos

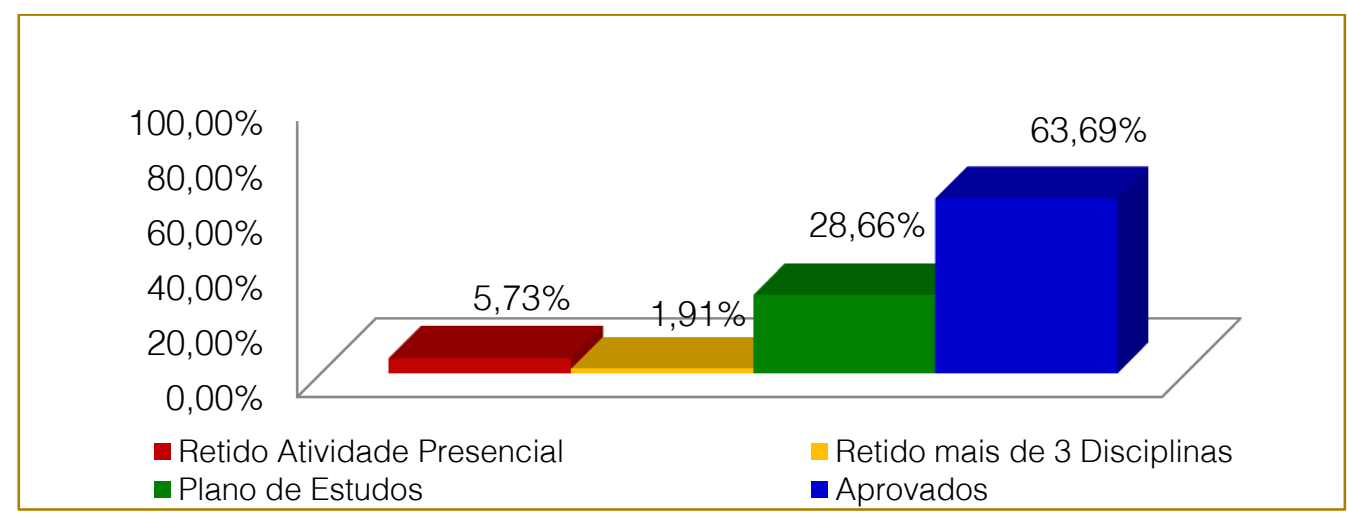

Fonte: Dados da Pesquisa

Pelos números apresentados, é possível identificar que do total de alunos, $7,64 \%$ ficaram retidos, o que corresponde a 12 alunos, sendo 9 retenções decorrentes da não entrega da atividade presencial e 3 por não atingirem conceito suficiente em mais de três disciplinas, gerando impedimento no prosseguimento do curso. Um percentual de $28,66 \%$ dos alunos, apesar de não atingirem conceito mínimo necessário para aprovação ainda tiveram a oportunidade do plano de estudos, como uma forma de recuperação das atividades.

A avaliação da aprendizagem para este curso foi dividida em duas fases, sendo: uma primeira fase na oferta regular das disciplinas e outra aplicada somente aos alunos que não atingiram conceito mínimo necessário para a aprovação. A primeira fase contemplou atividades no Ambiente Virtual de Aprendizagem - AVA, avaliações online, atividade presencial e atividade complementar.

De acordo com a Resolução no 035/2006 COU/UNICENTRO, que aprova o Regimento Geral da Universidade Estadual do CentroOeste, UNICENTRO, a avaliação é caracterizada em notas de zero $(0,0)$ a dez $(10,0)$ em cada disciplina. O aluno será aprovado na disciplina, sem a necessidade de prestar exame final (plano de estudos no caso desta oferta), se obtiver média igual ou superior a sete $(7,0)$ ou 70 pontos.

Desse modo, o percentual de nota de acordo com cada atividade é distribuído em 40 pontos para as atividades realizadas no decorrer da disciplina dentro da plataforma virtual. As atividades no transcorrer da disciplina envolviam a produção de textos, resolução de bancos de questões, participação em fóruns de discussão, envio de arquivo, glossário, diário, wiki, lições e outras ferramentas avaliativas, sempre mediadas pelo professor e por um grupo de tutores selecionados de acordo com a área do conhecimento da disciplina.

Como material de estudos tem-se o livro produzido pelo professor relacionado ao conteúdo considerado mais denso da disciplina e um e-book com ferramentas e atividades que vão além dos tópicos tratados no livro e, ainda, vídeos de conteúdos que são disponibilizados na plataforma de aprendizagem, para auxiliar na elaboração das atividades propostas.

A primeira etapa da disciplina apresenta uma duração que varia de acordo com a carga horária, de modo que cada semana de estudos equivale a 10 horas da disciplina, ou seja, uma disciplina com 40 horas tem uma duração aproximada de 30 dias.

Ao final deste período o aluno realiza uma avaliação online a partir de um banco de questões. As avaliações foram realizadas preferencialmente nas quintas, sextas, sábados e domingos, de modo que essa ficava aberta neste período e o aluno poderia escolher o melhor horário para realizar.

De acordo com o que estabelece a Resolução n. ${ }^{\circ}$ 1, de 8 de junho de 2007 "os cursos de pós-graduação lato sensu oferecidos a distância deverão incluir, necessariamente, provas presenciais e defesa presencial individual de monografia ou trabalho de conclusão de curso".

Para tanto, neste curso o aluno precisava cumprir com atividade presencial ou estaria retido na disciplina conforme exige a legislação sobre o assunto. Por exemplo, mesmo que um aluno tenha obtido $100 \%$ de aproveitamento nas atividades do AVA e na 
avaliação online, caso não entregasse a atividade presencial ficaria retido na disciplina sem possibilidade de concluir o curso. Para a oferta em questão, a atividade presencial versou sobre um estudo do aproveitamento de cada uma das disciplinas e sua aplicação prática no trabalho, o qual deve ser apresentado em forma de banner durante um seminário integrador que reúne todos os acadêmicos.

Caso ainda na primeira fase de oferta algum aluno não atinja o conceito mínimo para a aprovação, pode durante a oferta da próxima disciplina realizar a atividade complementar da disciplina anterior como forma de complementar a nota e atingir o conceito necessário. Essa segunda oportunidade somente se aplica aos alunos que obtiveram minimamente conceito inferior a 69\% de aproveitamento e superior a $50 \%$ de aproveitamento na disciplina, e equivaleria somente à diferença da nota necessária para atingir o conceito necessário.

Por exemplo, um aluno que ficou com 69 nas atividades do AVA, no seminário integrador e na avaliação online poderia fazer a atividade complementar valendo 1 ponto, já um aluno que ficou com 55 pontos faria a atividade valendo 15 pontos. Estas atividades complementares foram elaboradas pelos professores e o acadêmico deveria atingir um aproveitamento mínimo.
A segunda fase da disciplina foi denominada de Plano de Estudos e se aplicava somente aos alunos que não atingiram o conceito mínimo de 70 pontos na primeira oferta e ficaram retidos (a atividade é uma espécie de exame final). Vale pontuar que os alunos que não entregaram a atividade presencial não tiveram direito ao plano de estudos, bem como aqueles alunos que ficaram retidos em mais de três disciplinas, uma vez que alunos que ficaram retidos em mais de três ou que não realizaram nenhuma disciplina poderiam ser simplesmente premiados com um plano de estudos sem sequer ter cursado na oferta normal, diante disso este impedimento para realizar.

O plano de estudos consistiu em uma avaliação e atividade substitutiva a oferta normal da disciplina, para o qual foram propostas formas alternativas de avaliação. A atividade teve peso de 100 pontos e substitui a nota obtida na oferta regular da disciplina e foi realizada em janeiro de 2018, ou seja, ao final de todas as disciplinas e anterior ao início do TCC.

O índice de aproveitamento dos alunos nas disciplinas da primeira fase, anterior à realização do plano de estudos está representado no Quadro 03.

Quadro 03 - Índice de aproveitamento disciplinas na primeira fase

\begin{tabular}{|c|c|c|}
\hline CÓDIGO DISCIPLINA & DISCIPLINA & $i_{a}$ \\
\hline 91913 & Introdução à Educação à Distância & 0,885350318 \\
\hline 91914 & Fundamentação e Desafios do Cooperativismo & 0,866242038 \\
\hline 91915 & Estratégias Cooperativas & 0,878980892 \\
\hline 91916 & Elaboração e Gestão de Projetos I & 0,898089172 \\
\hline 91903 & Regulamentação e Normatização para Cooperativas de Crédito & 0,853503185 \\
\hline 91907 & Introdução ao Crédito Rural & 0,828025478 \\
\hline 91917 & Introdução ao Mercado Financeiro & 0,898089172 \\
\hline 91902 & Matemática Financeira Aplicada ao Cooperativismo De Crédito & 0,859872611 \\
\hline 91918 & Análise de Negócio e Contratação de Crédito & 0,808917197 \\
\hline 91919 & Elaboração e Gestão de Projetos II & 0,923566879 \\
\hline
\end{tabular}

Conforme destacado na metodologia o índice de aproveitamento $-i_{a}$ varia de 0 (zero) a 1 (um) sendo que 1 (um) reflete que todos os alunos que cursaram a disciplina foram aprovados e 0 (zero) indica que todos os alunos que cursaram ficaram retidos. Vale pontuar que todas as disciplinas consideraram um grupo de alunos como não concluintes, ou seja, isso faz com que nenhuma disciplina atinja índice igual a 1 ou 100\% de aproveitamento.

Este grupo de alunos é representado pelos que deixaram de entregar a atividade presencial, critério obrigatório para a aprovação do curso, portanto ficaram retidos mesmo que a nota obtida fosse superior a 70 pontos e teoricamente estivessem aprovados 
na disciplina. Este grupo corresponde a $7,64 \%$ dos alunos, ou seja, 0,0764 pontos a menos no índice apresentado no Quadro 03.

Os dados do Quadro 03 apontam que a disciplina de Elaboração e Gestão de Projetos Il obteve o melhor índice de aproveitamento $(0,92)$ e que se considerado somente os alunos que efetivamente cursaram a disciplina, excluindo aqueles que não entregaram a atividade presencial 0 aproveitamento seria de 100\%. A disciplina consistia na elaboração da segunda fase do projeto de pesquisa a ser desenvolvido para o TCC, onde os acadêmicos já iniciaram a construção dos artigos e em um momento da disciplina todos apresentaram por meio de webconferência a proposta de TCC.

Por outro lado, a disciplina com menor índice de aproveitamento na oferta regular e anterior ao plano de estudos, foi à disciplina de Análise de Negócio e Contratação de Crédito. Esta disciplina foi uma das últimas a ser ofertada, justamente decorrente de sua complexidade. Envolvia a análise de projetos de investimento e de contratação de crédito exigindo dos acadêmicos o conhecimento dos conceitos das disciplinas teóricas anteriores, aliados à aplicação das ferramentas da matemática e relação com casos reais das cooperativas.

Os dados sobre os alunos aprovados na primeira fase e aqueles com direito ao plano de estudos estão representados no Gráfico
02, os quais indicam que as disciplinas de Análise e Contratação de Crédito e a disciplina de Introdução ao Crédito Rural foram as que mais apresentaram alunos retidos na primeira fase, o que demandou destes acadêmicos a realização do plano de estudos. Por outro lado, as disciplinas de Elaboração e Gestão de Projetos I e II e Introdução ao Mercado Financeiro foram às disciplinas que menos alunos ficaram retidos na primeira fase.

Os alunos descritos no Gráfico 02 e que fizeram o plano de estudos (segunda fase) somaram 45 casos o que corresponde a $28,66 \%$ do total de alunos. Estes casos estão distribuídos nos percentuais expressos no Gráfico. Vale pontuar que em alguns casos um mesmo aluno ficou retido em duas ou três disciplinas, de modo que o somatório dos percentuais de alunos em plano de estudos apresentados no Gráfico 02 supera 28,66\%.

Finalizado o plano de estudos observou-se que 6 alunos não cumpriram ou não atingiram nota suficiente para a aprovação, ficando retidos e impedidos de prosseguir com $\mathrm{O}$ trabalho de conclusão de curso - TCC, portanto o índice de aproveitamento médio do curso, considerando 9 casos sem entrega da atividade presencial, 3 casos retidos em mais de 3 disciplinas e 6 casos retidos no plano de estudos foi de 0,8853 , conforme apresentado na Tabela 01 a qual ainda expõe a estatística descritiva das notas finais em cada uma das disciplinas.

Gráfico 02 - Dados sobre o aproveitamento e retenção na primeira fase

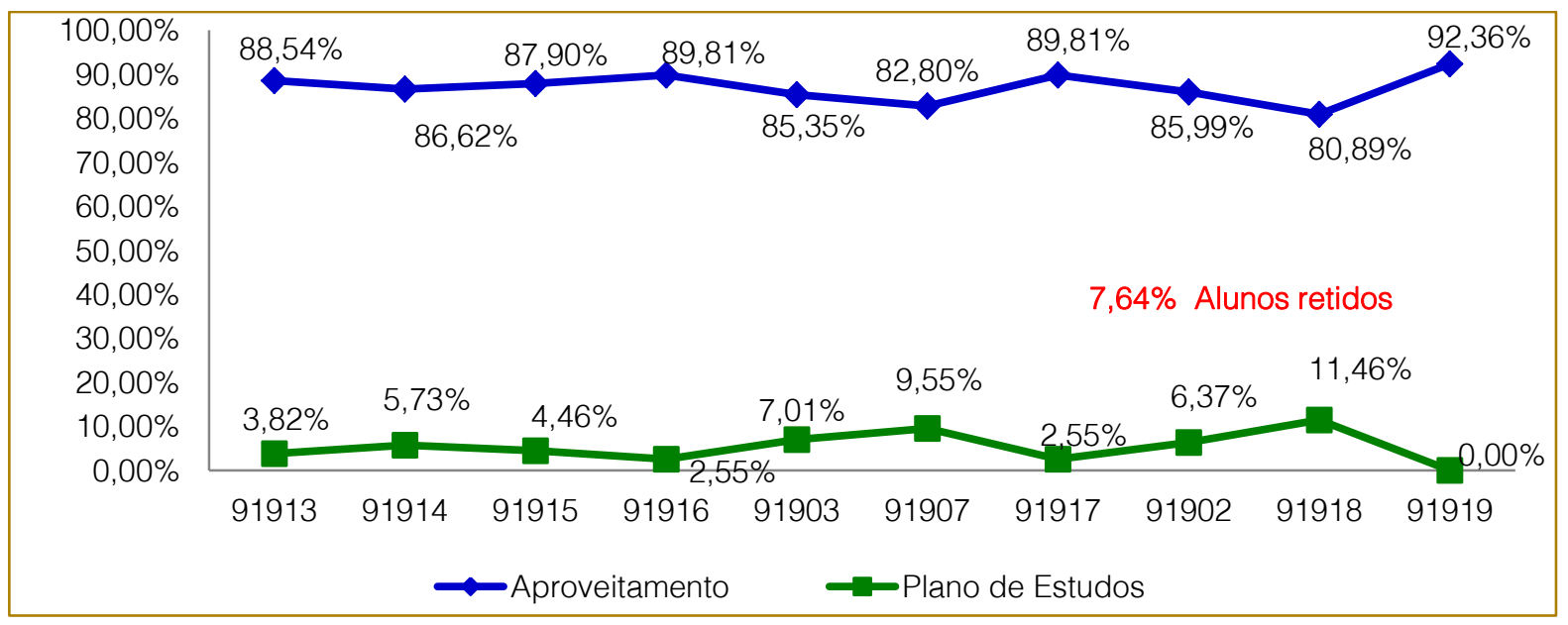

Fonte: Dados da Pesquisa 
Tabela 01 - Estatística descritiva das notas dos acadêmicos após o plano de estudos

\begin{tabular}{|c|c|c|c|c|c|c|c|c|c|c|}
\hline & & & Estatí & tica Des & itiva das & Jotas fin & & & & \\
\hline & & & & & Disc & linas & & & & \\
\hline & 91913 & 91914 & 91915 & 91916 & 91903 & 91907 & 91917 & 91902 & 91918 & 91919 \\
\hline Média & 83,61 & 83,36 & 86,36 & 82,69 & 84,74 & 83,27 & 82,41 & 80,77 & 79,04 & 87,15 \\
\hline Mediana & 89,00 & 88,67 & 95,00 & 87,25 & 91,00 & 88,50 & 87,13 & 85,00 & 86,91 & 94,00 \\
\hline Modo & 95,00 & 100,00 & 100,00 & 0,00 & 98,00 & 0,00 & 70,00 & 95,00 & 70,00 & 100,00 \\
\hline $\begin{array}{l}\text { Desvio } \\
\text { padrão }\end{array}$ & 21,53 & 21,31 & 25,07 & 22,04 & 22,12 & 21,32 & 21,00 & 22,24 & 23,17 & 24,44 \\
\hline Mínimo & 0,00 & 0,00 & 0,00 & 0,00 & 0,00 & 0,00 & 0,00 & 0,00 & 0,00 & 0,00 \\
\hline Máximo & 100,00 & 100,00 & 100,00 & 100,00 & 100,00 & 100,00 & 100,00 & 100,00 & 100,00 & 100,00 \\
\hline Contagem & 149,00 & 152,00 & 157,00 & 157,00 & 149,00 & 151,00 & 152,00 & 150,00 & 152,00 & 157,00 \\
\hline $\begin{array}{l}\text { la pós } \\
\text { reoferta }\end{array}$ & 0,8853 & 0,8853 & 0,8853 & 0,8853 & 0,8853 & 0,8853 & 0,8853 & 0,8853 & 0,8853 & 0,8853 \\
\hline
\end{tabular}

Fonte: Dados da Pesquisa

O índice de aproveitamento expresso na Tabela 01 indica um bom desempenho da proposta pedagógica do curso, visto que a retenção e evasão principalmente em cursos ofertados na modalidade a distância é elevada. Os dados apontam ainda que a nota média mais elevada foi observada na disciplina de Elaboração e Gestão de Projetos Il e a menor média das notas na disciplina de Análise de Negócios e Contratação de Crédito, justamente as disciplinas que na primeira fase obtiveram respectivamente 0 melhor e o menor índice de aproveitamento.

Vale destacar que a contagem de notas apresentada na Tabela 01 reflete que nem todos os 157 alunos cursaram todas as disciplinas, sendo que somente nas disciplinas de Elaboração e Gestão de Projetos I e II e na disciplina de Estratégias Cooperativas todos os alunos tiveram que cursar. Este fator decorre da alteração da grade em relação à oferta I, sendo que essas disciplinas foram disciplinas criadas para a oferta II. As demais disciplinas permaneceram ou foram ajustadas se comparadas à oferta I do curso, o que permitiu que alunos retidos na primeira oferta do curso aproveitassem disciplinas na segunda oferta.

\section{CONSIDERAÇÕES FINAIS}

A formação continuada de indivíduos em um mercado de trabalho cada vez mais competitivo, tanto no setor privado como no setor público, torna-se um diferencial para a disputa em postos de trabalhos ou concursos públicos, pois seleciona os candidatos mais qualificados e preparados para assumir a vaga.

Qualificar-se nem sempre é tarefa fácil, exige empenho, dedicação, momentos de separação do convívio familiar para se dedicar não somente aos estudos, mas ao tempo necessário para se deslocar aos locais de oferta do estudo. E neste aspecto a educação a distância visa reduzir essas barreiras, levando a educação a regiões que muitas vezes não teriam o acesso a um curso profissionalizante ou de nível superior.

É nesta perspectiva de inclusão que a proposta do curso de especialização foi estruturada, permitindo se constituir em uma ferramenta para a inclusão e acesso do grupo objeto do curso a uma educação em nível superior (lato sensu), chegando às mais diversas regiões.

Os resultados permitiram comprovar a hipótese do estudo e cumprir com os objetivos. Uma vez que a partir dos resultados foram abordadas as especificidades do curso, bem como sua área de abrangência e a relevância na formação dos envolvidos.

A hipótese foi comprovada nos dados observados, principalmente no que se refere à abrangência do curso, o qual atingiu 11 estados brasileiros em 95 municípios. Municípios estes que em sua maioria estão distantes de grandes centros ou locais de oferta de cursos em nível superior, 
demonstrando que a proposta do curso é de extrema relevância para a promoção da educação e profissionalização dos colaboradores da cooperativa em regiões com acesso restrito ao ensino superior.

Os resultados são visíveis, mas os desafios para oferta de um curso neste formato são imensos. É possível citar alguns: desafios por parte dos acadêmicos e candidatos em aceitar e reconhecer a educação à distância como uma modalidade que pode ofertar ensino de qualidade, muitos veem esta forma de educação como inferior ao modelo presencial, e muitas vezes não percebem que essa exige do aluno dedicação igual ou até mesmo superior que a do presencial.

Desafios de infraestrutura, pois muitas regiões brasileiras ainda têm acesso restrito à internet, com conexões lentas ou até mesmo alunos que não dispõe de computadores e acesso a rede. Parte deste problema foi minimizado com o acesso a rede de computadores nas dependências dos postos da cooperativa. No entanto muitos alunos dependiam do uso de lan house para realizar as atividades.

\section{REFERÊNCIAS}

[1]. BRASIL. Decreto no. 5.800, de 8 de junho de 2006. Disponível em: http://www.planalto.gov.br/ccivil_03/_Ato20042006/2006/Decreto/D5800.htm Acesso em 27 de mar. de 2018.

[2]. BRASIL. Ministério da Educação, Conselho Nacional de Educação. Câmara de Educação Superior. RESOLUÇÃO $N^{\circ} 1$, de 8 de junho de 2007. Disponível em: http://portal.mec.gov.br/cne/arquivos/pdf/rces001_ 07.pdf Acesso em 31 de mar. de 2018.

[3]. BRASIL. Ministério da Educação.
Disponível http://portal.mec.gov.br/financiamentomunicipal/merenda-escolar/355-perguntasfrequentes-911936531/educacao-a-distancia1651636927/12823-o-que-e-educacao-a-distancia. Acesso em 30 de mar. de 2018.

[4]. CAGED - Cadastro Geral de Empregados e Desempregados, Ministério do Trabalho e Emprego. Evolução de Emprego do CAGED - EEC Disponível em: http://bi.mte.gov.br/eec/pages/consultas/evolucaoE mprego/consultaEvolucaoEmprego.xhtml\#relatorio Setor Acesso em 27 de mar. de 2018.

[5]. CAPES - Coordenação de Aperfeiçoamento de Pessoal de Nível Superior. O
Do ponto de vista da Cooperativa os desafios se apresentam no convencimento da participação no curso, mesmo com gratificações em planos de cargos e salários nem todos se sentem motivados para realizar uma formação.

E do lado institucional da Universidade os desafios são ainda maiores, envolvem infraestrutura e pessoal. A Unicentro é uma universidade pública e sua estrutura e desenvolvimento depende de repasses e investimentos do governo estadual. Apesar do curso ser realizado em parceria de modo que a universidade recebe recursos da cooperativa, essa ainda se depara com a falta de uma estrutura tanto de pessoal, como de equipamentos para executar suas ações.

Mesmo prevendo a aquisição de equipamentos e contratação de pessoal no contrato entre as partes, o tempo de licitações e outras providências muitas vezes vão além do tempo e da expectativa da contratante. Enfim conciliar interesses públicos de um lado e privados de outro se torna um grande desafio na execução de um curso nestes moldes.

que é o Sistema UAB? Publicado em 14 Março 2016. Disponível em: http://www.capes.gov.br/uab/o-que-e-uab Acesso em 27 de mar. de 2018.

[6]. COOPER, D. R.; SCHINDLER, P. S. Métodos de Pesquisa em Administração. Traduzido por: Iuri Duquia Abreu. 10.ed. Porto Alegre: Bookman 2011. 762 p.

[7]. CRESOL - Cooperativa de Crédito Rural com Interação Solidária. Relatório de Atividades e Balanço Social 2016. Disponível em: http://www.cresol.com.br/site/upload/downloads/24 7. pdf Acesso em 27 de mar. de 2018.

[8]. DRUCIAKI, F. P. et al. O capital humano na região Centro-Sul Paranaense. Revista Fae, v. 18, n. 2, p. 54 - 67. Curitiba, , jul./dez. 2015.

[9]. DRUCIAKI, F.P. Desenvolvimento territorial: Conceitos e Elementos. in: Economia e desenvolvimento territorial. Org: Ferrera de Lima, J. Bidarra, B.S. Voll, F. A. P. Ed. Parque Itaipú: Foz do Iguaçú, 2018.

[10]. FISHER, I. A teoria do juro: determinada pela impaciência de gastar a renda e pela oportunidade de investi-la. São Paulo: Abril Cultural, 1984 
[11]. INEP - Instituto Nacional de Estudos e Pesquisas Educacionais Anísio Teixeira, 2014. Disponível em: http://portal.inep.gov.br/. Acesso em 28 de Março de 2015.

[12]. MINAYO, M. C. S. Pesquisa social: teoria, método e criatividade. Petrópolis: Editora Vozes, 2001.

[13]

Censo da Educação Superior

2016: Principais Resultados. Disponível em: http://download.inep.gov.br/educacao_superior/ce nso_superior/documentos/2016/censo_superior_ta belas.pdf Acesso em 27 de mar. de 2018.

[14]. KAUARK, Fabiana. MANHÃES, Fernanda Castro e MEDEIROS, Carlos Henrique. Metodologia da pesquisa: guia prático. Itabuna: Via Litterarum, 2010.

[15]. MINCER, J. Human capital and economic growth. National Bureau of Economic Research. Cambridge, n. 803, 1981. Disponível em: . Acesso em: 28 mar. 2018.

[16]. SCHULTZ, T. W. Investment in human capital. The American Economic Review. Nashville, v. 51, n. 1, p. 1-17, 1961. Disponível em: . Acesso em: 28 mar. 2018.

[17]. SILVEIRA, Denise Tolfo; CÓRDOVA, Fernanda Peixoto. Unidade 2-A pesquisa científica. Métodos de pesquisa, p. 31-42, 2009.

[18]. TERNOSKI, Simão, et al Educação Aberta a Distância - EAD: Um estudo de caso sobre o curso de especialização e Aperfeiçoamento em Cooperativismo Solidário e Crédito Rural, in
INFOCOS - Instituto de Formação do Cooperativismo Solidário. Saberes da Cooperação. Grafisul: Francisco Beltrão. 2015b.

[19]. TERNOSKI, Simão, et al. A AVALIAÇÃO E AS PRÁTICAS PEDAGÓGICAS DE UM CURSO DE ESPECIALIZAÇÃO LATO SENSU: Um estudo sobre - curso de especialização em cooperativismo solidário e crédito rural . In 54ํㅡㄹ Congresso da Sociedade Brasileira de Economia, Administração e Sociologia Rural: "Desenvolvimento, Território e Biodiversidade". 14 a 17 de agosto de 2016, Maceió, Alagoas. Disponível em: http://icongresso.itarget.com.br/tra/arquivos/ser.6/1 /6282.pdf.

[20]. TERNOSKI, Simão, et al. EDUCAÇÃO ABERTA À DISTÂNCIA - EAD: Um Estudo de Caso sobre o Curso de Especialização e Aperfeiçoamento em Cooperativismo Solidário e Crédito Rural. In 53으 Congresso da Sociedade Brasileira de Economia, Administração e Sociologia Rural: "Agropecuária, Meio Ambiente e Desenvolvimento". 26 a 29 de Julho de 2015a, João Pessoa, Paraíba. Disponível em: http://icongresso.itarget.com.br/tra/arquivos/ser.5/1 /5297.pdf.

[21]. TRIVIÑOS, A. N. S. Introdução à pesquisa em ciências sociais: a pesquisa qualitativa em educação. São Paulo: Atlas, 1987.

[22]. YIN, Robert K. Estudo de Caso: Planejamento e Métodos. Bookman editora, 2015. 


\section{Gapítulo 18}

\section{CAFÉ: UMA ANÁLISE DO POTENCIAL DA CADEIA PRODUTIVA DO CAFE NO CRESCIMENTO ECONOMMICO DA MICRORREGIÃO DE PATOS DE MINAS}

\section{Ravilla de Castro Barbosa}

\section{Julienne de Jesus Andrade Widmarck \\ Áurea Lúcia Silva Andrade \\ Deivisson Costa de Carvalho \\ Vivian Raniere Mendes Silva}

Resumo: O Café é uma commodity de histórica importância na economia brasileira. A análise do potencial desta commodity no crescimento econômico da microrregião de Patos de Minas corrobora com a hipótese que a cafeicultura alavanca o desenvolvimento e a industrialização, bem como é preponderante na fixação da mão de obra na zona rural devido à capacidade da cadeia produtiva do café de gerar empregos. A Microrregião de Patos de Minas está inserida na demarcação do Café da Região do Cerrado Mineiro e o café mostra-se como força motora para o desenvolvimento da microrregião. Por meio de técnicas de estatística descritiva, econometria espacial e método dos momentos generalizados demonstra-se o potencial da cadeia produtiva do café na microrregião analisada tomando a geração de emprego e renda como ponto de análise, bem como os padrões de exportação do café. O café torna-se relevante na microrregião de Patos de Minas com participação acentuada no PIB agrícola e Geral e os efeitos positivos desta commodity se espalha por todos os elos que compõem uma cadeia produtiva.

Palavras-chave: Cadeia produtiva do café, agronegócio, GMM

*NEEAP- Núcleo de Estudos Econômicos do Alto Paranaíba da UFV- Campus Rio Paranaíba 


\section{INTRODUÇÃO:}

O café chegou ao Brasil em 1727 trazido da Guiana Francesa. Em um espaço de tempo curto o café passou de uma posição secundária para a de produto-base da economia brasileira (TAUNAY). Ao chegar a Minas Gerais, mais precisamente na região do Cerrado Mineiro, descobriu-se que as condições ambientais proporcionavam um café de ótima qualidade. O mercado para esse café veio tomando força. Assim, as lavouras da agricultura familiar deram lugar para as lavouras de café gerando novos empregos e renda para famílias que ali se fixaram.

A Microrregião de Patos de Minas faz parte dessa história do café e o desenvolvimento que ele proporcionou para a região. Apesar das especificidades e homogeneidades presentes em cada microrregião, conforme salientam Diniz e Batella (2005), ao analisarmos separadamente para cada município, podemos notar os diferentes produtos produzidos que ajudam a impulsionar a economia de cada localidade, porém, algumas delas possuem em comum a produção de commodities.

Um dos fatores importantes para a economia brasileira é a produção e exportação de commodities, tendo como um dos principais o café. (REVISTA CAFEICUTURA, 2010). Abordaremos uma análise do potencial dessa commodity na Microrregião de Patos de Minas com o objetivo de questionamento, se a cafeicultura alavanca o desenvolvimento, industrialização e geração de empregos na região, por meio do café denominado Café da Região do Cerrado Mineiro.

Este trabalho é fruto das pesquisas do NEEAP- Núcleo de Estudos Econômicos do Alto Paranaíba da UFV- Campus Rio Paranaíba, composto por alunos e professores que tem como objetivo propagar informações a respeito da economia e temas afins, num esforço coordenado para conhecer a região na qual está inserido o campus de Rio Paranaíba da Universidade Federal de Viçosa. A proposta central do núcleo de estudos é realizar pesquisas empíricas na Região do Alto Paranaíba ancoradas teoricamente na Administração, na Economia, na Estatística e no Direito para conhecermos a região e participar de forma ativa no desenvolvimento regional.

Dessa forma, buscou-se, neste artigo, analisar a cadeia produtiva do café na microrregião de
Patos de Minas na dimensão econômica e de estrutura. De maneira específica, buscou-se descrever o macrossegmento produtivo da CPA do café da microrregião de Patos de Minas, identificar a correlação produção de café, PIB agro e PIB total da microrregião e analisar estatisticamente Produção agrícola, PIBs de serviços, agrícola e industrial e o Emprego agrícola na microrregião de Patos de Minas. O enfoque deste recorte está amparado na economia, sem deixar de considerar a visão sistêmica e interdisciplinar na análise dos sistemas agroindustriais.

Este artigo está dividido em seis partes. Além desta introdução, o texto é composto pela parte 2, na qual descreve-se a base teórica para a análise de sistemas agroindustriais. $\mathrm{Na}$ parte 3 e 4, a metodologia utilizada, dados sobre a microrregião de Patos de Minas e as cidades que a compõe. As análises na parte 5 e finalizamos com a conclusão.

\section{UM OLHAR SOBRE A GOVERNANÇA DOS SISTEMAS AGROINDUSTRIAIS}

A economia das organizações propõe uma aproximação entre a teoria econômica e os estudos das organizações recuperando o comportamento humano como elemento central da atividade econômica e trazendo à tona as características cognitivas e de auto interesse dos atores econômicos (Zylbersztajn, 2014). Neste processo, a estrutura de governança alinhava novas formas de coordenação das transações entre os atores econômicos presentes em diferentes elos da cadeia produtiva com vistas a melhorar a competitividade dos sistemas agroindustriais.

Nesta perspectiva, a visão sistêmica dos sistemas agroindustriais amplia o conceito de firma para além da função de produção e proporciona um novo olhar sobre a governança dos sistemas agroindustriais. Para tanto um novo aporte teórico se faz necessário para a análise dos sistemas agroindustriais, por isso descreve-se, no próximo item, a visão sistêmica de análise dos sistemas agroindustriais e, posteriormente, a Economia de Custos de Transação. 
2.1. A VISÃO DE COMMODITY SYSTEM APPROACH (CSA) E ANÁLISE DE FILIÈRE: UMA PROPOSTA SISTÊMICA PARA A ANÁLISE DOS SISTEMAS AGROINDUSTRIAIS

A perspectiva da análise sistêmica dos sistemas agroindustriais teve origem nos trabalhos de Davis \& Goldberg, na Universidade de Harvard, na década de 1950. Na década subsequente, Goldberg passou a adotar o conceito de Commodity System Approach (CSA) para analisar os sistemas de produção de commodities como laranja, trigo e soja nos EUA. Nestes trabalhos Goldberg parte do paradigma da Economia Industrial (Estrutura, Conduta, Desempenho) para suas análises e predições. (BATALHA; SILVA, 2007)

Estes trabalhos representam 0 ponto de partida para pesquisas que trabalham a agricultura e pecuária além da propriedade rural. São estudos que perpassam pelo mapeamento dos canais de produção, distribuição, comercialização e varejo porque estão ancorados no conceito de agribusiness conforme delimita com propriedade Zylberstajn (1995, p.28): "[...] a soma de todas as operações associadas à produção e distribuição de insumos agrícolas, operações realizadas nas unidades agrícolas bem como as ações de estocagem, processamento e distribuição dos produtos, e também dos produtos derivados."

Desta forma, há uma ampliação do foco dos estudos que, conforme destaca Zylberstajn (2014), se desloca da unidade agrícola e passa a considerar todo o sistema de produção, inclusive o consumidor final. A perspectiva teórica passa a considerar as transações e relações entre os agentes que compõem um sistema agroindustrial tanto a jusante quanto a montante da unidade produtiva e traz à tona a relevância do ambiente institucional e do ambiente organizacional (ZYLBERSTAJN, 2000).

A corrente francesa propõe uma que há uma lógica de encadeamento das operações de jusante a montante em uma cadeia agroalimentar e, que esta lógica, assume o poder do consumidor final na alteração do status quo do sistema. No entanto, destaca-se que agentes econômicos de diferentes macrossegmentos _ _ produção, industrialização e comercialização - também são responsáveis pela introdução de inovações tecnológicas, mas estas geram posição competitiva somente se forem reconhecidas pelo consumidor final como geradoras de diferenciação. (BATALHA; SILVA, 2007)

Zylbersztajn (2000) defende a congruência de ambas as abordagens - Commodity System Approach e Filière - devido ao compartilhamento da visão sistêmica, da percepção da demanda por mecanismos de coordenação e governança das transações entre os atores econômicos e a importância dos ambientes organizacionais e institucionais, bem como da inovação na definição da competitividade dos sistemas agroindustriais. Nesta mesma linha, Batalha e Silva (2007) reforçam que, ambas as abordagens, adotam o aspecto dinâmico dos sistemas bem como a compreensão do sistema como uma sucessão de etapas ligadas entre si.

Neste sentido, as abordagens propõem uma análise sistêmica dos sistemas agroindustriais, que passam a ser vistos como um sistema aberto em interação constante com o meio ambiente. O sistema por si é dinâmico e evolui no espaço e no tempo em função das alterações do próprio sistema e do ambiente e a dinamicidade do sistema pressupõe a participação coordenada dos fornecedores de insumos, dos produtores agropecuários, da agroindústria, dos distribuidores que atuam no atacado e varejo, além de organizações de apoio e do ambiente institucional. (BATALHA; SILVA, 2007)

\subsection{ECONOMIA DOS CUSTOS DE TRANSAÇÃO (ECT)}

A Economia dos Custos de Transação (ECT) remonta do artigo de Ronald Coase, publicado em 1937, que propõe uma visão da firma para além da função de produção. A partir da contribuição teórica de Coase, Williamson, na década de 1970, avança no escopo teórico sobre os Custos de Transação e proporciona uma nova perspectiva teórica para compreender as estratégias da firma. Nesta perspectiva, a transação passa a ser a unidade de análise e a estrutura de governança adotada pelas firmas é ancorada nas características dos ativos transacionados, que são delineadas pela especificidade do ativo, pela frequência da transação e pelo grau de incerteza e nas características dos agentes, que são influenciadas pela racionalidade limitada e pelas ações oportunísticas. (BATALHA; SILVA, 2007) 
A análise conjunta das características dos ativos transacionados e das características dos agentes econômicos envolvidos na transação influencia na estrutura de governança adotada pelas firmas que, de acordo com Williamson, pode ser mercado, híbrida ou integração vertical. As decisões sobre a transação passam a considerar variáveis que vão além do funcionamento dos mercados e para cada transação pode haver uma estrutura de governança específica. Neste sentido, a firma passa a ser concebida como um nexo de contratos e o estudo das relações contratuais entre as firmas ganha relevância. (ZYLBERSZTAJN, 2014)

Com o aumento da complexidade dos sistemas agroindustriais estudos sobre governança ganharam relevância para auxiliar na compreensão da competitividade e dinâmicas destes sistemas, bem como para auxiliar nas estratégias de geração de valor nestes sistemas e do compartilhamento do valor gerado entre os atores envolvidos no sistema agroindustrial. (ZYLBERSZTAJN, 2014)

Análises sobre a cadeia produtiva do feijão constataram que as transações entre produtores e corretoras se dão via mercado. Apesar do mecanismo mercado ofertar possibilidades de ganho, esta estrutura de governança reduz a eficiência da cadeia produtiva e elimina a possibilidade compartilhamento de ganhos para todos os agentes econômicos. O estudo aponta que, devido à alta especificidade temporal do ativo transacionado e a alta incerteza quanto ao preço, a transação deveria ser coordenada por meio de contratos para reduzir os riscos de ações oportunísticas por parte de produtores e corretores. (LEITÃO; BRISOLA, 2010)

Begnis, Estivalete, Pedrozo (2007) analisam o comportamento dos agentes econômicos na cadeia produtiva do fumo no Sul do Brasil comprovando que, mesmo em cadeias coordenadas e com elevado nível de comprometimento entre os agentes, o autointeresse dos agentes econômicos pode levar à desarticulação da cadeia produtiva. A integração produtor-indústria aumentou a frequência das transações, a especialização da atividade e do ativo transacionado na cadeia do fumo e viabilizou a presença brasileira no mercado internacional de fumo. Apesar da relação coordenada e do crescente ganho compartilhado entre os participantes da cadeia produtiva do fumo o risco da quebra de contrato existe e é reforçado pela presença de intermediários especuladores ou agentes intermediários, especialmente quando há descompasso entre e oferta e demanda. A reputação dos agentes bem como a evolução na relação entre fumageiras e agricultores fortalecem a confiança na cooperação dos parceiros e garante o retorno financeiro esperado em função do investimento em ativos altamente especializados. (BEGNIS, ESTIVALETE, PEDROZO, 2007)

Tanto na análise da cadeia produtiva do feijão quanto na análise da cadeia produtiva do fumo há a percepção da incompletude dos contratos. A reputação passa a ser um valor intrínseco que os agentes econômicos buscam construir nas transações frequentes no longo prazo, mas ela não elimina as atitudes dos agentes que buscam beneficiar a si próprio de forma oportunística (Rosina et al., 2007) nem exclui os limites cognitivos dos agentes, ou seja, a racionalidade limitada apontada por Simon, conforme assevera Zylbersztajn (2000).

Estudo realizado no setor sucroalcooleiro conduzido por Barbosa, Cândido e Barbosa (2016) confirmou que quanto maior a frequência das transações, maior será o nível de reputação entre os agentes. Baseado nos resultados, os autores consideram que a reputação contribui para diminuir os riscos de ruptura de contrato, no entanto enfatizam que as firmas podem adotar mecanismos complementares para reduzir a probabilidade de ações oportunísticas como ações que ampliem e melhorem o nível de compartilhamento de informações, sistema de incentivo focado no padrão desejado pelo mercado final e sistemas de controle do comportamento dos agentes econômicos.

A perspectiva de análise dos sistemas agroindustriais como sistema aberto reforça a importância do ambiente institucional e como as mudanças da legislação afetam o processo produtivo e o papel do ambiente organizacional na melhoria da eficiência e competitividade dos agentes de todos os elos da cadeia. No estudo sobre a piscicultura no Mato Grosso do Sul, Satolani, Corrêa, Fagundes (2008, p.232) afirmam que os ambientes institucional e organizacional "afetam o desempenho econômico da atividade, pois suas ações são diretamente responsáveis e vitais para a manutenção da piscicultura no estado do Mato Grosso do Sul". Nesta mesma linha, no estudo realizado 
por Oliveira e Silva (2012) é possível verificar a expectativa dos agricultores familiares de não serem expulsos da pecuária leiteira frente à implantação do Plano Nacional de Qualidade do Leite (PNMQL), em 1997, que representa um marco na aproximação da produção nacional aos patamares mundialmente aceitos. A característica heterogênea do setor produtivo do leite e os níveis díspares de produtividade e eficiência reforçam que a permanência da agricultura familiar na pecuária leiteira está atrelada a políticas públicas específicas para criar condições de inclusão deste grupo de produtores no novo padrão de produção, conforme destacam Oliveira e Silva (2012). Além disso, os referidos autores apontam que o fomento a processos de cooperação entre os produtores pode reduzir os riscos de exclusão da agricultura familiar da cadeia produtiva do leite. Oliveira e Silva (2012) comprovam que o ambiente institucional tem o poder de reposicionar a cadeia produtiva em termos de qualidade, mas sem políticas públicas de inclusão este ambiente pode impedir a inserção de agricultores familiares em uma cadeia produtiva mais competitiva.

\section{METODOLOGIA}

A metodologia adotada baseia-se nos dados do IBGE e da PAM e denomina-se como estatística descritiva, econometria espacial e análise de dados em painel (Método dos Momentos Generalizados). Baum (2006) descreve o modelo GMM através da técnica mais geral de estimação. Sendo a equação de interesse Yit $=$ yit- $1 \gamma+x i t \beta+$ ui + eit .

Como resultado foram encontrados o foco produtivo agrícola da microrregião $e$ especialmente analisado a relação: crescimento do PIB, produção de café e exportação de café da microrregião. O mérito do artigo está no ineditismo da análise profunda dos dados da microrregião de Patos de Minas e no questionamento de que o principal produto agrícola dessa região era milho.

\section{MICRORREGIÃO DE PATOS DE MINAS}

Minas Gerais foi divido em mesorregiões para subsidiar o planejamento do desenvolvimento econômico e social do Estado. Esta divisão foi construída com base nas potencialidades econômicas de cada região e que admitiu uma certa arbitrariedade na delimitação das fronteiras respeitando os limites dos municípios para facilitar a análise de estatísticas disponíveis. Cada uma das mesorregiões do Estado é composta por regiões menores, denominadas microrregiões. Estas, por sua vez, possuem especificidades comuns e certa homogeneidade em pontos específicos como produção e consumo. (DINIZ; BATELLA, 2005)

Os referidos autores destacam que, ao fazer um resgate histórico da regionalização do Estado de Minas Gerais, perceberam que as regiões de Minas representam frações de um todo, mas nunca deixaram de representar os estágios evolutivos do Estado e as transformações sociais que a civilização vivencia.

A mesorregião do Triângulo Mineiro e Alto Paranaíba é uma das 12 mesorregiões de Minas Gerais, sendo esta responsável pela segunda maior economia do Estado, representando, desta forma, uma potência econômica estadual. A região do Alto Paranaíba é subdividida em sete microrregiões, todas pertencentes ao cerrado mineiro. São elas: Araxá, Frutal, Ituiutaba, Patos de Minas, Patrocínio, Uberaba e Uberlândia.

Para a análise deste trabalho, propomos a análise da microrregião de Patos de Minas, que é composta pelos municípios de Arapuá, Carmo do Paranaíba, Guimarânia, Lagoa Formosa, Matutina, Patos de Minas, Rio Paranaíba, Santa Rosa da Serra, São Gotardo e Tiros.

Apesar das especificidades e homogeneidades presentes em cada microrregião, conforme salientam Diniz e Batella (2005), ao analisarmos separadamente para cada município, podemos notar os diferentes produtos produzidos que ajudam a impulsionar a economia de cada localidade, bem como a trajetória ao longo dos anos com as trocas de culturas por outras e a conservação da mesma cultura.

Arapuá é um município com 2.555 habitantes com uma área total de $172,529 \mathrm{Km}^{2}$ (IBGE, 2010). Sua produção agrícola se baseava em feijão, milho, batata, arroz, mandioca, cana de açúcar, maracujá e hortigranjeiros, sendo o tomate um destaque da cidade. A partir da década de 70 o café veio ganhando força na cidade e sendo um produto muito importante para a economia do município (PMA/2017). 
Atualmente, apesar de o município possuir uma agroindústria da cadeia produtiva do leite de atuação nacional, a cafeicultura é importante atividade no macrossegmento produtivo. O laticínio contribui sobremaneira no fomento da pecuária leiteira no munícipio.

Carmo do Paranaíba possui 30.823 habitantes com uma área total de 1.307,119 Km² e está localizada nas dividas entre os municípios de Rio Paranaíba, Tiros, Lagoa Formosa e Arapuá. (IBGE, 2016) Sua economia está diretamente ligada às atividades agropecuárias, sendo a agricultura a principal fonte de renda com o plantio do Café do Cerrado, sendo esse considerado um dos melhores cafés do mundo. Desde a colonização da região até o inicio da década de 1970, a economia era de agricultura de subsistência e pouco volume da produção era comercializado em outras regiões. Porém, após a década de 1970 a economia do município teve um aumento por dois fatores: o primeiro devido a construção da BR 354 que pavimentou a interligação da cidade à capital do estado e, no outro sentido, à região oeste do Estado, com saída para o Triângulo Mineiro e São Paulo. Favorecendo o escoamento da produção e a chegada de bens de capital, motivando e viabilizando investimentos na região. O segundo fator foi a chegada da tecnologia e o empreendedorismo no campo como consequência da vinda de grandes cooperativas agrícolas. Essas cooperativas fizeram demonstrações que motivaram os produtores locais e investidores de fora, evidenciando a qualidade produtiva do cerrado, além de implementarem as ideias das novas técnicas de produção e gestão de negócios. Assim, a partir da década de 1990 a economia local se consolidou com altos níveis de produtividade, tanto na agricultura quanto na pecuária de leite e corte. Com tecnologias de ponta em alta escala nas lavouras grandes empresas do agronegócio surgiram principalmente no ramo cafeeiro, que fez da região um centro de excelência mundialmente conhecido, tanto pela produtividade quanto pela qualidade excepcional de seus produtos (PMC/2016).

Guimarânia com 15.716 habitantes e uma área total de $370 ; 807 \mathrm{Km}^{2}$ se localiza na ponta da microrregião fazendo divisa com Patos de Minas. Guimarânia era um território que servia como rota para bandeirantes a procura de ouro, possui montanhas e planícies formadas pelo "cerradão" (IBGE, 2016). Embora se encontre em uma ótima área para cultivos, seu desenvolvimento na agricultura ainda não é muito explorado, tendo a economia impulsionada por plantio de café e bens e serviços (PMG/2003).

Lagoa Formosa possui 17.161 habitantes com uma área total de $841 \mathrm{Km}^{2}$, se localiza entre duas potências da economia da microrregião, de um lado Patos de Minas e do outro Carmo do Paranaíba. (IBGE, 2016). Sua principal cultura é o feijão, sendo esse o município referência em produção de feijão na região, cultura a qual se manteve durante os anos (PMLF/2017).

Matutina possui 3.849 habitantes e uma área de 260, $957 \mathrm{~km}^{2}$, se localiza nas divisas de São Gotardo e Tiros. (IBGE, 2016). Sua economia sempre esteve relacionada a pecuária leiteira (PMT/2016).

Patos de Minas, conhecida como a capital do milho, possui 147.614 habitantes e uma área de $3.187,771 \mathrm{Km}^{2}$. (IBGE,2016). Os fatores econômicos que predominavam no município durante o período da Segunda Guerra Mundial era o Trigo e o Diamante, porém com o fim do conflito, os preços internacionais do trigo começaram a cair e os incentivos estatais cessaram, o que levou a queda da cultura na cidade. Após cinco anos, houve a recuperação do setor primário com a produção de milho, que até aquela época, nunca havia sido produzido para comercialização em regiões tropicais. Com o sucesso do município, todo o país começou a produzir milho, o que tornou o Brasil o maior produtor de milho do mundo. Atualmente, o milho vem dando lugar as plantações de soja no município, e mesmo a agricultura estado presente o fator principal de sua economia é o setor de serviços (PMPM/2016).

Rio Paranaíba, berço de um dos mais importantes rios da hidrografia brasileira, possui 12.364 habitantes e sua área é de 1.353, $423 \mathrm{~km}^{2}$. (IBGE, 2016). A economia gira totalmente em torno da agropecuária, vindo da atividade leiteira até as principais culturas como café, soja, milho, cenoura, alho, abacate, batata e cebola. Com a chegada da Universidade Federal de Viçosa, o setor imobiliário começou a ser parte importante da economia do município, além de bens e serviços (PMRP/2015).

Santa Rosa da Serra, possui 3.224 habitantes com área territorial de 296,342 km². (IBGE, 2016). O município é considerado como polo regional devido a sua elevada produção de 
café que conquistou tanto o mercado interno como o externo (PMSRS/2016).

São Gotardo, Capital nacional da cenoura, possui 35.016 habitantes e sua área territorial de $853,745 \mathrm{Km}^{2}$. (IBGE, 2016). Teve sua economia potencializada com a chegada de imigrantes japoneses que ali fixaram residência, a partir daí a agricultura foi tornando-se grande fonte geradora de recursos. A produção agrícola dessa junção de empresas do município plantando em áreas pertencentes a Rio Paranaíba abastecem grande parte dos estados brasileiros com produção de trigo, cenoura, soja, alho, café e beterraba (PMSG/2015).
Tiros, possui 6.871 habitantes com área territorial de 2.093,160 Km². (IBGE, 2016). É um município pequeno e um grande produtor de leite e derivados, contando com a participação de uma grande empresa que atual no setor, se referência nacional, o que ajuda a economia da localidade (PMT/2004).

\section{ANÁLISE ECONÔMICA E SISTÊMICA DA CADEIA PRODUTIVA DO CAFÉ DA MICRORREGIÃO DE PATOS DE MINAS}

Para apresentação da análise econômica e sistêmica da cadeia produtiva do café foi desenvolvido o Ecossistema Agro Produtor conforme afigura abaixo:

Figura 1 - Ecossistema Agro Produtor

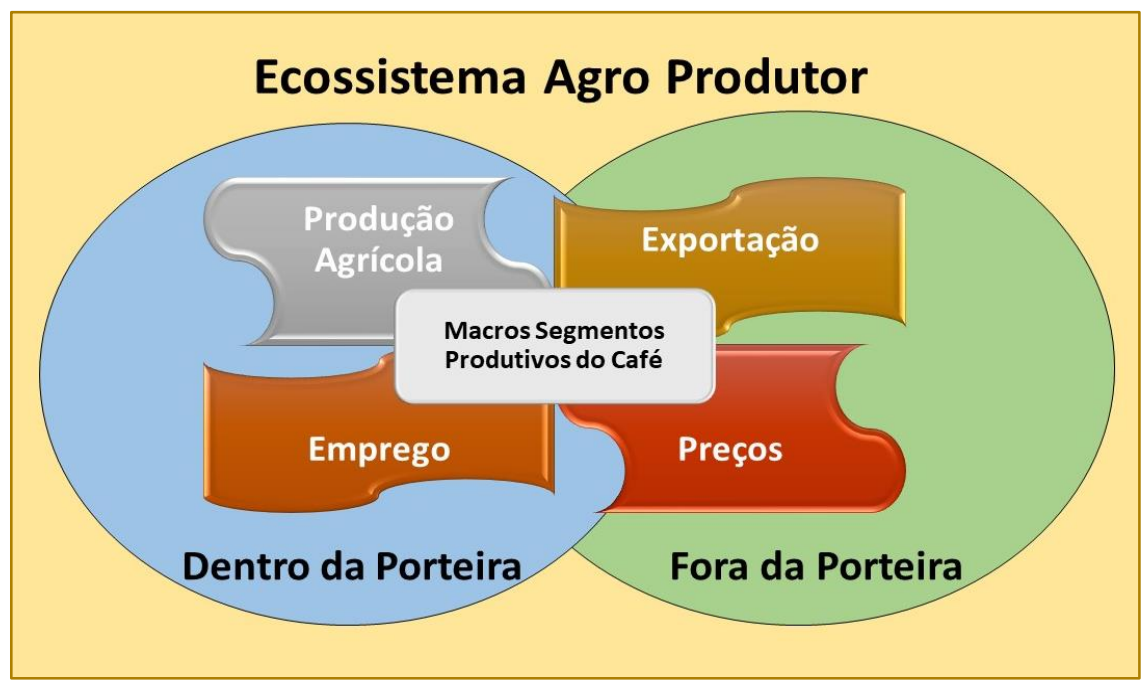

Fonte: Elaboração Própria, 2018.

O Ecossistema abriga a análise dos principais produtos agrícolas da microrregião de Patos de Minas entre 1990 a 2015, a apresentação espacial dos dados sobre essas culturas conjuntamente com a comparação entre a evolução de empregos agrícolas e no setor de serviços. Por último, é exposto o Produto Interno Bruto Agrícola, da Indústria e de Serviços para microrregião de Patos de Minas entre 2005 a 2012.

Já para a análise da produção de café dentro e fora da porteira foi desenvolvido o estudo Macro Segmentos Produtivos do Café. A análise dentro da porteira é feita com dados de produção agrícola e emprego no cultivo de café. E o estudo dos elementos fora da porteira foram utilizados dados sobre a cotação diária desde janeiro de 2006 do café arábica e robusta e sobre a exportação de café feita na microrregião de Patos de Minas.

Os dados utilizados para produção agrícola são provenientes da PAM - Pesquisa Agrícola Municipal do IBGE, os dados sobre Emprego foram retirados do Ministério do Trabalho, especificamente do sistema RAIS. Para análise dos preços de cotação do café robusta e arábica foi utilizada a base de dados do CEPEA - ESALQ, e para taxa de câmbio boletins diários do Banco Central. Por último, os dados de exportação foram captados do site Comexstat - do Ministério da Indústria, Comércio Exterior e Serviços. 


\subsection{ANÁLISE ECONÔMICA DA CADEIA PRODUTIVA DO CAFÉ}

A seguir, a figura 1 referente à Evolução da Produção Agrícola na microrregião de Patos de Minas evidencia que houve um crescimento considerável na produção de café e trocas de lavouras de milho e feijão por plantações de soja, devido à abertura do mercado internacional, o que ocasionou maior escoamento das produções por exportação.

Figura 1 - Gráfico da Evolução da Produção Agrícola da Microrregião de Patos de Minas (1990 a 2015).

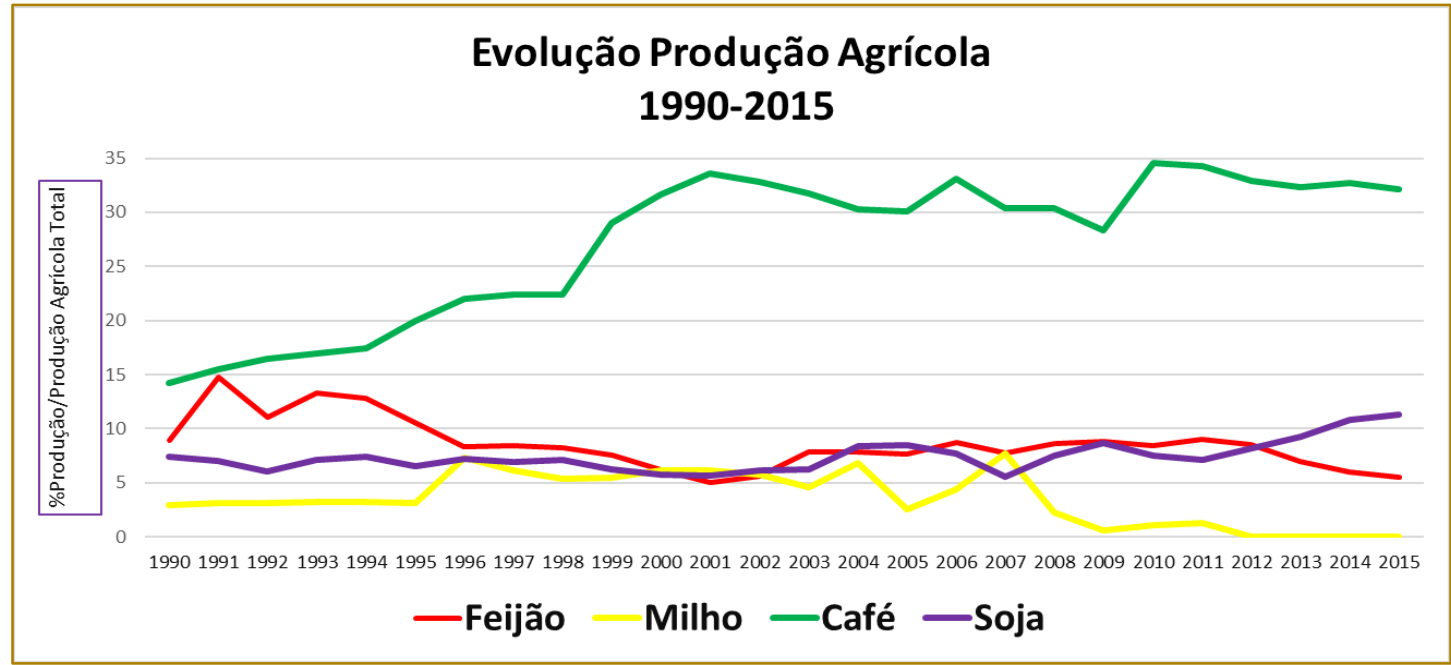

Fonte: Elaboração própria, Excel, 2018.

De acordo com a Pesquisa Agrícola Mensal as cidades de Rio Paranaíba e Patos de Minas têm-se, em média, 33\% da sua produção agrícola total sendo soja, Lagoa Formosa $15 \%$ sendo feijão e Carmo do
Paranaíba e Arapuá possuem $80 \%$ da sua produção sendo café. O que nos mostra que as culturas tradicionais da agricultura familiar deram lugar a novas lavouras, sendo o café o grão mais produzido.

Figura 2 - Gráficos de empregos do Alto Paranaíba (1990 a 2015).

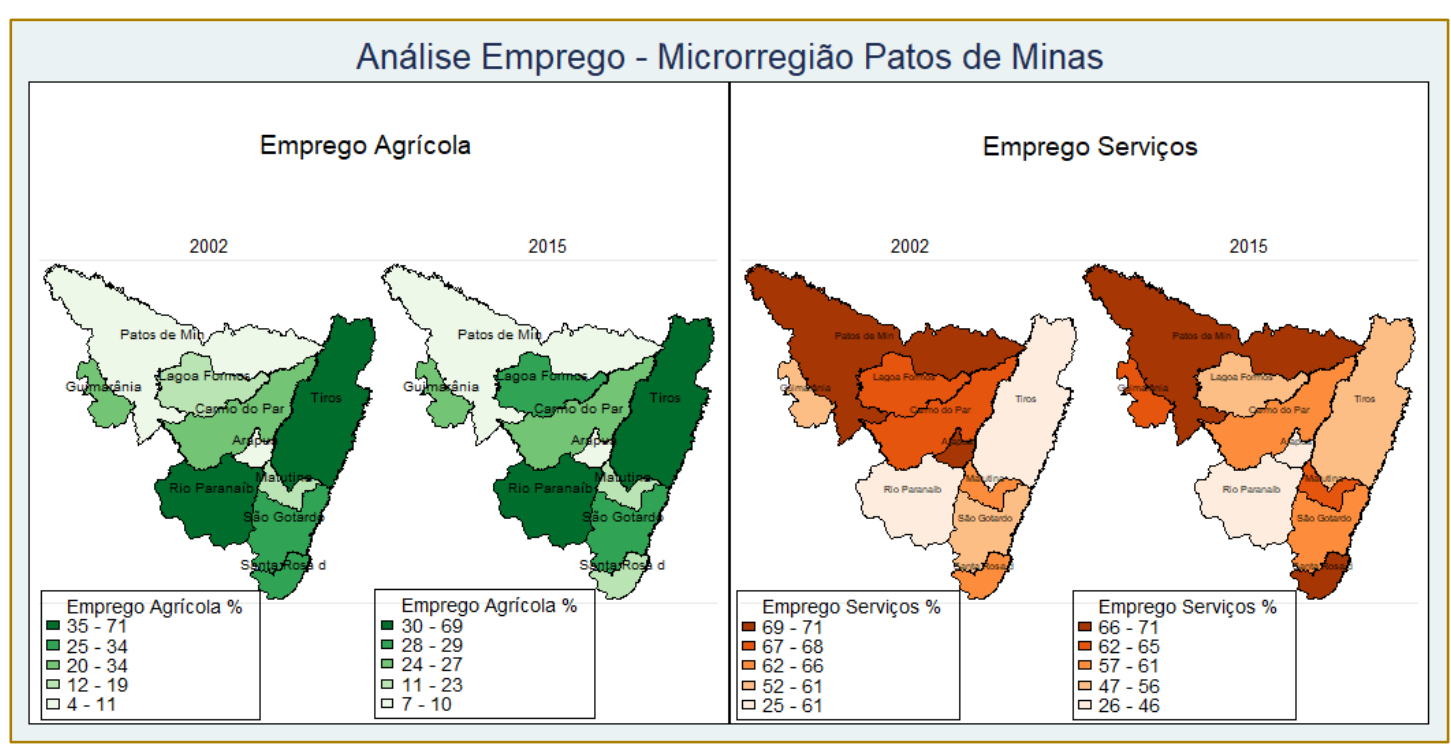

Fonte: Elaboração própria, Excel, 2018. 
Quando analisamos as fontes geradoras de emprego na microrregião percebemos que o emprego agrícola é muito importante para algumas cidades destacando-se Rio Paranaíba e Tiros, onde $70 \%$ do total de empregos na cidade são provindos da agricultura. Quando olhamos para Patos de
Minas observa-se que o emprego agrícola não possui importância, há uma demanda maior no setor de serviços onde $71 \%$ do emprego total da cidade são do setor de serviços e vem crescendo ao longo do período. A figura 3 mostra as áreas onde há a maior geração de empregos na microrregião.

Figura 3 Gráficos de empregos do Alto Paranaíba (2005 e 2015).

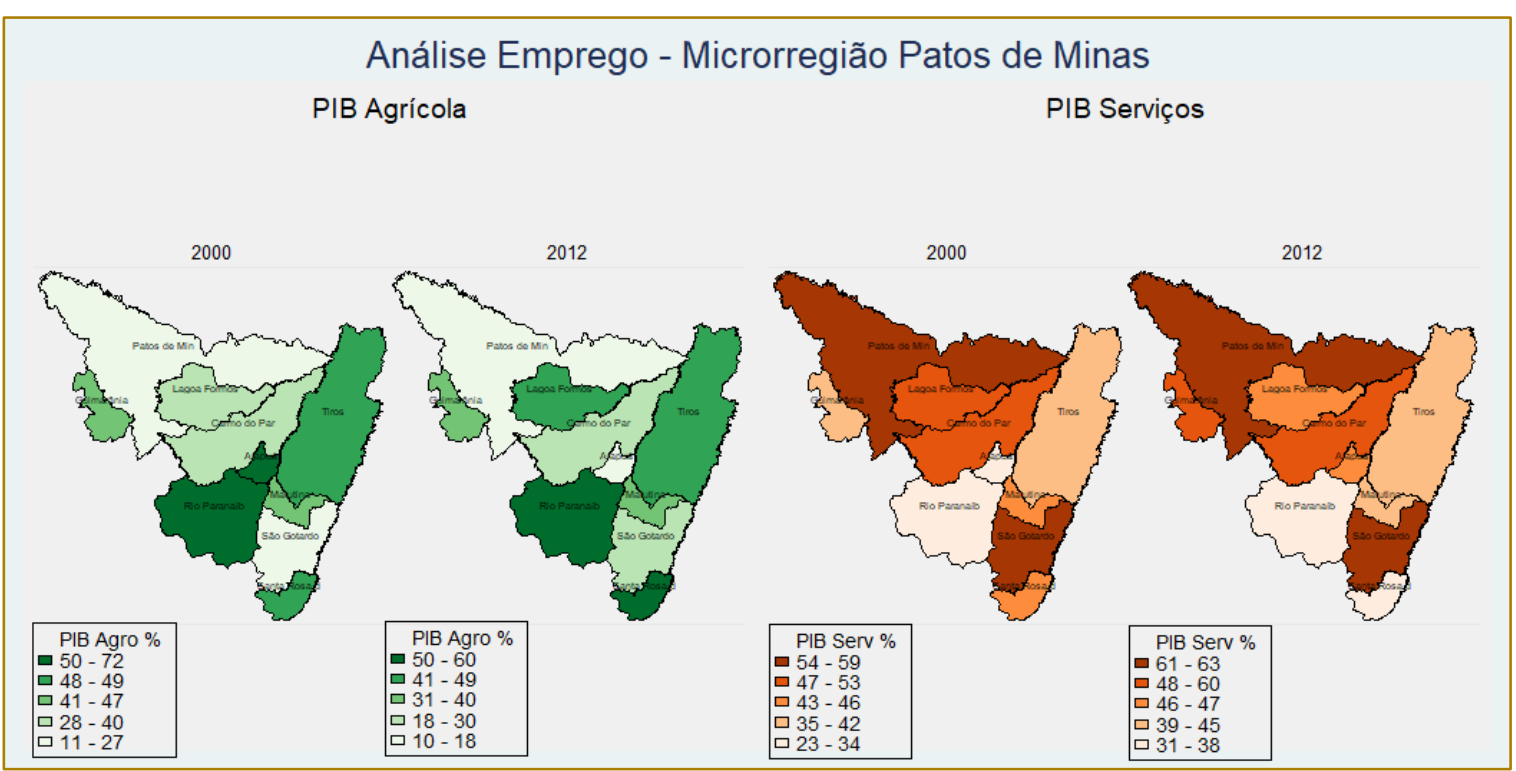

Fonte: Elaboração própria, StataMP 13, 2018.

Em relação ao PIB da microrregião, o de serviços tem um aumento considerável em algumas cidades, e há um descolamento do agrícola em relação ao industrial a partir de 2008 devido à crise internacional. Assim, percebemos que essa microrregião está se especializando na produção agrícola.

Através de estatística descritiva ficou evidente que a produção de café é elementar para o PIB agrícola, que compõem a maior parte do
PIB da microrregião. Levando-se em consideração que o atual cenário brasileiro é de reprimarização com foco em exportação de commodities tornou-se necessário complementar a análise de dados com análise específica da importância da produção agrícola do café para o PIB. Para tornar nossos resultados estatisticamente aceitos foi utilizada a técnica GMM, como mostra a figura 4.

Figura 3 Análise GMM: café x pibagrícola e café x pibgeral

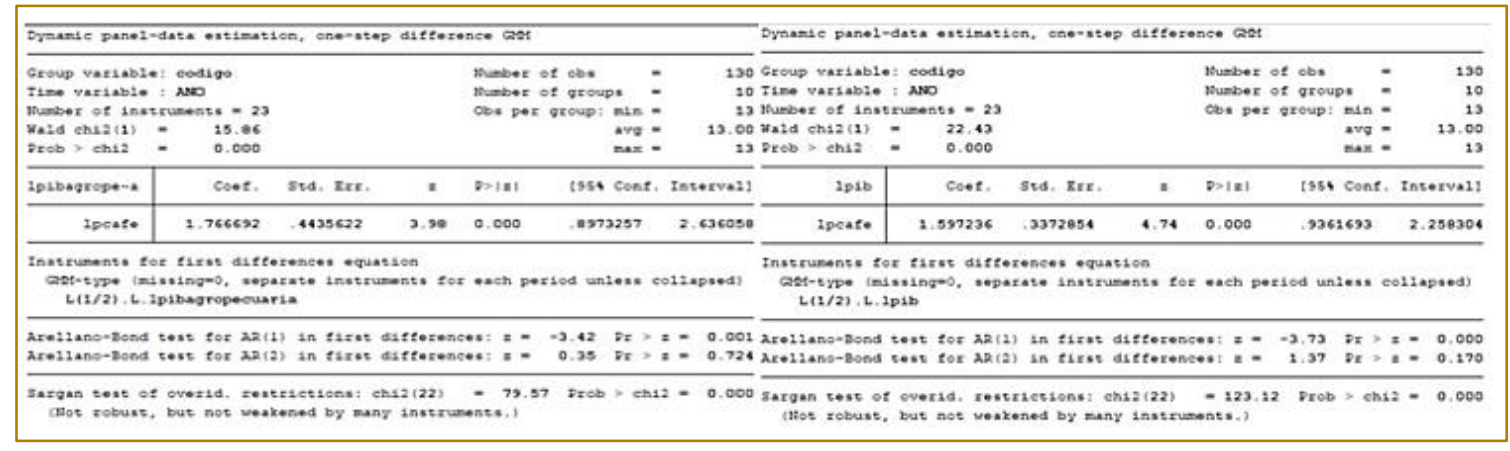

Fonte: Elaboração Própria, STATA 13, 2018. 
Pela figura 4 obtivemos que quando o Ipcafe aumenta 1\% o Ipibagricola aumenta 1.76\% evidenciando a correlação positiva e o impacto do café para o pib agrícola da microrregião. Já a relação proporção de café sobre produção agrícola total versus PIB geral da microrregião encontramos correlação de $1 \%$ para $1,59 \%$.

\subsection{ANÁLISE SISTÊMICA DA CADEIA PRODUTIVA DO CAFÉ}

A análise sistêmica da cadeia produtiva do café foi feita utilizando dos conceitos de dentro da porteira e fora da porteira para abarcar os principais fatores que influenciam no resultado da cadeia.
Dentro da porteira foram analisados a produção agrícola e os empregos agrícolas relacionados ao cultivo de café que podem ser visualizados na figura 6 .

A área de café plantada no Brasil sob a produção total agrícola vem se reduzindo ano a ano desde 2002 com 4,5\% de área plantada para 2,2\% em 2017. De modo geral, a microrregião de Patos de Minas caminha de modo contrário ao restante do país. Principalmente, as cidades de Santa Rosa da Serra, Arapuá e Rio Paranaíba, onde o café representa mais que $50 \%$ de todas as culturas temporárias e permanente. Sendo que Arapuá se destaca em 2017 com 95\% de toda área agrícola cultivada sendo o café.

Figura 4: Área plantada de café na Microrregião de Patos de Minas

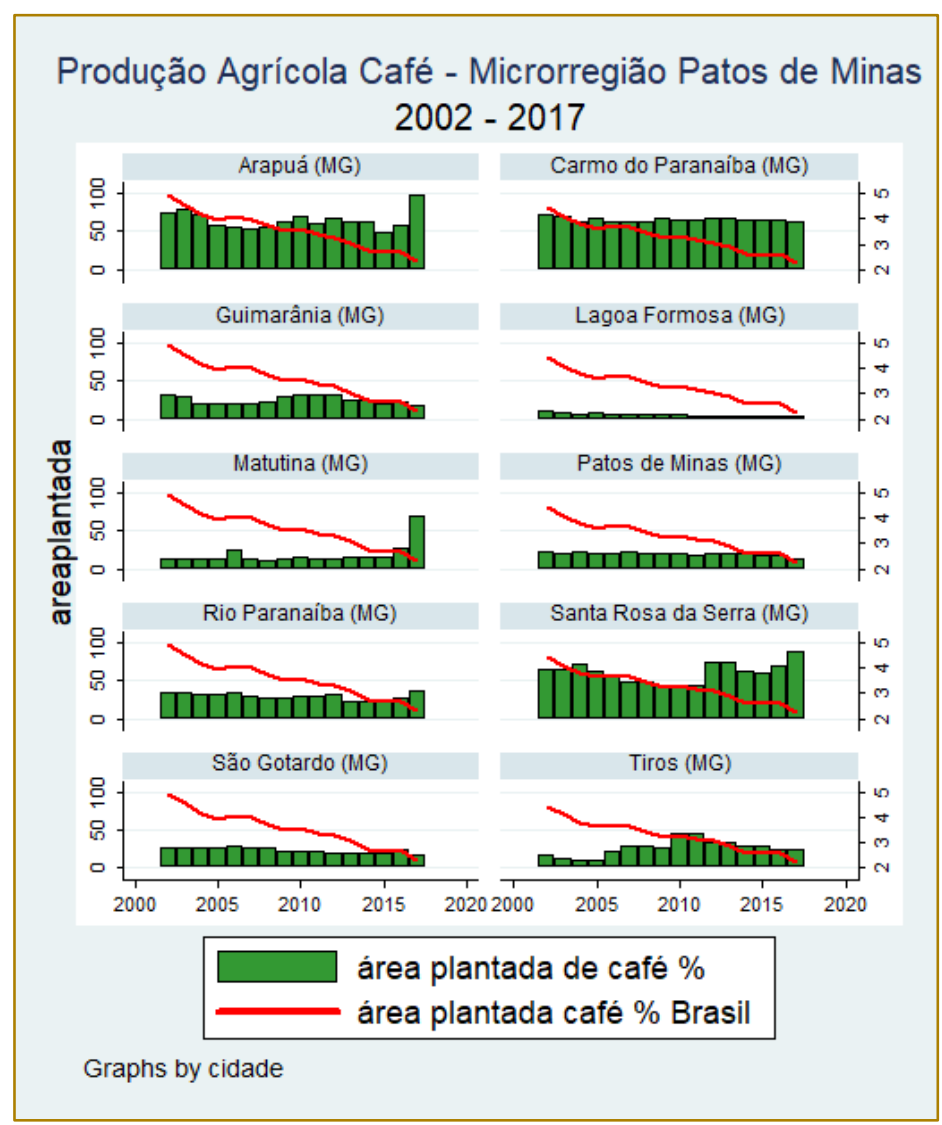

Fonte: Elaboração Própria, 2018.

$\mathrm{Na}$ figura abaixo é apresentada a relação entre os empregos no cultivo de café e o emprego agrícola em relação ao total de empregos com carteira assinada na microrregião em 2006; 
Figura 5. Empregos Cultivo de Café x Empregos Agrícolas 2006

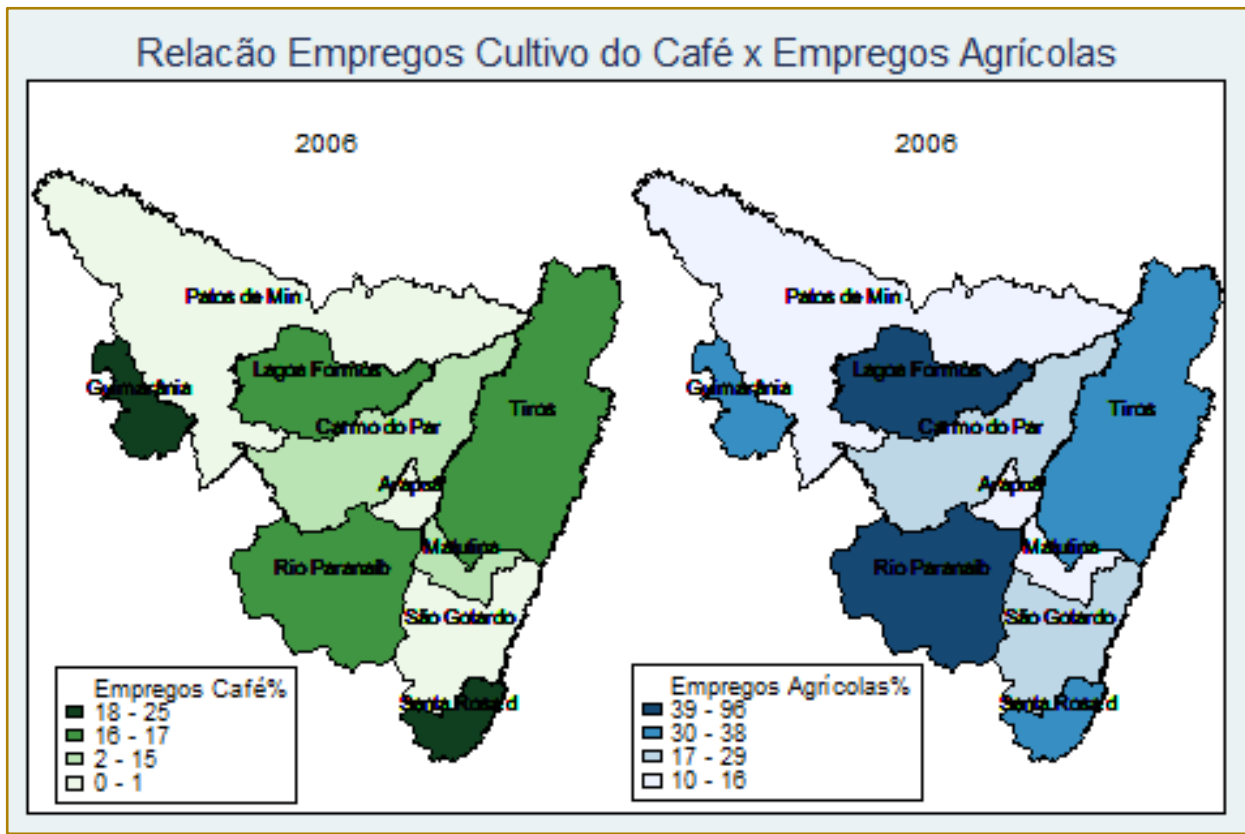

Fonte: Elaboração Própria, 2018.

Em 2006 o emprego de carteira assinada no cultivo de café, Classificação Nacional de Atividades Econômicas - CNAE 2.0, código 0134, representava entre 18 a $25 \%$ dos empregos totais de carteira assinada nas cidades de Santa Rosa da Serra e Guimarânia. Já os empregos agrícolas como porcentagem do emprego total representavam 39\% dos empregos em Rio
Paranaíba e $96 \%$ de todos os empregos com carteira assinada em Lagoa Formosa. Ou seja, para Rio Paranaíba e Lagoa Formosa o emprego agrícola foi importante, porém para a cidade de Santa Rosa onde 30\% dos empregos eram empregos agrícolas, e 90\% desses empregos estavam diretamente relacionados ao cultivo do café.

Figura 6. Empregos Cultivo de Café x Empregos Agrícolas 2017

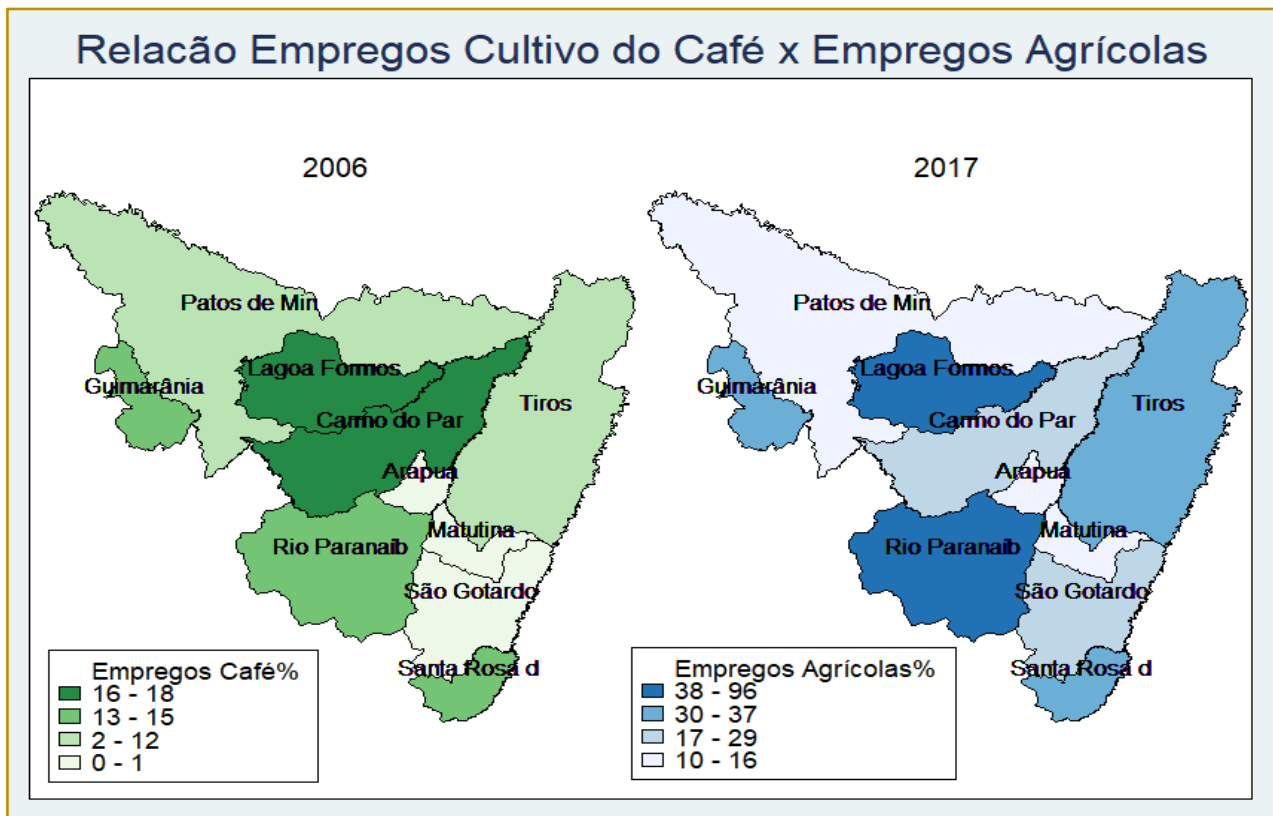

Fonte: Elaboração Própria, 2018. 
Em 2017 Lagoa Formosa permanece com o numero de empregados com carteira assinada no cultivo de café em $16 \%$ dos empregos totais, enquanto Santa Rosa da Serra diminuiu o número desse tipo de emprego de $25 \%$ para $13 \%$. Em relação aos empregos agrícolas Lagoa Formosa e Rio Paranaíba continuam na liderança. Esse diminuição do número de empregados no cultivo do café pode ser compreendido através da mecanização da colheita da lavoura por contratos de prestação de serviços a empresas especializadas.

Em seguida, é feita a análise de cotação diária dos preços de café arábica e robusta e exportação de café entre 2006 a 2017, conforme ilustrado na Figura 9.

Figura 7. Análise da Cotação do Café é feita a comparação com a taxa de câmbio (média taxa de venda e taxa de compra de dólares).

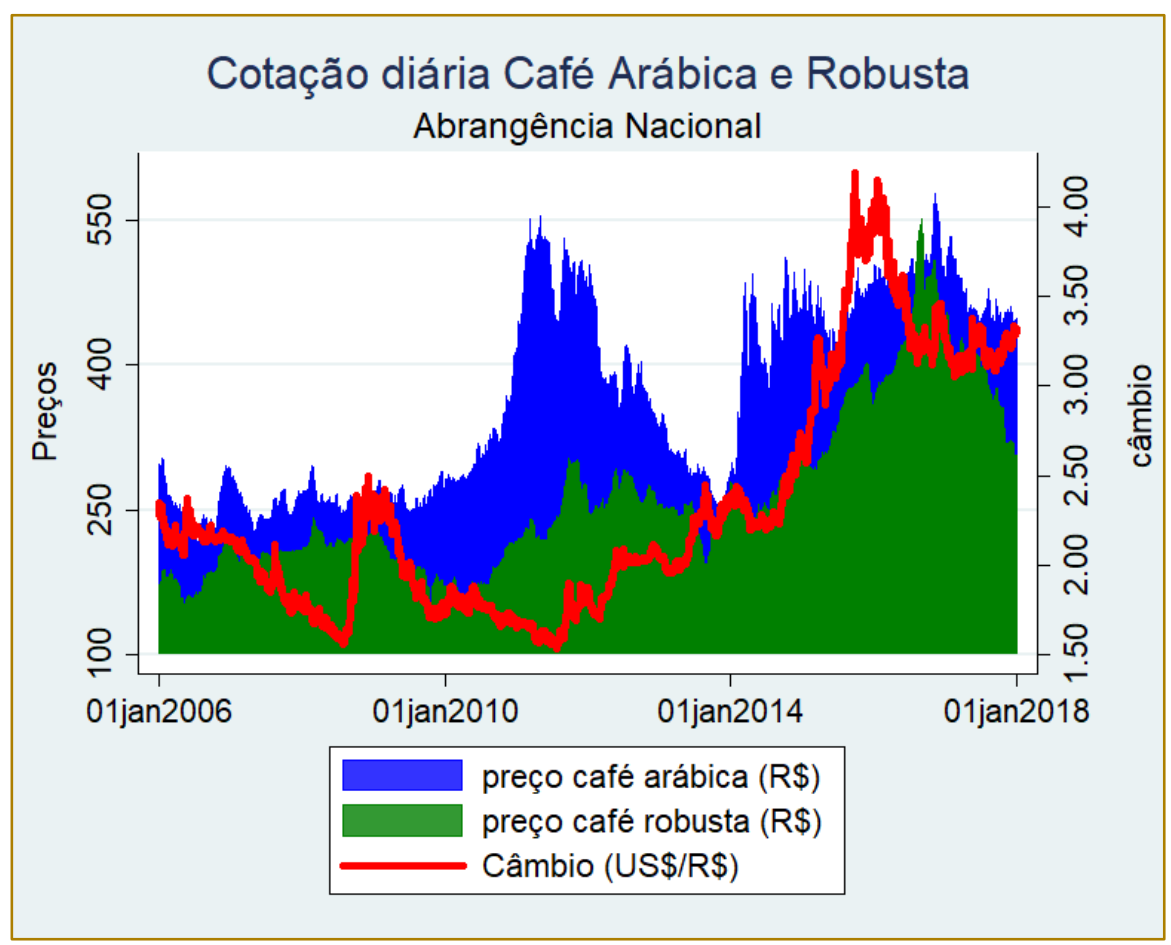

De acordo com a figura acima o café arábica representa de 20 a $30 \%$ de valor maior que o café robusta. A cotação mais baixa que esses cafés alcançaram no período analisado foi 250 reais para o café arábica e 130 reais para o café robusta em dezembro de 2009, mesmo com a taxa de câmbio subindo para 2,50 reais. Ou seja, a crise econômica internacional afetou diretamente os preços do café, e por ser uma commodity cotada internacionalmente isso interferiu no rendimento da lavoura durante o período. Porém, os preços se recuperaram a partir de
2014. Entre 2016 a 2017 o dólar se apreciou frente ao real, o que fez o câmbio subir para 4 reais, sendo a primeira vez dentro do período analisado, em janeiro de 2017, o café robusta teve sua cotação mais próxima do café arábica, custando 542 reais. Graficamente, é possível visualizar que a última apreciação do dólar colaborou para o aumento dos preços do café no geral, contudo o ano de 2017 apresentou declínio nos preços.

Por último, é feita a análise espacial dos municípios exportadores de café de acordo com a figura 10. 
Figura 8 - Exportação de Café na Microrregião de Patos de Minas.

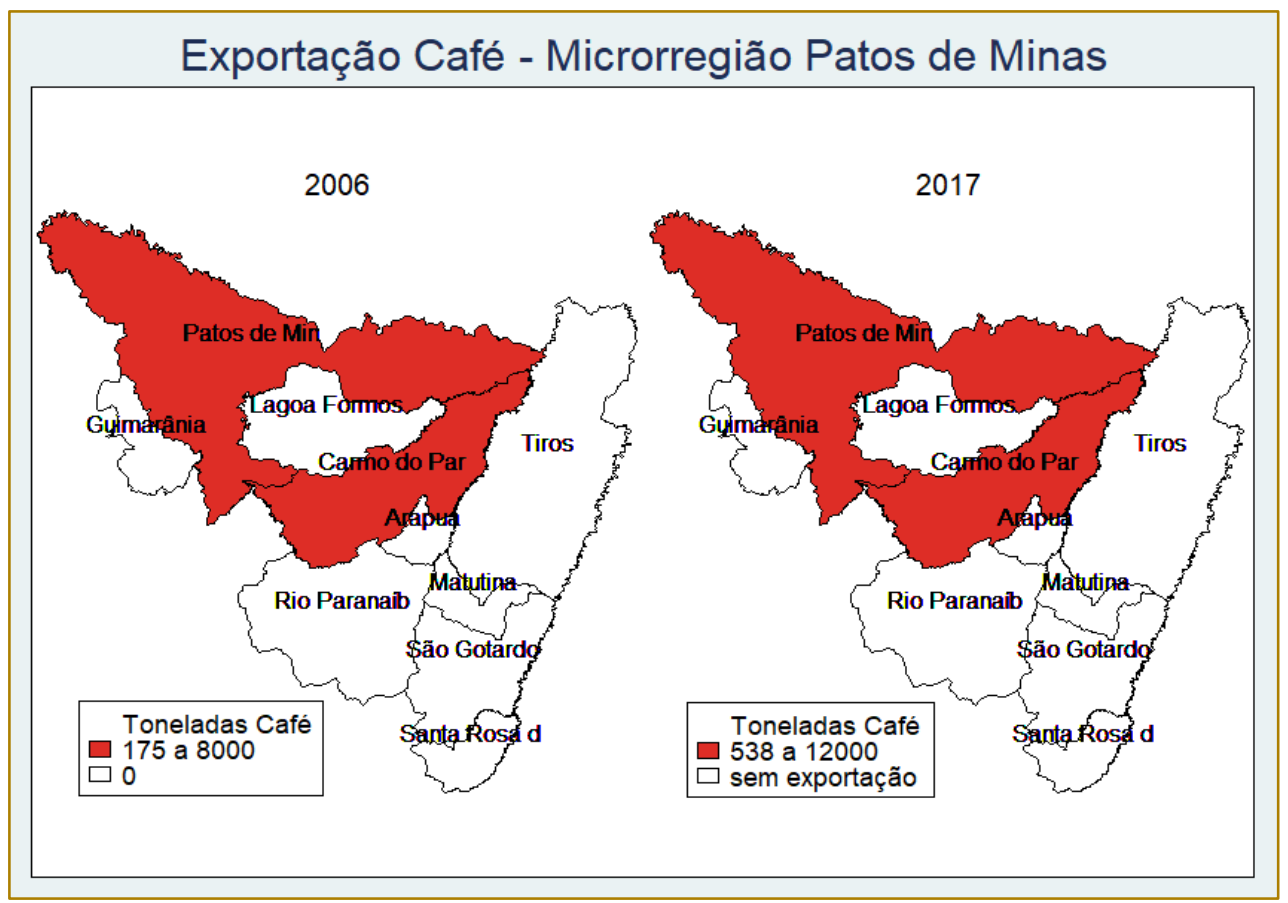

Em 2006 as únicas cidades exportadoras de café da região eram Patos de Minas com 175 toneladas de café e Carmo do Paranaíba exportando 8000 toneladas. As duas cidades aumentam vertiginosamente sua exportação, em especial Patos de Minas que salta para 538 toneladas de café em 2017. E Carmo do Paranaíba aumenta em 50\% sua exportação, passando de 8000 toneladas para 12000 toneladas. Os dados da exportação reforçam o fortalecimento dos elos da cadeia produtiva do café e como a microrregião consolida-se com player desta cadeia produtiva.

\section{CONCLUSÃO}

Com base na análise sistêmica da cadeia produtiva do café observamos que dentro da porteira para a microrregião de Patos de Minas o cultivo de café é relevante tanto em produção agrícola com observação do aumento da área plantada quanto pelo volume de trabalhadores com carteira assinada em relação ao número total de trabalhadores empregados da microrregião. Fora da porteira vemos que os preços da cotação do café arábica e robusta e o câmbio variam de forma correlacionada, porém não concomitante temporalmente. Mesmo assim, os preços no geral aumentaram $80 \%$ nos 11 anos analisados. Sobre exportação, há concentração da produção de café da região nas cidades de Patos de Minas e Carmo do Paranaíba responsáveis por toda a exportação da microrregião.

A metodologia adotada - análise de estatística descritiva, econometria espacial e análise de dados em painel - confirma a importância do café para Microrregião de Patos de Minas. Assim, conclui-se que o café não é somente o principal produto agrícola da região, como sua produção é altamente relevante para o aumento do PIB agrícola e também do PIB Geral, que se espalha pelos elos da cadeia produtiva com efeitos virtuosos na economia gerando empregos e crescimento das dez cidades compreendidas nessa microrregião.

A nova face da Microrregião de Patos de Minas mostra a importância da cadeia produtiva do café na microrregião e este estudo apresenta-se como referência para análises mais profícuas sobre os impactos da emergência do café em uma região reconhecida nacionalmente como berço do milho. Milho e café são commodities com características diferentes e a mudança da participação de uma commodity na economia local demanda novos arranjos produtivos e organizacionais para garantir 0 desenvolvimento da microrregião. 


\section{REFERÊNCIAS}

[1]. BARBOSA, M. F. N.; CÂNDIDO, G. A.; BARBOSA, E. M. Coordenação e Competitividade em Empresa do Setor Sucroalcooleiro: Uma Análise a Partir dos Custos de Transação. Revista de Ciências da Administração, v. 18, n. 46, p. 81-95, 2016.

[2]. BATALHA, M.O.; SCARPELLI, M. Gestão do agronegócio: aspectos conceituais. In: BATALHA, M.O. (Coord.) Gestão do agronegócio: textos selecionados. São Carlos: EdUFSCar, 2005. p. 7-25.

[3]. BATALHA, M.O.; SILVA A.L.da Gerenciamento de sistemas agroindustriais: definições, especificidades e correntes metodológicas. In: BATALHA, M.O. (Coord.) Gestão agroindustrial. 3.ed. São Paulo: Atlas, 2007. p.1-62.

[4]. BAUM, Christopher F. An introduction to modern econometrics using Stata. Stata Press, 2006 .

[5]. BEGNIS, H.S.M.; ESTIVALETE, V.de F.B.; PEDROZO, E.A. Confiança, comportamento oportunista e quebra de contratos na cadeia produtiva do fumo no sul do Brasil. Gest. Prod., São Carlos, v. 14, n. 2, p. 311-322, maio-ago. 2007. Disponível <http://www.scielo.br/pdf/gp/v14n2/08.pdf>. Acesso em: 07 de maio de 2018.

[6]. BRASIL. Secretaria de Relações Internacionais do Agronegócio, Agronegócio brasileiro: desempenho do comércio exterior = Brasilian agribusiness: foreign trade performance/ Ministério da Agricultura, Pecuária e Abastecimento. Secretaria de Relações Internacionais do Agronegócio. - 2. Ed. - Brasília: MAPA/SRIA/DPIA/CGOE, 2006

[7]. DINIZ, Alexandre Magno Alvez, BATELLA, Wagner Barbaso. O Estado de Minas Gerais e suas regiões: um resgate histórico das principais propostas oficiais de regionalização. Sociedade \& Natureza. Uberlândia, n.17, p.59-77, 2005. Disponível em: <http://www.seer.ufu.br/index.php/sociedadenature za/article/viewFile/9208/5670>. Acesso em: 04 de maio de 2018.

[8]. IBGE, Fundação Instituto Brasileiro de Geografia e Estatística e Ministério da Economia, fazenda e planejamento; Divisão Regional do Brasil em Mesorregiões e Microrregiões Geográficas. Volume I. Rio de Janeiro. 1990. Disponível em: $<$ http://biblioteca.ibge.

gov.br/visualizacao/monografias/GEBIS\%20-

\%20RJ/DRB/Divisao\%20regional_v01.pdf>; Acesso em: 26/05/2017.

[9]. LEITÃO, F.O.; BRISOLA, M.V. Análise das estruturas de governança adotadas entre produtores rurais e corretores na cadeia produtiva do feijão. Revista em Agronegócios e Meio Ambiente, v.3, n.1, p. 29-46, jan./abr. 2010 - ISSN
1981-9951. Disponível no link: < http://periodicos.unicesumar.edu.br/index.php/ram a/article/view/1357/1015>. Acesso em: 07 de maio de 2018.

[10]. OLIVEIRA, L. F. T.; SILVA, S. P. Mudanças institucionais e produção familiar na cadeia produtiva do leite no Oeste Catarinense. Rev. Econ. Sociol. Rural [online]. 2012, v.50, n.4, pp.705-720. Disponível em: <http://dx.doi.org/10.1590/S010320032012000400007>. Acesso em: 07 de maio de 2018.

(PMA/2017) - PREFEITURA MUNICIPAL DE ARAPUÁ. Disponível em: <http://arapua.mg.gov.br/cidadeapresentacao.html >. Acesso em: 10 de janeiro de 2018.

(PMC/2016) - PREFEITURA MUNICIPAL DE CARMO DO PARANAÍBA. Disponível em: <https://www.carmodoparanaiba.mg.gov.brl>. Ace sso em: 07 de maio de 2018. (PMG/2003).PREFEITURA DE GUIMARÂNIA. Disponivel em: $<$ https://www.guimarania.mg.gov.br/>. Acesso em: 10 de janeiro de 2018.

[12]. (PMLF/2017)-PREFEITURA MUNICIPAL DE LAGOA FORMOZA. Disponível em: < http://lagoaformosa.mg.gov.br/apresentacao/>. Acesso em: 10 de janeiro de 2018.

[13]. (PMT/2016)-PREFEITURA MUNICIPAL DE MATUTINA. Disponível em: < http://matutina.mg.gov.br>. Acesso em: 10 de janeiro de 2018.

[14]. (PMPM/2016)-REFEITURA MUNICIPAL DE PATOS DE MINAS. Disponível em:< http://www. patosdeminas.mg.gov.br> Acesso em: 10 de janeiro de 2018.

[15]. (PMRP/2015)-PREFEITURA MUNICIPAL DE RIO PARANAÍBA. Disponível em: < http://www.rioparanaiba.mg.gov.br.> Acesso em: 10 de janeiro de 2018.

[16]. (PMSRS/2016)- PREFEITURA MUNICIPAL DE SANTA ROSA DA SERRA. Disponível em:< https://santarosadaserra.mg.gov.br>. Acesso em: 10 de janeiro de 2018.

[17]. (PMSG/2015)-PREFEITURA MUNICIPAL DE SÃO GOTARDO: Disponível em: < http://www.saogotardo.mg.gov.br> Acesso em: 10 de janeiro de 2018.

[18]. (PMT/2004)- PREFEITURA MUNICIPAL DE TIROS: Disponível em: < http://www.tiros.mg.gov.br> Acesso em: 10 de janeiro de 2018.

[19]. REVISTA CAFEICULTURA. Disponível em: <http://revistacafeicultura.com.br/?mat=5548>.

Acesso em: 08 jan. 2018

[20]. SATOLANI, M.F.; CORRÊA, C.C.; FAGUNDES, M.B.B. Análise do ambiente institucional e organizacional da piscicultura no 
Estado do Mato Grosso do Sul. Revista de Economia e Agronegócio, v.6, n.2, p. 215-234, $2008 . \quad$ Disponível em: $<$ https://revistarea.ufv.br/index.php/rea/article/view File/130/134> . Acesso em: 07 de maio de 2018.

[21]. TAUNAY, Afonso de Escragnolle, História do Café no Brasil, Departamento Nacional do Café, Rio de Janeiro, 1939.

[22]. ZILBERSZTAJN, D. Conceito geral, evolução e apresentação dos sistemas agroindustrial. In: ZILBERSZTAJN, D. e NEVES, M. F. Economia e gestão de negócios agroalimentares. São Paulo: Pioneira. 2000.

[23]. ZILBERSZTAJN, D. Coordenação e governança de sistemas agroindustriais. In: BUAINAIN, A.M.; ALVES, E.; SILVEIRA, J.M. da; NAVARRO, Z. (Ed.Técnicos). O mundo Rural no Brasil do Século 21: a formação de um novo padrão agrário e agrícola. Brasília, DF: Embrapa, 2014.

p.267-294. 


\section{Capítulo 19}

\section{PIB, PRODUÇÃO E EMPREGO DOS MUNICÍPIOS QUE COMPÕEM A REGIÃO DO ALTO PARANAÍBA: UMA ANÁLISE A PARTIR DA PERSPECTIVA DO AGRONEGÓCIO.}

Vivian Raniere Mendes Silva

Fábio André Teixeira

Julienne de Jesus Andrade Widmarck

Hernani Martins Júnior

Ravilla de Castro Barbosa

Resumo: Nas últimas décadas, o agronegócio tem sido o motor da economia brasileira, movimentando bilhões de dólares, gerados pela produção agrícola, em mercado nacional e internacional anualmente, mesmos em tempos de crise, estabilizando assim os números do PIB. Em 2017 o agronegócio foi responsável por $23,5 \%$ do PIB total do país, sendo o principal contribuinte o estado de Minas Gerais, com uma participação de 13,80\%. O estado é dividido em 12 mesorregiões, sendo que as maiores contribuintes para a geração do PIB do agronegócio são, a mesorregião Metropolitana de Belo Horizonte e a mesorregião do Triângulo Mineiro e Alto Paranaíba. Este estudo isolou as microrregiões de Araxá, Patos de Minas e Patrocínio, abrangendo 31 municípios, determinando, assim, o Alto Paranaíba, com o intuito de responder qual o motor do desenvolvimento econômico desta região? Os resultados obtidos mostram o agronegócio focado em serviços, impulsionado pelo setor agrícola movido pelas lavouras de milho, soja e café principalmente, como o motor do desenvolvimento econômico da região do Alto Paranaíba nos últimos 30 anos.

Palavras-chave: Araxá, Patos de Minas, Patrocínio, Microrregião, Motor do Crescimento.

*Grupo de Pesquisa: Núcleo de Estudos Econômicos do Alto Paranaíba - NEEAP 


\section{INTRODUÇÃO}

O agronegócio é um setor de suma importância para economia brasileira e tem evoluído consideravelmente desde a implementação, na década de 70 , do processo de modernização agrícola. A Confederação da Agricultura e Pecuária do Brasil (CNA), estimou no PIB do país no ano de 2017, uma participação do agronegócio de $23,5 \%$ (IBRAHIM, 2018). Um dos principais contribuintes para este resultado é o estado de Minas Gerais, com uma participação de 13,80\% no PIB do Agronegócio mineiro. (CEPEA, 2017). Por essa razão, o estado se consolidou como um dos maiores produtores e influenciadores do agronegócio.

Minas Gerais é dividido em 12 mesorregiões, sendo as maiores contribuintes para a geração do PIB do agronegócio, a mesorregião Metropolitana de Belo Horizonte, com 44\% e a mesorregião do Triângulo Mineiro e Alto Paranaíba com 15\% do PIB Agronegócio do estado no ano de 2014, dado mais recente encontrado. (FERREIRA\&OLIVEIRA, 2017).

O Triângulo Mineiro e Alto Paranaíba é uma das 12 mesorregiões que fazem parte do estado de Minas Gerais, dividindo-se em duas regiões de planejamento, compostas por 7 microrregiões, sendo as microrregiões de Araxá, Ituiutaba, Patrocínio, Uberlândia, Frutal, Patos de Minas e Uberaba, abarcando 66 municípios (IBGE\&MEFP,1990). A região de planejamento Alto Paranaíba, com polo econômico em Patos de Minas, se caracteriza por sua elevada produção agrícola e agroindustrial. (FEELT, 2018).

Tendo em vista o exposto, o NEEAP (Núcleo de Estudos Econômicos do Alto Paranaíba), com o objetivo de responder ao seguinte questionamento: qual 0 motor do desenvolvimento econômico desta região? Isolou as microrregiões de Patos de Minas, Araxá e Patrocínio, formadas por 31 municípios, determinando assim a região de planejamento Alto Paranaíba. Propondo-se a analisar o papel do agronegócio para a região do Alto Paranaíba a partir dos indicadores de produção agrícola, PIB e emprego. Para tal, procurou-se, de maneira específica, identificar as principais lavouras impulsionadoras da produção agrícola para a região do Alto Paranaíba; demonstrar a relação entre emprego no setor de serviços e do emprego agrícola, sobre o emprego total na região; apontar qual papel do setor industrial e, consequentemente 0 agroindustrial, no desenvolvimento produtivo da região; e identificar quais as regiões mais produtivas.

Dessa forma o artigo é estruturado da seguinte maneira, na segunda sessão apresenta-se a Mesorregião Triângulo Mineiro e Alto Paranaíba, com enfoque na região de planejamento Alto Paranaíba, construída após se isolar as microrregiões de Patos de Minas, Araxá e Patrocínio. Na terceira sessão consta a metodologia utilizada com dados de produção agrícola total da PAM (Pesquisa Agrícola Municipal) do IBGE (Instituto Brasileiro de Geografia e Estatística) entre 1988 a 2017. O emprego agrícola, de indústria e construção civil e do setor de serviço foram obtidos da RAIS (Relação Anual de Informações Sociais), do ministério de emprego e trabalho entre 2002 a 2017. E por último o Produto Interno Bruto com dados provenientes do IBGE/SIDRA no período correspondente a 1999 a 2015. O método econométrico utilizado é econometria espacial através do comando SPMAP, de Maurizio Pisati (2014). A quarta sessão é constituída pela apresentação dos resultados por categorias. E por último o trabalho é concluído com a constatação que a região de planejamento do Alto Paranaíba, nos últimos 30 anos, tem como motor de crescimento econômico o agronegócio focado no setor de serviços, impulsionado pelo agronegócio focado no milho, soja e café.

\section{DIVISÃO POR MESORREGIÕES, MICRORREGIÕES E REGIÕES DE PLANEJAMENTO DO ESTADO DE MINAS GERAIS}

O Conselho Nacional de Geografia foi criado no fim da década de 30, pouco tempo após a sua criação, o IBGE (Instituto Brasileiro de Geografia e Estatística) propôs que o Estado de Minas Gerais fosse dividido em Zonas Fisiográficas, em 1941. Porém, essa divisão possuía critérios ecléticos que passado algum tempo tornaram-se uma limitação, devido a quantidade de propósitos que essa buscava atender ao mesmo tempo. (DINIZ\&BATELLA, 2005)

Em 1968, o IBGE, buscando atender a necessidade de divulgar e compilar dados estatísticos, propôs a dividir o Brasil em Microrregiões homogêneas, diferenciando áreas que se discernem pelo arranjo de elementos geográficos. (IBGE, 1970). 
Assim como a divisão em Zonas Fisiográficas tornou-se obsoleta, deixado de atender as necessidades atuais, a divisão em microrregiões homogenias foi considerada inadequada, e em 1972 o IBGE legitimou a divisão do Brasil em Regiões Funcionais Urbanas. Em paralelo a essas propostas do IBGE o CED, em conjunto com o BDMG e o TLPES, apresentou uma proposta mais próxima a realidade atual, dividindo-se as regiões para fins de planejamento, em 1973. 8 grandes regiões foram criadas a partir do agrupamento de $46 \quad$ Microrregiões homogêneas de Minas Gerais, com o intuito de incentivar o planejamento do desenvolvimento social e econômico do Estado. Cada uma dessas regiões era formada por regiões menores equivalentes a uma Microrregião homogênea. (DINIZ\&BATELLA, 2005).

A divisão para fins de planejamento do território de minas gerias, segundo a FJP 1973, pode ser observada na Figura 1.

Figura 1 - Regiões para fins de planejamento de Minas Gerais (FJP - 1973)

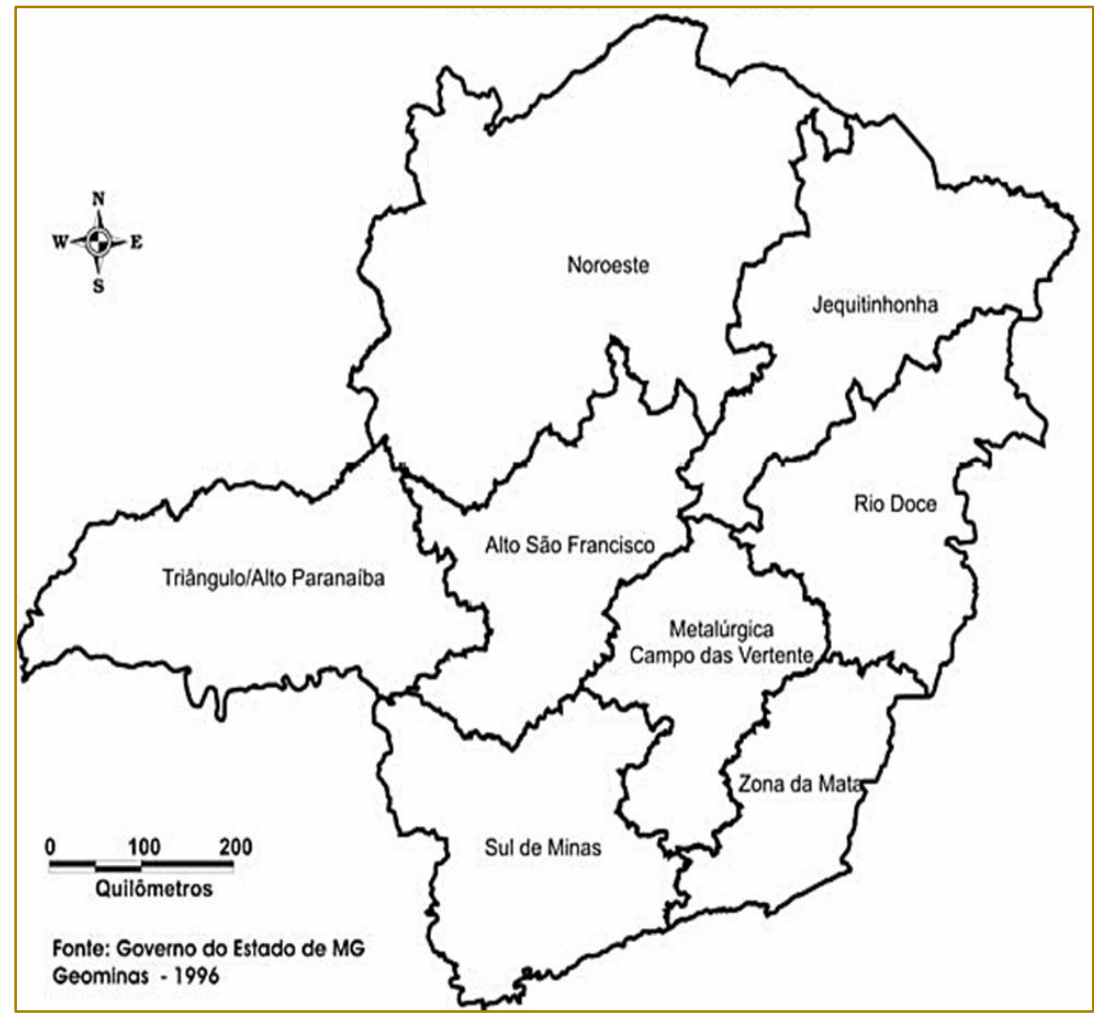

Fonte: DINIZ\&BOTELLA, 2005. O Estado de Minas Gerais e suas Regiões: Um

Resgate Histórico das Principais Propostas Oficiais de Regionalização.

Disponível em: <

http://www.seer.ufu.br/index.php/sociedadenatureza/article/viewFile/9208/5670 >.

Em 1990, substituindo a projeto das microrregiões homogêneas, o IBGE oficializou a divisão do Brasil, utilizada até os tempos atuais, em Mesorregiões e Microrregiões, buscando respeitar limites políticoadministrativos bem como estaduais $e$ municipais.

\subsection{MESORREGIÕES}

A concepção de mesorregião é dada por uma área individualizada com espaço geográfico definido pelo processo social, a rede de comunicação de lugares e o quadro natural propiciando que a mesorregião tenha uma identidade regional. (IBGE; 1990).

Minas Gerais abarca 12 mesorregiões, sendo: a mesorregião de Campo das Vertentes (1), Central Mineira (2), Jequitinhonha (3), Metropolitana de Belo Horizonte (4), Noroeste de Minas (5), Norte de Minas (6), Oeste de Minas (7), Sul e Sudoeste de Minas (8), Triângulo Mineiro e Alto Paranaíba (9), Vale do Mucuri (10), Vale do Rio Doce (11) e, por fim, a mesorregião da Zona da Mata (12), como pode ser observado na figura 2. 
Figura 2 Divisão em Mesorregiões do Estado de Minas Gerais (IBGE 1990).

Fonte: Guia Gerais, 2018. Microrregiões. Disponível em:

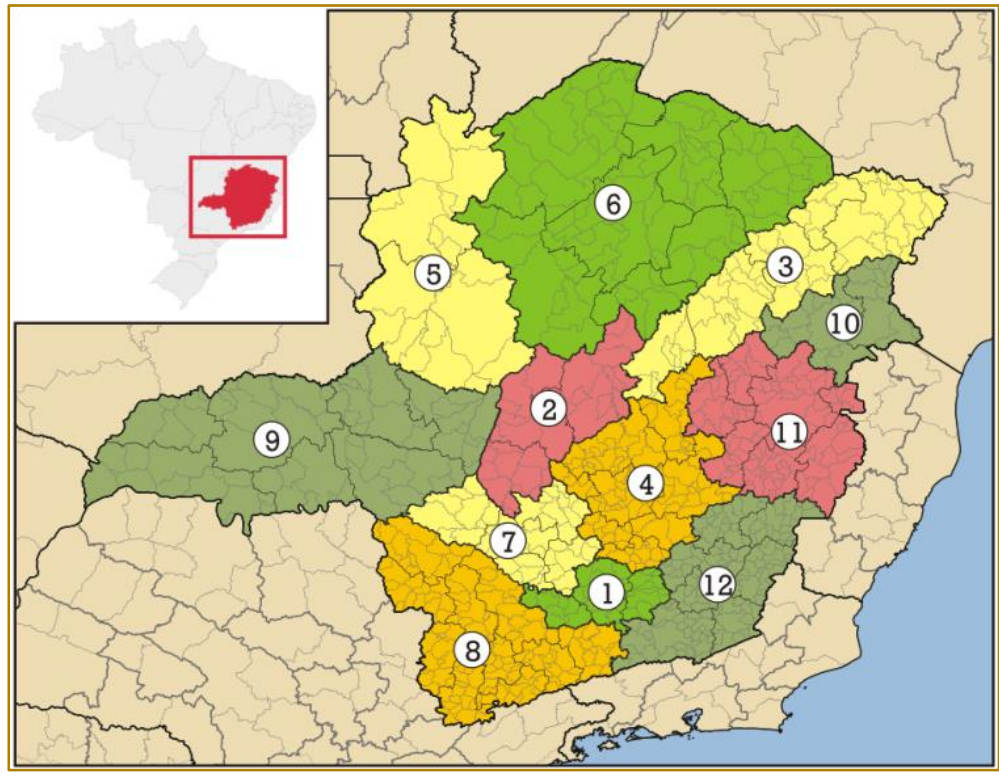

$<$ http://www.guiagerais.com.br/minas-gerais/mesorregioes/>

Essas 12 mesorregiões subdividem-se em 66 microrregiões apresentadas, em seguida, na sessão 2.2.

\subsection{MICRORREGIÕES}

As mesorregiões dividem-se em microrregiões de forma a apresentar especificidades quanto a agropecuária, extrativismo mineral, indústria, pesca ou estrutura de produção. (IBGE; 1990). A Figura 3 apresenta a divisão de microrregiões, do estado de Minas Gerais, por Mesorregião Geográfica.

Figura 3 Divisão em Microrregiões, do Estado de Minas Gerais, por Mesorregião Geográfica, (IBGE 1990).

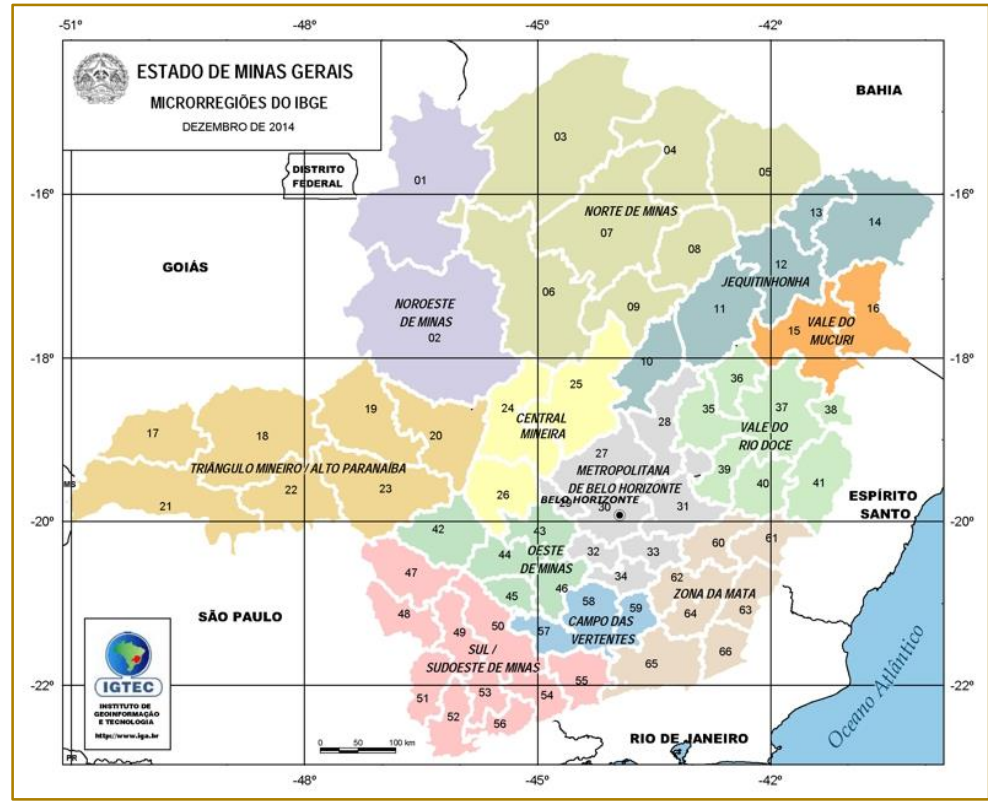

Fonte: Estado de Minas, 2016. Mesorregiões e microrregiões (IBGE).

Disponível em: <http://mg.gov.br/conteudo/conheca-

minas/geografia/localizacao-geografica> 
A tabela 1 apresenta a subdivisão de microrregiões por mesorregiões geográficas do estado de Minas Gerais, complementando a Figura 3 trazendo os códigos de cada microrregião expostos na figura.

Tabela 1 Microrregiões por Mesorregiões de Minas Gerais.

\begin{tabular}{|c|c|}
\hline \multicolumn{2}{|c|}{$\begin{array}{l}\text { DIVISÃO DE MICRORREGIÕES POR MESORREGIÕES DE MINAS GERAIS } \\
\begin{array}{lr}\text { Mesorregião do Noroeste de Minas } & \text { Mesorregião do Vale do Mucuri }\end{array}\end{array}$} \\
\hline Paracatu (1) & Teófilo Otoni (15) \\
\hline Unaí (2) & Nanuque (16) \\
\hline Mesorregião do Norte de Minas & Mesorregião do Triângulo Mineiro e Alto Paranaíba \\
\hline Januária (3) & Ituiutaba (17) \\
\hline Janaúba (4) & Uberlândia (18) \\
\hline Salinas (5) & Patrocínio (19) \\
\hline Pirapora (6) & Patos de Minas (20) \\
\hline Montes Claros (7) & Frutal (21) \\
\hline Grão Mogol (8) & Uberaba (22) \\
\hline Bocaiúva (9) & Araxá (23) \\
\hline \multicolumn{2}{|l|}{ Mesorregião do Jequitinhonha } \\
\hline Diamantina (10) & Três Marias (24) \\
\hline Capelinha (11) & Curvelo (25) \\
\hline Araçuaí (12) & Bom Despacho (26) \\
\hline \multicolumn{2}{|l|}{ Pedra Azul (13) } \\
\hline \multicolumn{2}{|l|}{ Almenara (14) } \\
\hline Mesorregião Metropolitana de Belo Horizonte & Mesorregião do Sul e Sudoeste de Minas Gerais \\
\hline Sete Lagoas (27) & Passos (47) \\
\hline Conceição do Mato Dentro (28) & São Sebastião do Paraíso (48) \\
\hline Pará de Minas (29) & Alfenas (49) \\
\hline Belo Horizonte (30) & Varginha (50) \\
\hline Itabira (31) & Poços de Caldas (51) \\
\hline Itaguara (32) & Pouso Alegre (52) \\
\hline Ouro Preto (33) & Santa Rita do Sapucaí (53) \\
\hline \multirow[t]{3}{*}{ Conselheiro Lafaiete (34) } & São Lourenço (54) \\
\hline & Andrelândia (55) \\
\hline & Itajubá (56) \\
\hline \multicolumn{2}{|l|}{ Mesorregião do Vale do Rio Doce } \\
\hline Guanhães (35) & Lavras (57) \\
\hline Peçanha (36) & São João Del Rei (58) \\
\hline Governador Valadares (37) & Barbacena (59) \\
\hline Mantena (38) & Mesorregião da Zona da Mata \\
\hline Ipatinga (39) & Ponte Nova (60) \\
\hline Caratinga (40) & Manhuaçu (61) \\
\hline Aimorés (41) & Viçosa (62) \\
\hline Mesorregião do Oeste de Minas & Muriaé (63) \\
\hline Piumhi (42) & Ubá (64) \\
\hline Divinópolis (43) & Juiz de Fora (65) \\
\hline Formiga (44) & Cataguases (66) \\
\hline Campo Belo (45) & \\
\hline Oliveira (46) & \\
\hline
\end{tabular}

Fonte: Adaptado de "Estado de Minas Gerais Meso E Microrregiões do IBGE". Disponível em: < http://mg.gov.br/sites/default/files/paginas/arquivos/2016/ligminas_10_2_04_listamesomicro.pdf> 


\subsection{REGIÕES DE PLANEJAMENTO}

Em 1992, a Fundação João Pinheiro, atendendo a pedidos da SEPLAN-MG, dividiu, em 10 regiões de planejamento, o território do estado de Minas Gerais. (DINIZ\&BOTELLA,2005). A região de planejamento se refere a áreas onde à dinâmica socioeconômica e geográfica de suas várias partes "é dependente da aplicação de critérios administrativos instrumentalizados pelo setor público, a partir das necessidades de execução de determinados serviços públicos, do exercício do poder regulatório do Estado" (IPECE, 2015).

Figura 4 Divisão de Regiões de Planejamento, do Estado de Minas Gerais (Fundação João Pinheiro, 1992).

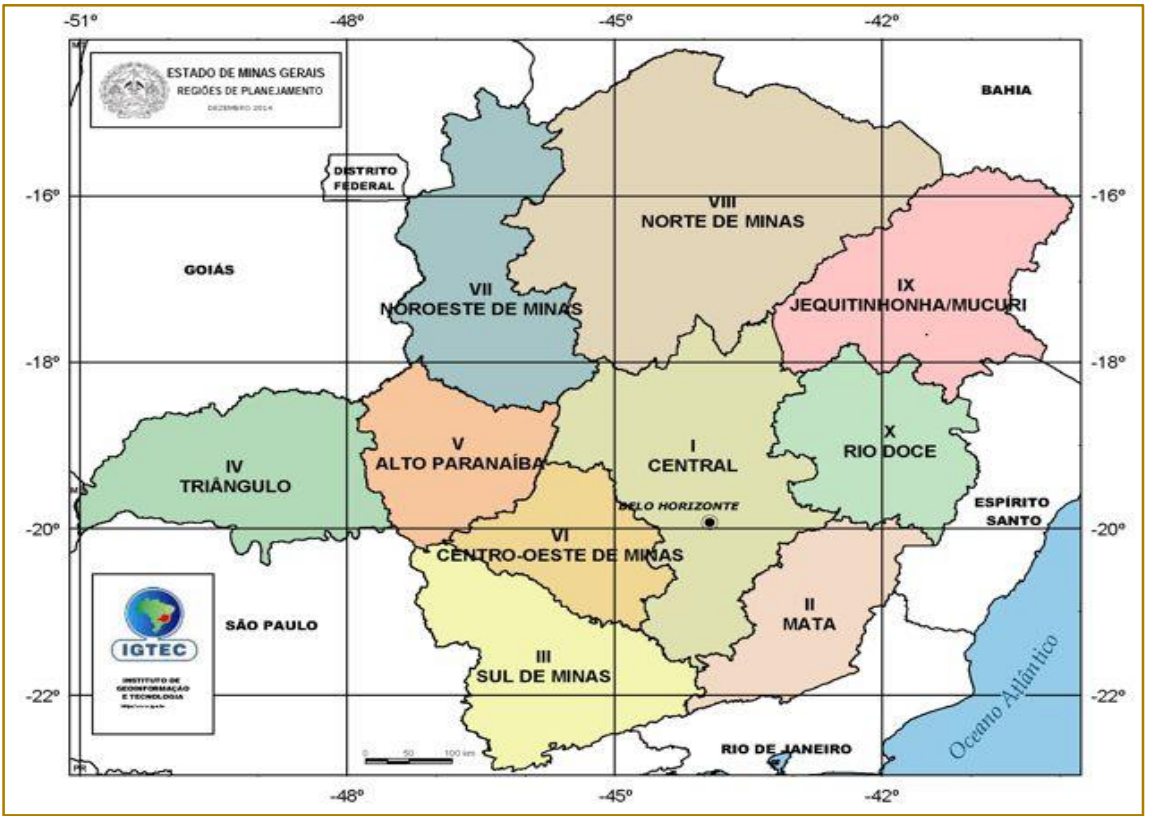

Fonte: Estado de Minas, 2016. Mesorregiões e microrregiões (IBGE). Disponível em: <http://mg.gov.br/conteudo/conheca-minas/geografia/localizacaogeografica>

Constatada a preciosa contribuição da mesorregião do Triangulo Mineiro e Alto Paranaíba na composição do PIB do estado, segunda maior contribuinte, atrás apenas da mesorregião metropolitana de Belo Horizonte (FERREIRA\&OLIVEIRA, 2017), a proximidade com a região, e ainda considerando sua elevada produção agrícola e agroindustrial, isolou-se a região de planejamento Alto Paranaíba, com a finalidade de identificar qual é o seu motor de desenvolvimento econômico. A sessão 3 trata das especifidades desta região.
Conforme pode ser observado na figura 4 , as regiões dividem-se me: região do Alto Paranaíba, com 31 municípios; região Central, com 158 municípios; região Centro-Oeste de Minas, com 56 municípios; região do Jequitinhonha/Mucuri, com 66 municípios; região da Mata, com 142 municípios; região Noroeste de Minas, com 19 municípios; região Rio Doce, 102 municípios; região Norte de Minas, com 89 municípios; região Sul de Minas, com 155 municípios; e região do Triângulo Mineiro, com 35 municípios. (ESTADO DE MINAS,2016). 
A segunda análise econômica é a "Análise Sobre o Emprego", apresentando as proporções de emprego agrícola, de indústria e construção civil e do setor de serviço sobre o emprego total. Os dados de emprego foram obtidos da RAIS (Relação Anual de Informações Sociais), do ministério de emprego e trabalho entre 2002 a 2017.

Por último, é apresentado a "evolução do PIB (Produto Interno Bruto)" das 31 cidades, especificamente O PIB agrícola, PIB da Indústria e PIB de serviços, com dados provenientes do IBGE/SIDRA no período de 1999 a 2015. O método econométrico utilizado é o da econometria espacial através do comando SPMAP, de Maurizio Pisati (2014).

Assim, elaborou-se tabelas constituídas de dados das seguintes culturas: milho, soja, feijão, café arábica, cana de açúcar, arroz, trigo, batata inglesa, sorgo, mandioca, algodão herbáceo, banana, cebola, alho, maracujá, abacate, laranja, tomate, ervilha, batata doce, girassol, borracha látex coagulado, manga, tangerina, triticale, fumo, limão, amendoim, mamão, aveia, cevada, melancia, abacaxi, pêssego, palmito, coco da baía, goiaba, mamona, figo, uva, urucum, marmelo, pimenta do reino e maçã.
Posteriormente, através do software Stata, adaptou-se as tabelas para a produção de mapas utilizando os comandos sh2dta e spmap, tornando possível a visualização dos dados de forma mais clara e facilitando assim a compreensão dos resultados obtidos.

\section{O TRIÂNGULO MINEIRO/ ALTO PARANAÍBA}

O Triângulo Mineiro e Alto Paranaíba 12 mesorregiões que fazem parte do estado de Minas Gerais. Essa mesorregião se subdivide em 2 regiões de Planejamento, compostas por sete microrregiões, sendo: a microrregião de Ituiutaba, Patrocínio, de Uberlândia, Patos de Minas, Uberaba, Frutal e de Araxá, totalizando assim, 66 municípios (IBGE\&MEFP, 1990).

Ao isolar as microrregiões de Araxá, Patos de Minas e Patrocínio, tem-se uma área composta por 31 municípios aqui denominada, região de planejamento Alto Paranaíba, segundo a classificação do IBGE. Os municípios dividem-se de acordo com as informações apresentadas na Tabela 2.

Tabela 2 - Divisão dos municípios por microrregião

\begin{tabular}{|l|l|l|}
\multicolumn{2}{c}{ ARAXÁ } & \multicolumn{1}{c|}{ PATOS DE MINAS } \\
\hline Araxá & Arapuá & PATROCÍ́NIO \\
\hline Campos Altos & Carmo do Paranaíba & Coromandel \\
\hline Ibiá & Guimarânia & Cruzeiro da Fortaleza \\
\hline Nova Ponte & Lagoa Formosa & Douradoquara \\
\hline Pedrinópolis & Matutina & Estrela do Sul \\
\hline Perdizes & Patos de Minas & Grupiara \\
\hline Pratinha & Rio Paranaíba & Iraí de Minas \\
\hline Sacramento & Santa Rosa da Serra & Monte Carmelo \\
\hline Santa Juliana & São Gotardo & Patrocínio \\
\hline Tapira & Tiros & Romaria \\
\hline & & Serra do Salitre
\end{tabular}

Fonte: IBGE, 1990; Divisão Regional do Brasil em Mesorregiões e Microrregiões Geográficas. Volume I.< http://biblioteca.ibge.gov.br/visualizacao/monografias/GEBIS\%20\%20RJ/DRB/Divisao\%20regional_v01.pdf> 
Dentre os municípios acima listados, destacam-se o município de Perdizes, responsável por $10,25 \%$ da área plantada total ou destinada a colheita na Região de Planejamento Alto Paranaíba, o município de Coromandel com 9,15\%, Sacramento, com cerca de 8,81\%, Patrocínio com 8,33\%, Nova ponte com 7,28\%, Rio Paranaíba com 6,35\%, Ibiá com 5,88\%, Patos de Minas com 5,85\% e Santa Juliana com 5,38\%, como pode ser observado na Tabela 3.

Tabela 3 - Ranking dos Municípios por participação na produção da Região do Alto Paranaíba, 1988 a 2017.

\begin{tabular}{|c|c|c|}
\hline MUNICÍPIO & HECTARES & $\%$ \\
\hline Perdizes & 1859224 & $10,25 \%$ \\
\hline Coromandel & 1660081 & $9,15 \%$ \\
\hline Sacramento & 1598111 & $8,81 \%$ \\
\hline Patrocínio & 1510644 & $8,33 \%$ \\
\hline Nova Ponte & 1319847 & $7,28 \%$ \\
\hline Rio Paranaíba & 1151010 & $6,35 \%$ \\
\hline Ibiá & 1065688 & $5,88 \%$ \\
\hline Patos de Minas & 1061155 & $5,85 \%$ \\
\hline Santa Juliana & 975071 & $5,38 \%$ \\
\hline Monte Carmelo & 788687 & $4,35 \%$ \\
\hline Serra do Salitre & 586108 & $3,23 \%$ \\
\hline Romaria & 544086 & $3,00 \%$ \\
\hline Campos Altos & 483843 & $2,67 \%$ \\
\hline Carmo do Paranaíba & 479310 & $2,64 \%$ \\
\hline Lagoa Formosa & 410254 & $2,26 \%$ \\
\hline Araxá & 375605 & $2,07 \%$ \\
\hline Pedrinópolis & 347540 & $1,92 \%$ \\
\hline São Gotardo & 294112 & $1,62 \%$ \\
\hline Estrela do Sul & 276808 & $1,53 \%$ \\
\hline Irai de Minas & 235288 & $1,30 \%$ \\
\hline Tapira & 193947 & $1,07 \%$ \\
\hline Tiros & 190681 & $1,05 \%$ \\
\hline Guimarânia & 138322 & $0,76 \%$ \\
\hline Abadia dos Dourados & 118184 & $0,65 \%$ \\
\hline Pratinha & 117635 & $0,65 \%$ \\
\hline Matutina & 86881 & $0,48 \%$ \\
\hline Cruzeiro da Fortaleza & 85206 & $0,47 \%$ \\
\hline Santa Rosa da Serra & 83014 & $0,46 \%$ \\
\hline Arapuá & 55464 & $0,31 \%$ \\
\hline Grupiara & 24868 & $0,14 \%$ \\
\hline Douradoquara & 17318 & $0,10 \%$ \\
\hline TOTAL & 18133992 & $100,00 \%$ \\
\hline
\end{tabular}

Fonte: Elaboração própria, Excel 2018.

A região do Alto Paranaíba, entre os anos de 1988 a 2017, teve como principais lavouras, o milho, ocupando $31,10 \%$ da área total plantada ou destinada a colheita na região, seguido pela soja, com 30,60\% e o Café com
$20,42 \%$. A Tabela 4, que apresenta a soma da área plantada no período de 1988 a 2017 por lavoura, possibilita a visualização desses resultados, bem como das participações das demais lavouras na região. 
Tabela 4 - Principais Lavouras da Região do Alto Paranaíba, 1988 a 2017.

\begin{tabular}{|c|c|c|}
\hline LAVOURA & HECTARES & $\%$ \\
\hline Milho & 5639542 & $31,10 \%$ \\
\hline Soja & 5549343 & $30,60 \%$ \\
\hline Café & 3702969 & $20,42 \%$ \\
\hline Feijão & 1016085 & $5,60 \%$ \\
\hline Cana De Açúcar & 621766 & $3,43 \%$ \\
\hline Arroz & 367906 & $2,03 \%$ \\
\hline Trigo & 292972 & $1,62 \%$ \\
\hline Batata Inglesa & 282758 & $1,56 \%$ \\
\hline Sorgo & 250750 & $1,38 \%$ \\
\hline Mandioca & 104447 & $0,58 \%$ \\
\hline Algodão & 71833 & $0,40 \%$ \\
\hline Banana & 35075 & $0,19 \%$ \\
\hline Cebola & 30454 & $0,17 \%$ \\
\hline Alho & 29611 & $0,16 \%$ \\
\hline Maracujá & 24405 & $0,13 \%$ \\
\hline Abacate & 21102 & $0,12 \%$ \\
\hline Laranja & 20764 & $0,11 \%$ \\
\hline Tomate & 19822 & $0,11 \%$ \\
\hline Ervilha & 18109 & $0,10 \%$ \\
\hline Batata Doce & 8869 & $0,05 \%$ \\
\hline Girassol & 7049 & $0,04 \%$ \\
\hline Borracha & 3699 & $0,02 \%$ \\
\hline Manga & 3387 & $0,02 \%$ \\
\hline Tangerina & 2462 & $0,01 \%$ \\
\hline Triticale & 1250 & $0,01 \%$ \\
\hline Fumo & 889 & $0,00 \%$ \\
\hline Limão & 818 & $0,00 \%$ \\
\hline Amendoim & 810 & $0,00 \%$ \\
\hline Mamão & 760 & $0,00 \%$ \\
\hline Aveia & 698 & $0,00 \%$ \\
\hline Cevada & 624 & $0,00 \%$ \\
\hline Melancia & 608 & $0,00 \%$ \\
\hline Abacaxi & 533 & $0,00 \%$ \\
\hline Pêssego & 500 & $0,00 \%$ \\
\hline Palmito & 313 & $0,00 \%$ \\
\hline Coco Da Baia & 282 & $0,00 \%$ \\
\hline Goiaba & 246 & $0,00 \%$ \\
\hline Mamona & 168 & $0,00 \%$ \\
\hline Figo & 161 & $0,00 \%$ \\
\hline Uva & 99 & $0,00 \%$ \\
\hline Urucum & 42 & $0,00 \%$ \\
\hline Marmelo & 7 & $0,00 \%$ \\
\hline Pimenta do Reino & 3 & $0,00 \%$ \\
\hline Maca & 2 & $0,00 \%$ \\
\hline TOTAL & 18133992 & $100,00 \%$ \\
\hline
\end{tabular}

Fonte: Elaboração própria, Excel 2018

\subsection{EVOLUÇÃO DA PRODUÇÃO NA REGIÃO DO ALTO PARANAÍBA}

No ano de 1988 a cultura de maior relevância para a Região do Alto Paranaíba, era o milho com $30,98 \%$, soja com $24,81 \%$, café com $19,27 \%$, e o feijão com $10,58 \%$ da produção total, como pode ser observado na Figura 5. 
Figura 5 Evolução da Produção Agrícola do Alto Paranaíba (1988 a 2017).

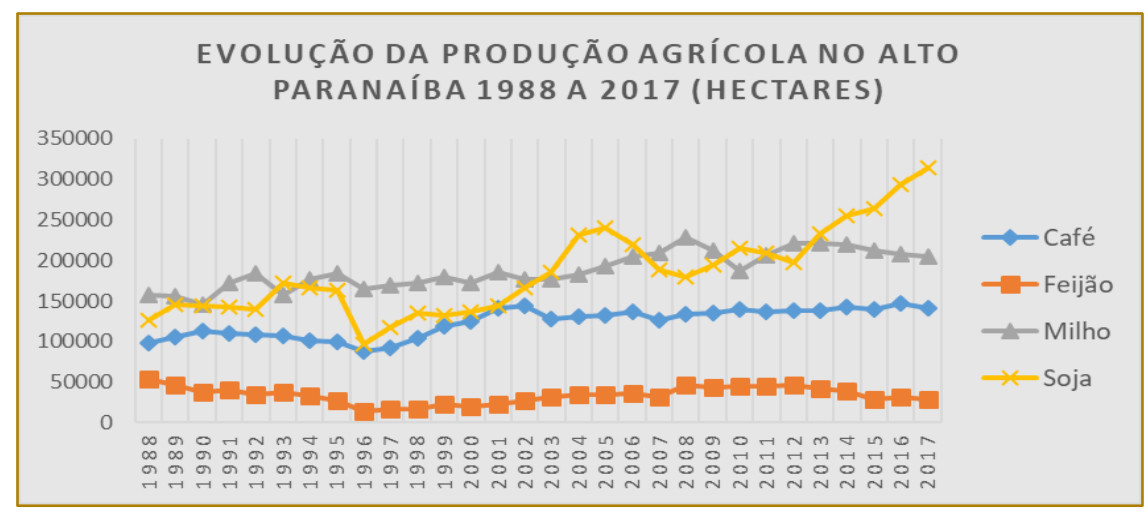

Fonte: Elaboração própria, Excel 2018.

Já no ano de 2017, a soja, que se alternou com o milho durante todo o período, tomou a frente, representando $37,49 \%$ da produção agrícola total, o milho, em segundo lugar representou $24,39 \%$, o café, $16,86 \%$ e o feijão, 3,41\%.
Segundo informações da Conab (Companhia Nacional de Abastecimento), ente os anos de 2011 a 2017, a soja saiu de um patamar de 25 milhões de hectares plantados para 35,1 milhões de hectares. (BRASILAGRO,2018).

Figura 6 - Produção de Soja do Alto Paranaíba (1988 e 2017).

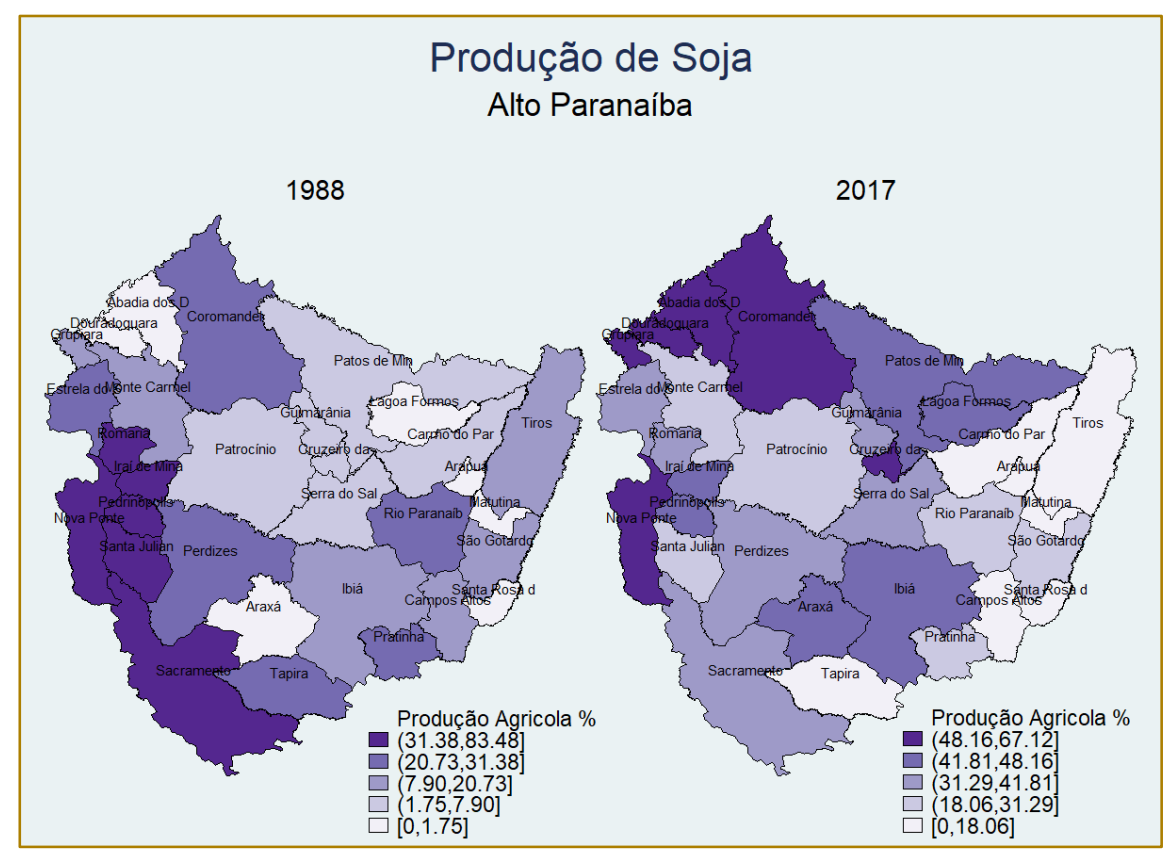

Fonte: Elaboração própria, StataMP 13, 2018.

Quanto a produção da soja no Alto Paranaíba, municípios como Coromandel, Abadia dos Dourados, Douradoquara, Grupiara e Cruzeiro da Fortaleza no ano de 2017 possuíam cerca de $48 \%$ a $67 \%$ da sua produção agrícola municipal, pautada neste commodite (Figura 6). Enquanto Iraí de Minas, Romaria, Pedrinópolis, Santa Juliana e Sacramento perderam força na produção de soja, migrando grande parte da sua produção para o milho (Figura 7).
É possível perceber então, uma queda na produção de soja nos municípios que abarcavam a maior parte da produção voltada para este commodite, passando para - milho, enquanto municípios com maior produção de milho, observados na Figura 7 , migraram grande parte da sua produção para a soja, como exemplo, Grupiara, Cruzeiro da Fortaleza, Lagoa Formosa, Patos de Minas, entre outros, corroborando com o que pode ser observado na Figura 5, em que a soja e o milho se intercalam durante todo o período. 
Figura 7 Produção de Milho do Alto Paranaíba (1988 e 2017).

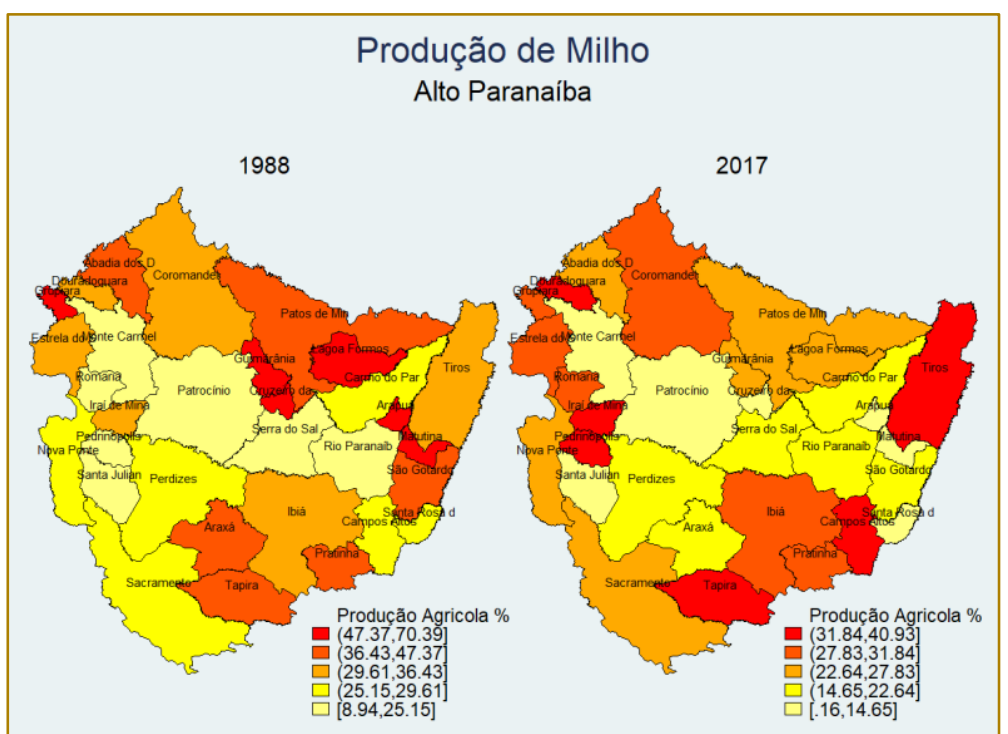

Fonte: Elaboração própria, StataMP 13, 2018.

Essas oscilações podem ser explicadas por variáveis como o preço e incidência de doenças que fazem com que os produtores optem por uma ou outra cultura ano após ano, ou ainda pelo plantio rotativo, em que se tem milho e soja intercalando-se em função de uma maior viabilidade e rentabilidade, o ideal é que essa troca de cultivo ocorra a cada 3 anos. (JANDREY et al., 2018).
Quanto a produção de café, os municípios de Perdizes, Coromandel, Sacramento, Araxá, Serra do Sal e Campos Altos, migraram parte de sua produção para outras lavouras, perdendo participação neste commodite, enquanto Carmo do Paranaíba, Arapuá e Matutina diminuíram sua produção de soja e milho passando a produzir entre $36 \%$ a $97 \%$ da sua produção total municipal em café (Figura 8).

Figura 8 - Produção de Café do Alto Paranaíba (1988 e 2017).

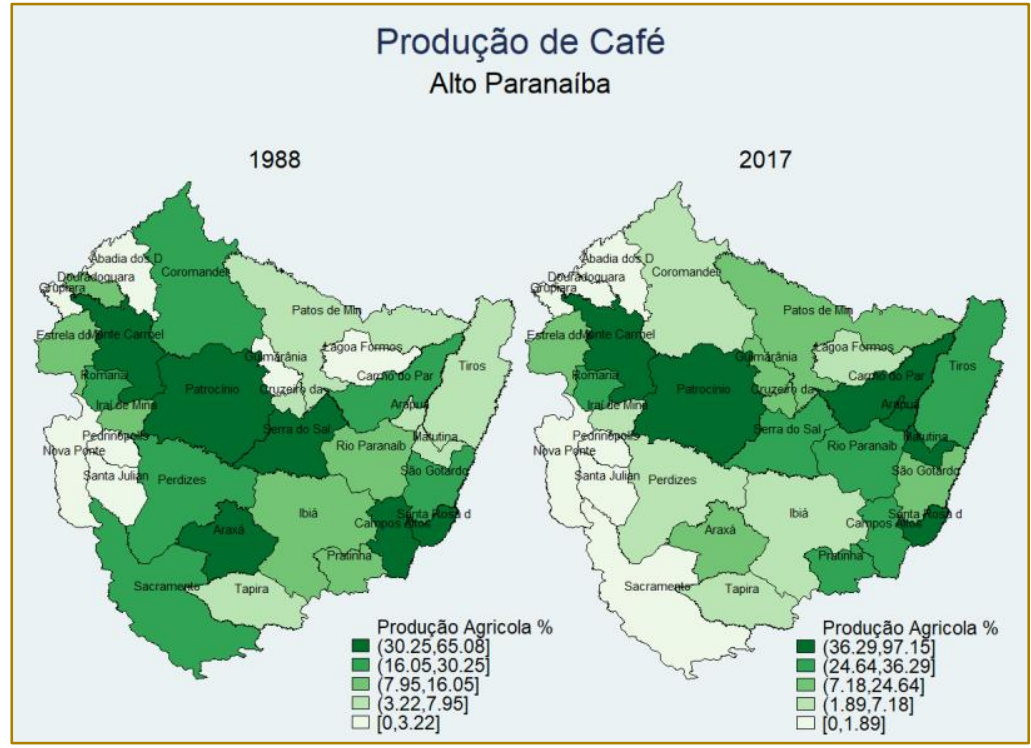

Fonte: Elaboração própria, StataMP 13, 2018. 


\subsection{RANKING POR MICRORREGIÃO.}

Classificados em sua própria microrregião, tem-se como destaque na microrregião de
Araxá, como pode ser observado na Tabela 5, a soja e o milho, ocupando respectivamente $42,34 \%$ e $34,93 \%$ da área total plantada ou destinada a colheita na microrregião.

Tabela 5 - Principais Lavouras da Microrregião de Araxá, do Alto Paranaíba (1988 a 2017).

\begin{tabular}{|l|c|c|}
\hline \multicolumn{3}{|c|}{ MICRORREGIÃO DE ARAXÁ } \\
\hline Soja & TOTAL (HECTARES) & $\%$ \\
\hline Milho & 3298740 & $42,34 \%$ \\
\hline Cana de açucar & 2721626 & $34,93 \%$ \\
\hline Feijão & 577680 & $7,41 \%$ \\
\hline Batata inglesa & 331856 & $4,26 \%$ \\
\hline
\end{tabular}

Fonte: Elaboração própria, Excel 2018.

Essa microrregião contribui com 51\% da produção total da Região de Planejamento Alto Paranaíba. O município de Perdizes lidera 0 ranking por hectares, correspondendo a 22,02\% da área plantada total ou destinada a colheita, Sacramento tem 19,73\%, Nova Ponte 16,81\%, Ibiá 12,81\%; e Santa Juliana tem $12,44 \%$, como pode ser observado na Tabela 6.

Tabela 6 - Participação dos Municípios da Microrregião de Araxá, do Alto Paranaíba (1988 a 2017).

\begin{tabular}{|l|c|c|}
\hline \multicolumn{2}{|c|}{ MICRORREGIÃO DE ARAXÁ } \\
\hline Perdizes (MG) & TOTAL (HECTARES) & $\%$ \\
\hline Sacramento (MG) & 1715483 & $22,02 \%$ \\
\hline Nova Ponte (MG) & 1537347 & $19,73 \%$ \\
\hline Ibiá (MG) & 1309886 & $16,81 \%$ \\
\hline Santa Juliana (MG) & 998079 & $12,81 \%$ \\
\hline Pedrinópolis (MG) & 969144 & $12,44 \%$ \\
\hline Campos Altos (MG) & 342615 & $4,40 \%$ \\
\hline Araxá (MG) & 325578 & $4,18 \%$ \\
\hline Tapira (MG) & 315210 & $2,39 \%$ \\
\hline Pratinha (MG) & 186419 & $1,18 \%$ \\
\hline TOTAL & 91821 & $100 \%$ \\
\hline
\end{tabular}

Fonte: Elaboração própria, Excel 2018.

Na microrregião de Patrocínio, responsável por $28,05 \%$ de toda a área plantada ou destinada a colheita, do Alto Paranaíba, os municípios de maior destaque são
Coromandel, com 32,46\% da área plantada ou destinada a colheita; Patrocínio, com 20,59\%; Monte Carmelo com 11,88\% e Romaria com 10,35\%, dispostos na Tabela 7. 
Tabela 7 - Participação dos Municípios da Microrregião de Patrocínio, do Alto Paranaíba (1988 a 2017).

\begin{tabular}{|l|c|c|}
\multicolumn{2}{|c|}{ MICRORREGIÃO DE PATROCÍNIO } \\
\hline Coromandel (MG) & 1391186 & $32,46 \%$ \\
\hline Patrocínio (MG) & 882525 & $20,59 \%$ \\
\hline Monte Carmelo (MG) & 509087 & $11,88 \%$ \\
\hline Romaria (MG) & 443660 & $10,35 \%$ \\
\hline Serra do Salitre (MG) & 383599 & $8,95 \%$ \\
\hline Estrela do Sul (MG) & 241410 & $5,63 \%$ \\
\hline Iraí de Minas (MG) & 204817 & $4,78 \%$ \\
\hline Abadia dos Dourados (MG) & 113869 & $2,66 \%$ \\
\hline Cruzeiro da Fortaleza (MG) & 76035 & $1,77 \%$ \\
\hline Grupiara (MG) & 24473 & $0,57 \%$ \\
\hline Douradoquara (MG) & 15366 & $0,36 \%$ \\
\hline
\end{tabular}

Fonte: Elaboração própria, Excel 2018.

As principais lavouras são a soja, com $38,72 \%$, seguida pelo milho com $33,47 \%$ e o café com 10,70\%, como pode ser observado na Tabela 8.

Tabela 8 - Principais Lavouras da Microrregião de Patrocínio, do Alto Paranaíba (1988 a 2017)

\begin{tabular}{|l|c|c|}
\multicolumn{3}{|c|}{ MICRORREGIÃO DE PATROCÍNIO } \\
LAVOURA & TOTAL (HECTARES) & $\%$ \\
\hline Soja & 1659467 & $38,72 \%$ \\
\hline Milho & 1434708 & $33,47 \%$ \\
\hline Café & 458494 & $10,70 \%$ \\
\hline Feijão & 259128 & $6,05 \%$ \\
\hline Arroz & 132226 & $3,09 \%$ \\
\hline
\end{tabular}

Fonte: Elaboração própria, Excel 2018.

Já a microrregião de Patos de Minas representa $20,95 \%$ do total de área plantada ou destinada a colheita na região. Seus municípios de maior destaque, de acordo com a Tabela 9, são: Patos de Minas, com 29,31\%; Rio Paranaíba com 28,47\% e Lagoa Formosa com 12,35\%. 
Tabela 9 - Participação dos Municípios da Microrregião de Patos de Minas, do Alto Paranaíba (1988 a 2017)

\begin{tabular}{|l|c|c|}
\hline \multicolumn{3}{|c}{ MICRORREGIÃO DE PATOS DE MINAS } \\
MUNICÍPIO & 938147 & $29,31 \%$ \\
\hline Patos de Minas (MG) & 911087 & $28,47 \%$ \\
\hline Rio Paranaíba (MG) & 395356 & $12,35 \%$ \\
\hline Lagoa Formosa (MG) & 264244 & $8,26 \%$ \\
\hline Carmo do Paranaíba (MG) & 238823 & $7,46 \%$ \\
\hline São Gotardo (MG) & 168355 & $5,26 \%$ \\
\hline Tiros (MG) & 116136 & $3,63 \%$ \\
\hline Guimarânia (MG) & 80939 & $2,53 \%$ \\
\hline Matutina (MG) & 45098 & $1,41 \%$ \\
\hline Santa Rosa da Serra (MG) & 42335 & $1,32 \%$ \\
\hline Arapuá (MG) & 3200520 & $100 \%$ \\
\hline TOTAL & & \\
\hline
\end{tabular}

Fonte: Elaboração própria, Excel 2018.

Como pode ser observado na Tabela 10, existe predominância do milho na microrregião, com $46,34 \%$, seguido pela soja com $18,47 \%$ e o feijão com $13,28 \%$.

Tabela 10 - Principais Lavouras da Microrregião de Patos de Minas, do Alto Paranaíba (1988 a 2017)

\begin{tabular}{|l|c|c|}
\multicolumn{3}{|c|}{ MICRORREGIÃO DE PATOS DE MINAS } \\
\hline Milho & TOTAL & $\%$ \\
\hline Soja & 1483208 & $46,34 \%$ \\
\hline Feijão & 591136 & $18,47 \%$ \\
\hline Café & 425101 & $13,28 \%$ \\
\hline Arroz & 212482 & $6,64 \%$ \\
\hline
\end{tabular}

Fonte: Elaboração própria, Excel 2018.

\subsection{ANÁLISE DO EMPREGO POR SETOR NA REGIÃO DO ALTO PARANAÍBA}

O emprego gerado pelo setor de serviços, aparece em primeiro lugar durante todo o período, seguido pelo setor da indústria e da agropecuária respectivamente, como pode ser observado na Figura 9. No ano de 2002 o setor de serviços representava 59,65\% do percentual total na geração de empregos, ou seja, o equivalente a 54903 empregos, seguido pelo setor da agropecuária, responsável por 18618 empregos (20,23\%), e o setor da indústria gerando 18524 empregos $(20,12 \%)$. 
Figura 9 - Empregos do Alto Paranaíba (2002 a 2017).

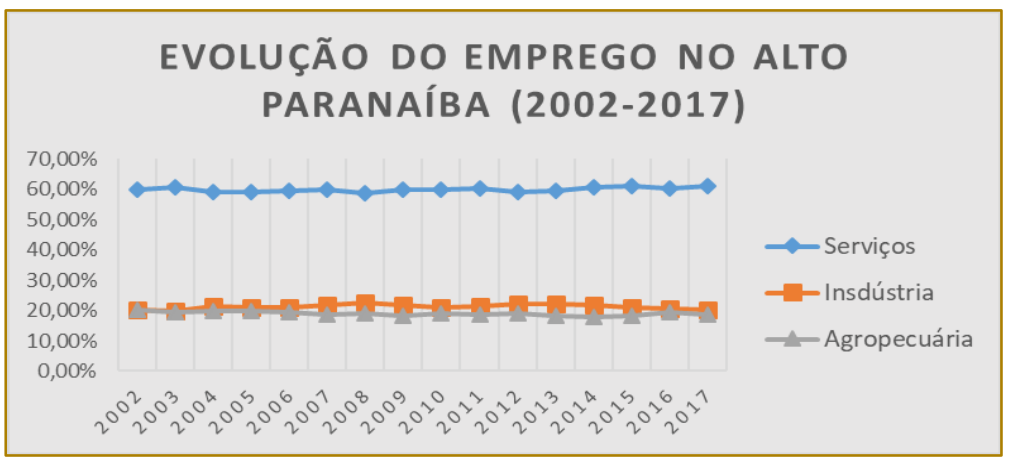

Fonte: Elaboração própria, StataMP 13, 2018.

Em 2017 o setor de serviços permaneceu em primeiro, gerando uma média de 103865 empregos $(61,10 \%)$, seguido pelos setores da indústria com 34527 (20,31\%) e agropecuária com 31588 (18,58\%).
O comportamento dos setores na região se dá da mesma forma que se comportam no estado, em que o setor com maior fluxo de geração de empregos é o de serviços e o menor é o setor da agropecuária, como pode ser observado na Figura 10.

Figura 10 - Empregos Formais do Estado de Minas Gerais (2016).

\begin{tabular}{|l|}
\hline \multicolumn{1}{|c|}{ EMPREGOS FORMAIS (2016) } \\
\hline AGROPECUÁRIA \\
259 mil (5.59\% do estado). \\
INDÚSTRIA \\
1.06 milhōes ( $22.87 \%$ do estado). \\
SERVIÇOS \\
3.31 milhōes (71.54\% do estado). \\
Fonte: IBGE / Fundaçăo Joāo Pinheiro (FJP) / MET (Anuário RAIS) \\
\hline
\end{tabular}

Fonte: Adaptado de Minas Gerais Business. Disponível em: < http://www.minasguide.com/pt/conhecaeconomia-de-minas-gerais/>

Uma vez que a região tem como base a produção agrícola, espera-se que uma maior oferta de empregos do setor de serviços para atender esse setor, seja o responsável pelo maior volume de empregos no setor de serviços. Combina-se se a oferta por empresas prestadoras de serviços agropecuários (ou agroempresas) que começam a se instalar na região para oferecerem serviços diversos (aluguel e venda de máquinas e equipamentos, defensivos agrícolas, consultorias, sementes etc). Esta combinação é a responsável pelo crescimento do agronegócio na região. 
Figura 11 - Emprego de Serviços do Alto Paranaíba (2002 e 2017).

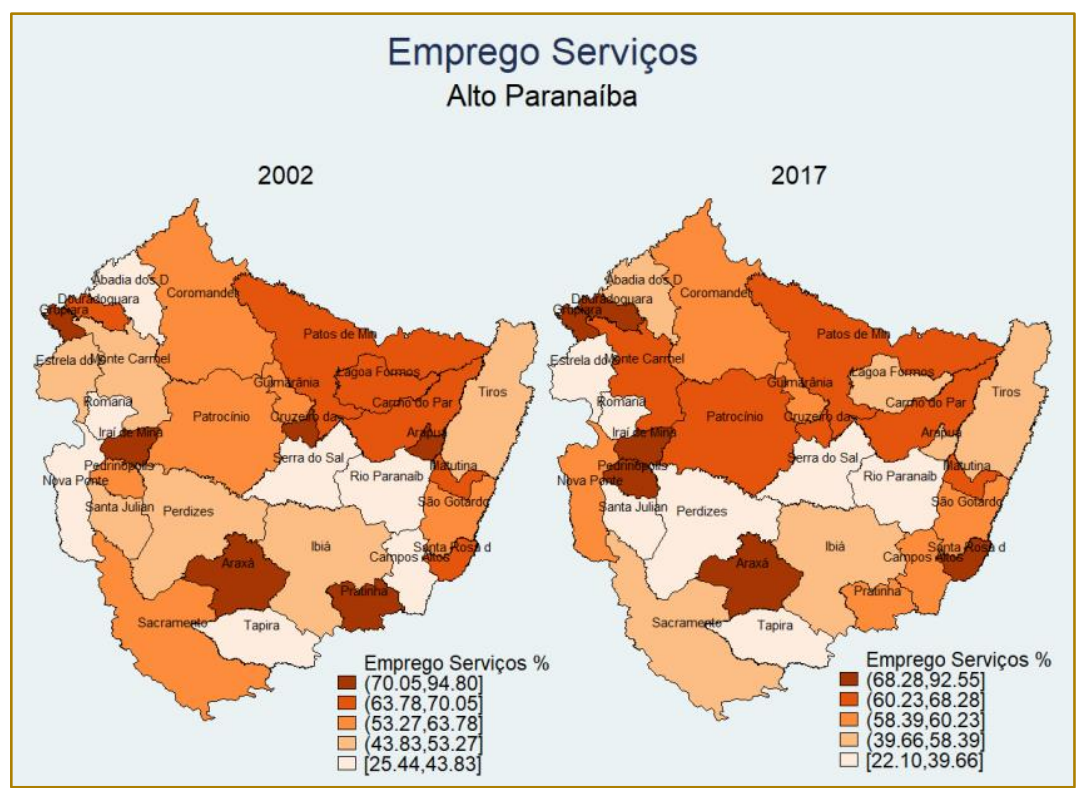

Fonte: Elaboração própria, StataMP 13, 2018.

De forma mais detalhada, tem-se que nos municípios de Douradoquara, Iraí de minas, Pedrinópolis, Grupiara, Araxá e Santa Rosa da Serra, entre 68\% a 92\% dos empregos formais dos municípios são gerados pelo setor de serviços. (Figura 11).

Municípios como Cruzeiro da Fortaleza e Pratinha entre os anos de 2002 e 2017 perderam força nesse setor, e obtiveram uma oferta maior do número de empregos no setor da agropecuária. (Figura 12).
Campos Altos perdeu força no setor do agronegócio em que entre $40 \%$ a $70 \%$ dos empregos neste município eram gerados por esse setor, aumento a participação do setor de serviços, ficando entre $58 \%$ a $60 \%$ dos empregos ofertados. Já Santa Juliana e Tapira, migraram em parte para o setor de Industria (Figura 13), ficando entre 22\% a $48 \%$ e $16 \%$ a $22 \%$, respectivamente, na oferta de empregos nesse setor.

Figura 12 - Emprego Agrícola do Alto Paranaíba (2002 e 2017).

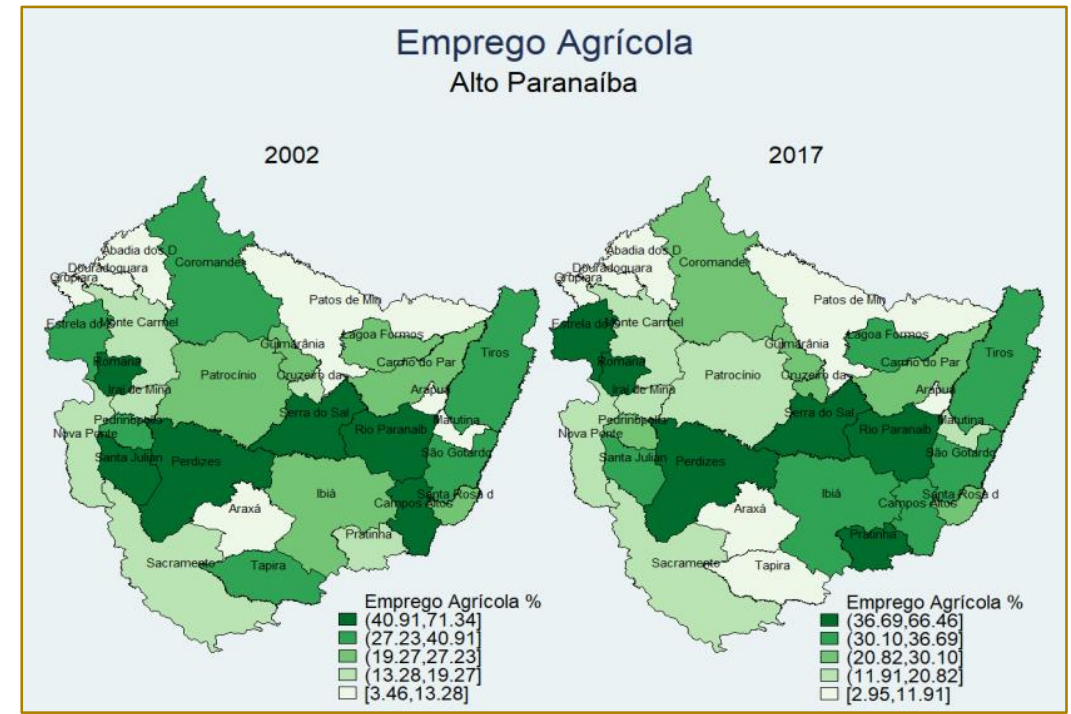

Fonte: Elaboração própria, StataMP 13, 2018. 
No setor da indústria, também houve migrações dos municípios de Douradoquara, Monte Carmelo e Nova Ponte, que possuíam de $22 \%$ a $53 \%$ da renda gerada por esse setor passaram a ter parte da renda gerada pelo setor de serviços.

Figura 13 - Emprego da Industria e Construção Civil do Alto Paranaíba (2002 e 2017).

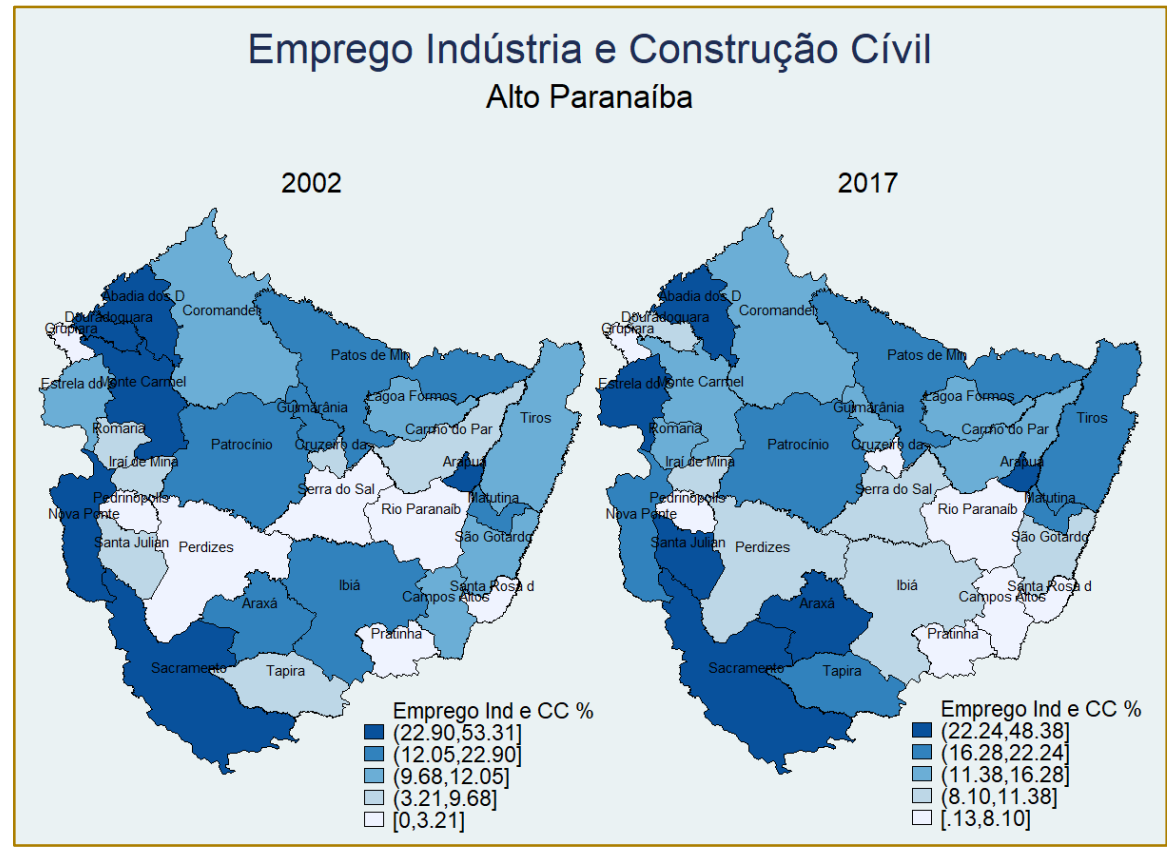

Fonte: Elaboração própria, StataMP 13, 2018.

\subsection{ANALISE DO PIB POR SETOR NA REGIÃO DO ALTO PARANAÍBA}

O setor de serviços é preponderante e se assemelha a de países desenvolvidos. Entretanto, na região esse setor se relaciona principalmente com a agricultura por ser uma região onde o agronegócio é mais forte. (Figura 14).

Figura 14 - Proporção do PIB Industria do Alto Paranaíba (1999 a 2012).

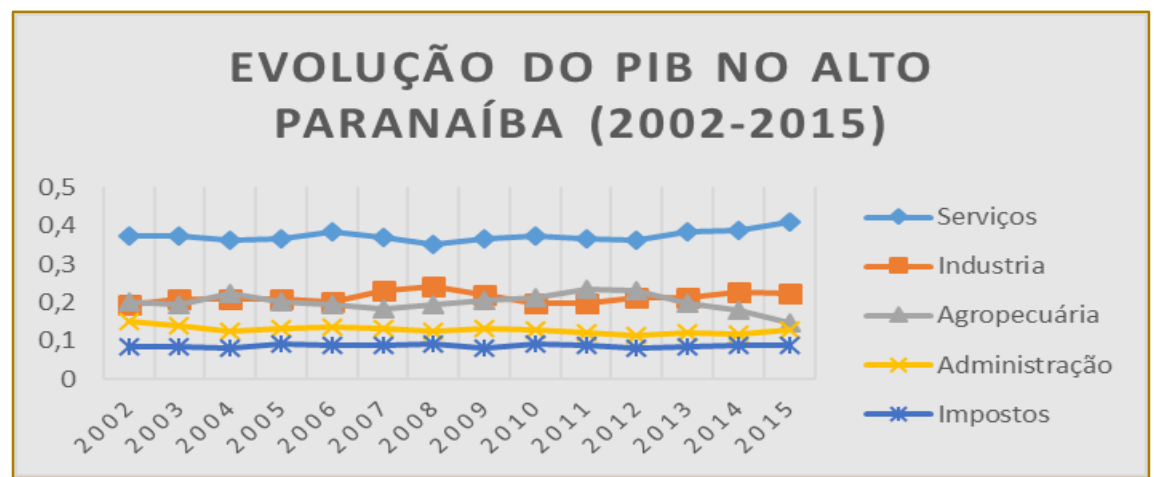

Fonte: Elaboração própria, StataMP 13, 2018.

Outro ponto de destaque é que o setor agrícola sofreu uma crise a partir de 2012, provavelmente, em decorrência da valorização cambial. (AGROLINK,2015).
De forma mais especifica, quando se fala do PIB nos diferentes setores, tem-se nos municípios de Douradoquara, Romaria, Perdizes, Serra do Sal, Rio Paranaíba e Pratinha, cerca de $36 \%$ a $48 \%$ da renda gerada pelo setor agrícola. (Figura 15). 
Figura 15 - PIB Agrícola do Alto Paranaíba (1999 e 2015).

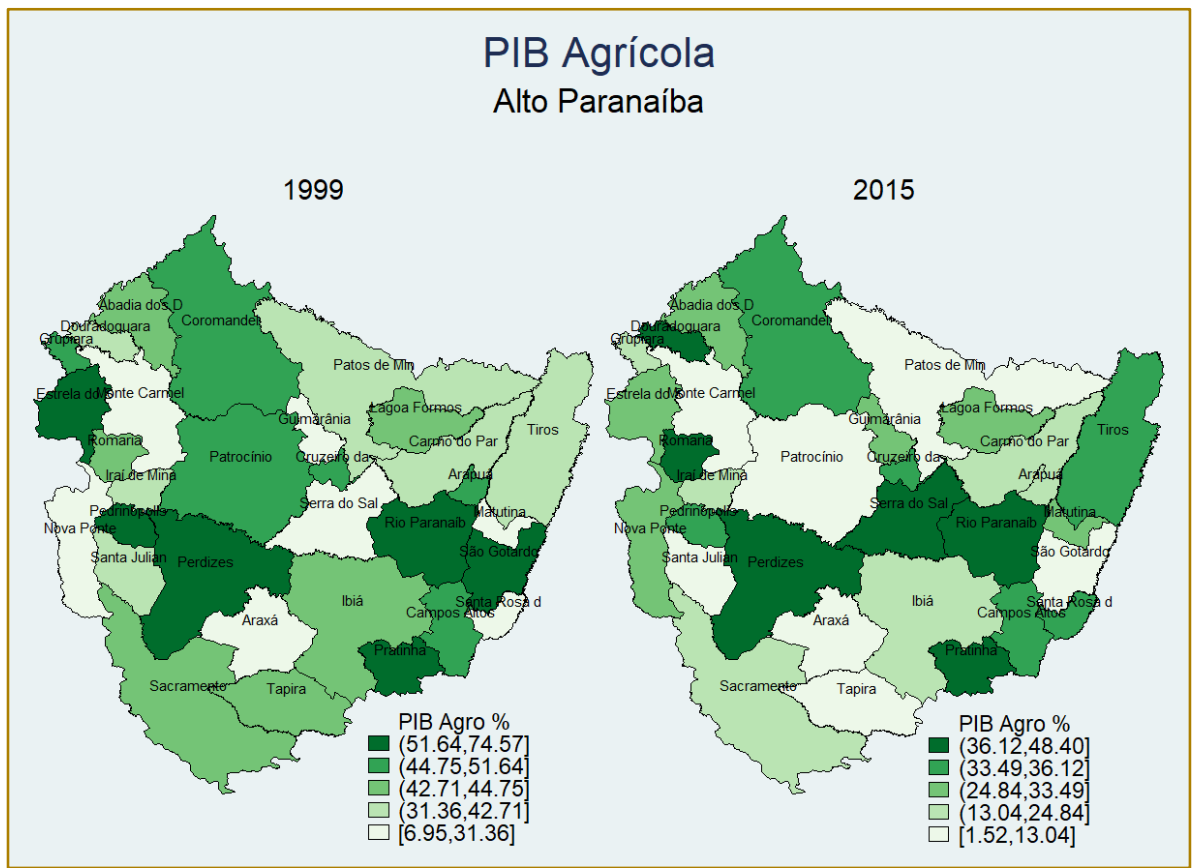

Fonte: Elaboração própria, StataMP 13, 2018.

Em relação a 1999 em que o município de São Gotardo possuía entre 51\% a 74\% do PIB gerado pelo setor agrícola, tem-se uma mudança passando para o setor de serviços, gerando entre $36 \%$ a $54 \%$ da renda dos municípios. Os municípios de Estrela do Sul e
Pedrinópolis também perderam participação no PIB agrícola e aumentaram sua participação no PIB de serviços, entretanto em uma proporção menor, sendo de $29 \%$ a $33 \%$ da renda gerada por esse setor. (Figura 16).

Figura 16 - PIB Serviços do Alto Paranaíba (1999 e 2015).

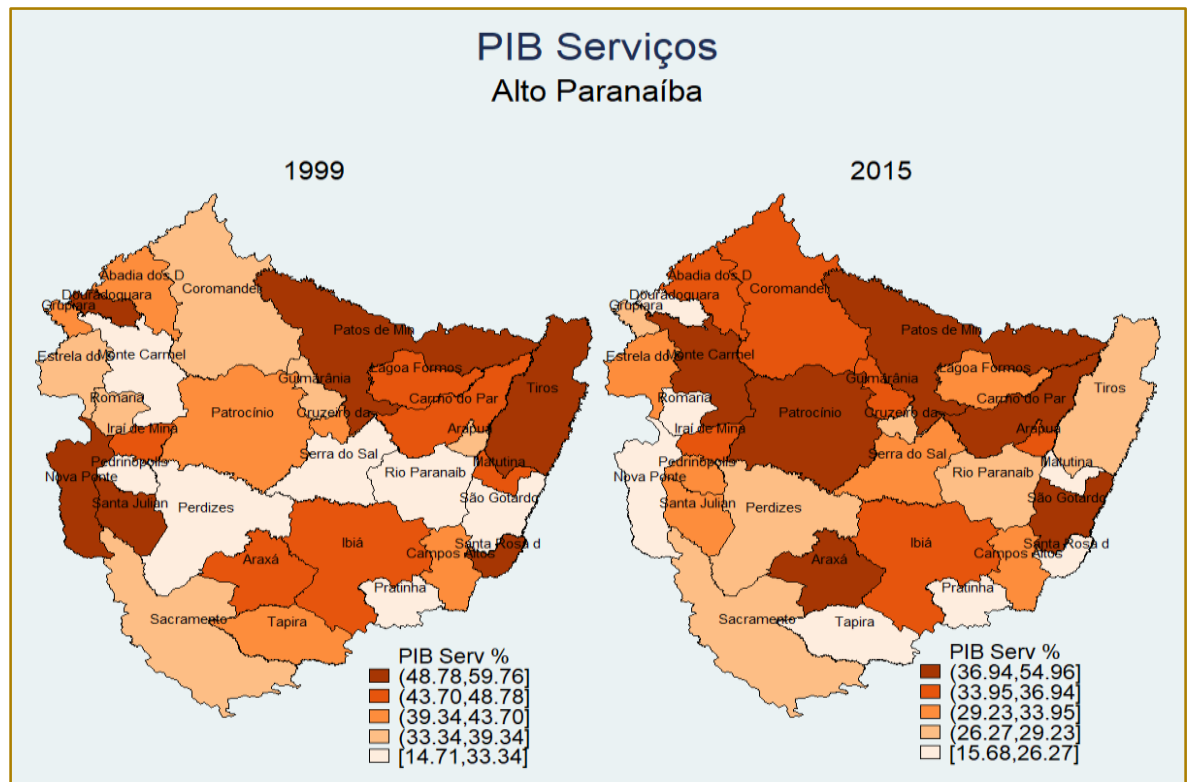

Fonte: Elaboração própria, StataMP 13, 2018.

Monte Carmelo, Patrocínio, Patos de Minas, Carmo do Paranaíba, São Gotardo e Araxá possuem entre $36 \%$ a $54 \%$ da renda gerada pelo setor de serviços. Já os municípios de 
Douradoquara, Santa Juliana, Tiros e Santa Rosa da Serra que em 1999 possuíam o setor de serviços gerando renda entre $48 \%$ a $59 \%$, em 2017 migraram para os setores da agropecuária e indústria.

$\mathrm{Na}$ indústria, os principais municípios dependentes da renda gerada por esse setor são Nova Ponte, Santa Juliana, Sacramento, Araxá, Tapira e Arapuá, sendo entre 18\% a $54 \%$ da renda total do município. (Figura 17). Monte Carmelo, Serra do Sal, Guimarânia e Matutina, em 1999, possuíam entre 14\% a $56 \%$ da renda gerada por esse setor, migrando para os setores de serviço e agrícola.

Figura 17 - PIB Industria do Alto Paranaíba (1999 e 2015).

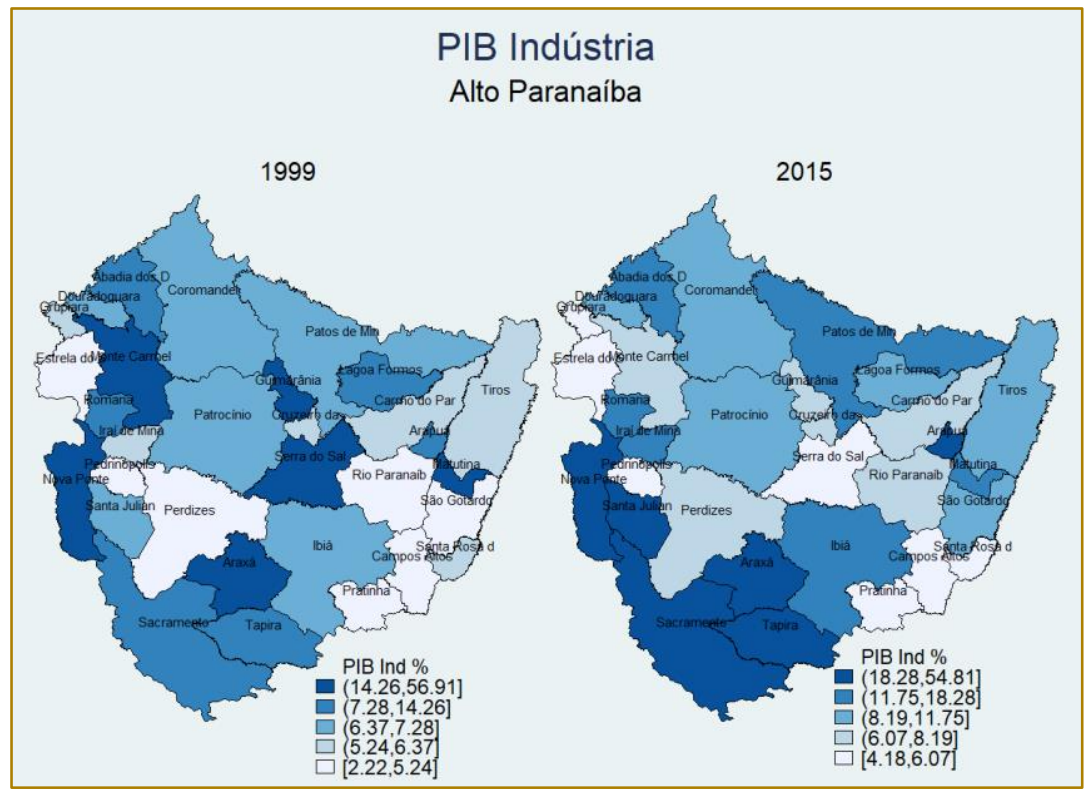

Fonte: Elaboração própria, StataMP 13, 2018.

\section{CONCLUSÃO}

O trabalho é pioneiro em sua área de pesquisa ao delimitar e, analisar, profundamente o Alto Paranaíba. Com essa metodologia, foi possível identificar o milho, a soja e o café como as lavouras de maior participação na região.

Os municípios com maior participação por hectares plantados ou destinados a colheita no período analisados são: Perdizes, responsável por 10,25\% (1859224 hectares), Coromandel com 9,15\%, (1660081 hectares), Sacramento com 8,81\% (1598111 hectares), Patrocínio com 8,33\% (1510644 hectares), Nova Ponte com 7,28\% (1319847 hectares), Rio Paranaíba com 6,35\% (1151010 hectares), Ibiá com 5,88\% (1065688 hectares), Patos de Minas 5,85\% (1061155 hectares) e Santa Juliana com 5,38\% (975071 hectares).

O setor de serviços permaneceu em primeiro lugar durante o período, seguido pelo setor da indústria e agropecuária respectivamente, no que se refere a geração de empregos.
Também foi possível perceber uma troca entre a dependência dos municípios na agropecuária, serviços e indústria, com o passar dos anos. Além do que, é possível ver claramente a distinção entre os setores sobrepondo os mapas, onde se tem a região sudoeste do Alto Paranaíba voltada para a indústria, a região norte e parte da região nordeste para o serviço e tomando parte da região centro-oeste e nordeste, tem-se a prevalência da agropecuária como maior gerador de renda. O mesmo vale para a análise do emprego. Onde há municípios com maior dependência do PIB desses setores há também a maior geração de empregos nesses setores.

Constatou-se também a importância da indústria no desenvolvimento do Alto Paranaíba, sendo que o setor foi responsável por cerca de $20,31 \%$ dos empregos gerados em 2017 e 22,41\% do PIB da região.

Dessa forma foi comprovado através de análise estatística descritiva e econometria espacial, que o agronegócio focado em 
serviços, impulsionado principalmente pela agropecuária movida pelo milho, a soja e o

\section{NOTAS}

1 - Os conceitos e divisões a respeito das mesorregiões serão tratados logo em seguida, no tópico 2.1

2 - O tópico 2.3 destina-se a conceituação e exposição das divisões referentes as regiões de planejamento.

3 - Os conceitos e divisões a respeito das microrregiões serão devidamente expostos no tópico 2.2

4 - NEEAP - Núcleo de Estudos Econômicos do Alto Paranaíba da UFV - Campus Rio Paranaíba, é um grupo de pesquisa, composto por alunos e professores, que tem como objetivo propagar informações a respeito da economia e temas afins, visando promover debates sobre o tema mencionado e ao mesmo tempo estimular a pesquisa dentro do ambiente universitário, promovendo e organizando grupos de estudos e de pesquisas, destinados a fomentar o conhecimento sobre a economia na Região

\section{REFERÊNCIAS}

[1]. AGROLINK. Valorização cambial prejudica competitividade do agronegócio brasileiro. 2015. Disponível em: <https://www.agrolink.com.br/noticias/valorizacaocambial-prejudica-competitividade-doagronegocio-brasileiro_100207.html> Acesso em: 25/10/2018.

[2]. BRASILAGRO. Área plantada de soja voltará a aumentar. 2018. Disponível em: < http://www.brasilagro.com.br/conteudo/areaplantada-de-soja-voltara-a-aumentar-.html> Acesso em: 24/10/2018.

[3]. CEPEA. Centro De Estudos Avançados Em Economia Aplicada. Relatório Pib Agro Minas Gerais. Análise referente a março/17 elaborada com dados disponíveis até junho/17. 2017. Disponível em:

http://www.sistemafaemg.org.br/Conteudo.aspx?Co de $=1892 \&$ Portal $=2 \&$ ParentCode $=67 \&$ ParentPath $=$ None\&ContentVersion $=$ C > Acesso em 04/05/2018.

[4]. CORRÊA, Roberto Lobato. Região e Organização do Espaço. $7^{\circ}$ edição, São Paulo: Editora Ática, 2000. Disponível em: < http://www.ebah.com.br/content/ABAAAAtOYAD/re giao-organizacao-espacial?part=3\#> Acesso em: $13 / 10 / 2018$

[5]. CNA, Confederação da Agricultura e Pecuária do Brasil. PIB do agronegócio mineiro café, é o motor do crescimento da região de Planejamento do Alto Paranaíba.

do Alto Paranaíba, trazendo temas como: Desenvolvimento econômico, político e territorial; Economia Aplicada ao Agronegócio; Emprego, Inflação e Desdobramento Macroeconômico; Finanças Corporativas; Gerenciamento de Sistemas Agroindustriais; Mercado de Trabalho no Agronegócio; Mercado de Capitais e Mercado Futuro de Commodities Agrícolas, atuais linhas de pesquisa, fomentando e apoiando a publicação de obras e artigos que correspondam aos objetivos do Núcleo e viabilizando a participação nos eventos.

5 - Conselho Estadual de Desenvolvimento do Estado de Minas Gerais

6 - Banco de Desenvolvimento de Minas Gerais

7 - Instituto Latino americano y del Caribe de Planificacion Economica y Social

8 - Secretaria de Planejamento do Estado de Minas Gerais

chega a R\$162 bilhões. Brasília, DF, Brasil. 2016. Disponíve em: http://www.cnabrasil.org.br/noticias/pib-doagronegocio-mineiro-chega-r162-bilhoes> Acesso em: 18/03/2018.

[6]. DINIZ, A. M. A; BOTELLA, W. B. O Estado de Minas Gerais e suas Regiões: Um Resgate Histórico das Principais Propostas Oficiais de Regionalização. Sociedade \& Natureza, Uberlândia, 17 (33): 59-77, dez. 2005. Disponível em:

http://www.seer.ufu.br/index.php/sociedadenaturez a/article/viewFile/9208/5670 > Acesso em: 13/10/2018.

[7]. FEELT. Faculdade de Engenharia Elétrica. Sobre a cidade de Patos de Minas. UFU. 2018. Disponível em: <http://www.feelt.ufu.br/Patos-deMinas/Engenharia-Eletronica-e-de-

Telecomunicacoes/Sobre-a-cidade-de-Patos-deMinas> Acesso em: 13/10/2018.

[8]. FERREIRA, E. W; OLIVEIRA, A. S. Análise do Emprego Formal - Vínculos e Estabelecimentos - na Mesorregião do Triângulo Mineiro e Alto Paranaíba - TMAP. In: CORRÊA, V. P. (Org.). Dinâmica Socioeconômica da Mesorregião do Triângulo Mineiro e Alto Paranaíba. Uberlândia: CEPES/IEUFU, V. 4, maio 2017.133 p. Disponível em: <http://www.ie.ufu.br/CEPES> Acesso em: 13/10/2018. 
[9]. FIEMG. Regional Alto Paranaíba: Ocupa o 7ㅇ lugar no ranking geral em relação ao número de estabelecimentos industriais. Sistema FIEMG. 2017.

$$
\text { Disponivel }
$$

em:

$<$ https://pcir.fiemg.com.br:446/regionais/detalhe/altoparanaiba > Acesso em: 24/09/2018.

[10]. IBGE - Instituto Brasileiro de Geografia e Estatística. Divisão do Brasil em Microrregiões Homogêneas - 1968. Rio de Janeiro. Fundação IBGE, 1970. Disponível em: < https://biblioteca.ibge.gov.br/visualizacao/livros/liv1 3891. pdf > Acesso em: 13/10/2018.

[11]. IBGE, Fundação Instituto Brasileiro de Geografia e Estatística; MEFP, Ministério da Economia, fazenda e planejamento; Divisão Regional do Brasil em Mesorregiões e Microrregiões Geográficas. Volume I. Rio de Janeiro. 1990. Disponível em: < https://biblioteca.ibge.gov.br/visualizacao/monogra fias/GEBIS\%20-
\%20RJ/DRB/Divisao\%20regional_v01.pdf >; Acesso em: 26/05/2017.

[12]. IBRAHIM, N. Agro maduro e moderno. Confederação da Agricultura e Pecuária do Brasil (CNA). Brasília, DF, Brasil. 2018. Disponível em: < http://www.cnabrasil.org.br/artigos/agro-maduro-emoderno > Acesso em: 18/03/18

[13]. IPCE, Instituto de Pesquisa e Estratégia Econômica do Ceará. As Regiões de Planejamento do Estado do Ceará. Texto Para Discussão, № 111 - novembro / 2015. Disponível em: $<$ http://www.ipece.ce.gov.br/textos_discussao/TD_ 111.pdf > Acesso em: 13/10/2018.

[14]. JANDREY, D. et al. 5 motivos para incluir milho na rotação de culturas visando a sustentabilidade da soja. 2018. Disponível em: $<$ http://www. pioneersementes.com.br/blog/42/5motivos-para-incluir-milho-na-rotacao-de-culturasvisando-a-sustentabilidade-da-soja> Acesso em: 23/10/2018 


\section{Gapítulo 20}

\section{ASPECTOS DA PRODUÇÃO E EXPORTAÇÃO CAFEEIRA NA REGIÃO DO TRIÂNGULO MINEIRO/ALTO PARANAÍBA E SUL DE MINAS}

\section{Isaac Resende Araújo}

Joabe Santos Sousa

Ricardo Freitas Martins da Costa

Fábio André Teixeira

Julienne de Jesus Andrade Widmarck

Resumo: O agronegócio é de grande importância para a economia brasileira, e dentre as culturas existentes no Brasil, destaca-se a cultura do café. Após chegar ao Brasil, o café também se tornou uma cultura de grande influência na economia brasileira. Com existência de grandes plantações em diversos estados, um estado merece destaque por possuir duas das mesorregiões que mais produzem e exportam. Através do presente trabalho, buscamos analisar dados em busca de compreender como essa cultura afeta a economia dessas mesorregiões, qual a proporção dela em relação as outras culturas e números em relação a exportação de cada mesorregião, além de fazer uma leitura e análise da exportação da cultura em uma microrregião em específico, traçando seu perfil exportador e a relevância da cultura para essa microrregião.

Palavras Chave: Café; Exportação; Sul, Sudoeste, Triângulo Mineiro e Alto Paranaíba. 


\section{INTRODUÇÃO}

O Brasil tem uma predisposição natural para - agronegócio devido às características e diversidades encontradas no clima favorável, no solo, na água, no relevo e na luminosidade. Essas características tornaram possível o agronegócio ter grande participação na economia brasileira, representando aproximadamente $21,6 \%$ do PIB Brasileiro (CEPEA/USP, 2016).

Figura 1 - PIB Brasil x PIB Agronegócio

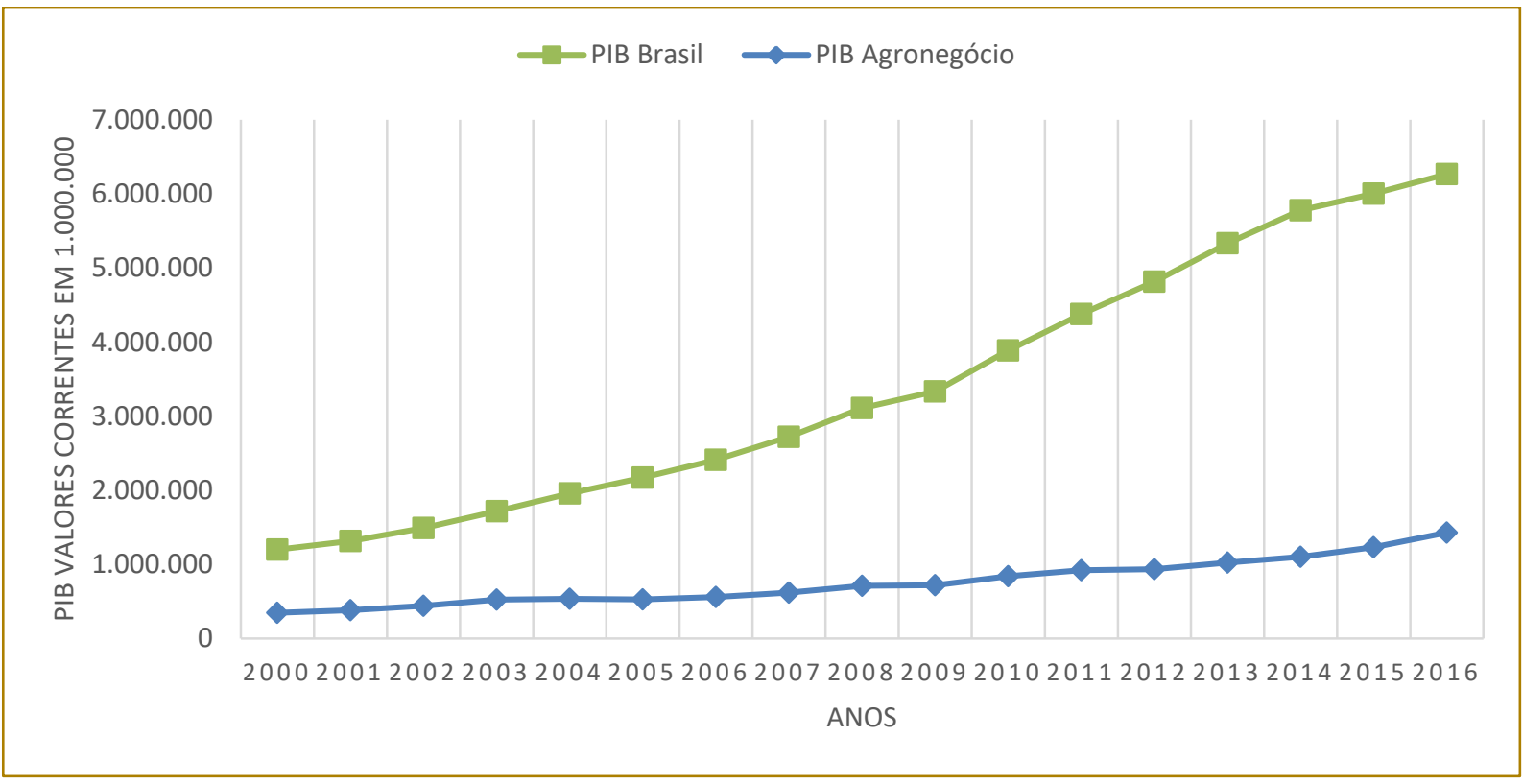

Fonte: IBGE e CEPEA - ESALQ/USP

Das diversas culturas existentes no agronegócio do Brasil, destaca-se a cafeicultura, pois ela contribui em larga escala para a geração de emprego e de divisas no país (GOMES, M, F. M.; ROSADO, P. L., 2005).

O café é um dos principais produtos agrícolas na pauta das exportações brasileiras, tornando-se um grande fornecedor de receitas cambiais. O estado de Minas Gerais está entre os maiores produtores de café, com cerca de 50 a $60 \%$ da produção total do café brasileiro e com o predomínio de produção de café arábica, totalizando 99\% da produção total de café.

Do Vale (2014), diz que a cafeicultura se efetivou no estado de Minas Gerais na década de 1970, superando os principais produtores na época. $\mathrm{E}$ isso se deu principalmente pela existência de um Plano de Renovação e Revigoramento dos Cafezais, proposto pelo Instituto Brasileiro do Café (IBC).
Sendo assim, Minas Gerais se tornou um grande polo produtor e exportador cafeeiro, com duas mesorregiões de destaque: Triângulo Mineiro/Alto Paranaíba (Cerrado Mineiro) e Sul de Minas. Portanto, ao longo desse estudo, trabalharemos com a hipótese de que a mesorregião do Triângulo Mineiro/Alto Paranaíba (Cerrado Mineiro) exporta mais do que o Sul de Minas, embora produza menos, logo, o objetivo principal se dará em explicar o porquê dessa disparidade.

Como objetivos específicos, será feito uma análise das exportações de café na região do cerrado mineiro entre os anos de 2012 a 2015, definindo o perfil exportador e as vinte cidades da região que possuem maior representatividade no quesito produção de café; calculando a relevância da exportação de café na região, frente ao volume total exportado pelo Brasil no período em análise e mapear possíveis municípios poloexportadores. 


\section{O CAFÉ NO BRASIL}

Em 1727 o café chegou ao Brasil na cidade de Belém, trazido através do Sargento-Mor Francisco de Mello Palheta que foi enviado a Guiana Francesa pelo governador do Maranhão e Grão Pará com essa missão (COMPANHIA NACIONAL DE ABASTECIMENTO - CONAB, 2010). Para conseguir uma muda do café, foi necessário que Palheta aproximasse da esposa do Governador de Caiena, capital da Guiana Francesa, obtendo assim a muda que foi trazida clandestinamente em sua bagagem.

Após chegar no Brasil e graças às nossas condições climáticas o café se expandiu no estado do Maranhão, Bahia, Rio de Janeiro, São Paulo, Minas Gerais, Paraná, Espírito Santo e Rondônia, com a produção voltada para o mercado doméstico (MATIELLO et al, 2005). Então, rapidamente o café passou de uma posição relativamente secundária para a de produto-base da economia brasileira (SREENATH, 2000).

Como já dito, as condições favoráveis brasileiras fizeram com que o café se estabelece no Vale do Paraíba resultando num novo ciclo econômico do país. Assim o Brasil aumentou significativamente sua produção dando início às exportações, que até então era em pequenas escalas, exportando cerca de 79 arrobas na sua primeira exportação. Já em 1808 as exportações atingiram um número mais significativo, chegando a 80 mil arrobas (MARTINS, A. L., 2012), e em 1830, o produto já era o mais exportado pelo Brasil, desbancando o ouro e o açúcar (PORTAL SÃO FRANCISCO, 2017)

Depois de avançar pelo Vale do Paraíba e chegar em Campinas, o Brasil se torna em 1860 uma grande potência exportadora de café, com 26 milhões de pés plantados (ABIC, 2018), fazendo com que durante muitos anos o café fosse de extrema importância para a riqueza brasileira, resultando num aceleramento do desenvolvimento brasileiro, inserindo o país nas relações internacionais de comércio. Cidades emergiram nos vales, montanhas e interiores dos estados, surgindo bancos e casas bancárias e também a industrialização na região centro-sul, principalmente em São Paulo e Paraná.

Apesar do grande sucesso da cultura do café no Brasil, houve também tempos ruins. Com a quebra da bolsa na crise de 1929, o café atingiu preços baixos levando a insolvência da cultura do café, fazendo com que milhares de sacas fossem queimadas e milhões de pés de cafés foram erradicados, criando a maior crise da história do setor cafeeiro em todo o mundo (ABIC, 2018). Porém, depois de uma longa crise, o Sudeste do Brasil voltou a crescer, apoiado na cafeicultura e na indústria.

\section{DELIMITANDO AS REGIÕES SUL,} TRIANGULO MINEIRO E ALTO PARANAÍBA

\subsection{REGIÃO DO SUL DE MINAS}

O Sul de Minas é composto por 146 municípios, ocupando uma área de $49.523 \mathrm{~km}^{2}$ e possui 2.463 .618 habitantes. A altitude do relevo é entre 850 e 1250 metros, com temperatura média anual entre 22 e $24^{\circ} \mathrm{C}$, e um PIB de $\mathrm{R} \$ 49.617 .024,00$ (IBGE, 2012).

Silva; Santos; Lima (2001, p. 1-2), diz que como maior estado produtor de café do país, o sul de minas tem grande parte de seus municípios com economia baseada no agronegócio cafeeiro, resultando num fator de desenvolvimento regional. A região possui $38 \%$ da produção total do estado. É fundamental ressaltar que o café produzido pela região é o café arábica, conhecido também como café de altitude, contribuindo para que Minas Gerais se torne o maior produtor desse tipo de café, e responsável por 15,5 milhões de sacas de café (IBGE, 2007).

Silva; Santos; Lima nos lembram que existem fatores explicativos para essa evolução do processo agroindustrial do café nessa região. De acordo com pesquisadores que atuam nesse setor: "a existência de financiamento, assistência técnica, introdução de novas tecnologias, aumento das exportações, aumento dos preços internacionais e a renovação a cafeicultura via apoio governamental". Sendo assim o resultado é uma expansão da área plantada e um aumento da lucratividade do café no Sul de Minas, com destaque para a tecnologia, que foi de extrema importância para que a região se tornasse competitiva, com boa estrutura comercial, possibilitando que cooperativas trouxessem insumos para as áreas de produção do café.

Por ter um relevo acidentado, a cafeicultura no Sul de Minas é destacada pela "elevada densidade do trabalho nas operações de 
cultivo devido à impossibilidade topográfica de desenvolver uma agricultura mais mecanizada e poupadora de mão-de-obra" (VILELA; RUFINO, 2010, p. 9). A partir disso, Teixeira (2000, p. 186) diz que os produtores dessa região lidam com graus reduzidos de flexibilidade de ajustamento no uso de insumos, recursos financeiros e trabalho, nos curto e médio prazos, levando, pelo menos no curto prazo, à uma baixa elasticidade de substituição de trabalho por recurso financeiro.

Por apresentar uma região montanhosa, a região do café é mais voltada para cafés especiais, orgânicos e ecológicos do que nas regiões de relevo plano, como nas áreas do cerrado, a qual descreveremos mais adiante.

As cidades que apresentam maior produção são: Varginha, Pouso Alegre, Passos, Itajubá, São Sebastião do Paraíso, Santa Rita do Sapucaí, Andradas, Alfenas, Paraguassu, Três Corações, Três Pontas, Fama, Muzambinho e Guaxupé.

O café produzido na região tem características de corpo aveludado, acidez alta, adocicado, com notas de caramelo, chocolate, amêndoa, cítricas e frutadas.

Portanto o Sul de Minas é classificado como uma região característica do café, e possui uma rede produtiva tradicional da cultura, contendo cooperativas importantes como a COOXUPÉ, COOPARAíSO (Cooperativa Regional de Cafeicultores em São Sebastião do Paraíso Ltda.) a COCATREL (Cooperativa dos Cafeicultores da Zona de Três Pontas Ltda.), a Minasul (Cooperativa dos Agricultores Familiares de Poço Fundo e Região), dentre outras.

\subsection{REGIÃO DO TRIANGULO MINEIRO E ALTO PARANAÍBA}

A região do Triângulo Mineiro e Alto Paranaíba é formado pela união de 66 municípios, numa área de $90.545 \mathrm{~km}^{2}$ e conta com 2.279.478 habitantes, possuindo um PIB de $R \$ 63.507 .374,00$ (IBGE, 2012), formando assim uma das 12 mesorregiões do estado de Minas Gerais.

Saes; Jayo (1997), explicam que a região (que também é conhecida como Cerrado de Minas) possui estações bem definidas e altitudes entre 800 e 1000 metros, chuvas concentradas nos meses de setembro a abril, com índice pluviométrico que variam entre
1.200 e 1.800 milímetros anuais, favorecendo assim o cultivo do café e proporcionando maior qualidade ao produto final. Dos 66 municípios da mesorregião, 55 são produtores de café e juntos possuem cerca de 4.500 fazendas cafeicultoras dentro de uma área de 210 mil hectares, produzindo em média 35 sacas por hectare e totalizando 5 milhões de sacas por ano. Sendo responsável então por $12,7 \%$ da produção total brasileira e $25,4 \%$ da produção mineira (CAFÉ DO CERRADO, 2017).

Segundo Ortega; J. (2011), outro fator muito importante que contribui para a qualidade do café do cerrado é a questão da irrigação. Devido ao seu uso no momento da florada, foi possibilitado uma uniformização do amadurecimento dos frutos, o que favoreceu o uso de máquinas na colheita.

As maiores cidades produtoras de café são: Patrocínio, Monte Carmelo, Araguari, Carmo do Paranaíba, Rio Paranaíba, Coromandel, Serra do Salitre, Campos Altos, Patos de Minas e Perdizes.

O café produzido nessa área é em um terroir singular, com uma definição perfeita das estações climáticas, sendo o verão quente e úmido e inverno ameno seco, resultando num café com identidade única e alta qualidade, aroma intenso, com notas de caramelos e nozes, acidez delicada e cítrica, encorpado, sabor doce com notas de chocolate e finalização de longa duração. Essa forma de produção nessa área específica agrega valor ao produto e poder de negociação junto a mercados internacionais e nacionais, fazendo com que o mesmo seja reconhecido e exportado mundialmente.

No próximo tópico, abordaremos sobre os aspectos metodológicos do trabalho.

\section{ASPECTOS METODOLÓGICOS}

Para construirmos a base metodológica desse trabalho, foram utilizados dados de produção obtidos na Pesquisa Mensal Agrícola - PAM, através do Instituto Brasileiro de Geografia e Estatística - IBGE, referentes às regiões do Triangulo Mineiro, Alto Paranaíba e Sul de Minas onde coletamos dados de produção entre os anos de 2000 e 2016 das seguintes culturas: alho, arroz, batata inglesa, cana de açúcar, cebola, mandioca, milho, soja, sorgo, tomate, trigo, abacate, algodão, banana, café, laranja e maracujá. 
Os dados de exportação foram coletados através do Sistema IBGE de Recuperação Automática - SIDRA, que também é um banco de dados do IBGE, onde extraimos dados de exportação apenas da cultura de café, como o peso líquido, quantidade de sacas e o US\$ FOB movimentado entre o período de 2000 a 2016.

A próxima etapa se deu no software STATA, onde criamos as variáveis pcafe, ou seja, a porcentagem de produção de café sobre a produção agrícola total nesse período, e a variável tonelada, que se trata da divisão do peso líquido exportado de café por 1000 (que está em kilos). Assim, depois de determinar o avanço da produção e exportação de café das mesorregiões Triangulo Mineiro, Alto Paranaíba e Sul de Minas, fizemos o uso da Econometria Espacial, através dos comandos shp2dta e spmap para a construção dos mapas. Em outras palavras, escolhemos a aplicação de análise geográfica dos dados como metodologia. Para Neder (2011), o uso da Econometria Espacial para elaboração de mapas e compreensão das variáveis, proporciona um entendimento mais detalhado da realidade, visto que há dentro de uma mesorregião um alto grau de heterogeneidade.

Pisati (2014) mostra a funcionalidade do comando shp2dta, que foi desenvolvido por
Kevin Crow, como o conversor de arquivos shapefiles em pares de conjuntos de dados para o software Stata 13, pois ele atribui coordenadas geográficas para os dados. Por outro lado, o comando spmap criado por Pisati permite uma visualização de diversos tipos de análises de dados espaciais, fazendo com que eles sejam mostrados em forma de mapas temáticos.

Sendo assim, foi possível a construção de mapas que nos mostram a evolução da produção e exportação do café entre o período de 2000 e 2016 nas mesorregiões do Triangulo Mineiro, Alto Paranaíba e Sul de Minas

\section{RESULTADOS}

A partir dos dados obtidos através da Pesquisa Mensal Agrícola - PAM e do Sistema IBGE de Recuperação Automática - SIDRA elaborou-se tabelas que serão apresentadas a seguir.

A tabela 1 representa a produção de café no Brasil, Minas Gerais e Cerrado Mineiro entre os períodos de 2012 a 2015, e na tabela 2 temos a relação dos 20 municípios com maior produção de café no Cerrado Mineiro, respectivamente.

Tabela 1 - Produção de café - Brasil, Minas Gerais e cerrado mineiro - Entre os anos de 2012 a 2015

\begin{tabular}{|c|c|c|c|c|c|}
\hline \multirow[b]{2}{*}{ Localidade } & \multicolumn{5}{|c|}{ Período } \\
\hline & 2012 & 2013 & 2014 & 2015 & Média dos 4 Anos \\
\hline Brasil & RS $7.065 .362 .459,71$ & $\mathrm{RS} 4.809 .291 .838,53$ & RS $5.407 .950 .875,40$ & RS 3.873.113.617,95 & RS 5.288.929.697,90 \\
\hline Minas Gerais & RS 5.043.840.487,03 & RS 3.350.991.333,36 & RS 3.952.562.043,18 & RS 2.770.151.810,63 & RS 3.779.386.418,55 \\
\hline $\begin{array}{c}\text { Região do Cerrado } \\
\text { Mineiro }\end{array}$ & RS $1.244 .590 .474,24$ & RS $\quad 740.996 .431,39$ & RS $1.109 .678 .735,34$ & RS $\quad 571.499 .504,97$ & RS $916.691 .286,48$ \\
\hline
\end{tabular}

Fonte: elaborado pelo autor 
Tabela 2 - Municípios produtores de café no serrado brasileiro

\begin{tabular}{|c|c|c|c|c|c|c|c|}
\hline & 2012 & 2013 & 2014 & 2015 & $\begin{array}{l}\text { MEDIA DOS } 4 \\
\text { ANOS }\end{array}$ & $\begin{array}{c}\text { \% PRODUÇÃO EM } \\
\text { RELAÇÃO À REGIÃO DO } \\
\text { CERRADO }\end{array}$ & Posição \\
\hline PATROCÍNIO & R\$2 $212.460 .735,66$ & R\$ 113.138.527,14 & $\mathrm{R} \$ 201.835 .798,06$ & R\$ 82.207.554,53 & RS $152.410 .653,85$ & $16,63 \%$ & $1^{\circ}$ \\
\hline $\begin{array}{l}\text { SERRA DO } \\
\text { SALITRE }\end{array}$ & $\mathrm{R} \$ 125.325 .625,42$ & R\$ 46.887.426,43 & $\mathrm{R} \$ 93.756 .586,78$ & R\$ $33.710 .059,70$ & R\$ 74.919.924,58 & $8,17 \%$ & $2^{\circ}$ \\
\hline MONTE CARMELO & R\$ 95.385.992,74 & $\mathrm{R} \$ 51.728 .229,13$ & $\mathrm{R} \$ 86.837 .072,92$ & $\mathrm{R} \$ 31.353 .994,78$ & $\mathrm{R} \$ 66.326 .322,39$ & $7,24 \%$ & $3^{\circ}$ \\
\hline ARAGUARI & R\$ 81.389.983,12 & R\$ 49.890.160,82 & $\mathrm{R} \$ 80.638 .279,79$ & $\mathrm{R} \$ 35.976 .718,37$ & R\$ 61.973.785,52 & $6,76 \%$ & $4^{\circ}$ \\
\hline RIO PARANAÍBA & $\mathrm{R} \$ 87.412 .902,24$ & \begin{tabular}{|l|} 
R\$ 39.333.549,61 \\
\end{tabular} & R\$ 62.347.016,83 & R\$ 30.862.860,40 & \begin{tabular}{|l|} 
RS 54.989.082,27 \\
\end{tabular} & $6,00 \%$ & $5^{\circ}$ \\
\hline $\begin{array}{l}\text { CARMO DO } \\
\text { PARANAÍBA }\end{array}$ & $\mathrm{R} \$$ 66.331.917,94 & $\mathrm{R} \$ 41.851 .045,09$ & $\mathrm{R} \$ 50.218 .850,93$ & $\mathrm{R} \$ 31.585 .010,95$ & $\mathrm{R} \$ 47.496 .706,23$ & $5,18 \%$ & $6^{\circ}$ \\
\hline CAMPOS ALTOS & R\$ 55.332.276,05 & $\mathrm{R} \$ 37.228 .993,84$ & $\mathrm{R} \$ 46.745 .707,97$ & $\mathrm{R} \$ 38.936 .125,53$ & $\mathrm{R} \$ 44.560 .775,85$ & $4,86 \%$ & $7^{\circ}$ \\
\hline COROMANDEL & R\$ 55.996.316,57 & $\mathrm{R} \$ 36.513 .880,52$ & $\mathrm{R} \$ 45.690 .124,09$ & $\mathrm{R} \$ 36.551 .558,61$ & R\$ 43.687.969,95 & $4,77 \%$ & $8^{\circ}$ \\
\hline PERDIZES & R\$ 44.829.897,17 & R\$27.964.035,78 & $\mathrm{R} \$ 44.763 .725,99$ & $\mathrm{R} \$ 25.645 .795,21$ & $\mathrm{R} \$ 35.800 .863,54$ & $3,1 \%$ & $9^{\circ}$ \\
\hline PATOS DE MINAS & $\mathrm{R} \$ 38.782 .421,86$ & R\$ 34.759.234,37 & $\mathrm{R} \$ 30.107 .513,17$ & R\$ 24.449.911,49 & R\$32.024.770,22 & $3,49 \%$ & $10^{\circ}$ \\
\hline UNAI & $\mathrm{R} \$ 31.681 .076,38$ & R\$21.169.764,10 & $\mathrm{R} \$ 39.983 .001,87$ & $\mathrm{R} \$ 26.501 .755,12$ & R\$29.833.899,37 & $3,25 \%$ & $11^{\circ}$ \\
\hline ROMARIA & $\mathrm{R} \$ 35.453 .010,69$ & $\mathrm{R} \$ 22.628 .261,57$ & $\mathrm{R} \$ 37.060 .173,38$ & $\mathrm{R} \$ 11.749 .122,44$ & $\mathrm{R} \$ 26.722 .642,02$ & $2,92 \%$ & $12^{\circ}$ \\
\hline $\begin{array}{l}\text { PRESIDENTE } \\
\text { OLEGÁRIO }\end{array}$ & $\mathrm{R} \$ 29.518 .084,62$ & R\$ 21.173.935.21 & $\mathrm{R} \$ 23.266 .615,67$ & $\mathrm{R} \$ 12.909 .303,65$ & $\mathrm{R} \$ 21.716 .984,79$ & $2,37 \%$ & $13^{\circ}$ \\
\hline INDIANOPOLIS & R\$ 26.189.185,04 & R\$ $15.715 .345,04$ & $\mathrm{R} \$ 28.958 .014,62$ & $\mathrm{R} \$ 10.584 .740,93$ & $\mathrm{R} \$ 20.361 .821,41$ & $2,22 \%$ & $14^{\circ}$ \\
\hline IBIA & $\mathrm{R} \$ 17.091 .113,73$ & R\$ 16.325.253,74 & $\mathrm{R} \$ 20.079 .041,31$ & $\mathrm{R} \$ 15.008 .550,60$ & R\$ 17.125.989,84 & $1,87 \%$ & $15^{\circ}$ \\
\hline MEDEIROS & $\mathrm{R} \$ 22.827 .543,87$ & R\$ 13.328.080,83 & $\mathrm{R} \$ 13.921 .468,64$ & R\$9.347.154,30 & R\$ 14.856.061,91 & $1,62 \%$ & $16^{\circ}$ \\
\hline BAMBUI & $\mathrm{R} \$ 17.749 .526,78$ & R\$ 11.926.125,04 & $\mathrm{R} \$ 13.058 .813,53$ & R\$ 8.979.928,60 & R\$ $12.928 .598,49$ & $1,41 \%$ & $17^{\circ}$ \\
\hline $\begin{array}{l}\text { SANTA ROSA DA } \\
\text { SERRA }\end{array}$ & $\mathrm{R} \$ 18.185 .910,88$ & $\mathrm{R} \$ 11.637 .391,67$ & $\mathrm{R} \$ 13.207 .547,17$ & $\mathrm{R} \$ 6.014 .821,04$ & $\mathrm{R} \$ 12.26$ & $1,34 \%$ & $18^{\circ}$ \\
\hline PARACATU & $\mathrm{R} \$ 14.235 .432,55$ & $\mathrm{R} \$ 8.790 .842,10$ & $\mathrm{R} \$ 13.309 .535,95$ & R\$ 5.141.159,88 & RS 10.369.242,62 & $1,13 \%$ & $19^{\circ}$ \\
\hline JOÃO PINHEIRO & \begin{tabular}{|l|}
$R \$ 11.601 .780,32$ \\
\end{tabular} & R\$ $10.872 .688,51$ & $\mathrm{R} \$ 11.898 .266,19$ & \begin{tabular}{|l|}
$\mathrm{R} \$ 7.085 .295,97$ \\
\end{tabular} & RS $10.364 .507,75$ & $1,13 \%$ & $20^{\circ}$ \\
\hline
\end{tabular}

Fonte: elaborado pelo autor

A tabela 2 também nos mostra a classificação de cada município em relação a sua produção de café, além do seu porte em relação a arrecadação total da região do Cerrado. De um total de 55 municípios exportadores de café, foram extraídos 20 que possuem a maior produção em dólares (US\$). Juntos, esses 20 municípios são responsáveis por $86 \%$ da arrecadação total da região do cerrado mineiro. Portanto, ao analisarmos as tabelas 1 e 2, podemos identificar que a produção cafeeira na região do cerrado mineiro compreende $17,33 \%$ da produção brasileira e 24,26\% da produção de Minas Gerais. Podemos notar a expressividade da produção cafeeira na cidade de Patrocínio com 16,63\% da produção total da região.

Feito a seleção dos municípios que possuem a maior relevância no quesito produção de café, foi necessário a tabulação dos dados para verificar a exportação total de cada município nos quatro anos, bem como traçar o principal produto no quesito exportação de cada município. Dessa forma, a partir da tabela 3 podemos identificar que apesar de possuírem representatividade no quesito produção cafeeira na região, apenas 5 dos 20 selecionados possuem o café como principal produto exportado nos quatros anos analisados, que são os municípios de Patrocínio, Monte Carmelo, Coromandel, Carmo do Paranaíba e Perdizes. Também verificou-se que em cinco municípios não houve exportações nos anos entre 2012 a 2015, são eles: Romaria, Serra do Salitre, Presidente Olegário, Santa Rosa da Serra e Medeiros. Então, podemos afirmar que apesar do café ser uma cultura forte na região, os produtos que são exportados são bem diversificados. 
Tabela 3 - Principal produto exportado por município (U\$) de 2012 a 2015

\begin{tabular}{|c|c|c|c|c|c|c|c|c|c|c|c|c|}
\hline & \multicolumn{3}{|c|}{2012} & \multicolumn{3}{|c|}{2013} & \multicolumn{3}{|c|}{2014} & \multicolumn{3}{|c|}{2015} \\
\hline & \begin{tabular}{|c|} 
Total \\
exportado
\end{tabular} & Produto & \begin{tabular}{|c}
$\begin{array}{c}\text { Valor em } \\
\text { USS }\end{array}$ \\
\end{tabular} & \begin{tabular}{|c|} 
Total \\
exportado
\end{tabular} & Produto & \begin{tabular}{|c|}
$\begin{array}{c}\text { Valor em } \\
\text { USS }\end{array}$ \\
\end{tabular} & \begin{tabular}{|c|} 
Total \\
exportado
\end{tabular} & Produto & \begin{tabular}{|c} 
Valor em \\
USS \\
\end{tabular} & $\begin{array}{c}\text { Total } \\
\text { exportado }\end{array}$ & Produto & \begin{tabular}{|c|} 
Valor em \\
USS \\
\end{tabular} \\
\hline PATROCÍNIO & 184.260 .951 & Café & 166.373 .355 & 236.653 .057 & Café & 195.514 .341 & 269.176 .418 & Café & 240.026 .432 & 282.722 .344 & Café & 238.005 .742 \\
\hline PARACATU & 757.381 .340 & Ouro & 580.087 .214 & 761.657 .602 & Ouro & 386.485 .825 & 659.204 .917 & Ouro & 643.082 .092 & 569.502 .903 & Ouro & 546.992 .545 \\
\hline ARAGUARI & 408.471 .286 & Cames & 110.802 .193 & 500.150 .574 & Carnes & 135.905 .177 & 413.661 .879 & Café & 116.663 .048 & 363.653 .500 & Café & 97.522 .313 \\
\hline UNAÍ & 72.162 .822 & Soja & 59.427 .841 & 57.762 .011 & Soja & 50.186 .345 & 41.488 .994 & Soja & 37.663 .604 & 77.425 .003 & Soja & 67.622 .498 \\
\hline $\begin{array}{c}\text { JOÃO } \\
\text { PINHEIRO } \\
\end{array}$ & 93.634 .533 & $\begin{array}{l}\text { Açucar } \\
\text { de cana }\end{array}$ & 93.634 .533 & 116.309 .666 & $\begin{array}{l}\text { Açucar } \\
\text { de cana }\end{array}$ & 107.019 .270 & 78.941 .023 & $\begin{array}{c}\text { Açucar de } \\
\text { cana }\end{array}$ & 77.791 .023 & 61.633 .189 & \begin{tabular}{|c|} 
Açucar de \\
cana
\end{tabular} & 52.777 .392 \\
\hline $\begin{array}{l}\text { CARMO DO } \\
\text { PARANAÍBA }\end{array}$ & 47.191 .551 & Café & 47.191 .551 & 32.300 .444 & Café & 32.300 .444 & 37.950 .046 & Café & 37.950 .046 & 56.776 .398 & Café & 56.776 .398 \\
\hline $\begin{array}{c}\text { PATOS DE } \\
\text { MINAS } \\
\end{array}$ & 17.377 .301 & Café & 4.316 .661 & 15.909 .791 & $\begin{array}{l}\text { Farinha } \\
\text { Animal } \\
\end{array}$ & 7.171 .569 & 26.485 .268 & Farinha & 7.343 .566 & 24.853 .482 & Farinha & 8.587 .908 \\
\hline COROMANDEL & 7.442 .176 & Café & 7.442 .176 & 9.030 .420 & Café & 9.030 .420 & 15.692 .050 & Café & 9.692 .050 & 10.546 .421 & Café & 7.947.213 \\
\hline IBIÁ & 7.002 .900 & Soja & 7.002 .900 & 9.501 .540 & Soja & 9.501 .540 & 7.571 .113 & Soja & 7.571 .113 & 7.968 .100 & Soja & 7.943 .602 \\
\hline BAMBUÍ & 2.724 .717 & $\begin{array}{l}\text { Produto } \\
\text { Animal } \\
\end{array}$ & 2.710 .017 & 3.225 .435 & $\begin{array}{r}\text { Produto } \\
\text { Animal } \\
\end{array}$ & 3.208 .515 & 2.383 .793 & $\begin{array}{c}\text { Produtos } \\
\text { comestiveis } \\
\end{array}$ & 2.361 .185 & 1.833 .488 & $\begin{array}{c}\text { Produtos } \\
\text { comestiveis }\end{array}$ & 1.832 .088 \\
\hline $\begin{array}{c}\text { RIO } \\
\text { PARANAÍBA }\end{array}$ & 0 & - & 0 & 0 & - & 0 & 281.255 & Frutas & 281.255 & 1.138 .771 & Frutas & 1.121 .671 \\
\hline INDIANÓPOLIS & 0 & - & 0 & 7.882 & Café & 7.882 & 2.655 & Café & 2.655 & 87 & $\begin{array}{l}\text { Produtos } \\
\text { vegetais }\end{array}$ & 87 \\
\hline PERDIZES & 508.160 & Café & 508.160 & 341.624 & Café & 341.624 & 0 & - & 0 & 0 & - & 0 \\
\hline $\begin{array}{c}\text { MONTE } \\
\text { CARMELO }\end{array}$ & 48.662 .619 & Café & 48.662 .619 & 14.032 .139 & Café & 14.032 .129 & 3.550 .951 & Café & 3.550 .951 & 0 & - & 0 \\
\hline
\end{tabular}

Fonte: elaborado pelo autor

Definindo o principal produto exportado por município, foi analisada a porcentagem de exportação de café em relação a exportação total. Com este levantamento foi possível identificar, com base na tabela 4, que apenas sete municípios exportam café e que cinco deles tem suas economias voltadas principalmente para a produção cafeeira (Patrocínio, Monte Carmelo, Coromandel, Carmo do Paranaíba e Perdizes) com valores de exportação de café acima de $80 \%$ da sua exportação total nos quatros anos.

É possível analisar também, através da tabela 4, que Patos de Minas apesar de ser o principal município dessa região, em questão de PIB, possui pequena inserção internacional apesar de sua economia girar através de produção de bens e prestação de serviços. 
Tabela 4 - Exportação de café por município

\begin{tabular}{|c|c|c|c|c|c|c|c|c|}
\hline & \multicolumn{2}{|c|}{2012} & \multicolumn{2}{|c|}{2013} & \multicolumn{2}{|c|}{2014} & \multicolumn{2}{|c|}{2015} \\
\hline & $\begin{array}{c}\text { VALOR } \\
\text { EXPORTADO }\end{array}$ & $\begin{array}{l}\begin{array}{l}\text { \% em relação a } \\
\text { exportação total }\end{array} \\
\end{array}$ & $\begin{array}{c}\text { VALOR } \\
\text { EXPORTADO }\end{array}$ & \begin{tabular}{|l|} 
\% em relação a \\
exportação total
\end{tabular} & $\begin{array}{c}\text { VALOR } \\
\text { EXPORTADO }\end{array}$ & \begin{tabular}{|l|} 
\% em relação a \\
exportação total
\end{tabular} & \begin{tabular}{|c|} 
VALOR \\
EXPORTADO \\
\end{tabular} & $\begin{array}{l}\text { \% em relação a } \\
\text { exportação total }\end{array}$ \\
\hline PATROCÍNIO & $\$ 166.373 .355,00$ & $90,29 \%$ & \$ $195.514 .341,00$ & $82,62 \%$ & \$ $240.026 .432,00$ & $89,17 \%$ & \$ $238.005 .742,00$ & $84,18 \%$ \\
\hline ARAGUARI & $\$ \quad 86.760 .318,00$ & $21,24 \%$ & \$ $108.786 .224,00$ & $21,75 \%$ & S $116.663 .048,00$ & $28,20 \%$ & $\begin{array}{lr} & 97.522 .313,00 \\
\end{array}$ & $26,82 \%$ \\
\hline $\begin{array}{c}\text { MONTE } \\
\text { CARMELO }\end{array}$ & \$ $\quad 48.662 .619,00$ & $100,00 \%$ & $\$ \quad 14.032 .129,00$ & $100,00 \%$ & $3.550 .951,00$ & $100,00 \%$ & 0 & $0,00 \%$ \\
\hline $\begin{array}{l}\text { CARMO DO } \\
\text { PARANAÍBA }\end{array}$ & $\$ \quad 47.191 .551,00$ & $100,00 \%$ & $\$ \quad 32.300 .444,00$ & $100,00 \%$ & S $\quad 37.950 .046,00$ & $100,00 \%$ & S $\quad 56.776 .398,00$ & $100,00 \%$ \\
\hline IBIÁ & $7.002 .900,00$ & $100,00 \%$ & $9.501 .540,00$ & $100,00 \%$ & 0 & $0,00 \%$ & 0 & $0,00 \%$ \\
\hline $\begin{array}{l}\text { PATOS DE } \\
\text { MINAS } \\
\end{array}$ & $4.316 .661,00$ & $24,84 \%$ & $3.137 .543,00$ & $19,72 \%$ & $6.557 .341,00$ & $24,76 \%$ & $5.156 .900,00$ & $0,75 \%$ \\
\hline PERDIZES & $508.160,00$ & $100,00 \%$ & $341.624,00$ & $100,00 \%$ & 0 & $0,00 \%$ & 0 & $0,00 \%$ \\
\hline
\end{tabular}

Fonte: elaborado pelo autor

Indo em direção contrária ao que foi visto nas tabelas 2, 3 e 4, podemos notar que 0 município de Patrocínio exporta mais do que produz, e o mesmo acontece com o município de Araguari. Também podemos notar o inverso, há municípios que produzem muito café e que, ou não exportam nada de café ou a exportação de café é bem menor que a produção total, que é o caso das cidades de Serra do Salitre, Rio Paranaíba, Ibiá, Coromandel, Monte Carmelo, Presidente Olegário, Romaria, Unaí, Paracatu, Indianópolis, Medeiros, Patos de Minas, Santa Rosa, João Pinheiro, Bambuí. Em contrapartida, o município de Carmo do Paranaíba mostrou que quase toda sua produção foi exportada.

Sendo assim, pelo fato de Patrocínio ter exportado muito mais café do que produz e alguns municípios vizinhos terem uma produção significativa, porém sem exportação de café, podemos levantar a hipótese que
Patrocínio é um polo-exportador, ou seja, a produção das cidades vizinhas pode estar escoando para lá. Isso pode ser dado devido alguns fatores, como o reconhecimento de Patrocínio como cidade do café; a facilidade de comercialização na cidade; a facilidade de escoação através da logística pela linha férrea; os melhores preços, entre outros fatores que sustentam essa tese. É possível que isso também ocorra com Araguari.

Passando para a análise comparativa da produção e exportação de café entre as regiões do Triângulo Mineiro/Alto Paranaíba (Cerrado Mineiro) e Sul de Minas, utilizou-se também os dados obtidos através da Pesquisa Mensal Agrícola - PAM e do Sistema IBGE de Recuperação Automática - SIDRA, e elaborou-se tabelas que foram posteriormente usadas no software Stata que, através dos comandos shp2dta e spmap, foram transformados no mapa abaixo.

Figura 2 - Percentual de Produção Cafeeira do Triângulo Mineiro/Alto Paranaíba e Sul de Minas entre os períodos de 2000 - 2016

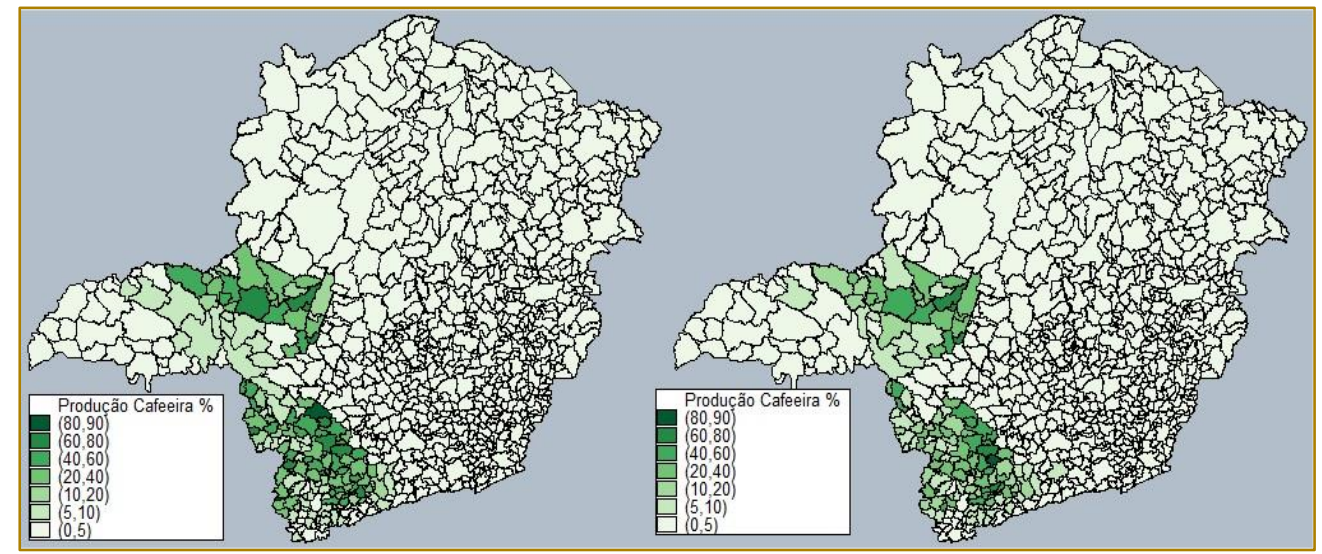

Fonte: Elaborado pelo autor 
Analisando o mapa acima, observamos que em 2016 a proporção de café plantado sobre a área agrícola total chegou em índices elevados em alguns municípios das regiões do Triângulo Mineiro/Alto Paranaíba e Sul de Minas. Em no Triângulo Mineiro, 5 municípios tiveram essa proporção entre 50 e 79\%. Já no Sul de Minas, 11 municípios tiveram essa proporção entre 50 e $79 \%$ e 3 municípios com índices acima de $80 \%$. São eles os municípios de Varginha (80\%), Ibitiúra de Minas (86\%) e Albertina (98\%).

Comparado com o ano base da coleta de dados o Triangulo Mineiro diminuiu sua área de plantação de café ao longo dos anos. Em
2000 a área plantada total de café na mesorregião girava em torno de $14 \%$ enquanto que em 2016 esse número passou pra menos de 12\%. Andrade J.J. (2017) explica que na mesorregião houve um incremento no setor agrícola, destacando algumas culturas devido à sua crescente e valorizada produção, como a soja e a cana de açúcar, pois a mesorregião apresenta condições necessárias para o cultivo dessas lavouras, dado pelo relevo com recorte espacial e de fácil implementação de recursos mecanizados, além de possuir clima, iluminação solar e boa relação do solo para o crescimento da produção.

Figura 3 - Exportação de Café Sobre a Produção Agrícola Total entre os períodos de 2000 - 2016

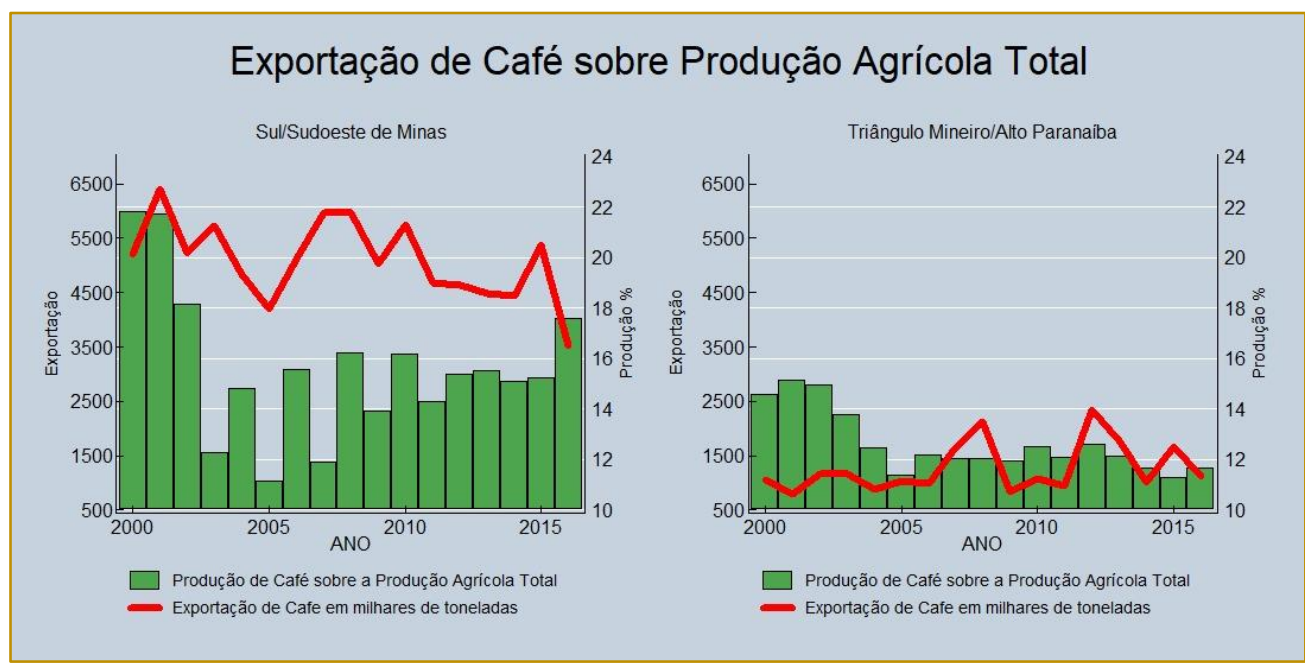

Fonte: elaborado pelo autor

Analisando a exportação sobre a produção cafeeira em relação a produção agrícola total, podemos ver que o Sul de Minas exporta mais do que é produzido, isso se dá devido ao fato da existência das importantes cooperativas localizadas nessa mesorregião, que recebem o café produzido de outras áreas, como o Triangulo Mineiro/Alto Paranaíba, e exportam para outros países. A Cooxupé e a Cocatrel são exemplos dessas cooperativas.

Também podemos ver que a exportação sofreu uma redução no período de 2003 a 2005, tanto no Triângulo Mineiro/Alto Paranaíba quanto no Sul de Minas, devido a baixa produção do período. A baixa produção pode ser explicada pela "péssima condição climática, da bianualidade da lavoura alternância anual de alta e baixa produção - e do preço. O Sul do Estado, responsável por $50 \%$ da produção, será a região mais atingida, devido ao longo período de chuva registrado este ano. No Triângulo Mineiro o recuo estimado na produção é de $22 \%$, já que a região não foi muito atingida pelas chuvas." (DCl, 2004). Já nos anos seguintes a produção e exportação voltou a aumentar, mesmo havendo quedas que são causadas pela bianualidade.

\section{CONCLUSÃO}

O presente trabalho buscou analisar a produção e exportação de café no Triângulo Mineiro/Alto Paranaíba (Cerrado Mineiro) e Sul de Minas, e além disso, estudar o perfil exportador do Cerrado Mineiro, as vinte cidades da região que possuem maior representatividade na produção de café, a relevância da exportação de café da região e 
mapear possíveis municípios poloexportadores.

Portanto, se tratando do estudo exportador do Cerrado Mineiro, na análise da exportação de café entre os períodos de 2012 a 2015 observou-se que as exportações do Cerrado Mineiro representaram 17,33\% da produção brasileira e 24,26\% da produção de Minas Gerais, além de mostrar também quais são as vinte cidades da região que possuem a maior representatividade no quesito produção de café. São elas: Patrocínio, Serra do Salitre, Monte Carmelo, Araguari, Rio Paranaíba, Carmo do Paranaíba, Campos Altos, Coromandel, Perdizes, Patos de Minas, Unaí, Romaria, Presidente Olegário, Indianópolis, Ibiá, Medeiros, Bambuí, Santa Rosa da Serra, Paracatu e João Pinheiro.

A partir das análises, verificou-se que o município de Patrocínio é um polo exportador. Isso se dá devido ao fato do expressivo volume de grãos de café exportado pela cidade, que chega a superar a própria produção.

Portanto, pode-se concluir que o café é uma cultura importante e base para a economia de muitos municípios para a região do Cerrado Mineiro, porém, quando comparado com a produção nacional e com a região do Sul de

\section{NOTAS}

1 - Terroir (palavra de origem francesa que significa "solo") é o conjunto de características especiais que a geografia, geologia e o clima de um determinado lugar, interagindo com a genética da planta, expressam em forma de sabor e aroma em produtos agrícolas como: vinho, café, chocolate, tomate, etc.

\section{REFERÊNCIAS}

[1]. ABIC - Associação Brasileira da Indústria de Café. Disponível em: <http://abic.com.br/cafecom/historia/> Acesso em: 20 mar. 2018

[2]. ANDRADE, J. J. et al. Potencial de Geração de Biocombustíveis: Um estudo da Mesorregião Triangulo Mineiro e Alto Paranaíba. In: Encontro Nacional da Sociedade Brasileira de Economia Ecológica, 2017, Uberlândia - MG. Economia Ecológica Institucionalidade em Tempos de Crise, 2017

[3]. BACEN - Banco Central. Disponível em $<$ http://www4.bcb.gov.br/pec/taxas/port/ptaxnpesq
Minas, percebe-se que o percentual de participação é menor.

Em relação ao objetivo geral do trabalho, trabalhou-se com a hipótese de provar o porquê de o Triângulo Mineiro/Alto Paranaíba exportar mais mesmo tendo uma produção consideravelmente menor do que o Sul de Minas, porém, após a coleta e análise de dados, a hipótese foi rejeitada.

Como vimos anteriormente através dos mapas e gráficos o Sul de Minas produz e exporta mais do que o Triangulo Mineiro/Alto Paranaíba e isso se deve em sua grande parte pelo maior foco que essa mesorregião tem na produção de café.

O Triângulo Mineiro/Alto Paranaíba tem maior diversidade de culturas produtivas, fazendo com que sua produção de café não seja tão elevada como a do Sul de Minas.

As cooperativas têm um importante papel nesse cenário da agricultura cafeeira do Sul de Minas, visto que elas funcionam como uma agroindústria, um intermediário entre o agricultor e o mercado, que exige elevado padrão de qualidade difícil de ser alcançado com poucos recursos, fazendo com que a região se torne a maior exportadora dessa commodity.

2 - A sigla FOB significa free on board e em português pode ser traduzida por "Livre a bordo". Neste tipo de frete, o comprador assume todos os riscos e custos com o transporte da mercadoria, assim que ela é colocada a bordo do navio. Por conta e risco do fornecedor fica a obrigação de colocar a mercadoria a bordo, no porto de embarque designado pelo importador.

.asp? $\mathrm{id}=\mathrm{t}$ xcotacao\&id=txcotacao $>$ Acesso em: 20 mar. 2018

[4]. CAFE DO CERRADO. Dados da Região. Disponível em < http://www.cafedocerrado.org/index.php?pg=regia o> Acesso em: 13 mar. 2018.

[5]. CEPEA - ESALQ/USP. PIB do Agronegócio Brasileiro. Disponível em < https://www.cepea.esalq.usp.br/br/pib-doagronegocio-brasileiro.aspx > Acesso em: 20 mar. 2018

[6]. COMPANHIA NACIONAL DE ABASTECIMENTO. Quarto levantamento de café 
safra 2010 - dezembro 2010. Disponível em <www.conab.br> Acesso em: 10 mar. 2018.

[7]. DCl - Diário Comércio Industria e Serviços. Federação de Minas prevê queda de 30\% na produção de café. Disponível em $<$ https://www.dci.com.br/agronegocios/federac-ode-minas-preve-queda-de-30-na-produc-o-decafe-1.44343> Acesso em: 20 mar. 2018.

[8]. DO VAlE, A. R.; CALDERARO, Rodrigo Alexandre Pereira; FAGUNDES, Francielly Naves. A cafeicultura em Minas Gerais: estudo comparativo entre as regiões Triângulo Mineiro/Alto Paranaíba e Sul/Sudoeste/. Campo-Território: Revista de Geografia Agrária, v. 9, n. 18, 2014.

[9]. GOMES, M. F. M.; ROSADO, P. L. Mudança na produtividade dos fatores de produção da cafeicultura nas principais regiões produtoras do Brasil. Revista de Economia e Sociologia Rural, v. 43, n. 4, p. 633-654, 2005.

[10]. MARTINS, A. L. História do café. Editora Contexto, 2012

[11]. MATIELLO, J. B. et al. Cultura de Café no Brasil: novo manual de recomendações. Rio de Janeiro; Varginha: Ministério da Agricultura, da Pecuária e do Abastecimento - SARC; PROCAFÉSPAE; DECAF, 2005. 438 p.

[12]. SAES, M. S. M.; JAYO, M. CACCER: Coordenando ações para a valorização do café do cerrado. In: SEMINARIO INTERNACIONAL PENSA DE AGRIBUSINESS, 7, PENSA/FIA/USP, 1997. Disponível em $<$ www.fundacaofia.com.br/pensa/anexos/biblioteca /1552008163143_texto.pdf> Acesso em: 13 mar. 2018

[13]. SILVA, S. M.; SANTOS, A. C.; LIMA, J. B. Competitividade do agronegócio do café na região Sul de Minas Gerais. Organizações Rurais e
Agroindustriais. Lavras: UFLA, v. 3, n. 1, (não há páginas) jan./jun./2001. Disponível em: <revista.dae.ufla.br/index.php/ora/article/viewArticl e/276>. Acesso em: 13 mar. 2018.

[14]. SREENATH, H. L. Biotechnology for genetic improvement of Indian Coffee. In: INTERNATIONAL SEMINAR ON BIOTECHNOLOGY IN THE COFFEE AGROINDUSTRY, 3., 1999, Londrina. Proceedings... LONDRINA: IAPAR/IRD, 2000. p. 247-250.

[15]. TEIXEIRA, T. D. Política estratégica para a cafeicultura brasileira. In: SIMPÓSIO DE PESQUISA DOS CAFÉS DO BRASIL, I., 2000. Poços de Caldas. Anais... Brasília: Embrapa Café MINASPLAN, 2000. p. 169-193. Disponível em: $<$ www.sbicafe.ufv.br/handle/10820/24>. Acesso em: 13 mar. 2018.

[16]. VILELA, P. S.; RUFINO, J. L. S. (Org) Caracterização da cafeicultura de montanha de Minas Gerais. Belo Horizonte: INAES, 2010 (Estudos INAES. Cadeias Produtivas de Café; 1). Disponível em: $<$ www.inaes.org.br/publica/Livro_cafeicultura_de_ montanha.pdf>. Acesso em: 13 mar. 2018.

[17]. ORTEGA, A. C.; JESUS, C. M. Território café do Cerrado: transformações na estrutura produtiva e seus impactos sobre o pessoal ocupado. Revista de Economia e Sociologia Rural, v. 49, n. 3 , p. $771-800,2011$

[18]. NEDER, H. Análise de Políticas Sociais. No prelo. 2011. Disponível em: <http://www.ecn26.ie.ufu.br/TEXTOS_ESTATISTICA /ANALISE_POLITICAS_SOCIAIS.pdf> Acesso em: 16 mar. 2018

[19]. PISATI, $M$. et al. The $A$ to $Z$ of how to create thematic maps of Italy using spmap. In: Italian Stata Users' Group Meetings 2014. Stata Users Group, 2014. 


\section{Gapítulo 21}

\section{IMPACTO DA MECANIZACẼ̃O NA QUALIDADE DE EMPREGO NA CULTURA DO CAFÉ MEDIDO A PARTIR DOS INDICADORES DE QUALIDADE DO EMPREGO (IQE).}

\section{Fábio André Teixeira}

Antônio Marcos de Queiroz

Ricardo Freitas Martins da Costa

Walter Luiz dos Santos Júnior

Joabe Santos Sousa

Resumo: A produção de café é uma considerável fonte para gerar riqueza e trabalho na economia brasileira, sendo este produto parte importante do agronegócio e também um produto que leva o nome do Brasil internacionalmente. A medida que novas tecnologias são desenvolvidas, são possibilitadas formas mais eficientes de produção, seja com melhoramento genético, com técnicas de plantio, defensivos para controle de praga e máquinas agrícolas. Quando a produção agrícola aumenta a taxa de mecanização, uma nova relação de emprego é criada, dispensado a necessidade de mão de obra para a colheita manual e exigindo mão de obra para operar as novas máquinas, logo, ocorrerá um efeito sobre os índices de empregabilidade e consequentemente afetando a qualidade de emprego tanto da mão de obra qualificada e da não qualificada. Tais modificações impactam diretamente a forma como se administra a empresa rural uma vez que mais recursos devem ser dispensados na implementação de novas tecnologias. Este trabalho tem como objetivo relacionar o impacto que a crescente mecanização da lavoura do café traz para a qualidade de vida da mão de obra, seja qualificada ou não qualificada. Ao analisar os dados disponibilizados pelo IBGE nos censos demográficos de 1991, 2000 e 2010 nos estados de Minas Gerais, São Paulo e Paraná, pode-se perceber que há um aumento da mão de obra qualificada, porém utilizando o Indicador de Qualidade do Emprego (IQE), é visto que o aumento da qualificação, trazido pela mecanização, nem sempre se traduz em melhor qualidade de emprego para o trabalhador.

Palavras-chave: Indicadores de qualidade (IQE's); qualificação; agronegócio; mão de obra; mecanização 


\section{INTRODUÇÃO}

A interação do homem com a tecnologia é uma das características mais importantes na era pós-moderna. É notável como o desenvolvimento tecnológico, através do desenvolvimento de novas máquinas, tecnologia da informação, de ferramentas da telecomunicação, entre outras, contribui para o desenvolvimento de diversos setores como a comunicação, mercado financeiro, educação, agronegócios, entre outros.

No agronegócio, desde técnicas apropriadas de manejo do solo até máquinas para plantio e colheita, o desenvolvimento tecnológico traz muitos ganhos na produção agrícola, baixando custos, aumentando produtividade e a quantidade de informação sobre a produção, assim facilitando a tomada de decisão.

No caso da agricultura cafeicultura, esta vem se modernizando a medida que vai aumentado o número de máquinas utilizadas, principalmente na sua colheita, trazendo alguns dos benefícios como os citados acima, porém a mecanização da lavoura exige uma contrapartida, com máquinas mais complexas é necessário a mão de obra mais qualificada para manejá-las. Neste caso, é esperado uma diminuição no número de empregados não qualificados e um aumento nos qualificados, porém a troca não ocorre de forma uniforme, porque uma colhedeira, por exemplo, substitui inúmeros trabalhadores não qualificados e contrata poucos qualificados, assim influenciando o índice de empregabilidade e de distribuição de renda do país, devido a importância do agronegócio e desta cultura em específico na economia brasileira.

Quando um trabalhador se qualifica é esperado que algumas variáveis como renda, formalização e educação também melhorem. $\mathrm{Na}$ cultura do café, tem-se percebido um aumento no número de colhedeiras em substituição à colheita manual. Contudo, o questionamento que se faz é se a mecanização, observada ao longo de 20 anos, afeta diretamente a qualidade do emprego do trabalhador, qualificado ou não qualificado, na cultura de café? Em complementação, o objetivo geral deste estudo foi analisar a qualidade do emprego da mão de obra qualificada e não qualificada na cultura de café, por meio do cálculo do Índice de Qualidade do Emprego (IQE), a partir do aumento da mecanização.
Partindo deste objetivo inicial, o trabalho tenta definir, de forma específica, se há diferença entre a qualidade de emprego entre qualificados e não qualificados, traçar a evolução deste índice ao longo do tempo, denotar se a mecanização realmente se traduz em qualidade de emprego e por último, analisar como as variáveis de renda, educação e formalização do emprego se comportam ao longo de 20 anos, a partir dos censos demográficos.

A partir de microdados do IBGE dos censos de 1991, 2000 e 2010 é feita a análise dos indicadores que afetam a qualidade do emprego em estados brasileiros que se destacam na produção do café, sendo esses, Minas Gerais, Paraná e São Paulo.

Este trabalho, que propõe a discussão sobre o impacto da mecanização no café e seu impacto na qualidade do emprego, divide-se em quatro partes: a introdução, contendo a problematização e contextualização dos impactos da mecanização e seus afeitos sobre a mão de obra; em um segundo momento, o referencial teórico, que procura explicar conceitos relacionados a qualificação da mão de obra, mecanização e importância economia do café no agronegócio brasileiro; em um terceiro momento, a metodologia, explicando como será análise quantitativa, usando indicadores de renda, formalização do emprego e educação, para analisar a qualidade do emprego e, por último, as considerações finais, ponderando sobre os resultados encontrar a partir da análise dos dados.

\section{EVOLUÇÃO DA QUALIFICAÇÃO DO TRABALHADOR E OS EFEITOS DA MECANIZAÇÃO}

A vinculação entre educação, qualificação profissional e produtividade é algo contemplado na literatura econômica desde que o conhecimento em economia se apropria da importância da relação entre qualidade da força de trabalho, produtividade e lucro no capitalismo.

Uma conclusão importante desse estudo é a de que a automatização não redunda inevitàvelmente em falta de oportunidade para a mão de obra não qualificada. Ao contrário, a maquinaria automatizada tende a exigir menor habilidade do operador, depois que são atingidos certos níveis de mecanização. (BRIGHT, 1962; pag. 107-108) 
Apesar das mudanças das necessidades de trabalho, a forma como é definida a qualificação da mão de obra por vezes gera discussão. Para Barbara (1999) a qualificação da mão de obra está alinhada com demandas do mercado, sendo estas demandas volúveis, o empregado, mesmo que acompanhe as mudanças, não tem garantia de seu emprego, portanto, partindo desta definição, o processo de qualificação da mão de obra pode não trazer benefícios para o trabalhador.

A grande parte das mudanças dos meios de produção é alcançada, devido ao desenvolvimento de novas tecnologias que demandam profissionais especializados preparados para o novo ciclo de mudança e o aumento de complexidade do funcionamento da atividade. Para Aguiar \& Gomas (2013, pg.1) "ao longo do século $X X$ e início do século $X X I$, os processos de urbanização, industrialização e os progressos da tecnologia acarretaram mudanças nos perfis do mercado de trabalho e da formação profissional de forma intensa.", ou seja, o modo pelo qual a formação do profissional e a capacidade dos colaboradores acompanharem o ciclo de mudança tecnológica são afetadas também pela estrutura industrial e tecnológica do país, se este já está com alto grau de industrialização, se consegue gerir o conhecimento e as mudanças tecnológicas.

SCHWARTZMAN \& CASTRO (2013) defende que a qualificação e a educação andam juntas, sendo portanto, ambas necessárias para deixar a economia mais dinâmica, proporcionando melhores trabalhos e rendimentos para a mão de obra. Porém quando a necessidade de qualificação não é respondida com educação, são desenvolvidas formas de trabalho com baixa qualificação. O autor destaca como não sendo o curso superior a única forma de qualificação, mas também cursos profissionalizantes e cursos técnicos, além de destacar que os melhores momentos para a mão de obra procurar a qualificação são em momentos em que a economia se encontra aquecida.

A capacidade de produzir de forma eficiente e manter grande escala está intimamente relacionada com o grau de mecanização do país, se este já se tornou um país industrializado, terá uma capacidade de produção completamente diferente de outro que ainda está no caminho da industrialização.
Para MARIM (1976) apesar de poder oferecer a sua mão de obra a baixo custo, em relação a países com elevado nível de industrialização e economicamente mais desenvolvidos, não é interessante para o país menos desenvolvido manter baixos, os níveis de qualificação de seus trabalhadores. Esta limitação impede o desenvolvimento em mercados que exigem um colaborador especializado, criando maior dependência de commodities e recurso naturais, que exigem uma menor qualificação da mão de obra.

O setor agrícola, um dos setores mais expressivos da economia brasileira, tem relevante participação do PIB e tem alta capacidade de gerar emprego, porém, este último apresenta mudanças à medida que o grau de mecanização aumenta.

Mesmo considerando a fragilidade da PNAD em retratar com precisão o universo das ocupações agrárias, dependentes diretamente do efeito sazonal da produção agrícola, é notória a redução na participação da classe agrícola na estrutura sócioocupacional. Como impacto direto da mecanização agrícola, os ocupados neste setor passaram de $19 \%$ da população ocupada em 1981 para menos de 11\% em 2005. Entre estes, os mais afetados foram os assalariados (redução de 5 pontos percentuais) e os proprietários conta própria (redução de 4 pontos percentuais). A acelerada redução das ocupações agrícolas impulsionou o êxodo rural ao longo das últimas décadas que, sem a devida compensação pelo crescimento das ocupações não agrícolas, foi um dos grandes responsáveis pela explosão do desemprego nos grandes centros urbanos." (MAIA, 2016.; pag. 14)

Aguiar \& Gomas (2013, pg.1) percebem uma "gradual mudança do cenário na indústria agrícola. (...) a ocupação agrícola representava quase $30 \%$ da mão de obra no Brasil no início dos anos 1980 e atualmente esse número beira os 11\%". O setor de serviços é o que apresenta o maior percentual de ocupação de mão de obra no país e é o que demanda trabalhadores mais qualificados. No Brasil, nos últimos 40 anos, o setor agrícola passou por um intenso processo de modernização, com implementação de colhedeiras, tratores, equipamentos de irrigação, novas técnicas de plantio (por exemplo o plantio direto), que remodelaram o setor rural brasileiro. 
Portanto a mudança na ocupação agrícola pode ser notada tanto no campo quanto na cidade. Para BASALDI (2001) "seja por alterações nas políticas agrárias, redução de área plantada ou até pela modernização e mecanização das principais culturas foi alcançado um aumento de produção física, fator que influenciou uma forte tendência de queda das ocupações agrícolas", o que evidencia a redução do número de trabalhadores no processo produtivo.

O café, que historicamente é uma das principais culturas brasileiras e que mantém elevada participação no mercado internacional, pelo elevado volume produzido, além do esforço dos produtores, cooperativas e do Governo, a partir de políticas específicas para o setor, com o intuito de associar o café a um perfil diferenciado e de alta qualidade. Tais incentivos podem ser observados em iniciativas como a das cooperativas, que ajudam o pequeno agricultor a comercializar o seu produto no mercado internacional, a partir da implementação do projeto Região do Cerrado Mineiro (criação de um selo de procedência), entre outros.

A disputa no mercado internacional do café havia sido posta a parte pelos produtores brasileiros" de acordo com PIRES et al (2003). Para COSTA et al (2013 pg.800) Observa-se que junto aos setores de metalurgia, têxteis e outros serviços para famílias, "os setores agroindustriais: indústria do açúcar e outros produtos alimentares foram aqueles com impactos mais significativos na economia em ambas as regiões. Isto mostra a importância do aumento de demanda sobre os produtos agrícolas processados na economia brasileira."

No Brasil, a contribuição da produção cafeeira para a formação econômica foi uma constante ao longo do tempo, porém, sua participação relativa diminuiu gradativamente, dada a contínua diversificação da pauta de exportações brasileiras. (SANTOS et al, 2009). Sendo essa diversificação ocasionada pelo estímulo a produção de outros produtos de exportação como a soja, milho e cana, decorrentes do avanço da produção agrícola para regiões anteriormente improdutivas, como o Cerrado, principalmente a partir da década de 70, período em que ocorreu a modernização agrícola brasileira.

Para PIRES et al (2003) as regiões do Cerrado, Sul de Minas e Mojiana Paulista, são destaque em produção de café de alta qualidade, necessidade ressaltada pelo aumento de exigência de qualidade do produto tanto pelo mercado externo e interno. Tais regiões conseguem produzir com maior qualidade principalmente pelo clima favorável, técnicas de cultivo e administração modernas.

Apesar dos desafios, a mecanização é uma tendência, devido a seus benefícios, como facilitação de planejamento da safra, redução de perda, redução do custo e de mão de obra, sendo esse último fator de grande relevância, pois gera 0 desemprego de muitos trabalhadores não qualificados e gera emprego, não na mesma proporção, para qualificados, ou seja, os habilitados a lidar com as novas máquinas. Observa-se, principalmente na região do Cerrado, uma intensa evolução da colheita mecanizada. Este novo padrão produtivo gera impactos positivos e negativos sobre a mão de obra, que historicamente tem-se utilizado da colheita manual, a partir da contratação de mão de obra não qualificada (bóias frias) no período de colheita do café. Ainda é comum, mas agora com menor intensidade, a vinda de trabalhadores de outras regiões, que migram a procura de emprego.

\section{PROCEDIMENTOS METODOLÓGICOS}

Para a análise da qualidade do emprego na cultura do café, foi feito o calculo do Índice de Qualidade do Emprego (IQE), que possibilita a visualização das mudanças durante os anos pesquisados (1991, 2000, 2010), com base nos microdados do censo demográfico do IBGE. Os dados iniciais focaram a análise em Minas Gerais e de forma comparativa, São Paulo e Paraná que são tradicionais produtores de café. Para o processamento dos dados foi utilizado o programa estatístico SPSS para extração dos microdados fornecidos pelo CD/IBGE e o Excell para cálculo dos índices, compilação e análise dos indicadores. A metodologia de cálculo foi adaptado de BASALDI (2007), direcionada a cultura do café.

Inicia-se com a construção dos índices parciais, com médias ponderadas dos indicadores simples e, posteriormente, usa-se médias ponderadas dos indicadores parciais para construção do IQE, de acordo como descrito por Balsadi (2007, pags. 41-46). Acrescentando a análise de sensibilidade dos coeficientes das médias ponderadas de acordo com TEIXEIRA (2015). 
A partir das informações extraídas do IBGE dos anos 1991, 2000, 2010 foram tabulados os Indicadores simples, em reais:

1) De rendimento do trabalho, qualificado ou não, na amostra (Rend1), indicadores simples em porcentagem:

2) de empregados com idade acima de 15 anos (Ninf), o que representa a proporção de trabalho não infantil empregada;

3) de empregados com jornada semanal de até 44 horas (Jorn), o que corresponderia à participação dos empregados sem sobretrabalho;

4) de empregados com carteira assinada (Cart);

5) de empregados contribuintes da Previdência Social (Prev) - Obs: Indicador ajustado em relação ao indicador Cart, nos anos 1991 e 2000, devido a problemas no banco de dados;

6) de empregados com remuneração acima de 1 salário mínimo (Npob);

7) de empregados não analfabetos ou com mais de um ano de estudo (Indalf);

8) de pessoas ocupadas com até 8 anos de estudo - fundamental incompleto (Indesc1);

9) de pessoas ocupadas com oito anos ou mais de estudo (Indesc2);

10) rendimento médio mensal dos empregados no trabalho principal, em Reais deflacionados para o ano de 2017 (Rendp); Sendo que no "rendimento médio mensal" é necessário ser padronizado para variar de 0 a 100, segundo a fórmula:

\section{Valor mínimo $x 100$ \\ máximo - mínimo}

Porém para utilização dos dados de rendimento mensal deve-se descartar outleirs, ou seja, valores que estão muito distantes dos valores, podendo assim gerar uma distorção na análise. De acordo com Silva et al(2010) em caso de dados extraídos de censos demográficos, pode-se utilizar o Teorema Central do Limite, este teorema consiste em retirar $2 \%$ das extremidades superiores e inferiores da distribuição normal, sendo utilizados 96\% dos dados, logo retirando dados muito extremos e mantendo a representatividade da amostra.

A partir dos índices simples são calculados os índices parciais:

TRABREND: 0,65 Npob + 0,35 Rend e pela análise de sensibilidade TRABREND: 0,60 Npob +0,40 Rend.

TRABFORMAL: $0,24 \mathrm{Ninf}+$ 0,12Jorn + 0,34Cart + 0,30Prev

INDEDUC: 0,45 Indesc2 + 0,36 Indesc $1+$ 0,19 Indalf

Depois de feitos esses indicadores, é proposta uma análise de sensibilidade destes, usando as mesmas variáveis, porém com coeficientes diferentes para percebermos o peso de cada variável na construção do índice.

Análise de sensibilidade para TRABFORMAL

INDFORMAL $=($ Ninf + Jorn + Cart + Prev $) / 4 ;$ indica o grau de informalização do trabalho.

INDFORMAL2 $=0,35$ cart $+0,29$ Prev $+0,24$ Ninf + 0,12 Jorn

Análise de sensibilidade para TRABRENDA

INDREND $=($ Rendp + Npob $) / 2$

INDREND2 $=0,40$ Rendp + 0,60 Npob.

Por fim é construído o IQE e suas devidas variação para ser feita a análise de sensibilidade deste indicador, o IQE está relacionado a exploração, sua variação é de 0 a 100. Quanto maior o resultado, melhor é a qualidade de vida do emprego. 
IQE $=0,34$ INDFORMAL + 0,33 INDREND + 0,33 INDEDUC

IQE' $^{\prime}=0,5$ INDFORMAL + 0,30 INDREND + 0,20 INDEDUC

IQE" = 0,3 INDFORMAL + 0,50 INDREND + 0,20 INDEDUC

IQE'" = 0,35 INDFORMAL + 0,4 INDREND + 0,25 INDEDUC

IQE4 = 0,34 INDFORMAL + 0,41 INDREND2 + 0,25 INDEDUC

\section{ANÁLISE DOS INDICADORES PARCIAIS E FINAIS DO IQE PARA O ESTADO DE MINAS GERAIS.}

Para a análise de Minas Gerais (MG) deve se acompanhar a tabela 1, portanto, percebe-se uma diferença na quantidade de trabalhadores com carteira assinada(Cart), entre os trabalhadores qualificados e não qualificados. Os não qualificados apresentam uma porcentagem de formalização bem menor, em 1991, a porcentagem de carteira assinada para o trabalhador não qualificado da cultura do café era de17,6\% contra 70,1\% do qualificado. Apesar desta disparidade, a não qualificado apresenta sempre um crescimento constante, ao contrário da qualificada que cai de forma expressiva, de 2000, com $81,4 \%$ com carteira assinada, para 2010 com $37,3 \%$.

No café, a porcentagem de contratação de menores de 15 anos (Ninf) é baixa tanto para qualificado, como os não qualificados, sendo alta também desde 1991, só apresentando maior variação de 1991, com 89,7\% para 2000 , com $95,1 \%$ para os não qualificados.

$\mathrm{Na}$ quantidade de horas trabalhadas mensalmente, em todos os anos os não qualificados apresentam uma porcentagem maior que os qualificados, nos anos 2000, $43,8 \%$ para não qualificados e $35,7 \%$ para qualificados, como o indicador mede a porcentagem de trabalhadores com jornada semanal de até 44 horas(Jorn), significa que quantos maiores essa porcentagem, maior é o cumprimento de trabalho exigido, sendo um ponto positivo para os não qualificados, terem maior participação.

Quanto à contribuição para previdência (Prev), os não qualificados e qualificados tem comportamento diferente. Os primeiros, tem um crescimento contínuo, em 1991 estavam com 17,6\% até em 2010, alcançar 55,5\%. O último, tem um crescimento até 2000, chegando em $81,4 \%$ e logo caindo de forma expressiva para $54,9 \%$.

Para uma análise mais aprofundada, é feita a combinação dos indicadores anteriormente citados, formando o TRABFORMAL. Este tem sua variação próxima aos indicadores simples Prev e Cart, tanto para qualificados, que tem crescimento até no ano 2000, 80,25\% e logo caindo para $59,69 \%$, quanto para os não qualificados, que em 1991 estava com $37,88 \%$ e por fim chegando em 2010 com $61,04 \%$. Quanto a análise de sensibilidade (indformal;indformal 2), percebe-se que o indformal por ter menor influência do Cart e do Prev apresenta valores menor, já o indformal 2 não apresenta uma variação significante.

A disparidade entre o rendimento dos trabalhadores qualificados e não qualificados com renda maior que 1 salário mínimo (Npob) é muito grande, em 1991, enquanto apenas $29,1 \%$ dos trabalhadores não qualificados tinham mais de 1 salário mínimo, dentro dos qualificados , 54,8\% tinham mais de 1 salário mínimo, essa diferença aumenta ainda mais nos anos 2000, quando os qualificados chegam a $99,2 \%$ dos trabalhadores acima do salário mínimo, porém, logo depois em 2010, há uma grande queda deste indicador, alcançando apenas 29,4\% qualificados, quase se igualando aos $28,9 \%$ dos não qualificados. O rendimento padronizado (Rendp), apresenta um contraste com o Npob, pois o Rendp apresenta-se maior, para trabalhadores não qualificados, ao contrário do Npob que é maior para o qualificado. É possível perceber, o rendimento padronizado apresenta tendência de crescimento ao longo dos anos tanto para qualificados quanto não qualificados. 
TABELA 1 - Índices parciais e IQE para o estado de MINAS GERAIS.

\begin{tabular}{|c|c|c|c|c|c|c|c|}
\hline \multicolumn{4}{|c|}{ Trabalhadores não-qualificados } & \multicolumn{4}{|c|}{ Trabalhadores qualificados } \\
\hline & 1991 & 2000 & 2010 & 1991 & 2000 & \multicolumn{2}{|l|}{2010} \\
\hline Cart & 17,6 & 33,2 & 40,9 & 70,1 & 81,4 & 37,3 & Simples \\
\hline Ninf & 89,7 & 95,1 & 97,9 & 98,9 & 99,5 & 98 & Simples \\
\hline Jorn & 42,4 & 43,8 & 61,3 & 34,9 & 35,7 & 58,5 & Simples \\
\hline Prev & 17,6 & 33,2 & 55,5 & 70,1 & 81,4 & 54,9 & Simples \\
\hline TRABFORMAL & 37,88 & 49,32 & 61,40 & 72,788 & 80,26 & 59,69 & Parcial \\
\hline Indformal & 41,82 & 51,32 & 63,9 & 68,5 & 74,5 & 62,17 & Sensibilidade \\
\hline Indformal 2 & 37,88 & 49,32 & 61,26 & 72,78 & 80,26 & 59,51 & Sensibilidade \\
\hline Npob & 29,1 & 19,1 & 28,9 & 54,8 & 99,2 & 29,4 & Simples \\
\hline Rendp & 24,38 & 34,05 & 36,99 & 17,84 & 20,79 & 36,99 & Simples \\
\hline TRABRENDA & 27,45 & 24,33 & 31,73 & 41,86 & 71,75 & 32,05 & Parcial \\
\hline Indrend & 26,74 & 26,58 & 32,95 & 36,32 & 60,00 & 33,20 & Sensibilidade \\
\hline Indrend2 & 27,22 & 25,08 & 32,14 & 40,02 & 67,84 & 32,44 & Sensibilidade \\
\hline INDALF & 70 & 82,2 & 84,2 & 89,1 & 88,9 & 85,8 & Simples \\
\hline INDESC1 & 69,1 & 77,9 & 65,3 & 80,6 & 79,4 & 66,8 & Simples \\
\hline INDESC2 & 0,9 & 4,3 & 18,8 & 8,5 & 9,5 & 18,8 & Simples \\
\hline Indeduc & 38,58 & 45,59 & 47,96 & 49,77 & 49,75 & 48,81 & Parcial \\
\hline IQE & 34,66 & 39,84 & 47,17 & 54,98 & 67,38 & 46,98 & Completo \\
\hline IQE' & 34,89 & 41,08 & 49,81 & 58,90 & 71,60 & 49,22 & Completo \\
\hline IQE" & 32,80 & 36,08 & 43,88 & 52,72 & 69,90 & 43,69 & Completo \\
\hline IQE'"' & 33,88 & 38,40 & 46,18 & 54,66 & 69,23 & 45,92 & Completo \\
\hline IQE4 & 35,0 & 39,1 & 46,9 & 52,1 & 65,6 & 46,6 & Completo \\
\hline \multicolumn{8}{|c|}{$\begin{array}{l}\text { Empregados com carteira assinada (Cart); empregados com idade acima de } 15 \text { anos (Ninf); empregados com jornada } \\
\text { semanal de até } 44 \text { horas (Jorn); empregados contribuintes da Previdência Social (Prev); indicadores parcial de formalidade } \\
\text { do trabalho (TRABFORMAL); análise de sensibilidade de formalidade (INDFORMAL); análise de sensibilidade de formalidade } \\
\text { (INDFORMAL 2); empregados com remuneração acima de } 1 \text { salário mínimo (Npob); rendimento médio mensal dos } \\
\text { empregados no trabalho principal, em Reais deflacionados para o ano de } 2014 \text { (Rendp); indicador parcial de rendimento dos } \\
\text { empregados (TRABRENDA); análise de sensibilidade dos indicadores de rendimento dos empregados (INDREND); análise } \\
\text { de sensibilidade dos indicadores de rendimento dos empregados (INDREND2); empregados não analfabetas ou com mais } \\
\text { de um ano de estudo (Indalf); pessoas ocupadas com até } 8 \text { ano de estudo - fundamental incompleto (Indesc1); pessoas } \\
\text { ocupadas com oito anos ou mais de estudo (Indesc2); indicador parcial de educação (Indeduc); índices de Qualidade do } \\
\text { Emprego (IQE), do (IQE até IQE"') são usados indicadores parciais, o (IQE4) é feito com os indicadores de analise de } \\
\text { sensibilidade. }\end{array}$} \\
\hline
\end{tabular}

Fonte: elaboração própria a partir dos dados dos censos demográficos do IBGE - 1991, 2000 e 2010.

O TRABRENDA, estabelece a relação do Npob e o Rendp, por Npob ter um peso maior neste cálculo, os qualificados apresentam um indicador maior em todos os anos, contudo deve-se destacar no ano de 2000, nos qualificados, um aumento para 71,75 e logo uma queda para 32,05 em 2010. Analisando também os indicadores de sensibilidade (Indrend, Indrend2), ambos menos sensíveis ao Npob, no ano de 2010 para os qualificados é vista a diferença, Indred, com 60,00 e Indred 2, com 67,84. Assim é visível a influência do Npob no TRABRENDA, pois quando é analisado os indicadores de sensibilidade, que tem menor influência deste indicador simples, é visto alguns valores mais baixos. Por fim, vemos os indicadores simples, parciais e de sensibilidade relativos a renda que se mantiveram com poucas alterações ao longo dos anos para não qualificados, e para não qualificados, grandes aumentos. Porém fechando 2010 com resultados até piores que em 1991, concluindo que a situação da renda não melhorou e, para os qualificados, piorou.

Sobre o grau de escolaridade, os qualificados, mantém sempre maior nível de escolaridade do que os não qualificados, algo 
que pode ser percebido com o indicador de não analfabetos ou com mais de um ano de estudo (INDALF), para não qualificados, 1991, $70 \%$ e qualificados, $89,1 \%$, predominância que se repete em 2000 e 2010. Também com grande proporção, pessoas com até 8 anos de estudo ( Indesc1), este se aproxima em proporção do Indalf, e também mantém a predominância dos qualificados, sendo somente o número de pessoas com 8 anos ou mais ( Indesc2) com participação menos expressiva.

O indicador parcial da educação (Indeduc) apresenta grandes alterações no nível de escolaridade dos trabalhadores do café, somente para os não qualificados de 1991, com 38,58 para 2000, com 45,59, com justificativa de aumento expressivo do INDALF e INDESC2 para esse período, nos outros anos, este indicador quase não apresenta alteração. Resumidamente, os índices de educação apresentaram evolução significativa ao longo dos anos e, tais modificações, repercutem positivamente no Índice de Qualidade do Emprego (IQE).

$\mathrm{O}$ indicador de qualidade de emprego (IQE) e suas variações apresentam resultados diferentes para qualificados e não qualificados. Nos não qualificados, de 1991, temos o IQE com 34,66. Comparativamente o IQE" tem o menor indicador, 32,8, isto porque este último concede mais relevância ao TRABRENDA. Em 2010, o IQE estava com 47,17 mostrando uma melhora na qualidade de emprego. Nos qualificados, os IQE's de uma forma geral são melhores que os não qualificados e sofrem variação positiva de 1991 para 2000, de 54,98 para 67,38 e, em 2010, 46,98. Tal evolução contesta a percepção de que quanto maior a qualificação melhor a qualidade do emprego, pois a medida que o indicador se aproxima de 0 , significa que a qualidade de trabalho no café diminuiu. Neste caso, fatores ligados ao rendimento dos trabalhadores qualificados mostram que a qualidade do emprego está em um nível inferior ao encontrado em 2000. É percebida esta queda nos indicadores parciais TRABFORMAL e TRABRENDA, maiores influenciadores da queda do IQE dos qualificados, uma justificativa para este comportamento, é o possível aumento de terceirização dos trabalhadores qualificados, quando um agricultor não tiver o capital para investir na máquina, nem contratar a mão de obra qualificada, encontra na terceirização uma forma de trabalho, além deste, é possível justificar a variação deste indicadores pelo adequação dos salários com as forças de oferta e demanda de profissionais no mercado, sendo que a medida que mais profissionais entre no mercado, aumentando a oferta, e o número de hectares plantados de café não crescer na mesma proporção, demanda, vemos salários mais baixos, logo qualidade de emprego mais baixa.

\section{ANÁLISE DOS INDICADORES PARCIAIS E FINAIS DO IQE PARA O ESTADO DE PARANÁ.}

No Paraná, segundo a tabela 2, o Cart para os trabalhadores não qualificados, só decresce com o tempo caindo de $62,8 \%$ em 1991 até 19,2\% em 2010, os qualificados, inicialmente apresentam um leve aumento, de $78,7 \%$ em 1991 para 79,4 em 2000 e logo após, uma queda muito expressiva até $20,4 \%$ em 2010. O Ninf, tanto para qualificados quanto não qualificados se apresenta constante e alto, destacando 1991, nos não qualificados, apresentava-se uma porcentagem $100 \%$ de empregados acima de 15, somente destacando uma queda dos qualificados de 2000, com 99\% para 2010 com $95,9 \%$.

O Jorn, empregados com jornada de trabalho de até 44 horas, aumenta com o passar dos anos tanto para qualificados quanto para não qualificados. Nos não qualificados, em 1991, tinha-se um percentual de 34,5\% em 2010, $67,5 \%$, para os qualificados, $39,1 \%$ em 1991 chegando a 67,6\% em 2010, logo é percebida melhora nas condições de emprego e comprimento da legislação trabalhista.

A contribuição para a previdência, para os não qualificados, tem forte queda em 2000, sendo que logo em 2010 se recupera e fecha o ano com $77,7 \%$, já uma situação contrária acontece com os qualificados, apresentando, primeiro um leve crescimento e logo após uma queda, chegando em 2010 com 67,7\%, número menor que os não qualificados, o que significa que no último ano o não qualificados contribuíam mais para a previdência que os qualificados.

O TRABFORMAL para não qualificados apresenta queda de 1991, com 68,33\%, sofrendo forte queda porém recuperando em 2010, contudo fechando abaixo do valor de 1991, portanto, nota-se uma diminuição da formalização do emprego para não 
qualificados. Os qualificados, não apresentam muita mudança de 1991 para 2000, porém tendo forte queda em 2010, fechando o ano 58,37 , significando uma diminuição grande na formalização. Por fim, a diminuição do grau de formalização do trabalho na cultura cafeeira no Paraná foi sentido tanto pelo qualificado como os não qualificados ao longo dos 20 anos. Uma explicação para este retrocesso pode estar relacionado ao aumento das contratações de terceirizados, como explicado anteriormente. O Npob, tanto no qualificado, como no não qualificado, sofre variações muito grande, começando o 1991, com 46,2 5 aumentando até 86,9 em 2000 e logo despencando até 18,3\% no ano de 2010, para os não qualificados, o mesmo movimento de alta e queda acontece com os qualificados, sendo em 1991, 52,4\%, 2000, 99,3\% logo 22,2\% em 2010. A renda padronizada, aumenta, tanto para os qualificados quanto para não qualificados ao longo dos anos e, também, sendo relativamente próximas, em 1991, os não qualificados com 18,07\% e em 2010 com $38,04 \%$, os qualificados, em 1991, com $18,41 \%$ e em $201034,99 \%$.

TABELA 2 - Índices parciais e IQE's para o estado de PARANÁ.

\begin{tabular}{|c|c|c|c|c|c|c|c|}
\hline & Traba & es não- & cados & Tra & dores qu & dos & \\
\hline & 1991 & 2000 & 2010 & 1991 & 2000 & 2010 & \\
\hline Cart & 62,8 & 28,9 & 19,2 & 78,7 & 79,4 & 20,4 & Simples \\
\hline Ninf & 100 & 95,8 & 96,9 & 98,6 & 99 & 95,9 & Simples \\
\hline Jorn & 34,5 & 49,9 & 67,5 & 39,1 & 44,8 & 67,6 & Simples \\
\hline Prev & 62,8 & 28,9 & 77,7 & 78,7 & 79,4 & 67,7 & Simples \\
\hline TRABFORMAL & 68,33 & 47,47 & 61,19 & 78,72 & 79,95 & 58,37 & Parcial \\
\hline Indformal & 65,02 & 50,87 & 65,32 & 73,77 & 75,65 & 62,9 & Sensibilidade \\
\hline Indformal 2 & 68,33 & 47,47 & 60,60 & 78,72 & 79,95 & 57,90 & Sensibilidade \\
\hline Npob & 46,2 & 86,9 & 18,3 & 52,4 & 99,3 & 22,2 & Simples \\
\hline Rendp & 18,07 & 33,35 & 38,04 & 18,45 & 18 & 34,99 & Simples \\
\hline TRABRENDA & 36,35 & 68,15 & 25,21 & 40,51 & 70,84 & 26,67 & Parcial \\
\hline Indrend & 32,14 & 60,13 & 28,17 & 35,43 & 58,65 & 28,60 & Sensibilidade \\
\hline Indrend2 & 34,95 & 65,48 & 26,20 & 38,82 & 66,78 & 27,32 & Sensibilidade \\
\hline INDALF & 83,6 & 75,7 & 76,6 & 83 & 92,5 & 82,8 & Simples \\
\hline INDESC1 & 67,8 & 69,4 & 58,8 & 74,3 & 74,3 & 59,6 & Simples \\
\hline INDESC2 & 15,9 & 6,4 & 17,8 & 8,7 & 18,3 & 23,1 & Simples \\
\hline Indeduc & 47,44 & 42,24 & 43,73 & 46,43 & 52,55 & 47,58 & Parcial \\
\hline IQE & 50,88 & 52,57 & 43,55 & 55,46 & 67,90 & 44,35 & Completo \\
\hline IQE' & 54,56 & 52,63 & 46,90 & 60,80 & 71,74 & 46,70 & Completo \\
\hline IQE" & 48,16 & 56,77 & 39,70 & 53,16 & 69,92 & 40,36 & Completo \\
\hline IQE'" & 50,32 & 54,44 & 42,44 & 55,37 & 69,46 & 43,00 & Completo \\
\hline IQE4 & 48,3 & 54,7 & 43,9 & 52,6 & 66,2 & 44,5 & Completo \\
\hline $\begin{array}{l}\text { Empregados } \\
\text { semanal de até } \\
\text { formalidade do } \\
\text { formalidade (IN } \\
\text { dos empregado } \\
\text { dos empregad } \\
\text { análise de sens } \\
\text { mais de um ano } \\
\text { ocupadas com } \\
\text { Emprego (IQE) } \\
\text { sensibilidade. }\end{array}$ & $\begin{array}{l}\text { a assina } \\
\text { (Jorn); er } \\
\text { RABFO } \\
\text { L 2); em } \\
\text { Iho prino } \\
\text { RENDA); } \\
\text { los indic } \\
\text { (Indalf) } \\
\text { ou mais } \\
\text { até IQE }\end{array}$ & $\begin{array}{l}\text { art); en } \\
\text { ados cc } \\
\text { ); anális } \\
\text { dos cor } \\
\text { m Reai } \\
\text { se de s } \\
\text { s de ren } \\
\text { oas ocl } \\
\text { studo (I } \\
\text { o usad }\end{array}$ & $\begin{array}{l}\text { ados cc } \\
\text { lintes da } \\
\text { sensibilic } \\
\text { uneraçã } \\
\text { acionadr } \\
\text { ilidade } \\
\text { tto dos } \\
\text { s com a } \\
\text { 2); indic } \\
\text { licadore }\end{array}$ & $\begin{array}{l}\text { ade aci } \\
\text { idência } \\
\text { de form } \\
\text { ma de } \\
\text { a o ano } \\
\text { ndicado } \\
\text { gados } \\
\text { no de e } \\
\text { parcial } \\
\text { ciais, o }\end{array}$ & $\begin{array}{l}\text { 15 an } \\
\text { I (Prev); } \\
\text { e (INDF } \\
\text { io mínin } \\
14 \text { (Rer } \\
\text { e rendir } \\
\text { END2); } \\
\text { - fundar } \\
\text { lucação } \\
\text { t) é feit }\end{array}$ & $\begin{array}{l}\text { Jinf); em } \\
\text { esenta o } \\
\text { AL); aná } \\
\text { pob); re } \\
\text { indicad } \\
\text { dos en } \\
\text { egados } \\
\text { lincomp } \\
\text { educ); ín } \\
\text { h os ind }\end{array}$ & $\begin{array}{l}\text { dos com jornad } \\
\text { cadores parcial d } \\
\text { e sensibilidade d } \\
\text { nto médio mens } \\
\text { cial de rendiment } \\
\text { ados (INDREND } \\
\text { nalfabetas ou cor } \\
\text { Indesc1); pessoa } \\
\text { de Qualidade d } \\
\text { res de analise d }\end{array}$ \\
\hline
\end{tabular}

Fonte: elaboração própria a partir dos dados dos censos demográficos do IBGE - 1991, 2000 e 2010. 
O TRABRENDA, fortemente influenciado pelo Npob, tem um aumento e depois uma grande queda, tanto para qualificados quanto não qualificados. Mesmo os indicadores de análise de sensibilidade, que amenizam os valores do Npob, sofrem grandes variações. O TRABRENDA em 1991, para os qualificados é de 40,51, em 2000, 70,84 e por fim 26,67.

Os indicadores de educação, apresentam que a grande maioria dos trabalhadores do café, desde 1991, qualificados ou não é no mínimo alfabetizada, porém o INDALF para não qualificados decresce ao longo dos anos passando de 83,6\% em 1991 para $76,6 \%$ em 2010, e o para qualificados cresce de 1991, com $83 \%$ para $92,5 \%$ em 2000 e depois decresce para $82,8 \%$ mantendo-se no mesmo patamar de 1991. Sobre a quantidade de tempo máxima na escola, é possível que a maioria se encontra no INDESC1, porém este decresce com o tempo, no caso dos qualificados, sai de 74,3\% em 1991 para $59,6 \%$ no ano de 2010, assim como nos não qualificados, que no ano de 1991 é $67,8 \%$ e no ano de 2010 é $58,8 \%$ e o INDESC2 aumenta, principalmente para os qualificados, saindo de $8,7 \%$ em 1991 e chegando a $23,1 \%$ no ano de 2010, somente para os não qualificados, pode-se perceber uma queda de 1991, com 15,9\% para 6,4\% em 2000, porém em 2010, há um aumento para 17,8\% ultrapassando o ano de 1991, portanto mostrando um sinal de crescimento no prazo maior.

Indeduc, demonstra uma pequena queda para os não qualificados, de 1991, com 47,44 para 2000, com 42,24 e mantendo-se quase inalterado em 2010, com 43,73, explicada porque todos os 3 indicadores simples sofrem queda neste período, para os qualificados, houve uma um aumento, saindo de 1991, com 45,43 para 52,55 em 2000 e logo caindo para 47,58 , ou seja, uma mudança pouco expressiva de 1991 até 2010.

A qualidade do emprego diminuiu para os dois perfis da pesquisa, o primeiro, tendo 50,88 no IQE e 43,55 em 2010, o segundo tendo 55,46 em 1991 em 44,35 em 2010. Mesmo com as variações do indicador de qualidade de para os qualificados no ano 2000, o resultado final em 2010 continua de decrescimento, demonstrando que mesmo com o aumento da qualificação no Paraná, ainda temos uma diminuição dos IQE's, logo, diminuição da qualidade de emprego.
6 ANÁLISE DOS INDICADORES PARCIAIS E FINAIS DO IQE PARA O ESTADO DE SÃO PAULO.

Em São Paulo, de acordo com a tabela 3, o número de carteiras assinadas, diminui, para os não qualificados, sendo em 1991, 74\%, logo caindo para 44,8\% em 2000 e expressando um leve aumento mas pouco expressivo, chegando a 45,4\% em 2010, para os qualificados, qualificados houve uma pequena queda, de $87,5 \%$, em 1991, para $85,2 \%$ em 2000, seguido de uma grande queda para $57,6 \%$ em 2010. O ano de 2010 representou queda tanto para qualificados quanto para não qualificados.

O Ninf apresenta-se alto ao longo do tempo tanto para qualificados quanto para não qualificados, tendo pouca variação desde 1991 até 2010, para não qualificados, começando com 99,4\% e acabando com 99\% e para qualificados começando com $98,8 \%$ e acabando com 98,7\%. O indicador Jorn, tem uma queda tanto para ambos os perfis, para os qualificados, em 1991 com 53,9\% e chegando a $36,3 \%$ em 2000 , para os não qualificados, em $1991 \mathrm{com} 52,5 \%$ para $43,7 \%$ em 2000, contudo, em 2010, há uma variação positiva para os dois indicadores, terminando 2010 com 64,8\% em ambos casos.

A contribuição para previdência, para não qualificados, começa com uma queda expressiva, de 74\% em 1991 para 44,8\% em 2000, logo sofrendo um leve aumento em 2010 , com $51,6 \%$, já os qualificados, em 1991 , com $87,5 \%$, tendo uma leve queda para $85,2 \%$ em 2000 , e tendo uma grande queda para 2010, 39,5\%, porém ainda em menor proporção que os não qualificados em 2010.

Quanto a formalização do trabalho como um todo, para os não qualificados, de 1991, com 77,51 acontece uma queda para 57,29 em 2000, puxada pelo indicador Prev, porém, em 2010, ocorre um crescimento para $2010 \mathrm{com}$ 51,6 , pode-se ver poucas variações dos indicadores de sensibilidade para os não qualificados. Para os qualificados, quase não vemos mudanças do indicador, até 2000, contudo finaliza 2010 com 39,5.

O Npob, tanto para qualificados quanto não qualificados tem um grande aumento no ano 2000 e logo depois uma grande queda para níveis abaixo dos indicadores de 1991. Nos anos de 1991, 2000 e 2010, para os não qualificados, respectivamente temos, 69,9\%, $95,3 \%$ e $41,1 \%$ e para os qualificados, respectivamente, $66,6 \%, 99,3 \%, 49,5 \%$. 
O Rendp é crescente tanto para os que são qualificados quanto para os que não são, porém para os não qualificados, o aumento se da do ano de 1991, com 8,14 para o ano de 2000, com 35,03\%, sendo que 2010 apresenta um leve crescimento para 40,67. Nos qualificados, de 1991, com 6,77\% há um pequeno crescimento para 0 ano de 2000, com 14,59 e logo um grande crescimento para o ano de 2010 com 41,86\%.

Em relação ao TRABRENDA, muito influenciado pelo Npob, teve um aumento grande no ano 2000 e depois uma queda em
2010, para os não qualificados, é visto o crescimento do ano de 1991 para 2000, começando $48,28 \%$ e terminando com $74,2 \%$ e decrescendo para 40,95 em 2010, é valido também notar, o Indred, que tem valores distante do TRABRENDA, 1991,com 39,02, 2000, com 65,17 e 40,89 em 2010, devido ao coeficiente menor do Npob na sua fórmula o Indred tem uma menor variação em relação ao indicador simples. Para os qualificados vemos um cenário próximo, sendo o TRABRENDA, em 1991, 45,66, crescendo para 69,65 em 2000 e queda para 46,82, em 2010.

TABELA 3 - Índices parciais e IQE's para o estado de SÃO PAULO.

\begin{tabular}{|c|c|c|c|c|c|c|c|}
\hline & Trab & res não- & ados & Trab & ores qui & ados & \\
\hline & 1991 & 2000 & 2010 & 1991 & 2000 & 2010 & \\
\hline Cart & 74 & 44,8 & 45,4 & 87,5 & 85,2 & 57,6 & Simples \\
\hline Ninf & 99,4 & 97,4 & 99 & 98,8 & 99,6 & 98,7 & Simples \\
\hline Jorn & 52,5 & 43,7 & 64,8 & 53,9 & 36,3 & 64,8 & Simples \\
\hline Prev & 74 & 44,8 & 51,6 & 87,5 & 85,2 & 39,5 & Simples \\
\hline TRABFORMAL & 77,51 & 57,29 & 62,45 & 86,18 & 82,78 & 62,89 & Parcial \\
\hline indformal & 74,97 & 57,67 & 65,2 & 81,92 & 76,57 & 65,15 & Sensibilidade \\
\hline Indformal 2 & 77,51 & 57,29 & 62,39 & 86,18 & 82,78 & 63,07 & Sensibilidade \\
\hline Npob & 69,9 & 95,3 & 41,1 & 66,6 & 99,3 & 49,5 & Simples \\
\hline Rendp & 8,14 & 35,03 & 40,67 & 6,77 & 14,59 & 41,86 & Simples \\
\hline TRABRENDA & 48,28 & 74,20 & 40,95 & 45,66 & 69,65 & 46,82 & Parcial \\
\hline Indrend & 39,02 & 65,17 & 40,89 & 36,69 & 56,95 & 45,68 & Sensibilidade \\
\hline Indrend2 & 45,20 & 71,19 & 40,93 & 42,67 & 65,42 & 46,44 & Sensibilidade \\
\hline INDALF & 89,8 & 82,5 & 85 & 90,2 & 93,7 & 86,1 & Simples \\
\hline INDESC1 & 75 & 76,8 & 64,5 & 83,4 & 78,1 & 64 & Simples \\
\hline INDESC2 & 14,8 & 5,6 & 20,3 & 6,8 & 15,7 & 21,9 & Simples \\
\hline Indeduc & 50,72 & 45,84 & 48,50 & 50,22 & 52,98 & 49,25 & Parcial \\
\hline IQE & 59,02 & 59,09 & 50,75 & 60,94 & 68,61 & 53,09 & Completo \\
\hline IQE' & 63,38 & 60,07 & 53,21 & 66,83 & 72,88 & 55,34 & Completo \\
\hline IQE" & 57,54 & 63,45 & 48,91 & 58,72 & 70,26 & 52,13 & Completo \\
\hline IQE'"' & 59,13 & 61,20 & 50,37 & 60,98 & 70,08 & 53,06 & Completo \\
\hline IQE4 & 56,7 & 60,3 & 51,1 & 57,9 & 66,1 & 53,5 & Completo \\
\hline $\begin{array}{l}\text { Empregados } \mathrm{cc} \\
\text { semanal de até } \\
\text { formalidade do } \\
\text { formalidade (IN } \\
\text { dos empregado } \\
\text { dos empregad } \\
\text { análise de sens } \\
\text { mais de um ano } \\
\text { ocupadas com } \\
\text { Emprego (IQE) } \\
\text { sensibilidade. }\end{array}$ & $\begin{array}{l}\text { ABFUR } \\
\text { princip } \\
\text { VDA); } \\
\text { indicac } \\
\text { ndalf); } \\
\text { mais } \\
\text { IQE'" }\end{array}$ & $\begin{array}{l}\text { t); empr } \\
\text { dos cont } \\
\text { análise } \\
\text { s com r } \\
\text { Reais d } \\
\text { de sen } \\
\text { de rendir } \\
\text { as ocupa } \\
\text { udo (Ind } \\
\text { usados }\end{array}$ & $\begin{array}{l}\text { ibilidade } \\
\text { ação a } \\
\text { hados } p \\
\text { de dos } \\
\text { los emp } \\
\text { m até } 8 \\
\text { ndicado } \\
\text { tores pa }\end{array}$ & $\begin{array}{l}\text { malidac } \\
\text { e } 1 \text { salá } \\
\text { no de } 2 \\
\text { dores } \\
\text { ss (INDF } \\
\text { estudo } \\
\text { ial de e } \\
\text { o (IQE }\end{array}$ & $\begin{array}{l}\text { IDFORN } \\
\text { nimo (N } \\
\text { Rendp); } \\
\text { dimente } \\
\text { 2); empr } \\
\text { dament } \\
\text { ão (Ind } \\
\text { eito cor }\end{array}$ & $\begin{array}{l}\text { empre } \\
\text { ta os inc } \\
\text { análise } \\
\text {; rendin } \\
\text { cador p } \\
\text { s empr } \\
\text { dos não } \\
\text { ompletc } \\
\text { ); índic } \\
\text { indicac }\end{array}$ & $\begin{array}{l}\text { Ds com jornada } \\
\text { dores parcial de } \\
\text { sensibilidade de } \\
\text { o médio mensal } \\
\text { al de rendimento } \\
\text { dos (INDREND); } \\
\text { Ifabetas ou com } \\
\text { desc1); pessoas } \\
\text { e Qualidade do } \\
\text { s de analise de }\end{array}$ \\
\hline
\end{tabular}

Fonte: elaboração própria a partir dos dados dos censos demográficos do IBGE - 1991, 2000 e 2010. 
Mesmo os qualificados e não qualificados tendo altos graus de alfabetização, os não qualificados, apresentam uma queda de 1991, com $89,8 \%$ para $82,5 \%$ em 2000 , logo um crescimento deste indicador para $85 \% \mathrm{em}$ 2010. Os qualificados, tendo uma porcentagem de alfabetizados maior que os não qualificados em todos os anos, tem um crescimento inicial de 1991, com 90,2\% para $93,7 \%$ em 2000, e posterior queda para $86,1 \%$ em 2010. A maioria dos trabalhadores do café tem até 8 anos de estudos, porém o Indesc1 vai diminuindo de forma gradual a medida que o indesc2 vai crescendo, ou seja, a cada ano a proporção de trabalhadores que tem mais de 8 anos de estudo aumenta. A única exceção são os indicadores INDESC1 e INDESC2 para não qualificados, de 1991, $75 \%$ e $14,8 \%$, para respectivamente, em $2000,76,8 \%$ e $5,6 \%$, onde o INDESC1 aumenta, contrariamente ao que ocorre nos outros casos e o INSDESC2 diminuiu, porém tal variação, positiva para INDESC1 e negativa para INDESC2, não altera a predominância dos que estudam menos de 8 .

O Indeduc, para não qualificados, decai de 1991, com 50,72 para 45,84 em 2000, puxado pela queda do INDALF e do INDESC2, porém volta a crescer em 2010, chegando a 48,5. Para os qualificados, o indicador sobe de 1991, com 50,22 para 52,98 em 2000, porém cai em 2010, chegando a 49,25, levado pela queda do INDALF e INDESC1 deste período.

Ao finalizar com a análise do IQE para o estado de São Paulo, observa-se que o indicador para os não qualificados de 1991, é 59,02, no mesmo período temos o maior indicador, IQE' 63,38, e o menor IQE4 56,7, devido ao aumento do TRABRENDA, O IQE" chega a 63,45 em 2000, também com a queda do mesmo indicador parcial, O IQE" chega a 48,91 em 2010. Para os qualificados, em 1991, o maior indicador é o IQE' com 66,83 e o menor o IQE4 57,9, o IQE era de 60,94 , este indicador aumenta para o ano 2000 , variando até 68,61 porém caindo até 53,09 em 2010, essa variação também se deve principalmente a variação do TRABRENDA, concluindo que houve perda de qualidade para os dois perfis de mão de obra.

\section{CONSIDERAÇÕES FINAIS}

A cafeicultura brasileira passou por um intenso processo de mecanização da lavoura, principalmente em áreas com fácil adaptação à colheita mecânica. A mecanização torna-se uma variável que influência diretamente a tomada de decisões do cafeicultor brasileiro e desta forma, sua implementação gera impactos positivos e negativos sobre o mercado de trabalho. Melhoras na produtividade com redução de custos a médio e longo prazo de um lado e desempregos, neste caso mão de obra não qualificada, de outro.

Inicialmente, foi percebido o aumento no número de trabalhadores qualificados que pode estar relacionado diretamente ao processo de mecanização da cultura. Contudo, o esperado processo de urbanização não é observado. Pode-se supor que os indivíduos que estão envolvidos com a cultura do café permanecem no campo ao longo do tempo. Não se observa êxodo rural aos moldes da economia brasileira, contrariando a ideia de que os trabalhadores no campo buscam a cidade como um norte para melhorar suas condições de vida. Ao contrário do que parece, existem perspectivas de melhores condições de vida no meio rural, mesmo com a mecanização e a diminuição do emprego para a mão de obra não qualificada..

Assim o artigo pautou-se em discutir a evolução da qualidade do emprego dos trabalhadores na cultura do café, a partir de índices de formalização, renda e educação como fatores que geram benefícios, ao longo do tempo, impactando positivamente no nível de vida do trabalhador.

O trabalho inicia com o questionamento de que a mecanização possa influenciar as relações de trabalho dentro da lavoura de café, ou não, aumentando o grau de qualificação dos trabalhadores e modificando a qualidade do trabalho, medida relevante para estabelecer melhora nas condições de vida. Para responder esse questionamento foi realizado o cálculo e análise do Indicador de Qualidade do Emprego (IQE).

Sobre a qualidade do emprego pode-se ver que houve pouca mudança no decorrer dos anos de 1991, 2000 e 2010. Em quase todos os estados, para ambos os perfis, IQE em 2010 estava mais baixo que em 1991, demonstrando uma diminuição de qualidade de emprego, sendo somente Minas Gerais, nos não qualificados, que foge desta regra. Dentro dos estados analisados, Minas Gerais, São Paulo e Paraná, os indicadores de formalidade, renda e educação tem um resultado próximo, algo que reflete no calculo 
de IQE, sendo notada proximidade em relação a seus resultados dos 3 estados.

Quando é feita a análise dos qualificados, em todos os estados, vê-se um aumento do indicador no ano de 1991 para o ano 2000, e logo uma queda expressiva, em 2010 em todos os estados. Para os não qualificados, temos somente Minas Gerais em 2010, com indicadores de qualidade mais altos que em 1991, nos outros estados encontra-se a situação oposta.

Conclui-se, com base nos dados dos censos demográficos do IBGE, que a mecanização na cultura cafeeira, ao contrário do que se espera, não necessariamente traduz em melhora na qualidade de trabalho, uma vez que esses indicadores têm como base os índices de renda, formalização do trabalho e escolaridade. E tais não são medidos a partir da percepção individual dos trabalhadores. Para os estados pesquisados, tanto para qualificados quanto para não qualificados, não se pode confirmar a ideia que a medida que se mecaniza uma lavoura de café, melhora a qualidade de vida dos trabalhadores. De uma forma geral, percebese uma evolução da qualidade do emprego o que pode ter sido gerado por diversos fatores como, por exemplo, os relacionados a uma maior renda, formalização do trabalho ou melhores níveis de educação. Contudo, essa evolução da renda, captado pelo indicador de renda, não apresenta evolução entre os anos de 2000 e 2010 e, contrariamente, mostra que o trabalhador tem reduzida sua remuneração, mesmo buscando a qualificação.

O processo de mecanização é positivo para a lavoura, pois, ajuda a melhorar o planejamento da safra, deixa a colheita mais rápida e eficiente, reduz perda, aumenta a produção, reduz custo e melhora a qualidade, portanto, tem papel fundamental para melhorar a competitividade da produção de café brasileira no nível internacional, construindo assim uma imagem para o Brasil não só de grande volume de produção, mas também, de produto de qualidade. Contudo, a discussão muda, quando se trata do efeito da mecanização sobre a qualidade de emprego dos trabalhadores do café. Somente o fato da produção mecanizada não necessariamente melhora a qualidade de emprego da mão de obra qualificada, na verdade temos uma diminuição da qualidade em todos os estados analisados. Tal resultado deve-se principalmente a fatores como a queda da formalização do emprego, que pode ser justificado por um possível aumento da terceirização de implementos e maquinários pelos produtores de pequeno porte, por não ter capital para investir no maquinário. Assim, supõe-se que o produtor prefere terceirizar o serviço ou se associar a uma cooperativa, resultando na diminuição TRABFORMAL. A queda do indicador de renda, que pode ser justificado como equilíbrio entre a oferta de trabalhadores qualificados, anteriormente baixa, e a demanda pelos serviços, anteriormente mais alta, levando a uma queda da oferta de emprego e de salários mais competitivos, nos dois casos uma resposta diferente do esperado.

Ou seja, em momentos de grande demanda por mão de obra qualificada a tendência é de aumento da remuneração, em um momento posterior em que o mercado de mão de obra está aquecido (maior oferta), a tendência é de queda na remuneração. Ao mesmo tempo, tem-se a crise econômica e política como um fator externo a influenciar negativamente no aumento da renda e formalização do trabalho.

Para o trabalhador não qualificado, esperavase o indicador do IQE fosse menor e que houvesse uma queda acentuada na qualidade de emprego. O IQE dos não qualificados não ficou significativamente abaixo. Na variação do indicador durante os 20 anos, observa-se uma queda menor deste perfil e, no caso de Minas Gerais, é percebida uma melhora no indicador. Um fator que explica este resultado, é o aumento da educação ao longo do período analisado, tal acontecimento pode ser creditado a políticas públicas que incentivam a educação.

Por fim, é percebido que apesar de trazer retornos econômicos para a produção, não pode ser afirmado que mecanização melhora a qualidade de emprego da mão de obra, qualificado ou não. Levando em consideração que o Brasil é o maior produtor de café, medidas devem ser tomadas para zelar sobre as condições de trabalho do empregado, pois como foi visto, existem benefícios econômicos de mecanização da produção de café, porém, no cenário atual, o empregado não desfruta da melhora na sua condição de vida. 


\section{REFERÊNCIAS}

[1]. AGUIAR, R. S. de e GOMES, M. Formação e mercado de trabalho no Brasil ontem e hoje. In ComCiência [online]. 2013, n.148, pp. 0-0. ISSN 1519-7654.

[2]. BALSADI, O. V. Mudanças no meio rural e desafios para o desenvolvimento sustentável. São Paulo Perspectiva [online]. 2001, vol.15, n.1, pp.155-165 ISSN 0102-8839.

http://dx.doi.org/10.1590/S010288392001000100017

[3]. BALSADI, O. V. O mercado de trabalho assalariado na agricultura brasileira no período de 1992-2004 e suas diferenciações regionais. Tese de doutorado - Universidade Estadual de Campinas, Instituto de Economia. SP, 2007.

[4]. BARBARA, M. M. Reestruturação produtiva, qualificação, requalificação e desemprego: percepção e sofrimento do trabalhador. Psicologia ciência prof. [online]. 1999, vol.19, n.1, pp.30-49. ISSN 1414-9893. http://dx.doi.org/10.1590/S141498931999000100004

[5]. BRIGHT, J. R. Exige a automatização maiores qualificações? Revista administração de empresa [online]. 1962, vol.2, n.6, pp.103-138. ISSN 0034-7590. http://dx.doi.org/10.1590/S003475901962000300008.

[6]. CONAB. SÉRIES HISTÓRICAS. 22/11/2016. Companhia Nacional de Abastecimento.

$<$ http://www.conab.gov.br/conteudos.php?a=1252 \&ordem=produto $>$.

[7]. COStA, C. C. da; GuILhOto, J. J. M. e IMORI, D. Importância dos setores agroindustriais na geração de renda e emprego para a economia brasileira. In Rev. Economia e Sociologia Rural [online]. 2013, vol.51, n.4, pp.787-814. ISSN 0103-2003. http://dx.doi.org/10.1590/S010320032013000400010

[8]. GRAZIANO DA SILVA, J. F. HOFFMANN, R. O Novo Rural Brasileiro. Pesquisa FAPESP. Páginas 48 - 55. Núcleo de Estudos Agrícolas.UNICAMP. 2000

[9]. MAIA, A. G. Distribuição de renda no mercado de trabalho brasileiro: uma análise para o período $1981 \quad$ a 2005 08/09/2016. <http://lanic.utexas.edu/project/etext/lli las/ilassa/2007/maia.pdf.>

[10]. MAPA. Sabia Mais. 16/11/2016. Ministério da Agricultura. http://www.agricultura.gov.br/vegetal/culturas/cafe/ saiba-mais.

MARIM, W. C. Absorção de mão de obra e modernização da agricultura no Brasil. Revista administração de empresa. [online]. 1976, vol.16, n.5, pp.33-47. ISSN 0034-7590. http://dx.doi.org/10.1590/S003475901976000500004

[12]. IBGE. Censo demográfico. Microdados dos censos de1991, 2000, 2010.

[13]. ICO. Trade Statistics Table. 16/11/2016. International Coffee Organization. < http://www.ico.org/trade_statistics.asp>.

[14]. PIRES, M. de M. CAMPOS, A. C. BRAGA, M. J. e RUFINO, J. L. dos S. Impactos do crescimento do consumo de cafés especiais na competitividade inter-regional da atividade cafeeira. Revista Economia Sociologia Rural [online]. 2003, vol.41, n.3, pp.53-71. ISSN 0103-2003. http://dx.doi.org/10.1590/S010320032003000300003.

[15]. SANTOS, V. E. dos. GOMES, M. F. M. BRAGA, M. J. e SILVEIRA, S. de F. R. Análise do setor de produção e processamento de café em Minas Gerais: uma abordagem matriz insumoproduto. Revista Economia Sociologia Rural [online]. 2009, vol.47, n.2, pp.363-388. ISSN 0103-2003. http://dx.doi.org/10.1590/S010320032009000200003.

[16]. SCHWARTZMAN, S. e CASTRO, C. de M. Ensino, formação profissional e a questão da mão de obra. Ensaio: avaliação políticas públicas Educação. [online]. 2013, vol.21, n.80, pp.563-623. ISSN 0104-4036. http://dx.doi.org/10.1590/S010440362013000300010

[17]. SILVA, E. M. et al Estatística. 4. Ed. - São Paulo: Atlas, 2010.

[18]. SILVA,F. M. da. SALVADOR, N. PÁDUA, T. de S. QUEIROZ, D. P. Colheita do café mecanizada e semimecanizada. UFLA. 11/09/2016. < http://www.editora.ufla.br/index.php/component/ph ocadownload/category/56-boletins-deextensao?download=1101: boletinsextensao $>$.

[19]. TEIXEIRA, F. A. O processo de expansão da cana-de-açúcar e seus impactos sobre a qualificação do trabalhador: análise comparativa para os estados de minas gerais, goiás, são paulo, paraná e mato grosso do sul. 2015. 193 f. Tese (doutorado em economia). Instituto de Economia. Universidade Federal de Uberlândia. Uberlândia. 2015. 


\section{Gapítulo 22}

\section{EVOLUCÃO DA DISTRIBUICÃO DA RENDA DOMICILIAR PER CAPITA E SUA DECOMPOSICÃO PARA O SETOR RURAL GOIANO NO PERIODO 2001-2015}

\section{Edson Roberto Vieira}

\section{Danilo Troncoso Chaves Martines \\ Antônio Marcos de Queiroz \\ Cleidinaldo de Jesus Barbosa}

Resumo: O presente trabalho tem como objetivo avaliar o comportamento da renda domiciliar per capita (RDPC) no setor rural do estado de Goiás no período 20012015. Cada componente da RDPC do setor rural do estado foi analisado, buscando-se apontar quais deles contribuíram para a ocorrência de uma maior ou menor desigualdade de renda neste setor. A partir da RDPC, foi realizado o cálculo do índice de Gini para os setores urbano e rural do estado de Goiás. Na sequência, foi procedida a decomposição deste índice para verificar quais dos componentes da RDPC foram mais importantes para aumentar ou reduzir a desigualdade de renda no setor rural do estado. Os resultados do trabalho sugerem que, dentre os componentes da RDPC, os principais responsáveis pelo aumento da concentração de renda no setor rural de Goiás foram as rendas do trabalho, os aluguéis e as aposentadorias e pensões públicas. Por sua vez, as aposentadorias e pensões privadas e os abonos e doações inicialmente contribuíram para aumentar a concentração neste setor, mas terminaram por apresentar um caráter progressivo em relação à distribuição de renda em 2015. Os outros rendimentos foram os que mais contribuíram para a redução da desigualdade de renda no setor rural goiano ao longo do período analisado, especialmente por abrangerem os programas de transferência de renda do Governo Federal.

Palavras chave: Desigualdade de Renda; Goiás; Índice de Gini; Renda Domiciliar per capita. 


\section{INTRODUÇÃO}

Nos últimos anos, parece ter havido um movimento consistente da melhora na distribuição de renda no Brasil. Os dados da Pesquisa Nacional por Amostra de Domicílios (PNAD), do IBGE, mostram que o índice de Gini da distribuição dos rendimentos tem caído sistematicamente no país desde 2002. No caso de Goiás, o processo é similar. Os dados disponíveis indicam haver uma melhora na distribuição de renda no estado e que as famílias goianas mais carentes tiveram sua renda média superior à nacional.

Analisando a dinâmica da desigualdade de renda nos setores urbano e rural de Goiás, fica evidente que o índice de Gini deste último setor aponta para um aumento da concentração de renda em nível maior do que no setor urbano a partir de 2008. E, na comparação com a média nacional, percebese que o processo de desconcentração de renda no setor rural goiano, que parecia ser mais vigoroso do que o do Brasil, foi interrompido em 2013, tendo ocorrido aumento do seu índice de Gini no biênio de 2014-2015.

Nesta perspectiva, o presente trabalho tem como objetivo avaliar o comportamento da renda domiciliar per capita (RDPC) no setor rural do estado de Goiás no período 20012015. Cada componente da RDPC do setor rural do estado foi analisado, buscando-se apontar quais deles contribuíram para a ocorrência de uma maior ou menor desigualdade de renda neste setor. Seguindo a metodologia proposta por Hoffman (2009), a partir RDPC, foi realizado o cálculo do índice de Gini para os setores urbano e rural do estado de Goiás. Na sequência, foi procedida a decomposição deste índice para verificar quais dos componentes da RDPC foram mais importantes para aumentar ou reduzir a desigualdade de renda no setor rural do estado.

Além desta introdução e das considerações finais, o trabalho conta com outras três seções. A segunda delas apresenta uma revisão dos principais trabalhos que abordam a estrutura da distribuição de renda e suas causas no Brasil. Na seção seguinte são expostos os procedimentos metodológicos utilizados na mensuração da renda domiciliar per capita (RDPC) em Goiás e em sua decomposição para o setor rural do estado. Já na quarta seção tem-se a apresentação e a discussão dos resultados.

\section{REVISÃO DA LITERATURA}

A análise dos trabalhos que estudaram a desigualdade de renda no Brasil revela que os dois objetivos principais perseguidos pelos autores são (i) aferir se houve aumento ou redução dessa desigualdade no Brasil em algum período e (ii) apontar as causas desse movimento. A apresentação abaixo segue uma ordem cronológica desses trabalhos, de modo a perceber não apenas a evolução da desigualdade de renda no país, mas também de verificar suas explicações em cada momento.

Barros e Mendonça (1995) investigaram a evolução da desigualdade da renda no Brasil nas décadas de 1960, 1970 e 1980. Os autores evidenciaram que houve intensificação dessa desigualdade nas décadas de 1960 e de 1980 e queda na década de 1970. O trabalho também apontou a liderança do Brasil em termos da desigualdade de renda dentre vários países no período analisado. Em seu exame sobre o mercado de trabalho brasileiro, os autores defenderam que esse mercado seria um agente transformador da desigualdade de condições do país e não um gerador dessa desigualdade.

Soares (2006) ressalta fundamentalmente que, apesar da queda da desigualdade de renda vivenciada entre 1995 e 2004, esta veio acompanhada de uma queda da renda real de 5\%, mesmo com o índice de Gini atingindo níveis mínimos nos últimos 30 anos. Barros et al. (2007) evidenciam que a desigualdade da renda no Brasil caiu de forma considerável entre 2001 e 2005. Nesse período, os autores destacaram que a desigualdade de renda no Brasil atingiu seu nível mais baixo dos últimos 30 anos, independentemente da medida de desigualdade, ainda que tenham concluído que o país ainda continuava como um dos líderes mundiais neste campo.

Os resultados dos trabalhos de Hoffman (2006), Araújo (2010) Baptistella (2010) e Araújo e Morais (2014) sugerem que o rendimento do trabalho e as transferências de renda têm significativas contribuições para a formação e distribuição da renda das famílias no Brasil. A grande maioria dos autores credita às políticas econômicas e sociais assumidas no início dos anos 2000, como transferências de renda e valorização real do salário mínimo, como os principais catalisadores da queda da desigualdade de renda no Brasil. 
Araújo (2009) buscou testar o crescimento da renda sobre a desigualdade de renda nas regiões brasileiras entre o período de 1995 a 2005, diferenciando a investigação para o meio rural, para os centros urbanos e para o agregado nacional. Seus principais resultados indicam que, quando se analisa o efeito do crescimento sobre a desigualdade de renda, tal efeito é inibido nos estados que detém elevada desigualdade de renda e baixo nível de desenvolvimento social.

Barros, Franco e Mendonça (2010) apontaram que a renda do trabalho e a renda não derivada do trabalho foram os principais determinantes da melhoria da distribuição de renda entre os mais pobres do país no período 2001-2007. Verificaram que a desigualdade educacional da força de trabalho e a sensibilidade da remuneração do trabalho à escolaridade foram importantes na queda das desigualdades de renda do Brasil, assim como a redução nas diversas formas de discriminação e segmentação do mercado de trabalho.

Da Cruz et al. (2016) estimou modelos de determinantes de renda salarial nas macrorregiões brasileiras, entre o período de 2001 a 2006. Os autores apontaram que o nível educacional é um importante determinante da renda salarial para todas as regiões brasileiras, mesmo perdendo participação na explicação da desigualdade salarial, ao tempo em que as variáveis idade e gênero vêm apresentando um aumento na explicação dessa desigualdade, principalmente nas regiões Norte e Nordeste do país. Os resultados demonstraram também um significativo impacto da formalização do trabalho na renda salarial no Nordeste, mas pouco significante no Centro-Oeste brasileiro no período analisado.

Araújo (2010) buscou encontrar um padrão no comportamento da queda da desigualdade de renda ao decompor a RDPC das principais regiões brasileiras entre 2002 e 2008. A autora aponta que a evolução da desigualdade de renda na primeira década do século XXI no Brasil não vem apresentando um padrão uniforme. Inferiu que tal evolução é fruto das seguintes combinações: mudanças no mercado de trabalho, programas de transferência de renda, novos arranjos estruturais do mercado de trabalho, rendas de aposentadorias e pensões oficiais. Seus resultados sugerem que, com exceção do Centro-Oeste brasileiro, todas as regiões apresentaram relevante redução na concentração de renda, embora com menor intensidade na região Nordeste.

Oliveira e Silveira Neto (2016) investigaram a queda da desigualdade por meio da decomposição do índice de Gini, durante o período de 2003 a 2001, com foco nas fontes de renda do trabalho, associadas à escolaridade e às fontes de rendas não relacionadas ao trabalho, como aquelas associadas aos programas de transferência de renda. Os autores apontaram que a renda do trabalho de indivíduos com níveis intermediários de educação formal e a renda oriunda dos programas sociais de transferência de renda foram as principais responsáveis pela queda do índice de Gini no período. Esses resultados estão em consonância com os de Ramos (2007), que apontam que a distribuição da escolaridade na força de trabalho, bem como os retornos à educação, vêm evoluindo para favorecer a redução da concentração da renda no Brasil desde 1995.

Barros, Foguel e Ulyssea (2006) examinaram a efetividade de políticas salariais sobre a desigualdade de renda entre as pessoas mais pobres do país. Isso foi feito por meio de simulações contrafactuais, a partir de dados da PNAD 2005. Os autores demonstraram que o salário mínimo é um instrumento menos efetivo que o Programa Bolsa Família para qualquer linha da pobreza e desigualdade. Assim, o trabalho sinaliza que intervir nos parâmetros de negociação no mercado de trabalho não contribui para o aumento da renda dos mais pobres e que a transferência direta de renda age de forma mais focada e eficaz sobre quem mais necessita.

Resultados que corroboram a importância das transferências de renda e dos rendimentos de salários foram encontrados também por Silva e Araújo (2015), ao analisarem a decomposição da pobreza no Brasil entre 2001 a 2012. Os autores demonstraram que, para todos os estados brasileiros, as elasticidades renda-pobreza e desigualdadepobreza foram negativas e positivas, respectivamente, o que sugere que uma elevação na renda média e uma redução na desigualdade de renda provocariam uma queda da proporção de pobres no país. Os autores apontaram também que, quanto mais concentrada fosse a distribuição de renda no período analisado, menor seria a apropriação por parte dos mais pobres quanto aos benefícios derivados do aumento da renda. 
Araújo e Vasconcelos (2014), ao investigarem a evolução da desigualdade de rendimentos no Nordeste brasileiro e os determinantes de salários no estado do Ceará, apontaram que a educação e a formalidade no mercado de trabalho foram importantes para o aumento do nível de renda das famílias cearenses, entre 2001 e 2012. Esses resultados estão em linha com os de De Sampaio Morais, Araújo e Santana (2014), que buscaram examinar os efeitos das parcelas da RDPC na distribuição de renda no estado do Ceará. Estes autores demonstraram que, no período de 2004 a 2012, a parcela de rendimento do trabalho foi a que mais contribuiu para o aumento da RDPC do estado, embora sua participação na composição da renda tenha diminuído. Por outro lado, a parcela de outras transferências, na qual se encontram os rendimentos referentes às políticas assistenciais, aumentou a sua participação da RDPC das famílias cearenses durante o período analisado.

Alguns trabalhos também têm investigado as desigualdades de renda no setor rural brasileiro e identificado suas particularidades. Kageyama e Hoffman (2000) demonstraram que as atividades não agrícolas, a localização regional e escolaridade têm influenciado positivamente a formação da renda neste setor. Ney e Hoffman (2008) reforçaram a importância das atividades não agrícolas na formação da renda rural. Por sua vez, Ney e Hoffman (2004) constataram que as presenças de atividades não agrícolas vêm contribuindo para aumentar a desigualdade da renda no setor. Já para Waquil e Mattos (2002) essas desigualdades no setor rural brasileiro estão enraizadas na instabilidade de marcos políticos, nas políticas de desenvolvimento adotadas, na elevada concentração fundiária, na baixa rentabilidade das atividades agrícolas e nos baixos investimentos em capital humano e infraestrutura.

\section{PROCEDIMENTOS METODOLÓGICOS E DADOS}

\subsection{PROCEDIMENTOS METODOLÓGICOS}

Como se sabe, o índice de Gini é um indicador que varia de 0 a 1 , sendo que, quanto mais perto da unidade, mais concentrada é a renda de um país ou região. Para a decomposição desse índice, adotouse fundamentalmente 0 procedimento utilizado Hoffman (2007) e por Araújo e Morais (2014). O índice de Gini foi dividido em diferentes componentes do rendimento domiciliar per capita (RDPC) e, a partir dessa divisão, buscou-se aferir qual é a participação relativa de cada componente no total da RDPC, bem como sua contribuição para aumentar ou reduzir o valor do índice de Gini.

Para o procedimento de decomposição do índice de Gini, considera-se inicialmente uma população com $n$ pessoas e que a renda das pessoas, $x_{i}$, seja ordenada de maneira que $x_{1}$ $\leq x_{2} \leq \ldots \leq x_{n}$ (1). A renda média dessas pessoas é constituída por $\mu=\frac{1}{n} \sum_{i=1}^{n} x_{i}$ (2). Quando as pessoas mais pobres até a posição i-ésima são agregadas na série (1), a proporção acumulada da população é dada por $p_{i}=\frac{i}{n}$ (3), com a proporção acumulada da renda sendo indicada pela expressão (4) a seguir: $\phi_{i}=\frac{1}{n \mu} \sum_{j=1}^{i} x_{j}$.

Por sua vez, o índice de Gini é calculado pela expressão (5), $G=\frac{2}{n} \sum_{i=1}^{n-1}\left(p_{i}-\phi_{i}\right)$, podendo variar entre 0 e 1 . A curva de Loren ilustra que o resultado da expressão (4), $\phi_{i}$, se altera de acordo com alterações em $p_{i}$. Considerandose que $x_{i} \geq 0$ e a área $b$ entre a curva de Lorenz e o eixo das abscissas $\left(p_{i}\right)$, o índice de Gini também pode ser apresentado por $\mathrm{G}=1$ 2 b (6).

Para proceder à decomposição do índice de Gini, deve-se levar em conta que a renda das pessoas, $x_{i}$, seja composta por $k$ parcelas, de modo que: $x_{i}=\sum_{h=1}^{k} x_{h i}$ (7). Ao manter a ordenação das rendas, ou seja, $x_{1} \leq x_{2} \leq \ldots \leq$ $x_{n}$, a curva de concentração da parcela ilustra que a proporção acumulada dos $x_{h i}$ se altera em função da proporção acumulada da população. Sendo $B_{h}$ a área entre a curva de concentração da parcela e o eixo das abscissas, a razão de concentração da parcela $x_{h i}$ é dada pela expressão (8), $C_{h}=1$ $2 B_{h}$, sendo que $-1<C_{h}<1$.

Quando a participação da h-ésima parcela total é indicada por $\phi_{h}$, pode-se apresentar o índice de Gini da seguinte forma: $G=$ $\sum_{h=1}^{n} \phi_{h} C_{h}$ (9). Dada a expressão (9), este índice pode ser dividido em $k$ componentes, que correspondem a $k$ parcelas da RDPC. Por seu tuno, a decomposição do índice de Gini quando se toma dois anos distintos (1 e 2) pode ser dada pelas expressões $G_{1}=$ $\sum_{h=1}^{n} \phi_{1 h} C_{1 h}(10)$ e $\quad G_{2}=\sum_{h=1}^{n} \phi_{2 h} C_{2 h}$ (11), respectivamente, a partir das quais sua decomposição será dada por $\Lambda G=G_{2}-G_{1}=$ $\sum_{h=1}^{n}\left(\phi_{2 h} C_{2 h}-\phi_{1 h} C_{1 h}\right)$ (12). Tendo em conta 
essa expressão, pode demonstrar que $\Lambda G=\sum_{h=1}^{n}\left(C_{2 h} \Lambda \phi_{h}+\phi_{1 h} \Lambda C_{h}\right)(13)$.

Somando e subtraindo $\phi_{1 h} C_{2 h}$ dentro da expressão (12) e realizando a fatoração, chega-se à expressão (14) $\Lambda G=\sum_{h=1}^{n}\left(\begin{array}{lll}C_{1 h} \Lambda \phi_{h} & \phi_{2 h} \Lambda C_{h}\end{array}\right)$. A média aritmética das expressões (13) e (14) é utilizada na decomposição de $\Lambda G$, sendo dada por $\Lambda G=\sum_{h=1}^{k}\left(C_{h}^{*} \Lambda \phi_{h}+\phi_{h}^{*} \Lambda C_{h}\right)$ (15), tal que, $\phi_{h}^{*}=\left(\phi_{1 h}+\phi_{2 h}\right)$ e $C_{h}^{*}=\frac{1}{2}\left(C_{1 h}+C_{2 h}\right)$.

A média dos índices de Gini nos dois anos considerados é dada por $G^{*}=\frac{1}{2}\left(G_{1}+G_{2}\right)$ (16). Considerando-se que $\sum \phi_{2 h}=\sum \phi_{2 h}=1$, chega-se à expressão (17) $\sum_{h=1}^{k} G^{*} \Lambda \phi_{h}=$ $G^{*} \sum_{h=1}^{k}\left(\phi_{2 h}-\left(\phi_{1 h}\right)=0\right.$. Subtraindo-se a expressão (17) do segundo membro da expressão (15), encontra-se: $\Lambda G=$ $\left.\sum_{h=1}^{k}\left[\left(C_{h}^{*}-G^{*}\right) \Lambda \phi_{h}+\phi_{h}^{*} \Lambda C_{h}\right)\right](18)$.

Araújo e Morais (2014) argumentam que, de forma matemática, tanto a expressão (15), como a expressão (18) são válidas, mas que Hoffman (2009) recomenda o uso da a expressão (18) na decomposição do índice de Gini. Seguindo essa recomendação, a contribuição total da h-ésima parcela do rendimento para essa mudança é dada pela expressão (19) $(\Lambda G)_{h}=\left(C_{h}^{*}-G^{*}\right) \Lambda \phi_{h}+$ $\phi_{h}^{*} \Lambda C_{h}$. Já a contribuição percentual é dada por $S_{h}=\frac{100}{\Lambda G}\left[\left(C_{h}^{*}-G^{*}\right) \Lambda \phi_{h}+\phi_{h}^{*} \Lambda C_{h}\right](20)$.

Araújo e Morais (2014) salientam que as expressões (19) e (20) diferenciam um efeito associado à mudança na composição do rendimento (efeito-composição) e um efeito associado à mudança nas razões de concentração (efeito-concentração). O efeitocomposição total é dado por $\sum_{h=1}^{k}\left(C_{h}^{*}-G^{*}\right) \Lambda \phi_{h}$ e o efeito-concentração da h-ésima parcela por $\phi_{h}^{*} \Lambda C_{h}$.

\subsection{OS DADOS}

A base de dados utilizada no trabalho é oriunda das informações da Pesquisa Nacional de Amostras e Domicílios (PNAD), referente ao período 2001-2015. A PNAD considera como renda mensal domiciliar a totalidade dos rendimentos obtidos pelos moradores do domicílio de todas as fontes de rendimento, exclusive crianças abaixo de 10 anos. Já a renda domiciliar per capita (RDPC) pode ser entendida como a razão entre o total dos rendimentos domiciliares (em termos nominais) e o total dos moradores, considerando sempre os valores expandidos pelo peso anual da pesquisa.

Mais especificamente, a RDPC é formada pela adição de todas as rendas disponíveis, sejam elas monetárias ou não-monetárias, de todos os residentes do domicílio, abrangendo os seguintes componentes: renda do trabalho principal, secundário e de outros trabalhos; rendimentos previdenciários (pensões públicas e privadas); alugueis; doações de outros domicílios; rendas de juros, dividendos, outros rendimentos, e transferências de programas oficiais, como Bolsa Família, Renda Cidadã, Renda Mínima, Benefício de Prestação Continuada (BRCLOAS), Programa de Erradicação do Trabalho Infantil (PETI), entre outros.

As parcelas da RDPC analisadas neste trabalho foram as seguintes: (i) rendimentos de todos os trabalhos, que são formados pelas rendas do trabalho principal, do trabalho secundário e de outros trabalhos, tanto monetárias quanto não monetárias (valor de produtos); (ii) aposentadorias e pensões públicas, que constituem os rendimentos de aposentadorias e pensões da previdência federal; (iii) aposentadorias e pensões privadas, as quais correspondem aos rendimentos privados de pensões e aposentadorias; (iv) aluguéis, que compreendem aos rendimentos provenientes de aluguéis; (v) abonos e doações, que são doações recebidas de não moradores e abonos de permanência; e (vi) outros rendimentos, que incluem juros de caderneta de poupança, outras aplicações, dividendos e rendimentos de programas de transferência de renda por programas sociais.

\section{RESULTADOS E DISCUSSÕES}

\subsection{EVOLUĈ̃̃ DA RENDA DOMICILIAR PER CAPITA (RDPC) EM GOIÁS}

Em primeiro lugar, foi examinado como vem se comportando o rendimento da renda domiciliar per capita (RDPC) no estado de Goiás. Na Tabela 1, os rendimentos estão expostos em valores reais para ano de 2015 e estratificados em níveis de renda por meio de percentis. Os dados apontam para uma queda real dos rendimentos médios domiciliares entre 2001 a 2015. No Brasil a queda foi de $5,5 \%$, enquanto no estado de Goiás a queda se aproximou de $4 \%$.

Quando a análise é feita por estratificação, verifica-se que, em 2001 , os $10 \%$ mais pobres 
detinham uma RDPC de até $R \$ 123,74$ em Goiás e de até $R \$ 98,99$ no Brasil. Esses valores oscilaram significativamente até 2015 , ano que registrou uma RDPC de cerca de $R \$ 150,00$ e $R \$ 100,15$ em Goiás e no Brasil, respectivamente, com acréscimos reais de $21,2 \%$ na primeira região e de 1,2\% na segunda. No estrato das famílias que estão entre as $10 \%$ mais ricas, percebe-se que no estado de Goiás houve uma queda real de $1,1 \%$ na RDPC desta faixa social (passando de $R \$ 1.348,84$ para $R \$ 1.333,33$ ), enquanto que no Brasil a perda real da RDPC chegou a $9,6 \%$ (de $R \$ 1.603,76$ para $1.450,00$ ).
A partir desses dados, é possível notar que a distância entre ricos e pobres diminuiu no período analisado. Em 2001, a proporção da RDPC das famílias que compunham as 10\% mais ricas no Brasil e em Goiás era de 16,2 e 10,9 vezes, respectivamente, maior do que as $10 \%$ mais pobres. Em 2015, essa relação passou a ser de 14,5 para o Brasil e de 8,9 para o estado de Goiás. Ou seja, estado de Goiás parece estar reduzindo o gap entre ricos e pobres um pouco mais rapidamente do que o Brasil, no que tange à formação da RDPC.

Tabela 1: Evolução da RDPC de Goiás e do Brasil de 2001 a $2015(\mathrm{R} \$)^{\star}$

\begin{tabular}{|c|c|c|c|c|c|c|c|c|}
\hline Percentis & $\begin{array}{l}\text { Brasil } \\
2001\end{array}$ & $\begin{array}{l}\text { Goiás } \\
2001\end{array}$ & $\begin{array}{l}\text { Brasil } \\
2005\end{array}$ & $\begin{array}{l}\text { Goiás } \\
2005\end{array}$ & $\begin{array}{l}\text { Brasil } \\
2009\end{array}$ & $\begin{array}{l}\text { Goiás } \\
2009\end{array}$ & $\begin{array}{l}\text { Brasil } \\
2015\end{array}$ & $\begin{array}{l}\text { Goiás } \\
2015\end{array}$ \\
\hline $1 \%$ & 27,84 & 43,31 & 6,62 & 13,25 & 14,88 & 17,85 & 20,00 & 24,80 \\
\hline $5 \%$ & 68,06 & 92,81 & 28,27 & 44,17 & 37,93 & 49,58 & 47,00 & 75,00 \\
\hline $10 \%$ & 98,99 & 123,74 & 54,11 & 79,51 & 74,37 & 98,81 & 100,15 & 150,00 \\
\hline $25 \%$ & 185,62 & 222,74 & 132,51 & 132,51 & 172,92 & 173,54 & 201,36 & 250,00 \\
\hline $50 \%$ & 371,24 & 371,24 & 247,35 & 265,02 & 310,89 & 327,50 & 394,44 & 394,00 \\
\hline $75 \%$ & 750,73 & 676,48 & 530,04 & 494,71 & 595,01 & 595,01 & 750,91 & 750,00 \\
\hline $90 \%$ & $1.603,76$ & $1.348,84$ & $1.060,08$ & 971,75 & $1.289,18$ & $1.115,64$ & $1.450,00$ & $1.333,33$ \\
\hline $95 \%$ & $2.557,44$ & $2.179,43$ & $1.766,81$ & $1.572,46$ & $2.082,53$ & $1.732,96$ & $2.250,00$ & $2.000,00$ \\
\hline $99 \%$ & $6.187,35$ & $5.840,86$ & $4.858,74$ & $4.417,04$ & $5.503,82$ & $4.760,06$ & $6.000,00$ & $4.500,00$ \\
\hline Média & 744,23 & 686,50 & 519 & 510,95 & 620,81 & 568,79 & 703,00 & 658,44 \\
\hline Obs. & 357.739 & 15.312 & 217.672 & 9.139 & 225.925 & 9.878 & 213.578 & 8.995 \\
\hline
\end{tabular}

Fonte: Elaboração própria. * Todos os valores foram colocados na mesma unidade monetária de 2015, utilizando-se o Índice de Preços ao Consumidor (INPC).

A Tabela 2 demonstra a evolução da RDPC no setor urbano. Embora na média a RDPC no setor urbano em Goiás esteja abaixo da média nacional, a perda real da RDPC de ambos (Goiás e Brasil) se aproximou de $8 \%$. Os dados demonstram que a RDPC das famílias 10\% mais pobres no setor urbano em Goiás foi superior à do Brasil por todo o período analisado, saindo de uma proporção de $16 \%$ maior em 2001 , para $20 \%$ maior em 2015. Resultados similares foram encontrados por Barros et al. (2010), que argumentam que a grande diferença entre ricos e pobres vem diminuindo no Brasil, acompanhada de um aumento real da renda per capita entre os mais pobres. Monsueto e Simão (2010) também encontraram resultados na mesma direção dos resultados aqui apresentados. Os autores apontam que a RDPC do estado de Goiás entre 2001 a 2008 cresceu em uma média superior à da região Centro-Oeste e à do Brasil. 
Tabela 2: Evolução da RDPC de Goiás e do Brasil nas áreas urbanas de 2001 a 2015 (R\$)*

\begin{tabular}{|c|c|c|c|c|c|c|c|c|}
\hline Ano & \multicolumn{4}{|c}{2001} & \multicolumn{2}{c}{2005} & \multicolumn{2}{c}{2009} \\
Percentis & $\begin{array}{c}\text { Brasil } \\
\text { Urban. }\end{array}$ & $\begin{array}{c}\text { Goiás } \\
\text { Urban. }\end{array}$ & $\begin{array}{c}\text { Brasil } \\
\text { Urban. }\end{array}$ & $\begin{array}{c}\text { Goiás } \\
\text { Urban. }\end{array}$ & $\begin{array}{c}\text { Brasil } \\
\text { Urban. }\end{array}$ & $\begin{array}{c}\text { Goiás } \\
\text { Urban. }\end{array}$ & $\begin{array}{c}\text { Brasil } \\
\text { Urban. }\end{array}$ & $\begin{array}{c}\text { Goiás } \\
\text { Urban. }\end{array}$ \\
\hline $1 \%$ & 36,00 & 49,00 & 8,83 & 14,13 & 16,36 & 18,59 & 22,00 & 25,00 \\
\hline $5 \%$ & 83,00 & 101,00 & 35,34 & 44,17 & 44,63 & 55,78 & 56,66 & 80,00 \\
\hline $10 \%$ & 118,00 & 137,00 & 70,67 & 88,34 & 89,00 & 104,00 & 125,00 & 150,00 \\
\hline $25 \%$ & 219,00 & 223,00 & 132,51 & 141,34 & 175,00 & 179,00 & 237,50 & 250,00 \\
\hline $50 \%$ & 421,00 & 404,00 & 265,02 & 265,02 & 346,00 & 335,00 & 394,00 & 394,00 \\
\hline $75 \%$ & 843,00 & 742,00 & 530,04 & 530,04 & 669,00 & 595,00 & 788,00 & 750,00 \\
\hline $90 \%$ & $1.746,00$ & $1.435,00$ & $1.177,88$ & $1.015,92$ & $1.388,00$ & $1.140,00$ & $1.500,00$ & 1333,33 \\
\hline $95 \%$ & $2.788,00$ & $2.269,00$ & $1.943,50$ & $1.590,13$ & $2.231,00$ & $1.785,00$ & $2.500,00$ & $2.000,00$ \\
\hline $99 \%$ & $6.682,00$ & $5.939,86$ & $5.300,44$ & $4.417,04$ & $5.950,00$ & $4.958,00$ & $6.250,00$ & $4.500,00$ \\
\hline Média & 818,00 & 724,00 & 564,83 & 523,43 & 670,00 & 577 & 754,25 & 662,01 \\
\hline Obs. & 305.939 & 13.440 & 185.823 & 8.096 & 193.855 & 8.858 & 184.205 & 8.266 \\
\hline
\end{tabular}

Fonte: Elaboração própria. * Todos os valores foram colocados na mesma unidade monetária de 2015, utilizando-se o Índice de Preços ao Consumidor (INPC).

Na Tabela 3 está exposta a evolução da RDPC na zona rural, para o Brasil e para Goiás. Os dados apontam que a RDPC em Goiás neste setor foi maior do que a média nacional no período estudado. Enquanto que a RDPC média do Brasil no setor rural era de
$\mathrm{R} \$ 307,00$, em 2001, no estado esse valor foi de $R \$ 419,94$, superando em $38 \%$ a média brasileira. Já em 2015, a RDPC média do setor rural goiano superou a nacional em $68 \%$, ficando em aproximadamente em $\mathrm{R} \$ 617,98$.

Tabela 3: Evolução da RDPC de Goiás e do Brasil nas áreas rurais de 2001 a $2015(\mathrm{R} \$)^{\star}$

\begin{tabular}{|c|c|c|c|c|c|c|c|c|}
\hline Ano & \multicolumn{2}{|c|}{2001} & \multicolumn{2}{|c|}{2005} & \multicolumn{2}{|c|}{2009} & \multicolumn{2}{|c|}{2015} \\
\hline Percentis & $\begin{array}{l}\text { Brasil } \\
\text { Rural }\end{array}$ & $\begin{array}{l}\text { Goiás } \\
\text { Rural }\end{array}$ & $\begin{array}{l}\text { Brasil } \\
\text { Rural }\end{array}$ & $\begin{array}{l}\text { Goiás } \\
\text { Rural }\end{array}$ & $\begin{array}{l}\text { Brasil } \\
\text { Rural }\end{array}$ & $\begin{array}{l}\text { Goiás } \\
\text { Rural }\end{array}$ & $\begin{array}{l}\text { Brasil } \\
\text { Rural }\end{array}$ & $\begin{array}{l}\text { Goiás } \\
\text { Rural }\end{array}$ \\
\hline $1 \%$ & 15,00 & 41,25 & 4,12 & 12,37 & 10,91 & 13,01 & 14,40 & 14,29 \\
\hline $5 \%$ & 37,00 & 61,87 & 13,25 & 26,50 & 25,29 & 29,75 & 32,00 & 36,75 \\
\hline $10 \%$ & 54,00 & 89,09 & 24,73 & 44,17 & 37,19 & 48,96 & 40,40 & 73,50 \\
\hline $25 \%$ & 99,00 & 148,49 & 66,25 & 110,40 & 89,25 & 148,75 & 100,50 & 238,00 \\
\hline $50 \%$ & 186,00 & 235,12 & 141,35 & 212,02 & 208,25 & 274,7 & 262,66 & 394,00 \\
\hline $75 \%$ & 351,00 & 433,11 & 265,02 & 403,02 & 345,85 & 483,44 & 400,00 & 625,00 \\
\hline $90 \%$ & 594,00 & 705,36 & 530,04 & 795,07 & 691,70 & 868,34 & 788,00 & $1.294,00$ \\
\hline $95 \%$ & 854,00 & $1.113,72$ & 765,62 & $1.192,60$ & 991,68 & $1.383,39$ & $1.100,00$ & 1800,00 \\
\hline $99 \%$ & $2.110,00$ & $3.935,16$ & $1.766,81$ & $3.336,92$ & $2.231,28$ & $3.718,80$ & $2.333,33$ & $5.000,00$ \\
\hline Média & 307,00 & 419,94 & 250,62 & 414,06 & 325,95 & 493,64 & 379,80 & 617,98 \\
\hline Obs. & 51.800 & 1.872 & 31.849 & 1.043 & 32.070 & 1.020 & 29.373 & 729 \\
\hline
\end{tabular}

Fonte: Elaboração própria. * Todos os valores foram colocados na mesma unidade monetária de 2015, utilizando-se o Índice de Preços ao Consumidor (INPC). 
A RDPC em Goiás também foi superior à média nacional quando se analisa as diferentes camadas sociais. Em 2015, a RDPC média das famílias goianas que estavam entre as $10 \%$ mais pobres foi superior à média nacional em $82 \%$. Por outro lado, enquanto a RDPC rural entre as famílias $10 \%$ mais ricas em Goiás estava em, aproximadamente, $\mathrm{R} \$ 1.294,00 \mathrm{em} 2015$, a média nacional, no mesmo período, chegou a $\mathrm{R} \$ 788,00$ (TABELA 3).

\section{2 ÍNDICE DE GINI DA RDPC DE GOIÁS E DO BRASIL NO PERÍODO DE 2001 A 2015}

A Tabela 4 traz a evolução da distribuição de renda no estado de Goiás no período de 2001 a 2015. Como visto em outros estudos, o estado de Goiás apresentou queda no índice de Gini, sobretudo a partir de 2008. A queda foi de aproximadamente 7 pontos percentuais (p.p.) no período analisado. Parece haver uma melhora na distribuição de renda no estado no período recente, uma vez que a queda do índice de Gini foi substancialmente maior entre 2012 e 2015.

O Gráfico 1 retrata a evolução do índice de Gini para o Brasil e para Goiás. Nos últimos quinze anos, é perceptível que no estado de Goiás houve um processo de desconcentração de renda em maiores patamares do que se vinha apresentando no Brasil. Isso ocorreu mesmo com ambos tendendo à queda na concentração de renda. Os anos recentes, além de apresentarem uma queda do índice de Gini em Goiás, foram também o período em que se mais ampliaram as diferenças entre o estado e o país no que diz respeito a tal indicador. Enquanto em 2015 o estado de Goiás apresentou um índice de 0,506, os dados apontam que o Brasil apresentou um índice de 0,567, com uma diferença de 6 p.p.

Tabela 4: Índice de Gini de Goiás de 2001 a 2015

\begin{tabular}{|c|c|c|c|c|c|c|c|}
\hline Ano & Gini & $\begin{array}{c}\text { Desvio } \\
\text { Padrão }\end{array}$ & $t$ & \multicolumn{5}{c|}{ P>t } & \multicolumn{3}{c|}{ Conf Intervalo de } & $N$ \\
\hline 2001 & 0.5675277 & 0.0003314 & 1712.66 & 0.000 & 0.5668782 & 0.5681771 & 3960 \\
\hline 2002 & 0.5453100 & 0.0002474 & 2203.73 & 0.000 & 0.544825 & 0.545795 & 15137 \\
\hline 2003 & 0.5720055 & 0.0003574 & 1600.39 & 0.000 & 0.571305 & 0.5727061 & 8503 \\
\hline 2004 & 0.5271716 & 0.0001823 & 2892.13 & 0.000 & 0.5268144 & 0.5275289 & 15607 \\
\hline 2005 & 0.6007291 & 0.0006729 & 892.70 & 0.000 & 0.5994102 & 0.6020481 & 9139 \\
\hline 2006 & 0.5667256 & 0.0003583 & 1581.92 & 0.000 & 0.5660234 & 0.5674278 & 9415 \\
\hline 2007 & 0.5694416 & 0.0005961 & 955.34 & 0.000 & 0.5682733 & 0.5706098 & 7683 \\
\hline 2008 & 0.5765898 & 0.0003882 & 1485.35 & 0.000 & 0.575829 & 0.5773507 & 9653 \\
\hline 2009 & 0.5588241 & 0.0004034 & 1385.32 & 0.000 & 0.5580335 & 0.5596148 & 9878 \\
\hline 2011 & 0.5404113 & 0.0005735 & 942.24 & 0.000 & 0.5392872 & 0.5415354 & 8967 \\
\hline 2012 & 0.5479744 & 0.0003481 & 1574.24 & 0.000 & 0.5472922 & 0.5486567 & 9408 \\
\hline 2013 & 0.5483239 & 0.0003949 & 1388.34 & 0.000 & 0.5475498 & 0.549098 & 8930 \\
\hline 2014 & 0.5197802 & 0.0003103 & 1674.95 & 0.000 & 0.519172 & 0.5203884 & 9295 \\
\hline 2015 & 0.5069889 & 0.0002789 & 1817.55 & 0.000 & 0.5064422 & 0.5075356 & 8995 \\
\hline
\end{tabular}

Fonte: Elaboração própria.

Esse resultado é interessante para o estado, já que outros trabalhos empíricos, como o de Araújo (2010), demonstraram que a região Centro-Oeste brasileira vinha mantendo um nível de concentração de renda alto e estável na primeira década de 2000. Por outro lado, tal qual se verifica aqui, Monsueto e Campos
(2010) e Monsueto, Guimarães e Silva (2015), ao analisarem a desigualdade de renda na região metropolitana goiana, também apontaram uma significativa melhora nos indicadores de distribuição de renda. Para esses últimos autores, esse fenômeno estaria ligado ao amadurecimento do mercado de 
Gráfico 1: Evolução do índice de Gini de Goiás e do Brasil de 2001 a 2015

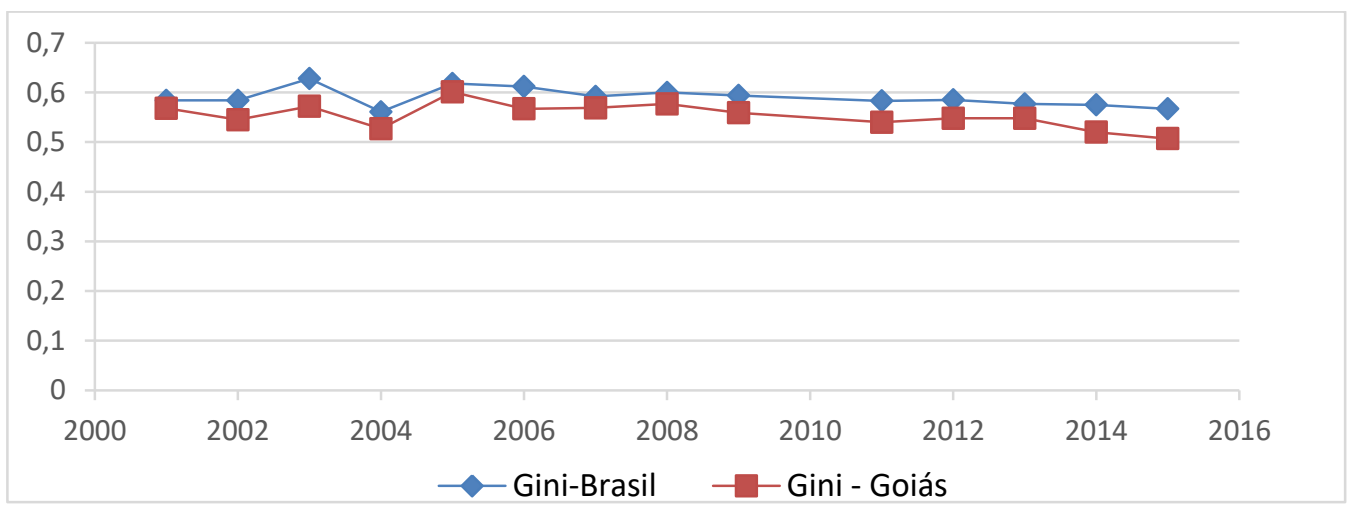

Fonte: Elaboração própria.

Quanto à distribuição de renda entre os setores urbano e rural, há um comportamento que é importante salientar. No início dos anos 2000, o índice de Gini no setor rural em Goiás indicava uma menor concentração de renda do que o setor urbano. Contudo, após 2008, é possível notar que o índice de Gini no setor rural goiano tornou-se maior do que o do setor urbano, mesmo havendo uma menor concentração de renda nestes últimos anos, como pode ser observado na Tabela 5.

Tabela 5: Índice de Gini urbano e rural de Goiás de 2001 a 2015

\begin{tabular}{|c|c|c|c|c|c|}
\hline Ano & Gini-Urbano & \multicolumn{1}{c|}{ Gini-Rural } & Ano & Gini-Urbano & Gini-Rural \\
\hline 2001 & 0,563 & 0,525 & 2008 & 0,574 & 0,596 \\
\hline 2002 & 0,542 & 0,523 & 2009 & 0,556 & 0,582 \\
\hline 2003 & 0,572 & 0,546 & 2011 & 0,541 & 0,525 \\
\hline 2004 & 0,526 & 0,485 & 2012 & 0,549 & 0,522 \\
\hline 2005 & 0,600 & 0,598 & 2013 & 0,551 & 0,509 \\
\hline 2006 & 0,563 & 0,589 & 2014 & 0,517 & 0,546 \\
\hline 2007 & 0,572 & 0,514 & 2015 & 0,505 & 0,532 \\
\hline
\end{tabular}

O Gráfico 2 retrata a evolução da distribuição de renda nos setores rurais brasileiro e goiano. Nota-se certa estabilidade ao longo do tempo do indicador, mas o setor rural goiano demonstra maior variabilidade ao longo do tempo em relação ao brasileiro. Isto é, enquanto o Brasil apresentou certa estabilidade no índice de concentração de renda no setor rural, entre 2008 e 2013, houve em Goiás uma melhora na distribuição de renda. Porém, no biênio de 2014-2015, a concentração de renda no setor rural goiano aumentou e aproximou-se dos patamares do indicador nacional.
Em suma, os resultados encontrados neste trabalho seguem em linha com a literatura empírica sobre o tema. As indicações são de uma melhora na distribuição de renda no Brasil e em Goiás, mesmo diante de perdas reais da renda nos últimos anos. Os dados sugerem também que as famílias goianas mais carentes tiveram sua renda média superior à nacional. Contudo, ao analisar o meio rural goiano, percebe-se que houve certa reversão da melhora que a distribuição de renda havia percebido até 2013. A decomposição da desigualdade de renda neste setor que será feita na próxima seção 
contribuirá para a compreensão desses resultados.

Gráfico 2: Evolução do índice de Gini dos setores rurais de Goiás e do Brasil de 2001 a 2015

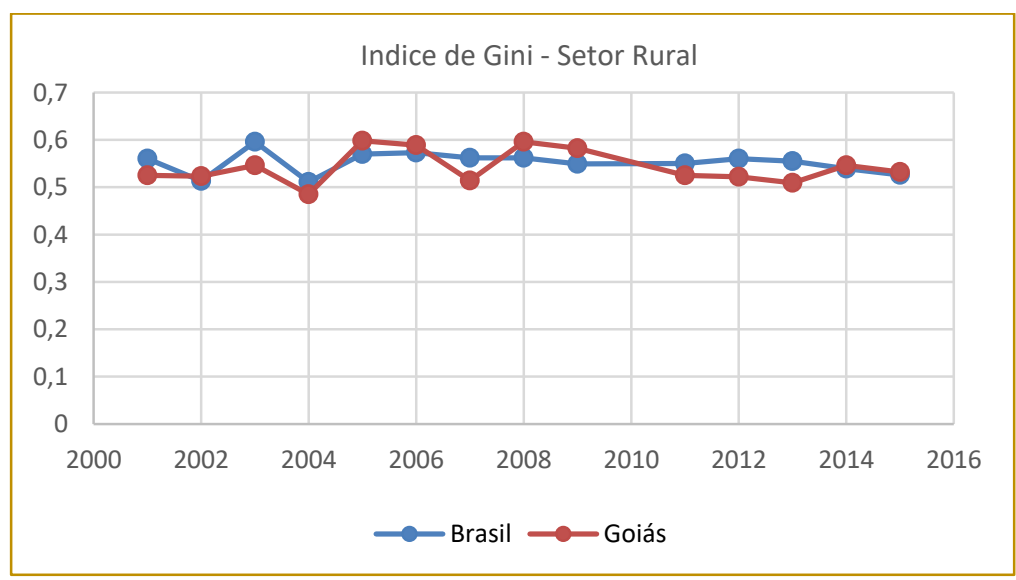

Fonte: Elaboração própria.

\subsection{DECOMPOSIÇÃO DO ÍNDICE DE GINI DO SETOR RURAL EM GOIÁS NO PERÍODO 2001-2015}

$\mathrm{Na}$ presente seção busca-se apresentar e compreender a evolução da distribuição da RDPC do setor rural no estado de Goiás, por meio da decomposição do índice de Gini nas seis parcelas que compõem a RDPC, a saber: rendimentos de todos os trabalhos; aposentadorias e pensões públicas; aposentadorias e pensões privadas; aluguéis; abonos e doações; e outros rendimentos. Essa análise busca verificar o impacto de cada um dos componentes elencados na formação da RDPC e na disparidade de renda em Goiás.
$\mathrm{Na}$ Tabela 6 foram expostas as participações de cada componente entre o primeiro e último quadriênio ao longo de 2001 a 2015 no total da RDPC. Pode-se perceber inicialmente que a estrutura da RDPC rural em Goiás tem se modificado ao longo dos últimos 15 anos. A participação das rendas provenientes do trabalho diminuiu de 90\%, em 2001, para $74 \%$, em 2015; a parcela referente às aposentadorias e pensões públicas experimentou um salto no mesmo período, saindo de $5 \%$ para $14 \%$; os abonos e as doações permaneceram estáveis; já as aposentadorias e pensões privadas, os aluguéis e os outros rendimentos tiveram ligeiros aumentos de sua participação na formação da RDPC rural em Goiás no período analisado.

Tabela 6: Participação de cada parcela da RDPC rural de Goiás de 2001 a 2015

\begin{tabular}{|l|c|c|c|c|}
\hline \multicolumn{2}{|c|}{2001} & 2005 & 2011 & 2015 \\
\hline Rendimentos do Trabalho & 0,90 & 0,87 & 0,9 & 0,74 \\
\hline Apos. e pensões públicas & 0,05 & 0,09 & 0,06 & 0,14 \\
\hline Apos. e pensões privadas & 0,02 & 0,01 & 0,01 & 0,02 \\
\hline Aluguéis & 0,01 & 0,01 & 0,01 & 0,02 \\
\hline Abonos e doações & 0,01 & 0,01 & 0,01 & 0,01 \\
\hline Outros rendimentos & 0,01 & 0,01 & 0,01 & 0,07 \\
\hline \multicolumn{1}{|c|}{ Total } & 1,00 & 1,00 & 1,00 & 1,00 \\
\hline
\end{tabular}

Fonte: Elaboração própria. 
Seguindo a tendência de resultados encontrados na literatura, a parcela dos outros rendimentos na RDPC rural goiana cresceu nos últimos anos, podendo indicar um efeito potencial dos programas oficiais de transferências de renda. Por outo lado, a redução da participação das rendas provenientes do trabalho na formação desta RDPC pode estar refletindo uma modernização do campo em Goiás, com uma agropecuária buscando trabalhar com menor utilização de terras, aumento da produtividade e novos cultivares, poupadores de mão de obra e minimizadores dos gastos com salários.

A Tabela 7 contém os valores das razões de concentração do índice de Gini da distribuição RDPC do setor rural em Goiás. Para compreender seus resultados, basta ter em mente que, quando a razão de concentração de um determinado componente da RDPC for superior ao índice de Gini, esse componente possui um caráter regressivo, ou seja, contribui para ampliar a desigualdade de renda; já quando ocorre o contrário, isto é, quando a razão de concentração do componente for menor do que índice de Gini, o mesmo é classificado como progressivo, contribuindo para queda da desigualdade de renda.

Os resultados mostram que valores das razões de concentração das aposentadorias e pensões públicas, das rendas do trabalho e dos aluguéis situaram-se acima do valor do índice de Gini em todos os anos analisados. Vale ressaltar que as rendas do trabalho apresentaram certa tendência à redução da concentração e da regressividade na formação da RDPC ao longo do período analisado, enquanto que as rendas provenientes dos aluguéis e das aposentadorias e pensões públicas foram na direção de aumentar a concentração e a regressividade.

Tabela 7: Razões de concentração relativas ao índice de Gini da RDPC do setor rural de Goiás de 2001 a 2015

\begin{tabular}{|l|l|l|l|l|}
\hline & 2001 & 2005 & 2011 & 2015 \\
\hline Rendimentos do Trabalho & 0,995 & 0,997 & 0,983 & 0,985 \\
\hline Apos. e pensões públicas & 0,608 & 0,931 & 0,959 & 0,995 \\
\hline Apos. e pensões privadas & 0,700 & 0,483 & 0,738 & 0,444 \\
\hline Aluguéis & 0,650 & 0,998 & 0,624 & 0,733 \\
\hline Abonos e doações & 0,607 & 0,999 & 0,990 & 0,215 \\
\hline Outros rendimentos & 0,033 & $-0,076$ & $-0,176$ & $-0,074$ \\
\hline \multicolumn{1}{|c|}{ Total } & 0,525 & 0,598 & 0,525 & 0,532 \\
\hline
\end{tabular}

Fonte: Elaboração própria

Em relação às aposentadorias e pensões privadas e aos abonos e doações, é interessante notar que, inicialmente, eles têm um maior grau de concentração, mas que seus resultados terminaram por apresentar um caráter progressivo em 2015. Aliás, em termos de progressividade, 0 destaque especial deve ir para os outros rendimentos, que foram os que mais contribuíram para a redução da desigualdade de renda no setor agrícola goiano ao longo do período analisado.

\section{CONSIDERAÇÕES FINAIS}

O presente trabalho buscou elucidar e fomentar a discussão sobre a distribuição de renda no estado de Goiás nos últimos 15 anos, verificando sua evolução e sua distribuição por meio da análise da renda domiciliar per capita (RDPC) do estado.

Os resultados sugerem que as famílias mais pobres tiveram aumento da sua RDPC maior do que as mais ricas durante o período analisado. Nesta faixa social, a média goiana foi superior à nacional e houve redução da distância entre os rendimentos das pessoas mais ricas e os das pessoas mais pobres do estado, em razão principalmente do aumento da renda das famílias mais pobres. 
Especialmente no meio rural goiano, as famílias mais pobres detêm uma RDPC superior à média nacional. Contudo, quando se analisa a distribuição de renda no setor, há indicações de que a concentração de renda em Goiás vinha diminuindo ao longo dos últimos anos, mas voltou a se elevar a partir de 2014. Os resultados do trabalho apontam que, dentre os componentes da RDPC do setor rural de Goiás, os principais responsáveis pelo aumento da concentração de renda no setor são as rendas do trabalho, os aluguéis e as aposentadorias e pensões públicas, com aparente caráter regressivo ao longo dos anos analisados.

Do ponto de vista das rendas do trabalho, esses resultados podem estar relacionados com o processo de modernização da agricultura, que, de um lado, poupa mão de obra, diminui a demanda de emprego e comprime os salários; mas, de outro lado, cria outros tipos de empregos mais qualificados e que pagam maiores salários. Em relação às

\section{NOTAS}

5 A Curva de Lorenz foi proposta pelo economista Max Otto Lorenz (1876-1959) em seu trabalho intitulado Methods of measuring the concentration of wealth, o qual teve grande influência nos estudos posteriores no campo da desigualdade de renda.

6 Vide, por exemplo, Barros, Franco e Mendonça (2007), Hoffman (2013, 2009), De Almeida Gabriel (2014) e Monsueto, Guimarães e Silva (2015).

7 Resultados similares foram encontrados em Hoffman (2009) e Araújo (2010) ao analisarem a evolução da RDPC para a desigualdade de renda brasileira.

8 Vide Barros, Foguel e Ulyssea (2006), Hoffman (2009, 2010), Araújo (2010) e Araújo e Morais (2014).

9 No caso específico de Goiás, cumpre ressaltar que, além dos programas de transferência de renda do Governo Federal, as famílias contam com o Programa Renda Cidadã, lançado pelo Governo Estadual por meio do Decreto 5.211, de 10 de abril de aposentadorias e pensões públicas, os resultados encontrados aqui podem dar luz ao fato de que, além de serem mais elevadas do que os valores das pensões privadas, elas não estão sujeitas às mesmas perdas reais que geralmente recaem sobre essas últimas ao longo dos anos.

Por fim, cumpre destacar o papel dos outros rendimentos na redução das desigualdades de renda no estado. Estes rendimentos abrangem os programas públicos de transferência de renda e sua progressividade está entre os principais resultados de outros trabalhos sobre o tema. Embora passíveis de críticas, especialmente pela quase ausência de portas de saída do sistema, os resultados encontrados nesse e nos outros trabalhos sobre o tema reforçam a ideia de que os programas de transferências de renda devem continuar existindo como catalisadores para o combate à desigualdade de renda, tanto no meio urbano quanto no meio rural.

2000. De acordo com informações da Caixa Econômica Federal

(http://www.caixa.gov.br/programas-

sociais/renda-cidada/Paginas/default.aspx), o programa se destina aos seguintes grupos: Grupo I: grupo familiar composto por membros de idade igual ou superior a 65 anos; ou grupo com, pelo menos, um membro portador de deficiência permanente e incapacitante total ou parcial, doença que impossibilite, comprovadamente, a realização de atividade laboral, hemofilia, epilepsia, doença renal crônica, HIV, fibrose cística, anemia falciforme ou neoplasia maligna; Grupo II: constituído por famílias de baixa renda em situação de risco social.

10 Hoffman (2009), Araújo (2010) e Araújo e Morais (2014) também demonstram que as rendas do trabalho e as aposentadorias e pensões públicas contribuem para aumentar o grau de desigualdade da distribuição de renda.

11 Vide, por exemplo, Barros, Foguel e Ulyssea (2006), Hoffman (2009, 2010), Araújo (2010), De Sampaio Morais, Araújo e Santana (2014) e Araújo e Morais (2014). 


\section{REFERÊNCIAS}

[1]. ARAÚJO, Jair Andrade. Pobreza, desigualdade e crescimento econômico: três ensaios em modelos de painel dinâmico. 2009. 101f. Tese (Doutorado em Economia). Universidade Federal do Ceará, Fortaleza, 2009.

[2]. ARAUJO, Jair Andrade; DE SAMPAIO MORAIS, Gabriel Alves. Desigualdade de Renda e sua decomposição no Brasil e nas Regiões Brasileiras. Revista Econômica do Nordeste, v. 45, n. 4, p. 35-49, 2014

[3]. ARAÚJO, Jair Andrade. Decomposição da recente queda da desigualdade da renda per capita no Brasil: uma análise a partir do índice de concentração. 2010. 114f. Dissertação (Mestrado em Economia). Universidade Federal do Rio Grande do Sul, Porto Alegre, 2010.

[4]. ARAÚJO, Jair Andrade; VASCONCELOS, Joyciane Coelho. Decomposição da Desigualdade de Renda Salarial do Estado do Ceará. Revista de Economia, v. 40, n. 1, 2014.

[5]. BAPTISTELLA, J. C. F. Os impactos dos programas de transferência condicionada de renda na desigualdade do rendimento domiciliar per capita nas macrorregiões brasileiras pós 2000. Brasília: Finanças Públicas, 2010.

[6]. BARROS, Ricardo Paes de. FOGUEL, Miguel Nathan; ULYSSEA, Gabriel (Orgs). Desigualdade de renda no Brasil: uma análise da queda recente. Instituto de Pesquisa Econômica Aplicada (Ipea). Brasília, 2006.

[7]. BARROS, Ricardo; CARVALHO, Mirela; FRANCO, Samuel; MENDONÇA, Rosane. Determinantes da queda na desigualdade de renda no Brasil. Instituto de Pesquisa Econômica Aplicada (Ipea). Brasília, 2010.

[8]. BARROS, Ricardo; CARVALHO, Mirela; FRANCO, Samuel. MENDONÇA, Rosane. A queda na desigualdade de renda no Brasil. Instituto de Pesquisa Econômica Aplicada (Ipea). Brasília, 2007.

[9]. BARROS, Ricardo; MENDONÇA, Rosane. Os determinantes da desigualdade no Brasil. Instituto de Pesquisa Econômica Aplicada (Ipea). Brasília, 1995

[10]. DA CRUZ, Mércia Santos; BARRETO, F. A; DOS SANTOS, L. M.; DE SOUTO, K. C. Determinantes das Desigualdades Salariais nas Macrorregiões Brasileiras: Uma Análise para o Período 2001-2006. Revista Econômica do Nordeste, v. 42, n. 3, p. 551-576, 2016.

[11]. DE SAMPAIO MORAIS, Gabriel Alves; ARAUJO, Jair Andrade; DE SANTANA, Denise Moreira Araújo. Análise da decomposição da desigualdade de renda no Estado do Ceará. Revista Ciências Administrativas, v. 20, n. 2 , p. 692-723, 2014.
[12]. HOFFMANN, R. Transferências de Renda e Desigualdade, Brasil, 1995-2011. In CAMPELLO, T.; NERI, M. C. (Orgs). Programa Bolsa Família: uma década de inclusão e cidadania. Brasília: IPEA, 2013

[13]. HOFFMANN, Rodolfo. Desigualdade da distribuição da renda no Brasil: a contribuição de aposentadorias e pensões e de outras parcelas do rendimento domiciliar per capita. Economia e Sociedade, 2009.

[14]. HOFFMANN, Rodolfo. Transferências de renda e redução da desigualdade no Brasil e em cinco regiões, entre 1997 e 2005. In: BARROS, R. P.; FOGUEL, M. N.; ULYSSEA, G. (Org). Desigualdade de renda no Brasil: uma análise da queda recente. IPEA, v-2, p. 17-40. Brasília, 2007.

[15]. HOFFMANN, Rodolfo. Transferências de renda e a redução da desigualdade no Brasil e cinco regiões entre 1997 e 2004. Econômica, v. 8, n. 1, p. 55-81, 2006.

[16]. HOFFMANN, Rodolfo. Desigualdade da distribuição da renda no Brasil: a contribuição de aposentadorias e pensões e de outras parcelas do rendimento domiciliar per capita. Economia e Sociedade, Campinas, v. 18, n. 1 (35), p. 213-231, abr. 2009

[17]. KAGEYAMA, Angela; HOFFMAN, Rodolfo. Determinantes da renda e condições de vida das famílias agrícolas no Brasil. Economia, v. 1, n. 2, p. 147-183, 2000

[18]. MONSUETO, S.E.; CAMPOS, F.R. Distribuição de Renda na Região Metropolitana de Goiânia: os Censos de 1991 e 2000 e perspectivas para o novo Censo. Goiânia: NEPEC/FACE/UFG, Textos Para Discussão do Curso de Ciências Econômicas n. 18. 2010.

[19]. MONSUETO, Sandro Eduardo; SIMÃO, Rosycler C. S. Distribuição de renda e mercado de trabalho em Goiás durante a década recente. Conjuntura Econômica, Instituto Mauro Borges, jun. 2010 .

[20]. MONSUETO, Sandro Eduardo; GUIMARÃES, Adriana Moura; SILVA, Gabriela de Moura. Distribuição de Renda na Região Metropolitana de Goiânia: o que diz o censo de 2010 e o que esperar para 2020? Curso de Ciências Econômicas da Universidade Federal de Goiás-FACE, 2015.

[21]. NEY, Marlon Gomes; HOFFMANN, Rodolfo. A contribuição das atividades agrícolas e não-agrícolas para a desigualdade de renda no Brasil rural. Economia Aplicada, v. 12, n. 3, p. 365393, 2008

[22]. HOFFMANN, Rodolfo; NEY, Marlon Gomes. Desigualdade, escolaridade e rendimentos na agricultura, indústria e serviços, de 1992 a 2002. Economia e Sociedade, v. 13, n. 2, p. 51-79, 2004. 
[23]. RAMOS, Lauro. A desigualdade de rendimentos do trabalho no período pós-Real: o

papel da escolaridade e do
desemprego. Economia aplicada, v. 11, n. 2, p. 281-301, 2007.

[24]. SOARES, Sergei. Análise de bem-estar e decomposição por fatores da queda na desigualdade entre 1995 e 2004. Econômica, v. 8, n. 1, p. 83-115, 2006.
[25]. SILVA, Janaina Cabral da; ARAUJO, Jair Andrade. Estudo Sobre a Decomposição dos Determinantes da Variação da Pobreza nos Estados Brasileiros no Período 2001 a 2012. Revista de Economia e Sociologia Rural, v. 53, n. 4, p. 627-644, 2015.

[26]. WAQUIL, Paulo D.; MATTOS, Ely J. Distribuição de renda no Rio Grande do Sul: um comparativo entre o rural e o urbano. Revista Ensaios FEE, v. 23, p. 621-644, 2002. 


\section{Gapítulo 23}

\section{PROGRAMA CHAPÉU DE PALHA: PERPETUAĊÃO DA POBREZA NA ZONA CANAVIEIRA?}

\section{Érika Sabrina Felix Azevedo}

\section{Tales Wanderley Vital}

Resumo: Essa investigação, qualitativa, objetivou analisar o Programa Chapéu de Palha na zona canavieira de Pernambuco no que concerne a erradicação da pobreza e geração de trabalho e renda. Dito programa busca enfrentar o problema do contingente de trabalhadores desempregado do setor canavieiro em Pernambuco, sobretudo nos meses de entressafra. Em 2007, o Governo de Pernambuco retomou o programa Chapéu de Palha do ex-governador Miguel Arraes, e este ano completa dez anos dessa política pública, porém algumas lacunas de planejamento e execução precisam ser analisadas. O programa consiste na ajuda financeira e social para os trabalhadores desempregados no período da entressafra da produção de cana, com a obrigação de que os mesmos participem de cursos de capacitação e qualificação profissional. Diante do contexto, fez-se necessário perscrutar as limitações e possibilidades desse programa para o meio rural, considerando a persistência da sazonalidade do trabalho agropecuário, a mobilidade geográfica dos trabalhadores, a precarização do trabalho e os conflitos envolvendo a relação mediado pelo Estado, empregadores do setor do agronegócio e trabalhadores rurais.

Palavras Chaves: Mercado de trabalho, Política Pública, Programa Chapéu de Palha. 


\section{INTRODUÇÃO}

Apesar de muitas discussões sobre o novo modelo de desenvolvimento brasileiro nas últimas décadas visando reorientar as práxis do Estado e das políticas públicas, muitas mudanças precisam ser estabelecidas quanto ao papel do estado, principalmente no que diz respeito a sua relação com os territórios e com os atores locais.

Relativamente ao desenvolvimento rural, ganham proeminência os enfoques local e territorial como perspectivas analíticas atribuídas da responsabilidade de contemplar essa complexidade emergente e oferecer respostas às questões recentemente incorporadas ao debate público e à reflexão científica: a sustentabilidade e as novas ruralidades (SCHNEIDER, 2004).

Nesta perspectiva busca-se dar ênfase às preocupações que objetivam apreender as novas dinâmicas das áreas rurais, que resultam da nova arquitetura política, social e cultural engendrada por transformações decorrentes dos processos de globalização e da reforma do Estado.

Uma vez consideradas essas transformações no mundo rural e nas representações sociais sobre o mesmo, faz-se necessário nas análises de políticas públicas entender as lógicas que passam a predominar no ambiente no qual se dá, muitas vezes implícito, o embate de interesses opostos e das forças desiguais entre os atores sociais (CARNEIRO, 1998).

Diante disso é improvável que políticas públicas possam promover um efeito de desenvolvimento territorial quando não reconhecem os conflitos e as disparidades sociais em sua condição de elementos constitutivos do território.

Uma perspectiva sustentável do desenvolvimento territorial tende a lançar um olhar conectivo sobre os diferentes aspectos que o impulsionam ou dificultam, sobretudo, devido à importância central dada à mobilização das capacidades endógenas a partir de uma abordagem conjuntural, de modo a não desprezar a problematização sobre os condicionantes concretos da ação política dos homens e mulheres locais (JARA, 2001). É nesse espaço que a necessidade de políticas efetivas voltadas para o trabalhador rural, devem ganhar uma inquestionável relevância nas ações para o desenvolvimento territorial.
Porém, é necessário refletir sobre a reciprocidade dessa associação, ou seja, se políticas públicas para trabalhadores rurais consideram, para além do discurso, as relações estabelecidas entre os grupos sociais e as posições ocupadas por estes no tecido sociocultural do território.

Ante a gravidade do fenômeno e inequívoca ressonância social, essa investigação norteou-se pela seguinte questão problematizante: como o programa chapéu de palha tem contribuído para redução da pobreza dos trabalhadores rurais da zona canavieira em Pernambuco?

À luz dessa diretiva, foi estabelecido o seguinte objetivo: analisar o Programa Chapéu de Palha na zona canavieira de Pernambuco no que concerne a redução da pobreza e geração de trabalho e renda.

A motivação principal à realização desse trabalho, que é parte de uma pesquisa com maior amplitude, se assenta na crença de que a dignidade do trabalhado rural, mais que uma prioridade social, representa um direito natural, portanto, de caráter universal

\section{REVISÃO DA LITERATURA}

\subsection{O PROGRAMA CHAPÉU DE PALHA: DEZ ANOS DE HISTÓRIA}

O Programa Chapéu de Palha foi criado em 1988, durante a segunda gestão (1987-1990) do governador Miguel Arraes. O Programa Chapéu de Palha possuía como principal objetivo a transferência de renda para o trabalhador rural que se encontrava desempregado no período da entressafra da cultura da cana-de-açúcar, ou seja, buscava amenizar a vulnerabilidade a qual estavam submetidos/as os/as trabalhadores/as da produção e beneficiamento de cana-deaçúcar na Zona da Mata do Estado de Pernambuco durante os períodos de entressafra (maio a agosto).

Para Santos (2007), "O Programa Chapéu de Palha foi criado para preencher o período de esfriamento da microeconomia e de desajuste social, quando muitas pessoas precisam se deslocar para áreas urbanas na busca de trabalho. Neste contexto, os trabalhadores executavam serviços de manutenção das estradas e limpeza urbana, capinação de acostamentos das rodovias e outras demandas do serviço público, e recebiam uma bolsa. As mulheres não eram 
beneficiárias do programa (LONGHI, 2009). Segundo Rabelo et al. (2013), no lançamento da primeira edição do programa, realizaramse alguns protestos por parte dos usineiros e empregadores, que criticavam o fato de o trabalhador rural oferecer seu trabalho pela metade do salário que recebiam durante a safra para desempenhar atividades que não eram voltadas para o plantio da cana-deaçúcar. O Chapéu de Palha também recebeu críticas de setores da direita pernambucana, que o classificava como um programa paternalista, clientelista e populista. Rabelo et al. (2013, p. 17), afirma em seu estudo:"[...] fontes relatam que Miguel Arraes era chamado de, "Pai Arraia" pelos agricultores. Roberto Magalhães, ex-governador, atacava o Chapéu de Palha propondo a alternativa de fornecer seguro-desemprego aos trabalhadores e assim também formalizá-los."

No ano de 1990, após dois anos de execução do programa, Miguel Arraes renunciou ao governo para disputar o mandato a deputado federal. Tem-se nesse período um processo de desestruturação das iniciativas campesinas de Arraes. "[...] Elas são gradualmente esquecidas até mesmo com a reeleição de Arraes em 1994, pois seu governo nesse período (1994-1998) foi marcado por crises administrativas e financeiras" conforme Rabelo et al. (2013, p. 17). O Chapéu de Palha só seria retomado em 2007, após a eleição do governador Eduardo Campos, neto de Miguel Arraes, em um contexto político e econômico de ampliação dos programas de transferência de renda e de combate à pobreza no país.

De acordo com a Lei n.. 13.244, de 11 de junho de 2007, o Programa Chapéu de Palha foi instituído para 54 municípios da zona canavieira pernambucana:

Art. 1. Fica instituído, no âmbito do Estado de Pernambuco, o Programa Chapéu de Palha, que tem por finalidade adotar medidas de combate aos efeitos do desemprego em massa decorrentes da entressafra da canade-açúcar, que resultem em geração de renda, reforço alimentar, capacitação e melhoria da qualidade de vida da população afetada, especialmente nas áreas de educação, saúde, cidadania, habitação, infraestrutura e meio ambiente.

Art. 2.ㅇ O Programa, ora instituído, terá como destinatárias às famílias dos trabalhadores rurais desempregados em virtude $\mathrm{da}$ entressafra do cultivo da cana-de-açúcar, residentes nos municípios discriminados no Anexo Único da presente Lei, que se encontrem em situação de pobreza, conforme definido no Programa Bolsa Família, criado pela Lei Federal n. 10.836, de 09 de janeiro de 2004. (PERNAMBUCO, 2007a)

O artigo 2.. dessa lei foi alterado em 2009, pela Lei n. -13.975 , ampliando os critérios de participação para os trabalhadores que estavam desempregados em até três safras anteriores. "Art. 2.. O Programa, ora instituído, terá como destinatárias às famílias dos trabalhadores rurais desempregados em virtude da entressafra, bem como dos desempregados que atuaram em até 3 (três) safras anteriores no cultivo da cana-deaçúcar" (PERNAMBUCO, 2009b). A mesma legislação garantiu que o pagamento do benefício fosse feito preferencialmente em nome da mulher, seguindo as prerrogativas do Programa Bolsa Família, que também prevê que a mulher seja a responsável, preferencialmente, pelo recebimento da bolsa, possibilitando maior autonomia das mulheres na utilização do recurso disponibilizado."Art. 8.. Para efeito do pagamento dos benefícios de que tratam o art. 6. e art. 7.ㅇ desta Lei, cada família somente poderá cadastrar um beneficiário no Programa, preferencialmente a mulher, na qualidade de responsável, na forma do regulamento." (PERNAMBUCO, 2009b).

Após a reformulação, o programa passa a oferecer, anualmente, aos trabalhadores capacitações visando à melhoria da qualidade de vida e geração de renda. A instituição do programa por meio de legislação específica garante sua continuidade, deixando de ser uma política de governo, pontual e estratégica, caracterizadora de um determinado governo; e passou a ser política de estado, abrangente e com participação de várias agências de estado (HEILBORN; ARAÚJO; BARRETO, 2010).

O novo formato do programa passou a ser desenvolvido na perspectiva da intersetorialidade envolvendo o trabalho de secretarias: Saúde; Educação; Mulher; Juventude; Agricultura e Reforma Agrária; Trabalho e Emprego; Desenvolvimento Social e Direitos Humanos; e Ciência, Tecnologia e Meio Ambiente, sob a coordenação da Secretaria de Planejamento e Gestão (Seplag), permitindo que as ações sejam pensadas de forma conjunta e com diálogo 
permanente entre essas áreas, fator importantíssimo no desenvolvimento de políticas públicas. De modo diverso da primeira edição do programa, o recebimento do benefício passou a se condicionar à participação nos cursos oferecidos pelas secretarias que compõem a Comissão Gestora do Programa, conforme previsto no $\S$ 1. do artigo 7.-Oda Lei n. 13.244/2007: "Para ser destinatário do benefício de que trata o caput deste artigo é exigida, obrigatoriamente, a título de contrapartida, a participação em cursos de capacitação profissional."
No momento da retomada, a Secretaria Especial da Mulher (atualmente denominada Secretaria da Mulher - SecMulher), havia sido recentemente criada e passou, juntamente com as demais secretarias do governo de Pernambuco, a compor a Comissão Gestora do Programa Chapéu de Palha, que, a exemplo do Programa de 1988, atuava na Zona da Mata do estado. Essas secretarias teriam, segundo material informativo (PERNAMBUCO, 2007) disponibilizado pela Comissão Executiva, as seguintes atribuições (Tabela 1) a seguir descriminadas:

Tabela 1: Atribuições das Secretarias do Governo de Pernambuco no Programa Chapéu de Palha da Zona Canavieira

\begin{tabular}{|c|c|}
\hline Secretarias & Atribuições \\
\hline Sec. de Educação & $\begin{array}{l}\text { Realização de cursos de alfabetização para adultos e } \\
\text { reforço escolar. }\end{array}$ \\
\hline Sec. de Des. Social e Cidadania & Emissão de documentos básicos. \\
\hline Sec. de Juventude e Emprego & Realização de cursos de capacitação profissionalizante. \\
\hline Sec. de Agricultura e Reforma Agrária & $\begin{array}{c}\text { Distribuição de } 1 \text { litro de leite para famílias cadastradas que } \\
\text { tenham crianças com até seis anos de idade. }\end{array}$ \\
\hline Sec. de Ciência, Tec. e Meio Ambiente & $\begin{array}{l}\text { Realização de capacitações nas áreas de meio ambiente e } \\
\text { reflorestamento e revitalização de praças e canteiros. }\end{array}$ \\
\hline Sec. de Saúde & $\begin{array}{c}\text { Desenvolvimento de ações de prevenção e tratamento de } \\
\text { doenças. }\end{array}$ \\
\hline Sec da Mulher & $\begin{array}{l}\text { Realização de atividades de conscientização dos direitos } \\
\text { das mulheres, mobilizando estas e seus grupos organizados, } \\
\text { oferecendo cursos, seminários e atividades de } \\
\text { fortalecimento sociopolítico e econômico, com distribuição } \\
\text { de livros e capacitações para que as mulheres conheçam e } \\
\text { acessem as políticas públicas. }\end{array}$ \\
\hline Sec de Planejamento e Gestão & Coordenação de todas as ações do Programa. \\
\hline
\end{tabular}

Fonte: Autor, 2017

Em 2009, o Programa Chapéu de Palha expandiu-se para os trabalhadores da fruticultura irrigada, que também sofriam com o desemprego no período da entressafra. A nova versão do programa passou a beneficiar os municípios de Petrolina, Lagoa Grande, Santa Maria da Boa Vista, Belém do São Francisco, Cabrobó, Orocó e Petrolândia, de acordo com a Lei n. .0 13.766/2009.

Em 2011, pela Lei $n .-14.492$, foi atendida demanda do movimento de pescadores e pescadoras artesanais, com a criação do
Chapéu de Palha da Pesca Artesanal, beneficiando 57 municípios pernambucanos. A inclusão desse segmento no programa justifica-se pelas condições adversas para a pesca no período de inverno, vez que as condições climáticas não possibilitam o desenvolvimento de suas atividades, resultando, consequentemente, na redução da renda familiar.

Art. 2.ㅇ O Chapéu de Palha - Pesca Artesanal terá como destinatárias as famílias das pescadoras e dos pescadores artesanais e 
de subsistência, inclusive pescadoras e pescadores de marisco, sem renda em virtude das condições adversas para a pesca durante $O$ período de inverno. (PERNAMBUCO, 2011a).

Entre 2007 e 2017, dez anos de execução do Programa, o Chapéu de Palha atendeu trabalhadores dos três segmentos canavieiros, fruticultores e pescadores, com investimentos que ultrapassaram os 100 milhões de reais.

Em 2012, o governo de Pernambuco criou em caráter emergencial o Chapéu de Palha Estiagem, pela Lei $\mathrm{n}$. - 14.768, de 18 de setembro, para atender 115 municípios pernambucanos que decretaram estado de calamidade pública em decorrência da estiagem prolongada. Segundo dados da Secretaria de Planejamento - Seplag, o Chapéu de Palha Estiagem foi disponibilizado para mais de 192 mil famílias de agricultoras e agricultores inscritos no Bolsa Estiagem ou no Garantia Safra do Ministério da Agricultura, compondo uma das ações da Operação Seca, coordenada pela Sara (PERNAMBUCO, [2014h]).

O Programa Chapéu de Palha insere-se no perfil de programas de transferência de renda mínima, existentes em todo o país, nas três esferas de governo. No plano federal, o Programa Chapéu de Palha insere-se no Plano Nacional Brasil sem Miséria, englobando os eixos da garantia de renda, inclusão produtiva e acesso a serviços públicos. O benefício do Chapéu de Palha interliga-se ao Programa Bolsa Família, sendo necessário, dessa forma, o cadastramento das trabalhadoras e trabalhadores no Cadastro Único para os programas sociais. $\mathrm{O}$ bolsa família é um programa de transferência de renda para famílias em situação de pobreza (renda mensal por pessoa entre $R \$ 77,01$ e $R \$ 154,00$ ) ou extrema pobreza (com renda familiar per capita inferior a $\mathrm{R} \$ 77,00)$, que recebem benefícios que variam de $R \$ 35,00$ a $R \$ 77,00$ de forma cumulativa e variável dependendo da composição e renda familiar (BRASIL, [2014b]). O Chapéu de Palha, seguindo os moldes do Bolsa Família, prevê o pagamento de uma bolsa ao trabalhador (a) que varia de acordo com cada segmento. Em 2014, o valor do benefício foi reajustado em $6 \%$, estabelecendo o piso mínimo de $R \$ 100,00$, independentemente do valor recebido pelo beneficiário no Bolsa Família (LOPES, 2013).
Em 2014, o valor do benefício na região da zona canavieira foi de $R \$ 246,45$; na fruticultura irrigada, foi de $R \$ 246,45$; e na pesca artesanal de $R \$ 256,52$. E estes valores permanecem até o presente ano, sem sofrer nenhum reajuste. Os valores são pagos durante quatro meses. Os recursos financeiros são provenientes de dotação orçamentária própria do governo de Pernambuco e complementa a bolsa recebida pela família cadastrada no Programa Bolsa Família. O pagamento do benefício se faz por cartão magnético, emitido pela Caixa Econômica Federal, seguindo o calendário de pagamento do Bolsa Família (PERNAMBUCO, [2017h])

No caso específico do Chapéu de Palha da Zona Canavieira, para participar do programa, as trabalhadoras e os trabalhadores precisam atender aos seguintes critérios: ser trabalhador(a) rural do corte da cana-de-açúcar; ser maior de 18 anos; ter carteira assinada por, no mínimo trinta dias, referente às safras de três anos anteriores; residir e trabalhar em um dos 54 municípios de abrangência do programa (PERNAMBUCO, 2012b).

O cadastramento é feito nos sindicatos, por uma empresa de tecnologia da informação, contratada pela Coordenação do programa (PERNAMBUCO, 2012c). Caso o trabalhador não possa ou não queira participar das atividades oferecidas, ele pode indicar uma pessoa do núcleo familiar para participar da atividade. As mulheres, enquanto trabalhadoras, podem cadastrar-se diretamente no programa ou ser indicada por seu companheiro, pai ou irmão. Quando indicadas pelo trabalhador cadastrado, a mulher pode participar das atividades educativas desenvolvidas pelas secretarias, mas não recebem o benefício.

No caso específico da zona canavieira, o número de mulheres diretamente envolvidas no corte da cana é reduzido. A participação delas no programa corresponde a cerca de $10 \%$ do total de beneficiários por ano. (PERNAMBUCO, 2014a). A participação da SecMulher/PE na Comissão Gestora do programa permitiu a incorporação do recorte de gênero com o desenvolvimento de atividades específicas para as mulheres canavieiras, com o objetivo de contribuir na correção dos desequilíbrios entre mulheres e homens, com enfoque no empoderamento social e político das mulheres, valorização da 
sua capacidade produtiva, acompanhando as necessidades colocadas pela agenda dos movimentos sociais rurais e feministas (PERNAMBUCO, 2010). Dessa forma, surgiu em 2007 o Projeto Chapéu de Palha Mulher da Zona Canavieira, como uma das estratégias da SecMulher/PE de formação da Rede de Agentes de Políticas Públicas para Mulheres Rurais.

Como política pública, o Programa Chapéu de Palha se inscreve em um cenário de interesses conflitantes: de um lado, os/as trabalhadores/as necessitados/as de condições objetivas para uma existência digna; do outro, seus empregadores, proprietários das usinas e de fornecedores de cana-de-açúcar, beneficiados pela manutenção das condições sociais favoráveis à disponibilidade de mão de obra barata, sujeita às condições precárias de trabalho. Entende-se, então, que para atuar no cerne das problemáticas de "desajuste social", o Chapéu de Palha deveria atentar para o conflito, promover outro desenvolvimento, com elementos diametralmente opostos aos estruturantes do orquestrado pelas oligarquias do sistema de produção sucroalcooleira. Do contrário, estaria apenas remediando problemas sem atingir sua fonte geradora, pois o modelo dominante de desenvolvimento da Zona da Mata de Pernambuco é excludente.

O modelo mostra quatrocentos anos de concentração fundiária, monocultura da canade-açúcar, exclusão social, desemprego, analfabetismo e mortalidade infantil, além do desmatamento desordenado e da poluição hídrica. A persistência desse modelo, já esgotado, implica um grave risco social e político, traduzido num maior empobrecimento e exclusão de uma parte considerável da população, violência social e ingovernabilidade, definida como crescente incapacidade de os governos estaduais e locais darem respostas aos problemas prioritários e reivindicações populares (JARA, 1998, p.237).

Sobre o fazer político incidem críticas que denunciam que o governo Arraes "deu muita atenção e, até mesmo, prioridade àqueles projetos de pequeno alcance que não levam a modificações estruturais profundas, mas que atingem um grande número de pessoas" (ROCHA, 1991, p.35). Contudo, é necessário reconhecer o mérito de ter enfrentado a oposição do então presidente da república,
José Sarney, que dificultava a liberação de recursos para investimentos, e, ainda assim, não ter sacrificado as políticas sociais. Dessa forma, o Programa Chapéu de Palha garantia emprego (mão de obra para pequenos serviços) para aproximadamente 60 mil trabalhadores/as, com remuneração mensal de um salário mínimo e duas cestas básicas (ROZOWYKWIAT, 2006).

O processo de redemocratização favoreceu o "reordenamento dos laços sociais entre os trabalhadores", pois até a década de 1970, "os trabalhadores foram submetidos a coações pelos patrões para negociarem individualmente em detrimento da coletividade" (SIGAUD, 1986 apud SANTOS, 2007, p.30). Embora o soerguimento das organizações civis e a proximidade de Arraes com estas - sobretudo com o Sindicato dos Trabalhadores Rurais (STR), a Federação dos Trabalhadores na Agricultura do Estado de Pernambuco (FETAPE) e Confederação Nacional dos Trabalhadores na Agricultura (CONTAG) - fossem favoráveis a mudanças mais profundas, como as relacionadas à reforma agrária, a postura assumida foi a de "mediar os conflitos de classe e manter, dentro de um princípio de paz social, a dinâmica socioeconômica fluindo sem grandes rupturas funcionais" (SANTOS, 2007, p.3).

Todavia, o cunho popular do governo Arraes não pode ser menosprezado, havia uma constante preocupação com o proletariado rural, tanto que o abandono dos programas sociais voltados para os/as trabalhadores/as do setor sucroalcooleiro foi um dos principais motivadores da crítica ao governo de Joaquim Francisco (1991-1993). Assim, paradoxalmente, a oposição estigmatizou o governo Arraes como comunista e a extrema esquerda o considerava lento e ineficiente. Martinelle (2006, p.201), ao falar da "revolução do povo", no capítulo ironicamente intitulado "Arraes: fundando o reino de Deus em Pernambuco", afirma: "o grande mérito de Arraes é que ele estava conseguindo sustentar uma democracia liberal de cunho social mobilizando o trabalho de forças antagônicas"

O tom conciliador e a consequente falta de transformações estruturais também foram marcantes, o que pode ser explicado pela observação de que as práticas políticas dos governos de Pernambuco, Bahia e Ceará demonstram que "a legitimidade dos 
governadores esteve, nos últimos anos, relacionada aos resultados alcançados pelas economias dos seus estados" (CARVALHO, 2005, p.177). Para se dimensionar a importância da agroindústria sucroalcooleira na economia e, consequentemente, na política pernambucana, basta saber da sua participação nas exportações do estado, que, até em 2005, se manteve sempre em torno de $60 \%$ (CAVALCANTI et al., 2002). A centralidade do crescimento econômico nesses estados está relacionada ao "baixo nível de acumulação daquelas sociedades, o que tornou este objetivo obrigatório nos debates, nas expectativas sociais e nas iniciativas governamentais" (CARVALHO, 2005, p.183)

\subsection{O CENÁRIO DA ZONA CANAVIEIRA EM PERNAMBUCO E AS REPERCUSSÕES SÓCIAIS DO PROGRAMA CHAPÉU DE PALHA}

Pernambuco tem 185 municípios que dividese em 12 Regiões de Desenvolvimento (RDs): Sertão do Araripe; Sertão do São Francisco; Sertão Central; Sertão de Itaparica; Sertão do Pajeú; Sertão do Moxotó; Agreste Central; Agreste Meridional; Agreste Setentrional; Mata Sul; Mata Norte; Região Metropolitana; e um Distrito Estadual - Fernando de Noronha (PERNAMBUCO, 2014a).

A zona canavieira é a região de maior concentração de latifúndios dedicados a monocultura da cana-de-açúcar e agrega a população de cerca de 1,3 milhão de pessoas, segundo dados do IBGE (2011). Compreende 54 municípios: 19 da Zona da Mata Norte; sete da Região Metropolitana do Recife; 24 municípios da Zona da Mata Sul; um do Agreste Setentrional; um do Agreste Central e um do Agreste Meridional. Segundo Gaspar (2009, p. 1):

No Brasil, o plantio da cana-de-açúcar (matéria prima das usinas) se iniciou em São Vicente, no ano de 1522, trazida da Ilha da Madeira, por Martim Afonso de Souza. Foi em Pernambuco, porém, que ela floresceu, encontrando condições ideais para seu desenvolvimento nas terras úmidas em massapé. [...] A cana-de-açúcar é plantada na zona da mata de Pernambuco, na chamada zona canavieira há quase 5 séculos. [...] No início, os engenhos de açúcar devem ter sido movidos à tração humana, como as casas de farinha. Depois evoluíram para a tração animal (bois e éguas) e para os engenhos d'água. Só a partir do século XIX é que seriam introduzidos em Pernambuco os engenhos movidos a vapor e haveria uma revolução no comércio e indústria do açúcar. [... A primeira usina implantada em Pernambuco foi a de São Francisco da Várzea, cuja primeira moagem aconteceu em 1875.

Na Zona da Mata, o setor sucroalcooleiro emprega um contingente de 90 a 100 mil trabalhadores e cerca de dois terços desses são dispensados na entressafra, como afirmam Campos, Raposo e Maia (2007). A entressafra constitui um período de grande problema para a região, considerando a forte dependência dessa atividade explicada por Campos, Raposo e Maia (2007, p. 330) da seguinte forma:

Naquela época, a produção canavieira se estruturou no sistema de plantation, que se baseava no uso intenso de mão-de-obra escrava, monocultura da cana-de-açúcar em grandes extensões de terra e produção voltada para exportação ao mercado mundial. Desde então, a cana-de-açúcar ainda é a única cultura com significância econômica, o plantio continua a utilizar largas extensões de terra e, embora a mão- de-obra não seja mais escrava e tenha havido algumas inovações tecnológicas, o trabalho ainda é intensamente utilizado e mal remunerado

A monocultura canavieira, considerada vocação econômica da região, "[...] inibiu o surgimento de outras atividades econômicas, gerando problemas estruturais: desemprego e subemprego, déficits sociais elevados e a degradação do meio natural" (JANSEN; MAFRA, 2010, p. 1). A baixa diversidade econômica dificultou a diminuição da concentração fundiária rebaixando os indicadores sociais e econômicos da região. Os municípios da zona canavieira têm o IDH médio de 0,606; estando os menores índices nos municípios da Zona da Mata Sul (IBGE, 2011).

Segundo pesquisa realizada por Campos, Raposo e Maia (2007), a jornada média de trabalho de um(a) cortador(a) de cana é de 9,2 horas por dia e, nesse período, cortam aproximadamente 4,3 toneladas de cana. A jornada intensa de trabalho faz do corte da cana seu único trabalho em razão da dificuldade de conciliar com outras atividades. 
A intensa carga laboral leva à manifestação de várias doenças segundo Alessi, Navarro (1997 apud Andrade Júnior, 2010), como dores na coluna, dores torácicas, lombares e de cabeça, dermatites, desidratação, infecções respiratórias, hipertensão e alcoolismo. Ainda segundo pesquisa feita por Campos, Raposo e Maia (2007, p. 332), "[...] - corte da cana é realizado quase que exclusivamente por homens: 98,8\% dos entrevistados eram do sexo masculino".

As mulheres estão presentes nessa atividade, seja como trabalhadora com carteira assinada, como clandestina sem direitos trabalhistas, como ajudante do companheiro ou dos pais (na infância), na maioria das vezes invisibilizadas na cadeia produtiva da cana-de-açúcar. Segundo Silva (2002), essa participação vem sendo reduzida em consequência da falência das usinas e do desemprego no campo, que tem atingido mulheres e homens.

Em sua pesquisa Campos, Raposo e Maia (2007) afirmam que a renda média familiar e a renda per capita dos cortadores de cana pesquisados era inferior à da população da Zona da Mata, e uma das fontes de renda dessas famílias é o benefício concedido pelos programas governamentais de transferência de renda, principalmente durante o período da entressafra, a exemplo do Programa Chapéu de Palha.

Como é possível observar, o ciclo de plantação, colheita e moagem da cana-deaçúcar tem etapa de menor demanda por mão de obra, período conhecido como entressafra, em que os trabalhadores são dispensados das atividades ficando desempregados. Muitos são readmitidos no início da nova safra considerando-se a demanda da produção, o que demonstra certa instabilidade e precariedade nos vínculos empregatícios estabelecidos com as usinas, com flutuações nas contratações e empregos temporários.

O trabalho precário é marcado por três indicadores, segundo Hirata (2009): 1) ausência de proteção social e de direitos sociais, inclusive de direitos sindicais; 2) baixos salários; 3) baixos níveis de qualificação. As novas configurações das relações trabalhistas, empregos temporários e clandestinos, caracterizam o atual momento de crise do setor sucroalcooleiro.

Segundo o presidente da União Nordestina de Produtores de Cana (Unida) e da Associação dos Fornecedores de Cana de Pernambuco (AFCP), Alexandre Andrade Lima, o setor passa por uma crise, "[...] um colapso por falta de ação governamental" (ROBERTO, 2013, p.1). Ainda segundo Lima, o setor canavieiro ocupa um total de 310 mil hectares na Zona da Mata de Pernambuco; desses, "[...] 100 mil hectares são de terras desapropriadas para reforma agrária [...] onde está a maioria dos pequenos produtores, que representam 95\% dos fornecedores de cana do Estado" (ROBERTO, 2013, p.1).

Segundo dados da Rais, ver na (tabela 2), os dados sobre a produção de cana de açúcar em Pernambuco dos últimos cinco anos, revelam que a quantidade produzida, em toneladas, vinha crescendo, mostrando o quanto esse setor é importante para economia, embora tenha diminuído no ano de 2016, o que pode ser um reflexo da crise econômica que todos os setores enfrentaram.

Tabela 2: Dados sobre a cana de açúcar no estado de Pernambuco:2012- 2016

\begin{tabular}{|c|c|c|c|c|c|}
\hline \multicolumn{2}{|c|}{2012} & 2013 & 2014 & 2015 & 2016 \\
\hline Quantidade produzida(t) & 14.242 .228 & 14.834 .139 & 15.417 .362 & 15.965 .218 & 13.421 .235 \\
\hline $\begin{array}{c}\text { Valor da Produção }(x \\
\text { 1000) R\$ }\end{array}$ & $908.785,00$ & $939.032,00$ & $962.841,00$ & $1.199 .039,00$ & $1.299 .358,00$ \\
\hline Área plantada(ha) & 309.928 & 302.752 & 305.376 & 315.467 & 260.195 \\
\hline Área Colhida (há) & 299.901 & 296.823 & 302.932 & 309.487 & 259.155 \\
\hline $\begin{array}{c}\text { Rendimento Médio } \\
\text { (kg/há) }\end{array}$ & 47.490 & 49.976 & 50.894 & 51.586 & 51.788 \\
\hline
\end{tabular}

Fonte: RAIS, 2016 
De acordo com ranking nacional de produção de cana, Pernambuco ocupa a oitava posição em quantidade produzida, do Nordeste, é o estado que mais produz, mais de 13 mil toneladas, como apresentado na tabela 3:

Tabela 3: Ranking do Brasil da quantidade produzida de Cana de Açúcar (t)

\begin{tabular}{|c|c|c|}
\hline \multicolumn{1}{|c|}{ Posição } & Estado & Quantidade Produzida (t) \\
\hline $1^{\circ}$ & São Paulo & 442.282329 \\
\hline $2^{\circ}$ & Goiás & 71.061 .922 \\
\hline $3^{\circ}$ & Minas Gerais & 69.934887 \\
\hline $4^{\circ}$ & Mato Grosso do Sul & 51.927 .246 \\
\hline $5^{\circ}$ & Paraná & 47.466 .596 \\
\hline $6^{\circ}$ & Mato Grosso & 19.209 .764 \\
\hline $7^{\circ}$ & Alagoas & 18.982 .504 \\
\hline $8^{\circ}$ & Pernambuco & 13.421 .235 \\
\hline $9^{\circ}$ & Paraíba & 6.908 .885 \\
\hline $1^{\circ}$ & Bahia & 6.413 .820 \\
\hline
\end{tabular}

Fonte: RAIS, 2016

Como uma das consequências da crise instalada no setor, se dá pela migração dos trabalhadores do campo para a cidade, que segundo Jansen e Mafra (2010, p. 4) ocorre em duas direções, "[...] (a) para o Centro-Sul na busca de conseguir emprego; e (b) outra parte migra para as periferias do Recife e de outras cidades de porte médio da Região, em condições precárias, passando à condição de subempregados na informalidade". O setor passou por uma recuperação em 2001, mas não conseguiu alcançar os patamares anteriores aos anos 1990, época em a monocultura da cana esteve em alta.. "Segundo o Sindaçúcar, foram extintas 20 unidades produtivas de açúcar e álcool, nos últimos 10 anos." (CAMPOS; RAPOSO; MAIA, 2007, p. 330). Hoje contam apenas com 17 usinas: Trapiche, Cucaú, Cental Olho D'Agua, CAN, Petribú, São José, Ribeirão, Pumaty, Copersul, Ipojuca, Bom Jesus, Primavera, Liberdade, Santa Tereza, Cruangi, Tamandaré e Laranjeiras, conforme dados de 2018 do Sindicado de Açúcar e Álcool de Pernambuco.

\section{METODOLOGIA}

Dada característica qualitativa da investigação. Essa classificação justifica-se em razão da natureza dos dados evocados no processo de buscar-se os significados, as experiências subjetivas, os costumes, os sentidos e as impressões. Abrange-se, igualmente, a análise de sentimentos, atributos, entendimentos e posições filosóficas, alcançando histórias biográficas, diálogos, dentre outras subjetividades, explorando problemas humanos (âmbito individual) ou sociais (coletivos) (Srivastava \& Thomson, 2009).

Para atender ao objetivo proposto, produziuse análise exploratória-descritiva, centrada na inclusividade, hierarquia e abrangência do objetivo. O propósito norteador dessa pesquisa, de lógica indutiva, diz respeito à análise do fenômeno, com as finalidades secundárias de identificar conceitos, fatores contingentes e facilitadores, com ênfase na conivência (ativa ou passiva) dos pares.

Em harmonia com a escolha metodológica descrita, optou-se pela pesquisa de levantamento documental, cujo corpus se compõe por dados evocados do campo através da Secretaria de Mulher de Pernambuco, executora do Programa e também da Secretaria de Planejamento e Gestão de Pernambuco, responsável pela promoção do Chapéu de Palha. Entretanto, a 
análise (de conteúdo) realizada se pautou essencialmente no teor dessas informações e significações manifestas, segundo as categorias determinadas.

Nas ações de pesquisa foram realizadas inferências acerca desses conteúdos (arrazoados aduzidos no contexto social). A partir dos elementos caracterizadores da política pública segundo a doutrina (revisão de literatura), conseguiu-se tratar de um importante grupo social, o que permitiu lançar-se questões sobre as condições de vida dos trabalhadores no campo e na cidade; as formas de emprego e subemprego; a mobilidade geográfica dos trabalhadores, a relação entre empregadores e empregados e a atuação do Estado no quadro de conflitos entre capital e trabalho no campo.

Buscou-se avaliar o Programa Chapéu de Palha através de uma avaliação de processo, comum quando se pretende investigar as etapas para alcance dos resultados de políticas públicas, focalizando seus processos e mecanismos de execução. Preocupa-se mais em observar se o programa está sendo executado conforme planejado, visando diagnosticar possíveis falhas no programa, no que diz respeito aos instrumentos, procedimentos, conteúdos e métodos, adequação ao público-alvo, ensejando o seu aperfeiçoamento, através da interferência direcionada para seus aspectos intrínsecos. Esta modalidade de avaliação tem por objetivo "fazer as coisas certas" (FARIA, 1999, p. 46).

Assim, o modelo de processo busca agrupar as atividades com relação ao desenvolvimento da política pública a que se refere, tendo como resultado um conjunto de processos político-administrativos, que conforme Dye (2005) segue as seguintes fases: Identificação do problema (Ações governamentais com base nos problemas sociais); Montar agenda de deliberações (Escolha dos problemas emergenciais a serem tratados); Formular propostas de políticas (Desenvolver propostas de políticas para solucionar os problemas); Legitimar Políticas (Transformar a proposta em lei com o apoio político); Implementar Políticas (Organizar burocracias, prestar serviço e gerar impostos) e Avaliar Políticas (avaliar os impactos do programa sobre o público alvo e os demais públicos, além de propor mudanças e ajustes).
Semelhante ao modelo citado, tem-se o modelo de processo adotado para o Programa Chapéu de Palha, desenvolvido pela Secretária de Planejamento do Estado de Pernambuco (Seplag), que foi usado como modelo analítico deste trabalho, para análise dos resultados, cujas fases são apresentadas a seguir:

I. Planejamento: uma avaliação anual que determina o quanto será investido e consequentemente a quantidade de beneficiários atendida em cada município. Além de definir a participação de cada secretaria e os cursos que serão ofertados, articulando as escolas e sindicatos para realização das capacitações.

II. Cadastramento: processo que compreende a entrega dos documentos obrigatórios para se tornar um beneficiário do Programa (PIS/NIS do participante ou representante legal, CPF do participante e do indicado, RG, CTPS ou contrato de trabalho reincidido e comprovante de endereço).

III. Capacitação: Os cursos são oferecidos ao beneficiário ou a um dependente da família, indicado no ato de cadastramento, são ofertados na cidade onde residem, acontecem em prédios escolares ou do sindicato da região. Além dos cursos, no período de capacitação, são oferecidos lanches, recreadores para acompanhar as crianças da mães que estão em processo de capacitação e precisam levar seus filhos e disponibilizado material didático.

IV. Folha de Pagamento Corrente: os pagamentos que são feitos aos beneficiários do programa e dos demais envolvidos (recreadores, instrutores e organizações executoras).

V. Folha de Pagamento Retroativa: esses pagamentos acontecem em dois períodos, antes e depois da execução da capacitação. Referem-se aos custos para implementar a capacitação (material didático, lanches, estruturação mínima do programa) e também para finalizar 0 pagamentos dos envolvidos (recreadores, instrutores e organizações executoras).

VI. Avaliação do Programa: ao final da execução do programa, é elaborado um relatório onde são avaliados a frequência dos beneficiários e dos instrutores a 
quantidade de evasão, possíveis falhas que dificultaram o desenvolvimento do trabalho e alcance dos objetivos propostos.

De acordo com Dye (2005), o modelo de processo é útil para auxiliar no entendimento das diversas atividades desenvolvidas na formulação de políticas, o que pode facilitar uma avaliação mais ampla ao final de sua execução.

\section{ANÁLISE DOS RESULTADOS}

No Estado de Pernambuco a exploração canavieira é marcada pela exploração de mão de obra barata e desqualificada, por um regime de produção que degrada o solo. Além disso, tem uma estrutura que dificulta a transição para a produção mecanizada. Essa estruturação socioeconômica da região canavieira também marca no cenário político articulações e lutas pela melhoria das condições de vida dos canavieiros e das canavieiras, que passaram a demandar políticas públicas que minimizem as consequências do desemprego em massa durante a entressafra.

Para atender ao objetivo do programa Chapéu de Palha é estabelecido um cronograma anual, conforme tabela 4, onde são previstos os períodos de: planejamento, processo de cadastro, período de capacitação, geração das folhas de pagamento do programa (corrente e retroativa) e a realizada uma avaliação final do programa por ano.

Tabela 4: Macro Cronograma do Programa na zona Canavieira

\begin{tabular}{|c|c|c|c|c|c|c|c|c|c|c|c|c|}
\hline Programa & Jan & Fev & Mar & Abr & Mai & Jun & Jul & Ago & Set & Out & Nov & Dez \\
\hline \multirow{3}{*}{ Cana } & PLAN & PLAN & PLAN & CAD & CAD & CAD & & & & AP & AP & AP \\
\hline & & & & & & CAP & CAP & CAP & CAP & & & \\
\hline & FR & FR & FR & FR & FC & FC & FC & $\mathrm{FC}$ & FR & FR & FR & $F R$ \\
\hline
\end{tabular}

Fonte: Elaborado pelo autor, fonte de dados Seplag/2017

Para melhor compreensão do funcionamento operacional do programa, ver figura 1 , onde são expressas as ações de planejamento, cadastramento, execução, gerenciamento e avaliação detalhadamente, apontando os processos realizados em cada fase, com base no cronograma do Programa. 
Figura 1: Modelo Operacional do Programa

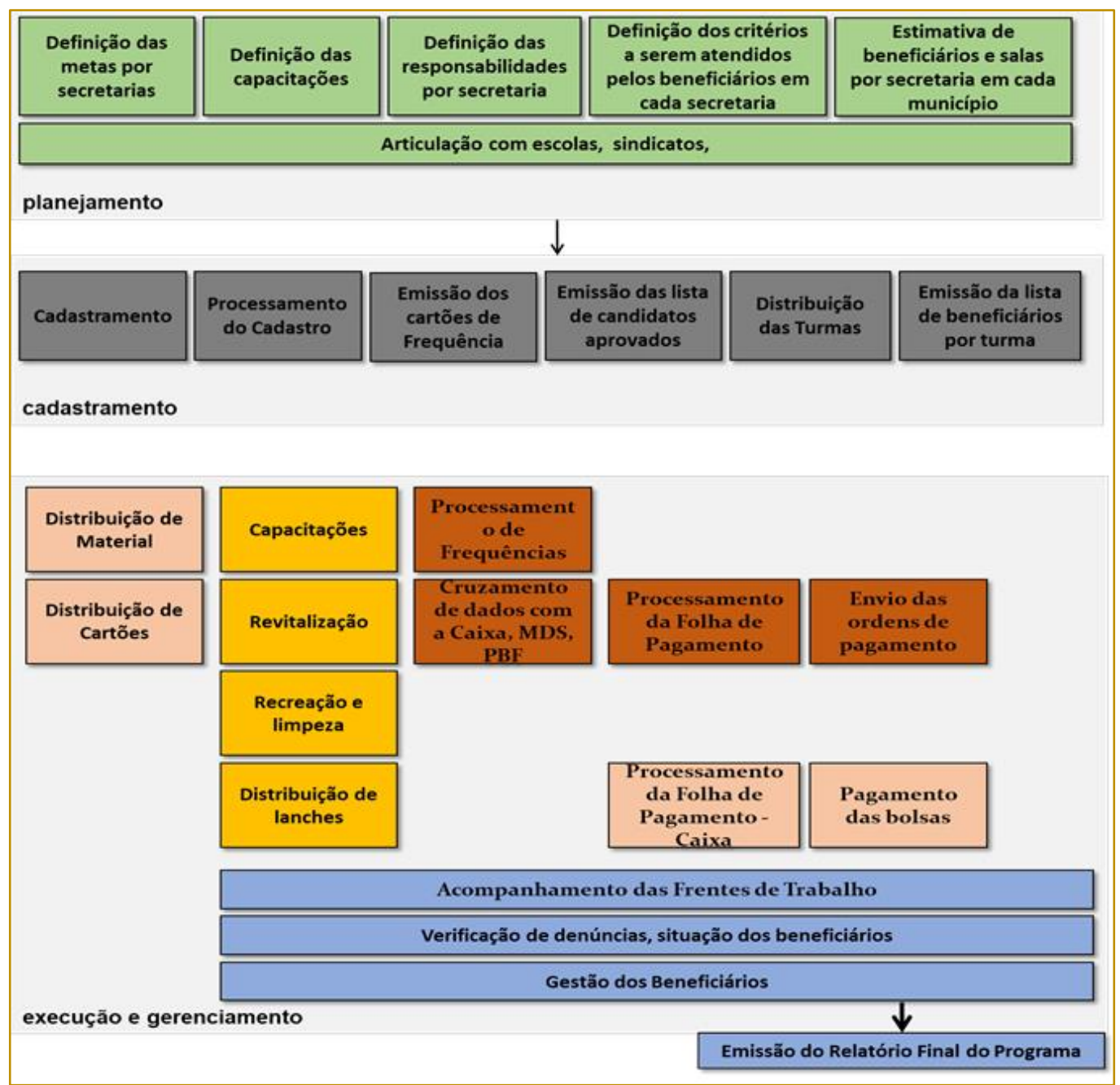

Fonte: Elaborado pelo autor, fonte de dados Seplag/ 2017

Existe um sistema que faz o trabalho de monitoramento e gestão do programa, subdivido em outros sistemas para o desempenho das funções essenciais, são eles:

Sistema de Cadastramento e Alocação: Integração com a Base do Ministério de Desenvolvimento Social;

Sistema de Frequência Digital: Acompanhamento da frequência dos beneficiários em sala de aula;

Sistema de Monitoramento de Incidentes: Registro de incidentes (Exemplo: Não recebimento do benefício);

Mapa com acompanhamento Geográfico das ações: Acompanhamento das ações por Município atendido pelo Programa.
Sistema de Processamento de Benefícios: Criação de Folha de Pagamento complementar ao Bolsa Família

É feito o acompanhamento de frequência através do registro digital de entrada e saída dos beneficiários e instrutores no período do curso, onde é feita uma vinculação direta ao pagamento do benefício, pois caso a frequência não seja confirmada a suspensão do pagamento pode ser solicitada pela gestão do programa.

No que se trata da execução e desempenho, nos últimos dez anos, vê-se na tabela 5 , a evolução do Programa como um todo: a quantidade de beneficiários, quantidade de municípios envolvidos, o quantitativo de mulheres, crianças, que são os filhos dos beneficiários, a quantidade de organização, recreadoras (para auxílio com as crianças) e o valor investido pelo governo. 
Tabela 5: Panorama Geral do Programa Chapéu de Palha (10 anos)

\begin{tabular}{|c|c|c|c|c|c|c|c|c|c|c|c|c|}
\hline & 2007 & 2008 & 2009 & 2010 & 2011 & 2012 & 2013 & 2014 & 2015 & 2016 & 2017 & Total \\
\hline Municípios & 36 & 47 & 53 & 52 & 54 & 54 & 54 & 54 & 37 & 30 & 09 & 54 \\
\hline Mulheres & 1.093 & 2.113 & 2.880 & 3.130 & 4.500 & 3.300 & 3.150 & 2.550 & 3.000 & 2.400 & 540 & 28.656 \\
\hline Crianças & & 1.440 & 1.960 & 1.129 & 2.900 & 1.980 & 1.512 & 1.224 & 1.200 & 800 & 180 & 14.325 \\
\hline Organizações & 11 & 13 & 12 & 17 & 17 & 19 & 18 & 17 & 15 & 13 & 04 & 19 \\
\hline Educadoras & 39 & 79 & 108 & 111 & 162 & 132 & 126 & 102 & 120 & 80 & 18 & 1.077 \\
\hline Recreador & & 79 & 108 & 111 & 162 & 132 & 126 & 102 & 120 & 80 & 18 & 1.038 \\
\hline $\mathrm{R} \$$ & $\begin{array}{l}8 \\
8 \\
8 \\
8 \\
8 \\
8\end{array}$ & $\begin{array}{l}8 \\
8 \\
8 \\
8 \\
8 \\
\\
-\end{array}$ & 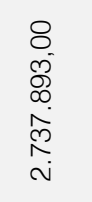 & 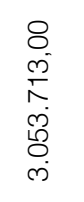 & 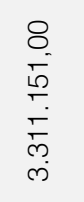 & 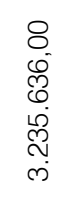 & 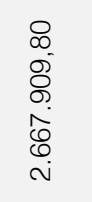 & 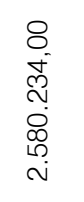 & 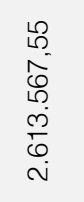 & 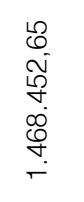 & $\begin{array}{l}8 \\
\infty \\
\infty \\
0 \\
0 \\
\text { लే } \\
\bar{\gamma}\end{array}$ & 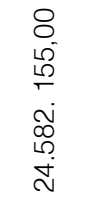 \\
\hline
\end{tabular}

Fonte: Secretaria de Mulher/2017

Com base no conjunto de dados e informações coletados e apresentados na tabela 4, percebe-se que o impacto do programa no que tange ao número de municípios atendidos e de valor investido vem diminuindo nos últimos anos, principalmente nos três últimos.

Vale ressaltar também que, no caso específico da zona canavieira, o número de mulheres diretamente envolvidas no corte da cana é reduzido. A participação delas no programa corresponde a cerca de $10 \%$ do total de beneficiários por ano, a exemplo de 2014, que, do total de 29.835 trabalhadores cadastrados, foram beneficiadas 2.550 mulheres (PERNAMBUCO, 2014a)

No que se refere a zona canavieira, observase (tabela 5) situação semelhante, comparado ao ano de 2010, onde mais de 39 mil beneficiários foram atendidos. Nos últimos anos não passaram de 33 mil beneficiados. Entende-se como uma restrição orçamentária que consequentemente exclui diversos beneficiários.

Tabela 5: Dados do Chapéu de Palha na zona canavieira (10 anos)

\begin{tabular}{|c|c|c|c|}
\hline \multirow{2}{*}{$\begin{array}{c}\text { Programa } \\
\text { Ano de referência }\end{array}$} & $\begin{array}{c}\text { Quantidade de } \\
\text { beneficiados }\end{array}$ & Valor pago \\
\cline { 2 - 4 } & 2007 & 18.385 & $\mathrm{R} \$ 12.482 .255,00$ \\
\cline { 2 - 4 } & 2008 & 20.402 & $\mathrm{R} \$ 13.023 .788,00$ \\
\cline { 2 - 4 } & 2009 & 28.004 & $\mathrm{R} \$ 24.914 .198,50$ \\
\cline { 2 - 4 } Chapéu de palha zona \\
\cline { 2 - 4 } canavieira & 2010 & 39.282 & $\mathrm{R} \$ 30.026 .095,50$ \\
\cline { 2 - 4 } & 2011 & 36.483 & $\mathrm{R} \$ 27.523 .454,50$ \\
\cline { 2 - 4 } & 2012 & 28.664 & $\mathrm{R} \$ 23.011 .858,00$ \\
\cline { 2 - 4 } & 2013 & 30.150 & $\mathrm{R} \$ 24.860 .823,50$ \\
\cline { 2 - 4 } & 2014 & 30.183 & $\mathrm{R} \$ 24.796 .727,70$ \\
\cline { 2 - 4 } & 2015 & 29.886 & $\mathrm{R} \$ 26.795 .022,40.174,45$ \\
\cline { 2 - 4 } & 2016 & 31.841 & $\mathrm{R} \$ 27.715 .560,00$ \\
\cline { 2 - 4 } & 2017 & 32.850 & $\mathrm{R} \$ 259.339 .957,55$ \\
\hline
\end{tabular}

Fonte: Seplag/2017 
Por outro lado, tendo em vista que os beneficiários reais e potenciais do programa compõem um dos segmentos mais vulneráveis da sociedade, uma vez que não possuem vínculo empregatício permanente; apresentam baixos níveis de escolaridade; altos índices de violência e encontram-se mais afastadas das políticas públicas básicas, espera-se a realização de investimentos focados no tratamento desses beneficiados, de modo a promover a valorização desse trabalhador, principalmente através da oferta de cursos que realmente tenham um impacto significativo na geração de renda desses canavieiros.

$\mathrm{Na}$ tabela 6, lista-se alguns cursos de capacitação oferecidos nos últimos dez anos no período de entressafra na zona canavieira e a quantidade de cursos por ano. De acordo com o objetivo do Programa Chapéu de Palha, esses cursos são promovidos para gerar renda aos beneficiários e as suas famílias no período de entressafra, para que possam com base no aprendizado poder empreender ou conseguir ser absorvido pelo mercado de trabalho.

Porém, com os cursos ofertados não se pode garantir que esse objetivo seja atingido, porque é necessário uma aderência das capacitações oferecida pelo Programa ao mercado de trabalho.

Conforme dados do IBGE, publicados em março de 2018, referente ao ano de 2017, o Produto Interno Bruto Brasileiro (PIB) voltou a crescer, crescimento de 1\% em relação ao ano anterior, em valores correntes representa $\mathrm{R} \$ 6,6$ trilhões. O grande impulsionador desse cenário foi o agronegócio, que avançou 13\% em 2017, destacando a agropecuária com um peso de 5,3\% na composição do PIB, seguido do setor de serviços, com avanço de 0,3\%, o comércio $1,8 \%$, e atividades imobiliárias $1,1 \%$. Porém a economia ainda não melhorou de forma generalizada, a indústria por exemplo, teve seu desempenho estagnado em 2007, o que consequentemente gera o fechamento de muitos postos de trabalho.

Informações do Cadastro Geral de Empregados e Desempregados (Caged) de 2017, pelo Ministério do Trabalho e Emprego (MTE), apontam que o setor da agropecuária tem alavancado a empregabilidade no país, em 2017 foram gerados 118 mil novos postos de emprego. Outros setores com saldo positivo na geração de emprego são: setor de serviços (51 mil postos de trabalho), setor de transformação (38 mil postos de trabalho) e a administração pública (16 mil postos de trabalho).

Diante desses dados e da lista de cursos que vem sendo ofertados nos últimos anos, de 2007 até 2016, no Programa Chapéu de Palha, para zona canavieira, podemos analisar que essas capacitações pouco poderão agregar na geração de renda dos beneficiários, caso os trabalhadores desejem empreender ou desejem concorrer a uma vaga de emprego.

Os cursos tem um baixo impacto no mercado de trabalho, a maioria das capacitações ofertadas são cursos em: formação sócio política (381 cursos), artesanato e trabalhos manuais (248 cursos), técnicas de cozinha (92 cursos). Pois são atividades que não estão associadas aos setores que mais geram renda, caso os trabalhadores decidam empreender.

Já os cursos na área de edificações (Pedreiro de Alvenaria, Assentamento de Cerâmica, Pintura Imobiliária, Execução de Gesso, Instalações Elétricas, Instalações Imobiliárias, Soldador - 109 cursos), assim como os cursos voltados para serviços comerciais (Zelador, Auxiliar de Creche, Refrigeração, Frentista, Embalador, Cobrador de ônibus, Vendedor, Almoxarife - 34 cursos) e os cursos de serviços pessoais (Cabelereiro, Maquiador, Designer de Sobrancelha e Penteados - 32 cursos), são capacitações voltadas para o setor de serviços, que pode gerar renda caso os trabalhadores venham a abrir seu próprio negócio, porém isso não significa que os mesmos venham a ter sucesso como empreendedores, pois o período de capacitação é reduzido, não sendo suficiente para realmente capacitar e formar um bom profissional.

Outros cursos que também pode contribuir para evolução os trabalhadores são os de: informática (9 cursos), Turismo (5 cursos) e Agricultura (2 cursos), porém, em 10 anos do Programa Chapéu de Palha, foram ofertados apenas 16 capacitações nessas áreas.

A contribuição desses cursos para os trabalhadores é pequena. Perpetuando assim um cenário de pobreza e assistencialismo, pois são capacitações em funções com baixo impacto na economia e em um curto período de tempo, não se pode garantir que em três meses uma pessoa que nunca esteve em contato com outro cenário, senão o da cana, 
possa de fato conseguir gerar renda com nova atividade.

Portanto, os cursos não garantem que o trabalhador tenha sucesso como empreendedor, nem contribuem significativamente para que ele possa ser absorvido pelo mercado de trabalho.

Tabela 6: Cursos oferecidos a zona canavieira nos últimos anos (2007 - 2016)

\begin{tabular}{|l|c|}
\hline \multicolumn{1}{|c|}{ CURSOS } & QUANTIDADE \\
\hline $\begin{array}{l}\text { Educação } \\
\text { Formação Sócio Política. }\end{array}$ & 381 \\
\hline $\begin{array}{l}\text { Trabalhos Manuais } \\
\text { Artesanato, Corte e Costura, Customização de Roupas e Pintura de } \\
\text { Tecido, decoração. }\end{array}$ & 248 \\
\hline $\begin{array}{l}\text { Serviços em Edificações } \\
\text { Pedreiro de Alvenaria, Assentamento de Cerâmica, Pintura } \\
\text { Imobiliária, Execução de Gesso, Instalações Elétricas, Instalações } \\
\text { Imobiliárias, Soldador. }\end{array}$ & 109 \\
\hline $\begin{array}{l}\text { Serviços com Alimentação } \\
\text { Doces e Salgados, técnicas de cozinha, drinques e coquetéis. }\end{array}$ & 92 \\
\hline $\begin{array}{l}\text { Serviços Comerciais } \\
\text { Zelador, Auxiliar de Creche, Refrigeração, Frentista, Embalador, } \\
\text { Cobrador de ônibus, Vendedor, Almoxarife. }\end{array}$ & 34 \\
\hline $\begin{array}{l}\text { Serviços Pessoais } \\
\text { Cabelereiro, Maquiador, Designer de Sobrancelha e Penteados. }\end{array}$ & 32 \\
\hline $\begin{array}{l}\text { Telecomunicações } \\
\text { Informática }\end{array}$ & 919 \\
\hline $\begin{array}{l}\text { Serviços de Limpeza } \\
\text { Camareira, Jardinagem, lavagem de veículos. }\end{array}$ & 9 \\
\hline $\begin{array}{l}\text { Turismo } \\
\text { Monitor de Turismo, Conservação do Patrimônio Histórico. }\end{array}$ \\
\hline $\begin{array}{l}\text { Agricultura } \\
\text { Horta Agroecológica. }\end{array}$ & 7 \\
\hline
\end{tabular}

Fonte: Elaborado pela autora com base de dados da Seplag/2017

Sendo assim, as atividades de profissionalização não são adequadas aos objetivos propostos, pois ela está politicamente comprometida com o atendimento de interesses díspares, ou seja, com a viabilização de governabilidade (BENTO, 2003). Objetivamente, o governo "atende" o interesse dos empregadores, assegurando a disponibilidade de um grande contingente de mão de obra; e "atende" o interesse das trabalhadoras rurais, garantido sempre alguma renda em um período de instabilidade financeira. O resultado de uma política com esse viés consensual favorece a classe hegemônica.

Considerando o conjunto de dados apresentados e avaliados, percebe-se que 0 projeto carece de uma maior preocupação com o que Abramovay (2007) considera o desafio central da atualidade: "desvendar" quem são e, sobretudo, quais são as demandas dos atores do "novo mundo rural". Nesse sentido, compreender os trabalhadores da cana também como novos atores, pessoas atraídas por um "novo mundo rural" mecanizado e capitalizado parece ser uma tarefa instigante para qualquer ação política que pretenda atuar no cerne dos problemas sociais, mas absolutamente dispensável se os objetivos são assistencialistas.

Mesmo compreendendo o assistencialismo como expressão das ações que priorizam a estabilidade política em detrimento da superação dos quadros de desigualdade (DELGADO et al., 2008; JARA, 1998), resta identificar a perspectiva política que dá 
sustentação social a essas ações. No caso do Programa Chapéu de Palha, as evidências apontam para o paradigma tradicional de desenvolvimento de comunidade, que, segundo Jara (1998), ao mesmo tempo em que melhora as condições materiais de vida em comunidades rurais, conserva as dependências e subalternidades.

\section{CONSIDERAÇÕES FINAIS}

Na perspectiva de analisar a implementação de uma política pública para os trabalhadores rurais em Pernambuco - o Projeto Chapéu de Palha da Zona Canavieira - e sua contribuição para o processo de fortalecimento do trabalho no campo, a pesquisa debruçou-se sobre os principais debates relacionados com os conceitos de políticas públicas, desenvolvimento, relação Estado-sociedade e zona canavieira.

Buscou-se refletir sobre sua prática do programa, tendo em vista seus fundamentos históricos relacionados ao assistencialismo e ao populismo, sobretudo no que diz respeito à articulação entre transferência de renda e a ausência de uma efetiva proposta de reforma agrária. A identificação dessas características foi importante para que esta análise tivesse a compreensão de como as mesmas seriam superadas ou reproduzidas no atual contexto de atuação do Programa no qual se sobressai a dinâmica territorial do assalariamento sazonal, que abriga interesses conflitantes entre o projeto político, econômico e social do agronegócio e as demandas das

\section{REFERÊNCIAS}

[1]. ANDRADE JÚNIOR, José Roberto Porto de. A realidade do trabalho rural canavieiro e a necessidade de políticas públicas compensatórias: um diálogo sobre as condições de trabalho e a mecanização da colheita da cana. In: SEMINÁRIO DE SAÚDE DO TRABALHADOR DE FRANCA, 7. ., 2010, São Paulo. Anais... São Paulo: Unesp. 2010. p. 1-14.

[2]. BRASIL. Constituição da República Federativa do Brasil. Promulgada em 5 de outubro de 1988. Brasília: 2004.

[3]. BENTO, Leonardo Valles (2003). Governança e governabilidade na reforma do Estado: entre eficiência e democratização. Barueri: Manole. trabalhadoras rurais, no esforço de situar o Programa no atual momento político, no que diz respeito à atual orientação hegemônica das políticas públicas, que negam a estrutura de classes e reduzem a inclusão social e a cidadania ao incremento na renda e ao consumismo

As implicações práticas desses elementos objetivos do Programa revelam incoerências que apontam para a necessidade da realidade ser reinterpretada. A principal incoerência está no fato do Programa se afirmar como motivador do desenvolvimento sustentável, mas sua prática estar comprometida justamente com a manutenção do quadro de desigualdade, pois atua no sentido de reservar mão de obra barata para o agronegócio e garantir a governabilidade por meio de mecanismos de manipulação, que estão baseados, sobretudo, no fascínio que $\mathrm{o}$ acesso à renda exerce sobre as trabalhadoras rurais (GRANJA, 2006).

O programa Chapéu de Palha na zona canavieira aponta limitações no campo da autonomia aos trabalhadores rurais, a necessidade de maior integração das políticas públicas com políticas setoriais de saúde, de educação, emprego e renda, carece de uma prática transformadora, que atenda não apenas demandas explícitas, enunciadas nos discursos dos atores sociais, mas, sobretudo, que atue no cerne, na estrutura das problemáticas enfrentadas pelos trabalhadores rurais. Sem isso, o Programa é apenas apaziguador de sobrevivência e reprodutor de pobreza.

[4]. CAMPOS, Luís Henrique Romanide; RAPOSO, Isabel; MAIA, André. Empregabilidade do cortador de cana-de-açúcar da zona da mata pernambucana no período de entressafra. Revista Econômica do Nordeste, Fortaleza, v. 38, n. 3, p. 329-342, jul.-set. 2007

[5]. CARNEIRO, M. J. T. (1998). Ruralidade: novas identidades em construção. Estudos Sociedade e Agricultura, Rio de Janeiro: UFRRJ/CPDA, n.11, p.53-75, out.

[6]. CARVALHO, Ricardo Ismael de (2005). Nordeste: a força da diferença - os impasses e desafios da cooperação regional. Recife: Massangana.

[7]. CAVALCANTI, Clóvis et al. (2002). Programa de Apoio ao Desenvolvimento 
Sustentável da Zona da Mata de Pernambuco PROMATA. Trabalhos para discussão, Recife, n. 135, fev. Disponível em: $<$ http://www.fundaj.gov.br/tpd/135.html>. Acesso em: 07 nov. 2017

[8]. DYE, T. R. Mapeamento dos modelos de análise de políticas públicas. In: HEIDEMANN, F.

[9]. G.; SALM, J. F. Políticas Públicas e Desenvolvimento: bases epistemológicas e modelos de análise. 3. ed., Brasília: Editora UnB, 2014

[10]. FARIA, Regina. Avaliação de programas sociais: evoluções e tendências. In: RICO, Elizabeth Melo (Org.). Avaliação de políticas sociais: uma questão em debate. São Paulo: Cortez; Instituto de Estudos Especiais, 1999. p. 4149

[11]. HEILBORN, Maria Luiza; ARAÚJO, Leila; BARRETO, Andreia. Políticas Públicas: conceitos, objetivos e práticas de participação social: Unidade I.In:HEILBORN, Maria Luiza; ARAÚJO, Leila; BARRETO, Andreia (Org.).Gestão de Políticas Públicas em Gênero e Raça, GPP, GeR: módulo I. Rio de Janeiro: Cepesc, Secretaria de Políticas para as Mulheres, 2010. p. 1-55.

[12]. HIRATA, Helena. A precarização e a divisão internacional e sexual do trabalho. Sociologias, Porto Alegre, ano 11, n. 21, p. 24-41, jan/jun 2009

[13]. IBGE. Censo demográfico 2010: características da população e dos domicílios: resultados do universo. Rio de Janeiro, 2011. Disponível em: $<$ http://biblioteca.ibge.gov.br/visualizacao/periodic os/93/cd_2010_caracteristicas_populacao_ domicilios.pdf>. Acesso em: 2 dez. 2017

[14]. GRANJA, Maria Sueli (2006). Inclusão social pelo trabalho sazonal: é possível? Um estudo sobre trabalhadoras na cultura da uva em Petrolina-PE. 142f. Dissertação (Mestrado em Extensão Rural). Universidade Federal de Viçosa, Minas Gerais

[15]. JANSEN, Wilame; MAFRA, Rivaldo. A zona da mata de Pernambuco. 2010. p. 1-7. Disponível em: <http://www.ancora.org.br/textos/011_jansenmafra.html>. Acesso em: 8 nov. 2017.

[16]. JARA, Carlos Júlio (2001). As dimensões intangíveis do desenvolvimento sustentável. Brasília: IICA.

LONGHI, Márcia Reis. O Programa Chapéu de Palha: reflexões a partir de macro e micro visões. Recife: SecMulher/PE, 2009

[18]. LOPES, Gabriela. Eduardo anuncia reajuste na bolsa do Chapéu de Palha. 2013. Disponível em: <http://blogs.ne10.uol.com.br/jamildo/2013/05/01/e duardo-anuncia-reajuste- na-bolsa-do-chapeu-depalha/>. Acessoem:8 nov. 2017.
[19]. MARTINELLI, Marcos (2006). Antonio Callado, um sermonário à brasileira. São Paulo: FAl ; Annablume.

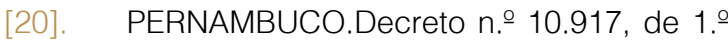
de novembro de 1985. Cria a Delegacia da Mulher e dá outras providências. Diário Oficial, Poder Executivo, Recife, PE, 2 nov. 1985. Disponível em:<http://200.238.101.22/docreader/docreader.as px?bib=DO_198511\&pasta=Dia\%2004>. Acesso em: 3 nov. 2017.

[21]. Lei no 13.244, de 11 de junho de 2007. Institui o Programa Chapéu de Palha, e dá outras providências. Recife, 2007a. Disponível em: <http://legis.alepe.pe.gov.br/arquivoTexto.aspx?tip onorma $=1$ \& numero $=13244 \&$ complemento $=0 \&$ ano $=$ 2007\&tipo=\&url= http://>. Acesso em: 3 sete. 2017.

[22]. Lei no 13.766/2009. Recife, 2009a.

[23]. Lei no 13.975/2009. Recife, 2009b.

[24]. Lei $n^{\circ}$ 14.492/2011, de 29 de novembro de 2011. Institui o Chapéu de Palha - Pesca Artesanal, e dá outras providências Recife, 2011a. Disponível em:

$<$ http://legis.alepe.pe.gov.br/arquivoTexto.aspx?tip onorma $=1 \&$ numero $=$

$14492 \&$ complemento $=0 \& a n o=2011 \&$ tipo $=\& u r \mid=>$. Acesso em: 3 set. 2017.

[25]. RABELO, Caio Leite; ABREU, Diego; EGERTON NETO; GOMES, Jorge Oliveira. Construção de uma agenda e Chapéu de Palha: estudo dos programas de 1988 e 2007. In: SEMINÁRIO DE CIÊNCIA POLITICA E RELAÇÕES INTERNACIONAIS, 7., 2013, Recife. Anais... Recife: UFPE, 2013. p. 14-23

[26]. ROBERTO, Clivonei. Aumenta o fechamento de usinas em Pernambuco. Universoagro, 5 ago. 2013. Disponível em: <http://www.uagro.com.br/editorias/agroindustria/ sucroenergetica/2013/08/05/aumenta-ofechamento-de-usinas-em-pernambuco.html>. Acesso em: 8 set. 2017.

[27]. ROCHA, Abelardo Baltar da (1991). A esquerda em Pernambuco: acertos e equívocos do Governo Arraes. Recife: Inojosa.

[28]. ROZOWYKWIAT, Tereza (2006). Arraes. São Paulo: Iluminuras, 2006.

[29]. SANTOS, Pedro da Silva (2007). Miguel Arraes de Alencar e as diferentes perspectivas de Reforma Agrária nas últimas quatro décadas do século XX na Zona da Mata pernambucana. (Bacharelado em Ciências Sociais) - Universidade Federal Fluminense, Rio de Janeiro. [Orientador: Prof. Dr. Marcelo Carvalho Rosa]. Disponível em: $<$ http://pt.scribd.com/doc/51679138/Pedro-SantosMonografia>. Acesso em: 10 set. 2017.

[30]. SCHNEIDER, Sergio (2004). A abordagem territorial do desenvolvimento rural e suas articulações. Sociologias, Porto Alegre, ano 6, no 11, jan./jun., pp. 88-125. 
[31]. SILVA, Maurício Roberto da. Recortando e colando as imagens da vida cotidiana do trabalho e da cultura lúdica das meninas-mulheres e das mulheres-meninas da zona da mata canavieira pernambucana. Cadernos Cedes, ano 22, n. 56, abr. 2002.
[32]. Srivastava, A.; \& Thomson, S. B. (2009) Framework analysis: a qualitative methodology for applied policy research. 


\section{Capítulo 24}

\section{IDENTIFICAÇÃO E ANÁLISE DE VANTAGENS COMPETITIVAS EM EMPRESAS DE AQUICULTURA}

\section{Luisa Paseto}

Resumo: A problemática ambiental ocupa importante papel nas discussões sobre os rumos da economia e as políticas públicas. O conhecimento científico para um desenvolvimento econômico sustentável confronta-se com a necessidade de encontrar soluções capazes de integrar as diversas características e as relações de interdependência dos processos ambiental, produtivo e econômico. Objetivouse com isso identificar e analisar os indicadores de boas práticas de gestão ambiental presentes nos dados primários coletados pelo sistema APOIA/Aquicultura e seu grau de influência na formação de vantagem competitiva na cadeia de valor tendo como referência as estratégias de organização industrial de Porter, as competências essenciais coletivas de Prahalad e as abordagens da Teoria dos Stakeholders. A pesquisa foi realizada por questionários aplicados com 26 stakeholders e as variáveis multidimensionais trabalhadas de maneira descritiva e interpretativa pelos métodos de regressão e análise swot. Os resultados apontam que os indicadores se inter-relacionam nas atividades produtivas e permitem indicar a necessidade do produtor, em conhecimento e capacitação em gestão ambiental e administração a partir de pequenos ajustes comportamentais, culturais e ou de gestão em suas atividades produtivas.

Palavras-Chave: empresa rural, competências essenciais, ciclo produtivo, diferenciação do produto, custos aquícolas. 


\section{INTRODUÇÃO}

A problemática ambiental ocupa importante papel nas discussões sobre os rumos da economia e as políticas públicas. O conhecimento científico para um desenvolvimento econômico sustentável confronta-se com a necessidade de encontrar soluções capazes de integrar as diversas características e as relações de interdependência dos processos ambiental, produtivo e econômico.

Para as empresas de um modo geral, o aprimoramento na análise dos impactos socioambientais é um componente essencial em seu planejamento estratégico, pois permite no longo prazo, que elas não dependam apenas do lucro para aproveitarem as oportunidades de participação no mercado, podendo agregar valor pela sua responsabilidade social e ambiental.

Ações estratégicas com foco em gestão socioambiental discutidas por vários autores Porter(1998), Prahalad (2010) entre outros, permitem observar ganhos de competitividade no diferencial de valor do produto auferido no mercado. Algumas iniciativas socioambientais provocam mudanças que não dependem apenas de soluções técnicas, mas em alguns casos, da compreensão dos hábitos naturais dos agentes envolvidos, da inovação enquanto tecnologia de produção utilizada e da capacitação e conhecimento dos processos, além das relações com o entorno, entre outras.

Também faz parte da análise estratégica nas organizações a distinção entre custos e investimentos, cuja importância no âmbito do planejamento e gestão das empresas agrícolas é fundamental, uma vez que, a gestão só tem capacidade efetiva para influenciar os custos quando estes, em sua maioria encontram-se associados a decisões de longo prazo.

As análises propostas tornam-se relevantes ao serem aplicadas às empresas do setor de aquicultura onde o gerenciamento da produção requer amplo conhecimento do processo produtivo e maior abrangência nas informações sobre desempenho.

A aquicultura é o setor de maior crescimento na economia alimentícia mundial, em torno de $11 \%$ ao ano, durante as últimas décadas esse crescimento recorde sinaliza uma mudança fundamental na dieta alimentar dos povos de maneira global (FAO, 2012).

O desenvolvimento de uma aquicultura sustentável definida como a criação comercial de animais aquáticos, está associada ao monitoramento da qualidade ambiental, à disponibilidade de recursos naturais e uso eficiente dos insumos, ou seja, depende em grande parte da adoção e conformidade com Boas Práticas de Manejo (BPM) nas atividades produtivas, e de gestão ambiental para as propriedades rurais e seu entorno.

Neste contexto, o problema deriva da necessidade de se identificar um conjunto de indicadores de sustentabilidade, que exerçam a função de advertir às empresas aquícolas, sobre os riscos e tendências do desenvolvimento, provendo indicadores que possam se constituir em uma referência para a adequação organizacional (planejamento estratégico)

Assim a identificação de indicadores econômicos socioambientais para este estudo partiu de dados primários auferidos pelo sistema APOIA/Aquicultura, desenvolvido pela EMBRAPA Meio Ambiente (RODRIGUES et al., 2010) e testado com sucesso em diversos setores produtivos rurais, no Brasil e no Exterior.

Para analisar e identificar esses indicadores de sustentabilidade foram propostas duas perguntas direcionadoras desta pesquisa:

1. Quais variáveis econômicas, sociais e ambientais geram vantagem competitiva nas empresas de aquicultura e permitem definir estratégias de competitividade?

2. Qual é a função dos indicadores econômicos socioambientais na geração de competitividade?

A busca das respostas a essas questões como principal resultado deste trabalho orientam a hipótese fundamental que contempla a análise dos indicadores econômicos e socioambientais, como estratégia para o desenvolvimento de competências que envolvam as partes interessadas (stakeholders) e geram soluções criativas que envolvam práticas eficientes na gestão ambiental das empresas aquícolas.

Justifica-se desta maneira, encontrar evidências que demonstrem o aumento da eficiência na cadeia de valor produtiva, como oportunidade e diferencial de vantagem competitiva, além de contribuir ao 
planejamento estratégico para a gestão ambiental da aquicultura.

\section{ESTRATÉGIA ORGANIZACIONAL}

A bibliografia revisada para nortear cientifica e tecnicamente este estudo, segundo os autores Porter (1985 e 1998), Prahalad (1998 e 2010), Andrade e Rosseti (2004), Freeman (1984), permite afirmar que é crescente a atenção dos consumidores e produtores brasileiros e mundiais, quanto aos impactos socioambientais causados pelas atividades rurais produtoras de bens de consumo alimentar.

Duas correntes entre as teorias de estratégias empresariais consultadas nortearam a busca pela evidência de vantagem competitiva. A primeira na estratégia de posicionamento onde a vantagem competitiva é um atributo do desempenho interior e exterior da organização Porter (1985) e, em Prahalad (1998 e 2010) onde capacidades dinâmicas, são a fonte de vantagem competitiva na interação entre competências e oportunidades de mercado (rotina dos processos organizacionais).

A maioria dos modelos teóricos, evidenciaram empiricamente as dimensões responsáveis pelo aumento da complexidade ambiental e de seus impactos nos processos e recursos intraorganizacionais, indicando que para o século XXI espera-se níveis de incerteza e ambiguidade ambiental cada vez mais frequentes nas atividades e decisões organizacionais.

Porter (1980 e 1991), introduziu a ideia de análise coletiva (diferente da ideia neoclássica), onde a determinação do comportamento dos agentes na estrutura industrial é a principal responsável pelo fracasso ou sucesso competitivo organizacional. Este movimento de mercado é reconhecido na transição organizacional da eficiência individual, outrora preconizada pelo Taylorismo e Fordismo, para a contemporânea eficiência coletiva, indicada por outros autores, como Bartlett e Ghoshal (1995) e Prahalad (1998), para os quais o processo de eficiência coletiva empresarial e as competências essenciais individuais se somam na formação de vantagem competitiva.

Em complementariedade a esta teoria Prahalad (2009), Hamel (1993) e Teece, (1997), analisam a vantagem competitiva pela dimensão das capacidades dinâmicas, onde a avaliação dos processos e rotinas organizacionais permite entender, os fluxos de recursos e suas competências essenciais (no longo prazo com desenvolvimento sistemático de aprendizagem e inovação para a captação de valores de competitividade e produtividade operacional).

Por definição a competência essencial designa as competências estratégicas, únicas e distintivas de uma organização, sob o ponto de vista das habilidades que, as empresas devem desenvolver para competir pela participação nas oportunidades de mercado e não pela participação no mercado. Essa estratégia de competência essencial tem conexão com a teoria dos stakeholders, quando enfatizam a importância da criação de competências para aperfeiçoar o atendimento ao mercado.

A Teoria dos Stakeholders é mais flexível em explicar e guiar a estrutura e a operação de uma empresa já estabelecida, o investimento intelectual, com gestão de conhecimento eficiente, pode alavancar a organização. Desta maneira, os empregados e colaboradores estão sendo valorizados como stakeholders, com objetivos e interesses e na medida em que se desenvolvem essas competências, a organização torna-se eficaz (Andrade e Rosseti, 2004).

O uso de ferramentas administrativas aumenta a eficiência na cadeia de valor organizacional, o planejamento estratégico das atividades organizacionais na cadeia de valor, permite a análise do conjunto de atividades de desenvolvimento, produção, comercialização, suprimentos de cada atividade específica.

Na opinião de Montgomery e Porter (1998), alguns dos problemas mais difíceis que os gestores enfrentam vai além da concorrência, envolvendo muitas vezes mudanças em parte ou em toda a sua cadeia de valor, tornandose essencial que se tenha a perfeita compreensão da estrutura e do desempenho das inter-relações, para se obter vantagem competitiva sustentável.

A vantagem competitiva foco deste estudo é um processo de contínuo de desafio para os decisores organizacionais. Os estudos de Porter (1985) sobre gestão empresarial, indicam em suas análises de competitividade e produtividade, que o diferencial fluxo de cadeia de valor, como relevância estratégica empresarial de responsabilidade social, bem como potenciais de diferenciação em cada 
processo de negócio, pode contribuir na otimização do valor final que o produto representa para o mercado.

Essas características da empresa familiar rural, estão presentes nas análises de Porter (1980 e 1996) que considera, "que a liderança de custo e a diferenciação pela qualidade na cadeia de valor e seus elos, podem acrescer valor ao produto final" e desta forma, proporcionarem vantagem competitiva à organização através da "sinergia benéfica que se forma na somatória do envolvimento das partes e a indução de alianças para capacitação, tecnologia e inovação na gestão".

Dessa maneira a empresa rural será tão mais eficiente e lucrativa quanto maior for 0 domínio do produtor sobre o processo produtivo e acerca das técnicas de execução e gerência (Oliveira et al. 2013).

As experiências de diversos países em produção aquícola apontam para um futuro promissor, no Brasil apresenta-se um cenário propício ao seu desenvolvimento, que a favor conta com atrativas margens de lucro e taxas de crescimento da demanda, principalmente se comparadas às demandas por outras proteínas animais como as carnes bovinas, suínas e avícolas (FAO, 2012).

Exemplos do sucesso das produções aquícolas no mundo não faltam nas diversas literaturas disponíveis. China, o maior produtor mundial de pescados, Noruega com a adoção de uma estratégia de coordenação vertical, produziu uma indústria eficiente e altamente especializada que hoje busca, por meio da inovação e do rígido controle da sustentabilidade, manter sua posição competitiva no cenário mundial.

\section{METODOLOGIA}

A identificação de vantagem competitiva, através de dados primários coletados pelo Sistema APOIA/Aquicultura em Capitólio/MG no período de agosto de 2012, se apresentou como uma 'ferramenta de gestão' (Rodrigues et al. 2006 ).Escolhido por ser um programa de pesquisa para monitoramento ambiental e de gestão, voltado para o conhecimento e capacitação dos stakeholders envolvidos na cadeia de valor da aquicultura, suas dimensões e critérios básicos de impactos e fragilidades da produção, refletem um diagnóstico considerando-se uma produção adequada às Boas Práticas Aquícolas (BPA) ou de Manejo.

Sabe-se, que a conformidade às BPA nas propriedades aquícolas de sua produção garante a aceitação pelo mercado como uma conduta documentada e rastreável, proporcionando gestão do ambiente organizacional produtivo.

As 26 empresas aquícolas analisadas de agosto de 2012 a dezembro de 2013, estão localizadas na cidade de Capitólio, no Estado de Minas Gerais, às margens do Reservatório de Furnas, no curso médio do Rio Grande, abrangendo os municípios de Guapé, Capitólio e Pimenta. A vantagem competitiva investigada no conjunto de variáveis explicativas determinadas em agosto de 2012 pelo Sistema Apoia/Aquicultura, aplicadas em questionário junto aos stakeholders foram: tempo de experiência, diversidade na renda, necessidade de conhecimento técnico e de gestão ambiental, tipo de conhecimento técnico, tipo de conhecimento em gestão ambiental e tipo de conhecimento em administração.

Os dados primários coletados pelo sistemas APOIA/Aquicultura, utilizados na construção do questionário foram consideradas a partir da necessidade de ajustes e aprimoramentos de acordo com as seguintes variáveis: Frequência Horário de Alimentação, Quantidade de Ração e Cálculo de Consumo, Qualidade dos Sedimentos, Planejamento Ciclo Produtivo, Conhecimento Uso Medicamento, Controle e Registro Produto Final, Densidade Populacional dos Tanques, Qualidade da Água, Procedimento Descarte Peixes Mortos, Medição Tamanho e Peso, Ajuste Tipo de Ração, Origem dos Alevinos, Conhecimento de Saúde e Mortalidade, Adensamento Tanques Rede, Distância Fonte Poluição.

O grupo de 26 stakeholders é formado por, 17 produtores associados e independentes, 6 colaboradores pertencentes a assistência técnica, pesquisa e extensão rural, 1 representante de gestor público, 01 gestor comunitário e 01 fornecedor de ração, insumos e equipamentos. O perfil dos stakeholders apresentou-se como $35 \%$ de produtores associados e independentes com tempo de experiência em atividade aquícola em tanques-rede com até 5 anos e $65 \%$ com até 10 anos. Também, 55\% destes produtores possuem outras atividades que influenciam na formação de sua renda total e $45 \%$ vivem 
exclusivamente da atividade aquícola em tanques-rede.

As perguntas formuladas foram agrupadas, para o alcance do patamar mínimo de produção aceitável com Boas Práticas Aquícolas (BPA) ou de Manejo (BPM). A concordância dos stakeholders para 0 recebimento das sugestões técnicas, sócio ambientais geradas neste estudo, foi o foco da pergunta número 1 do questionário, assim como a pergunta número 2 compreendeu o entendimento dos stakeholders de que, conservação ambiental e BPA são fatores de agregação de valor e influenciam na vantagem competitiva do produto.

A pergunta número 6 foi elaborada especificamente para a exploração de como e com quem os produtores aquícolas buscam encontrar soluções para as suas dificuldades na produção e comercialização. As respostas foram fundamentais para entendimento do diálogo e fluxo contínuo entre os stakeholders e consequentemente seu reflexo nos interrelacionamentos da cadeia de valor.

Para consolidação das respostas aplicou-se uma análise de regressão múltipla de variáveis qualitativas (dummy), flexível e capaz de lidar com algumas necessidades de intervenção detectados, permitindo-se por fim a distinção entre pontos fortes e fracos das empesas aquícolas. O método utilizado para se "quantificar" os atributos de vantagem competitiva com os indicadores em desalinho já citados, assumiram valores de 1 a 5 (5 indicando ausência de um atributo chegando a 1 que indica sua presença fortemente). Desta maneira, cada variável utilizada nos questionários e suas respectivas respostas, possibilitaram a determinação da vantagem competitiva, Onde:

- $\quad$ VC = Vantagem Competitiva (VC), foi reconhecida como variável dependente dummy, com valores probabilísticos de 0 ou 1 , onde 1 significa que o indicador gera $\mathrm{VC} e$ 0 indica que não há formação de VC;

- $\quad$ V1 = Indicou o tipo de conhecimento técnico que o produtor julga prioritário para melhorar sua atividade e aproveitar as oportunidades de participação no mercado. É uma variável de escala mensurada de 1 a 5 , onde 1 representa maior prioridade e 5 baixa prioridade, os indicadores formadores desta variável são: Densidade Populacional dos Tanques Rede, Medição de Tamanho e Peso, Frequência e Horário de Alimentação, Ajuste no tipo de Ração e Quantidade de Ração e Cálculo de Consumo;

- V2 = Representou 0 tipo de conhecimento em gestão ambiental que gera diferencial competitivo sob a ótica do produtor aquícola. É uma variável de escala mensurada de 1 a 5 , onde 1 representa maior prioridade e 5 baixa prioridade, esta variável é formada pelos indicadores: Adensamento no Tanque Rede, Distância da Fonte de Poluição, Qualidade de Água, Qualidade de Sedimento e Origem dos Alevinos;

- $\quad \mathrm{V} 3=$ Apresentou 0 tipo de conhecimento em gestão e administração que o produtor acredita necessitar para criar diferencial competitivo no seu produto, ou seja, melhor eficiência na produção. É uma variável de escala mensurada de 1 a 5 , onde 1 representa maior geração de diferencial e 5 menor geração de diferencial, com as variáveis formadoras representadas pelos indicadores: Planejamento do Ciclo Produtivo, Conhecimento em Saúde e Mortalidade, Conhecimento e Uso de Medicamentos, Procedimentos de Descarte/Descarte de Peixes Mortos e Controle e Registro do Produto Final;

- $\quad$ V4= Representou como e com quem os stakeholders produtores associados e independentes, buscam orientações para solução de problemas de produção e comerciais. As respostas oferecem uma visão do fluxo de diálogo entre os stakeholders da cadeia de valor. É uma variável hierárquica e é representada pelos stakeholders: Proprietário Associado, Proprietário Independente, Gestor Público e Comunitário, Assistência Técnica, Pesquisa e Extensão Rural e finalmente os Fornecedores de Ração, Equipamentos e outros Insumos.

Para a avaliação competitiva da orientação do posicionamento das empresas quanto as oportunidades de participação no mercado aquícola, aplicou-se de maneira adaptada uma Análise SWOT. Esta análise permitiu uma interpretação dos indicadores de maneira integrada, conjugando os elementos externos e internos à organização, resultando em um diagnóstico fonte de informação e suporte, adequada às necessidades da gestão estratégica. Para o reconhecimento dos pontos fortes e pontos fracos (Análise SWOT), os indicadores expressaram as relações entre o conjunto de variáveis explicativas de interrelacionamento, grau de influência na necessidade de conhecimento técnico e de 
gestão ambiental, tipo de conhecimento técnico, tipo de conhecimento em gestão ambiental e tipo de conhecimento em administração.

Goldschimidt, 2006 e Duncan et al.,1998 exploram uma visão para vantagem competitiva onde um ponto forte ou fraco (externo ou interno), afeta o funcionamento da empresa e provoca a necessidade de aperfeiçoamento transformando-se em oportunidade. Neste sentido os autores classificam as ações ou operações do processo de produção como indutores diferenciadores de produto (uniqueness driver) e ou indutores de diferenciação de custo (cost driver) quando da criação de vantagens competitivas. Em seus estudos Prahalad 2009), entende que a inovação é a chave motora para a sustentabilidade e a postura ambientalmente amigável de uma empresa. Seus conceitos corroboram com as BPA reconhecidas neste estudo como oportunidade para o desenvolvimento de competências que envolvam trabalho coletivo das partes interessadas envolvidas, possibilitando a implantação de soluções criativas de menor custo; aumento da eficiência na cadeia de valor e seus stakeholders, aproveitando expertises em técnicas de gestão para operações produtivas menos carbono intensivas; e o desenvolvimento da flexibilidade organizacional para adaptar-se a novos modelos de diálogo com consumidores e stakeholders, agregando valor aos produtos com modelos de gestão capazes de capturar as bases da competitividade das empresas.

Para esta pesquisa os indicadores estudados, positivos ou negativos (Gallopin, 1996), apontam uma determinada condição onde um coeficiente negativo implicará que menor será a probabilidade do proprietário aquícola, alcançar conhecimento de gestão e administração para a criação de diferencial de competitividade. Os conceitos de Mangabeira et al. (2002) suportam a mesma abordagem, quando definem que as propriedades rurais têm relação direta de aprimoramento e crescimento da produção, em relação ao nível de desenvolvimento e capacitação dos proprietários rurais, assim as inter-relações técnicas e socioambientais não podem ser consideradas externalidades e simplesmente desprezadas na composição da rentabilidade e lucratividade de uma empresa.

\section{RESULTADOS E DISCUSSÃO}

Os questionários aplicados geraram respostas que permitiram interpretar as necessidades de capacitação e conhecimento dos stakeholders necessários no exercício da atividade produtiva de criação de pescado em tanques-rede. Porém a maior contribuição foi o reconhecimento de quais são os pontos fracos e fortes prioritários ao aprimoramento e adequação às BPA da produção (correlação dos indicadores e a necessidade de intervenção nos processos de manejo produtivo, de gestão e administração detectados pelo sistema Apoia/Aquicultura).

As respostas dos 26 stakeholders às 6 perguntas apresentadas, indicam que 0 ambiente institucional reage positivamente quando da introdução de ferramentas de gestão nas propriedades, considerados assim fortes indutores às mudanças, $(73 \%$ dos stakeholders). Foi consenso também entre os proprietários (69\%), que as estratégias para acesso e manutenção nos mercados exigem diferenciais de produtividade, principalmente em qualidade e custo final do produto.

A vasta literatura pesquisada pondera que a capacidade de evolução da empresa no mercado, está ligada à forma como os gerentes adquirem conhecimentos, comprometendo-se com o investimento intelectual, no intuito de alavancar recursos, para além das fronteiras da organização e reempregar as competências essenciais para surpreender constantemente os clientes (Prahalad e Hamel, 1998).

As respostas apresentadas indicam que 0 fluxo contínuo de diálogo entre o produtor e os demais stakeholders, em alguns casos apresenta possibilidade de intervenção para melhoria, isto porque os stakeholders produtor associado $e$ independente, prioritariamente compartilham entre si, suas dúvidas com soluções técnicas e comercialização e apenas secundariamente buscam o stakeholder assistência técnica, pesquisa e extensão rural. Esta situação apesar de indicar que o fluxo de diálogo na cadeia de valor ainda não é contínuo, pode ser considerada como um ponto forte na implantação dos aprimoramentos e aceitação de conhecimento e capacitação para a produção

O stakeholder fornecedor de ração, equipamentos e insumos, de acordo com as análises é o que necessita maior foco, para a 
correção do fluxo de diálogo, uma vez que para a atividade aquícola, a ração tem peso significativo no custo final da produção. Ainda os stakeholders gestores públicos e comunitários apresentam possibilidades de aprimoramento quanto a custos no aperfeiçoamento do ciclo produtivo e ou diferenciação do empreendimento e seu entorno.
As respostas à pergunta 6 indicam por stakeholder o seu grau de influência na solução de problemas técnicos e de comercialização, com score de 1 a 5 , sendo 1 o principal influenciador e o número 5 o stakeholder de pouca ou irrelevante influência (Tabela 1).

Tabela 1: Stakeholder influenciador para as soluções de produção e comercializador

\begin{tabular}{|l|c|}
\hline \multicolumn{1}{|c|}{ Stakeholder } & Grau de influência \\
\hline Produtor Associado & 1 \\
\hline Apoio Técnico, Pesquisa e Extensão Rural & 2 \\
\hline Gestor Público e Comunitário & 3 \\
\hline Fornecedor de Insumos e Equipamentos & 4 \\
\hline Produtor Independente & 5 \\
\hline
\end{tabular}

Fonte: Elaborado com dados primários de pesquisa

Três perguntas específicas sobre os temas conhecimentos técnicos, gestão e administração foram desenvolvidas nos questionários e as respostas indicaram alianças, sinergias benéficas e informações do ponto de vista do produtor (como este entende o que é prioritário em sua atividade) de como as ferramentas de administração aplicadas ao ciclo produtivo podem reconhecer ações necessárias ao aperfeiçoamento das vantagens competitivas.
Os produtores associados e independentes apresentarem conhecimento técnico como oportunidade de melhoria em suas atividades de manejo de produção (BPA), e na pergunta 3 suas respostas elencaram de 1 a 5 (maior importância 1, até pouca ou irrelevante considerada 5), as atividades do ciclo produtivo com necessidade de aprimoramento em capacitação e conhecimento em gestão (Tabela 2).

Tabela 2: Quais conhecimentos representam Oportunidades de Melhoria

\begin{tabular}{|l|c|}
\hline Indicador de conhecimento técnico & Grau de Importância \\
\hline Densidade Populacional nos Tanques-Rede & 1 \\
\hline Quantidade de Ração e Calculo de Consumo & 2 \\
\hline Ajuste no Tipo de Ração & 3 \\
\hline Medição de Tamanho e Peso & 4 \\
\hline Frequência e Horário de Alimentação & 5 \\
\hline
\end{tabular}

Fonte: Elaborado com dados primários de pesquisa

Os indicadores frequência e horário de alimentação, medição de tamanho e peso apresentaram pouca ou baixa influência nas oportunidades de melhoria em BPA, do ponto de vista do stakeholders específicos produtores independente e associado. Podese ainda observar que a densidade populacional nos tanques-rede e a quantidade de ração e cálculo de consumo são bem considerados pelos produtores e assim pontos fortes nas suas atividades produtivas já desenvolvidos em suas atividades produtivas.

Quando os mesmos indicadores e resultados foram analisados pelos conceitos de organização industrial, competência essencial e sustentabilidade (proposição teórica deste estudo) observou-se que, um indicador julgado de baixa ou pouca influência para a melhoria da produção, pode implicar na maior necessidade de intervenção para o aprimoramento das práticas produtivas em conhecimentos técnicos para as oportunidades de melhoria e adequação às BPA.

A literatura revisada permitiu entender que os índices de sustentabilidade, têm sido desenvolvidos, para refletir resumidamente as alterações sofridas pelo meio ambiente e tem como característica principal, o poder de 
sintetizar um conjunto complexo de informações.

Nas análises referentes a questão 4 , onde os stakeholders se posicionaram quanto a quais conhecimentos de gestão ambiental podem trazer diferencial de competitividade para o produto e no mercado (com indicador de 1 a 5 , sendo 10 indicador de maior influência e 5 o de pouca influência). As respostas indicaram que os proprietários enxergam importância para a produção na qualidade da água (QA), distância da fonte de poluição (DFP) e origem dos alevinos (OA), porém as variáveis adensamento populacional dos tanques-rede (APTR) e qualidade dos sedimentos (QS), tem menor ou pouca importância na formação de diferencial competitivo na visão dos proprietários (Tabela 3).

Tabela 3: Quais conhecimentos em Gestão Ambiental trazem diferencial competitivo

\begin{tabular}{|l|c|}
\hline \multicolumn{1}{|c|}{ Indicador de Gestão Ambiental } & Grau de Influência \\
\hline Qualidade da Água & 2 \\
\hline Distância Tanques-rede & 3 \\
\hline Origem dos Alevinos & 4 \\
\hline Adensamento Populacional dos Tanques-rede & 5 \\
\hline Qualidade dos Sedimentos & \\
\hline
\end{tabular}

Fonte: Elaborado com dados primários de pesquisa

O entendimento sistêmico destes indicadores (regressão e Swot), permitiu reconhecer o indicador prioritário para intervenção estratégica, contribuindo para a conscientização dos proprietários. Nestes resultados estratégicos os indicadores encontram diferencial competitivo no índice de adensamento populacional dos tanques- rede (APTR), qualidade dos sedimentos (QS) e distância de fontes de poluição (DFP indicando quais as intervenções necessárias na gestão ambiental, são agregadores de diferencial competitivo entre as práticas estratégicas organizacionais em interface com o mercado (Tabela 4).

Tabela 4: Conhecimentos de Gestão Ambiental e Diferencial Competitivo

\begin{tabular}{|l|c|c|c|c|}
\multicolumn{1}{c|}{ Indicador } & Coeficiente & Se coeficiente & Z & P \\
\hline DFP & 0,748968 & 0,629082 & 1,19 & 0,234 \\
\hline APTR & $-0,145694$ & 0,554345 & $-0,26$ & 0,793 \\
\hline QS & 0,590497 & 0,547429 & 1,08 & 0,281 \\
\hline
\end{tabular}

Aplicado Regressão dummy

Fonte: Elaborado com dados primários da pesquisa

De maneira geral nas respostas à pergunta 5 sobre quais os conhecimentos de gestão e administração são diferenciais de competitividade, os indicadores planejamento do ciclo produtivo (PCP), controle e registro do produto final (CRPF) e controle de saúde e mortalidade (CSM) foram destacados pelos stakeholders como os de maior até mediana importância. Já os indicadores de procedimentos de descarte e descarte de peixes mortos (PDDPM) e conhecimento de saúde e mortalidade (CSM), são considerados pelos stakeholders ações de baixo ou menor influência de diferencial competitivo em suas atividades produtoras (Tabela 5). 
Tabela 5: Quais os conhecimentos de gestão e Administração por diferencial direcionador de Competitividade.

\begin{tabular}{|l|c|}
\hline \multicolumn{1}{|c|}{ Indicador de Gestão Ambiental } & Grau de Influência \\
\hline Planejamento do Ciclo Produtivo & 1 \\
\hline Controle e Registro do Produto Final & 2 \\
\hline Controle de Saúde e Mortalidade & 3 \\
\hline Procedimento de Descarte/ Descarte Peixes Mortos & 4 \\
\hline Controle e Uso de Medicamento & 5 \\
\hline
\end{tabular}

Fonte: Elaborado com dados primários de pesquisa

Considerando - se um índice ou indicador segundo Gallopin (2003), uma ferramenta que permite a obtenção de informações sobre uma dada realidade, ao se aplicar uma análise de regressão para os mesmos indicadores, encontra-se uma maior necessidade de atenção para formação de diferencial competitivo, em ordem de prioridade técnica socioambiental (Tabela 6) nas atividades produtivas de controle de saúde e mortalidade (CSM), controle e uso de medicamentos (CUM), procedimentos descarte/descarte de peixes mortos (PDDPM) e planejamento e controle produtivo (PCP) respectivamente.

Tabela 6: Conhecimento de Gestão e Administração como Diferencial de Competitividade

\begin{tabular}{|l|c|c|c|c|}
\multicolumn{1}{|c|}{ Indicador } & Coeficiente & SE Coeficiente & $Z$ & $P$ \\
\hline PCP & $-5,06225$ & 795,151 & $-0,01$ & 0,995 \\
\hline CSM & $-9,19853$ & 1282,22 & $-0,01$ & 0,994 \\
\hline CUM & $-8,0996$ & 1281,31 & $-0,01$ & 0,995 \\
\hline PDDPM & $-5,69819$ & 719,909 & $-0,01$ & 0,994 \\
\hline
\end{tabular}

Fonte: Elaborado com dados primários da pesquisa

As diversas análises propiciadas pelas respostas dos stakeholders permitiram o reconhecimento dos indicadores geradores de vantagem competitiva e de maneira adaptada aplicou-se uma análise swot, para determinar qual a função destes indicadores econômicos socioambientais na geração de competitividade na empresa aquícola.

A leitura dos dados da pesquisa do APOIA/Aquicultura, em conjunto com as respostas dos stakeholders, permitiu reconhecer pontos fortes e pontos fracos na vantagem competitiva (competitividade), ao analisar as empresas de aquicultura de dentro para fora, demonstrando com clareza as intervenções necessárias e onde elas se localizavam na cadeia de valor.

Cada potencial de criação de vantagem competitiva foi analisado sob a ótica da influência na cadeia de valor produtiva e também identificando-se qual a consequente área para intervenção. Os pontos fortes direcionadores de controle de custos, identificados nas unidades de arraçoamento pelos indicadores de frequência e horário de alimentação, quantidade de ração e cálculo de consumo e densidade populacional dos tanques-rede e na sanidade animal como conhecimento e uso de medicamentos estão correlacionados no ciclo produtivo com o fornecimento de ração (desperdício ou excesso), doenças e mortalidade do pescado.

A identificação da percepção dos stakeholders no processo produtivo possibilitou o direcionamento de conhecimentos em gestão ambiental e capacitação em gestão e administração e a interpretação de que pequenos ajustes e melhor aproveitamento de sinergias e diálogos entre os stakeholders, apresentamse como ferramenta para o aproveitamento de oportunidades potenciais de criação de vantagem competitiva para a tomada de decisões pelos proprietários.

Os resultados positivos quanto ao reconhecimento e aprimoramento dos indicadores apresentados quando da intervenção na cadeia de valor, são significativos e expressam a possibilidade do aproveitamento de oportunidades de participação no mercado de maneira inovadora, criativa e de baixo custo.

A Tabela 7 indica o reconhecimento dos pontos fortes, a correlação de sua influência 
na cadeia produtiva e finalmente a identificação da unidade de produção com necessidade de intervenção. Os pontos fortes foram classificados entre direcionadores para diferenciação do produto e direcionadores de custo.

Tabela 7 - Potencial de Criação de Vantagem Competitiva - Pontos Fortes

Direcionadores de Controle de Custos

\begin{tabular}{|c|c|c|}
\hline Pontos Fortes & Influencia na cadeia de Valor Produtiva & $\begin{array}{l}\text { Unidade para } \\
\text { intervenção }\end{array}$ \\
\hline $\begin{array}{l}\text { Frequência Horário de } \\
\text { Alimentação }\end{array}$ & $\begin{array}{l}\text { O número de tratos diários e horários fixos de } \\
\text { fornecimento da ração são importantes para se evitar } \\
\text { desperdício ou falta de alimento bem como doenças. }\end{array}$ & *Arraçoamento \\
\hline $\begin{array}{l}\text { Quantidade de Ração e } \\
\text { Cálculo de Consumo }\end{array}$ & $\begin{array}{l}\text { Necessário acompanhar a quantidade de ração } \\
\text { administrada, pois interfere diretamente na mortalidade e } \\
\text { no consumo de ração. }\end{array}$ & Arraçoamento \\
\hline $\begin{array}{l}\text { Conhecimento } \\
\text { Medicamento }\end{array}$ & $\begin{array}{l}\text { O uso de medicamentos indiscriminadamente pode não } \\
\text { proporcionar a efetiva correção do problema onerando } \\
\text { custo de produção. }\end{array}$ & Sanidade Animal \\
\hline $\begin{array}{l}\text { Densidade Populacional dos } \\
\text { Tanques }\end{array}$ & $\begin{array}{l}\text { Nas condições ideais de cultivo em tanques-rede, } \\
\text { espera-se uma conversão alimentar de } 1,5 \text { a } 1,8 \text { com } \\
\text { uma sobrevivência de } 95 \% \text {. }\end{array}$ & Arraçoamento \\
\hline Qualidade dos Sedimentos & $\begin{array}{l}\text { Diretamente ligado a quantidade de fosforo e nitrato são } \\
\text { um registro dos efeitos cumulativos de deficiências, com } \\
\text { relação a matéria orgânica e outros indicadores. }\end{array}$ & $\begin{array}{l}\text { Qualidade } \\
\text { Sedimentos }\end{array}$ \\
\hline Planejamento Ciclo Produtivo & $\begin{array}{l}\text { Acompanhar o cultivo de tilápias nos tanques-rede } \\
\text { contribui para aplicação das estratégias de gestão e } \\
\text { administração na produção. }\end{array}$ & $\begin{array}{l}\text { Manejo } \\
\text { Operações }\end{array}$ \\
\hline $\begin{array}{l}\text { Controle e Registro Produto } \\
\text { Final }\end{array}$ & $\begin{array}{l}\text { Permite introdução tecnologia de rastreabilidade, } \\
\text { indicando origem do pescado }\end{array}$ & Sanidade Animal \\
\hline
\end{tabular}

\footnotetext{
*Arraçoamento: ato de distribuir ração com planejamento e regra.

Adaptado Duncan et al.1998

Elaborado com dados primários da pesquisa
}

Estrategicamente, os pontos fracos direcionadores para diferenciação do produto apresentam-se nas atividades relacionadas com sanidade animal são fatores determinantes para a qualidade e apresentação do produto final no mercado. Os pontos fracos identificados como direcionadores para diferenciação do produto, encontrados foram os índices de qualidade da água, procedimentos de descarte de peixes mortos e ou descartes de peixes mortos, ajuste no tipo de ração e origem dos alevinos (sanidade animal).

Enfim a análise e definição dos pontos fracos e fortes do processo produtivo de criação de tilápias em Capitólio, encontrou indicadores de criação potencial de vantagens competitivas que podem ser reduzidos ou eliminados com intervenções em conhecimento de processos na dimensão organização industrial (capacidades dinâmicas) entre as variáveis frequência e horário da alimentação (pontos fortes) e adensamento tanques- rede; ajuste tipo de ração; medição tamanho e peso , conhecimento de saúde e mortalidade (pontos fracos).

$\mathrm{Na}$ Tabela 8 os pontos fracos identificados como direcionadores de controle de custos são identificados como potenciais criadores de VC nos índices de medição de tamanho e peso, conhecimento em saúde e mortalidade, (manejo e operações), ajuste no tipo de ração, (arraçoamento), densidade populacional nos tanques rede e distância das fontes de poluição (organização espacial).

As análises também demonstraram que, para as oportunidades de participação no mercado em posicionamento, os indicadores pontos fortes com necessidade de capacitação em gestão e administração são qualidade de sedimentos e controle e registro do produto 
final e para os pontos fracos destaca-se o

peixes indicador de procedimentos de descarte de

Tabela 8- Potencial de Criação de Vantagem Competitiva - Pontos Fracos

Direcionadores de Controle de Custos

\begin{tabular}{|c|c|c|}
\hline Pontos Fracos & Influencia na cadeia de valor produtivo & $\begin{array}{l}\text { Unidade para } \\
\text { intervenção }\end{array}$ \\
\hline Medição Tamanho e Peso & $\begin{array}{l}\text { Para acompanhamento das diversas etapas de } \\
\text { crescimento e qualidade do pescado é necessário } \\
\text { fazer biometrias dos peixes a cada } 15 \text { ou } 30 \text { dias e o } \\
\text { controle do número de peixes mortos diariamente. }\end{array}$ & $\begin{array}{l}\text { Despesca e } \\
\text { Qualidade do } \\
\text { Produto }\end{array}$ \\
\hline Ajuste Tipo de Ração & $\begin{array}{l}\text { A ração é o insumo com maior peso sobre o custo da } \\
\text { produção e pode representar de } 50 \% \text { a } 70 \% \text { do total. } \\
\text { O estado nutricional dos peixes depende da } \\
\text { quantidade e qualidade dos nutrientes da ração. }\end{array}$ & Arraçoamento \\
\hline $\begin{array}{l}\text { Conhecimento de Saúde e } \\
\text { Mortalidade }\end{array}$ & $\begin{array}{l}\text { Importante indicador de deficiências nutricionais que } \\
\text { prejudicam o crescimento, e aumentam a incidência } \\
\text { de doenças e de mortalidade. }\end{array}$ & Manejo e Operações \\
\hline Adensamento Tanques Rede & $\begin{array}{l}\text { O aumento na densidade interfere na qualidade da } \\
\text { água e acesso da pesca ao alimento, limitando a } \\
\text { produtividade. }\end{array}$ & $\begin{array}{l}\text { Organização } \\
\text { Espacial }\end{array}$ \\
\hline Distância Fonte Poluição & $\begin{array}{l}\text { Quantidade disponível de oxigênio e concentração de } \\
\text { gases tóxicos, limitam a quantidade de peixes a serem } \\
\text { criados. }\end{array}$ & $\begin{array}{l}\text { Organização } \\
\text { Especial }\end{array}$ \\
\hline Qualidade da Água & $\begin{array}{l}\text { Interferem na quantidade de alimento consumido pelos } \\
\text { peixes, nos indicadores de turbidez e oxigênio } \\
\text { dissolvido entre outros. }\end{array}$ & Qualidade da Água \\
\hline $\begin{array}{l}\text { Procedimento Descarte Peixes } \\
\text { Mortos }\end{array}$ & $\begin{array}{l}\text { Os peixes mortos necessitam ser retirados e } \\
\text { enterrados. Essa prática deve ser feita nas horas mais } \\
\text { frias do dia para minimizar o estresse e a mortalidade } \\
\text { dos peixes. }\end{array}$ & Sanidade Animal \\
\hline Origem dos Alevinos & $\begin{array}{l}\text { Peixes de boa qualidade genética respondem de } \\
\text { forma positiva ao manejo intensivo (tanques-rede). }\end{array}$ & Sanidade Animal \\
\hline
\end{tabular}

\section{CONCLUSÕES}

As análises dos indicadores técnicos e socioambientais (boas práticas de gestão ambiental para a competitividade), apresentaram conformidade com as dificuldades relatadas pelos produtores em terem acesso às ferramentas de gestão, administração e custos de produção das propriedades de cultivo de tilápias nos tanques-rede.

As respostas apontam à necessidade do produtor associado e individual, perceberem que sua produção pode melhorar em custos, desempenho alimentar e qualidade nos tanques-rede, a partir do aperfeiçoamento na gestão das atividades que integram seu ciclo de produção.

As soluções criativas estão associadas aos indicadores de gestão identificados como: treinamentos formais e informais sobre ciclo de produção e atividades produtivas, criação e utilização de planilhas de acompanhamento, intercambio de aprendizagem e melhoria com os fornecedores de insumos entre outras.

O produtor deixa claro nas suas respostas, o quanto para ele é importante o planejamento do ciclo produtivo, porém na análise dos indicadores, percebe-se que o proprietário necessita de capacitação e conhecimento em saúde, mortalidade e medicamentos aplicados na produção de peixes. Também são importantes, um adequado descarte e controle dos peixes mortos para agregar valor ao produto e diferencia de competência à sua empresa.

Os resultados do estudo mostram que os indicadores de gestão ambiental identificados destacam-se como oportunidade de melhoria na eficiência da cadeia de produção das tilápias de Capitólio/MG. 


\section{REFERÊNCIAS}

[1] ANDRADE.A; ROSSETTI.J.P. ,2004. Governança Corporativa: Fundamentos, Desenvolvimento e Tendências. Editora Atlas. São Paulo. 594p.

[2] BARTLETT.C.A.; GHOSHAL.S ,1995. Transnational Management - 2a ${ }^{\underline{a}}$ Edição Editora McGraw-Hill. 840p.

[3] BRINKMAN L.G., 1987. The Competitive Position of Canadian Agriculture - Canadian Journal of Agricultural Economics/Revue canadienne d'agroeconomie. v. 37. 263-288p

[4] COSTA-PIERCE. 2007 "An ecosystem approach to marine aquaculture: a global review". In: D. Soto, J. Aguilar-Manjarrez \& N. Hishamunda (Eds.). Building an ecosystem approach to aquaculture. FAO/Universitat de les Illes Balears Experts Workshop. Palma de Mallorca, Spain. FAO Fisheries and Aquaculture Proceedings, Rome, FAO, n. 14, 2008

[5] DUNCAN. J W, et al. , 1988. Competitive advantage and internal organizational

[6] assessment, Academy of Management Executive, vol 12 no 3 , disponível em: <http://turbo.kean.edu/ jmcgill/assess.pdf>. Acessado em: 20 set. 2013.

[7] FAERJ/REDETEC, 2010 - DIAGNOSTICO DA CADEIA PRODUTIVA DO PESCADO FLUMINENSE, disponível em $<$ http://www.querodiscutiromeuestado.rj.gov.br/CM S/uploads/publicacoes/09.08.13-09.37.56-

diagnostico_pesca_maritima_comercial_rio_de_jan eiro.pdf>. Acessado em: 20 set. 2013.

[8] FAO - 2012. Organização das Nações Unidas para Agricultura e Alimentação. The state of world fisheries and aquaculture. Roma, disponível em:

<http://www.fao.org/docrep/016/i2727e/i2727e00.ht m>. Acessado em: 05 jul. 2013.

[9] 2012. Fishery and aquaculture country profile. Disponível em:

[10] <http://www.fao.org/fishery/countrysector/F I-CP_CN/5/ >. Acessado em: 17 set. 2013.

[11] FREEMAN, R. E.; REED, D. L.1984. Stockholders and Stakeholders: A New Perspective on Corporate Governance. California Management Review. Spring 83, Vol. 25 Issue 3, p88 Academic Journal.

[12] GALLOPÍN, G.,1996. Environmental and sustainability indicators and the concept of situational indicators. A systems approach. Environmental Modeling and Assessment, v. 1, n. 3, p. 101-117.

[13] GALLOPIN, G.C. 1997. Indicators and their use: information for decision-making .In MOLDAN, B.; BILLHARDZ, S. Sustainability Indicators: report of project on indicators of sustainable development. New York: J.Wiley and Sons.

[14] GOLDSCHMIDT, A., 2006 "Análise SWOT na captação de recursos - avaliação de

[15] oportunidades, ameaças, pontos fortes e pontos fracos", acessado em abril 2014 em

[16]

http://integracao.fgvsp.br/ano6/06/financiadores.ht $\mathrm{m}$

[17] HAMEL, GARY \& PRAHALAD, C. K. 1993. Strategy as stretch and leverage. Harvard Business Review. 71 (3): 75-84.

[18] MANGABEIRA, J. A. de C.; ROMEIRO, A. R.; AZEVEDO, E.C. de; ZARONI, M. M. H. Tipificação de sistemas de produção rural: a abordagem da análise de correspondência múltipla emMachadinho d OesteRO.Campinas:Embrapa, 2002. 30 p. (Embrapa monitoramento por satélite - circular técnica, 8).

[19] MONTGOMERY, C.A.; PORTER, M.E.,1998. Estratégia: a busca da vantagem competitiva. 3. ed. Rio de Janeiro: Campus.

[20] OLIVEIRA, T. B. A.; BORNIA, A. C.; OLIVEIRA, M. W. Gestão do conhecimento na produção de cana-de-açúcar. Anais. XIII SEPROSUL - Semana de la Ingeniería de Producción Sudamericana- Junho de 2013, Gramado - Brasil. Meio magnético.

[21] PORTER, M. ,1980. Competitive strategy. New York : Free Press.

[22] M. 1985. Vantagem Competitiva: Criando e sustentando um desempenho superior. Ed. Campos, RJ.

[23] M. Towards a dynamic theory of strategy. Strategic Management Journal, v. 12, p. 95-117. Winter, 1991.

[24] M. 1996. What is strategy? Harvard Business Review, v. 74, n. 6, Nov./Dec.

[25] 1998. A vantagem competitiva das nações. Rio de Janeiro: Campus.

[26] PRAHALAD, C. K., HAMEL, G., 1990.The core competence of the corporation. Harvard Business Review, v. 68, n. 3, May/June.

[27] PRAHALAD,C,K, 2009 .Em busca do novo - Entrevista Revista HSM.

[28] 2010. Why Sustainability is now the key driver of Innovation. Harvard Business Review. Disponível em:< http://hbr.org $>$. Acessado em setembro 2013.

[29] ROBERTSON. G . C , BROOKS D.J ., 2001 Assessment of the Competitive

[30] Position of the Forest Products Sector in Southeast Alaska, 1985-94. Disponível em: 
<http://www.fs.fed.us/pnw/pubs/pnw_gtr504.pdf>. Acessado em: 07 set. 2013.

[31] RODRIGUES, G. S.; CAMPANHOLA, C.; RODRIGUES, I.; FRIGHETTO, R. T. S.; VALARINI, P. J.; RAMOS-FILHO, L. O.,2006. Gestão ambiental de atividades rurais: estudo de caso em agroturismo e agricultura orgânica. Agricultura em São Paulo. v. 53, n. 1.

[32] RODRIGUES, G. S. , QUEIROZ, J. F. de , FRIGHETTO, R. T. S. , SAMPAIO, F. G. , FRASCASCORVO, C. M. D. , COUTO, K. R. , RODRIGUES, I. A. 2013. Best Management Practices and Environmental Management in Aquaculture Indicators for Monitoring in Multiple Scales. 4th International Workshop Advances in Cleaner Production. São Paulo, Brazil. Disponível em:
$<$ http://www.advancesincleanerproduction.net/fourt h/files/sessoes/6B/7/rodrigues_gs_et_al_work.pdf >. Acessado em: 13 ago. 2013.

[33] SEBER, G. A. F. and WILD, C. J. 2003: Nonlinear regression, 2nd Ed. John Wiley.

[34] SHAPIRO,C. 1990.Competition and Innovation: Did Arrow Hit the Bull's Eye?, in The Rate \& Direction of Economic Activity Revisited, Josh Lerner and Scott Stern, eds. National Bureau of Economic Research, University of Chicago Press.

[35] TEECE,.D.J, 1997. Dynamic Capabilities and Strategic Management Foss (ed.), Resource Firms and Strategies, PP.268-285., Oxford. (7-2). 


$$
\text { Alutary }
$$




\section{ADRIANO NASCIMENTO DA PAIXÃO}

Doutor em Economia Aplicada pela Universidade Federal de Viçosa (2008). Professor Associado I do Departamento de Economia da Universidade Federal da Paraíba, professor permanente do Pŕograma de Pós-graduação em Desenvolvimento Regional (PGDR-UFT) e professor do Mestrado Profissional em Economia do Setor Público (MESP-UFPB).

\section{AFFONSO AMARAL DALLA LIBERA}

Possui graduação em Agronomia pela Universidade Federal do Rio Grande do Sul (2006), graduação em Administração de Empresas pela Universidade do Vale do Rio dos Sinos (2006), mestrado em Agronegócios pela Universidade Federal do Rio Grande do Sul (2009) e doutorado em Desenvolvimento Econômico pela Universidade Estadual de Campinas (2016) com período sanduíche em Universität Hohenheim (Orientador: Thomas Berger). Atualmente é professor do Instituto Federal de Mato Grosso. Tem experiência na área de Economia, com ênfase em Economia agrícola, atuando principalmente nos seguintes temas: difusão tecnológica, simulação agent based e análise de mercados agropecuários.

\section{ALESSANDRA TROIAN}

Doutora em Desenvolvimento Rural, professora adjunta na Universidade Federal do Pampa, campus Santana do Livramento/RS.

\section{ANA ELISA BRESSAN SIMITH LOURENZANI}

Possui graduação em Agronomia pela Universidade Federal de Viçosa (1998), mestrado em Engenharia de Produção pela Universidade Federal de São Carlos (2003), doutorado em Engenharia de Produção pela Universidade Federal de São Carlos (2006) e Pós-doutorado na Kansas State University (2013). Atualmente é professor assistente da Universidade Estadual Paulista, Campus de Tupã. Tem experiência na área de Gestão de Sistemas Agroindustriais, atuando principalmente nos seguintes temas: agricultura familiar, acesso a mercados, compras institucionais, certificação e indicações geográficas.

\section{ANTÔNIO CORDEIRO DE SANTANA}

Graduado em Agronomia pela Universidade Federal do Ceará. Mestre em Economia Rural pela Universidade Federal do Ceará. Doutor em Economia Aplicada pela Universidade Federal de Viçosa. Professor Titular da Universidade Federal Rural da Amazônia.

\section{ANTONIO MARCOS DE QUEIROZ}

Graduado, Mestre e Doutor em Economia pela Universidade Federal de Uberlândia; Professor Adjunto na Universidade Federal de Goiás. Tem experiência na área de Economia, com ênfase em Desenvolvimento Econômico, Rural e Territorial, Economia agrária e do Agronegócio, Economia Industrial, Estatística e Econometria Espacial, atuando principalmente nos seguintes temas: Desenvolvimento econômico, reespacialização e territorialidade na agricultura, avicultura de corte, complexos agroindustriais, setor sucroenergético, Nova Economia Institucional, cadeias produtivas, coordenação dos agentes, inovações tecnológicas na agricultura.

\section{ÁUREA LÚCIA SILVA ANDRADE}

Mestre em Administração (2003) e graduação em Administração (1998) pela Universidade Federal de Lavras. É professora Adjunto da Universidade Federal de Viçosa, campus Rio Paranaíba. Atualmente está na Coordenação do Curso de Administração da UFV-CRP. Atua no ensino superior desde 2002 e possui interesse em pesquisas sobre o agronegócio como análise de sistemas agroindustriais, cooperação em rede e gestão do agronegócio. Na área 
didático-pedagógica possui interesse em pesquisas sobre a aplicação de metodologias ativas no ensino superior.

\section{BENJAMIN ALVINO DE MESQUITA}

Possui graduação em Ciências Econômicas pela Universidade Federal do Ceará (1976); mestrado em Desenvolvimento Agrícola pela Universidade Federal Rural do Rio de Janeiro (1982) e Doutorado em Geografie, Amenegement et urbanism pelo IHEAL/ Sorbonne Nouvelle/Paris III (2006) e em Politicas Publicas pela Universidade Federal do Maranhão em 2006. Atualmente é professor associado 3 do departamento de economia, onde respondeu pela chefia (1993/1995), e professor permanente dos Programas de Pós-Graduação em Políticas Públicas e de Desenvolvimento Socioeconômico da UFMA nos quais exerceu a função de Coordenador-adjunto no biênio 1995/1999 (PPGPP) e de coordenador no período de 2010/2012 (PPGDSE).Atualmente coordena projetos (2) e um grupo de pesquisa (desenvolvimento e agricultura)) e participa de outros dois (Observatório de Políticas Publicas/PPGPP/UFMA e PNCSA/UEAM/BNDES).Todos com bolsistas da IC, os quais possibilitaram mais de uma dezena de publicações (artigos/livros e resumos completos). Tem desenvolvido e orientado pesquisas nas seguintes áreas: desenvolvimento e política agrícola, agroextrativismo, economia e desenvolvimento regional, economia regional; desenvolvimento local; agronegócio e agricultura familiar, e meio ambiente ;povos e comunidades tradicionais, conflitos socioambientais resultantes da implantação de grandes projetos ;foi membro do corpo editorial da revista de Políticas Publicas (1996/1999); Foi bolsista Produtividade da FAPEMA (2012 e 2013), esteve também trabalhando com ONGs e entidade de apoio aos trabalhadores rurais.

\section{CLEIDINALDO DE JESUS BARBOSA}

Graduado em Economia (2005), Mestrado em Agronegócios pela Universidade Federal de Goiás (2008) e Doutorado em Ciências Ambientais pela Universidade Federal de Goiás (2015). Atualmente é professor de cursos da graduação e Pós-Graduação da Universidade Federal de Goiás.

\section{DALLAS KELSON FRANCISCO DE SOUZA}

Graduado em Ciências Econômicas pela Universidade Estadual de Montes Claros UNIMONTES (2014), Mestre em Economia Aplicada pela Universidade Federal de São Carlos - UFSCar (2018), campus Sorocaba. Atualmente é Doutorando em Desenvolvimento Econômico pelo Programa de Pós Graduação do Instituto de Economia da Universidade Estadual de Campinas - Unicamp atuando na área de Economia Agricultura e Meio Ambiente. Tem experiência na área de Economia em pesquisas com ênfase em Mercados Agrícolas, Comércio Internacional, Organização Industrial e Métodos Econométricos.

\section{DANILO TRONCOSO CHAVES MARTINES}

Graduado em Ciências Econômicas pela Faculdade de Administração, Ciências Contábeis e Ciências Econômicas - FACE, da Universidade Federal de Goiás - UFG.

\section{DEIVISSON COSTA DE CARVALHO}

Estudante de graduação em Administração pela Universidade Federal de Viçosa - Campus Rio Paranaíba. Membro do NEEAP UFV-CRP (Núcleo de Estudos Econômicos do Alto Paranaíba, colabora na pesquisa e elaboração de artigos no âmbito agro econômico. Atualmente exerce o cargo de vice-presidente na EJ do curso de Administração a Integra Consultoria. Participa de projetos culturais voltados à musicalização onde leciona aulas de violino e teoria musical. 


\section{DIEGO SARTI DE SOUZA}

Graduado em Engenharia Mecânica pela Universidade Estadual Paulista "Júlio de Mesquita Filho" - UNESP/Guaratinguetá (2012) Trabalhou com Engenharia de Materiais no Departamento de Ciência e Tecnologia Aeroespacial/- Instituto de Aeronáutica e Espaço DCTA/IAE (2011), Mestre em Economia Aplicada pela Universidade Federal de São Carlos UFSCar/Sorocaba (2017). Tem como áreas de interesse: Teoria Econômica, Microeconomia, Organização Industrial, Avaliação de Políticas Públicas e Métodos Quantitativos.

\section{EDENILSON LENCINA MACHADO}

Bacharel em Ciências Econômicas pela Universidade Federal do Pampa.

\section{EDSON ROBERTO VIEIRA}

É doutor em Economia Aplicada pela Universidade Federal de Uberlândia e possui mestrado em Desenvolvimento Econômico e graduação em Economia pela mesma instituição. É professor adjunto da Universidade Federal de Goiás e Superintendente do IBGE em Goiás. Foi Coordenador Operacional do Censo 2010, é Coordenador do Boletim de Conjuntura Econômica da FACE/UFG e investiga principalmente os seguintes temas: determinantes das exportações, teorias do comércio internacional, financiamento de longo prazo, taxa de juros e desenvolvimento econômico.

\section{ELANE CONCEIÇÃO DE OLIVEIRA}

Graduada em Ciências Econômicas pela Universidade Federal do Amazonas, Mestre em Ciências do Ambiente e Sustentabilidade na Amazônia pelo Centro de Ciências do Ambiente/Universidade Federal do Amazonas e Doutora em Desenvolvimento Sustentável pelo Centro de Desenvolvimento Sustentável, Universidade de Brasília. Atualmente é professora adjunta na Escola Superior de Estudos Sociais, da Universidade do Estado do Amazonas.

\section{ELIZANGELA BECKMANN}

Elizangela Beckmann. Graduada em Ciências Econômicas pela Universidade do Estado de Mato Grosso. Mestre em Agronegócios e Desenvolvimento Regional pela Universidade Federal de Mato Grosso. Doutora em Ciências Agrárias pela Universidade Federal Rural da Amazônia. Professora Interina na Universidade do Estado de Mato Grosso e na Universidade de Cuiabá.

\section{ÉRIKA SABRINA FELIX AZEVEDO}

Mestre em Administração -UFRPE, Especialista em Gestão de Projetos- Anglo Americano, Bacharel em Administração. Pesquisadora sobre as relações de trabalho e seus impactos sobre a vida do trabalhador. Professora. Consultora Empresarial. Palestrante.

\section{EVANDRO JARDIM DOS SANTOS}

Possui Graduação em Administração - UNIFAl (2000); Especialização em Gestão de Marketing - REGES(2005); Especialização (MBA) em Gestão Estratégica de Marketing e Negócios - REGES (2005); Licenciatura em Administração - Centro Paula Souza (2008); Licenciatura em Pedagogia - IEC - Instituto Educacional de Carapicuíba (2010). Licenciatura em Contabilidade - Centro Paula Souza (2011); Especialização em Gestão Escolar - CEALCA (2012). Mestre em Agronegócio e Desenvolvimento pela Unesp/Tupã (2017). Atualmente é Professor do Centro Paula Souza na área de Gestão e Negócios. Professor do Programa de Pós Graduação em Gestão de Pessoas da UNIFAI. Diretor de Serviços Acadêmicos da ETEC Engenheiro Herval Bellusci de Adamantina/SP. 


\section{FÁBIO ANDRÉ TEIXEIRA}

Possui graduação em Ciências Econômicas pela Universidade Federal de Uberlândia (1998), Mestrado em Desenvolvimento econômico pela Universidade Federal de Uberlândia e doutorado em Economia pela Universidade Federal de Uberlândia. Atualmente é professor Adjunto II/40 horas dedicação exclusiva na Universidade Federal de Viçosa Campus Rio Paranaíba. É professor da área de Economia, tendo ministrado disciplinas nas áreas de Macroeconomia, Microeconomia, Economia Internacional, Desenvolvimento Econômico, Contabilidade Social e Ambiental, Economia Agrícola e organização Industrial. Atua nas discussões dos seguintes temas: Conjuntura Econômica, Economia Monetária e Financeira, Economia Agrícola, Microeconomia, Finanças e agronegócios. Professor das disciplinas Gestão Social e Ambiental e Gestão de Projetos Públicos no Mestrado Profissional em Administração Pública em Rede Nacional (PROFIAP) da Universidade Federal de Viçosa. Atualmente é o Diretor de Ensino do Campus UFV Rio Paranaíba.

\section{FABIO JOSÉ DIEL}

Possui graduação em Ciências Contábeis pela Universidade Comunitária da Região de Chapecó - UNOCHAPECÓ (2011). Tem experiência na área de Controladoria e Contabilidade de Custos. Mestre em Ciências Contábeis pela Universidade Regional de Blumenau (FURB). Professor do curso de Ciências Contábeis da Universidade Comunitária da Região de Chapecó - UNOCHAPECÓ atuando nas disciplinas de Planejamento e Orçamento Empresarial, Contabilidade Gerencial, Contabilidade de Custos e Auditoria.

\section{FELIPE POLZIN DRUCIAKI}

Mestre em Desenvolvimento Regional e Agronegócio pela Universidade do Oeste do Paraná (UNIOESTE), especialista em Gestão Econômica e Financeira pela Universidade Estadual do Centro Oeste (UNICENTRO), bacharel em Ciências Econômicas (2011) também pela UNICENTRO, técnico em Gestão de Negócios. Possui experiência em docência no ensino superior, além de experiência em consultoria empresarial e gestão de micro e pequenas empresas. Atualmente é docente do departamento de Ciências Econômicas da UNICENTRO, membro da equipe de coordenação do Curso de Especialização em Cooperativismo Solidário e Crédito rural, membro titular do colegiado e da coordenação do Curso de Tecnologia em Gestão Pública modalidade EAD/ Unicentro. Também faz parte do grupo de estudos Ciências Econômicas na perspectiva da teoria e da aplicação - GPCE e desenvolve pesquisas nas linhas vinculadas ao cooperativismo, Desenvolvimento Econômico, Economia Regional e Desenvolvimento Econômico Territorial.

\section{FERNANDA CRISTINA SANCHES}

Doutoranda em Educação (UEM). Mestre em Ciências Ambientais (UNIOESTE). Bacharel em Secretariado Executivo (UNIOESTE). Tecnóloga em Marketing (UNINTER). Atua como docente colaboradora do curso de Secretariado Executivo da UNIOESTE. Membro do Grupo de Pesquisa em Secretariado Executivo Bilíngue (GPSEB - UNIOESTE) e do Grupo de Estudos e Pesquisas em Escola, Família e Sociedade (UEM). Sócia efetiva da Associação Brasileira de Pesquisa em Secretariado (ABPSEC). Editora-chefe do periódico científico Revista Expectativa.

\section{GEOVANNE FERREIRA REBOUÇAS}

Zootecnista formado na Turma 1 da UFT (2004); - Mestre em Zootecnia/Melhoramento Genético Animal pela UFLA (2006); - Iniciou na docência em 2007 atuando em cursos de Administração Rural, Agronomia e Zootecnia; - Em 2012 entrou no IFMT Campus São Vicente ministrando aulas para cursos de Zootecnia, Agronomia e Técnico em Agropecuária; Doutorando em Zootecnia/Melhoramento Genético Animal desde 2017/2 pela UFG. 


\section{HENRIQUE LEAL PEREZ}

É Técnico em Agropecuária pelo colégio Técnico Agrícola da Unesp de Jaboticabal, possui graduação em Zootecnia pela Universidade São Marcos (2005) Mestrado e Doutorado em Zootecnia pela Universidade Estadual Paulista Unesp, Jaboticabal - SP. Realizou estagio sanduíche na Massey University, Nova Zelândia. Desenvolveu estudos sobre a utilização de alimentos alternativos e co-produtos na nutrição de ruminantes. Tem experiência na área de Zootecnia, com ênfase em Produção de Ovinos, atuando principalmente nos seguintes temas: Manejo nutricional ,produtivo e reprodutivo.

\section{HERNANI MARTINS JÚNIOR}

Doutor em Estatística Aplicada, Mestre em Estatística Aplicada, Professor de Estatística da Universidade Federal de Viçosa, Campus de Rio Paranaíba. Trabalha com modelagem de dados: modelos de regressão econométricos.

\section{ILNAR FERNANDES FEITOZA}

Possui graduação em Ciências Econômicas pela Universidade Federal de Mato Grosso (1999), especialista em Economia Agroindustrial em 2002 e em gestão pública em 2004, cursadas na UFMT/ Cuiabá. Mestra do programa de Pós Graduação em Desenvolvimento Socioeconômico da Universidade Federal do Maranhão em 2018. Desde 2005 é funcionária pública do Instituto Nacional de Colonização e Reforma Agrária no cargo de orientadora de projetos de assentamentos.

\section{ISAAC RESENDE ARAÚJO}

Graduando em Administração pela Universidade Federal de Viçosa, pesquisador do NEEAP Núcleo de Estudos Econômicos do Alto Paranaíba, atuação como professor e coordenador pedagógico em instituição de ensino de Língua Inglesa e experiência gerencial em atividades empreendedoras.

\section{IVANETE DAGA CIELO}

Doutora em Desenvolvimento Regional e Agronegócio pela Universidade Estadual do Oeste do Paraná - UNIOESTE (2015) e mestre em Engenharia de Produção pela Universidade Federal de Santa Catarina (2001). Possui graduação em Secretariado Executivo Bilíngue pela Universidade Estadual do Oeste do Paraná (1994) e especialização em Desenvolvimento Gerencial, também pela UNIOESTE. É professora adjunta da Universidade Estadual do Oeste do Paraná, atuando no curso de graduação em Secretariado Executivo e na pós-graduação lato sensu em Assessoria Executiva. Desenvolve pesquisas nas áreas de secretariado, gestão, agronegócio e empreendedorismo.

\section{JEAN MARCOS DA SILVA}

Atualmente é bacharel em Ciências Contábeis pela Universidade Federal de Rondônia-UNIR e Mestre em Administração pela Universidade Federal de Rondônia-UNIR. Atua como pesquisador no Centro de Estudos Interdisciplinar em Desenvolvimento Sustentável da Amazônia-CEDSA e desenvolve trabalhos na linha de pesquisa Sustentabilidade, Agricultura Familiar e Gestão do Agronegócio. É pesquisador-formador efetivo em regime de dedicação exclusiva no Instituto Federal de Educação Ciência e Tecnologia Sul-rio-grandense - IFSul. 


\section{JOABE SANTOS SOUSA}

Formação em Técnico de Recursos Humanos pelo SENAC, graduando em Administração pela Universidade Federal de Viçosa - UFV. Atualmente é bolsista pelo CNPq no projeto "Crises cambiais e políticas e seus impactos no mercado econômico e financeiro". Possui experiência em folha de pagamento, com atuação por quatro anos em Departamento Pessoal.

\section{JOSÉ DE RIBAMAR SÁ SILVA}

Professor Associado, Departamento de Economia, Universidade Federal do Maranhão. Professor e pesquisador nos programas de pós-graduação PPG Políticas Públicas e PPG Desenvolvimento Socioeconômico. Bacharel em Ciências Econômicas (1990) e especialista em Metodologia do Ensino Superior (1994), pela Universidade Federal do Maranhão. Mestre em Economia Rural (1997), pela Universidade Federal da Paraíba. Doutor em Políticas Públicas (2007), pela Universidade Federal do Maranhão, com estágio de doutorado no Instituto de Economia da Universidade Estadual de Campinas (2005). Realizou estágio de pós-doutorado na Middlesex University/ Londres (2014-2015), com financiamento da CAPES. Tem experiência em gestão acadêmica, ensino e pesquisa, nas áreas de Economia, Políticas Públicas e Educação do Campo, com interesse principalmente nos temas: formação social e econômica do Brasil; desenvolvimento socioeconômico; economia agrária e dos recursos naturais; economia do Maranhão; políticas públicas para o campo; assentamentos da reforma agrária; agricultura familiar e segurança alimentar e nutricional.

\section{JOSEFA ESTEVO DE SOUZA ARAÚJO}

Possui graduação em ciências sociais pela universidade federal do acre (2016). Especialização no curso de Pós Graduação Lato Senso em Economia Regional e Políticas Públicas pela Universidade Federal do Acre (2018).

\section{JOSIANE CASTRO PEREIRA}

Bacharel em Ciências Econômicas pela Universidade Federal do Pampa.

\section{JULIENNE DE JESUS ANDRADE WIDMARCK}

Professora substituta da Universidade Federal de Viçosa - Campus Rio Paranaíba - Instituto de Ciências Humanas e Sociais, entre julho/2017 a julho/2018. Aceita para o doutorado em Economia no Instituto Internacional de Estudos Sociais na Universidade Erasmus de Rotterdam que será iniciado a partir de setembro de 2018. Concluiu o Mestrado em Economia no Programa de Pós-Graduação em Economia da Universidade Federal de Uberlândia (2016). Especialista em Finanças e Planejamento Empresarial pelo Instituto de Economia da Universidade Federal de Uberlândia. Atualmente é consultora em Desenvolvimento Territorial, Agroindústria e Planejamento Empresarial. Tem Experiência na Área de Economia, com Ênfase em Economia Aplicada, Métodos Econométricos e Agricultura Familiar.

\section{JUNIOR GIACOBBO}

Mestrando em Engenharia de Produção pela UFRGS (2018), Engenheiro de Segurança do Trabalho pela UCAM (2016) e Engenheiro Eletricista pela UFRGS (2015). Exerce suas atividades profissionais no Badesul Desenvolvimento - Agência de Fomento RS. 


\section{LEONARDO GUIMARÃES MEDEIROS}

Está cursando Mestrado em Agronegócio pela Universidade Federal de Goiás - UFG (2017). Possui graduação em Administração pela Universidade de Rio Verde - UniRV (2014) e pós graduação latu sensu em Gestão Estratégica Empresarial pela Faculdade Almeida Rodrigues - FAR (2016). Atualmente é professor substituto do Ensino Básico, Técnico e Tecnológico do Instituto Federal Goiano - Campus Rio Verde. Possui experiência administrativa, comercial, acadêmica com ênfase em Planejamento Estratégico e Gestão no Agronegócio, atuando principalmente nos seguintes temas: Administração Financeira, Gestão da Qualidade, Empreendedorismo, Planejamento Estratégico, Políticas Agrícolas e Comercialização no Agronegócio

\section{LOISEANE SANTOS CORREIA PINTO}

Estudante de Economia, do 6ำ período, da Universidade do Estado do Amazonas (UEA). Pesquisadora do Programa de Iniciação Científica (PAIC/UEA)

\section{LUCAS FERREIRA LIMA}

Graduado em Ciências Econômicas pela Universidade Federal de Uberlândia (2009). Mestre em Desenvolvimento Econômico pelo Instituto de Economia da UNICAMP. Doutorando em Desenvolvimento Econômico pelo Instituto de Economia da UNICAMP. Professor Universitário do Complexo Educacional FMU em São Paulo. Atua principalmente nos seguintes temas: economia ecológica, economia do meio ambiente, desenvolvimento econômico, políticas públicas territoriais, políticas de desenvolvimento territorial rural, metodologias de apoio multicritério à decisão, comunidades ribeirinhas tradicionais.

\section{LUISA PASETO}

Dra. e Mestre em Engenharia Agrícola - Gestão de Sistemas na Agricultura e Desenvolvimento Rural (Feagri/Unicamp); Economista e Administradora de Empresas (Puccamp/SP); MBA em Marketing e Planejamento Organizacional (ESPM/SP), Especialista em Business Ethic (Word Bank) e Ética Empresarial (OWCP/FGV). Docente Convidada do SENAC/SP em Marketing e Meio Ambiente; Tutora e Docente pela plataforma EAD SitEscola/SP para os cursos de Marketing e Responsabilidade Social e MDL; Colaboradora e Palestrante nos GIEs de Meio Ambiente e Mudanças Climáticas da AHK Brasil e CSRMERCOSUL.

\section{MARCUS VINICIUS MENDONÇA}

Analista Ambiental do Instituto Chico Mendes de Conservação da Biodiversidade, Engenheiro Agrônomo pela Escola Superior de Agricultura Luiz de Queiroz/Universidade de São Paulo, especialização em Educação Ambiental, Cidadania e Desenvolvimento Regional pela Universidade Federal do Pará, mestrando do Programa de Pós-Graduação em Desenvolvimento Regional/Universidade Federal do Tocantins.

\section{MARIA APARECIDA CRISSI KNUPPEL}

Professora Adjunta da Universidade Estadual do Centro-Oeste, UNICENTRO. Tenho graduação em Letras Português Inglês pela Universidade Estadual do Centro-Oeste (1982), mestrado em Educação pela Universidade Estadual de Campinas (1999) e doutorado em Educação pela Universidade Estadual de Maringá (2013). Tenho experiência na área de Educação, com ênfase em Educação, atuando principalmente nos seguintes temas: história da educação, história dos manuais escolares, história das disciplinas escolares, história da leitura, educação a distância e tecnologias da educação. Coordenadora do Núcleo de Educação a Distância da Unicentro e Coordenadora UAB da Unicentro. 


\section{MARIA GILCA PINTO XAVIER}

É graduada em Ciências Sociais pela Universidade Federal da Paraíba, fez mestrado em Ciências Sociais pela Universidade Estadual de Campinas e Doutorado pela Universidade Federal de Pernambuco em Desenvolvimento urbano. Atualmente é professora Associada da Universidade Federal Rural de Pernambuco. É pesquisadora líder do grupo de Pesquisa para Caracterização de Aglomeração Produtiva, Inovação e Empreendedorismo: CARISMA. Faz parte do corpo Docente Permanente do Curso Pós-Graduação em Administração e Desenvolvimento Rural (strictu-sensu)/UFRPE. O seu interesse de pesquisa é em Políticas Públicas e Desenvolvimento Econômico e Social e Desenvolvimento Urbano, principalmente em temas: Planejamento e Desenvolvimento Regional; Reestruturação Produtiva; Regiões de Capitalismo Tardio, Aglomerações Produtivas, Inovação e Análises de fluxos de Cadeia Produtiva; Políticas de Crescimento Econômico e Social.

\section{MARIA RAÍZA VICENTE DA SILVA}

Bacharel em Turismo pela UFPE (2014) e Mestre em Administração e Desenvolvimento Rural pela UFRPE (2018). Possui experiência na área de Turismo, com ênfase em Agências de Viagens, Eventos e Marketing. Atualmente desenvolve pesquisas na área de Inovação, Geotecnologias e Geomarketing.

\section{MARICELIA ALMEIDA SILVA}

Graduanda em Ciências Econômicas pelo Complexo Educacional das Faculdades Metropolitanas Unidas FMU (2015-2019). Atua principalmente nos seguintes temas: economia ecológica, economia do meio ambiente, desenvolvimento econômico, políticas públicas territoriais, políticas de desenvolvimento territorial rural, agricultura familiar.

\section{MATHEUS SODRÉ FERREIRA}

Estudante de Zootecnia, participou como voluntário, durante os anos de 2015 e 2016, nos diversos setores do campus. Foi aprovado como monitor durante 2016/2 no setor de fabrica de ração, estagiário, em 2017, no setor de bovinocultura de leite e participou como voluntário em projetos pesquisa. Construiu uma nova família na faculdade, onde estes levará pra vida toda.

\section{MAURICIO ANTÔNIO BOTTINI}

Bacharel em Ciências Contábeis pela Unochapecó.

\section{MAURÍCIO BENEDETI ROSA}

Mestre em Economia Aplicada pela Universidade Federal de São Carlos - UFSCar/Sorocaba (2015/2016). Possui graduação em Engenharia de Controle e Automação pela Universidade Estadual Paulista "Júlio de Mesquista Filho" - UNESP/Sorocaba (2012). Realizou trabalhos nas áreas de Economia Internacional e Economia Financeira.

\section{MEYRIANNY SANTANA REIS}

Graduanda no curso de Ciências Econômicas pela Universidade do Estado do Amazonas (UEA). 


\section{MILLER DE JESUS TEODORO}

Graduando em Bacharelado em Zootecnia no Instituto Federal de Educação, Ciências e Tecnologia de Mato Grosso, Campus São Vicente. Atualmente no 10 semestre, com previsão de conclusão em 2018/2. Foi estagiário do Instituto entre 2015 e 2017, atuando nos setores de Fábrica de Ração e Ovinocultura. Entrou para o programa de Iniciação Científica em 2017. com projeto focado no uso de coprodutos na nutrição de ruminantes de pequeno porte.

\section{NEULER ANDRÉ SOARES DE ALMEIDA}

Doutor em Biotecnologia pela Rede de Biodiversidade e Biotecnologia da Amazônia Legal (PPGBIONORTE/UEA), na área de Biodiversidade e Conservação (2016). Mestrado em Economia do Desenvolvimento na Pontifícia Universidade Católica do Rio Grande do Sul (PPGE/PUCRS) na área de Desenvolvimento Econômico e Economia Regional (2012). Graduado em Ciências Econômicas pela Universidade Federal do Amazonas (UFAM) (2009). Pesquisador do Núcleo de Estudo e Pesquisa em Economia (NEPE). Vice Líder do Grupo de Pesquisa em Desenvolvimento Regional e Sustentabilidade (GDERS).

\section{NILTON MARQUES DE OLIVEIRA}

Economista pela UEM, Mestre em Economia Aplicada pela UFV e Doutor em Desenvolvimento Regional e Agronegócio pela UNIOESTE. Professor do Programa de Pós-Graduação em Desenvolvimento Regional (PGDR/UFT) e do curso de Ciências Econômica da Universidade Federal do Tocantins (UFT). Líder do Grupo de Pesquisa: Desenvolvimento Regional e Territorial do Centro Norte do Brasil (DRT- Centro Norte) E-mail; niltonmarques@uft.edu.br http://lattes.cnpq.br/9714154982299224

\section{OLEIDES FRANCISCA DE OLIVEIRA}

Doutora em Desenvolvimento Regional pela Universidade de Santa Cruz do Sul - UNISC (2012). Mestre em Desenvolvimento Regional e Meio Ambiente pela Universidade Federal de Rondônia - UNIR/RO (2009), Graduação em CIENCIAS CONTABEIS pela FACULDADE CIÊNCIAS HUMANAS E EXATAS - FARO (2001). Docente titular da Universidade Federal do Acre - UFAC, no curso de graduação em Ciências Econômicas, nas disciplinas de contabilidade e áreas afins. Coordenadora e Docente do curso de Pós-Graduação Lato Sensu em Economia Regional e Políticas Públicas - ERPP, nas disciplinas: Desenvolvimento Regional e Políticas Públicas; Gestão de Territórios e Políticas de Desenvolvimento.

\section{POLIANA FERNANDES DE ALMEIDA}

Possui Doutorado em Ciências na área de Tecnologia de Alimentos pela Faculdade de Ciências Farmacêuticas da Universidade de São Paulo - USP, Mestrado em Engenharia de Produção pela Universidade Nove de Julho de São Paulo (2012) e Especialização em Didática do Ensino Superior pela Universidade de Cuiabá (2006). Possui graduação em Tecnologia de Alimentos pelo Instituto Federal de Educação, Ciência e Tecnologia de Mato Grosso - Campus São Vicente (2004) e atualmente é Professora do IFMT - Campus São Vicente. Atua na área de Ciência e Tecnologia de Alimentos, com ênfase em gestão da qualidade e desenvolvimento de novos produtos. 


\section{RAVILLA DE CASTRO BARBOSA}

Graduanda em Administração pela Universidade Federal de Viçosa - Campus Rio Paranaíba. Atua como Assistente de Pesquisa no Núcleo de Estudos Econômicos do Alto Paranaíba NEEAP UFV-CRP. Atua como Estagiária no Grupo Tsuge Importação e Exportação. Atua como Assistente de Pesquisa no Núcleo de Estudos em Gestão do Trabalho - NEGEST UFV-CRP. Atua como Diretora de Projetos na Empresa Júnior Integra Consultoria. Trabalhou como Gerente de Projetos no Time Enactus UFV-CRP (2014/2018). Participou de mobilidade acadêmica junto à Universidade de Coimbra- Portugal (2015/2016)

\section{RICARDO FREITAS MARTINS DA COSTA}

Possui graduação em Ciências Econômicas pela Pontifícia Universidade Católica de Minas Gerais (1988), Especialização em Administração Financeira (PUC -MG) e Mestrado em administração pelo Centro Universitário do Triângulo (2003). Atualmente é professor adjunto II da Universidade Federal de Viçosa. Tem experiência na área de Economia Aplicada, com ênfase em Planejamento Financeiro e Estudos Industriais. Trabalha como consultor sênior, na elaboração e implantação de projetos, estudos de viabilidade econômica financeira, Diagnóstico Empresarial. Assessoria Econômica e Financeira: -Analise, Projeto e Acompanhamento de Reestruturação Empresarial, -Estudos de Viabilidade EconômicoFinanceira; -Financiamentos Empresariais (Projeto e acompanhamento junto a Instituições Financeiras); -Orientação Econômica e Financeira; -Finanças Pessoais (Orientação e planejamento do orçamento familiar e pessoal, orientação em financiamentos pessoais); Orçamento Empresarial (Análise das Variações Orçamentárias, Elaboração de Orçamentos); Sistema de Cobrança Negociada; -Programa de Otimização de Despesas; -Reestruturação Financeira; -Intermediação de Negociação com Credores; -Intermediação de Negociações com Devedores; -Sistema de Fluxo de Caixa; -Evolução de Custos e Receitas; -Contabilidade Gerencial (Relatórios Gerenciais, Balanços Gerenciais); -Perícias Judiciais e Extra Judiciais

\section{RICARDO TEIXEIRA MARTINS DA COSTA}

Possui graduação em Ciências Econômicas pela Pontifícia Universidade Católica de Minas Gerais (1988), Especialização em Administração Financeira (PUC -MG) e Mestrado em administração pelo Centro Universitário do Triângulo (2003). Atualmente é professor adjunto II da Universidade Federal de Viçosa. Tem experiência na área de Economia Aplicada, com ênfase em Planejamento Financeiro e Estudos Industriais. Trabalha como consultor sênior, na elaboração e implantação de projetos, estudos de viabilidade econômica financeira, Diagnóstico Empresarial. Assessoria Econômica e Financeira: -Analise, Projeto e Acompanhamento de Reestruturação Empresarial, -Estudos de Viabilidade EconômicoFinanceira; -Financiamentos Empresariais (Projeto e acompanhamento junto a Instituições Financeiras).

\section{RODOLFO ALVES DA LUZ}

Possui Graduação em Geografia (2007), Mestrado (2010) e Doutorado em Geografia Física (2014), todos pela Universidade de São Paulo. Foi pesquisador visitante na Universidade de Manchester - Reino Unido (bolsa sanduíche do Programa Ciência Sem Fronteira). Atualmente é Professor da Universidade Federal do Tocantins, Curso de Geografia, Campus Porto Nacional, e no Programa de Pós Graduação em Desenvolvimento Regional, Campus Palmas. É vinculado ao Laboratório de Geoprocessamento (Campus Porto Nacional). Tem experiência na área de Geografia, com ênfase em Cartografia, Sistemas de Informação Geográfica, Desenvolvimento Regional e Urbano, Planejamento Ambiental e Geografia Física. 


\section{ROSANE NUNES DE FARIA}

Possui graduação em Ciências Econômicas pela Universidade Federal de Viçosa (2003), mestrado em Economia Aplicada pela Universidade Federal de Viçosa (2004), doutorado em Ciências (Economia Aplicada) pela Universidade de São Paulo (2009) e pós-doutorado pelo Institute for Food and Resource Economics, Bonn University (2014). Atualmente é professora do Departamento de Economia da Universidade Federal de São Carlos. Tem experiência na área de Economia, com ênfase em Economia Internacional, atuando principalmente nos seguintes temas: comércio internacional, exigências técnicas, exportação de alimentos, desempenho logístico, exportações e competitividade.

\section{SILVANA DALMUTT KRUGER}

Graduada em Ciências Contábeis pela Universidade Comunitária Regional de Chapecó (2000), Pós-Graduação em Gerência da Qualidade dos Serviços Contábeis (2002) e Contabilidade Gerencial Estratégica (2010). Mestra em Contabilidade pela Universidade Federal de Santa Catarina- UFSC (2012) e Doutora em Contabilidade pela UFSC (2017). Professora do Programa de Mestrado em Ciências Contábeis e Administração da Unochapecó. Participante dos Grupos de Pesquisa Controle de Gestão e Desenvolvimento (Unochapecó) e do Grupo Contabilidade, Organizações e Sociedade (Unochapecó).

\section{SIMÃO TERNOSKI}

Mestre em Desenvolvimento Regional pela Universidade Tecnológica Federal do Paraná (UTFPR). Graduado em Ciências Econômicas pela Universidade Estadual do Centro-Oeste (2006). Especialista em MBA - Comércio Internacional, Faculdade de Tecnologia Internacional (FATEC) e Especialista Formação de Docentes e de Orientadores Acadêmicos (UNINTER). Professor da Universidade Estadual do Centro-Oeste - UNICENTRO - Departamento de Ciências Econômicas. Coordenador Financeiro da UAB/NEAD/UNICENTRO. Faz parte do Núcleo de Estudos e Práticas Econômicas - NEPE e do grupo de estudos em Ciências Econômicas na perspectiva da teoria e da aplicação - GPCE.

\section{TALES WANDERLEY VITAL}

Engenheiro Agrônomo pela Universidade Federal Rural de Pernambuco (1969), Mestre em Economia Agrícola pela Universidade Federal do Ceará (1977) e Doutor em Economia pela Universidade Federal de Pernambuco (1991). Pós - Doutor em Comércio Internacional Agrícola por Paris1 Pantheon Sorbonne (1997) e Pós - Doutor em Economia Territorial por Grenoble II (2008). Professor Associado IV da Universidade Federal Rural de Pernambuco. Atua na área de Economia Agrícola, nos temas: política agrícola, cadeia produtiva, agricultura familiar e desenvolvimento rural

\section{TATIANA SILVA FONTOURA DE BARCELLOS GIACOBBO}

Doutoranda em Economia pela UNISINOS (2018), Mestre em Economia pela UFRGS (2016) e graduada em Ciências Econômicas pela UFRGS (2018). Exerce suas atividades profissionais no Badesul Desenvolvimento - Agência de Fomento RS.

\section{VANDERLEI GOLLO}

Graduado em Ciências Contábeis pela Universidade Comunitária da Região de Chapecó UNOCHAPECÓ (2010). Pós-Graduação em Contabilidade e Controladoria pela Universidade Comunitária da Região de Chapecó - UNOCHAPECÓ (2012). Mestre em Ciências Contábeis pela Universidade Regional de Blumenau - FURB (2014). Professor na UNOCHAPECÓ nas disciplinas de Contabilidade a Análise de Custos, Gestão estratégica de Custos, Teoria da Contabilidade, Projeto de Pesquisa. 


\section{VIVIAN RANIERE MENDES SILVA}

Graduanda em Administração pela Universidade Federal de Viçosa - Campus Rio Paranaíba. Atua Como Supervisora no Núcleo de Estudos Econômicos do Alto Paranaíba - NEEAP UFVCRP. Atua Como Bolsista no Projeto Educação Financeira: Aprendendo a Lidar Com Dinheiro UFV-CRP. Trabalhou como Diretora de Pesquisa e Desenvolvimento na empresa Integra Consultoria (2018/2). Estagiou na empresa Paranaíba FM (2018/1). Trabalhou como Gerente de Marketing na empresa Integra Consultoria (2018/1). Trabalhou como Trainee na empresa Carminha Fernandes Photos (2013-2017). Estagiou na empresa TRE Minas (2015 - 2016).

\section{WAGNER LUIZ LOURENZANI}

Graduado em Engenharia de Alimentos pela Universidade Federal de Viçosa - UFV (1997), mestre em Ciência e Tecnologia de Alimentos pela UFV (2000) e doutor em Engenharia de Produção pela UFSCar (2005). Atualmente é professor assistente da Faculdade de Ciências e Engenharia da UNESP/Campus Tupã, e docente orientador do Programa de Pós-Graduação em Agronegócio e Desenvolvimento (PGAD). Tem experiência na área de Gestão do Agronegócio, atuando principalmente nos temas de análise de sistemas agroindustriais e desenvolvimento regional. É Coordenador do Grupo CEPEAGRO (Centro de Estudos e Pesquisas em Administração e Agronegócios).

\section{WALTER LUIZ DOS SANTOS JÚNIOR}

Doutorando no PPGE do Instituto de Economia da Universidade Federal de Uberlândia. É graduado em Ciências Econômicas (1995) e Mestre em Economia (1999) pela Universidade Federal de Uberlândia (UFU). Foi coordenador do Núcleo de Pesquisa e Estágio do Curso de Administração da União Educacional Minas Gerais Ltda - UNIMINAS - e Editor da Revista Mineira de Gestão de Negócios - RMGN/UNIMINAS. Foi coordenador do MBA em Gestão Estratégica da UNIMINAS, atualmente Faculdade Pitágoras de Uberlândia, após sua aquisição pelo Grupo Kroton Internacional SA. Atuou como professor em cursos de pósgraduação em diversas instituições de ensino superior de Uberlândia e região, notadamente no Curso de Especialização Lato Sensu; MBA em Gestão Empresarial; da Faculdade de Gestão e Negócios da UFU (FAGEN/UFU). No momento, é Professor Assistente II da Universidade Federal de Viçosa, campus Rio Paranaíba (UFV/CRP), e ocupou a Coordenação do Curso de Administração no biênio 2014/2016.

\section{WEIMAR FREIRE DA ROCHA JUNIOR}

Engenheiro Agrônomo formado pela Universidade Federal de Lavras (1989), Mestre em Economia Agrária (Economia Aplicada) pela Universidade de São Paulo (1994) e Doutor em Engenharia de Produção pela Universidade Federal de Santa Catarina (2001). Professor Associado da Universidade Estadual do Oeste do Paraná onde leciona no Curso de Ciências Econômicas. Atualmente é Coordenador do Programa de Pós-graduação em Desenvolvimento Regional \& Agronegócio (Mestrado e Doutorado). Atua como pesquisador nos grupos GEPEC e TRANSLOG, direcionando suas pesquisas nos seguintes temas: agronegócio, erva-mate, nova economia institucional e logística.

\section{ZORAIDE DA FONSECA COSTA}

Possui graduação em Ciências Econômicas - Faculdades Integrada de Botucatu (1999), mestrado em Agronomia (Energia na Agricultura) pela Universidade Estadual Paulista Júlio de Mesquita Filho (2007) e doutorado em Energia na Agricultura pela Faculdade de Ciências Agronômicas (2009). Atualmente é professor do programa de pós-graduação de ADM da Universidade Estadual do Centro Oeste do Paraná, membro comissão própria de avaliação instituição da Universidade Estadual do Centro Oeste do Paraná, coordenador de curso especialização da Universidade Estadual do Centro Oeste do Paraná, professor efetivo da Universidade Estadual do Centro Oeste do Paraná e chefe do departamento de ciências econômicas da Universidade Estadual do Centro Oeste do Paraná. Tem experiência na área 
de Sociologia, com ênfase em Economia e Energia, atuando principalmente nos seguintes temas: agricultura familiar, sustentabilidade, desenvolvimento regional, agronegócio e desenvolvimento rural. 


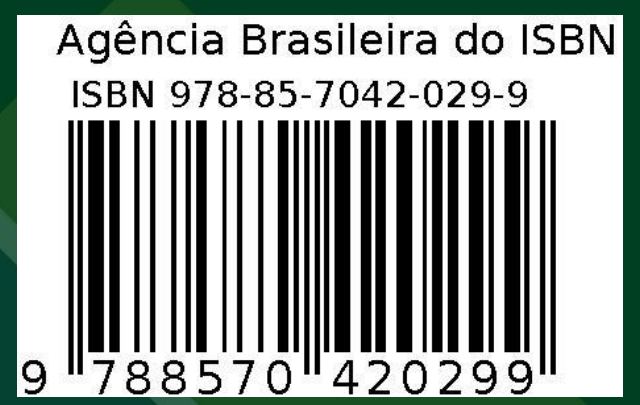

